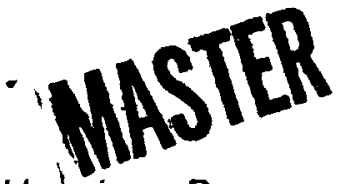

National Uranium Resource Evaluation

\title{
GEOLOGY AND RECOGNITION CRITERIA FOR URANIUM DEPOSITS OF THE QUARTZ-PEBBLE CONGLOMERATE TYPE
}

\section{FINAL REPORT}

BY: Andrew Button

SOUTH DAKOTA SCHOOL OF MINES AND TECHNOLOGY

Rapid City, South Dakota

Samuel S. Adams

SAMUEL S. ADAMS AND ASSOCIATES

Boulder, Colorado

March 1981

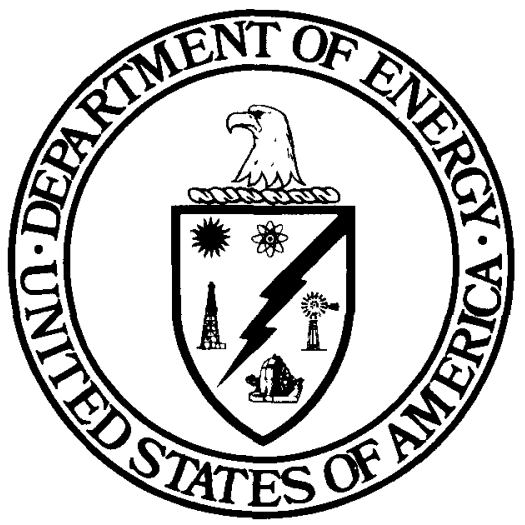

PREPARED FOR THE U.S. DEPARTMENT OF ENERGY

Grand Junction Office, Colorado 
This report is a result of work performed by Samuel S. Adams and Associates through a Bendix Field Engineering Corporation Subcontract, as part of the National Uranium Resource Evaluation. NURE is a program of the U.S. Department of Energy's Grand Junction, Colorado, Office to acquire and compile geologic and other information with which to assess the magnitude and distribution of uranium resources and to determine areas favorable for the occurrence of uranium in the United States.

This report was prepared as an account of work sponsored by an agency of the United States Government. Neither the United States Government nor any agency thereof, nor any of their employees, makes any warranty, express or implied, or assumes any legal liability or responsibility for the accuracy, completeness, or usefulness of any information, apparatus, product, or process disclosed, or represents that its use would not infringe privately owned rights. Reference herein to any specific commercial product, process, or service by trade name, trademark, manufacturer, or otherwise, does not necessarily constitute or imply its endorsement, recommendation, or favoring by the United States Government or any agency thereof. The views and opinions of authors expressed herein do not necessarily state or reflect those of the United States Government or any agency thereof. 


\section{DISCLAIMER}

Portions of this document may be illegible in electronic image products. Images are produced from the best available original document. 


\title{
GEOLOGY AND RECOGNITION CRITERIA FOR URANIUM DEPOSITS
}

OF THE QUARTZ-PEBBLE CONGLOMERATE TYPE

FINAL REPORT

\author{
Andrew Button \\ South Dakota School of Mines and Technology \\ Rapid City, South Dakota 57701 \\ and \\ Samuel S. Adams \\ Samuel S. Adams and Associates \\ 2342 Broadway \\ Boulder, Colorado 80302
}

December 1980

PREPARED FOR THE U.S. DEPARTMENT OF ENERGY

GRAND JUNCTION OFFICE, COLORADO

UNDER CONTRACT NO. DE-AC13-76GJ01664

AND BENDIX FIELD ENGINEERING CORPORATION

SUBCONTRACT NO. 79-296-S

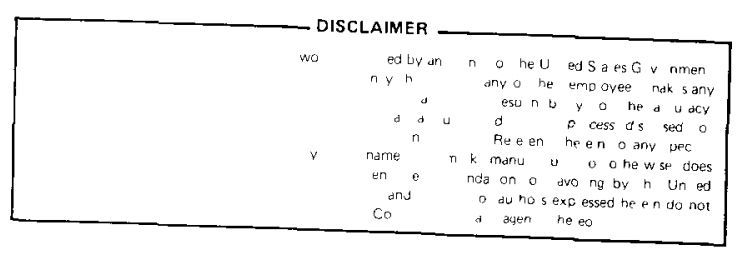


0

0 
SUMMARY. . . . . . . . . . . . . . . . . . . . . . 29

Tectonic Setting ...................... 29

Geochronologic Setting . . . . . . . . . . . . . . 29

Stratigraphic setting . . . . . . . . . . . . . . . 29

Host Rock Character . . . . . . . . . . . . . . . 30

Conglomerate Character . . . . . . . . . . . . . . 30

Post-Depositional Modification of Conglomerates . . . . . . . . . . 31

Uranium Mineralization . . . . . . . . . . . . . . . 31

Recognition Criteria . . . . . . . . . . . . . . . . . 32

Reflections on Continuing Studies . . . . . . . . . . . . 32

United States Potential . . . . . . . . . . . . . . . . 33

INTRODUCTION . . . . . . . . . . . . . . . . . . 35

objectives . . . . . . . . . . . . . . . . . . . 37

Location of Uraniferous Conglomerates . . . . . . . . . . . 38

General Descriptions of Producing Districts . . . . . . . . . 38

E1liot Lake District, Ontario, Canada . . . . . . . 38

Regional Tectonic Setting . . . . . . . . . . 38

Structure.................... 42

Stratigraphy .................. 42

Paleogeography ................. 44

Distribution of Mineralization . . . . . . . . . 44

Witwatersrand District, South Africa . . . . . . . . . . 44

Regional Tectonic Setting . . . . . . . . . 47

Structure .................... 47

Stratigraphy ................. 49

Paleogeography ................. 50

Distribution of Mineralization .......... 51

Acknowledgements ...................... 51

TECTONIC SETTING OF BASINS CONTAINING URANIFEROUS CONGLOMERATES . • . 53

Crustal Architecture of Precambrian Shields . . . . . . . . . . 53

Gravity Patterns in Precambrian Shields . . . . . . . . . 55

Archean High-Grade Regions . . . . . . . . . . . . . 55

Metamorphosed "Basement" .............. 57

Supracrustal Metamorphic Rocks ........... 57

Geochronology . . . . . . . . . . . . . . 57

Metamorphism and Structure . . . . . . . . . . 57

Archean Greenstone Belts . . . . . . . . . . . . . 58

Geochronology .................. 58

Stratigraphy ................... 58

Structure ................... 59

Metamorphism ................. 59

Archean Granitoid Rocks . . . . . . . . . . . . 59

Tonalitic Gneisses .. . . . . . . . . . 59

Diapiric Plutons .............. . . 59

Potassic Granites . . . . . . . . . . . . . . 60

Sheet-Like Granites . . . . . . . . . . 60

Stock- and Plug-Like Intrusives. . . . . . . . 60 
Evolution of Archean Cratons . . . . . . . . . . . . . 61

Concept of a Layered Crust . . . . . . . . . . . . . . . 61

Tectonic Setting of Basins Containing Quartz-Pebble

Conglomerate Uranium Deposits . . . . . . . . . . 63

Summary ..................... 64

GEOCHRONOLOGIC SETTING . . . . . . . . . . . . . . . . . . . 65

Ages of Basins Containing Uraniferous Conglomerates . . . . . . . 65

South Africa . . . . . . . . . . . . . . . . . 65

Moodies Group . . . . . . . . . . . . . . 65

Uitkyk Formation .. . . . . . . . . . . 65

Mozaan Subgroup ................... 65

Dominion Reef Group .. . . . . . . . . . . . . 66

Witwatersrand Supergroup . . . . . . . . . . . . 66

Ventersdorp Supergroup . . . . . . . . . . . 67

Transvaal Supergroup ................ . 67

Younger Basins ................... 67

North America . . . . . . . . . . . . . . . . 67

Huronian, Elliot Lake District . . . . . . . . 67

Sakami Lake . . . . . . . . . . . . . . 68

Montgomery Lake-Padlei Area .. . . . . . . . . 68

Black Hills Area . . . . . . . . . . . . . . . 68

Medicine Bow Mountains and Sierra Madre... . . . . 68

South America .. . . . . . . . . . . . . . 68

Jacobina .................. 69

Quadrilatero Ferrifero .............. 69

Other Areas . . . . . . . . . . . . . . 69

Australia ..................... 69

Hamersley Basin... . . . . . . . . . . . 69

Asia and Europe .. . . . . . . . . . . . . . 70

Bababudan Group . . . . . . . . . . . . . . 70

Krivoy Rog Group . . . . . . . . . . . . . . 70

Karelian Supergroup ................. . 70

Summary of Ages of Basins Containing Uraniferous Conglomerates 70

Ages of Uranium Minerals . . . . . . . . . . . . . . . . 73

Krivoy Rog......................... 73

Witwatersrand Supergroup . . . . . . . . . . . 73

Huronian Occurrences . . . . . . . . . . . . . . . . 74

STRATIGRAPHIC SETTING OF URANIFEROUS CONGLOMERATES . . . . . . . . . . . 75

Sources of Sediments and Uranium . . . . . . . . . . . . . . . 75

Sources of Sediments . . . . . . . . . . . . . 75

Source of Uranium . . . . . . . . . . . . . . 76

Nature of Uranium Minerals . . . . . . . . . 77

Source Area Characteristics . . . . . . . . . . . 78

Summary .. . . . . . . . . . . . . . . 82

Late Archean and Early Proterozoic Paleoweathering . . . . . . . 82

Paleoatmospheric Composition . . . . . . . . . . . . 83

Paleosol Studies . . . . . . . . . . . . . . . . 83

Pyrite and Uraninite in Fluvial Sediments . . . . . . . 87

Archean and Early Proterozoic Red Beds. . . . . . . 88

Summary . . . . . . . . . . . . . . . . 88 
Paleohydrospheric $\mathrm{pH}$. . . . . . . . . . . . 89

Climatic Conditions .. . . . . . . . . . . . . 90

Paleotopography .. . . . . . . . . . . . . 93

Summary ........................ . 94

Paleotopographic Controls on Deposition . . . . . . . . . . . 94

Tectonic Controls on Paleotopography . . . . . . . . . . . . 94

Fold Controls, Regional Scale . . . . . . . . . . 95

Fold Controls, Local Scale . . . . . . . . . . . . 98

Fault Controls, Regional Scale . . . . . . . . . 98

Fault Controls, Local Scale . . . . . . . . . . . . . 99

Paleotopography Due to Differential Erosion. . . . . . . . 99

Differential Erosion of the Archean Basement . . . . 103

Differential Erosion on 01der Sedimentary Basins . . . 105

Stratigraphic-Sedimentologic Setting of Uraniferous Conglomerates - 108

Unconformity Control on Uraniferous Conglomerates . . . . . . 108

Scale of Unconformity . . . . . . . . . . . . . . 108

Classification of Unconformities . . . . . . . . . . 109

Fundamental Unconformities/Nonconformities (Type 1) . . 109

Fundamental Unconformity/Nonconformity Overlain by Fluvial Sediments (Type $1 \mathrm{f}$ ). . . . . . . . . 109

Fundamental Unconformity/Nonconformity Overlain by Marine Sediments (Type $1 \mathrm{~m}$ ) ... . . . . . 110

Fundamental Unconformity/Nonconformity Overlain by a Volcanic Sequence (Type $1 \mathrm{v}$ ). . . . . . . 113

Intraformational Unconformities/Disconformities (Type 2) 115

Intraformational Unconformities Overlain by Fluvial Sediments (Type $2 \mathrm{f}$ ) . . . . . . . . . . . 115

Intraformational Unconformities Overlain by Marine Arenites (Type $2 \mathrm{~m}$ ). ........... . 117

Unconformity Control on Heavy Mineral Concentration . . . . . . . 118

Paleoenvironments of Deposition . . . . . . . . . . . 121

HOST ROCK CHARACTERIZATION . . . . . . . . . . . . . . . . . 123

Petrology, Mineralogy, and Chemistry of Host Rocks . . . . . . . 123

Subarkose-Quartz Wacke Association . . . . . . . . . . 123

Color . . . . . . . . . . . . . . . . . 123

Mineralogical Composition . . . . . . . . . . . 124

Texture ..................... 127

Fine-Grained Components of the Subarkose-Quartz Wacke Association . . . . . . . . . . . . . 128

Chemical Composition . . . . . . . . . . . . 128

Summary . . . . . . . . . . . . . . . . . . 132

Quartz-Arenite Association . . . . . . . . . . . . 133

Witwatersrand Basin . . . . . . . . . . . . 133

Pongola Basin ................... 134

Jacobina, Bahia, Brazil . . . . . . . . . . 134

Belo Horizonte, Brazil ............. . 135

Black Reef Quartzite ............... 135

Summary ................... 135

Basalt Association . . . . . . . . . . . . . 136 
Sedimentology of Host Rocks . . . . . . . . . . . . . . 136

Subarkose-Quartz Wacke Association . . . . . . . . . 137

Matinenda Formation . . . . . . . . . . . . . . 137

Witwatersrand Formations . . . . . . . . . . 137

Quartz-Arenite Association . . . ............ 140

Basalt Association.... . . . . . . . . . . 140

CONGLOMERATE CHARACTERIZATION . . . . . . . . . . . . . . . . 143

Pebble Fraction . . . . . . . . . . . . . . . . . . . 143

Composition ....................... 143

Fluid Inclusions in Quartz Pebbles... . . . . . . . . 147

Pebble Packing. . . . . . . . . . . . . . . 147

Sorting . . . . . . . . . . . . . . . . . . 149

Shape, Sphericity, and Roundness . . . . . . . . 150

Orientation . . . . . . . . . . . . . . . . . . . 152

Size-Distribution Patterns . . . . . . . . . . . . 153

Matrix Fraction (Light Minerals). . . . . . . . . . . . 157

Composition and Texture . . . . . . . . . . . . . 157

Allogenic Quartz .................. 157

Authigenic Quartz ................. 157

Sericite . . . . . . . . . . . . . . . 158

Chlorite ................... 158

Chloritoid ................... 158

Pyrophyllite .................... 158

Other Minerals .. . . . . . . . . . . . 158

Lateral Variations in Matrix Composition . . . . . . . . 159

Lateral Variations in Matrix Texture . . . . . . . . . 159

Grain Size ................... 159

Sorting . . . . . . . . . . . . . . 159

Summary ......................... 161

Matrix Fraction (Heavy Minerals Excluding Uraniferous Phases) . . . 161

Detrital (Allogenic) Constituents . . . . . . . . . . 163

Pyrite ................... 163

Compact Pyrite.................. 164

Concretionary Pyrite............... 165

Chemistry of Pyrite . . . . . . . . . . . 171

Summary .................... 172

Pyrrhotite ..................... . 172

Marcasite . . . . . . . . . . . . . . 174

Chromite ..................... 174

Zircon .................... 174

Arsenopyrite ................... 175

Garnet . . . . . . . . . . . . . . . 175

Diamond ................... 175

Apatite ................... 176

Ilmenite ..................... 176

Magnetite.................... 176

Hematite . . . . . . . . . . . . . . . 176

Cobaltite..................... 177

Molybdenite . . . . . . . . . . . . . . 177

Dyscrasite . . . . . . . . . . . . . . . 177

Tourmaline . . . . . . . . . . . . . . . 177 
Rutile ..................... 177

Spinel ..................... 177

Very Rare Detrital Grains . . . . . . . . . . . 178

Gold . . . . . . . . . . . . . . . . . 178

Platinoids . . . . . . . . . . . . . . . 180

Non-Detrital (Authigenic) Constituents . . . . . . . . . 180

Authigenic Pyrite . . . . . . . . . . . . . . 180

Pyrrhotite . . . . . . . . . . . . . . . 181

Galena .................... 182

Cobaltite and Gersdorffite . . . . . . . . . . . 182

Sphalerite .. . . . . . . . . . . . . 182

Pentlandite................... . 182

Millerite.................... 183

Bravoite .................... . 183

Linnaeite and Skutterudite . . . . . . . . . 183

Chalcopyrite . . . . . . . . . . . . . 183

Cubanite . . . . . . . . . . . . . . . 183

Stibnite . . . . . . . . . . . . . . . 183

Tucekite .................... 183

Silver-Bearing Phases............... 183

Mackinawite . . . . . . . . . . . . . . . 184

Rutile, Anatase, and Leucoxene .. . . . . . . . 184

Very Rare Authigenic Minerals . . . . . . . . . 185

Variations in Matrix Composition . . . . . . . . . . . . . . 185

Comparison of Conglomerate Matrix to Host Sediment . . . . . . 185

Comparison of Matrix Compositions of Different Conglomerates . 186

Size-Distribution Patterns of Heavy Minerals . . . . . . . . . . . 189

Two-Dimensional Plots . . . . . . . . . . . . . . 189

Contoured Plots ...................... 190

Sorting Patterns of Heavy Mineral Grains . . . . . . . . . . 191

Conglomerate Geochemistry . . . . . . . . . . . . . . . 193

Whole-Rock Full Silicate Analyses . . . . . . . . . 193

Trace-Element Analyses . . . . . . . . . . . . 196

Latera1 Variations in Conglomerate Chemistry . . . . . . 202

Two-Dimensional Plots ............... 202

Contoured Geochemical Maps . . . . . . . . . . 203

Post-Depositional Modification of Conglomerate Matrix . . . . . . 205

Low-Temperature Modification . . . . . . . . . . . . 208

Dissolution of Iron-Titanium Minerals . . . . . . . . 208

Sulfidization of Black Sands . . . . . . . . . 208

Formation of Concretionary Pyrite . . . . . . . . 209

Formation of Brannerite... ............ 209

Intermediate- and High-Temperature Modification . . . . . 209

Sulfide Minerals and Gold . . . . . . . . . . . 210

Uraninite . . . . . . . . . . . . . . 210

Silicate Minerals . . . . . . . . . . . . 211

Conglomerate Sedimentology . . . . . . . . . . . . . . 211

Matinenda Conglomerates . . . . . . . . . . . . . 211

Conglomerate Fabric . . . . . . . . . . . . . . 211

Internal Structure . . . . . . . . . . . . 212 
Witwatersrand Conglomerates . . . . . . . . . . 212

Lateral Variation . . . . . . . . . . . . . 213

Uranium and Gold Distribution . . . . . . . . . . 216

Relation of Uranium and Carbon . . . . . . . . . 218

Sediment Dispersal Patterns . . . . . . . . . . . . . 221

Diverging Radial Braided Distributary Pattern . . . . . 221

Converging Braided Tributary Pattern . . . . . . . . 223

Unconfined Subparallel Braided Pattern . . . . . . . 223

Confined Subparallel Braided Pattern . . . . . . . 223

Dendritic Tributary Pattern . . . . . . . . . . 223

Trellis Pattern... . . . . . . . . . . . 224

Meandering Pattern ............... 224

Entrenched Linear Channel Pattern... . . . . . 224

Summary ..................... 225

Geometry of Conglomerate Occurrences . . . . . . . . . . 225

Fundamenta1 Unconformities/Nonconformities . . . . . . . 225

Nonconformity on Archean Basement . . . . . . . . . 225

Unconformity on Older Sediments or Volcanics . . . . . 228

Small Angular Difference Across Unconformity . . . 229

Large Angular Difference Across Unconformity . . . 229

Intraformational Unconformities . . . . . . . . . . . 231

Erosion-Etched Surfaces . . . . . . . . . . . . 231

Braided Erosion-Channeled Surfaces . . . . . . . . 231

Linear Erosion-Channeled Surfaces . . . . . . . . . 233

Summary . . . . . . . . . . . . . . . . . . 233

URANIUM MINERALIZATION . . . . . . . . . . . . . . . . . . . . 235

Background Uranium Content of Mineralized Formations . . . . . . 235

Uranium Minerals in Quartz-Pebble Conglomerates . . . . . . . . . 235

Brannerite and Uraniferous Leucoxene . . . . . . . . 236

Habit ..................... 236

Crack Fillings................ 236

Wisps and Clouds.............. 236

Overgrowths and "Ghosts"............ . 238

Grains and Grain Aggregates ........... 238

Chemistry .................... 238

Areal Distribution . . . . . . . . . . . 242

Origin .................... 242

Summary ................... . . 246

Coffinite .. . . . . . . . . . . . . . . 247

Columbite ...................... 247

Euxenite . . . . . . . . . . . . . . . . 247

Ferrian Thorite ................... 247

Gummite and Thorogummite . . . . . . . . . . . . . 247

Monazite . . . . . . . . . . . . . . . . . 248

Thorite and Uranothorite. . . . . . . . . . . . . 248

Uraninite ...................... 249

Distribution ................ 250

Grain Size .. . . . . . . . . . . . . 250

Grain Shape .. . . . . . . . . . . . . . 251

Primary Inclusions ... . . . . . . . . . . 251

Secondary Inclusions .. . . . . . . . . . . 251 
Uraninite Zoning and Cleavage . . . . . . . . . 251

Alteration of Uraninite Grains . . . . . . . . . . . 258

Composition of Uraninite Concentrates . . . . . . . . 258

Single-Grain Analyses of Uraninite . . . . . . . . 259

Origin of the Uraninite . . . . . . . . . . . . . 262

Physica1 Durability of Uraninite. . . . . . . 263

Chemical Stability of Uraninite . . . . . . 263

Distribution .............. 264

Recycling ................ 264

Grain Size . . . . . . . . . . . . . 264

Grain Shape .. . . . . . . . . . . 264

Inclusions . . . . . . . . . . . . . . 264

Grain Structure . . . . . . . . . . . . . 264

Development with Detrital Components... . . . 265

Composition . . . . . . . . . . . . . 265

Uraniferous Carbon . . . . . . . . . . . . . 265

Distribution in Conglomerates ........... 266

Structure of Carbon . . . . . . . . . . . . . 266

Elemental Chemistry of Carbon ............ 268

Organic Geochemistry of Carbon .. . . . . . . . 269

Isotopic Character of Witwatersrand Carbon . . . . . 270

Uranium in Carbon . . . . . . . . . . . . . . 270

Summary . . . . . . . . . . . . . . . . . 272

Xenotime . . . . . . . . . . . . . . . . . 272

Zircon . . . . . . . . . . . . . . . . . . 272

"Dispersed" Uranium in Quartz-Pebble Conglomerates..... . 272

Phyllosilicates . . . . . . . . . . . . 273

Detrital Pyrite................. 273

Concretionary Pyrite ............... 273

Lithic Granules and Pebbles . . . . . . . . . . 273

Other Minerals ................. . 274

Discussion ...................... . 274

Uranium Orebody Parameters . . . . . . . . . . . . 275

RECOGNITION CRITERIA . . . . . . . . . . . . . . . . 279

Introduction .. . . . . . . . . . . . . . . . . 279

Evaluation of Recognition Criteria . . . . . . . . . . . . 282

Description of Recognition Criteria. . . . . . . . . . . . . 284

Regional Geologic Setting . . . . . . . . . . . 285

Nature of Basement .............. 285

Geotectonic Setting . . . . . . . . . . 285

Basement Lithology . . . . . . . . . . 285

Uranium Source in Basement........... 285

Regional Gravity Pattern of Basement . . . . . . . . 287

Nature of Basin . . . . . . . . . . . . . . 287

Basin Development ............ . 287

Basin Paleogeography ............. 287

Basin Structure .. . . . . . . . . . . 287

Basin Metamorphism .............. 288

Stratigraphic Setting . . . . . . . . . . . 288

Basin Parameters . . . . . . . . . . . . 288 
Age of Basin............... . . 288

Area of Basin ................. 288

Thickness of Basin Fill . . . . . . . . . 288

Lithology of Basin Fill . . . . . . . . . . . 288

Unconformity Parameters... . . . . . . . . . 288

Type of Unconformity/Nonconformity . . . . . . 288

Paleoweathering . . . . . . . . . . . . 290

Paleotopography ............... 290

Accumulation-Burial Time-Lapse . . . . . . . . 290

Host Rock Character . . . . . . . . . . . . . . . 290

Subarkose-Quartz Wacke Association . . . . . . . 290

Environment of Deposition ........... 290

Color ................... 291

Texture .................. 291

Mineralogy .................. 291

Geochemistry . . . . . . . . . . . . . . . 291

Quartz-Arenite Association . . . . . . . . . . 292

Environment of Deposition ............ 292

Color . . . . . . . . . . . . . . 292

Texture .................... 292

Mineralogy . . . . . . . . . . . . . . 292

Basalt Association . . . . . . . . . . . . 292

Environment of Extrusion ........... 292

Color . . . . . . . . . . . . . . . 292

Texture and Structure ............ 292

Mineralogy .................. 292

Conglomerate Character . . . . . . . . . . . . 294

Conglomerate Geometry .. . . . . . . . . . . . 294

Thickness . . . . . . . . . . . . 294

Lateral Extent . . . . . . . . . . . . 294

Internal Stratigraphy . . . . . . . . . . 294

Pebble Assemblage . . . . . . . . . . . . . 294

Size . . . . . . . . . . . . . . . 294

Composition .................. 295

Packing . . . . . . . . . . . . . 295

Sorting . . . . . . . . . . . . . 295

Shape ................... 295

Quartz Color ................ 295

Matrix Characteristics ............. 296

Texture .................. 296

Mineralogy .. . . . . . . . . . . 296

Geochemistry . . . . . . . . . . . . 296

Mineralization . . . . . . . . . . . . . . 298

Radioactivity ............... 298

Uranium Minerals . . . . . . . . . . . 298

REFLECTIONS ON FUTURE STUDIES. . . . . . . . . . . . . . . . . 299

Source of Uraninite . . . . . . . . . . . 299

Source Area Evaluation . . . . . . . . . . 299

Host Rock Evaluation . . . . . . . . . . . . 299

Metamorphic Destruction of Uraniferous Conglomerate

Deposits.............. 300 
Solution Transport of Uranium ......... . 300

Uraninite Destruction on Unconformities . . . . 301

UNITED STATES POTENTIAL FOR PRECAMBRTAN URANIFEROUS CONGLOMERATES • • • 303

Archean Provinces of the United States . . . . . . . . . . . 303

The Superior Province . . . . . . . . . . . . . . . . 305

Lithology and Tectonic Level of the Archean Basement . . . . 305

Nature of Basins . . . . . . . . . . . . . . 308

Area .................. 308

Paleogeography ................ 310

Structure and Metamorphism . . . . . . . . . . 310

Stratigraphic Setting ................... 310

Age ...................... 310

Stratigraphy of the Lake Superior Area . . . . . . . . . 311

Archean Formations . . . . . . . . . . . . . . . 313

Knife Lake Group and Lake Vermilion Formation . . . . 313

Dickinson Group ... . . . . . . . . . . . . 314

Lower Proterozoic Formations . . . . . . . . . . 315

Units Filling Paleovalleys on the Archean Basement . . 315

Fern Creek Formation . . . . . . . . . . 315

Enchantment Lake Formation . . . . . . . . 315

Reany Creek Formation . . . . . . . . . . . 316

Uranium Potential . . . . . . . . . . . . 317

Blanket Arenites on the Archean Basement . . . . . . 317

Sturgeon Quartzite.............. 317

Mesnard Quartzite .............. 318

Ajibik Quartzite ............. 318

Other Quartzites............... 318

Uranium Potential . . . . . . . . . . . . . 319

Unexposed Lower Proterozoic Formations . . . . . . . 319

Geological Approach . . . . . . . . . . . 321

Geophysical Approach . . . . . . . . . . . 321

Application . . . . . . . . . . . . . . . 321

Subsurface Exploration for Elliot Lake Group Strata . . 321

Summary . . . . . . . . . . . . . . . . 322

The Wyoming Province . . . . . . . . . . . . . . 322

Tectonic Level in the Wyoming Province... . . . . . . 322

Archean Greenstone Belts ... . . . . . . . . . . 324

Supracrustal Sediments in Gneissic Terrane . . . . . . . . 324

Beartooth Mountains................. 324

Southwestern Montana ............. . 324

Northern Utah and Southern Idaho . . . . . . . . 325

Albion and Raft River Ranges . . . . . . . . 325

Wasatch Range and Antelope Island . . . . . . 325

Uranium Potential of Supracrustal Metasediments . . . . 325

Lower Proterozoic Basins of the Wyoming Province . . . . . 326

The Black Hills................. 326

Age ................... 326

Structure ................ 326

Stratigraphy ............... 328

Mineralization ............ 330 
Source of Uranium . . . . . . . . . . . . 331

Other Areas in the Black Hills . . . . . . . . . 331

Potential of the Black Hills . . . . . . . . . 331

Summary . . . . . . . . . . . . . . 333

The Medicine Bow and Sierra Madre Ranges . . . . . . 334

Age ................... 334

Nature of Basement . . . . . . . . . 334

Structure ................. 334

Stratigraphy . . . . . . . . . . . . . . 335

Correlation with the Huronian Supergroup . . . . . 340

Uranium Mineralization . . . . . . . . . . . . 341

Uranium Potentia1 . . . . . . . . . . . . 341

Summary of United States Resource Potential . . . . . . . 344

APPENDIX: ESTIMATION OF GEOLOGIC FAVORABILITY FOR THE OCCURRENCE OF

URANIFEROUS CONGLOMERATE . . . . . . . . . . . . . . . . . 345

Calculation of Estimated Favorability . . . . . . . . . . 345

Completeness and Confidence of Geologic Data . . . . . . . 347

Interpretation of Results . . . . . . . . . . . . . 348

Examples of Favorability Estimates for Three Areas . . . . . . 350

Nature of Basement . . . . . . . . . . . . . . . 351

Geotectonic Setting . . . . . . . . . . . . 351

Basement Lithology . . . . . . . . . . . . . 351

Uranium Source in Basement . . . . . . . . . . . 352

Nature of Basement Score . . . . . . . . . . 352

Regional Gravity Pattern of Basement . . . . . . . . . . 352

Nature of Basin . . . . . . . . . . . . . 353

Basin Development . . . . . . . . . . . . 353

Basin Paleogeography .. . . . . . . . . . 353

Basin Structure................ . 353

Style of Deformation ............ 353

Basin-Bounding Faults .......... 353

Folds .................. 353

Basin Structure Score ............ 353

Basin Metamorphism . . . . . . . . . . . . 354

Nature of Basin Score .. . . . . . . . . . . . 354

Regional Geologic Setting Score . . . . . . . . . 355

Stratigraphic Setting . . . . . . . . . . . . . 355

Basin Parameters .. . . . . . . . . . . . . . 356

Age .................... 356

Area .................... . 356

Thickness of Fill . . . . . . . . . . . . 356

Lithology of Fill . . . . . . . . . . . . . 356

Basin Parameter Score . . . . . . . . . . 356

Unconformity Parameters .............. . 357

Type of Unconformity/Nonconformity . . . . . . . 357

Paleoweathering . . . . . . . . . . . . . 357

Paleotopography . . . . . . . . . . . . . . 357

Accumulation-Burial Time-Lapse . . . . . . . . . 357

Unconformity Parameter Score . . . . . . . . . . 357

Stratigraphic Setting Score . . . . . . . . . . 358 
Host Rock Character . . . . . . . . . . . . . . . 358

Environment of Deposition . . . . . . . . . . . 358

Color . . . . . . . . . . . . . . . . . 359

Texture ..................... 359

Mineralogy . . . . . . . . . . . . . . . . 359

Geochemistry . . . . . . . . . . . . . . 359

$\mathrm{K} / \mathrm{Na}$ Ratio............... 359

$\mathrm{K} / \mathrm{Ca}$ Ratio.............. 359

U Background ................. 359

Trace Element Geochemistry . . . . . . . . 359

Geochemistry Score. . . . . . . . . . . . 359

Host Rock Character Score . . . . . . . . . . . 360

Conglomerate Character . . . . . . . . . . . . . 360

Conglomerate Geometry . . . . . . . . . . . . . 360

Thickness.................. 360

Lateral Extent ................ 361

Internal Stratigraphy ................ 361

Conglomerate Geometry Score . . . . . . . . . . 361

Pebble Assemblage . . . . . . . . . . . . . . 361

Size ..................... 361

Composition .................. 361

Packing . . . . . . . . . . . . . . . 362

Sorting . . . . . . . . . . . . . . . 362

Shape..................... . 362

Color . . . . . . . . . . . . . . . . 362

Pebble Assemblage Score . . . . . . . . . . . 362

Matrix Characteristics . . . . . . . . . . . . 363

Texture ................... 363

Mineralogy ................... 363

Light Minerals................ . 363

Heavy Minerals................ 363

Carbon ................ . . 363

Mineralogy Score............. 363

Geochemistry . . . . . . . . . . . . . . 364

$\mathrm{K} / \mathrm{Na}$ Ratio............... . . 364

U/Th Ratio.................. 364

Trace Element Geochemistry . . . . . . . . . 364

Geochemistry Score... . . . . . . . . 364

Score for Matrix Characteristics . . . . . . . 365

Mineralization ................. 365

Radioactivity .. . . . . . . . . . . 365

Uranium Minerals .............. . 365

Mineralization Score .............. 365

Conglomerate Character Score . . . . . . . . . . . . 366

Comparison of the Potential of the Basins . . . . . . . . . . 366

SELECTED REFERENCES . . . . . . . . . . . . . . . . . . . 369 
-

- 


\section{LIST OF FIGURES}

Number

$\underline{\text { Page }}$

1. The distribution of uranium reserves in various deposit types through geologic time (after D.S Robertson and others, 1978).

2. The economic and subeconomic occurrences of Precambrian uraniferous conglomerates of the world.

3. Location of the El.liot Lake district (in box), Ontario, Canada (f rom Theis, 1979).

4. Regional structural geology of the Huronian Supergroup (from Roscoe, 1969).

5. Areal distribution of the Elliot Lake, Hough Lake, Quirke Lake and Cobalt groups, Huronian Supergroup, in Ontario, Canada (from Roscoe, 1969).

6. Location of the Witwatersrand Basin on the Kaapvaal Craton (from Anhaeusser, 1976).

7. The Witwatersrand Basin, showing the location of Archean basement domes and of Witwatersrand outcrop areas (from Pretorius, 1976).

8. The regional structural framework of the Witwatersrand Basin, showing the locations of the major mineralized areas (from Pretorius, 1976).

9. Schematic diagram of mobile belt-craton relations, including the development of greenstone belts, tonalitic diapiric intrusives, and high-level potassic grantes.

10. Tectonic units and their regional gravity signatures, Western Australian Shield (from Gee, 1979). Ap = Pilbara Craton; Ay = Yilgarn Craton; Ayn = gneiss terrane; $\mathrm{P}_{1}, \mathrm{P}_{2}$, etc., are Proterozoic mobile belts; Pz denotes Phanerozoic basins.

11. Schematic cross section through an Archean craton, showing relations of high-grade terrane, greenstone belts and granitic intrusives, and the uranium potential of basins resting on various units of the craton.

12. Schematic diagram illustrating the probable and possible range in age of basins containing uraniferous conglomerates.

13. Schematic diagram illustrating the probable controls on the development of the uraniferous quartz-pebble conglomerate metallogenic epoch from 3,200 to $2,200 \mathrm{~m} . \mathrm{y}$. ago. 
14. The distribution of ferrous and ferric iron through pre-Huronian paleosols of the Elliot Lake-Blind River area, Ontario, Canada (from Gay and Grandstaff, in press).

15. Diagrammatic representation of the major controls on paleotopography in Archean and early Proterozoic basins.

16. Trends of positive elements during deposition of the Matinenda Formation (from Roscoe, 1969).

17. Isopach map of the Schelem Formation, Wolkberg Group, Transvaal Supergroup, in the northeastern Transvaal (after Button, 1973). The thickness of the formation is controlled largely by the presence of major paleovalleys developed along the traces of Archean greenstone belts.

18. Cross section showing wedge-out of the Kimberley Reef against a paleo-island coincident with a footwall anticline (after Antrobus and Whiteside, 1964).

19. Restored cross section through part of the Welkom Goldfield, showing stratigraphic relations in the upper parts of the Witwatersrand Supergroup and in the overlying Ventersdorp lavas (after Olivier, 1965, Plate VI).

20. Geologic sketch map of the West Rand area, showing the development of mineralized fan systems in paleograben valleys adjacent to a paleohorst mountain range (modified after Minter, 1978).

21. Regional paleoenvironmental model of the Ventersdorp Contact Reef in the Carletonville Goldfield, showing the importance of horsts and grabens in the control of deposition and preservation of mineralized conglomerate (from Krapez, 1980).

22. Map showing pre-Huronian geology of the Quirke Syncline and neighboring areas. Major orebodies (in black) lie in paleovalleys cut on greenstone basalts (from Roscoe, 1969).

23. Detailed pre-Huronian geology of the Quirke Syncline, showing the development of the major orebodies (Quirke and Nordic) and subsidiary mineralized areas in paleovalleys cut on greenstone basalts (from J.A. Robertson, 1976).

24. Cross section through basal units of the Wolkberg Group, Transvaal Supergroup, in the northeastern Transvaal, South Africa. Basal units are restricted to a broad paleovalley cut on an Archean greenstone belt (from Button and Tyler, 1979).

25. Schematic block diagrams showing trellis and dendritic paleodrainage patterns on the pre-Transvaal unconformity. Strata below the unconformity are units of the Witwatersrand Supergroup (from Button and Tyler, 1979; based on information given by Papenfus, 1964). 
26. Stratigraphic relations within the Matinenda Formation in the Quirke Syncline, E1liot Lake district (from Roscoe, 1969).

27. Wedge-out of units of the Rio Algom-Denison ore reef against a basement paleohill (from Theis, 1979).

28. Geologic sketches showing the development of uraniferous conglomerates along or close to unconformities of varying types.

29. Restored stratigraphic cross section in the Central and East

Rand areas showing the low-angle unconformity between the Main

Reef Leader and its footwall units (from Cousins, 1965).

30. Restored stratigraphic cross section of the Klerksdorp area, showing the low-angle unconformity below the Vaal Reef (after Minter, 1976).

31. Schematic process-response model illustrating the control of the unconformity (or nonconformity) on the development of mechanical and chemical concentrations of uranium.

32. Triangular diagram showing compositional variations of arenites in the Matinenda Formation and in formations of the upper Witwatersrand succession (from information in Pienaar, 1963; Fuller, 1958; and Kent, 1961).

33. Detailed stratigraphic section showing vertical sequence of sedimentary structures in Witwatersrand quartz wackes from the Heidelberg area, East Rand district, Witwatersrand Basin (from Button, in press).

34. Triangular plot illustrating the composition of clasts in payable and unpayable uraniferous conglomerates (from information in Pienaar, 1963; Button, 1968; Armstrong, 1968; Minter, 1976, 1978; and Pretorius, 1976).

35. Scatter diagram showing pebble packing plotted against pebble size for samples of the Rio Algom-Denison ore reef, Quirke area of the Elliot Lake district (from Theis, 1979).

36. Plots of pebble:axial ratios, illustrating clast shape in Matinenda conglomerates (from Pienaar, 1963).

37. Maps of the Basal/Steyn paleoplacer, Welkom area (from Minter, 1978).

A. Main trends of mineralization (solid braided lines), paleocurrent vectoral means (arrows), contours of pebble size (average of 10 largest clasts per location; broken lines) and junction of the Steyn and Basal "facies" of the placer ( $T$ pattern). 
B. Gold distribution pattern (high-gold areas have an average concentration of $15-60 \mathrm{ppm} \mathrm{Au}$ ).

C. Uranium distribution pattern (high-uranium areas have an average concentration of $150-500 \mathrm{ppm} \mathrm{U}$ ).

D. Uranium/gold ratio (high ratio is over 20 ; low ratio ranges from 5 to 20 ).

38. Scatter diagram showing pebble size plotted against pyrite grain size, Rio Algom-Denison ore reef (from Theis, 1979).

39. Scatter diagram, showing weak correlation of pebble sizes and $\mathrm{U}_{3} \mathrm{O}_{8}$ content (after Theis, 1979).

40. Contour map showing the variation of the chlorite/sericite ratio in the matrix of the Main Reef Leader, East Rand area (after Lentha11, 1970). Proximal facies (in the northwest) is sericiterich, probably because the sericite precursor was transported as relatively coarse-grained clay aggregates.

41. Chart showing mineralogy and paragenesis of the matrices of

Witwatersrand conglomerates (from Feather and Koen, 1975). The most abundant (or economically important) minerals are shown in heavy typeface.

42. 1. (top left): Rounded compact pyrite grains, some of which have suffered pressure point solution and crushing, Basal Reef, Loraine Gold Mines, Welkom Goldfield (170x, from Schidlowski and Trurnit, 1966).

2. (top right): Major part of a spherical composite grain composed largely of rounded compact pyrite cemented by secondary pyrite, E1sburg A-1 Reef, Loraine Gold Mines, Welkom Goldfield (from Schidlowski, 1967a).

3. (center left): Rounded pyrite grain, pseudomorphous after titaniferous magnetite. Exsolution lamellae of ilmenite show triangular grid pattern and are now composed of rutile (dark gray). The magnetite part of the original grain is totally pyritized; Basal Reef, Welkom Goldfield (310x, from Saager, 1970).

4. (center right): Pseudomorph after hematite-ilmenite grain; now composed of pyrite (white) and rutile (dark gray), "basal conglomerate", East Rand area (106x, from Ramdohr, 1958). 
5. (lower left): Pyrite pseudomorph after a colloform limonite grain, showing delicate rhythmic layering, Black Reef, East Rand area (106x, from Ramdohr, 1958). Saager (1970, Plate II, Figure 11) interpreted similar grains as having been derived by sulfidization of banded ironformation.

6. (lower right): Rounded pisolith of pyrite, Ventersdorp Contact Reef, Venterspost Mine, Carletonville area (33x, from Schweigart and Von Rahden, 1964). Ramdohr (1958) interpreted similar pisolites to be the sulfidized remains of concentrically layered iron oxide grains.

43. 1\&2: (top left and right): "Porous" concretionary pyrite, etched with nitric acid in right hand diagram, Basal Reef, Welkom Goldfield (44x, from Saager, 1970).

3. (center left): Part of a "porous" concretionary pyrite grain composed of pyrite crystallites, preferentially pyrite-cemented near outer margin (top in photomicrograph) of grain, Kimberley Reef, East Rand area (182x, from Ramdohr, 1958).

4. (center right): Part of a pyrite grain showing microspherical structures likened to "mineralized bacteria", Elsburg A-1 Reef, Loraine Gold Mines, Welkom Goldfield (630x, Schidlowski, $1966 \mathrm{~b})$.

5. (lower left): Scanning electron photomicrograph of a pyrite "mudba11", showing indentation (top) and cracks (side) due to compaction by a neighboring clast while still in a plastic state, Elsburg Reef, Loraine Gold Mines, Welkom area (from Hallbauer and Utter, 1976).

6. (lower right): Detrital chromite grain with reflective margin (iron-rich, depleted in $\mathrm{Al}$ and $\mathrm{Mg}$ ), cut by pyritefilled fractures, Basal Reef, Welkom area (no magnification specified; from Saager, 1970).

44. Triangular plot showing the relative enrichment in heavy minerals of conglomerate matrices ("reef samples") relative to associated host arenites ("quartzite samples"), Witwatersrand a rea (from Coetzee, 1965).

45. Triangular plot showing the relative concentrations of zircon, chromite, and leucoxene in matrices of conglomerates of the Main Reef and Kimberley-Elsburg groups (from Coetzee, 1965).

46. Triangular plot showing the relative concentrations of zircon, chromite, and leucoxene in matrices of the Carbon Leader and other conglomerates of the Main Reef group, Witwatersrand Basin (from Coetzee, 1965). 
47. A. Pyrite and zircon grain-size histograms at locations 1 through 5 (see map, Figure 47C).

B. Changes in pyrite and zircon grain size and of U/Au ratio at locations 1 through 5 .

C. Map of Basal/Steyn paleoplacer, Welkom Goldfield, showing main mineralized channels (solid braided lines) and contoured pyrite grain size ( $\phi$ units, broken lines). From Minter, 1978.

48. Maps showing chromite and zircon mean grain-size variations in the Main Reef Leader over the East Rand Goldfield (from Lenthall, 1970).

49. Map of the East Rand fluvial fan, showing paystreaks and the extent of the mined Main Reef Leader (from Pretorius, 1976).

50. Scatter diagram showing Ce concentration plotted against La concentration in samples from the Rio Algom-Denison ore reef (from Theis, 1979).

51. Scatter diagram showing the $\mathrm{U}_{3} \mathrm{O}_{8} / \mathrm{ThO}_{2}$ ratio plotted against pebble size of the Rio Algom-Denison ore reef (from Theis, 1979).

52. Scatter diagram showing $Y$ concentration plotted against pebble size of the Rio Algom-Denison ore reef (from Theis, 1979).

53. Scatter diagram showing $\mathrm{ThO}_{2}$ concentration plotted against pebble size of the Rio Algom-Denison ore reef (from Theis, 1979).

54. Moving average maps of the Vaal Reef, Klerksdorp area, showing:

A. placer thickness;

B. gold distribution pattern (average gold content is 15 $\mathrm{ppm} \mathrm{Au})$; and

C. uranium distribution pattern (average uranium content is $500 \mathrm{ppm}$ U). From Minter, 1978.

55. Map of the Quirke Syncline, showing the distribution of uranium and thorium in Matinenda conglomerates. Note that main orebodies grade down paleoslope to areas of Th-rich uranium ores, and that these are fringed by thorium-rich conglomerate with some marginal uranium ore (from Lang and others, 1976).

56. Vertical cross sections through Matinenda conglomerates showing lensing and feathering out of well-packed and loosely packed conglomerates with subarkose and conglomeratic subarkose (after Pienaar, 1963). 
57. Scatter diagram showing gold and uranium concentrations in conglomerates and associated arenites of the Elsburg No. 5 Reef, Klerksdorp area (from Smith and Minter, 1980).

58. Scatter diagram of gold and uranium concentrations in arenites (SS), conglomerates $(\mathrm{Cg})$ with and without pyritic foresets for the Elsburg No. 5 Reef and Leader Reef (points marked L), Klerksdorp and Welkom Goldfields, respectively (f rom Smith and Minter, 1980).

59. Scatter diagram of gold versus uranium concentration in the Leader Reef, Welkom area, showing variations for arenites (SS), conglomerates $(\mathrm{Cg})$ and carbon-rich facies of the placer (from Smith and Minter, 1980).

60. Distribution of gold on the basal scoured surface of a channel, Leader Reef, Welkom Goldfield. Foresets in the associated arenite are inclined towards the channel margin that contains the highest gold concentrations. The sketch above shows the probable mechanism of formation of the basal gravel lag, the foresets, and the heavy mineral concentrations (from Smith and Minter, 1980).

61. Longitudinal cross section of the downstream end of a longitudinal gravel bar, Leader Reef, Welkom Goldfield. The bar is overlain by pebbly arenite containing pyritic foresets. This phase carries the highest concentrations of gold and uranium, probably due to convergence of two threads of the braided stream at the downstream end of the longitudinal bar (from Smith and Minter, 1980).

62. Diagram showing the different types of sediment dispersal patterns recognized in uranium-bearing conglomerates.

63. Development of uranium orebodies and thick "grits" within paleovalleys along the basal Huronian nonconformity (from Theis, 1979).

64. Typical plan-view configuration of a Matinenda Formation orebody, with a blunt, up-channel termination and a fingering down-current end. Based on relations in the Quirke Zone (from Theis, 1979).

65. Relations of basal formations of the Huronian Supergroup in the Quirke Syncline (from Lang and others, 1976). Onlap and wedgeout relations against an inclined paleosurface result in uraniferous conglomerates being developed at higher stratigraphic levels towards the north.

66. Schematic diagram showing the typical plan-view shapes of uraniferous conglomerates developed on fundamental and intraformational unconformities.

67. Plan view of the braided channel network of the UK9A (Kimberley) Reef of the East Rand area (after Armstrong, 1968). 
68. 1. (top left): Rutile pseudomorph after titaniferous magne-

tite. The original ilmenite exsolution lamellae of the magnetite are now composed of rutile. The magnetite fraction was entirely destroyed by diagenetic dissolution. "Bastard Reef", East Rand area (365x, from Ramdohr, 1958).

2. (top right): Brannerite (white) lining pore-spaces in leucoxene from a Witwatersrand conglomerate (214x, from Feather and Snegg, 1978).

3. (center): Grain of "Type II" brannerite with grains of uraninite (small, angular grains, upper right) and pyrite (large grain on left) in a quartz and sericite matrix, Rio Algom-Denison ore reef (54x, from Theis, 1979).

4. (lower left): Composite grain composed of oriented rutile laths in a skeletal arrangement with internal pores filled by silicate minerals. Brannerite is developed in very small grains around the margin of the grain aggregate, Rio AlgomDenison ore reef (144x, from Theis, 1979).

5. (lower right): Composite grain aggregate comprising quartz in original pores (darkest gray), brannerite (medium gray), rutile (1ightest gray), and galena (small white specks) ( $84 \mathrm{x}$, "A" reef of Quirke No. 1 Mine, from Theis, 1979).

69. Schematic diagrams showing downstream changes in a Matinenda

70. 1. (top left): Zoned uraninite grain from a panned heavy mineral concentrate from the Indus River, Chilas, Gilgit, Pakistan (163x, from Zeschke, 1960).

2. (top right): X-ray photomicrograph of thin section showing flat-based, sometimes cross-laminated, uraninite microlayers in a subarkose lens within an ore conglomerate from the Quirke Mine, E1liot Lake district (from Roscoe, 1969).

3. (center left): Photomicrograph of a uraninite microlayer showing angular nature of grains and fining-up size-grading; sample as in Figure 70.2 (from Roscoe, 1969).

4. (center right): Scanning electron photomicrograph of bundles of microcolumns in a Witwatersrand carbon seam (from Hallbauer, 1975).

5. (lower left): Scanning electron photomicrograph of a "fly speck" carbon granule, Basal Reef, St. Helena Gold Mine, Welkom Goldfield (from Hallbauer, 1975). 
6. (lower right): Gold (showing scratches) in a pressure shadow of a rounded compact pyrite grain in a mass of carbon, $B$ Reef, Loraine Gold Mines, Welkom Goldfield (96x, from Schidlowski, 1966a).

71. 1. (top left): Rounded grains of uraninite (some of them

"muffin-shaped") with a very fine-grained dusting of galena, Basal Reef, Loraine Gold Mines, Welkom Goldfield (198x, from Schidlowski, 1966c).

2. (top right): Uraninite grains in early stages of disintegration. Carbon fills cracks in, and forms a halo around, the uraninite grains. A halo of pyrite grains occurs around the carbon, B Reef, Loraine Gold Mines, Welkom Goldfield (173x, from Schidlowski, 1966d).

3. (center 1eft): Uraninite grain in a more advanced stage of disintegration in carbon. Note higher reflectivity of carbon near the uraninite. White specks in uraninite are radiogenic galena. From the B Reef, Loraine Gold Mines, Welkon Goldfield (249x, Schidlowski, 1966a).

4. (center right): Granule of carbon which has "digested" much of the original uraninite grain, leaving small angular uraninite remnants. Note pyrite halo around granule. B Reef, Loraine Gold Mines, Welkom area (173x, Schidlowski, 1966d).

5. (lower center): Polished section cut perpendicular to carbon columns. Note streamlined "flow" effects and small angular uraninite remnants surrounded by more reflective carbon. B Reef, Loraine Gold Mines, Welkom Goldfield (77x, Schidlowski, 1966a).

72. 1. (top left): Uraninite "ghosts", the shapes of which are preserved by rims of brannerite. Basal Reef, Free State Geduld Mine, Welkom Goldfield (no magnification given; Thiel and others, 1979).

2. (top right): Uraninite "ghost" composed of brannerite surrounded by pyrrhotite laths and filled by chalcopyrite, pyrrhotite, and some galena. Elsburg A-1 Reef, Loraine Gold Mines, Welkom Goldfield (265x, Schidlowski, 1966e).

3. (center): Uraninite grain, with dusting of galena, and cut by veins of carbon, enclosed in a mantle of pyrite. The pyrite is cracked due to radioactive "blasting". Elsburg A-3 Reef, Loraine Gold Mines, Welkom Goldfield (244x, Schidlowski, 1966f). 
4\&5: (1ower left and right): Porous pyrite grains with leucoxene (Lx) and chloritoid laths (gray). The right-hand photograph shows the fission tracks (due to ${ }^{235} \mathrm{U}$ disintegration) on a mica detector and indicates the concentration of uranium in a discontinuous coating around the pyrite. B Reef, Free State Geduld Gold Mine, Welkom Goldfield (Thiel and others, 1979).

73. $\mathrm{ThO}_{2}$ and $\mathrm{UO}_{2}$ content of individual uraninite grains from the Rio Algom Nordic Mine, Elliot Lake district, Ontario (closed circles), and from the Vaal Reef West Mine, Witwatersrand, South Africa (open circles). From Grandstaff, 1974b.

74. Fibrous "thucholite" seam at the base of a typical Witwatersrand conglomerate (from Schidlowski, 1969).

75. Structured net of recognition criteria for use in exploration for Precambrian uraniferous conglomerates.

76. Schematic diagram showing the method of assigning importance (or weight) to a recognition criterion.

77. Distribution of Archean cratons in North America (modified after Van Schmus, 1976).

78. Generalized geology of the Lake Superior area (from Sims, 1976).

79. Simplified geological map of the Lake Superior area showing the distribution of gneiss and greenstone terrane. Individual green308 stone belts are showh (in black) only in the area south of Lake Superior. The separation of the Archean terrane into two blocks by the Keweenawan rift system (cross-hatched) is emphasized (from Sims, 1976).

80. Outcrop areas of lower Proterozoic basins (black) in the Lake Superior area (from Sims, 1976).

81. Schematic fence diagram (not to scale) illustrating regional stratigraphic relations in the lower Proterozoic strata of the Lake Superior area. Compiled from descriptions in numerous sources, including Bayley and James (1973) and Sims (1976).

82. Schematic block diagram illustrating the fact that uraniferous conglomerates of Matinenda type need have no surface expression, being confined to non-outcropping paleovalleys.

83. Generalized Precambrian geology of the Wyoming Province (from Houston and Kar1strom, 1979).

84. Generalized geology of the Black Hills, South Dakota (from Houston and Kar1strom, 1979). 
85. Schematic cross section of the Nemo area, illustrating possible subsurface uranium targets.

86. Generalized Precambrian geology of the Medicine Bow Mountains, Wyoming (from Houston and Karlstrom, 1979).

87. Generalized Precambrian geology of the Sierra Madre, Wyoming (from Houston and Karlstrom, 1979).

88. Schematic block diagram illustrating the possible preferential

development of uraniferous conglomerates in paleovalleys associated with unconformities below the Magnolia Formation (Deep Lake Group) or below the upper assemblage of the Phantom Lake Suite.

89. Schematic relation between calculated favorability for uraniferous conglomerate deposits and the chances of a deposit being present within the area evaluated.

\section{LIST OF TABLES}

Number

Page

1. Stratigraphic succession of the Huronian Supergroup (after Roscoe, 1969).

2. Stratigraphic divisions of major units of the central regions of the Kaapvaal Craton.

3. Chemical analyses of pre-Huronian granitic rocks (after Pienaar, 1963; samples 55-54 and A-1 origina11y from J.A. Robertson, 1960).

4. Modal analyses (volume percent) of pre-Huronian granitic rocks (after Pienaar, 1963; sample 55-44 originally from J.A. Robertson, 1960).

5. Some geochemical parameters in a granitic paleoweathering profile beneath the Matinenda Formation in the Quirke Lake area, Elliot Lake district, Canada (after Roscoe, 1969; Appendix A).

6. Classification of unconformities associated with Precambrian uraniferous conglomerates. 
7. Mineralogical composition of arenites of the upper division of the Witwatersrand Supergroup in the Carletonville area, South Africa (after Kent, 1961).

8. Chemical analyses of Witwatersrand arenites (after Fuller, 1958).

9. Chemical analyses of Matinenda Formation arenites from the lower and upper members from both the north and south Jimbs of the Quirke Syncline (after Pienaar, 1963).

10. Trace element analyses of arenites from the Matinenda Formation (after Pienaar, 1963).

11. Trace element analyses of Witwatersrand arenites from the East Rand area (after Pretorius, 1976).

12. Geochemistry of 19 pebble-free arenites from the Nemo area, South Dakota (from Redden, 1980).

13. Composition of pebbles in upper Witwatersrand strata in the Welkom fluvial fan (after Sims, 1969).

14. Variations in composition and size of pebbles in different reef $s$ in the Western Holdings Mine, Welkom fluvial fan (after Sims, 1969; quoted by Pretorius, 1976).

15. Percentage mineral composition of conglomerate matrix and 157 arenite in Klerksdorp fluvial fan (after Pretorius, 1976).

16. Composition of pyrite concentrates from the E1liot Lake and 171 Agnew Lake uraniferous conglomerates (after Kimberley and others, in press).

17. Grouped results of trace element analyses (after Saager, 1976).

18. Percentages of chromite, zircon, and leucoxene in major Witwatersrand conglomerate reefs (after Pretorius, 1976; data originally from Coetzee, 1965).

19. Chemical analyses of conglomerates from the West Rand Consolidated Mine (after Pretorius, 1976).

20. Chemical analyses of matrices of Matinenda Formation conglomerates (after Pienaar, 1963).

21. Trace (and some major) element analyses of Kimberley conglomerate and associated arenite from the Durban Roodepoort Deep Mine, West Rand area (after Pretorius, 1976).

22. Spectrographic analysis of the $B$ placer and its foot- and hanging-wall sediments (after Minter, 1978). 
23. Statistical parameters of nine elements analysed from 109 samples of the Basal/Steyn placer, Welkom area (after Saager and Esselaar, 1969).

24. Correlation of selected elements in Witwatersrand conglomerates (after Pretorius, 1976; from data in Liebenberg, 1973).

25. Statistical summary for drill-core samples, Nemo area, South Dakota (modified from Redden, 1980).

26. Sedimentary features of several Precambrian placers expressed in terms of common stratification types in modern braided stream systems (after Minter, 1978).

27. Uranium-bearing phases in Precambrian quartz-pebble conglomerates.

28. Geochemistry of brannerite from the Matinenda conglomerates, Elliot Lake district, Canada (after J.A. Robertson, 1976).

29. Results of electron microprobe analyses of Witwatersrand brannerite grains (after Feather, in press).

30. Analyses of monazites from Matinenda uraniferous conglomerates (after J.A. Robertson, 1976).

31. The composition of uraninites from B1ind River/Elliot Lake conglomerates (after J.A. Robertson, 1976).

32. Chemical analyses of uraninite concentrates from Witwatersrand conglomerates (after Liebenberg, 1955).

33. $\mathrm{UO}_{2}$ and $\mathrm{ThO}_{2}$ characteristics of individual uraninite grains from the Witwatersrand, Dominion Reef, and Matinenda conglomerates.

34. Uranium content of mineral phases in uraniferous conglomerates from South Africa (after Thiel and others, 1979).

35. Parameters for uranium orebodies in the Witwatersrand and E1liot Lake districts.

36. Relative importance of the major criteria in establishing the likelihood of finding (or not finding) a uranium-bearing conglomerate orebody.

37. Score sheet for regional geologic setting of basins targeted for uraniferous conglomerates.

38. Recognition criteria score sheet for establishing favorability of stratigraphic setting.

39. Recognition criteria score sheet for establishing favorability of host rock character. 
40. Recognition criteria score sheet for establishing favorability of conglomerate character.

41. Revised stratigraphy of the Precambrian of the Nemo area, Black Hil 1s, South Dakota (after Kim, 1979; Redden, 1980).

42. Stratigraphic succession of the Sierra Madre and Medicine Bow a reas compared to that of the Huronian Supergroup in Ontario (from Houston and Karlstrom, 1979).

43. Hypothetical results determined from four field areas for three criteria that determine "nature of basement".

44. Numerical favorability values for use in calculating the overa11 relative favorability of three North American basins. 
This report is concerned with Precambrian uraniferous conglomerates. This class of deposit has been estimated to contain between approximately 16 and 35 percent of the global uranium reserve in two rather small areas, one in Canada, the other in South Africa. Similar conglomerates, which are of ten gold-bearing, are, however, rather widespread, being found in parts of most Precambrian shield areas. We have attempted to synthesize data on the geologic habitat and character of this deposit type. Our primary objective has been to provide the most relevant geologic observations in a structured fashion to allow resource studies and exploration to focus on the most prospective targets in the shortest possible time.

Tectonic Setting

Uraniferous conglomerates occur exclusively in Archean cratons which themselves are parts of larger Precambrian shield areas. Sub-provinces of Archean cratons that lie at a relatively high tectonic level constitute the most favorable source terrane for target basins. Lower tectonic levels (which have been subjected to granulite and upper amphibolite grade metamorphism) have lost much of their uranium to anatectic granite melts, which, once generated, tend to be emplaced at higher crustal levels.

Geochronologic Setting

Uraniferous conglomerates were formed in a metallogenic epoch that lasted about $1,000 \mathrm{~m} \cdot \mathrm{y} \cdot$, from 3,200 to $2,200 \mathrm{~m} \cdot \mathrm{y}$. ago. Economic deposits that are presently known have a narrower range from about 2,800 to 2,300 m.y. There is practically no chance of discovering economic deposits in basins younger than about $2,000 \mathrm{~m} \cdot \mathrm{y}$.

\author{
Stratigraphic Setting
}

Economically important uraniferous conglomerates occur in packages of coarsegrained, submature sericite- and/or $\mathrm{K}$ feldspar-bearing arenites. These host sediments were derived from paleoweathered detritus shed off granitic source areas. Available evidence indicates that granite-derived paleosols were formed under very weakly oxidizing atmospheric conditions that allowed some solution leaching of uranium but also permitted survival of uraninite as a clastic mineral phase. Some of the economically important uraniferous leucoxene and brannerite in the conglomerates may well have formed by reaction of uraniferous paleo-ground water with diagenetically formed titania skeletons. 
Some uraniferous conglomerates are associated with tillites, others are not. The presence of glacial sediments in basins of the right age is considered to be neither encouraging nor discouraging.

All economically important uraniferous conglomerates are associated with unconformities. We have developed a classification scheme for unconformities which allows a logical prediction of the likely geometry of paleovalleys on such unconformities. There is a tendency for economic mineralization to be found in paleovalleys. The location, trend, and geometry of paleovalleys can be predicted with some confidence if the correct observations are collected.

A crucial unconformity-related parameter is the deposition-burial time-lapse. There is unequivocal evidence that uraninite paleoplacers were destroyed, to varying degrees, by overexposure on some unconformities.

Host Rock Character

Uraniferous conglomerates occur in association with three types of host rock, namely, basalt, quartz-arenite, and subarkose-quartz wacke. The latter association is by far the most important, hosting the economic conglomerates of Canada and most of those in South Africa. These arenites are drab-colored and are composed of quartz and sericite (essential components) with or without $\mathrm{K}$ feldspar, pyrophyllite, chlorite, and, in some, chloritoid. They have several geochemical fingerprints, the most important being their low $\mathrm{CaO}$ and $\mathrm{Na}_{2} \mathrm{O}$ contents reflecting almost total destruction of plagioclase in their provenance areas.

The subarkose-quartz wacke arenites in question appear to have been deposited by low-gradient braided streams; some of which were confined to bedrock paleovalleys; others of which were free to migrate laterally on the surfaces of braided fan deltas.

\section{Conglomerate Character}

Mineralized conglomerates tend to be oligomictic, clast-supported types with well-rounded, spherical pebbles. The proportion of vein quartz to chert clasts is often an indication of the relative importance of uranium and gold in a conglomerate. Uraniferous conglomerates tend to be dominated by quartz clasts while gold-uranium conglomerates frequently contain variable amounts of chert clasts (often over 10 percent). Parameters of clast packing and composition cannot be rigidly applied in predicting payability. Some economic conglomerates are neither well packed nor oligomictic. In the case of composition, an apprectable content of locally derived, rip-up shale clasts in a conglomerate is not necessarily a discouraging factor.

Conglomerate matrices tend to be cleaner than the enclosing arenites and are composed of quartz and sericite with or without chlorite, pyrophyllite, and. chloritoid. An exceptionally wide array of heavy minerals accompanies these silicates. The most abundant are pyrite, zircon, leucoxene, and, in many, 
chromite and monazite. Ilmenite and magnetite are noticeably absent. As a general rule, the greater the proportion of heavy minerals, the greater the chances that the conglomerate will contain economic quantities of uranium (and gold). Some of the heavy minerals are unquestionably detrital, others were formed diagenetically or metamorphically.

The dispersal patterns that operated during deposition of conglomerates can be established by studies of conglomerate parameters including sedimentary structures, texture (especially size of pebbles and matrix grains), and mineralogical and geochemical composition. For example, the sericite/chlorite ratio has been found to decrease with distance down the paleoslope in one conglomerate sheet. An appreciation of sediment dispersal patterns is crucial to the rational evaluation and mining of mineralized conglomerate sheets.

\section{Post-Depositional Modification of Conglomerates}

We recognize several post-depositional changes within many uraniferous conglomerates. Some tend to enhance their value, others to diminish it. In particular, diagenetic dissolution of ilmenite and ilmenomagnetite yielded very porous titania skeletons which was the first step in the later formation of uranium-titanium grain aggregates. These were subsequently changed (during advanced diagenesis or low-grade metamorphism) to brannerite, an exceptionally important uranium mineral in many conglomerates.

The most damaging post-depositional reaction appears to be one in which thorian uraninites react with matrix silicates to yield uranothorite with associated loss of uranium. This reaction appears to become important with the onset of amphibolite grade metamorphism and effectively destroys the potential of any conglomerates metamorphosed at upper amphibolite and higher grades.

Uranium Mineralization

There is overwhelming evidence (sedimentological, textural, and geochemical) that uraninite was concentrated, along with many other heavy minerals, by placer processes. The geochemical character of most uraninite grains points to a pyrogenetic source, probably granite or associated granite pegmatites. Some uranium is present in monazite and has a similar origin. There is no question but that chemical concentration of uranium was also an important process in many conglomerates. Porous titania aggregates were very efficient collectors of dissolved uranium. Recent studies have shown that several other matrix minerals (for example, phyllosilicates) contain significant amounts of dispersed uranium. The nature and origin of the uraniferous fluids is in question, being interpreted as paleo-ground water by some and as metamorphic pore fluids by others.

Uranium-bearing carbon is a very important constituent of many conglomerates. There is convincing textural (and some geochemical) evidence to suggest that the carbon is a radiolytic polymerization product of organic molecules that 
fluxed through the conglomerates, probably as a dissolved phase in paleo-ground water. The organic molecules have been inferred to have formed by decomposition of the remains of primitive plants, probably algal or bacterial colonies. Growth of the polymerized carbon product has caused physical and chemical changes in uraninite including fragmentation of detrital uraninite grains and, in some cases, their total dissolution.

Some geologists have noted that the spatial distribution of carbon (mainly on temporarily abandoned sedimentation surfaces) suggests that it was formed and deposited syngenetically (that is, during sedimentation). It is difficult to reconcile this observation with the postulated origin (through radiolytic polymerization of organic molecules in aqueous solution) of carbon unless this substance formed very soon after burial of a sediment. Under such conditions, the normal channel switching associated with braided stream deposition could erode an older (but unconsolidated) conglomerate, thereby liberating carbon, which could then be deposited "syngenetically".

\section{Recognition Criteria}

Our synthesis has allowed us to develop a conceptual genetic model for Precambrian uraniferous conglomerates as a deposit type. The model is consistent with present knowledge of both producing districts and subeconomic deposits. The model has allowed us to identify, order, and rank several recognition criteria. We have organized the criteria to allow for changing scales of observation from the most regional studies to the evaluation of an individual conglomerate body.

Values have been assigned to each recognition criterion and a method developed to accumulate these values for the evaluation of potentially favorable areas. We have applied this approach to three basins within North America (Appendix I). The resulting numerical scores are entirely consistent with our overall appraisal of the uranium potential of the areas in question.

\section{Reflections on Continuing Studies}

Our review has identified several areas for productive, practical research into uraniferous conglomerates. A lack of data in certain crucial areas has hindered fine tuning of our recognition criteria. We feel that source area characteristics are absolutely crucial to the determination of the potential of a basin. Yet, in many instances, we have no preserved or exposed source area to study. We feel that refined mineralogical and geochemical studies of the host arenites should provide an accurate picture of source terrane. Such studies, on a global scale, are urgently needed if we are to progress in our ability to pick out the really attractive formations from a larger number of low-potential look-alikes. Recommendations for specific studies are presented in the text. 
We have applied the recognition-criteria approach to the United States at large in an attempt to evaluate different Precambrian basins. Areas with obvious potential include the Great Lakes area of Michigan, Wisconsin, and Minnesota, the Black Hills area (South Dakota), and the Sierra Madre-Medicine Bow area of southeastern Wyoming. None of these areas has the potential of the Elliot Lake district. The Wyoming occurrences, for example, are downgraded largely because of their relatively high metamorphic grade and structural complexity. The stratigraphic section in the Black Hills is dominated by relatively deep water marine metasediments, an unfavorable situation. The best-preserved basins in the Great Lakes area appear, on present geochronologic grounds, to be a shade too young (about 2,000 m.y.). However, experience has taught us that refinements in geochronological research in Precambrian terrane almost always result in the generation of older dates. We would not be surprised to see such dates emerge from future work and believe that it would be very premature to ignore the possibilities of the Great Lakes area.

The potential of the enormous areas of covered Precambrian rock in the United States is essentially untested. This vast expanse is bound to become one of the principal exploration areas of the future. Subsurface exploration for covered Precambrian targets to depths of over 4,000 meters is routinely practiced in some areas (the Witwatersrand district of South Africa, for example). It may well be that subsurface targets exist, for example, in the Upper Peninsula of Michigan, which lies on trend with the E11iot Lake basin of neighboring Ontario.

In short, we see no cause for undue pessimism regarding the uranium potential of uraniferous conglomerates in the United States. To be sure, none of the areas reviewed has the aura of a second E11iot Lake. The potential of available targets has in no way been adequately tested. New targets will emerge as our knowledge of the surface and subsurface geology of the United States advances. 
-

• 
Uranium is found and mined in igneous, metamorphic, and sedimentary rocks. Uraniferous conglomerates have been important contributors to past production and constitute a major portion of world reserves ${ }^{I}$ as shown in Figure 1 (D.S. Robertson and others, 1978). Recent reserve estimates based upon data compiled by federal and international agencies indicate that uraniferous conglomerates contain approximately $1,210 \times 10^{6}$ pounds $\mathrm{U}_{3} \mathrm{O}_{8}$ which constitutes about 20 percent of global reserves ${ }^{2}$ (U.S. Department of Energy, 1980). Whereas individual reserve estimates differ because dissimilar parameters are used, it is clear that uraniferous conglomerates are one of the three major types of uranium deposits together with Proterozoic vein-like and sandstone deposits.

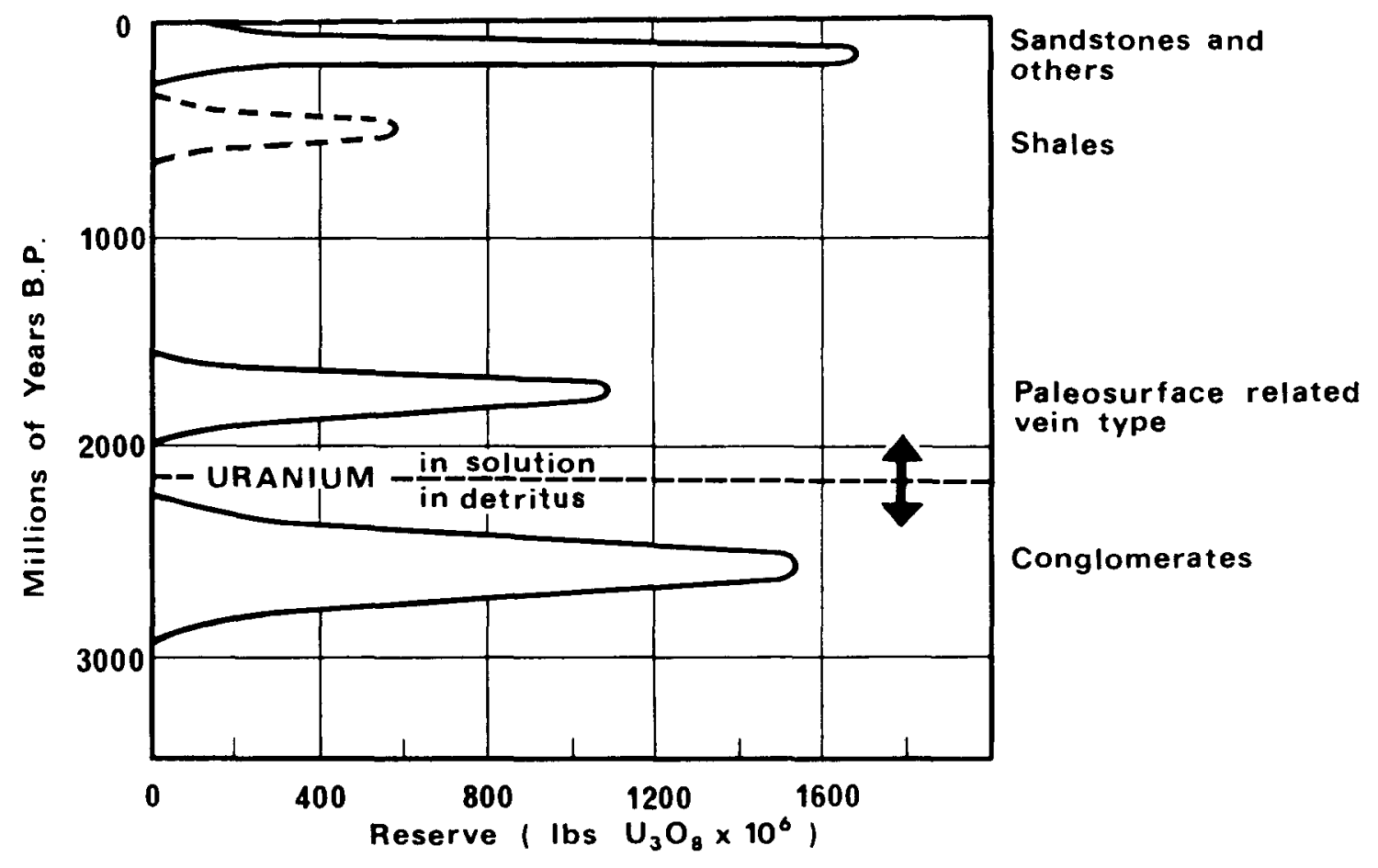

Figure 1. The distribution of uranium reserves in various deposit types through geologic time (after D.S. Robertson and others, 1978).

${ }^{1}$ D.S. Robertson and others (1978) defined an economically viable concentration of uranium as one which shows a reasonable profit potential at a forward price of $\$ 40$ per pound (1976 dollars).

${ }^{2}$ Reasonably assured reserves minable at forward costs of up to $\$ 50$ per pound $\mathrm{U}_{3} \mathrm{O}_{8}$ without allowance for profit, taxes, interest, or previously incurred expenses. 
Another important aspect of uranium deposits relates to the sizes of individual districts and orebodies. According to D.S. Robertson and others (1978), Precambrian conglomerate orebodies are very large. The Elliot Lake district is said to contain some $1,000 \times 10^{6}$ pounds of recoverable metal in two orebodies. By comparison, data for sandstone deposits in the United States suggest that only 2 percent of all U. S. domestic sandstone deposits contain mineable reserves of over $10 \times 10^{6}$ pounds $\mathrm{U}_{3} \mathrm{O}_{8}$ ( $\$ 30$ forward cost category), and these deposits account for 55 percent of total reserves (U.S. Department of Energy, 1980). Uraniferous conglomerates, therefore, are large targets which, in spite of their relative scarcity, deserve serious resource and exploration consideration.

Mineable conglomerates of the conglomerate 'type are developed in only a few districts worldwide, principally the Elliot Lake district of Canada and the Witwatersrand district in South Africa. In the Witwatersrand area, nearly all the mines produce uranium as a comproduct or by-product, the primary source of revenue being the gold associated with the uranium. The geologic conditions for the development of economically exploitable quartz-pebble conglomerate deposits are thus very specialized. Success in exploration requires a thorough understanding of the geologic factors controlling the formation of such deposits.

In this report, the characteristics of uraniferous conglomerates are documented. The physical and chemical environments of formation of the deposits are evaluated. A set of "recognition criteria" for this type of deposit is established and should prove useful in exploration and resource evaluation. Finally, the potential of various areas within the United States for uraniferous Precambrian conglomerates is evaluated in the light of the recognition criteria established.

The project leading to this report was originally proposed in 1978 by Adams as part of a project to review the geology of the six major types of uranium deposits considered to have significant potential for discovery in the United States. The work plan provided for retaining six geologic experts, each intimately familiar with one of the deposit types. The contract was awarded in November, 1979, and the descriptive and interpretative material was prepared over the next several months by Button. A system was developed for estimating the favorability of areas for quartz-pebble conglomerate deposits using selected geologic observations, referred to as recognition criteria. The recognition criteria were selected on the basis of the accumulated geologic observations and interpretations by Button.

Our approach to the characterization of uraniferous conglomerates differs somewhat from that taken by Houston and Karlstrom (1979), who have compiled an impressive volume on the subject. About 75 percent of their text is devoted to descriptions of individual districts. Our approach was to synthesize all available data in a single coherent statement of the characteristics of all aspects of the deposit type. This synthesis formed the basis for the selection and evaluation of the set of recognition criteria. 
Objectives

The objective of this study is to contribute to the National Uranium Resource Evaluation (NURE) program of the U.S. Department of Energy (DOE) by providing a more comprehensive synthesis of the geology of uraniferous conglomerate deposits and a more systematic methodology for handling geologic information. The mission of the NURE program is to prepare more reliable and comprehensive uranium reserve and resource estimates for the United States. Preliminary reports have presented interim estimates of reserves in a series of cost categories and estimates of resources in certainty categories (probable, possible, and speculative). Reserve estimates are based almost entirely on company data supplied to the Department of Energy. By comparison, estimates of undiscovered resources are based upon geologic judgment which compares the geologic characteristics of known uranium districts with areas perceived to have uranium potential and assigns to the latter resource potential estimates based upon the general geologic similarities, the comparative areas involved, and the grade and tonnage characteristics of the known district.

The uncertainties associated with resource estimation are considerable, and generally accepted procedures for preparing such estimates have not been available. One major uncertainty, to us the first and most fundamental uncertainty, is the selection, collection, and interpretation of geologic information. It seemed that the process of comparing geologic characteristics of known deposits with those of untested areas might be improved by identifying the most critical geologic observations (recognition criteria) and then estimating and accumulating the degree of geologic similarity. This possibility became an important part of the objectives of this study which may be summarized as follows:

(1) Review the geology of the quartz-pebble conglomerate districts, principally the Witwatersrand district in South Africa and the Elliot Lake district of Canada, and identify the important geologic characteristics.

(2) Identify geologic characteristics which can be expressed as recognition criteria, the presence or absence of which most strongly affects the favorability or potential of an area for the occurrence of quartz-pebble conglomerate uranium deposits.

(3) Develop a simple method for ranking the relative importance of the recognition criteria.

(4) Develop a method for accumulating the favorabilities derived from individual recognition criteria so as to estimate the favorability for quartz-pebble conglomerate deposits in a reasonably systematic but practical fashion.

We have attempted to be thorough in our coverage of the literature of the Witwatersrand and Elliot Lake regions and have included references to other important districts and technical studies where they contributed pertinent descriptive material or information. Our emphasis has been on the collection 
and review of well-documented data and observations so as to present a reliable data base for the interpretation of ore genesis and controls and the preparation of broadly useful recognition criteria.

Location of Uraniferous Conglomerates

Uraniferous conglomerates are known from most of the Precambrian shield areas around the globe (Figure 2). In that these areas will be repeatedly referred to in this report, their location is established in Figure 2 . Of the occurrences shown in Figure 2, only two districts are currently producing uranium on a commercial basis. These are the Witwatersrand of South Africa and the Elliot Lake district of Canada. Several other occurrences are under active investigation and may come into production in the future. These include areas such as the Pongola and Dominion Reef basins in South Africa. The ages and tectonic settings of these and other occurrences are reviewed in this report.

General Descriptions of Producing Districts

This report is primarily a review of the geologic and geochemical attributes of Precambrian uraniferous conglomerates. The amount of information available on any one area is usually in direct proportion to the dollar value of production from that area. Consequently, this review is biased towards the geologic relations seen in the Elliot Lake and Witwatersrand districts. Aspects of these areas will be repeatedly described in this report, thus a brief introduction into the geology and mining of these districts is given here.

\section{E11iot Lake District, Ontario, Canada}

Uraniferous conglomerates were discovered in the lowermost formation of the Huronian successsion in 1948. Their economic potential was realized later, and exploration began in 1953. The original discovery was made along the north shore of Lake Huron (Figure 3), some 12 miles east of the town of B1ind River (Pienaar, 1963). Since the time of the initial discovery, as many as twelve mines have been active in the Elliot Lake district (J.A. Robertson, 1976). A thirteenth property is located at Agnew Lake, about $65 \mathrm{~km}$ east of E1liot Lake.

\section{Regional Tectonic Setting}

The uraniferous conglomerates of the Elliot Lake area are basal members of a basin of sediments that covers parts of the "Southern Province" (Card and others, 1972) of the Canadian Shield. Sediments within this basin are units within the Huronian Supergroup and were deposited sometime after the 2,500 m.y. old Kenoran orogeny which marked the close of the Archean in this area (Roscoe, 1969). 


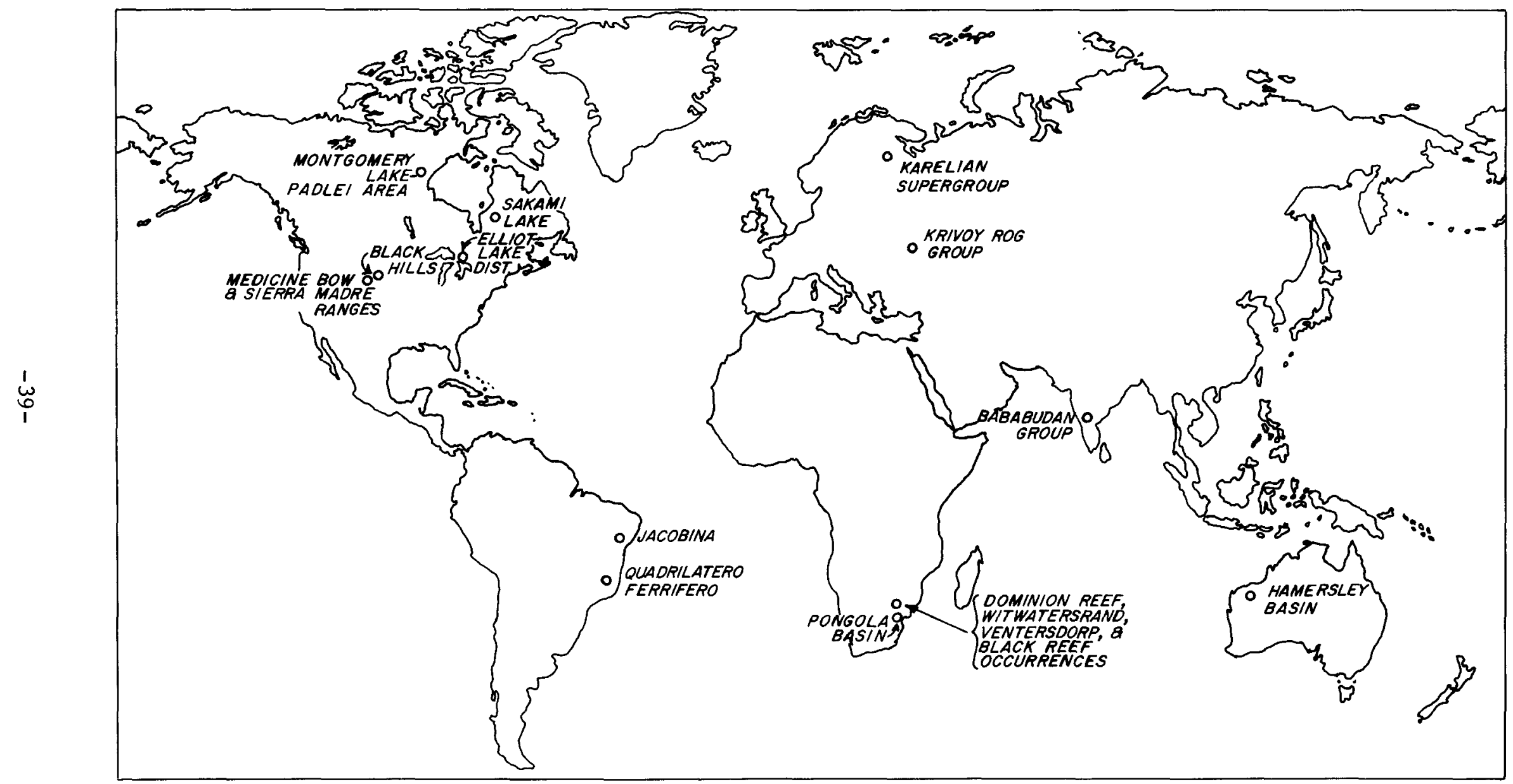

Figure 2. The economic and subeconomic occurrences of Precambrian uraniferous conglomerates of the world. 


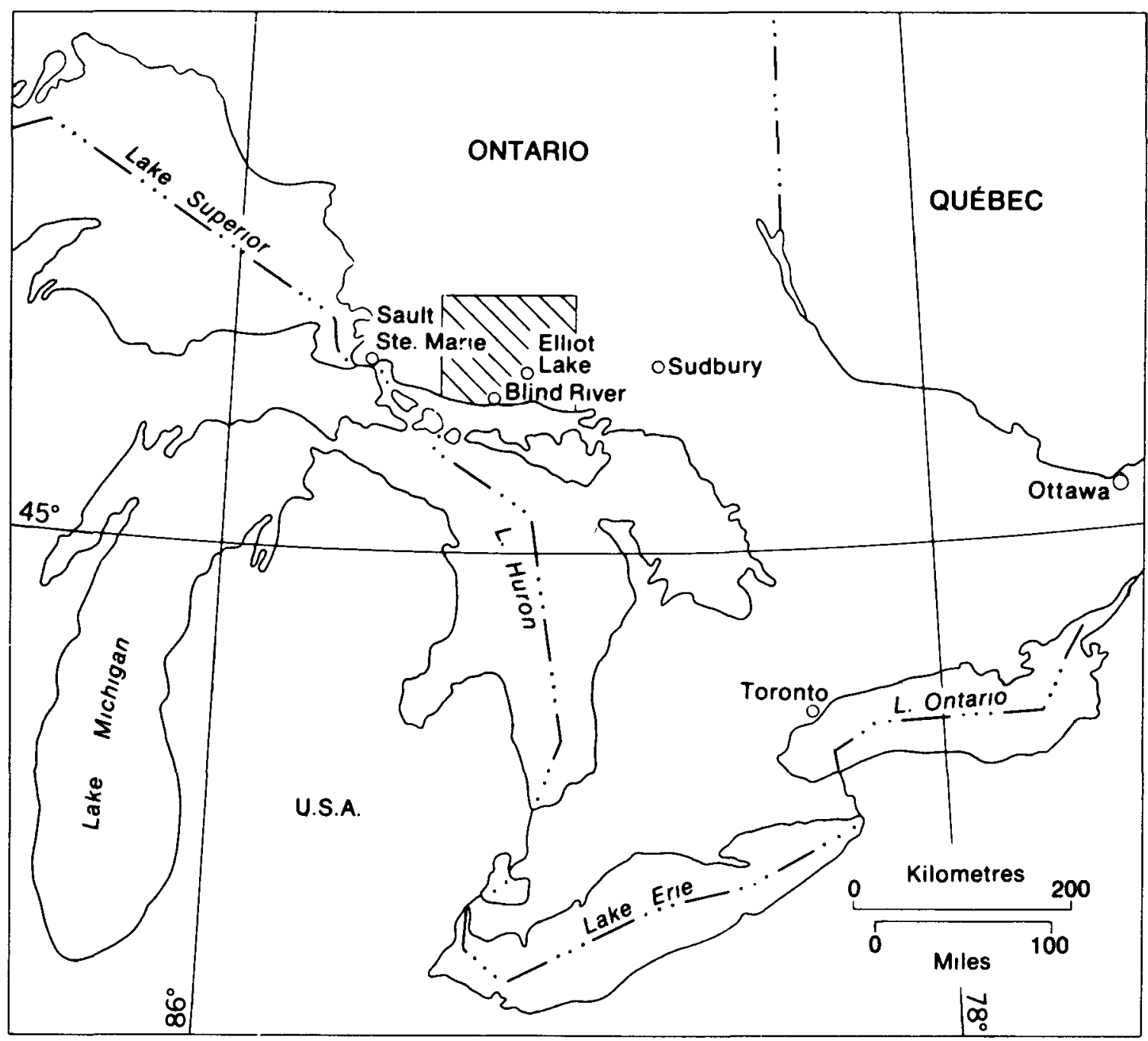

Figure 3. Location of the Elliot Lake district (in box), Ontario, Canada (from Theis, 1979).

Sediments of the Huronian Supergroup are sharply truncated (to the southeast) by the more-or-less linear Grenville Tectonic Province (Figure 4), metamorphic ages within which cluster at about 1,000 m.y. (Windley, 1977).

The basement of the southeastern margin of the Southern Province comprises mainly granitic and gneissic rocks with relatively few and relatively small greenstone belts (Figure 4). The southern edge of the very extensive Abitibi Greenstone Belt is located some $130 \mathrm{~km}$ north of the Elliot Lake area. 


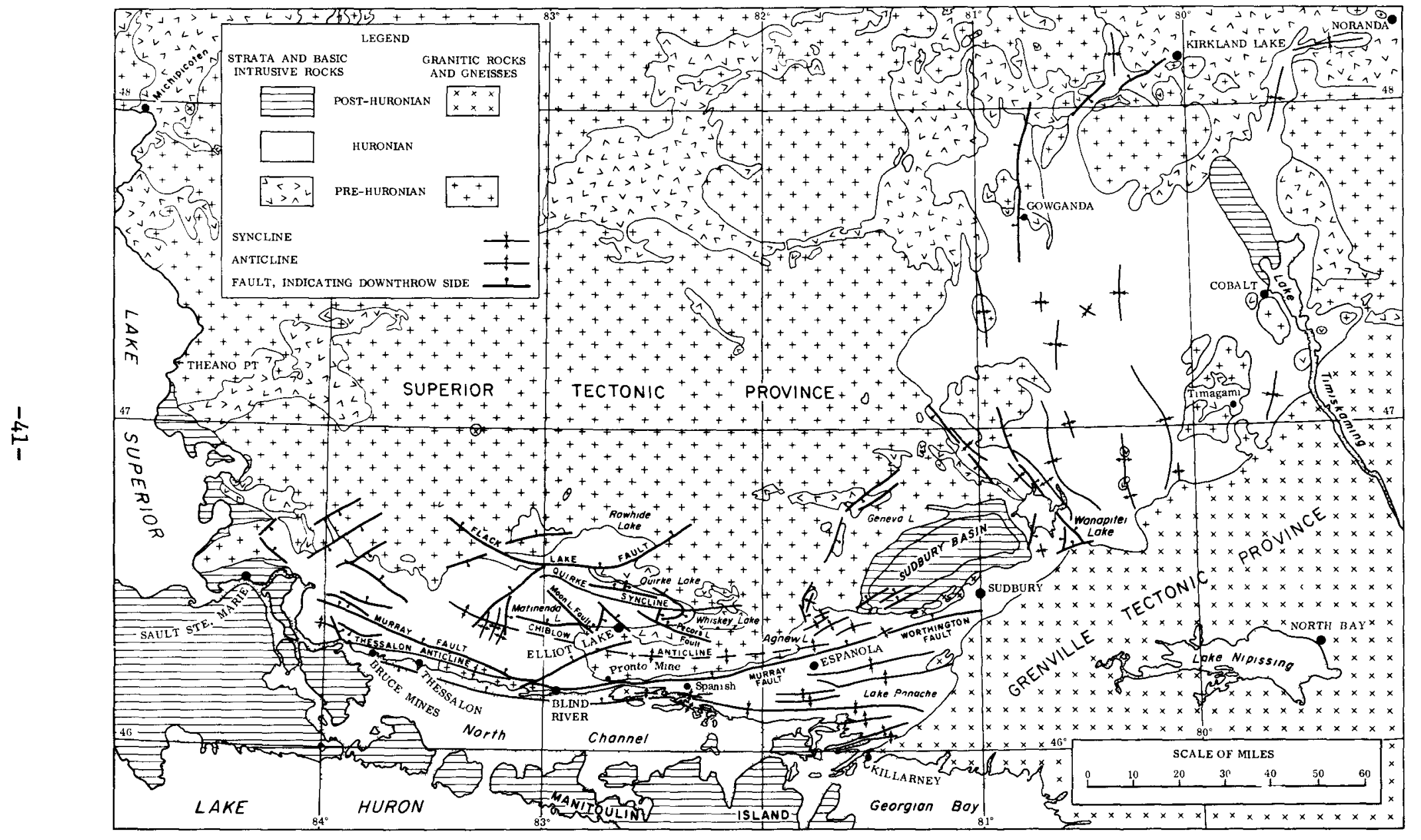

Figure 4. Regional structural geology of the Huronian Supergroup (from Roscoe, 1969). 
Structure

Sediments of the Huronian Supergroup are gently folded. In the area of the uranium deposits, the principal fold axes trend in an arcuate pattern, from a little north of west in the west, through east-west, to a little north of east in the east (Figure 4). Subsidiary folds with north-northeast-trending axes are developed west of Elliot Lake.

The principal faults in the area have the same general trend as the folds. The faults are of high-angle normal and reverse types. One such structure, the Pronto Fault (a reverse fault), truncates and terminates the ore conglomerate at the Pronto Mine (Figure 4).

The outcrop distribution of uraniferous conglomerates is largely controlled by two folds, the Quirke Syncline and the Chiblow Anticline. These structures are responsible for the inverse S-shaped outcrop pattern of Huronian rocks, (including the conglomerates) in the Elliot Lake area (Figure 4).

Stratigraphy

The Huronian Supergroup comprises a pile of clastic sediments (with some volcanics and minor carbonates) that attains thicknesses in excess of $6 \mathrm{~km}$. The assemblage is subdivided into four groups, the Elliot Lake, Hough Lake, Quirke Lake, and Cobalt (Table 1), which are separated by gentle unconformities or disconformities. Each of the upper three groups commences with a suite of rocks which includes a diamictite or "conglomeratic greywacke" (Table 1). There is evidence that some of these diamictites are tillites. Strongest evidence exists in the case of the Gowganda Formation, which displays glacial features such as facetted clasts and varved mudstones (Roscoe, 1969). The striations on clasts and on the basal contact of the Gowganda are now thought to have tectonic origins (J.A. Robertson, written communication, 1980).

Another interesting general observation made on the stratigraphic succession is the evidence for a changing oxygen content of the paleoatmosphere through the Huronian Supergroup (Roscoe, 1969). Arenites in the lowest formations (such as the Matinenda) are uniformly drab colored (mainly shades of green and grey). By contrast, arenites, conglomerates, and argillites of the Cobalt Group contain abundant hematite resulting in a red color in many of these sediments. These conglomerates are locally radioactive, containing some thorium but essentially no uranium.

The commercial uraniferous conglomerates of the Elliot Lake area are contained within the Matinenda Formation where it rests directly on the Archean basement. Locally, the Matinenda is separated from the basement by basic or acid volcanics and an arenaceous formation (see Table 1). Minor (subeconomic) occurrences of uranium are found in the Hough Lake Group. For example, the Ramsay Lake Conglomerate is uraniferous where it rests unconformably on the Matinenda Formation along the north limb of the Quirke Syncline (J.A. Robertson, 1978). 
Table 1. Stratigraphic succession of the Huronian Supergroup (after Roscoe, 1969).

\begin{tabular}{|c|c|c|}
\hline GROUP & FORMATION & COMPOSITE LITHOLOGICAL SEQUENCE \\
\hline \multirow{4}{*}{ Cobalt } & Bar River & quartzite, red siltstone \\
\hline & Gordon Lake & varicolored siltstone \\
\hline & Lorrain & $\begin{array}{l}\text { quartzite } \\
\text { arkose }\end{array}$ \\
\hline & Gowganda & $\begin{array}{l}\text { reddish argillite } \\
\text { argillite } \\
\text { conglomeratic greywacke } \\
\text { gray and pink arkose }\end{array}$ \\
\hline \multirow{3}{*}{$\begin{array}{l}\text { Quirke } \\
\text { Lake }\end{array}$} & Serpent & arkose-subgreywacke \\
\hline & Espanola & $\begin{array}{l}\text { dolomite, siltstone } \\
\text { siltstone, greywacke } \\
\text { limestone }\end{array}$ \\
\hline & Bruce & conglomeratic greywacke \\
\hline \multirow{3}{*}{$\begin{array}{l}\text { Hough } \\
\text { Lake }\end{array}$} & Mississagi & coarse subarkose \\
\hline & Pecors & argillite, siltstone \\
\hline & Ramsay Lake & conglomeratic greywacke \\
\hline \multirow{5}{*}{$\begin{array}{l}\text { Elliot } \\
\text { Lake }\end{array}$} & Mckim & subgreywacke, argillite \\
\hline & Matinenda & gritty subarkose \\
\hline & Copper $\mathrm{Cl}$ iff & acid volcanics \\
\hline & Thessalon Pater Stobie & basic volcanics \\
\hline & $\begin{array}{l}\text { Livingstone } \\
\text { Creek }\end{array}$ & subarkose \\
\hline
\end{tabular}




\section{Paleogeography}

The Huronian Supergroup was deposited on an east-west-trending, southsloping paleosurface. In common with other basins of this type and general age (Button, 1976), the depositional edge of the basin migrated up the paleoslope with time. Thus the northernmost limit of preservation of Elliot Lake Group sediments coincides with the north limb of the Quirke Syncline (Figure 5). Subsequent groups were deposited further and further to the north. A consequence of these wedge-out and onlap relations is that successively younger units come to rest on the basement towards the north. Thus E1liot Lake Group strata rest directly on the basement in the area south of the Quirke Syncline. Along the north limb of the syncline, the Hough Lake Group rests on the basement in places. In the outcrops furthest north of Elliot Lake, the Cobalt Group (in particular the Gowganda Formation) rests on the Archean basement (J.A. Robertson, 1976).

Another consequence of the relations described above is the thickness variation of the Huronian Supergroup. The Cobalt, Quirke Lake, and Hough Lake groups thin from 5,500 to about $2,400 \mathrm{~m}$ when traced from the North Channel of Lake Huron to Flack Lake, a north-south distance of about $55 \mathrm{~km}$ (J.A. Robertson, 1976).

\section{Distribution of Mineralization}

The center of uranium mining activity is the Quirke Syncline where properties have been exploited on both the north and south limbs of this structure. A single operation, the Pronto Mine, was located on the south limb of the Chiblow Anticline (Figure 4). According to J.A. Robertson (1978), a mineable uranium deposit is located near Agnew Lake, some $60 \mathrm{~km}$ east of the Elliot Lake area. Mining has ceased at this site, but leaching of broken ore is still being carried out (J.A. Robertson, personal communication, 1980).

Northeast of Sudbury (Figure 4), Huronian strata crop out in a large area known as the Cobalt Embayment. Lower Huronian strata, some of them equivalent to the Mississagi Formation, are developed locally. Argillaceous quartzites and conglomerates at the base of this succession contain anomalous concentrations of uranium and, in some cases, gold (J.A. Robertson, 1978).

\section{Witwatersrand District, South Africa}

Gold-bearing conglomerates were discovered near what is now the city of Johannesburg in 1886. The presence of radioactive constituents was first noted in 1923 (Liebenberg, 1955). The district has been in continuous production since 1886, during which time scores of mines have operated. Starting in the $1950^{\prime} \mathrm{s}$, some gold mines began commercial extraction of uranium both from accumulated mine tailings and from newly mined ore. A maximum of 26 mines were producing uranium-bearing ore in 1959-1960 (Von Backström, 1976). The number of uranium producers dropped to 9 in 1973 but has increased after that time. 

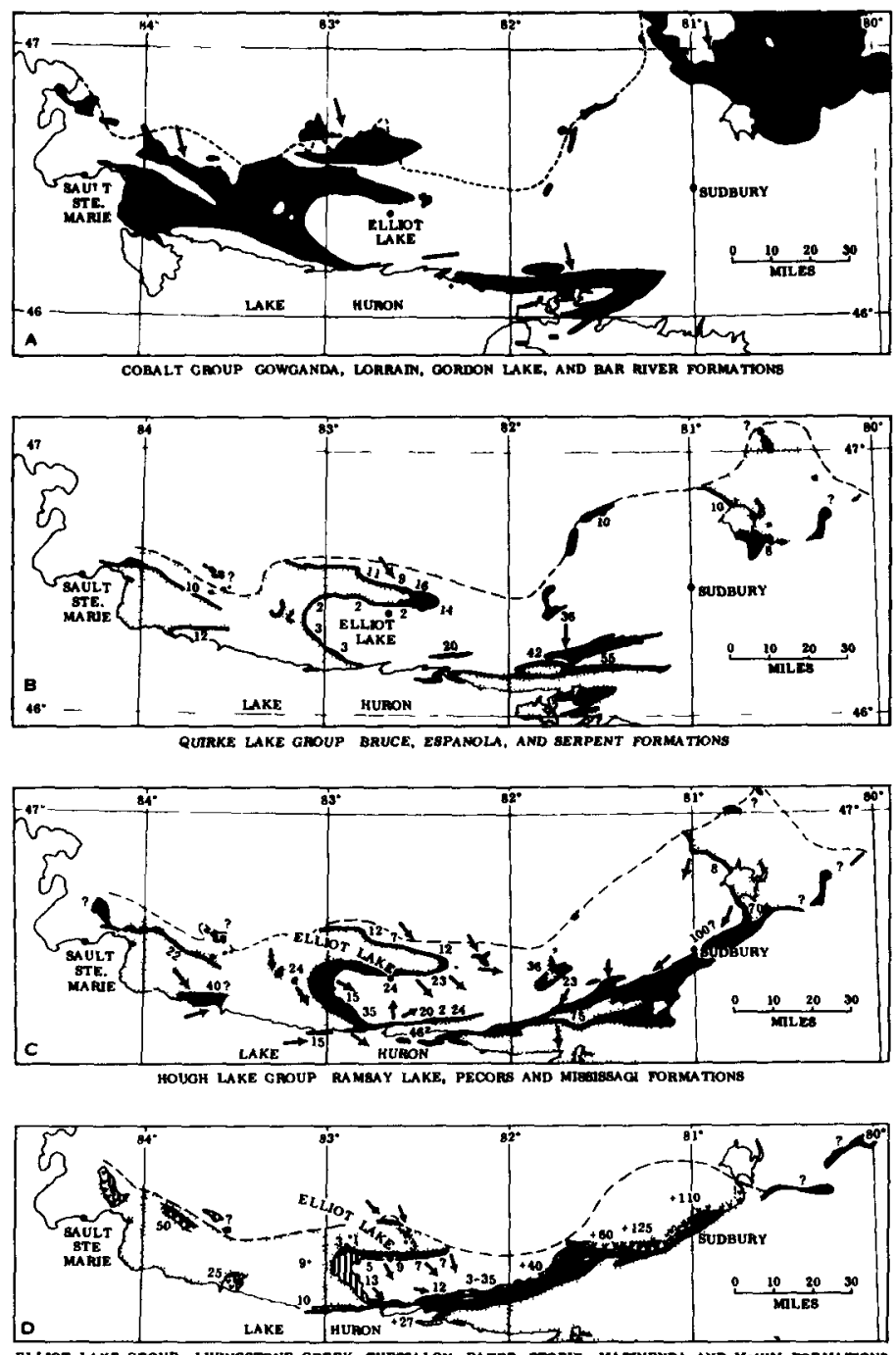

ELLLOT LAKE GROUP LJUINGSTONE CREEK, THEgeALON, PATER, BTOBE, MATINENDA AND MEKIM RORMATHONS

||||||||| Mat tinenda rormac ion

Volcanis rocks or Livingstone Creek, Pater, and Stoble Formations

subsurtare extent of groups

Nalenitintes of groups

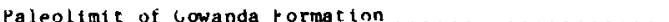

predominant atrection of primary incilnation of crossbeds

in ma jor arenaceous unt

tstimated thickness of groups in hundreds of feet $\ldots . .12$

Figure 5. Areal distribution of the E1liot Lake, Hough Lake, Quirke Lake, and Cobalt groups, Huronian Supergroup, in Ontario, Canada (from Roscoe, 1969). 


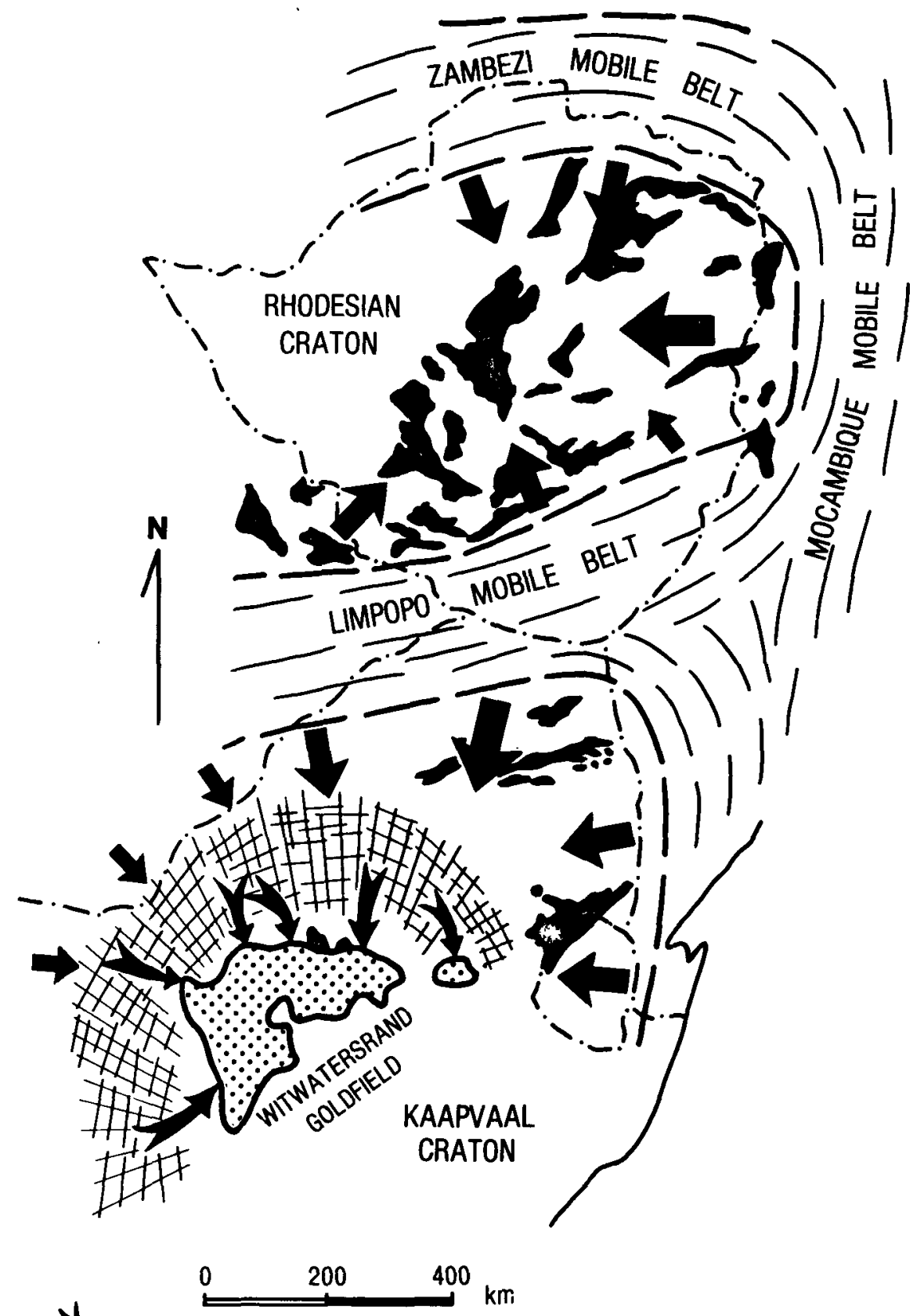

1 Known entry points of sediments and gold

\# Provenance area for Witwatersrand gold

E Gold-poor zones. High-grade metamorphic belts

Gold quantity increases towards craton centre

Archaean Greenstone Belts (Gold Belts)

Figure 6. Location of the Witwatersrand Basin on the Kaapvaal Craton (from Anhaeusser, 1976). 


\section{Regional Tectonic Setting}

The Witwatersrand district is situated near the center of the Archean Kaapvaal Craton (Figure 6), a tectonic unit analogous to (but older than) the Superior Province of North America. It is composed of gneissic and granitic rocks with some greenstone belts. The craton had assumed, for the most part, its present configuration prior to $3,000 \mathrm{~m} \cdot \mathrm{y}$. ago. The only significant basement events after that date were the emplacement of high-level granites in stocks and sheets. This intrusive activity ended some 2,600 m.y. ago.

\section{Structure}

The Witwatersrand Basin has an overall northeast-southwest trend, with a long axis dimension of at least $300 \mathrm{~km}$ (Figure 7). The $11 \mathrm{mits}$ of the basin have been delimited mainly by exploration drilling since only about 10 percent of the basin perimeter is seen in outcrop (Pretorius, 1976). At present, the northeast and southeast limits of the basin have not been firmly established. It could extend for a total distance (along the 1ong axis) of $500 \mathrm{~km}$.

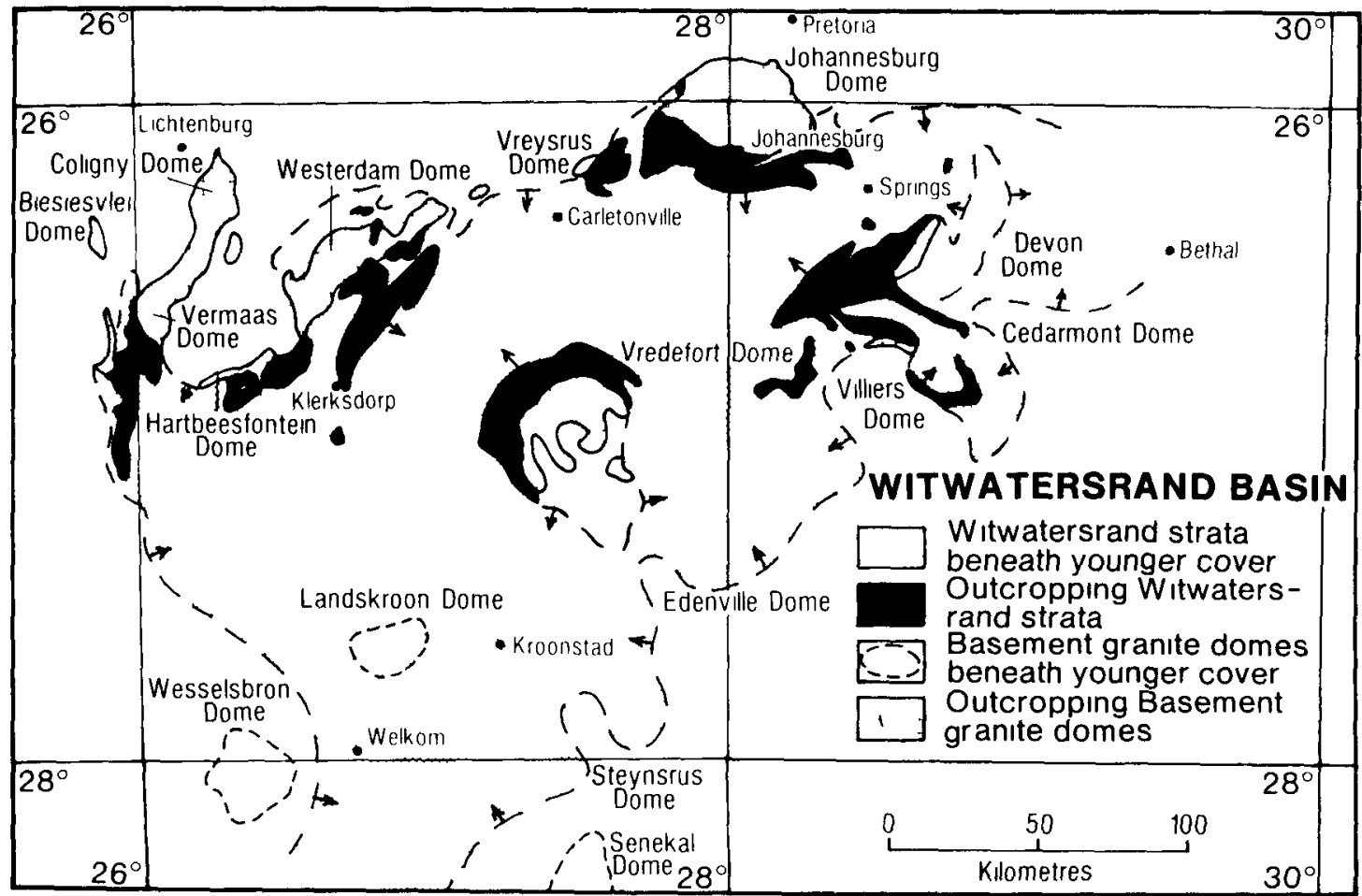

Figure 7. The Witwatersrand Basin, showing the location of Archean basement domes and of Witwatersrand outcrop areas (from Pretorius, 1976). 
The regional tectonic pattern of the basin is best expressed in terms of an interfering fold pattern (Pretorius, 1976). The older set of folds trended northeast but were deformed about a younger set of northwest-trending folds (Figure 8). Pretorius was of the opinion that most of the major dome structures which deform the basin (such as the Vredefort Dome, Figure 8) are located at the intersection points of regional anticlinal axes.

A set of high-angle, mostly normal faults can be followed parallel to the longitudinal tectonic pattern of the basin. The faults were active over a long period of geologic time. Pretorius (1976) belleved that the basin was formed in part as a response to uplift of the northwest margin of the basin along this fault system. Other geologists, including W.E.L. Minter (written communication, 1980) are of the opinion that the basin formed mainly as a response to tectonic downwarping of part of the Kaapvaal craton. Faults were certainly very active after Witwatersrand deposition, horst blocks of Witwatersrand sediments having been uplifted in places and subsequently removed by erosion.

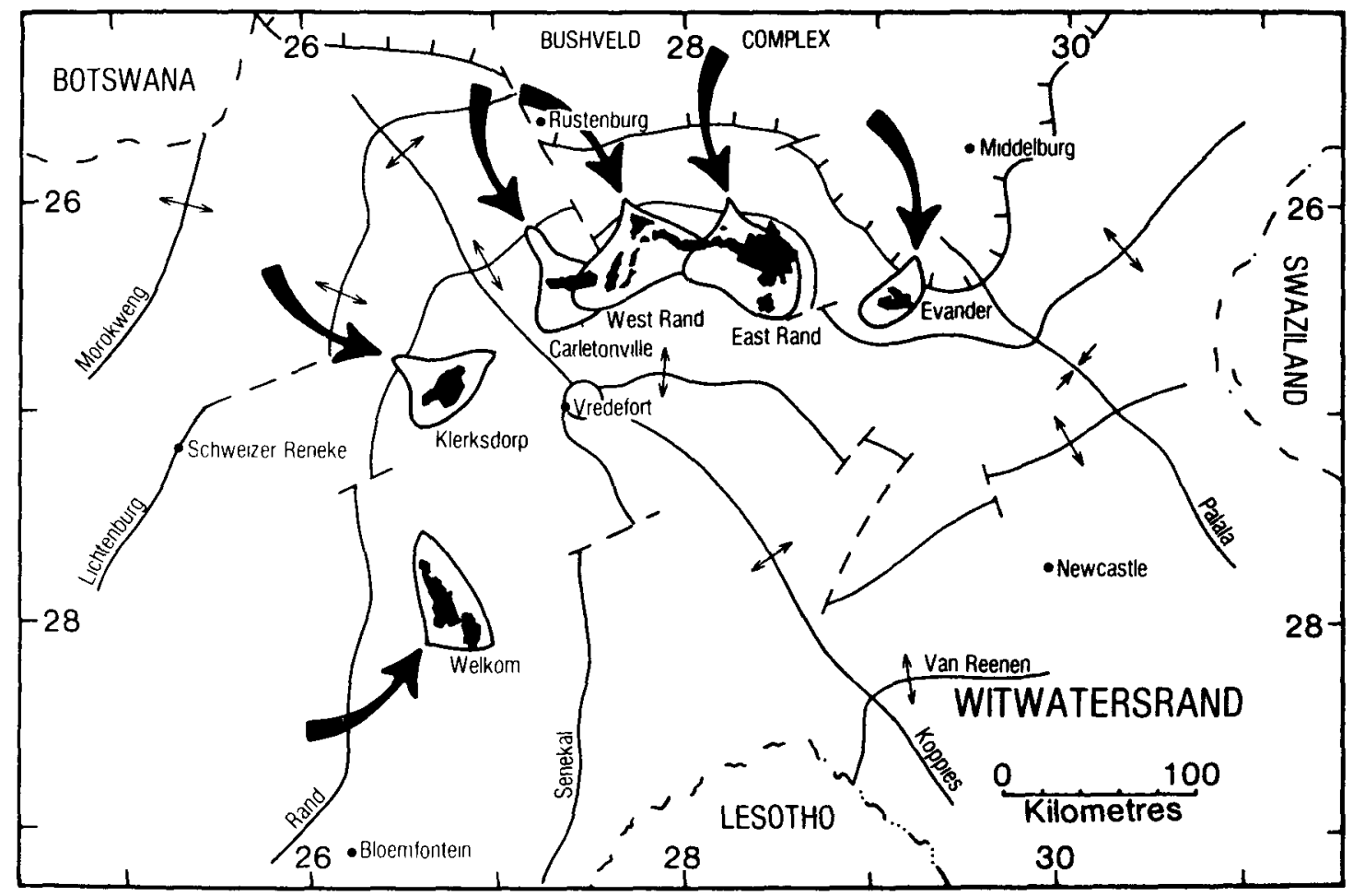

Figure 8. The regional structural framework of the Witwatersrand Basin, showing the locations of the major mineralized areas (modified after Pretorius, 1976). Areas shaded black mark the producing properties. Regional axes are shown using the conventional notation. Large black arrows mark sediment transport directions for the mineralized conglomerates of the six principal goldfields. The hachured line marks the southern limit of the Bushveld Complex. 
Stratigraphy

The W1twatersrand stratigraphic succession normally comprises four major stratigraphic packages, only two of which form the Witwatersrand Supergroup in the strict sense (Table 2). In the area west and north of Klerksdorp (see Figure 7), the Archean basement is overlain by a sequence of rocks commencing with arentte and conglomerate and passing upwards to basaltic and rhyolitic volcanics. These rocks comprise the Dominion Reef Group. This assemblage is overlain by the Witwatersrand Supergroup. Some confusion arises from the fact that several authors have included the Dominion Reef Group in the Witwatersrand Supergroup. There may be justification for this approach, since there is evidence that the Dominion Reef Group was deposited as a precursor to the Witwatersrand and is restricted to paleotopographic lows on the pre-Witwatersrand erosion surface (W.E.L. Minter, written communication, 1980).

Table 2. Stratigraphic divisions of major units of the central regions of the Kaapvaal Craton.

UNIT

Transvaal Supergroup

Ventersdorp Supergroup

Witwatersrand Supergroup

Dominion Reef Group
APPROXIMATE AGE

$2,300 \mathrm{~m} \cdot \mathrm{y} \cdot$

$2,650 \mathrm{~m} \cdot \mathrm{y}$

Mainly volcanic rocks
Upper Witwatersrand,
mainly fluvial clastic sediments

$2,700 \mathrm{~m} \cdot \mathrm{y} \cdot$

\begin{tabular}{c} 
Unconformity- \\
in eastern part of basin \\
Lower Witwatersrand, \\
main1y marine and marginal \\
marine clastics \\
\hline
\end{tabular}

$2,800 \mathrm{~m} \cdot \mathrm{y} \cdot$
LITHOLOGY

Mainly marine sediments Unconformity

\section{Volcanics with basal fluvial} clastic unit -Nonconformity-

The Witwatersrand Supergroup is itself subdivided into two units which have long been known as the "upper" and "lower" divisions. Proposals for lithostratigraphic names for these units are under consideration, and the units will henceforth become units of "group" status within the Witwatersrand Supergroup. In the eastern part of the basin, the upper and lower divisions are separated by a regional unconformity. The lower division (up to 4,500 
meters) contains minor basaltic volcanics and a varied assemblage of sediments, including quartz arenite, subgreywacke, shale, banded iron-formation, and diamictite. The arenaceous units of the lower division contain a few relatively minor occurrences of conglomerate, which contain gold and some uranium and have been mined locally in the Klerksdorp area (Figure 7). By contrast, the upper Witwatersrand (up to 3,000 m thick) comprises quartz wacke arenites and conglomerates with some quartz-arenite units, two tongues of basalt (in the eastern part of the basin), and a single shale formation. Al1 but a fraction of the gold and uranium mined from the Witwatersrand district was obtained from the upper division of the Supergroup.

It is important to emphasize here that the percentage of conglomerate in the Witwatersrand Supergroup is relatively sma11. Pretorius (1976, p. 52) estimated that only 8 percent of the pile is composed of conglomerate on the northwestern (proximal) side of the basin, and this figure decreases to 1 percent on the southeastern (distal) edge of the basin. Economically exploitable conglomerates comprise less than 0.2 percent of the column as a whole.

The Witwatersrand Supergroup is unconformably overlain by the basalt-dominated Ventersdorp Supergroup. This unit, itself divisible into a number of groups, comprises up to approximately 4,500 meters of basaltic volcanics with some rhyolitic units, volcaniclastic sediments, and minor stromatolitic carbonates. The Ventersdorp was formed in an extensional tectonic environment where older rocks, including the Witwatersrand Supergroup, were subjected to gravitational faulting and bimodal (but basalt-dominated) volcanism.

The Transvaal Supergroup, up to $12 \mathrm{~km}$ thick in places, rests unconformably on older formations, including the Ventersdorp, Witwatersrand, Dominion Reef, and Archean basement. It is possibly as much as 200 to 300 million years younger than the Ventersdorp. Lithologically, the Transvaal Supergroup is dominated by mature marine sediments, including shale, iron-formation, carbonates, and quartz arenites (Button, 1976).

\section{Paleogeography}

During the period of deposition of Witwatersrand conglomerates, the basin was apparently bounded to the north, northwest, and west by a mountainous uplifted block which supplied both sediment and water to the streams draining into the basin. Drainage was down a paleoslope inclined to the east and northeast (Welkom area), southeast (Klerksdorp area), and south (West and East Rand areas, Figure 8). In the Evander Goldfield (Figure 8), the principal mineralized conglomerate was deposited by a fluvial system flowing to the north and northeast (Tweedie, 1978; W.E.L. Minter, written communication, 1980).

Several geologists have suggested that the Witwatersrand fans were actually fan deltas building onto a marine shelf located to the south and east. At times, this marine shelf can be inferred to have transgressed across, and to have reworked parts of, the underlying fan-delta sedimentary assemblages (Minter, 1976; Button, in press). 
A total of six minerallzed areas have been delineated within the Witwaters rand Basin (Figure 8). From the east, these are the Evander, East Rand, West Rand, Carletonville, Klerksdorp, and Welkom Goldfields. Of these areas, only the Evander area has produced no uranium. The East Rand area was a major goldfield, but produced relatively insignificant amounts of uranium. The West Rand was a major producer of uranium but is in a declining stage at present, most of the mineable conglomerates having been removed. The bulk of the gold, and nearly a11 of the uranium, is currently being extracted from the remaining areas, the Carletonville, Klerksdorp, and Welkom fields.

\section{Acknowledgements}

The writers are indebted to many colleagues for assistance in the preparation of aspects of this report. D. Grandstaff, C. E. Feather, M. M. Kimberley, M. Schidlowsk1, and G. M. Young kindly permitted the use of unpublished manuscripts, and they also supplied other information. D. Grandstaff, M. Schidlowski, W. E. L. Minter, R. W. Ojakangas, H. L. James, and J. Trow made avallable reprints of published information. Discussions with R. W. Ojakangas, J. Trow, R. S. Houston, H. L. James, and J. A. Redden were particularly helpful, and we are grateful to them for sharing their observations and ideas. J. A. Redden, D. Grandstaff, Mary McNell, Jule Anderson, C. A. Jones, and, in particular, W. E. L. Minter and J. A. Robertson, reviewed part or all of the manuscript, and their careful and constructive comments have improved the text. Merle Crew, as project technical monitor for the Department of Energy, provided guidance and assistance of numerous sorts, and Dan Showalter prepared a most thorough editorial review. Assistance with clerical and drafting tasks was provided by M. Bradshaw, B. M. Button, K. Dandavat1, J. Winter, G. A. Miller, and W. E. Ary. Jo Ann Fankhauser prepared the final draft of the manuscript and performed innumerable other tasks essential to the completion of this contract. 
Blank

$-52-$ 
Mineral exploration can be conceived of as an exercise in which one passes information through a series of screens (or filters), eliminating at each step certain geologic environments from further consideration. It is logical to begin this screening exercise with the widest possible mesh, so that large areas of unsuitable terrane can be eliminated at the outset. Successive screens should be finer and finer, so that, at the end of the exercise, the explorationist can concentrate his efforts on relatively small areas.

One of the screens that has proved to be invaluable in exploration geology relates to tectonic environment. Thus porphyry copper deposits tend to occur in, and be explored for, near to convergent continent-ocean or oceanocean plate boundaries and the ancient sites of such boundaries.

A second important filter relates to geologic time. Certain ore deposit types show a very decided tendency to occur over a rather restricted span of time. For example, stratiform, sediment-hosted copper deposits occur preferentially in late-Precambrian basins such as the Katangan in Africa, the Adelaidean in Australia, and the Beltian and Keweenawan in the United States.

The first two chapters in this report are devoted to generating the parameters for tectonic and geochronologic filters to be applied in the search for Precambrian uraniferous conglomerates.

\section{Crustal Architecture of Precambrian Shields}

In the broadest possible outline, Precambrian shields can be subdivided into "stable areas" and linear tracts of country in which rocks have been highly deformed and metamorphosed, known as "mobile belts" (Figure 9). The stable areas have been referred to as "cratons", "provinces", or "blocks". For example, the Precambrian shield of Canada and the United States comprises units such as the "Superior Province" and the "Wyoming Province" in which there has been little or no high-grade metamorphism or associated deformation for the last $2,500 \mathrm{~m} . \mathrm{y}$. The Archean provinces (or cratons) are rimmed by younger mobile belts. These belts tend to be linear over hundreds (sometimes thousands) of kilometers. The Grenville Province is a good example. It extends northeast from the Great Lakes area for several hundred kilometers (Figure 4). Ages within this belt are mainly on the order of 1,000 m.y. (Windley, 1977).

Basins containing Precambrian uraniferous conglomerates of Witwatersrand and Elliot Lake type occur exclusively on the Archean "cratons". As far as the writers have been able to determine from an extensive review of the literature, no economic (or even sub-economic) uraniferous conglomerates (or their metamorphosed equivalents) have been found within younger (post-Archean) mobile belts. Consequently, the remainder of this chapter will be devoted to a brief analysis of the characteristics of Archean cratons in shield areas around the globe. 


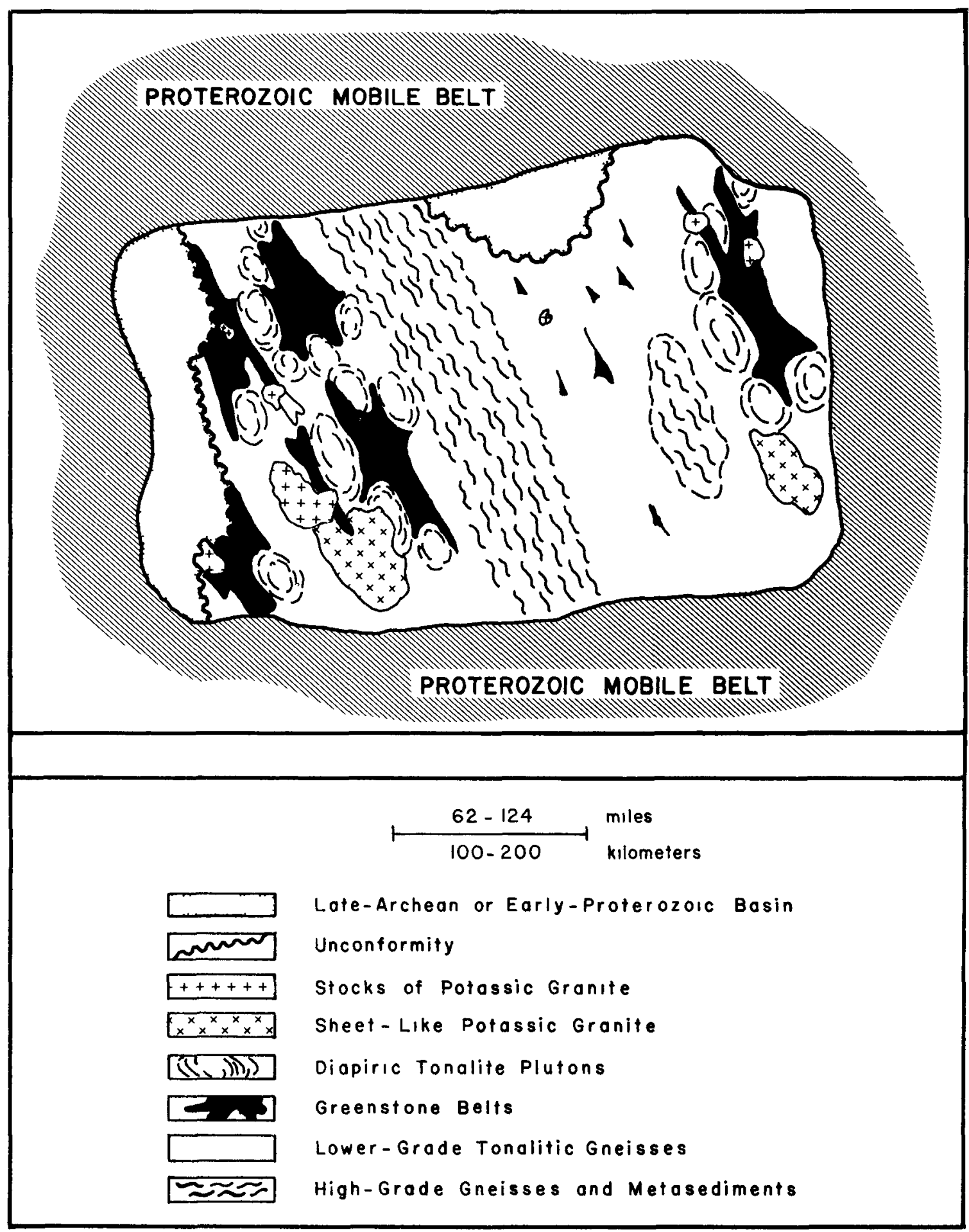

Figure 9. Schematic diagram of mobile belt-craton relations, including the development of greenstone belts, tonalitic diapiric intrusives, and high-level potassic granites. 
Geologists who have studied the tectonic and lithologic evolution of Archean cratons in continents around the world have noted a remarkable similarity in the development of these parameters in different continents (Anhaeusser and others, 1969; Windley, 1977). A generalized account, based in part on the work of these authors, is presented below.

Windley recognized a basic twofold subdivision of Archean cratons into "high-grade regions" and "Archean greenstone belts". There is, however, another important component of the craton which is neither "high-grade" nor part of a greenstone belt, namely the complex of gneisses and granitic rocks which separates most greenstone belts. Given the fact that some of these granitic rocks probably supplied uranium to the Precambrian conglomerates under discussion, they $\mathbf{w i l l}$ be discussed as an entity in this report.

\section{Gravity Patterns in Precambrian Shields}

The Western Australian Shield is relatively well exposed and provides a useful model that could be applied in other, poorly exposed or understudied shield areas. Granite greenstone terranes (Ay and Ap on Figure 10) are characterized by stubby, aligned or non-aligned gravity highs coincident with greenstone be1ts (Gee, 1979). The high-grade gneiss terrane in southwestern Australia (Ayn in Figure 10) is gravitationally "quiet". By contrast, the Limpopo high-grade area in southern Africa coincides with a regional gravity high.

Proterozoic mobile belts stand out as long, continuous, linear gravity highs with some complementary linear gravity lows. The tendency of the mobile belts to "wrap around" the older cratons is seen in the gravity anomaly map. Gravity patterns could possibly be used to attempt to map the unexposed edges of the Superior and Wyoming "cratons" in the United States.

Archean High-Grade Regions

The division of most shield areas into cratons and mobile belts is somewhat artificial since an older mobile belt can become part of a younger craton. The Archean high-grade regions under discussion are a case in point. They were formed under similar conditions to many younger mobile belts, yet because of their great age, they are included within Archean cratons. They have been largely unaffected by tectonic or thermal events for the last $2,500 \mathrm{~m} \cdot \mathrm{y} \cdot$

High-grade regions in Archean cratons comprise intricately deformed areas of varying size, metamorphosed under conditions of granulite or upper amphibolite grade. The regions occur in several different ways (Windley, 1977). Some make up very large areas, such as the North Atlantic Craton, which incorporates much of central Greenland and parts of the east coast of Labrador. Others, such as the Limpopo Mobile Belt in southern Africa and the western gneiss terrane in Australia (Figure 10), occur as linear belts many hundred kilometers long and several tens to a few hundred kilometers wide. Yet other high-grade areas occur between greenstone belts or in isolated occurrences, such as in the central uplift area of the Vredefort Dome in South Africa (Figure 6). 


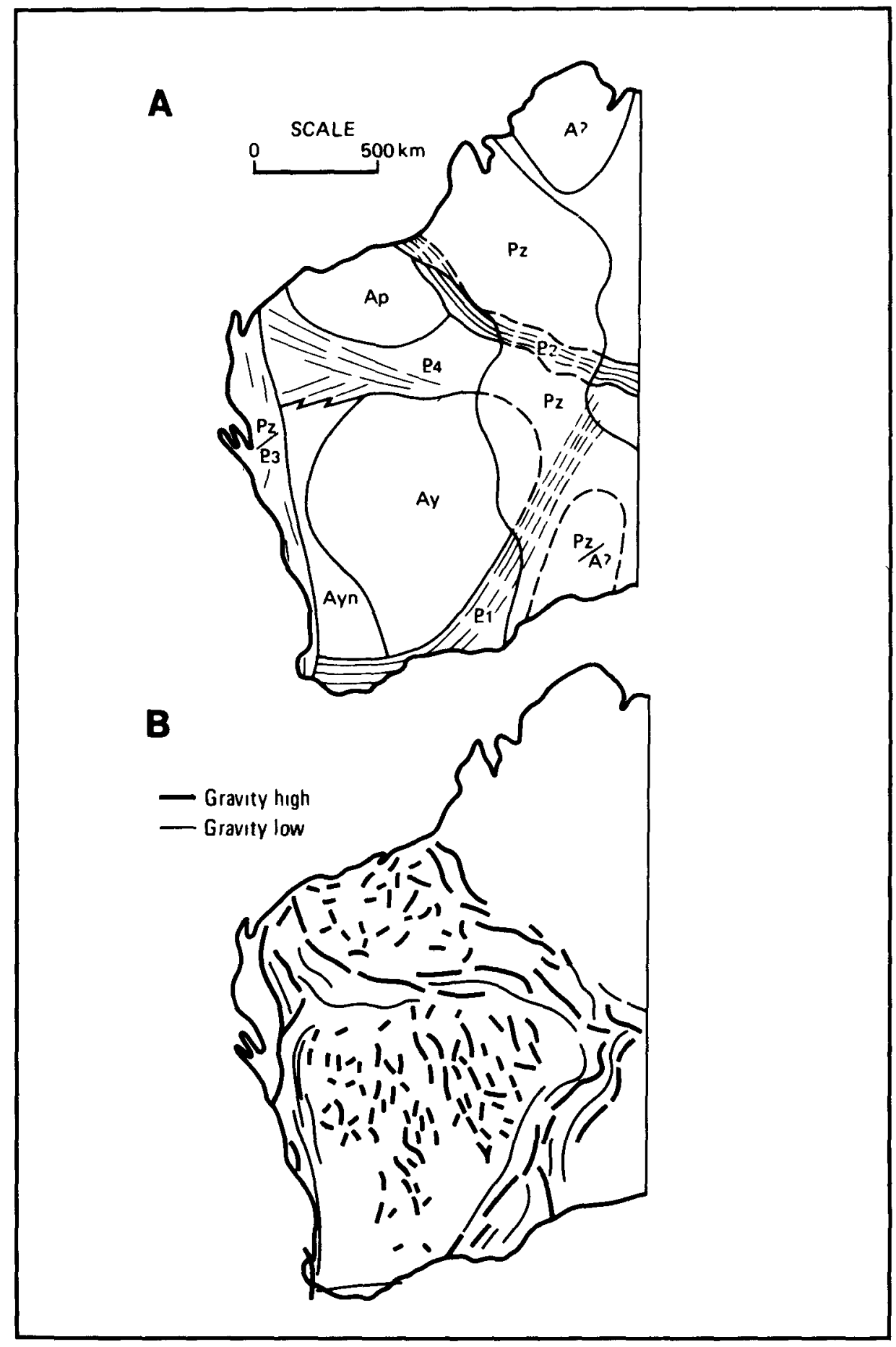

Figure 10. Tectonic units and their regional gravity signatures, Western Australian Shield (from Gee, 1979). Ap = Pilbara Craton; Ay = Yilgarn Craton; Ayn = gneiss terrane; $P_{1}, P_{2}$, etc., are Proterozoic mobile belts; $\mathrm{Pz}$ denotes Phanerozoic basins. 
The high-grade areas within cratons can usually be divided into two broad categories, a metamorphosed "basement" and a sequence of metamorphosed sediments, volcanics, and layered intrusives usually termed the "supracrustal" rocks. Once again, the division can be somewhat confusing, since metasediments and metavolcanics do occur within the "basement".

Metamorphosed "Basement"

The most common rock types of the metamorphosed basement are quartzo-feldspathic gneisses which comprise approximately 80 or 90 percent of the highgrade regions. The gneisses commonly incorporate metamorphic rocks, such as amphibolite, quartzite, meta-anorthosite, and smaller amounts of marble, meta-iron-formation and meta-ultramafics (Windley, 1977). The rocks have frequently undergone partial melting and are injected by granitic veins.

The origin of the gneisses is still an open question. Windley concluded that the balance of evidence favored their derivation from older tonalitic or granodioritic igneous intrusives.

\section{Supracrustal Metamorphic Rocks}

A wide variety of metamorphosed stratified rocks is present in high-grade areas. These rocks are usually considered to have been deposited on a preexisting granitoid basement.

Supracrustal metamorphic rocks include amphibolites (some of them with preserved pillows, indicating a subaqueous basaltic origin), mica schists (frequently graphitic, and probably representing meta-pelites), marbles, quartzites, and iron-formations. This assemblage is suggestive of deposition on shallow, tectonically stable epicontinental platforms. In addition to metasediments, many supracrustal sequences contain metamorphosed layered basic intrusives comprising ultramafics, anorthosites, and leucogabbros.

Geochronology

High-grade areas in Archean cratons have been dated over a wide span of time from 2,500 to $3,800 \mathrm{~m} \cdot \mathrm{y}$. In most areas, the oldest isotopic ages fall in the 2,700 to $3,100 \mathrm{~m} . \mathrm{y}$. bracket (Windley, 1977). Isolated areas of extremely old rocks are found in some high-grade areas. The Isua banded iron-formation in Greenland has been dated at $3,760 \pm 70 \mathrm{~m} . \mathrm{y}$. by the $\mathrm{Pb} / \mathrm{Pb}$ method (Moorbath and others, 1973). In southern Africa, Barton and others (1977) have dated metamorphosed basic dykes, intrusive into older gneisses, at 3,643 m.y. by the $\mathrm{Rb} / \mathrm{Sr}$ whole rock method.

\section{Metamorphism and Structure}

High-grade areas have been subjected to upper amphibolite and granulite facies metamorphism. Estimates of metamorphic temperatures range from 650 to $1,075^{\circ} \mathrm{C}$ and cluster around 700 to $900^{\circ} \mathrm{C}$ (Windley, 1977). Pressure estimates average in the area of 10 kilobars. High-grade areas are structurally very complex. They have been subjected to multiple episodes of folding, resulting in complex interference patterns and refolded isoclinal folds. 
Archean Greenstone Belts

Most Archean provinces contain some areas of "greenstone belt" in addition to high-grade gneisses and granttic plutons. Greenstone belts are usually synformal, linear belts composed of relatively unmetamorphosed volcanic and sedimentary rocks. The margins of the belts are characteristically ragged due to deformation caused by the intrusion of a series of diapiric plutons (Anhaeusser, 1975).

Greenstone belts vary greatly in size. Small greenstone "remnants" are common in some areas and measure only a few kilometers to a few hundred meters along their longest dimension. The Barberton greenstone belt in South Africa measures some 40 by 120 kilometers. It is exceptionally well preserved and has been used as a "model" for other greenstone be1ts by Anhaeusser and others (1969). It is, however, a relatively small greenstone belt, being dwarfed by the belts of Canada and Australia, some of which are up to $1,000 \mathrm{~km}$ long.

Geochronology

Windley (1977) has reviewed the ages of greenstone belts. They appear to belong to two major periods. The older (and generally smaller) belts are on the order of 3,300 to $3,500 \mathrm{~m} \cdot \mathrm{y}$. in age. At present, such older greenstone belts are known from the Kaapvaal and Rhodesian cratons in Africa, and the Pilbara Block in western Australia. The younger greenstone belts are usually larger. Their ages appear to cluster in the 2,600 to 2,700 m.y. bracket, with a range from about $2,900 \mathrm{~m} \cdot \mathrm{y}$. to possibly as young as $2,300 \mathrm{~m} \cdot \mathrm{y}$. Several authors have stressed that the younger greenstone belts were forming at the same time as stable shelf sediments in basins such as the Pongola, Dominion Reef, and Witwatersrand (see next chapter).

\section{Stratigraphy}

In general terms, greenstone belts tend to have similar stratigraphic successions (Anhaeusser and others, 1969; Anhaeusser, 1973; Windley, 1977). A lower, volcanic-dominated unit is generally overlain by an upper, sedimentdominated unit.

The volcanic succession usually commences with mafic and ultramafic basalts, usually including chemically distinctive komatiltes. The volcanic pile normally evolved upwards into one in which calc-alkaline or bimodal (basaltdacite) volcanics predominate. Interflow sediments are mainly of chemical types, principally chert and iron-formation.

Most greenstone belts have an upper sedimentary unit which varies in character from one belt to another. In most, the sediments are dominated by immature volcaniclastic sediments and relatively deep-water turbidite greywackes. In others, mature shelf sediments predominate and include pure quartz arenites, shales, and minor iron-formations. One such sequence, in the Moodies Group of the Barberton Mountain Land, was deposited on a tide-influenced shoreline (Eriksson, 1979). In a few instances, the upper sedimentary units of greenstone belts include tongues of fluvial conglomerate that carry pyrite, gold, and some uranium minerals (Saager and Muff, 1978). 
The conventional interpretation of greenstone belt structures is that they represent shallow synformal basins formed by sinking of a greenstone belt and a complementary diapiric rise of marginal granitoid plutons. Windley (1977) has stressed that detailed structural studies in some greenstone belts have indicated a more complex history, including episodes of horizontal stress, giving rise to shortening and nappe-type movements.

Metamorphism

Some greenstone belts are only weakly metamorphosed (zeolite facies) and contain some primary pyroxenes, for example, in the basalts. The typical belt has undergone greenschist-grade metamorphism. Amphibolite-grade rocks are normally restricted to relatively narrow selvedges around the greenstone belts where they are in contact with intrusive granitic rocks. Windley stressed that the metamorphic assemblages in greenstone belts are never of the high-pressure types associated with convergent plate boundaries.

Archean Granitoid Rocks

A third important element of Archean cratons is the suite of granitoid rocks which cannot be accommodated in the "high-grade" category. The distinction between high-grade gneisses and lower grade gneisses is not always easily made. There are large tracts of country between greenstone belts where this distinction has not been made. For this reason, gneisses are discussed under this heading, as well as under the high-grade heading.

In their review of Precambrian shield geology, Anhaeusser and others (1969) recognized three general categories of granitic rock. The oldest is a complex array of migmatites, banded gneisses, and some homogeneous granitic rocks. These are chemica1ly similar to, but structurally distinct from, a second group, composed of circular-to-elliptical diapiric plutons. The third (and youngest) type recognized comprises a suite of potassic granites and related rocks. Several subdivisions within this latter class are recognized.

Tonalitic Gneisses

Several Archean cratons comprise very large tracts of old, sometimes demonstrably pre-greenstone belt, tonalitic gneisses. The gneisses are characteristically soda-rich. In composition, they vary from trondhjemites and tonalites to diorites, granodiorites, and quartz diorites. In that they frequently contain slivers of greenstone belt, they could represent the eroded base of the former basal contact zones of now-eroded greenstone belts.

Diapiric Plutons

A series of diapiric tonalite plutons usually intrudes the margins of greenstone belts. They tend to be some of the oldest granitic rocks in the vicinity of greenstone belts. Those in the area of the Barberton greenstone belt are from 3,200 to $3,400 \mathrm{~m} \cdot \mathrm{y}$. old. 
The diapiric plutons are generally circular to oval in plan view and have diameters of up to a few tens of kilometers. The plutons have foliated margins and contain aligned xenoliths derived from neighboring greenstone belts. They comprise soda-rich igneous rock types, varying from tonalite to trondhjemite. The metamorphic effects of the plutons on the neighboring greenstone belts are minimal, which led Anhaeusser (1975) to suggest that they were emplaced in a semi-solid state, having lost much of their heat through slow cooling at greater depths.

\section{Potassic Granites}

The youngest of a series of granitoid intrusives in Archean blocks are usually "potassic granites". The composition, ages, and geometric shapes of these intrusives vary greatly. Some are sheet-like, while others are stockor plug-like intrusives. In composition, they vary from true granites to quartz monzonites and adamellites.

Sheet-Like Granites. Potassic granites are known to have been emplaced as near-horizontal sheets in several Archean granitic terranes (Hunter, 1974; Robb, 1978, 1979). The tectonic level of emplacement of these sheets is relatively high. They are usually underlain by older tonalitic gneisses and migmatites.

The sheet-like granites tend to be homogeneous, non-foliated rocks composed of quartz and microcline with lesser amounts of plagioclase and biotite. Some of the sheets are cut by complex stockworks of pegmatite carrying minerals such as cassiterite, euxenite, monazite, columbite, and yttrotantalite (Hunter, 1957).

There is frequently a downward transition of the granite to the underlying gneisses. In the transition zone, sheets of granite are intruded into the gneisses. In addition, gneisses in the transition zone are of ten porphyroblastic due to the development in them of potassium feldspar phenocrysts.

Sheet-like granites in southern Africa tend to be somewhat older than the stock- or plug-1ike types: The Lochiel Granite, a major sheet granite developed near the Barberton greenstone belt, has been dated at 3,070 m.y. This granite has $a^{87} \mathrm{Sr} /{ }^{86} \mathrm{Sr}$ initial ratio of 0.7054 (Hunter, 1974). Hunter concluded that the granite was derived, at least in part, from older crustal (rather than mantle) rocks.

Stock- and Plug-Like Intrusives. The youngest of all the granitoid rocks in Archean terranes tend to be circular-to-ovoid, steep-sided stocks or plugs, varying in diameter from a few kilometers to a few tens of kilometers. These intrusives are non-foliated. They tend to cut cleanly and sharply across older geologic structures, and in this respect are very different from the diapiric plutons. Anhaeusser (1975) noted that they tend to give rise to the highest metamorphic grades in the adjacent greenstone belts and were probably emplaced as liquid melts.

Textura11y, these intrusives are often coarse- or very coarse-grained. Many of them are conspicuously porphyritic. Pink or red colors are typical of such granitic rocks. They were emplaced over a wide span of time in southern Africa. The oldest of these intrusives is on the order of $3,050 \mathrm{~m} . \mathrm{y}$. old, 
while the youngest are some $2,550 \mathrm{~m} \cdot \mathrm{y}$. old (Anhaeusser, 1973). The climax of this intrusive episode occurred some 2,700 m.y. ago (Hunter, 1974).

In composition, the intrusives under discussion range from true granites to granodiorites and quartz monzonites. Many of these granitic stocks have relatively high ${ }^{87} \mathrm{Sr} /{ }^{86} \mathrm{Sr}$ initial ratios, indicating derivation from older crustal rocks (Hunter, 1974).

\section{Evolution of Archean Cratons}

Most Archean cratons appear to have evolved along fairly orderly lines. In that these cratons supplied the sediments which filled the basins that contain uraniferous quartz-pebble conglomerates, a brief review of their evolution is relevant.

In most cratons, the oldest rocks are known to be high-grade gneisses and metasediments. In places, greenstone belts can be shown to rest nonconformably on a high-grade basement. In most greenstone belts, however, contact relations with gneisses have been destroyed by the intrusion of a series of diapiric tonalite plutons along the margins of greenstone belts. Isotopic and rare earth element fractionation patterns indicate that some of the diapirs were derived by direct melting of upper mantle materials, while in others, melting of lower crustal material is indicated (Hunter, 1974).

Somewhat later in time, granitic rocks were emplaced at relatively high tectonic levels. The earliest of these are some $3,070 \mathrm{~m} \cdot \mathrm{y}$. old and were apparently derived by partial melting of older tonalitic gneisses (at depths on the order of 20 to $25 \mathrm{~km}$; Hunter, 1974) or of upper mantle materials at greater depths (Robb, 1978).

Most authors (for example, Kröner and others, 1973) belleve that the sequence of magmatic events outlined above resulted in thickening and stabilization of the crust. A stable crust was necessary for the formation of the cratonic sedimentary basins which contain uraniferous conglomerates. The sequence of magmatic events also resulted in the enrichment of the upper crust in elements such as uranium, thorium, and the rare earths. Such a step appears to be necessary for the development of uraniferous conglomerates in the late Archean and early Proterozoic basins.

\section{Concept of a Layered Crust}

A consequence of research in Archean cratons over the last 20 years has been the development of convincing evidence of the layered structure of the continental crust. The consensus of opinton, as expressed by windley (1977) and Hunter (1974), is that the deepest crustal layers are composed of relatively old to very old upper amphibolite- or granulite-grade gnelsses, with some metasediments. These rocks have been subjected to temperatures at which partial melting takes place. They have been stripped, to varying degrees, of their low-melting fraction. The mobilisate from these high-grade regions was emplaced as granitic intrusives at higher tectonic levels (Figure 11). The granitic melts can be expected to have been enriched in elements such as uranium and thorium (Gabelman, 1977, p. 44). 


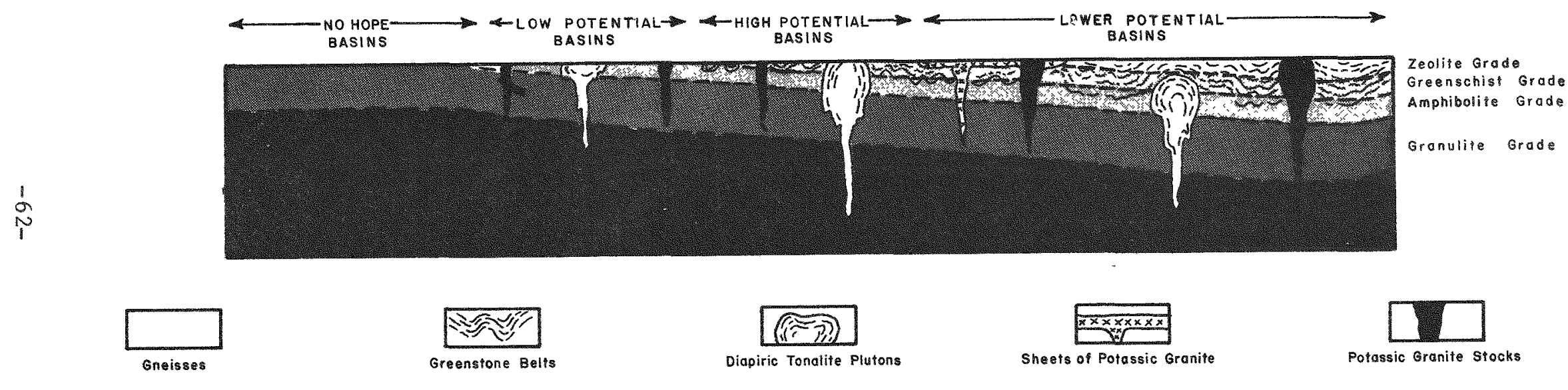

Figure 11. Schematic cross section through an Archean craton, showing relations of high-grade terrane, greenstone belts and granitic intrusives, and the uranium potential of basins resting on various units of the craton. 
The granulite-grade crustal unit is inferred to be overlain by amphibolitegrade material. Greenstone belts were formed on such a basement, but relations were subsequent1y largely obscured by deformation within greenstone belts and by intrusion of the tonalitic diapirs and granitic plutons, stocks, and plugs. The greenstone belts are usually only weakly metamorphosed, confirming the fact that they represent the highest tectonic levels of the Archean cratons.

The layered crust described above can be inferred to have been warped to varying degrees, the high-grade zones being brought to relatively shallow depths along areas of uplift. Subsequent erosion exposed high-grade zones to surface in certain areas, while the higher tectonic levels, including greenstone belts and potassic granites, are preserved in others.

A corollary of the concept developed above is that uranium and 1ithophile elements will be concentrated at relatively high tectonic levels. Subsequent erosion of high-level crustal material constitutes the most $11 \mathrm{kely}$ source for uranium in quartz-pebble conglomerates.

Tectonic Setting of Basins Containing Quartz-Pebble Conglomerate Uranium Deposits

A review of basins containing economic uraniferous conglomerates indicates that they all rest on the upper levels of the layered crust, as outlined above. A semiquantitative assessment of crustal level can be made from the relative size and metamorphic grade of greenstone belts in a particular area. For example, in eastern Brazil, the Saõ Francisco Craton is composed largely of gneisses, with a rather high percentage of high-grade gneisses (Cordani and others, 1968; De Sá and others, 1976). There are no large greenstone belts in this area. Small greenstone remnants are preserved in parts of the shield, most of them being of amphibolite-grade material.

By contrast, cratons such as those of Zimbabwe (Rhodesia) and Canada comprise very large areas of greenstone belts, some of them at zeolite grades of metarnorphism. These areas are considered to represent the highest tectonic levels in the Archean crust.

It is thought that the level of erosion within Archean cratons is of great importance to the uranium potential of basins resting on those cratons. Those basins resting on very deeply eroded crust are filled with sediment derived from a uranium-depleted level. Consequently, their uranium potential is considered to be rather low.

By contrast, the basement in the Witwatersrand and Elliot Lake areas appears to Indicate erosion of a shallower crustal level. Greenstone remnants, measuring a few tens of kilometers in size, are preserved immediately below the basins, and high-level potassic granites are found in the same general vicinity (Roscoe, 1969; Hunter, 1974; Robertson, 1978). Erosion to about this level appears to be most favorable for the development of uraniferous conglomerates since the uppermost levels of the potassic granites can be inferred to have been removed by erosion. 
In areas where greenstone belts are very extensively preserved, such as in the Pilbara Block of western Australia, the potential for the development of uraniferous conglomerates could be somewhat lower. None of the uraniferous conglomerates developed in this area have been shown to be payable. It may be that there was simply not enough erosion of high-level granitic rocks to supply the requisite uranium to the basin.

\section{Summary}

Archean cratons are composed of a layered crust comprising deep-level granulite-grade gneisses, intermediate-level amphibolite-grade gneisses with small greenstone relicts, and shallow-level greenstone belts and associated potassic granites. Those Archean and early Proterozoic basins resting on a high-grade basement are considered to have a very low potential for the development of uraniferous conglomerates. Those resting on amphibolitegrade basement with minor greenstone belt remnants have a low potential. The highest potential appears to coincide with those situations where erosion has proceeded to the extent that relatively small (on the order of a few tens of kilometers) greenstone relicts are preserved. Basins which rest on very extensively preserved greenstone belts appear to have a somewhat lower potential.

The tectonic filter applied in the search for uraniferous quartz-pebble conglomerates should first eliminate all areas which do not have (or cannot be inferred to have) an Archean basement. A secondary filter could be applied to eliminate from consideration those basins resting on a high-grade basement and to downgrade those resting on either an amphibolite-grade gneissic terrane or on a basement where there is very extensive preservation of greenstone belts. Where basement is well exposed adjacent to a basin of the appropriate age and general character, airborne gamma spectrometric and regional geochemical studies can be used to further define favorable source areas. 
The notion that basins containing uraniferous conglomerates were deposited over a rather restricted span of geologic time has become firmly entrenched (see, for example, D.S. Robertson and others, 1978). If this concept can be substantiated, it provides a very powerful tool for discriminating between basins with high and low potential for conglomerate-hosted uranium deposits in previously unexplored or underexplored areas. The review of geochronologic data presented below serves to test the validity of the concept of a late Archean to early Proterozoic uraniferous conglomerate metallogenic epoch. The review concentrates on producing areas in South Africa and Canada, but other occurrences are also considered.

\section{South Africa}

Uraniferous conglomerates are found over a very wide time span in South Africa from approximately $2,300 \mathrm{~m} . \mathrm{y}$. to over $3,000 \mathrm{~m} \cdot \mathrm{y}$. ago. The economically important occurrences are in basins ranging in age from about 2,800 to 2,650 m.y. The occurrences and the ages of the enclosing sediments are described below, starting with the oldest.

\section{Moodies Group}

Uraniferous conglomerates have been discovered in sediments of the Moodies Group in the Barberton Mountainland, eastern Transvaal (Thiel and others, 1979). The occurrence has not been evaluated; its size and potential are present1y unknown. The Moodies Group is the youngest unit in the Barberton greenstone belt. In places, it rests on volcanic rocks of the Onverwacht Group which contains felsic lavas dated at 3,360 $\pm 100 \mathrm{~m} \cdot \mathrm{y}$. (Van Niekerk and Burger, 1969). The Moodies Group is older than post-tectonic granites such as the Homogeneous Hood Granite $(3,070 \pm 60 \mathrm{~m} . \mathrm{y} . ;$ Allsopp and others, 1962) and the Salisburykop Pluton $(3,060 \pm 30 \mathrm{~m} . \mathrm{y} \cdot$; Oosthuyzen, 1970). The Moodies Group is thus bracketed between about 3,060 and $3,360 \mathrm{~m} \cdot \mathrm{y}$.

\section{Uitkyk Formation}

Auriferous conglomerates have been worked on a modest scale from the Uitkyk Formation, the uppermost sedimentary formation of the Pietersburg greenstone belt, located in the northern Transvaal. A recent mineralogical investigation of the conglomerates resulted in the identification of brannerite as a minor phase in the conglomerate matrix (Saager and Muff, 1978). Although the Uitkyk Formation has not been dated, its stratigraphic setting indicates an age probably in excess of $3,000 \mathrm{~m} . \mathrm{y}$.

\section{Mozaan Subgroup}

The Mozaan Subgroup is the upper sedimentary assemblage of the Pongola Group which is developed in the southeastern parts of the Transvaal and adjoining areas of Natal and Swaziland. The Pongola Basin rests on granitic rocks dated at $3,060 \mathrm{~m} \cdot \mathrm{y}$. by the $\mathrm{Rb} / \mathrm{Sr}$ whole rock method (Hunter, 1974). The lower 
Insuzi Subgroup of the Pongola Group has yielded a U/Pb age on zircons from lavas of $3,090 \pm 90 \mathrm{~m} . \mathrm{y}$. (Burger and Coertze, 1973) and $\mathrm{a} \mathrm{Rb} / \mathrm{Sr}$ whole rock age of $3,150 \pm 100 \mathrm{~m} . \mathrm{y}$. on felsic lavas from Swaziland.

The Pongola succession is intruded by differentiated sills of the Usushwana Complex, dated at $2,874 \pm 30 \mathrm{~m} . \mathrm{y}$. by the $\mathrm{Rb} / \mathrm{Sr}$ whole rock method (Davies and others, 1969). The auriferous-uraniferous conglomerates of the Denny Dalton Mine, located stratigraphically at the base of the Mozaan Subgroup, are thus bracketed between 2,874 and about 3,060 to 3,150 m.y. The Denny Dalton conglomerates were mined for gold on a sma11 scale in the past. They are being actively re-assessed for their gold and uranium content by a program of close-spaced core drilling.

Dominion Reef Group

The Dominion Reef Group rests nonconformably on an Archean granitic basement and is overlain by lower units of the Witwatersrand Supergroup. It is developed in the Klerksdorp area of the western Transvaal. The basal arenites of the group contain auriferous-uraniferous conglomerates, which have been exploited on a modest scale in the past. An extensive prospecting program (142 cored holes, cumulative depth 67,000 meters) has revealed "fairly extensive deposits of uranium of good grade" (Von Backström, 1976).

The Dominion Reef Group rests on a granitic basement. Allsopp (1964, p. 363) determined that the granite, about $1 \mathrm{~m}$ below the base of the Dominion Reef Group, yielded an age of $2,820 \pm 55 \mathrm{~m} . \mathrm{y}$. (Rb/Sr whole rock, assumed initial ratio). Since granite at such a depth below an unconformity has usually suffered paleoweathering, this age is considered to be a minimum for the granite. Pretorius (1976) quotes a 3,100 $\pm 100 \mathrm{~m} \cdot \mathrm{y} \cdot \mathrm{U} / \mathrm{Pb}$ date and a 2,900 \pm $50 \mathrm{~m} . \mathrm{y} . \mathrm{Rb} / \mathrm{Sr}$ date on granitic rocks below the Dominion Reef. Van Niekerk and Burger (1978) reviewed geochronological information from the western Transvaal and gave an age range of 2,820 to $3,100 \mathrm{~m} . \mathrm{y}$. for the Archean granitic basement. Dominion Reef lavas have been directly dated at 2,800 \pm $60 \mathrm{~m} . \mathrm{y}$. by the U/Pb method (Pretorius, 1976).

Witwatersrand Supergroup

The age of the Witwatersrand Supergroup can presently only be established by bracketing between over- and underlying successions. It rests on the 2,800 \pm $60 \mathrm{~m} . \mathrm{y}$. old Dominion Reef lavas (see previous section). The Witwatersrand sequence is unconformably overlain by the Ventersdorp volcanic succession. These volcanics were considered to be 2,300 m.y. old (Van Niekerk and Burger, 1964). Recent work on zircons from felsic lavas in the Ventersdorp has resulted in a revised date of $2,643 \pm 80 \mathrm{~m} . \mathrm{y}$. (Van Niekerk and Burger, 1978). The interpretation of this age is open to question, since some or all of the zircons could have been magmatically reworked from older basement rocks.

Allsopp (1964) dated a granitic rock below the Witwatersrand at 2,720 \pm $100 \mathrm{~m} . \mathrm{y}$. ( $\mathrm{Rb} / \mathrm{Sr}$ whole rock, assumed initial ratio). The age of the Witwatersrand could thus be bracketed between 2,643 and $2,720 \mathrm{~m} . \mathrm{y}$. In view of the uncertainties inherent in the assumption of an initial ${ }^{87} \mathrm{Sr} /{ }^{86} \mathrm{Sr}$ ratio, the older Dominion Reef age is preferred, and a range of 2,643 to 2,800 m. y. is considered to be the most realistic one for the Witwatersrand. 


\section{Ventersdorp Supergroup}

The basal conglomerate of the Ventersdorp Supergroup (the Ventersdorp Contact Reef) is both auriferous and uraniferous in parts of the Witwatersrand Basin. To date, it has not been mined for uranium. The conglomerate is probably somewhat older than $2,643 \pm 80 \mathrm{~m} . \mathrm{y}$. , since it underlies the felsic lavas dated by Van Niekerk and Burger (1978).

Transvaa1 Supergroup

This basin contains auriferous-uraniferous conglomerates in the Black Reef Quartzite which is the basal formation of the Transvaal Supergroup over much of its extent (Papenfus, 1964; De Waal and Herzberg, 1969). The conglomerates have been mined for gold, pyrite, and platinoids but have thus far not been exploited for uranium.

The Transvaal Supergroup rests on volcanic rocks dated at 2,460 $\pm 120 \mathrm{~m} . \mathrm{y}$. $(\mathrm{U} / \mathrm{Pb}$ on zircon, Coertze and others, 1978). Volcanics well above the Black Reef conglomerate have been dated at $2,224 \pm 21 \mathrm{~m} . \mathrm{y}$. by the $\mathrm{Rb} / \mathrm{Sr}$ whole rock method (D. Crampton, verbal communication, 1972). Associated shales have been dated by the same method at 2,263 $\pm 85 \mathrm{~m} . \mathrm{y}$. (Hamilton, 1976). The Transvaal Supergroup definitely predates the basic phase of the Bushveld Complex, dated at $2,095 \pm 24 \mathrm{~m} \cdot \mathrm{y}$. by the $\mathrm{Rb} / \mathrm{Sr}$ whole rock method (Hamilton, 1976).

Younger Basins

Several post-Bushveld Complex basins are developed in South Africa. These include the Waterberg and Soutpansberg successions, which contain abundant conglomerates and red-colored sandstones, but no conglomerate-hosted uranium deposits. The Waterberg is at least $1,790 \pm 70 \mathrm{~m} . \mathrm{y}$. old, since it is intruded by granitic rocks of that age (Oosthuyzen and Burger, 1964).

\section{North America}

Huronian, Elliot Lake District

The uraniferous conglomerates of the Elliot Lake District, Ontario, Canada, have been estimated to contain 1,000 million pounds of recoverable uranium metal (D.S. Robertson and others, 1978). This district constitutes one of the largest known uranium reserves on Earth.

The conglomerates form part of the Matinenda Formation of the Elliot Lake Group. This assemblage rests on an Archean basement of gneiss, granite, and greenstone belts. Granitoid rocks in the basement ("Algoman granites") have been dated at around 2,500 m.y. (Van Schmus, 1965; Wanless and others, 1965). The Huronian strata have been dated in places. Volcanics below the Matinenda are 2,400 m.y. old (Fairbairn, 1965; Fairbairn and others, 1969). The Gowganda Formation, stratigraphically above the uraniferous conglomerate, has been dated at 2,288 m.y. (Fairbairn and others, 1969).

The Huronian succession has been intruded by a suite of basic rocks known collectively as the "Nipissing Diabase". This suite has been dated at 2,155 
$\pm 80 \mathrm{~m} \cdot \mathrm{y}$. by the $\mathrm{Rb} / \mathrm{Sr}$ whole rock method (Van Schmus, 1965). Leads in galenabearing silver veins which cut the diabase have mode1 ages of $2,200-2,300 \mathrm{~m} \cdot \mathrm{y}$. (Roscoe, 1969), while biotites in the diabases are $2,100 \mathrm{~m} \cdot \mathrm{y}$. old (K/Ar method; Roscoe, 1969).

The Matinenda is constrained in the bracket 2,155-2,500 m.y. The upper age limit $\left(2,155 \mathrm{~m} \cdot \mathrm{y}_{\bullet}\right)$ is a $\mathrm{Rb} / \mathrm{Sr}$ date. Frequently, U/Pb dates on zircons from the same rocks are older by up to several hundred million years. It is thought that diabases could well be somewhat older than $2,155 \mathrm{~m} \cdot \mathrm{y}$. and that the age of the Matinenda will be found to lie closer to 2,500 m.y. than to the $2,155 \mathrm{~m} \cdot \mathrm{y} \cdot 1$ imit.

Sakam1 Lake

Uraniferous pyritic conglomerates rest directly on the Archean basement west of Sakami Lake in northern Quebec (Figure 2). The conglomerates were deformed by the Kenoran orogeny and are thus at least 2,500 m.y. old (D.S. Robertson, 1974). According to J.A. Robertson (written communication, 1980), the Sakami Lake conglomerates are now considered to be Proterozolc in age.

Montgomery Lake - Padlei Area

Uraniferous-auriferous pyritic conglomerates rest directly on the Archean basement in this area (Figure 2), located west of Hudson Bay (D.S. Robertson, 1974). The Archean basement includes granitic rocks dated at 2,500 m.y. (Be11, 1970). The conglomerates form part of the Montgomery Lake Series which was deformed by the Hudsonian orogeny, some $1,800 \mathrm{~m} \cdot \mathrm{y}$. ago.

Black Hills Area

Uraniferous pyritic conglomerates were discovered in the Nemo area of the Black Hills, South Dakota, in 1977 (Hills, 1977; 1979). The sedimentary pile containing the conglomerates rests on a suite of Archean granitic rocks dated at 2,500 m.y. (Zartman and Stern, 1967). The sediments are intruded by a basic differentiated sill, zircons from which have given $a^{207} \mathrm{~Pb} / 206 \mathrm{~Pb}$ age of $2,090 \pm 10 \mathrm{~m} \cdot \mathrm{y} \cdot($ Redden, 1980).

Mediclne Bow Mountains and Sierra Madre

The Phantom Lake Suite and the Deep Lake Group crop out in these ranges, located in south-central Wyoming. Both units contain uraniferous pyritic conglomerates. The Phantom Lake Sulte and the Deep Lake Group both rest on the Archean basement, which is some $2,500 \mathrm{~m} \cdot \mathrm{y}$. old in this area (Karlstrom and Houston, 1979a). They predate a magmatic-metamorphic event dated at $1,700 \mathrm{~m} \cdot \mathrm{y}$. (Hills and others, 1968). The upper age 1imit of 1,700 m.y. 1s unrealistically young. It is anticipated that direct dating of the sediments and of basic sills will yield dates older than $2,000 \mathrm{~m} \cdot \mathrm{y}$.

\section{South America}

Uraniferous conglomerates have been discovered in a number of locations in eastern Brazil, in sedimentary rock successions which rest unconformably on the Archean Saõ Francisco Craton. 
$\underline{\text { Jacobina }}$

Auriferous-uraniferous conglomerates occur near the base of the Jacobina Series, in Bahia, Brazil. The sediments rest nonconformably on parts of the Saó Francisco Craton. Early work showed that the basement of the craton is at least 2,000 m.y. old (Cordani and others, 1968). Almeida and others (1972) assigned an age of approximately 2,000 m.y. to the Jacobina Group. In an unpublished manuscript, De Sá and others (1976) showed that the Jacobina sediments rest on gneisses of the Caraiba Complex, which they dated at $2,600 \mathrm{~m} \cdot \mathrm{y}$. The sediments are intruded by the 2,000-m.y.-old Campo Formoso Granite.

The geochronological framework for the Jacobina conglomerates is still rather loose, but their age appears to be confined within a 2,000-2,600 m.y. bracket.

Quadrilatero Ferrifero

The Minas Group contains auriferous-uraniferous conglomerates in the vicinity of Belo Horizonte, in the Quadrilatero Ferrifero of Minas Gerais (McNeil, 1980). The Bacão gneissic complex predates the Minas Group and has an age $(\mathrm{Rb} / \mathrm{Sr}$ whole rock) of some $2,800 \mathrm{~m} . \mathrm{y}$. (Herz, 1970). The Minas sediments also rest on Rio das Velhas metasediments, muscovites from which have been dated at $2,700 \mathrm{~m} . \mathrm{y}$. by the $\mathrm{Rb} / \mathrm{Sr} \operatorname{method}(H e r z, 1970$ ). The younger limit on the age of the uraniferous conglomerates has not been well established. In that they underlie thick and extensive iron-formations, it is thought that they will eventually be found to predate $2,000 \mathrm{~m} . \mathrm{y}$., the age of the youngest widespread iron-formation.

\section{Other Areas}

The basal Minas Group conglomerates are uraniferous in other areas of Minas Gerais. D.S. Robertson (1974) mentioned occurrences in the Pitangui area, northwest of Belo Horizonte. Radioactive grits and conglomerates are also developed near Conceicao do Mato Dentro, $110 \mathrm{~km}$ north-northeast of Belo Horizonte (Button, unpublished information, 1976).

\section{Australia}

\section{Hamersley Basin}

Low-grade pyritic auriferous-uraniferous conglomerates are known from the Hamersley Basin, in the northern part of Western Australia (D.S. Robertson, 1974). Sediments of the Hamersley Basin postdate a suite of younger Archean granites, one of which has been dated at 2,670 $195 \mathrm{~m} . \mathrm{y}$. (De Laeter and Blockley, 1972). Granophyric intrusives within the lower units of the basin have been dated at 2,196 $\pm 26 \mathrm{~m} . \mathrm{y}$. (De Laeter and Trenda11, 1971). These same rocks have been dated at $2,768 \pm 24 \mathrm{~m} . \mathrm{y}$. by the $\mathrm{U} / \mathrm{Pb}$ method applied to zircons (M.R. Walter, personal communication, 1980). Since these zircons may have been magmatically reworked from older rocks, the validity of this date is in question. Recently, a date of $2,490 \pm 30 \mathrm{~m} . \mathrm{y}$. ( $\mathrm{U} / \mathrm{Pb}$ on zircon) has been determined for the Dales Gorge Member of the Brockman Iron Formation, and basic sills intrusive into upper units in the Hamersley Basin have been dated at 2,350 m.y. by the Rb/Sr method (James and Trendall, in press). 
Since the iron-formation overlies the uraniferous conglomerates, their age is bracketed between 2,490 and $2,670 \mathrm{~m} \cdot \mathrm{y}$.

Asia and Europe

Bababudan Group

Uraniferous-auriferous conglomerates are developed in parts of the Bababudan Group in the Dharwar Supergroup on the Karnataka Craton of India (Figure 2). The conglomerates rest nonconformably on an older Archean basement (Viswanatha and others, 1977) including units such as the Peninsula Gneiss, dated in the range 2,500 to $2,700 \mathrm{~m} . \mathrm{y}$. (Radhakrishna and Vasudev, 1977). The Dharwar Supergroup is intruded by the Closepet Granite, dated at 2,380 m.y. by Crawford (1969) and at 2,000 $\pm 80 \mathrm{~m} \cdot \mathrm{y}$. by Venkatasubramanian (1974).

\section{$\underline{\text { Krivoy Rog Group }}$}

Auriferous pyritic conglomerates occur locally at the base of the Krivoy Rog Group on the Ukrainian Shield. They contain syngenetic uranium-bearing pyrite grains which give $\mathrm{Pb}$ isotopic ages of 2,600 to 2,700 m.y. (Salop, 1977). The Krivoy Rog Group postdates the greenstone belts and intrusive granitoid domes, the latest of which were emplaced some 2,500 m.y. ago (Salop, 1977). The Krivoy Rog sediments are unconformably overlain by the Frunze Mine Group. Metamorphic minerals from the latter formation have been dated in the range from 1,700 to $2,000 \mathrm{~m} . \mathrm{y}$. The Krivoy Rog sediments are thus rather 100 sely bracketed between 2,000 and $2,500 \mathrm{~m} \cdot \mathrm{y}$.

\section{Karelian Supergroup}

There are a number of reported occurrences of pyritic uraniferous-auriferous conglomerate in the Karelian Supergroup of Finland and the adjoining areas of the U.S.S.R. The Karelian rests non-conformably on granitic rocks dated at $2,500 \mathrm{~m} . \mathrm{y}$. in Finland and at 2,600 m.y. in the U.S.S.R. (Gaál and others, 1978; Salop, 1977). The Karelian is intruded by a suite of basic dykes, emplaced some 2,000 to 2,150 m.y. ago (Wetherill and others, 1962; Salop, 1977).

\section{Summary of Ages of Basins Containing Uraniferous Conglomerates}

This worldwide survey of radiometric ages of basins containing uraniferous pyritic conglomerates suggests that there is indeed a very definite limit to the distribution of these deposits through geologic time. The ages of the basins are shown plotted in Figure 12.

The lower limit to the development of uraniferous conglomerates is timetransgressive, being 300 to $500 \mathrm{~m} \cdot \mathrm{y}$. older in southern Africa (and possibly western Australia) than elsewhere. Cloud (1976), in reviewing the tectonic and lithologic evolution of Precambrian rocks, recognized this local anomaly and termed it the "Zuluan Wedge". This period (3,000 to 2,500 m.y.) is characterized by "greenstone style" volcanism, sedimentation, and intrusion on all the major Precambrian shields except the Kaapvaal Craton in South Africa and, possibly, the Pilbara Block of Australia (Figure 13). Here, stable shelves promoted epeiric sedimentation from about $3,000 \mathrm{~m} \cdot \mathrm{y}$. on. Apparently these relatively stable conditions were necessary for the formation 


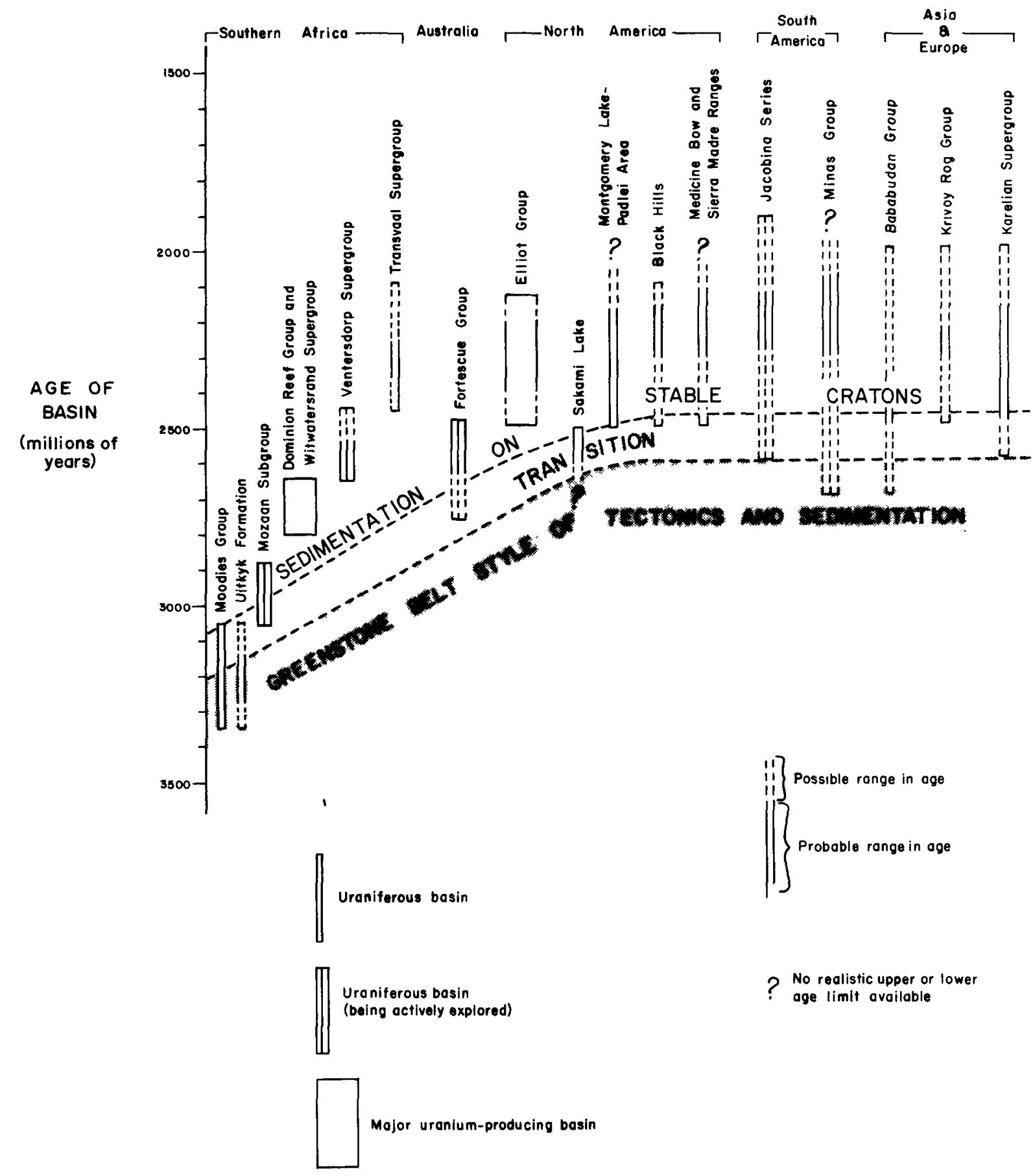

Figure 12. Schematic diagram illustrating the probable and possible range in age of basins containing uraniferous conglomerates. 
of uraniferous pebble conglomerates. In addition, the development of uraninite placers could not precede the evolution of granitic rocks rich enough in uraninite to act as source rocks (Figure 13).

The youngest uraniferous conglomerates appear to have formed no later than $2,000 \mathrm{~m} \cdot \mathrm{y}$. ago. If account is taken of the way basin ages are established by bracketing, the basins containing such conglomerates are probably at least $2,200 \mathrm{~m} \cdot \mathrm{y}$. old. This time coincides with the last development of major ironformations and the first development of large volumes of continental red-bed sediments (Cloud, 1976). The subject of paleoatmospheric evolution is addressed in a subsequent section and will not be discussed in detail here. The worldwide near-synchronous disappearance of uraniferous conglomerates and major iron-formations from the stratigraphic record and the first appearance of voluminous red-bed sediments certainly suggest a global event, such as a change in atmospheric composition.

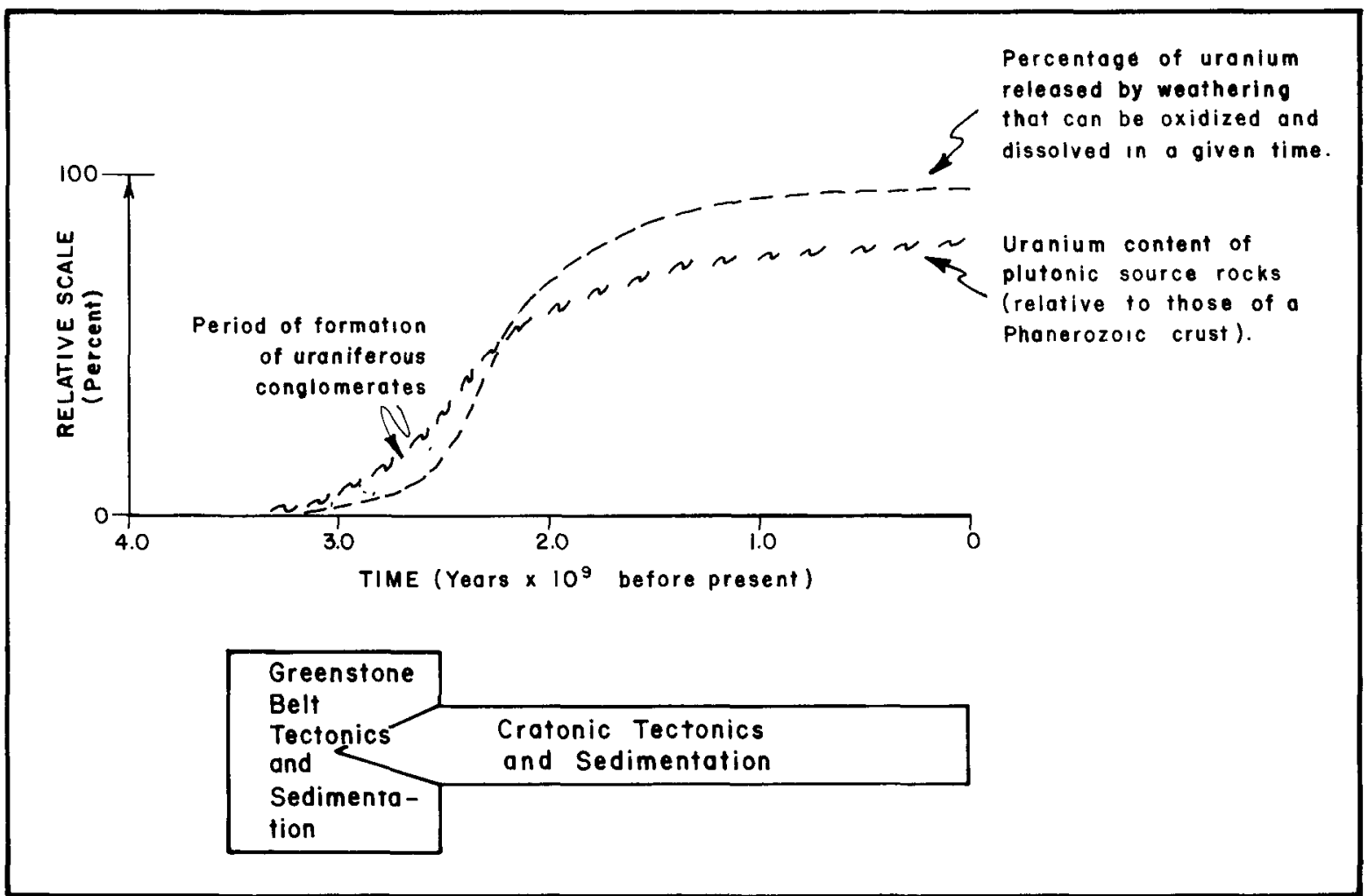

Figure 13. Schematic diagram 1llustrating the probable controls on the development of the uraniferous quartz-pebble conglomerate metallogenic epoch from 3,200 to $2,200 \mathrm{~m} \cdot \mathrm{y}$. ago. 
In summary, the uraniferous quartz-pebble conglomerate metallogenic epoch (Figure 13) is probably a response to:

(1) the development of continental nuclei on which fluvial depositional systems could become established;

(2) the development of granitic rocks rich enough in uranium to act as source rocks; and,

(3) the relative stability of uraninite as a detrital mineral, probably as a consequence of a lower oxygen content in the paleoatmosphere.

Ages of Uranium Minerals

The ages of uranium-bearing minerals in Precambrian conglomerates are significant for several reasons. First, if it can be shown that the uranium minerals are older than the rocks containing them, then the minerais must be detrital and can be inferred to have been eroded out of older rocks. Second, if the minerals are shown to be older than the containing rock, then the ages of the uranium minerals will provide a clue as to the identity of the uranium source.

The difficulties in dating minerals such as uraninite in 2,000 to 3,000 mil1ion year old sediments are formidable. Separation of pure fractions of uraniferous minerals posed major problems for earlier investigators. Loss of radiogenic lead can be confidently inferred by a study of radioactive minerals in the conglomerates. Uraninites normally contain a dusting of radiogenic galena which has not moved far from its site of formation. However, uraninite grains are usually cut by galena-filled fractures and are also surrounded by halos of radiogenic galena in many instances (Schidlowski, in press). Here, movement of radiogenic lead can be demonstrated over distances on the order of $0.1 \mathrm{~mm}$. "Secondary" galena is a fairly common constituent of Witwatersrand conglomerates and may well have been derived in part from radiogenic lead originally contained in uranium minerals. Finally, galena-bearing veins are not uncommon in the Witwatersrand and Elliot Lake districts (Feather and Koen, 1975; Roscoe, 1969) and could have had a simflar source.

Notwithstanding these difficulties, several authors have attempted to date uranium minerals in Precambrian conglomerates. The results are usually open to various interpretations.

\section{Krivoy Rog}

In the Krivoy Rog Group of the U.S.S.R., uraniferous pyrite grains have been isotopically dated at 2,600 to $2,700 \mathrm{~m} \cdot \mathrm{y}$. (Salop, 1977). Since the enclosing sediments are reckoned to be no older than $2,500 \mathrm{~m} \cdot \mathrm{y}_{\cdot}$, a detrital origin of the pyrite is suggested.

\section{Wi twatersrand Supergroup}

Pioneer attempts at dating Witwatersrand uraninites were undertaken by Louw (1954, 1955), who concluded that most Witwatersrand uraninites are 1,850 to $1,950 \mathrm{~m} \cdot \mathrm{y}$. old. Since, at that time, the Witwatersrand sediments were considered to be no older than about $1,000 \mathrm{~m} \cdot \mathrm{y} \cdot$, the uraninite ages were taken as indicative of a detrital origin of that mineral. 
Burger and others (1962) studied the lead isotopic compositions of Witwatersrand galenas and concluded that they contain part of the radiogenic lead lost by uraninite grains. Their data indicated that the probable age of crystallization of the uraninites was on the order of $3,000 \mathrm{~m} . \mathrm{y}$. In a companion paper, Nicolaysen and others (1962) presented evidence which suggested that the "radioactive minerals in the Dominion Reef have an age of crystallization close to 3,100 million years." Since the Dominion Reef Group strata are presently considered to be about $2,800 \mathrm{~m} . \mathrm{y}$. in age, these studies suggested a detrital origin of the Witwatersrand and Dominion Reef uraninite grains.

Rundle and Snelling (1977) presented new data and reinterpreted older information on the $\mathrm{U}-\mathrm{Pb}$ systematics of the Dominion Reef, Witwatersrand, and Ventersdorp conglomerates. They concluded that the uraniferous minerals in these successions are some $3,050 \pm 50 \mathrm{~m} . \mathrm{y}$. old. In the northern parts of the Witwatersrand Basin, the uraniferous minerals experienced a major reworking at $2,040 \pm 100 \mathrm{~m} \cdot \mathrm{y}$. This reworking brought about the partial or complete resetting of the original $3,050-\mathrm{m} . \mathrm{y}$. age. This period of reworking had 1ittle effect on the Welkom Goldfield at the southern end of the basin. Rundle and Snelling concluded from the location and timing of the resetting event that it was related to the intrusion of the Bushveld Complex at 2,095 $\pm 24 \mathrm{~m} \cdot \mathrm{y}$.

Feather (in press) reports the results of age determinations on single grains of uraninite, brannerite, and zircon from the Witwatersrand. The analyses were done using the ARL IMMA ion microprobe. ${ }^{207} \mathrm{~Pb} /{ }^{206} \mathrm{~Pb}$ ages for the uraninites studied average $1,770 \pm 60 \mathrm{~m} . \mathrm{y}$. Brannerite ages average $1,810 \mathrm{~m} . \mathrm{y}$. while zircon ages average $2,845 \mathrm{~m} . \mathrm{y}$. The uraninite and brannerite ages coincide fairly well with those originally inferred by Louw (1954). Feather concluded that the uraninite and brannerite ages reflect the resetting event related to the period of intrusion of the Bushveld Complex. The zircon ages could reflect the age of crystallization of the source rocks.

In summary, the ages of Witwatersrand radioactive minerals appear to be mainly in excess of $3,000 \mathrm{~m} . \mathrm{y}$. In the domain of the Bushveld Complex (mainly in the northern part of the Witwatersrand Basin), there has been partial or complete resetting of ages at approximately 1,800 to 2,000 m.y. ago. Radiogenic lead lost at this time is present as galena in Witwatersrand conglomerates and in veins which cut across Witwatersrand beds. In that the inferred ages of the primary uraniferous minerals are older than that of the sediments in which chey are now found, the conclusion has been drawn that the uraniferous minerals are mainly detrital.

\section{Huronian Occurrences}

Roscoe (1969) has reviewed the isotopic work undertaken on Huronian conglomerates. Detrital monazite and zircon have been dated at 2,500 and 2,450 m.y., respectively (Mair and others, 1960). Interpretations of $\mathrm{Pb}$ isotopic data from uraninites suggest an age no younger than $2,250 \mathrm{~m} \cdot \mathrm{y}$. The isotopic composition of some lead in the ores permits an interpretation that the uraninite may be as old as 2,600 m.y. (Roscoe, 1969). Since the Matinenda Formation could be as old as about 2,500 m.y., the isotopic dating of uraninites and other radioactive minerals in the range from 2,250 to $2,600 \mathrm{~m} . \mathrm{y}$. neither proves nor disproves a detrital origin for these minerals. 
STRATIGRAPHIC SETTING OF URANIFEROUS CONGLOMERATES

In the previous chapters, the tectonic and geochronologic setting of basins containing uraniferous conglomerates has been established. If these two "filters" are applied in the search for areas of development of uraniferous conglomerates, we are likely to be left with one or more sedimentary basins (with areas on the order of $10^{4}$ to $10^{5}$ square kilometers) in which to explore. To narrow the search area, a further set of geologic filters, related largely to stratigraphic relations, must be applied. Some of these filters relate to "extra-basina1" parameters, such as the character of the Archean basement in the immediate vicinity of the basins. Most of them are "intrabasinal" parameters, such as the presence of unconformities within tongues of fluvial sediment. These stratigraphic relations are examined in this chapter.

Sources of Sediments and Uranium

The recognition of probable sources of sediments and of uranium in basins containing Precambrian conglomerates is of potential importance and may allow us to select certain basins as being more prospective than others. Consequently, this section is devoted to reviewing the probable sources of the sedimentary fill (including the uranium fraction) of such basins.

\section{Sources of Sediments}

The character of the host sediments in the Elliot Lake and Witwatersrand basins will be discussed in detail in a subsequent section. Briefly stated, the dominant attributes of the host arenites are their medium- and coarseto very coarse-grained character and their textural and lithological immaturity. The average Witwatersrand arenite is a quartz wacke with some 20 percent of the rock being composed of a sericitic matrix. Elliot Lake host rocks are arkosic wackes with 5 to 25 percent sericitic matrix.

Canadian geologists (Pienaar, 1963; Roscoe, 1969; J.A. Robertson, 1976) have been impressed by the similarity of the lithology of the uranium-bearing Matinenda Formation and the underlying granitic paleosols. The mineralogical and geoch.mical characteristics of the two are very similar, both being composed of quartz, sericite, some chlorite, and varying amounts of $\mathrm{K}$ feldspar. The fact that the sediments contain a little less sericite than the paleosols has been interpreted as due to sediment sorting of eroded paleosol material before its final deposition. Chert grains, which compose about 2 percent of the arenites, were almost certainly derived from cherty units in the underlying greenstone belts.

Uraniferous conglomerates of the Dominion Reef Group in South Africa have a very similar stratigraphic setting. In this area, once again, it was quite obvious that the host arenites represent stripped paleosols (since paleoweathered granitic rocks directly underlie the Dominion Reef basal unconformity).

The uraniferous-auriferous sediments of the upper division of the Witwatersrand Supergroup do not rest directly on the older basement. The similarity of 
these quartz-sericite wackes to paleosols was thus not as evident as it was in the examples mentioned above. Some authors (for example, Fuller, 1958) suggested that the sericite in upper Witwatersrand arenites was formed by post-depositional "hydrothermal" alteration of feldspars in the arenites. By analogy with the Elliot Lake, Dominion Reef, and several other examples, there can no longer be any serious doubt that the Witwatersrand quartz wacke represents a stripped and redeposited paleosol. The aluminous minerals in upper Witwatersrand arenites and the associated shale partings (pyrophyllite, chloritoid) support this notion. They probably represent the diagenetic or low-grade metamorphic equivalents of aluminous clay minerals formed by intense weathering.

The ultimate source of the fluvial arenites in basins such as the Witwatersrand is thus logically Archean granite and gneiss with a smaller contribution coming from Archean greenstone belts. It has, however, been established in numerous examples, especially in South Africa, that sedimentary successions supply some of the sediment to younger, unconformably overlying successions. Thus, the Main Reef Leader conglomerate sheet of the East Rand has been shown to have been derived in part by reworking of "footwall beds". Similar relations have been observed or inferred for nearly all the sheet-like conglomerates of the Witwatersrand Basin. Older sediments can thus be the sources of younger formations. This recycling effect has been shown in some cases to cause a concentration of gold, uranium, and pyrite in the younger sediments (De Jager, 1964; Armstrong, 1968).

Conglomerate clasts give some indication of the source of sediments. However, the impression gained is probably biased since the clasts in the uraniferous conglomerates are usually composed of the most resistant types. The clast assemblage is discussed in detail elsewhere in this report. The lowermost, non-economic Matinenda conglomerates comprise clasts of metavolcanics, chert, quartz, quartzite, and some granite. The economically important conglomerates are dominated by vein-quartz clasts. The volcanic, chert, and quartzite pebbles were probably derived from greenstone belts, the quartz pebbles from vein systems in greenstone belts and the granitic basement.

Witwatersrand conglomerates are composed mainly of pebbles of quartz (white, smokey gray, or opalescent) and chert (dark gray massive, gray banded, green banded, and red banded). Lesser amounts of quartzite, "quartz porphyry", and silicified shale, and very small amounts of serpentinite, talc schist, and chlorite schist are represented. Witwatersrand pebbles are consistent with the concept of an Archean granite and greenstone belt source. The quartz clasts could have been derived from veins in both granites and greenstone belts. The chert, quartzite, quartz porphyry, serpentinite, talc, and chlorite schists were almost certainly derived from greenstone belts. Shaly clasts are known to have an intrabasinal source, representing rip-up clasts derived from shaly partings in Witwatersrand arenites.

\section{Source of Uranium}

There are severe problems associated with attempts aimed at identifying the source (or sources) of uranium in Precambrian quartz-pebble conglomerates. The very presence of a placer or paleoplacer deposit implies destruction, to 
varying degrees, of the source rock. Therefore, the lack of a readily identifiable source of heavy mineral grains in placer deposits should not be regarded as too surprising.

There are several approaches to the problem of identifying the source of uranium in Precambrian conglomerates. One approach is the study of the characteristics of the uraninite and associated heavy mineral grains. Another approach is to study the known geology of the rocks inferred to have been the source areas for basins containing uraniferous conglomerates.

Nature of Uranium Minerals

Uranium mineralogy is reviewed at length in a subsequent chapter of this report. At this point, all that is necessary is to stress that the dominant primary uranium mineral in quartz pebble conglomerates is usually thorian uraninite, containing from about 2 to 12 percent $\mathrm{ThO}_{2}$ (Roscoe, 1959a; Patchett, 1960; Thorpe, 1963; Grandstaff, 1974b). The uraninite grains contain variable proportions of rare earth elements often totaling on the order of 2 to 4 percent (Liebenberg, 1955; Theis, 1979). The elements 1isted all have disparate geochemical behaviors in low-temperature systems (Theis, 1979) but are characteristically associated with one another in pyrogenetic sources, such as granites and granite pegmatites (Fronde1, 1958, p. 16-20). Robertson (1978), for example, has described uraninite-bearing pegmatites in the Archean of the Wabigoon Subprovince of the Superior Province in northwestern Ontario. There can be no serious doubt that conglomeratehosted uraninite grains are detrital and that they were derived from a granitic source. This conclusion is supported by the associated heavy minerals in many cases. The Dominion Reef conglomerates in South Africa are associated with heavy minerals such as monazite, cassiterite, euxenite, and columbite, all typical of the pegmatitic setting (Hiemstra, 1968a).

The physical characteristics of uraninite grains in the conglomerates are also pertinent. The grains are very small, usually on the order of $0.1 \mathrm{~mm}$ in diameter. Moreover, the grains are very well size sorted. By contrast, the uraninite contained in some pegmatites occurs in larger crystals, frequently several centimeters in size (Frondel, 1958, p. 43). The small, well-sorted grains of uraninite in Precambrian conglomerates could have been formed by fragmentation and abrasion of larger uraninite crystals. An equally plausible explanation is that the uraninite grains occurred more or less in their present size as a widely dispersed phase through high-level, highly differentiated granites.

There is a range of secondary uranium-bearing phases in quartz-pebble conglomerates. The most important of these are uranium-titanium complexes. Most authors believe that these formed by diagenetic or metamorphic dissolution of uraninite, transport of uranium over short distances (on the order of 10 to $10^{3} \mathrm{~cm}$ ), and reaction of this uranium with titania skeletons produced by diagenetic dissolution of Fe-Ti phases. If this is the only method of formation of U-Ti complexes, then such complexes will only be found in association with uraninite-bearing conglomerates. However, it is also shown in a subsequent section of this report that Archean and early Proterozoic paleoweathering removed (in solution) from 30 to 60 percent of the uranium from Archean uraniferous granites. The uraniferous paleo-ground waters so 
produced may well have flowed through conglomeratic aquifers and could have reacted with titania skeletons to produce U-Ti phases. It is thus conceivable that some uraniferous conglomerates may never have contained detrital uraninite. This may well be the case in uraniferous conglomerates of the Black Hills in which no uraninite is present (Kim, 1979; Redden, 1980).

In summary, it appears that high-level, highly differentiated uraniferous granites or granite pegmatites are the most likely sources of the uraninite and of the uranium in Precambrian quartz-pebble conglomerates.

\section{Source Area Characteristics}

Given the strong evidence for a pyrogenetic source of uraninite in Precambrian conglomerates, it is appropriate to look at the basement rocks around wellstudied and well-preserved basins for evidence of uraniferous granites or pegmatites. Despite the numerous studies undertaken on the Witwatersrand Basin (sensu stricto), this is not a basin in which we are likely to have success in attempting identification of a uranium source. First, the uranium-bearing conglomerates in this basin are not in contact with Archean granitic rocks, being separated from them by several thousands of meters of barren, lower Witwatersrand sediments. Second, only about 10 percent of the perimeter of the Witwatersrand basin crops out, the remainder being covered by younger formations. The chances of identifying the source rocks in this basin are thus small.

A more favorable situation exists in the case of the Matinenda conglomerates of Ontario and the Dominion Reef conglomerates in South Africa, where the uraniferous formation rests directly on an older basement.

Hunter (1974) has reviewed the distribution and ages of granitic rocks of the Kaapvaal Craton in southern Africa. He showed that granitic rocks developed in the area around the Dominion Reef conglomerate occurrences are of two types, one emplaced at about 3,000 m.y., the other at about 2,700 m.y. Preliminary work on the granitic rocks below the Dominion Reef Group has shown that there are two types of granitic rock, one of which is coarse grained, pink. in color, and contains on the order of $10 \mathrm{ppm} U$. The one suite of samples studied in detail comprises quartz monzonite, made up of quartz, microcline, and partially sericitized plagioclase. It is characterized by both perthitic and myrmekitic intergrowths (Van Valkenburgh, 1979). It seems probable that the upper tectonic levels of this granitic rock provided the uraninite now present in the Dominion Reef conglomerates.

The best documented relation of uraniferous conglomerates to their probable source is found in the Elliot Lake district. Roscoe (1969) and J.A. Robertson (1978) have published maps of the pre-Huronian geology, based on surface mapping and subsurface exploration. Roscoe's map (reproduced in Figure 22 of this report) shows a number of stocks of "massive red granitic rocks" intrusive into gray granodiorites and into greenstone belt remnants. He has shown that these granitic stocks formed paleotopographic highs adjacent to paleovalleys, the latter underlain by the greenstone belts. The spatial arrangement of the major orebodies (shown in black on Figure 22) to the granitic stocks is strikingly shown. The orebodies lie in paleovalleys, one wa11 of which is comprised of red granite. The Quirke ore zone actually 
lies in a paleovalley bounded on either side by granitic stocks while the Nordic zone is located in a paleovalley bounded on one side by granite and on the other by a paleoridge of Archean iron-formation. Other paleovalleys to the east of the Nordic orebody contain sub-economic uraniferous conglomerates, probably because there are no nearby granitic stocks.

The relations in the Quirke Syncline imply an extremely strong control by source rock proximity on the development of payable uraniferous conglomerates. Paleovalleys that are more than some 5 to $10 \mathrm{~km}$ away from such source rocks contain largely sub-economic conglomerates. If this district is truly representative of this class of deposit, the search for uraniferous conglomerates could be restricted to areas where potential source rocks are either known or can be inferred to be present.

Pienaar (1963), Roscoe (1969), and J.A. Robertson (1976, 1978) have described the granitic rocks in the Elliot Lake region. The stocks in question are described as granites and quartz monzonites. They vary from pink to brick red in color and display sharp transgressive contacts against older greenstone belts. They are "massive" (probably meaning non-foliated) and commonly display a porphyritic texture. Roscoe recognized that these granitic rocks are concentrated in the vicinity of the greenstone belt remnant which underlies the Quirke Syncline and concluded that they are "relatively high level intrusives".

The high-level stocks are said to be anomalously radioactive in part due to their relatively high potassium content. They contain relatively abundant zircon and monazite. They are cut by minor dykes of granitic pegmatite, aplite, and quartz. J.A. Robertson $(1976,1978)$ has recorded that airborne gamma-ray spectrometric surveys have confirmed that much of the terrane north and northwest of Elliot Lake contains anomalous amounts of uranium.

Pienaar (1963) presented tables showing the mineralogical and chemical compositions of granitoid rocks from the Quirke Syncline area. Unfortunately, he did not distinguish in his tables between the high-level intrusives and gray, medium-grained to porphyritic granodiorites. The results of his analyses are presented in Tables 3 and 4 . The rocks are described as granites, quartz monzonites, and porphyritic granodiorites. They are composed of varying amounts of quartz, microcline, and partly sericitized oligoclase. Perthitic and myrmekitic intergrowth textures are developed. Most of the primary ferromagnesian minerals have been altered to chlorite.

Roscoe (1969, Appendix A) found that a sample of pink biotite-hornblende granite from the Quirke Lake area contains $30 \mathrm{ppm}_{3} \mathrm{O}_{8}, 29 \mathrm{ppm} \mathrm{ThO} \mathrm{T}_{2}$, and $67 \mathrm{ppm} \mathrm{ZrO}_{2}$. Data presented by Kimberley and others (in press) show a variation in the uranium content of 4 meters of drill core of "granite" from the Denison Mine of 6 to $35 \mathrm{ppm} U$. The average (of 25 analyses) through the $4 \mathrm{~m}$ of core is about $13 \mathrm{ppm} \mathrm{U}$.

Roscoe noted that a suite of 27 granitic rocks from the Elliot Lake area

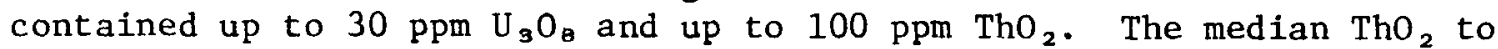
median $\mathrm{U}_{3} \mathrm{O}_{8}$ ratio is 2.25 , which is lower than that in the average igneous (acid to intermediate) rock, where the ratio is 3 to 4 . The red, radioactive granites have the lowest ratio, ranging from 0.8 to 1.8 . 
Table 3. Chemical analyses of pre-Huronian granitic rocks (after Pienaar, 1963; samples 55-54 and A-1 origina1ly from J.A. Robertson, 1960).

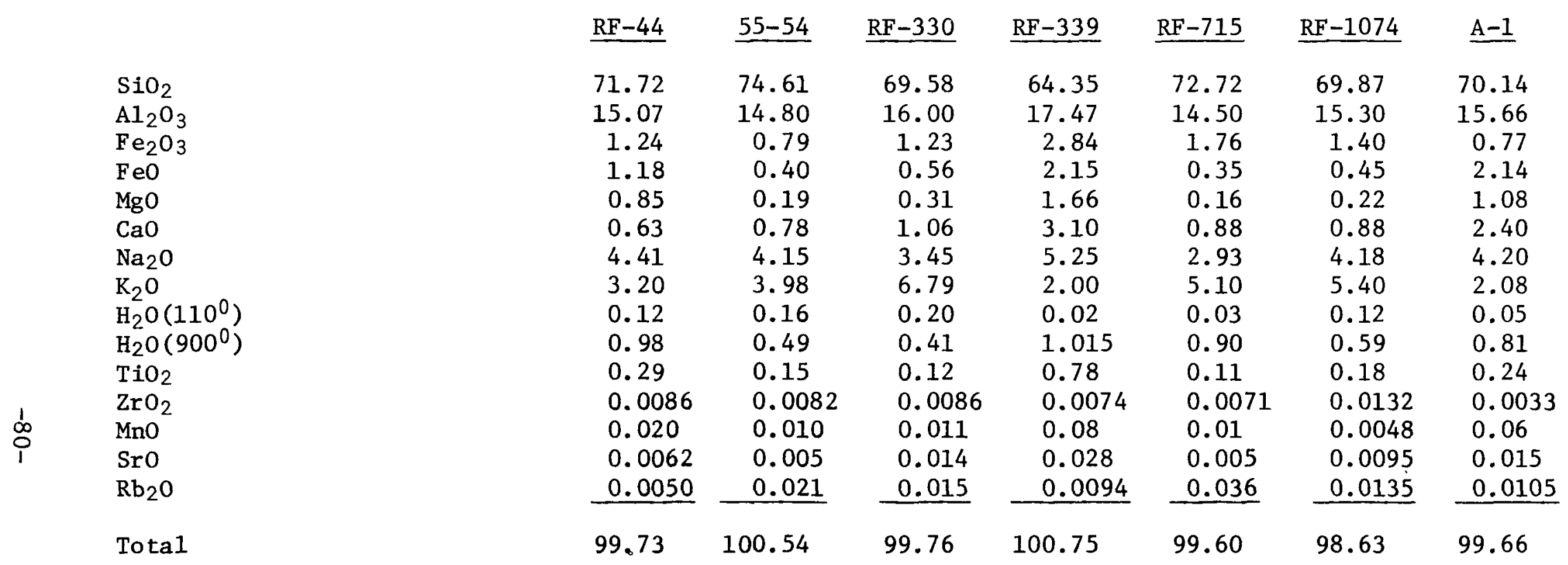

Carbon dioxide not determined. 
Table 4. Modal analyses (volume percent) of pre-Huronian granitic rocks (after Pienaar, 1963; sample 55-44 originally from J.A. Robertson, 1960).

\begin{tabular}{|c|c|c|c|c|c|c|}
\hline & $\underline{\mathrm{RF}-44}$ & 55-54 & $\underline{\mathrm{RF}-330}$ & $\underline{R F-339}$ & $\underline{\mathrm{RF}-715}$ & $\mathrm{RF}-1074$ \\
\hline Quartz & 29 & 30 & 17 & 12 & 32 & 27 \\
\hline Plagioclase ${ }^{I}$ and & 43 & 35 & 25 & 52 & 24 & 32 \\
\hline White mica & $\mathrm{An}_{12-14}$ & $\mathrm{An}_{10-12}$ & $\mathrm{An}_{18-20}$ & $\mathrm{An}_{26-28}$ & $\mathrm{An}_{10-12}$ & $\mathrm{An}_{16-1}$ \\
\hline Microcline & 21 & 23 & 33 & 13 & 29 & 32 \\
\hline Perthite & - & 8 & 19 & 10 & 10 & 6 \\
\hline Chlorite & 5 & 2 & 4 & 8 & 2 & 2 \\
\hline Biotite & - & - & - & 1 & - & $\mathrm{P}$ \\
\hline Calcite & $P$ & $\mathrm{P}$ & $\mathrm{P}$ & $\mathrm{P}$ & 2 & $\mathrm{P}$ \\
\hline Epidote & - & - & 1 & 2 & - & $\mathrm{P}$ \\
\hline Zircon & $P$ & - & $\mathbf{P}$ & $\mathrm{P}$ & $\mathbf{P}$ & $\mathrm{P}$ \\
\hline Apatite & $P$ & $P$ & $\mathrm{P}$ & $\mathrm{P}$ & $\mathrm{P}$ & $\mathrm{P}$ \\
\hline Black iron oxides & $\mathrm{P}$ & $\mathrm{P}$ & $\mathbf{P}$ & $\mathrm{P}$ & $\mathbf{P}$ & $P$ \\
\hline Sphene & - & - & - & - & - & $\mathrm{P}$ \\
\hline Allanite & - & - & - & $\mathrm{P}$ & - & - \\
\hline Muscovite & - & - & - & - & $\mathrm{P}$ & - \\
\hline Monazite & - & - & $\mathrm{P}$ & - & - & - \\
\hline Pyrite & - & - & - & - & $\mathbf{P}$ & $\mathrm{P}$ \\
\hline
\end{tabular}

P - Designates minor quantities.

${ }^{1}$ Plagioclase extensively altered to white mica. Results adjusted to the nearest one percent. 
The granitic rocks of the Elliot Lake area contain a varied heavy mineral suite (Roscoe, 1969). The most abundant are the opaque iron minerals (hematite, magnetite, ilmenite, and pyrite). Other common heavy minerals include sphene, rutile, anatase, zircon, and apatite. Radioactive minerals present include monazite and, in some samples, allanite and thorite. No uraninite grains were detected. One must assume that this mineral was preferentially concentrated in the upper levels of the stocks and was erosively removed during the pre-Huronian cycle of erosion (J.A. Robertson, 1978).

\section{Summary}

The primary source of both detrital uraninite and of uraniferous ground waters (that can be inferred to have fluxed through Precambrian conglomerates) was almost certainly a suite of high-level, highly differentiated granitic to quartz monzonitic intrusives. These rocks tend to occur in stocks which cut sharply across older structures, including gneissic basement rocks and greenstone belts. They are non-foliated, frequently coarsegrained and often porphyritic. Their high tectonic level of emplacement is reflected by their tendency to be found in and near to greenstone belts.

Chemically, these stocks are distinguished by their relatively high uranium contents (up to $35 \mathrm{ppm} \mathrm{U}$, average 10-15 ppm U) and by their anomalous1y low $\mathrm{ThO}_{2} / \mathrm{U}_{3} \mathrm{O}_{3}$ ratios $(0.8$ to 1.8$)$. Both the Matinenda and Dominion Reef occurrences are located essentially in contact with their probable source rocks. Proximity to a potential source rock should thus be regarded as an extremely important parameter during exploration. However, the apparent absence of a source rock should not be allowed to discourage exploration since there are no known source rocks for the uranium in much of the Witwatersrand Basin. Furthermore, Minter (1978) has shown that relatively high uranium values ( 150 to $500 \mathrm{ppm} \mathrm{U}$ ) occur for distances of up to $16 \mathrm{~km}$ down the paleoslope in the Basal/Steyn placer sheet of the Welkom Goldfield in South Africa. These uraniferous conglomerates are thus found on the order of $20 \mathrm{~km}$ from the nearest possible source. rocks.

Late Archean and Early Proterozoic Paleoweathering

A critical analysis of paleoweathering conditions during the period of formation of uraniferous pebble conglomerates is necessary to evaluate both the source of the conglomerates and their host sediments and of their contained uranium. The mineralogy of the material fed into the Precambrian streams was controlled in part by the type of weathering in the source area. In particular, the behavior of uranium during weathering is a function of the oxidation state of the paleoatmosphere and paleohydrosphere.

In the following paragraphs, the geologic evidence relating to the oxygen content of the paleoatmosphere, the paleoclimate, the character of the ancient ground water, and the paleotopography is reviewed. 


\section{Paleoatmospheric Composition}

Evidence for the composition of the late Archean and early Proterozoic atmosphere/hydrosphere comes from a number of areas, principally the nature of paleosols, the stability in fluvial systems of easily oxidized heavy mineral grains (such as uraninite and pyrite), the development of major iron-formations, and the scarcity of hematite in clastic sedimentary rocks.

It must be emphasized that interpretation of the geologic evidence in these areas is very complex. First, the question of chemical kinetics is difficult to evaluate. Thus, while uraninite is not a common detrital mineral today (due to the ease with which it is oxidized and rendered soluble), it can, under some circumstances, survive as a detrital mineral (Zeschke, 1960). Its survival in modern streams depends upon chemical kinetics. Grandstaff (1976) has shown that the rate of dissolution of thorian uraninites is relatively slow and that the mineral can survive fluvial transport even under present atmospheric conditions.

A second complication in the interpretation of geologic evidence is the possibility of non-oxydative oxidation of minerals. Baur (1978) has shown that $\mathrm{CO}_{2}$ will react spontaneously (but very slowly) with minerals such as fayalite and troilite to produce either hematite or magnetite. Oxidation by free radicals (if present) would be relatively rapid (D.E. Grandstaff, written communication, 1980). Thus, not all hematite found in, for example, paleosols need necessarily indicate the presence of free oxygen in the paleoatmosphere.

Third, Walker (1980) has shown that the oxygen content of the early atmosphere was probably largely dependent on the volume of reduced volcanic gases being vented at any one period. Photochemical dissociation of water vapor in the atmosphere will produce a certain amount of oxygen. During periods of low volcanic activity, the abundance of oxidizing free radicals could have risen above that of reducing species such as $\mathrm{H}$. Under these conditions, oxidation of ferrous minerals during paleoweathering could have produced a hematitic product.

Paleosol Studies

Paleosols have been distinguished below most of the better studied basins containing uraniferous conglomerates (Button and Tyler, 1979). Only some paleosols have been studied in sufficient detail to throw light on the question of paleoatmospheric composition.

There is a remarkable worldwide uniformity in the gross lithological character of paleosols developed on granitoid rocks during the late Archean and early Proterozoic. All are dominated by a quartz-sericite lithology and by drab colors, usually shades of yellowish green, olive, or gray (Button and Tyler, 1979). Potassium feldspars have survived paleoweathering in some paleosol profiles. Plagioclases were almost totally destroyed and are now seen as a sericitic mass. Biotite has been altered to vermiculite (Matthews and Scharrer, 1968) or to chlorite (Gay and Grandstaff, in press). In drillhole intersections of paleosols, a lower chlorite-rich zone can of ten be distinguished below the upper, sericite-rich zone. 
Evidence of silica mobility during paleoweathering or subsequent diagenesis of the paleosol is frequently observed. Features seen include small bodies of microcrystalline silica (Matthews and Scharrer, 1968), a higher quartz content in the paleosol than in the parent granite (Visser and Verwoerd, 1960), and aggregates of quartz smaller than those present in the parent rock (Gay and Grandstaff, in press). Petrographic studies have shown that sericitization of quartz grains (along cracks and grain boundaries) is a common feature of paleosols (Visser, 1956; Van Valkenburgh, 1979). This sericitization could have occurred during diagenesis or greenschist-grade metamorphism. Alkalis and alumina were probably derived from the paleosol itself.

A wide range of heavy and opaque minerals are found in granitic paleosols. Roscoe (1969) recorded the presence of some hematite, zircon, monazite, thorogumite, garnet, and amphibole. Gay and Grandstaff noted the presence of leucoxene, magnetite, rutile, and pyrite. The latter mineral occurs in amounts of up to 2 percent in the upper parts of a pre-Matinenda paleosol of the Pronto Mine area, Elliot Lake district, Canada.

Geochemical studies of granitic paleosols in the Elliot Lake area have been undertaken by Robertson (1960), Pienaar (1963), Roscoe (1969), Gay and Grandstaff (in press), and Kimberley and others (in press). In most cases, the paleosols have been shown to have been leached of $\mathrm{Na}$ and $\mathrm{Ca}$. The early workers stated that the total iron showed a marked reduction in the paleosol relative to the parent rock. By contrast, the granitic paleosol analysed by Gay and Grandstaff showed an upward increase in the total iron content and in the $\mathrm{Fe}_{2} \mathrm{O}_{3} / \mathrm{FeO}$ ratio (Figure 14). Many of the early workers concluded that weathering occurred in an oxygen-deficient paleoatmosphere. J.A. Robertson (written communication, 1980) is more cautious in his interpretation of the facts. He states that the reducing situation need only have been prevalent within the ancient weathering profile, and that the extension of this concept to include the paleoatmosphere is based on other circumstantial evidence. More recent work (Gay and Grandstaff, in press) has shown that at least local near-surface oxydative weathering occurred along the pre-Huronian paleosurface. The apparent contradiction could well be due to the paleotopographic location of the paleosol samples analysed. This concept will be developed in a subsequent section.

Little work has been directed at the vital question of uranium solution during paleoweathering. Roscoe and Steacy (1958, p. 4-5) studied the distribution of $U$ and $T h$ in two series of paleosol samples from the Quirke Lake area. They stated that "both show uranium to be about one-third less in the most altered samples than in the freshest granite". One series of samples showed a loss of thorium slightly less than that of uranium; the other showed a net gain in thorium.

Data from Roscoe (1969) indicate that a $30 \mathrm{ppm} \mathrm{U}_{3} \mathrm{O}_{8}$ background in a granitic rock was reduced to $13 \mathrm{ppm}$ at the top of the overlying paleosol (Table 5). 

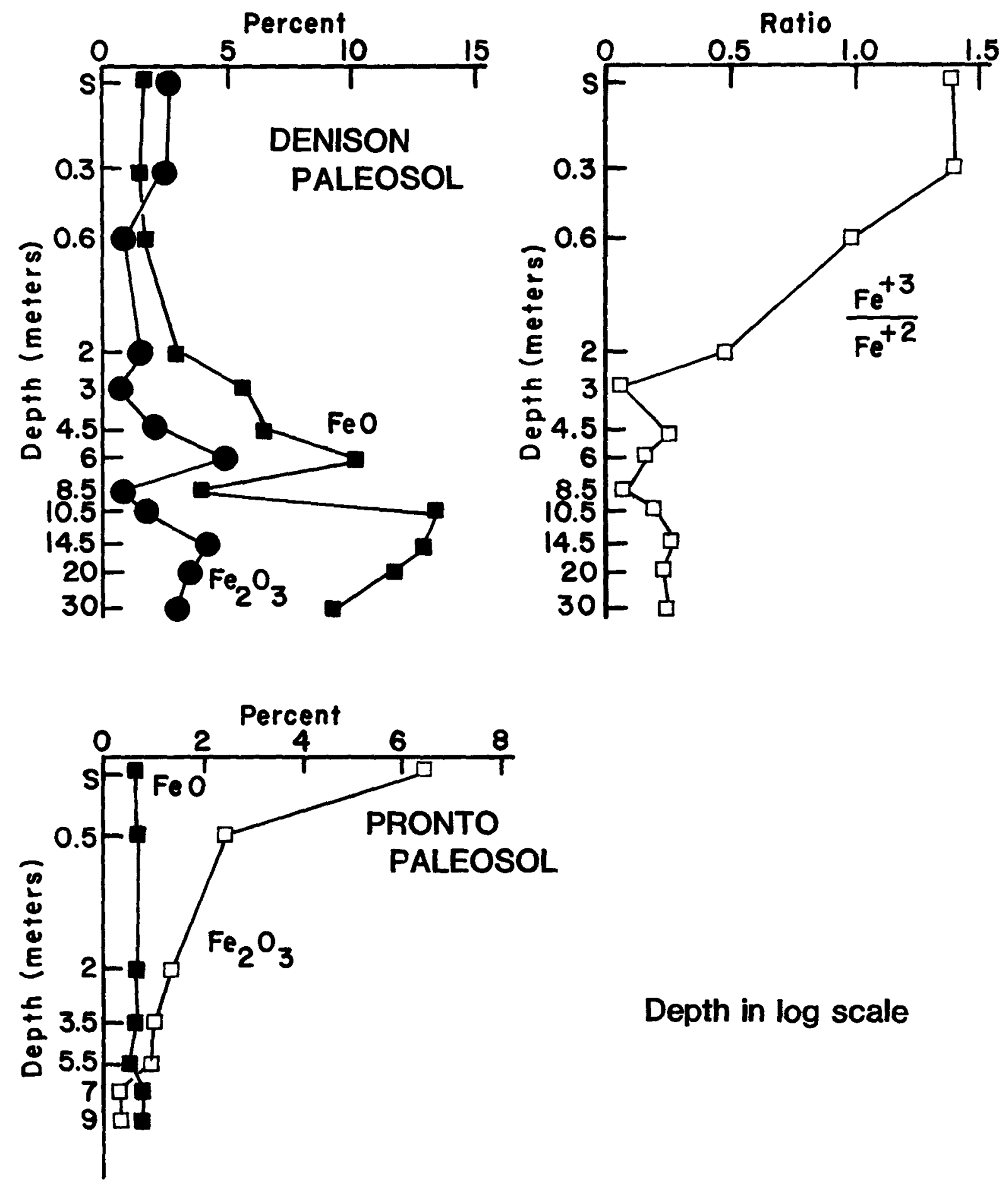

Depth in log scale

Figure 14. The distribution of ferrous and ferric iron through pre-Huronian paleosols of the Elliot Lake-Blind River area, Ontario, Canada (from Gay and Grandstaff, in press). 
Table 5. Some geochemical parameters in a granitic paleoweathering profile beneath the Matinenda Formation in the Quirke Lake area, E1liot Lake district, Canada (after Roscoe, 1969, Appendix A).

\begin{tabular}{|c|c|c|c|c|c|c|}
\hline Number & $\begin{array}{c}\mathrm{Fe}_{2} \mathrm{O}_{3} \\
\% \\
\frac{\%}{0}\end{array}$ & $\begin{array}{c}\mathrm{Fe} 0 \\
\%\end{array}$ & $\begin{array}{c}\mathrm{Fe}_{2} \mathrm{O}_{3} / \mathrm{FeO} \\
\text { Ratio }\end{array}$ & $\begin{array}{l}\mathrm{ThO}_{2} \\
\mathrm{ppm}\end{array}$ & $\begin{array}{l}\mathrm{U}_{3} \mathrm{O}_{8} \\
\mathrm{ppm}\end{array}$ & Rock Type \\
\hline 707 & 0.61 & 0.68 & 0.90 & 35 & 13 & Top of paleosol, $10 \mathrm{ft}$. above 709 \\
\hline 709 & 0.22 & 0.90 & 0.24 & 23 & 13 & Paleosol, $10 \mathrm{ft}$. above 711 \\
\hline 711 & 0.18 & 1.04 & 0.17 & 38 & 18 & Paleosol, $10 \mathrm{ft}$. above 713 \\
\hline 713 & 0.69 & 1.19 & 0.58 & 46 & 18 & Altered granite, $10 \mathrm{ft}$. above 715 \\
\hline 715 & 0.59 & 1.22 & 0.43 & 54 & 30 & Pink biotite granite \\
\hline
\end{tabular}

In a study of the uranium content of two series of samples from below the 2,800-m.y.-old Dominion Reef Group in South Africa, it was found that some uranium was lost during paleoweathering (Button, unpublished data). These analyses were undertaken by neutron activation analysis. In one paleosol, a $9.5 \mathrm{ppm}$ background of $U$ in the parent granitic rock was reduced to a level that fluctuated between 2.5 and $5.6 \mathrm{ppm}$ in the remainder of the profile. In this series of samples, the uppermost analysed rock, which was located $0.18 \mathrm{~m}$ below the unconformity, contained $24 \mathrm{ppm} U$, which suggests contamination from above or a uranium-rich surficial crust on the paleosol.

The behavior of uranium during Archean and early Proterozoic paleoweathering has not been adequately investigated. Future research in this area should do much to clarify arguments on the importance of solution transport of uranium in this time interval. Existing information suggests that between 30 and 60 percent of the uranium present in granitic rocks was leached during middle Precambrian weathering episodes. Given a $30 \mathrm{ppm} \mathrm{U}_{3} \mathrm{O}_{8}$ background in some of the basement granites in the Blind River area (Roscoe, 1969), paleoweathering may have been able to supply to surface and ground water a cumulative mass of 10 to $20 \mathrm{gm} \mathrm{U}_{3} \mathrm{O}_{8}$ per metric ton of weathered granite. Since solubility of uranium under reducing conditions is very low except at extremes of $\mathrm{pH}$ (Langmuir, 1978), the leaching of uranium from paleosols suggests at least a modest hydrospheric oxygen content.

Numerous examples of basalt paleoweathering are known from late Archean and ear1y Proterozoic basins, particular1y in southern Africa (Button and Tyler, 1979). In general, the weathered profiles are dominated by very finegrained sericite in their upper parts and by chlorite-rich lower horizons (Fryer, 1977; Button, 1979; Gay and Grandstaff, in press). Four paleosol horizons have been studied geochemically. Two studies are of paleosols developed on Archean greenstones below the Matinenda Formation, a third is of a paleosol developed on basalts interlayered with arenites of the upper division of the Witwatersrand Basin (Button and Fryer, unpublished data). The fourth profile occurs at the top of the 2,200-m.y.-old Hekpoort Basalt in the Pretoria Group of South Africa (Button, 1979).

The behavior of iron during paleoweathering indicates very high iron solubilities in the upper levels of the paleosols since they are uniformly strongly depleted in total iron. Mobility of iron suggests reducing conditions, which promote solution of iron in the divalent form. However, studies of the ferric-ferrous iron relationships through the paleosol 
profile indicates that the paleosols are enriched in trivalent iron relative to the parent basalt. In the 2,200-m.y.-old Hekpoort paleosol, the ferric/ ferrous ratio in the parent basalt averages 0.12 and increases upward through the paleosol from around 0.5 to over 10 (Button, 1979). In the Denison paleosol studied by Gay and Grandstaff, the ferric/ferrous ratio increases upward from a value of 0.25 in the basal zone ( $30 \mathrm{~m}$ below the unconformity) to between 1.3 and 1.6 just below the unconformity. In the Witwatersrand paleosol developed on the Bird Lava, the ratio ranges from 0.08 to 0.16 in the deeper levels to 3.8 near the disconformity (Button and Fryer, unpublished data).

A contradictory situation thus appears to exist. The upper levels of the paleosols are strongly depleted in iron (suggesting removal of iron in solution, hence reducing conditions). The same parts of the paleosols are characterized by a high ferric/ferrous ratio, suggesting oxidation of iron and thus a relatively high Eh. The probable solution is that the paleosol profile was originally Eh zoned. A low Eh probably prevailed at depth and promoted solution of iron. As the erosion surface was gradually lowered, the iron-leached horizon was exposed to the surface and the remnant iron in it largely oxidized to the higher valence state.

In summary, both granitic and basaltic paleosols developed in the period from 2,200 to about $2,700 \mathrm{~m} . \mathrm{y}$. ago show an upward increase in the ferric/ ferrous ratio. Such an observation suggests that the essentially anoxygenic atmosphere postulated by earlier workers is not strictly correct. An undetermined amount of free oxygen appears to have been present in the paleoatmosphere-paleohydrosphere in this time interval. This notion is supported by evidence of uranium leaching from paleosols and by the development of iron-rich weathering crusts on pillows from some Archean basalts (Dimroth and Lichtblau, 1978).

Iron-leached (gley) paleosols appear to be more abundant and widespread in the late Archean-early Proterozoic era than at present. For example, the paleosol developed on the 2,200-m.y.-old Hekpoort Basalt has suffered extensive iron loss in the upper horizons over an area of some $100,000 \mathrm{~km}^{2}$ (Button, 1979). Such soils are developed today in low-1ying, poorly drained areas. Gay and Grandstaff (in press) suggested that the preponderance of such a weathering style in the time frame under discussion could indicate a relatively low oxygen content in the paleoatmosphere, a conclusion reached independently by a study of the Hekpoort paleosol (Button, 1979).

Pyrite and Uraninite in Fluvial Sediments

Traditionally used evidence of an anoxic paleoatmosphere, such as the presence of detrital pyrite and uraninite, can probably be reconciled with a low partial pressure of oxygen in this atmosphere. Some contemporary river sediments contain both detrital uraninite, pyrite, and arsenopyrite (for example, Zeschke, 1960; Simpson and Bowles, 1977). However, the preservation of such minerals seems to require rather special conditions, such as very rapid erosion (as along the Himalayas and other mountain chains) or very cold river water (as in glacial or arctic areas). Furthermore, the detrital pyrite grains in contemporary fluvial sediments are usually coated by iron hydroxide (D.E. Grandstaff, written communication, 1980). Their fossil 
counterparts show no evidence for such coatings. Thus while unstable minerals such as uraninite and pyrite can survive fluvial transport under some circumstances under present atmospheric conditions, the scale of their preservation in the fluvial sediments of the late Archean and early Proterozoic (through thousands of meters of section in basins measuring on the order of $10^{4}$ to $10^{5}$ square kilometers in area) indicates significantly different conditions. A substantially lower level of atmospheric oxygen in the paleoatmosphere is suggested.

The effects of the kinetics of oxidation of pyrite and of uraninite must be considered when discussing their relevance to the subject of paleoatmospheric composition. Grandstaff (1974a, 1976, in press) has undertaken a study of the kinetics of uraninite oxidation and dissolution. He found that, while uraninite is thermodynamically unstable at oxygen pressures of greater than $10^{-21}$ atmospheres, the thorian uraninites of the Witwatersrand and E11iot Lake deposits could survive at oxygen levels as high as 0.01 of the present atmospheric level.

Thus the presence of significant quantities of detrital uraninite and pyrite in Archean and early Proterozoic arenites and conglomerates need not imply anoxic conditions. The scale of preservation of these minerals, together with the kinetic considerations developed by Grandstaff, suggests that oxygen levels in the paleoatmosphere were substantially lower than at present, probably less than 0.01 of the present atmospheric level.

Archean and Early Proterozoic Red Beds

Several occurrences of Archean red beds have been documented in parts of Canada (Shegelski, 1980; Dimroth, 1980). For example, the former author documented the presence of red arkosic arenites in the upper part of the stratigraphic succession of the greenstone belt in the Lake Shebandowan area in Ontario, Canada. Thus the presence of minor occurrences of Archean red beds is no longer in serious doubt. However, the question of the scale of their development remains. Despite numerous studies of Archean and early Proterozoic successions around the world, the number and volume of red bedtype successions is very small. Even in such thick and we11-preserved successions of fluvial sediment as are developed in the Witwatersrand and lower Huronian, no red beds have been reported. By contrast, thoroughly oxidized sediments of great thickness and extent (such as the Waterberg succession of South Africa) are developed from 2,000 million years ago through to the present.

\section{Summary}

The development and preservation of uraniferous conglomerates in the Archean and early Proterozoic does not require an anoxic paleoatmosphere. The evidence assembled suggests that the oxygen content of the atmosphere was rather low, probably less than 0.01 of the present level. Under these conditions, oxidation reactions could be expected to be relatively slow. In paleoweathering profiles, oxidizing conditions would be confined to a nearsurface crust. Below this, the Eh could be expected to drop rapidly as available oxygen was consumed by oxidation reactions. Extensive loss of 
iron in the lower parts of the paleosol profiles could be expected and is seen in many of the studies cited.

The oxygen level in the early Proterozoic and Archean atmosphere is crucial to the behavior of uranium. Paleosol profiles have suffered loss of uranium, which suggests the removal, in solution, of uranium, probably in the hexavalent state. These uraniferous solutions could have augmented the uranium found in conglomerates.

Despite the evidence of solution transport of some uranium, there is good reason to believe that high-thorium uraninites were stable enough to be transported and concentrated as detrital heavy minerals.

\section{Paleohydrospheric $\mathrm{pH}$}

The $\mathrm{pH}$ of contemporary continental water usually varies between limits of about 4 and 9 (Krauskopf, 1979). Rainwater has a pH of about 5.6. The pH of meteoric waters is locally lower than 4 (acid mine drainage, for example) or higher than 9 (in playa lakes).

The $\mathrm{pH}$ conditions prevailing in surface waters during the late Archean and early Proterozoic are difficult to assess. Non-alkaline meteoric water is certainly suggested by very widespread dissolution (and associated karstification) of the 2,200 to 2,300 m.y. old carbonates of the Transvaal Basin, South Africa (Button and Tyler, 1979). In basins such as the Witwatersrand, highly aluminous mineral phases (including pyrophyllite and chloritoid) are present in arenites and argillites (Fuller, 1958; Wiebols, 1961). Pyrophy1lite was probably formed from an original kaolinitic clay and is suggestive of intense (relatively acid) leaching of parent granitic rocks.

In Precambrian paleosols, the dominant phyllosilicate is sericite. This is true not only of the late Archean-early Proterozoic paleosols, but also of later Precambrian paleosols, such as those developed below the late Precambrian Jacobsville Sandstone (Kalliokoski, 1975). Yaalon (1961) predicted that illite would be the principal clay mineral in paleosols older than the oldest land plants (Devonian). It seems to be a logical step to conclude that the sericite in paleosols is the low-grade metamorphic equivalent of original illite.

The formation of illite in soils is favored by a $\mathrm{pH}$ of $9-10$ and by a high Si/Al ratio (Birkeland, 1974). Certain investigators of paleosols have used this evidence to suggest alkaline paleo-ground water during the period of formation of uraniferous conglomerates (Button, 1979; Fryer, 1977). The latter author also studied the behavior of rare earth elements in a preHuronian paleosol, which led him to conclude that the paleo-ground water had a $\mathrm{pH}$ of greater than 8. A high $\mathrm{pH}$ is also consistent with the leaching of silica from the upper levels of some paleosols (Button, 1979).

There are, however, several counterarguments to the concept of very widespread development of illite along Precambrian weathering surfaces. First, many Precambrian basalts (which are overlain by sericitic paleosols) contain less than 0.1 percent $\mathrm{K}_{2} \mathrm{O}$, so that a source of potassium for illite becomes a problem. Second, modern basalts usually weather to minerals such as 
halloysite, vermiculite, and montmorillonite (Gay and Grandstaff, in press). Montmorillonite and mixed-layer montmorillonite-illite are unstable during diagenesis and are converted to illite (Perry and Hower, 1972) starting at temperatures as $10 \mathrm{w}$ as $90^{\circ} \mathrm{C}$. The precursor to the sericite-rich paleosols may thus have been illite derived by diagenetic transformation of montmorillonite or a mixed-layer illite-montmorillonite clay. Using this reasoning, the dominance of potassium-rich phyllosilicates in paleosols need not be valid evidence of an alkaline paleo-ground water system.

In summary, the $\mathrm{pH}$ conditions prevailing during the early Proterozoic and late Archean have not been firmly established. While the balance of evidence points to a weakly acid rain and ground water system, rare earth element fractionation patterns in a pre-Huronian paleosol lead B.J. Fryer (1977) to postulate an alkaline paleo-ground water system. This apparent contradiction may well be explained by an increasing $\mathrm{pH}$ with increasing depth in a weathering profile. In contemporary ground water systems, near-surface waters are frequently acidic, while hydrolysis of silicate minerals at and below the water table results in neutral or alkaline ground water.

Given a weakly oxidizing ground water (see previous sections), it appears to matter little, in terms of solution transportation of uranium, whether the ground water was acid or alkaline. Hexavalent $U$ forms soluble complexes with silica and sulfate radicals at $\mathrm{pH}$ values of less than 5 and with carbonate radicals at $\mathrm{pH}$ values of over 7 (Langmuir, 1978).

\section{Climatic Conditions}

The climatic conditions during the era of deposition of uraniferous conglomerates can be judged by study of paleosols and of diamictites (some of them tillites) associated with sequences containing quartz-pebble conglomerates.

At the outset, it appears that we can eliminate hot, arid climates from consideration. The carbonate nodules so typical of soils formed in arid climates (Kalliokoski, 1975) are simply not present in any of the paleosols studied from the basins containing uraniferous conglomerates. While it might be argued that such carbonates were diagenetically removed, there is certainly no mineralogical or textural evidence for such a replacement. Furthermore, Kalliokoski's (1975) study of upper Precambrian paleosols has resulted in the recognition of well-developed paleocaliche horizons indicating that such features can survive burial and diagenesis.

The association of uraniferous conglomerates with rocks of presumed glacial origin has been emphasized by Trow (1977). A number of points related to this supposed association must be critically examined, including the evidence for a glacial origin of certain diamictites, the consistency and frequency of the glacial association, and the rationale for a glacial association.

The best documented diamictites (paraconglomerates) associated with uraniferous pebble conglomerates are located in the Huronian succession of Canada (Roscoe, 1969), where they cover disconformities. Three such paraconglomerates are present, in ascending order, the Ramsay Lake, Bruce, and Gowganda Formations. Strongest evidence for a glacial origin is in the Gowganda Formation which comprises greywacke, conglomerate, arkose, quartzite, and siltstone, in 
addition to paraconglomerate. Evidence that has been cited for a glacial origin includes a striated pavement ${ }^{1}$ in some of the locations where the Gowganda Formation rests on the Archean basement, some striated clasts ${ }^{1}$ and laminated siltstone containing dropstones (Roscoe, 1969). The evidence for a glacial origin of the Ramsay Lake Formation (stratigraphically closest to the Matinenda uraniferous conglomerates) and of the Bruce Formation is similar.

Paraconglomerates (known locally as puddingstones) are not uncommon in the Witwatersrand Basin. The puddingstones are usually limited in their distribution, being confined, along with shales, quartzites, banded pyritic quartzites and conglomerates, to deeply incised erosional channels on unconformities (Antrobus and Whiteside, 1964). One such channel complex has been mapped in the subsurface for over $10 \mathrm{~km}$ and has a well-defined meandering pattern. This channel is cut on the Jeppestown Shale. Bank undercutting could well have resulted in very large slugs of clay being dumped in the channel and moving down the channel as viscous mudflows. A similar origin is envisaged for the "puddingstone reef" of the East Rand area which is confined (along with associated conglomerates, quartzites, and chloritoid-bearing shales) to erosion channels cut, in part, into the underlying Kimberley Shale (De Jager, 1964).

Many of the tillite-like rocks in the upper Witwatersrand are thus found within erosional channel systems cut into clay-rich formations and probably formed by bank undercutting, followed by mudflows in the fluvial channels.

A glacial association for Witwatersrand uraniferous conglomerates is thus not indicated by a critical examination of the relationships. Furthermore, tillite-like rocks are not known to be associated with other uraniferous conglomerates, such as those in the Pongola, Dominion Reef, Jacobina, and Hamersley occurrences.

The supposed glacial association of uraniferous conglomerates in the Huronian of the Elliot Lake area is also questioned on the grounds of stratigraphic proximity. Even supposing that the Ramsay Lake Formation is partly of glacial origin, it is separated from the uraniferous Matinenda conglomerates by up to 2,000 meters of upper Matinenda and McKim Formation sediments. Gay and Grandstaff (in press) estimated that 1,000 $\mathrm{m}$ of McKim Formation might represent a period of time of greater than 3 million years. ${ }^{2}$ The paleoclimate during deposition of the Ramsay Lake Formation may have had little resemblance to that during the deposition of the older uraniferous. conglomerates.

\footnotetext{
${ }^{1}$ According to J.A. Robertson (written communication, 1980), the striations on the pavement and on the clasts are due to tectonic rather than glacial processes.

${ }^{2}$ Gay and Grandstaff use the maximum sustained sedimentation rate for Phanerozoic basins $(33 \mathrm{~cm} / 1,000 \mathrm{yr}$.$) on the basis of geologic evidence$ for relatively rapid sedimentation rates in the basal parts of the Huronian Supergroup.
} 
Trow (1977) implied that the lowered $\mathrm{CO}_{2}$ content of the (presumed oxidizing) paleoatmosphere during glacial periods of the Precambrian might have slowed uranium solution since the carbonate radical is a major complexing agent for uranium under conditions of $\mathrm{pH}$ ranging down to about 5 (Langmuir, 1978). However, other complexing agents are active in this $\mathrm{pH}$ range, including sulfate (up to a $\mathrm{pH}$ of 7), silica ( $\mathrm{pH}$ around 6), phosphate ( $\mathrm{pH} 4$ to 10), and hydroxide ( $\mathrm{pH}$ over 5). Under oxidizing conditions, uranium complexation and solution could occur with a wide range of common anionic species. Trow's model also supposed that, in a low $\mathrm{CO}_{2}$ atmosphere, uranium would be transported as a "clastic hydrated uranyl oxide" pseudomorph after uraninite and reduced in the depositional environment to form uraninite or brannerite. Not only is there no textural evidence to support this hypothesis, but there is some doubt that uranyl oxide clasts would have been able to withstand the rigors of sediment transport.

A further line of evidence relating to the supposed glacial association of the uraniferous conglomerates is that of paleomagnetic estimates of paleolatitude. Houston and Karlstrom (1979) quoted Piper (1976) and Symons and $0^{\prime}$ Leary (1978) as giving latitude estimates of $65^{\circ}$ for the lower Ventersdorp lavas and $35^{\circ}$ for the Thessalon volcanics, respectively. The former rest directly on the Witwatersrand, the latter are developed under the Matinenda Formation in parts of the Huronian Basin.

In summary, evidence for a worldwide glacial association of uranium-bearing conglomerates is, at best, tenuous. Within North America, such an association may be a possible tool for correlation and could indicate a broad time equivalence of certain formations (such as those in the Medicine Bow Mountains) with the early Proterozoic (Huronian) section of Ontario, Canada. It is only as a tool in correlation that glacial horizons appear to have any relevance to the exploration for uraniferous conglomerates.

There are several features of paleosols which can be interpreted in climatic terms. First, paleosols of the late Archean and early Proterozoic are usually thick (frequently over $5 \mathrm{~m}$ ), laterally very extensive, and clay-rich. Granitic paleosols contain 50 to 70 percent sericite, almost certainly after a clay mineral in the original weathering profile. Basalt-derived paleosols are even richer in sericite, containing up to 90 percent of that mineral in the upper horizons (Button, 1979; Button and Fryer, unpublished information).

Gay and Grandstaff (in press) quote Jenny $(1935,1941)$ as suggesting that rates of clay production vary linearly with moisture and exponentially with temperature. Soils formed in arid or cold climates are composed largely of rock fragments, while the soils of hot, humid areas contain large amounts of alumina, iron oxides and hydroxides, and clay minerals. These relations are probably not quantitatively correct (Birkeland, 1974) but can be used as a qualitative guide. The high clay contents of paleosols associated with uraniferous conglomerates is probably an indication of a humid climate in tropical to temperate climes.

This conclusion is supported by relations within successions such as the Witwatersrand and Transvaal Basins. Thick weathering profiles are developed on basalts such as the Bird Lavas (in the Witwatersrand Supergroup) and 
Hekpoort Basalt (in the Transvaal Supergroup) despite the fact that there are, at most, mild disconformities at these stratigraphic levels (Button and Tyler, 1979).

Other indirect evidence is the abundance of sericite and pyrophyllite through the 3,000-m-thick upper division of the Witwatersrand Supergroup (Fuller, 1958). This study of the petrology of upper Witwatersrand arenites indicated a combined sericite-pyrophyllite content ranging from 1 to 47 percent and averaging about 18 percent. The sericite in this succession probably represents clay stripped from a paleosol in the source areas of the Witwatersrand Basin. Apparently weathering was fast enough to supply the enormous volume of sericite in the basin. Despite inferred relatively rapid rates of sedimentation in the Upper Witwatersrand, no detrital feldspar grains were detected by Fuller's study. The inference is thus that rates of weathering were rapid and that the climate was relatively humid and warm. To a lesser extent, similar arguments can be applied to the Huronian. Roscoe (1969, p. 73) concluded that the "bulk of the sediments carried to the Huronian depositional area were derived from weathered rock debris rather than directly from the rocks themselves".

The fine structure of the better studied paleosols may provide evidence of a seasonality to rainfall. The sericitic upper unit of the Hekpoort paleosol of the Transvaal Basin was cracked to a depth of $2.5 \mathrm{~m}$, the crack being filled by arenite from the overlying formation (Button, 1979). Deep cracking could suggest periodic desiccation of the paleosol. This paleosol and the pre-Huronian paleosol studied by Gay and Grandstaff (in press) show soil cracks filled by what are interpreted as translocated clay skins. In contemporary soils, downward moving water is required to produce such illuvial features. Illuvial horizons are characteristic of lowlands where soils become dry at some season. They require at least 1,000 years to form under contemporary conditions (Birkeland, 1974).

In summary, accumulated evidence on the paleoclimatic setting of the two major basins containing uraniferous conglomerates suggests seasonal, relatively high rainfalls, relatively high temperatures, and consequent rapid chemical weathering. Data on $\mathrm{pH}$ are equivocal; there is certainly some evidence of a low $\mathrm{pH}$, including the presence of pyrophyllite as a fairly common phase in Witwatersrand arenites. While other basins have not been as intensely studied, this reconstruction is consistent with our present knowledge of the Pongola, Dominion Reef, Hamersley, and Jacobina depositories.

\section{Paleotopography}

Elsewhere in this report, it is shown that pre-Huronian and other paleosurfaces were characterized by a local relief of up to 200 meters. In general, greenstone basalts formed lowlands (J.A. Robertson, 1976, 1978), while elevated ground was formed by some granitic rocks, iron-formations, and massive basalts. Gay and Grandstaff (in press) noted that the granitic paleosol they studied showed more evidence of oxygenic weathering than the paleosol developed in a valley over greenstone basalt. They concluded that paleotopography played as important a part in Precambrian weathering as it does today and that the "gley" type paleosols, characterized by iron loss, 
were formed in or near to paleovalleys, where the paleo water table stood relatively close to the surface.

\section{Summary}

Recent work on Archean and early Proterozoic paleosols has indicated the presence of at least small amounts of oxygen in the Precambrian atmosphere. Under'these conditions, some solution transportation of uraninite can be anticipated. However, the rates of oxidation of thorian uraninites are such that it can be transported as a detrital mineral (Grandstaff, 1974a, 1976, in press).

The $\mathrm{pH}$ conditions prevailing during weathering processes of the late Archean and early Proterozoic have not been firmly established and may well have varied both laterally and vertically within the ancient regolith.

There appears to be no genetic link between uraniferous Precambrian conglomerates and a glacial paleoclimate. Study of paleosols and of the sedimentary fill of the Witwatersrand and Huronian Basins indicates rapid weathering under temperate or tropical climates with a high, possibly seasonal, rainfall.

Paleoweathering was in part controlled by paleotopography. Gay and Grandstaff (in press) have assembled data which seem to indicate that gley soils formed in depressions (oxygen-deficient ground water) and that a spodsolic paleosol (enriched in iron and with a high ferric/ferrous ratio) formed on better drained uplands.

Paleotopographic Controls On Deposition

Paleotopography has a very marked effect on the deposition and distribution of uraniferous conglomerates. Simply stated, most of these conglomerates are fluvial sediments, and fluvial systems tend to be confined to paleovalleys or paleotopographic lows. The major controls on paleotopography are either due to tectonics or to the effects of differential erosion (Figure 15).

\section{Tectonic Controls on Paleotopography}

Detailed studies of stratigraphic and sedimentologic relations in basins such as the Witwatersrand have shown repeatedly the importance of tectonic controls on sedimentation (Brock and Pretorius, 1964). In numerous instances, fold patterns seen in present outcrops can be shown to coincide with axes of gentle warps active during deposition. This can have very important implications in exploration. For example, major synclines revealed by regional mapping may well coincide with downwarps in the depositional floor of the original sedimentary basin. These downwarps can control such important features as the entry points of fluvial fans into a basin. 


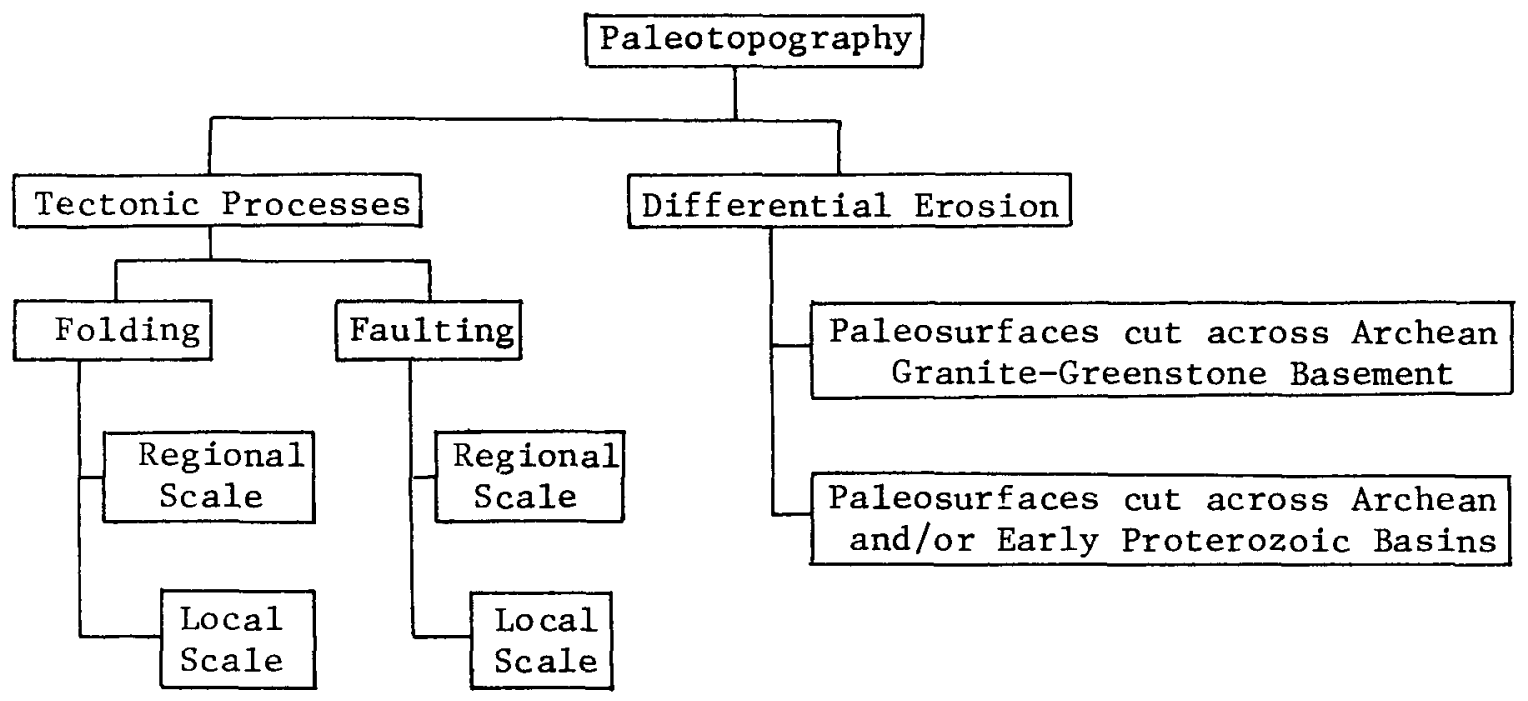

Figure 15. Diagrammatic representation of the major controls on paleotopography in Archean and early Proterozoic basins.

Fold Controls, Regional Scale

Brock and Pretorius (1964) and Pretorius (1976) have stressed the importance of regional deformation in the development and preservation of Witwatersrand orebodies. In this basin, the older fold axes originally trended northeast, but their trend has been altered by refolding about northwest-trending axes (Figure 8). These cross folds have a periodicity of $40-50 \mathrm{~km}$. The intersecting fold axes produced a series of depressions (intersecting synclines) and domes (intersecting anticlines) which were active before, during, and after deposition of the Witwatersrand sediments (Pretorius, 1976). Major gold and uranium mining districts, coincident with major fluvial fans, are located in structural depressions between structural domes (Figures 7 and 8). The downwarps were broad paleovalleys during Witwatersrand deposition and were the natural sites for the development of large fluvial fans.

In the Elliot Lake district, uranium orebodies coincide with areas of thickerthan-normal development of Matinenda coarse-grained arenites (Roscoe, 1969). While differential weathering is responsible for much of the paleotopography in this region, the effects of folding were also considered to be important. Roscoe (1969) interpreted the pattern of folding as shown in Figure 16. Longitudinal axes up uplift (anticlines) trend east-southeast and are crossed by north-northwest trending cross folds. Longitudinal axes are spaced some $13 \mathrm{~km}$ ( 8 miles) apart, while the transverse axes have an average spacing of $20 \mathrm{~km}$ ( 12.5 miles). The three major "ore zones" (shown black in Figure 16) are located in, or on the edges of, major structural depressions between the uplifts.

In certain late Archean and early Proterozoic basins, the location of major downwarps can be predicted accurately by a study of the configuration of the older Archean basement. In both the Transvaal Basin (South Africa) and the Hamersley Basin (Australia), paleovalleys coincide with synclinal downwarps 


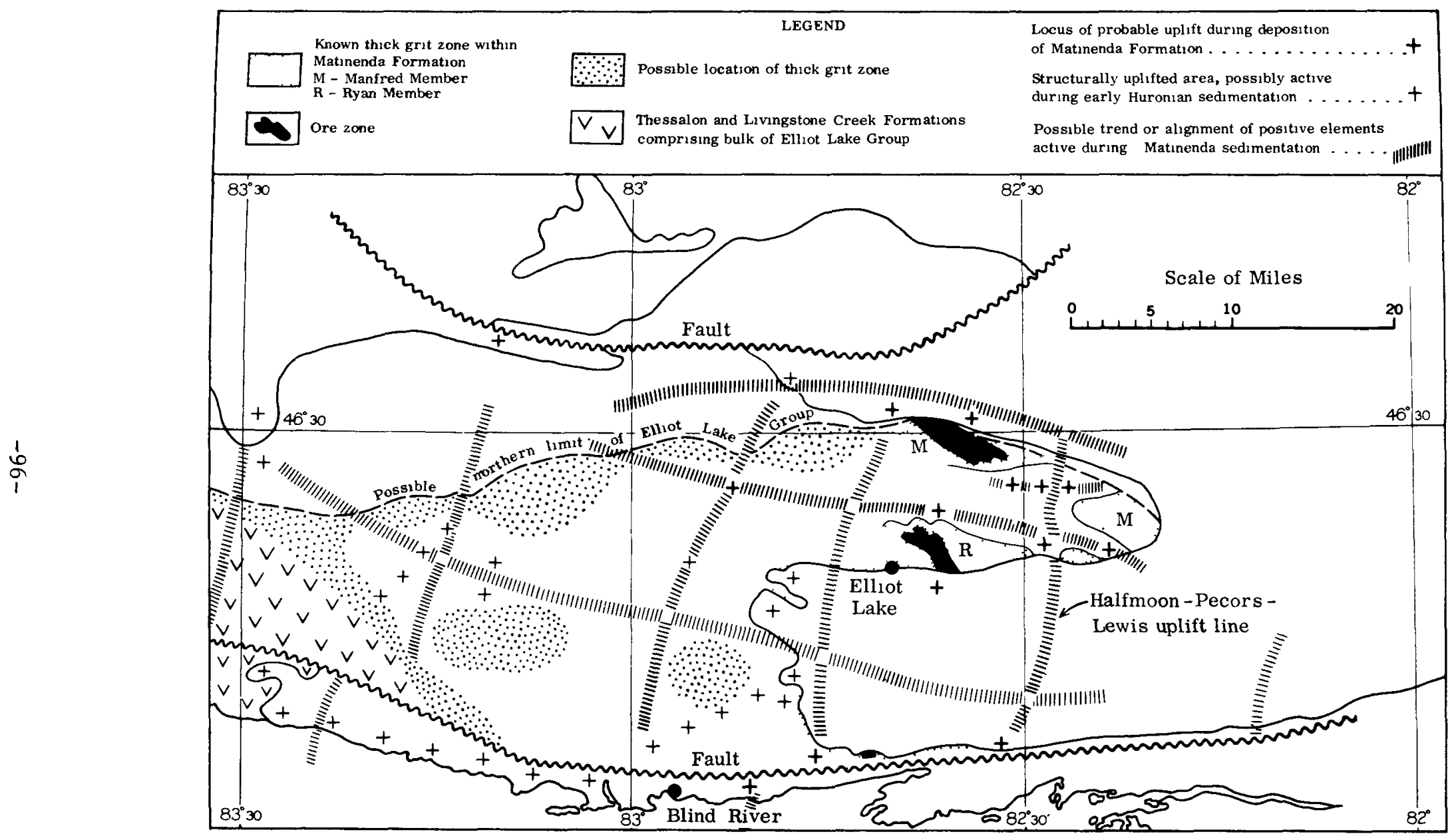

Figure 16. Trends of positive elements during deposition of the Matinenda Formation (from Roscoe, 1969). 
which are superimposed on Archean greenstone belts, while basinal paleohighs occur above the granitic elements of the Archean basement (Button, 1976). A classic example is in the Wolkberg Group of the Transvaal Supergroup in the northeastern Transvaal Basin (Button, 1973). One of the lowest coarseclastic units, the Schelem Formation, was deposited largely in paleovalleys coincident with underlying greenstone belts (Figure 17).

In summary, regional paleotopography in late Archean and early Proterozoic basins is controlled to a large degree by tectonic warping on a scale of tens to a few hundred kilometers. Paleovalleys colncide with downwarps. The location of downwarps can be predicted by studying present-day outcrop patterns in many instances since fold axes have remained in the same positions for extremely long spans of time. If the basement below a basin of interest comprises greenstone belts in addition to granites and gneisses, downwarps and paleovalleys are likely to be located over the greenstone belts.

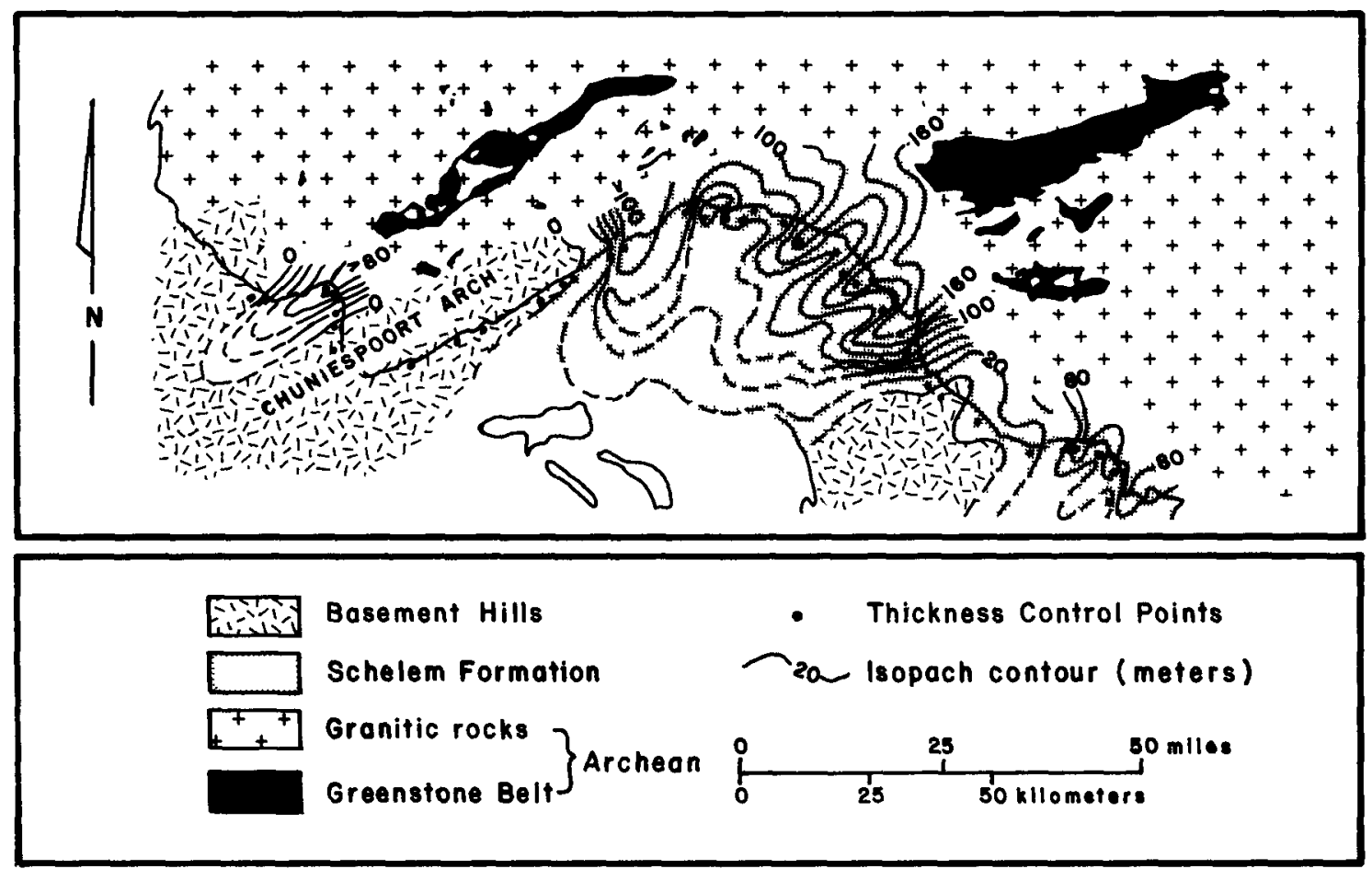

Figure 17. Isopach map of the Schelem Formation, Wolkberg Group, Transvaal Supergroup, in the northeastern Transvaal (after Button, 1973). The thickness of the formation is controlled largely by the presence of major paleovalleys developed along the traces of Archean greenstone belts. 


\section{Fold Controls, Local Scale}

There are numerous well-documented examples of the controls of folding on sedimentation on a scale of hundreds of meters to a few kilometers. Some of the best are in the uraniferous-auriferous Kimberley Reef of the East Rand district, Witwatersrand Basin (Armstrong, 1968; Antrobus and Whiteside, 1964; De Jager, 1964). These authors have shown that the beds below the Kimberley Reef were gently folded into a series of basins and domes. This folding had two very important effects on the deposition of the Kimberley Reef conglomerate. First, the domes stood out as elongate mounds around which the braided stream network responsible for Kimberley Reef deposition was deflected (Figure 18). Second, the domes were breached by erosion, and the older sediments so exposed (including mineralized conglomerates) acted as local sources of gold, uranium, pebbles, and pyrite.

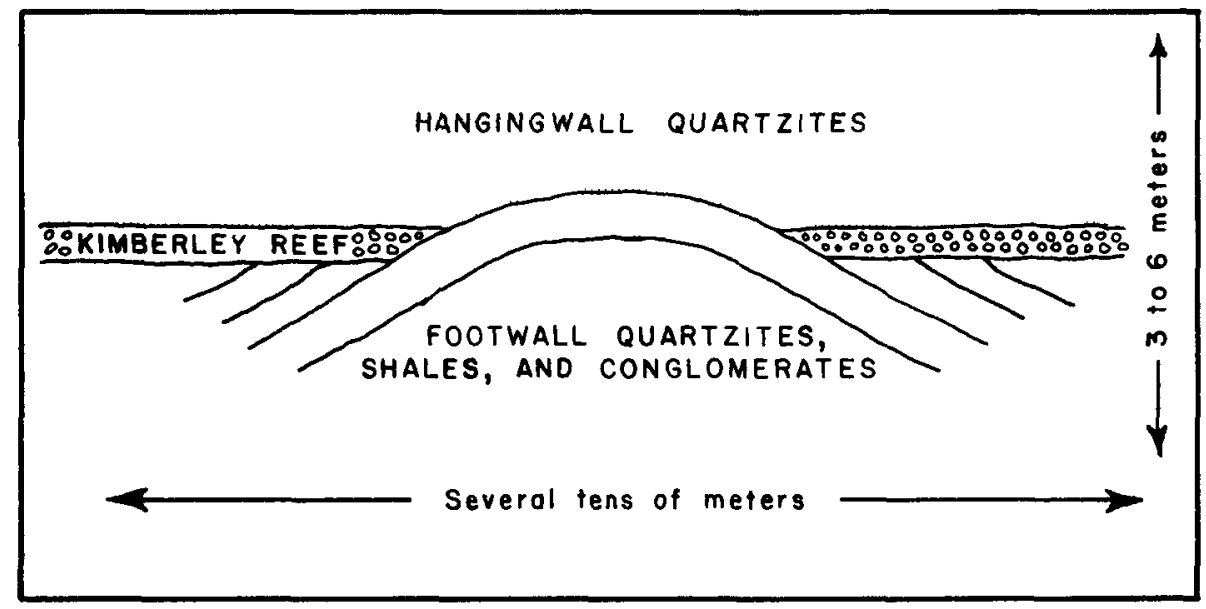

Figure 18. Cross section showing wedge-out of the Kimberley Reef against a paleo-island coincident with a footwall anticline (after Antrobus and Whiteside, 1964).

Some of the domes are as long as $1.5 \mathrm{~km}$, so that their presence has a marked influence on operations within a single mine.

\section{Fault Controls, Regional Scale}

The depositional basin in which the mineralized Witwatersrand sediments were deposited is thought to have formed in part as a response to episodes of regional normal faulting (Brock and Pretorius, 1964). The northern and western rim of the basin coincides with a series of normal faults with net downward movement on the southern and eastern sides. The uplifted block north and west of the basin-bounding fault system supplied much of the sedimentary fill for the complementary basin.

These relations have been illustrated in many parts of the basin. Olivier (1965) documented stratigraphic and structural relations in the northern 
part of the Welkom Goldfield. In this area, the upper Witwatersrand Basin is bounded on the west by the north-northwest-trending Border Fault, a normal fault with downward movement to the east. Isopach maps of Witwatersrand units indicate very abrupt wedging towards the fault. Units attain their maximum thickness some $3 \mathrm{~km}$ east of the fault, then thin gradually further east. The very rapid wedge-out of units within the Witwatersrand is due to a combination of thinning of individual Witwatersrand formations and repeated erosional truncation of underlying formations by overlying ones (Figure 19). The net effect is that the interval between the Basal Reef and the Boulder Beds, from 700 to $900 \mathrm{~m}$ thick in places, thins and wedges out over a lateral distance of less than $1 \mathrm{~km}$. The relationships described by Olivier (1965), are probably due to repeated uplift of the block west of the Border Fault. ${ }^{1}$

Fault Control, Local Scale

Normal faulting has been interpreted to have controlled the configuration of the Witwatersrand depository on a regional scale. It can also be shown to have exerted a strong influence on paleotopography on a local scale. For example, the West Rand Syncline is traversed by a pair of northeast-trending normal faults. The ground between these faults was raised tectonically by some $3,000 \mathrm{~m}$ in 1ate-Witwatersrand and immediate post-Witwatersrand times, forming a horst block some $4.5 \mathrm{~km}$ wide and at least $45 \mathrm{~km}$ long (Figure 20). The horst block was bounded by a complementary graben valley of undetermined width on the southeastern side. Fan-like sheets of gravel built out into this graben valley, being derived by erosion of the horst mountain block. Since the latter was composed in part of mineralized upper Witwatersrand sediments, these fans are themselves mineralized and have been extensively mined. Conglomerates formed in this way are thought to include the E1sburg conglomerates in the Cooke Section of the Randfontein Estates Gold Mine, the Ventersdorp Contact Reef in the South Roodepoort Mine (Minter, 1970), and the Ventersdorp Contact Reef and "Elsburg Massives" of Western Areas Gold Mine (W.E.L. Minter, written communication, 1980).

A classic study on the controls of faulting on sedimentation has just been completed by Krapez (1980). His synthesis (Figure 21) of the Ventersdorp Contact Reef in the Carletonville Goldfield shows that the conglomerate was confined to major paleovalleys between north to south-trending horst blocks. The horst blocks were obviously the source areas of the Ventersdorp Contact Reef in this area.

\section{Paleotopography Due to Differential Erosion}

The erosion surfaces (unconformities) of the past can be inferred to have been as topographically varied as the landscape of today. Much of the

\footnotetext{
${ }^{1}$ W.E.L. Minter (written communication, 1980) and some other South African geologists are of the opinion that the Witwatersrand Basin was formed entirely by warping. They see no evidence for faulting during Witwatersrand sedimentation. Minter interprets the relations along the Border Fault (described above) as due to thrust faulting from the west during latest Witwatersrand time.
} 


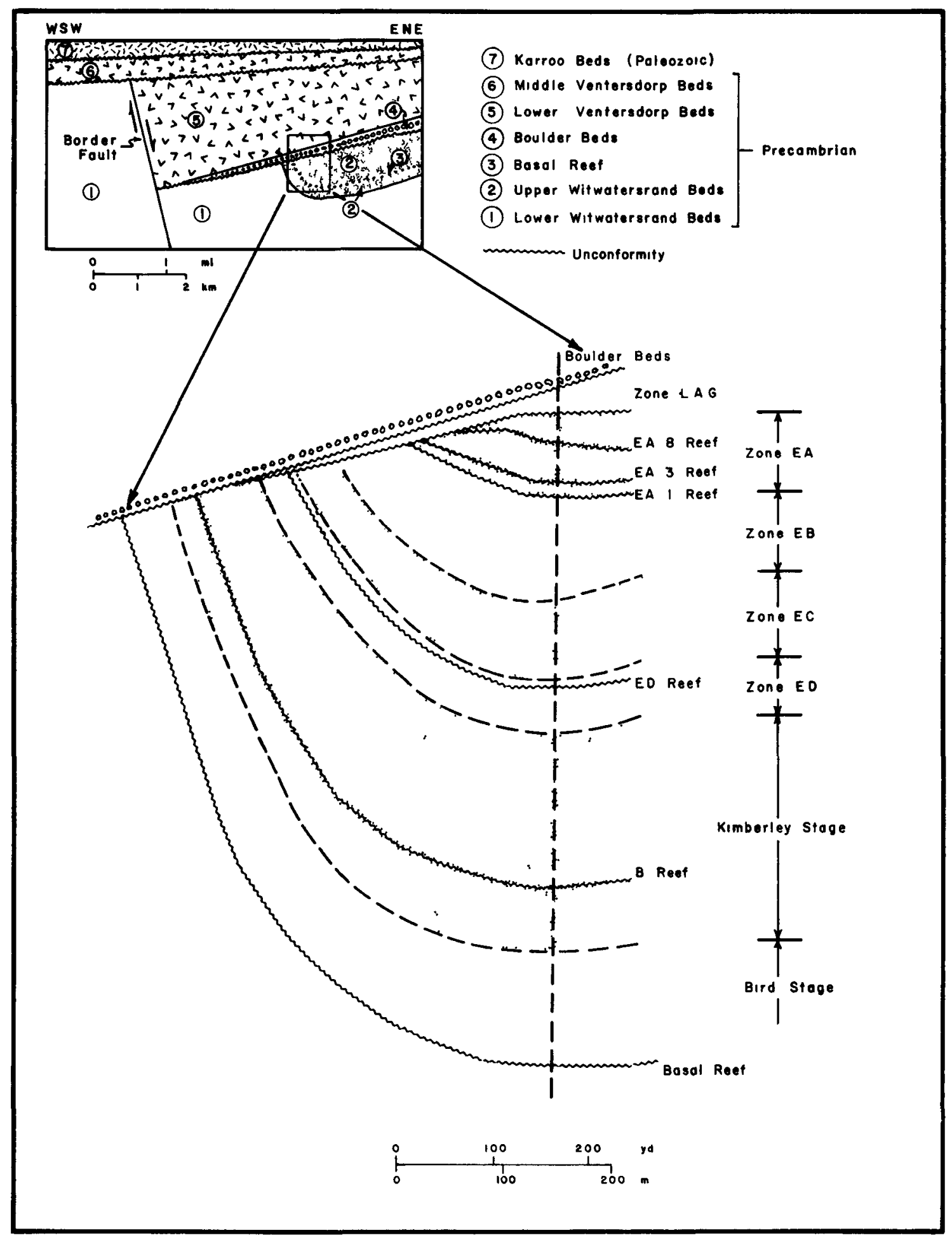

Figure 19. Restored cross section through part of the Welkom Goldfield, showing stratigraphic relations in the upper parts of the Witwatersrand Supergroup and in the overlying Ventersdorp lavas (after 0livier, 1965, Plate VI). 


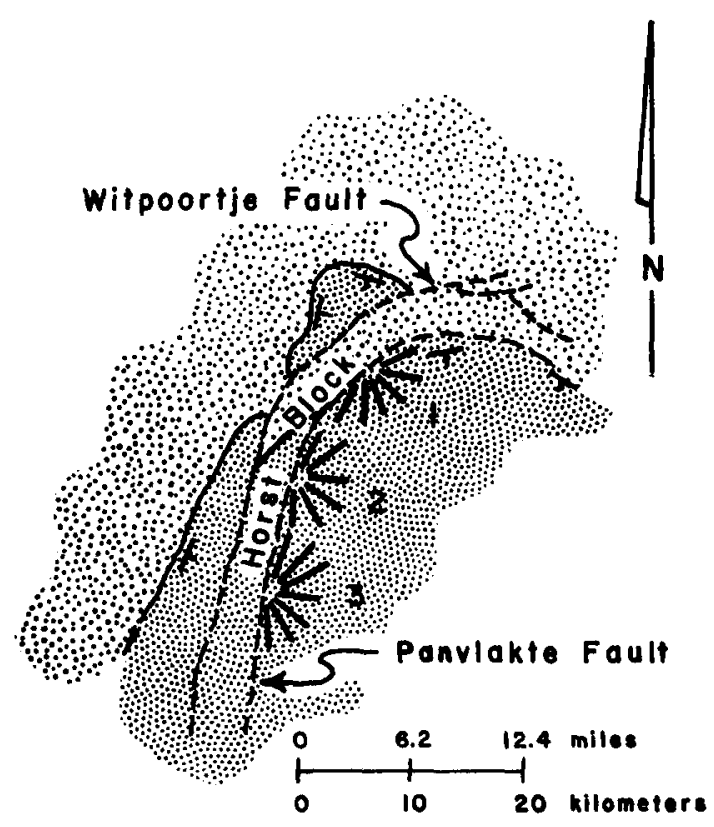

I. South Roodepoort Maln Reef Areos Gold Mine

2. Cooke Section, Randfontein Estotes Gold Mine

3. Western Areas Gold Mine

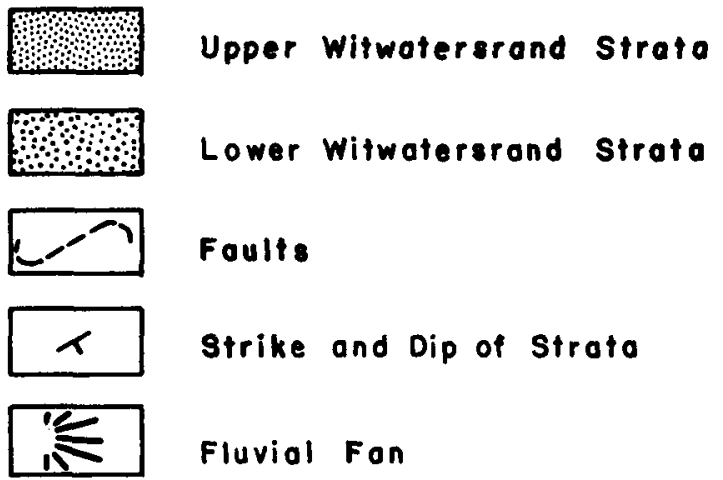

Figure 20. Geologic sketch map of the West Rand area, showing the development of mineralized $f$ an systems in paleograben valleys adjacent to a paleohorst mountain range (modified after Minter, 1978). 


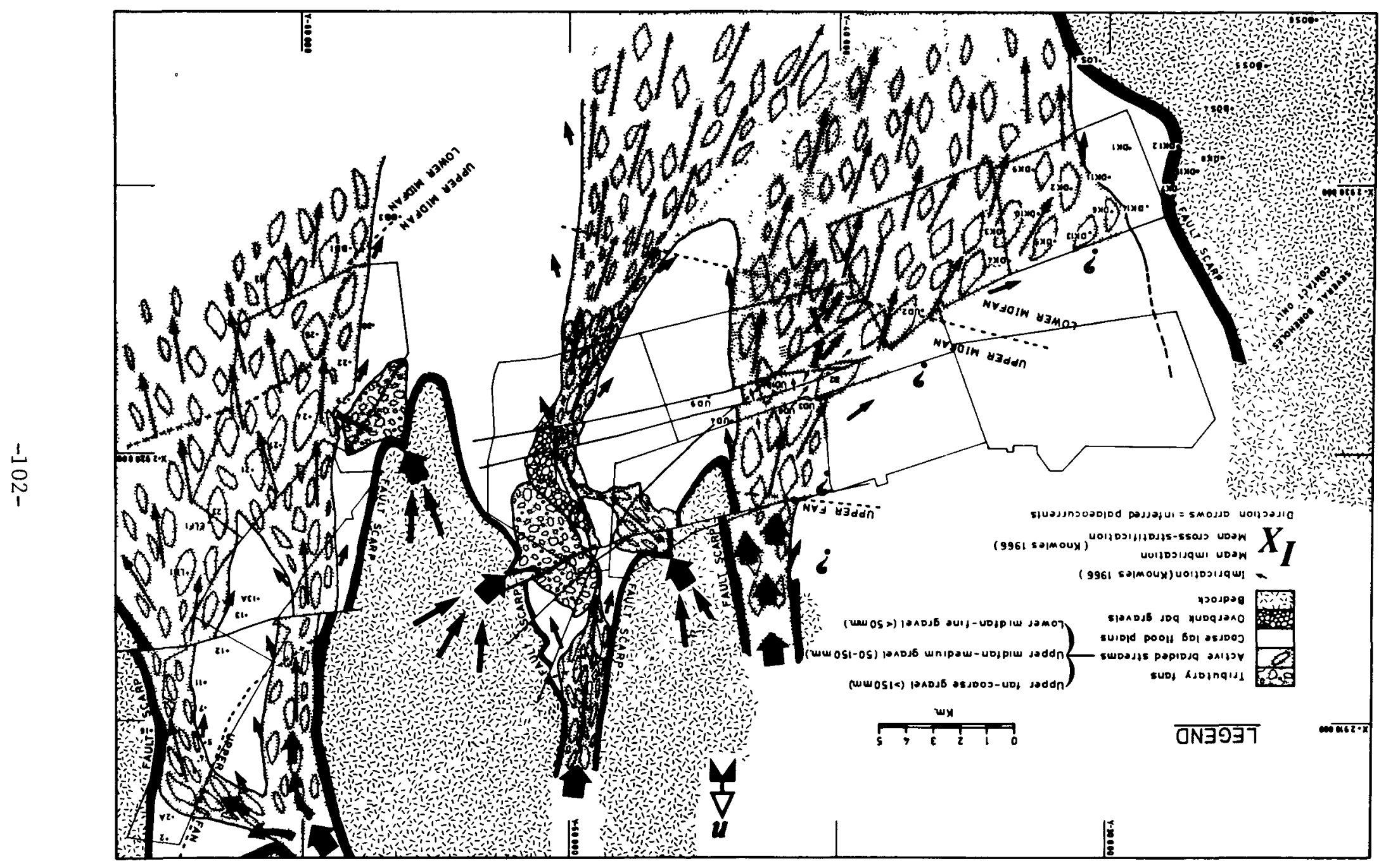

Figure 21. Regional paleoenvironmental model of the Ventersdorp Contact Reef in the Carletonville Goldfield, showing the importance of horsts and grabens in the control of deposition and preservation of mineralized conglomerate (from Krapez, 1980). 
topographic variety of landscapes (past and present) is due to the differing resistance of various rock types to the forces of chemical and mechanical weathering. Paleovalleys formed by differential weathering and erosion of certain rocks played an important part in controlling the location of uraniferous conglomerates.

\section{Differential Erosion of the Archean Basement}

The basement below the uraniferous conglomerates of the Matinenda Formation in the Elliot Lake district of Ontario is composed of greenstone belts (metavolcanics and metasediments) and a suite of granitoid rocks including granodiorites, massive red granites, and gneisses (J.A. Robertson, 1960, $1976,1978)$. Roscoe (1969) has shown that the Matinenda uraniferous conglomerates (black on Figure 22) were deposited in paleovalleys marginal to the massive red granites, which formed the valley walls and interfluves. The paleovalleys were carved on relatively soft, southeast-trending belts of greenstone metabasalt.

Greater detail is provided in maps and sections published by J.A. Robertson $(1976,1978)$. Robertson's map (Figure 23) shows that the mineralized conglomerates of the Quirke, Nordic, Pardee, Pecors, and Whiskey areas were a11 deposited in southeast-trending paleovalleys floored by greenstone basalt. Valley walls were formed by granitic rocks, by steep-dipping iron-formations, or by massive basic volcanics. Iron-formations formed spine-like paleoridges, some of which can be shown to have projected over $200 \mathrm{~m}$ (650 feet) above the adjacent valley bottoms.

Similar relationships have been established in other basins, including the Transvaal Basin (South Africa) and the Hamersley Basin (Australia). In both basins, greenstone belts formed paleovalleys, while granitic tracts formed uplands (Button, 1976; Button and Tyler, 1979). Figure 24 shows the paleotopographic relief on the Archean unconformity at the base of the Transvaal Supergroup in the northeastern Transvaal.

Greenstone belts are composed of a variety of volcanic and sedimentary rocks. Accumulated experience has shown that iron-formations, thick chert beds, quartzites, rhyolites, and massive basalts or serpentinites formed local spine-like ridges along ancient unconformities, while greenstone basalts and greywacke- or shale-dominated formations formed paleovalleys.

In summary, the paleotopography developed on an Archean basement can be one of the most important controls on the localization of uraniferous conglomerates. The fluvial subarkoses and quartz wackes which host uraniferous conglomerates are developed directly on the Archean basement paleosurface in many basins. They attain their maximum thickness in paleovalleys and wedge out against valley walls. Mapping of exposed Archean terrane in a prospective area will not only indicate the location of paleovalleys, but will also define their likely trend, which is usually parallel to formation boundaries in greenstone belts or to granite-greenstone contacts (Figure 23). 


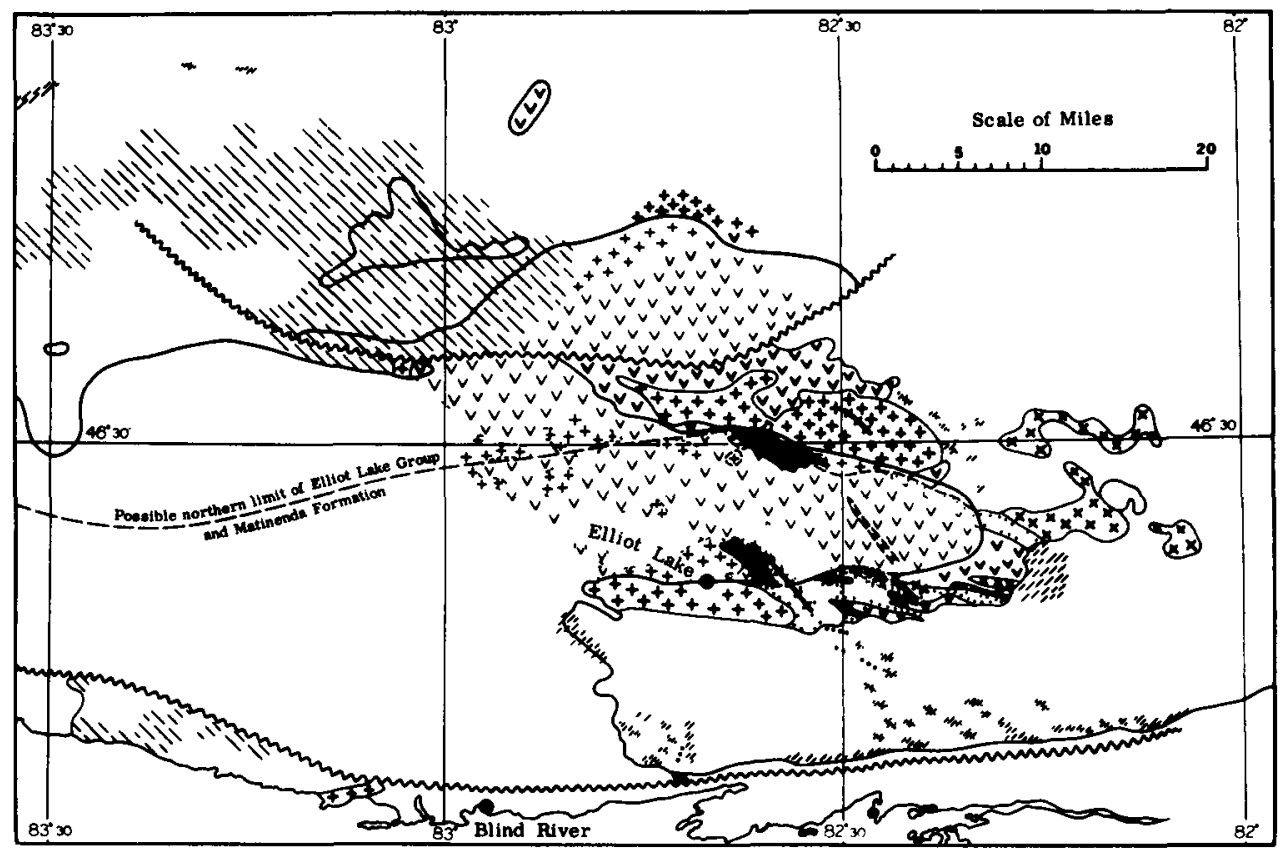

LEGEND

ARCHEAN ROCKS

$+_{++}^{++}+++$

Grey granodioritic rocks and unclassified Archean rocks

NIXy Amphibolite, migmatite and granitold gnefss

ANV (exposed, covered by Huronlan strata)

缘宷 Abundant inclusions of metavolcanic and metasedimentary rocks

(exposed, covered by Huronian strata)

\begin{tabular}{|l|l|l|l}
\hline$x_{x}^{x}$ & $x_{x}^{x}$ \\
\hline
\end{tabular} Metagabbro (exposed, covered by Huronian strata)

Tetasedtmentarv rocks (exposed, covered by llurontan strata)

\begin{tabular}{|l|l}
\hline$V$ \\
$V$ \\
$V$ & $V$ \\
$V$ & $V$ \\
\hline
\end{tabular}

Iron formation

$\ldots .00$ Glant quartz veln

Uranlum ore zones in Matinenda Formation

Boundary of Hurontan rocks

Possible northern limit of Flliot Lake Group and Matinenda Formation

Fault

Figure 22. Map showing pre-Huronian geology of the Quirke Syncline and neighboring areas. Major orebodies (in black) lie in paleovalleys cut on greenstone basalts (from Roscoe, 1969). 

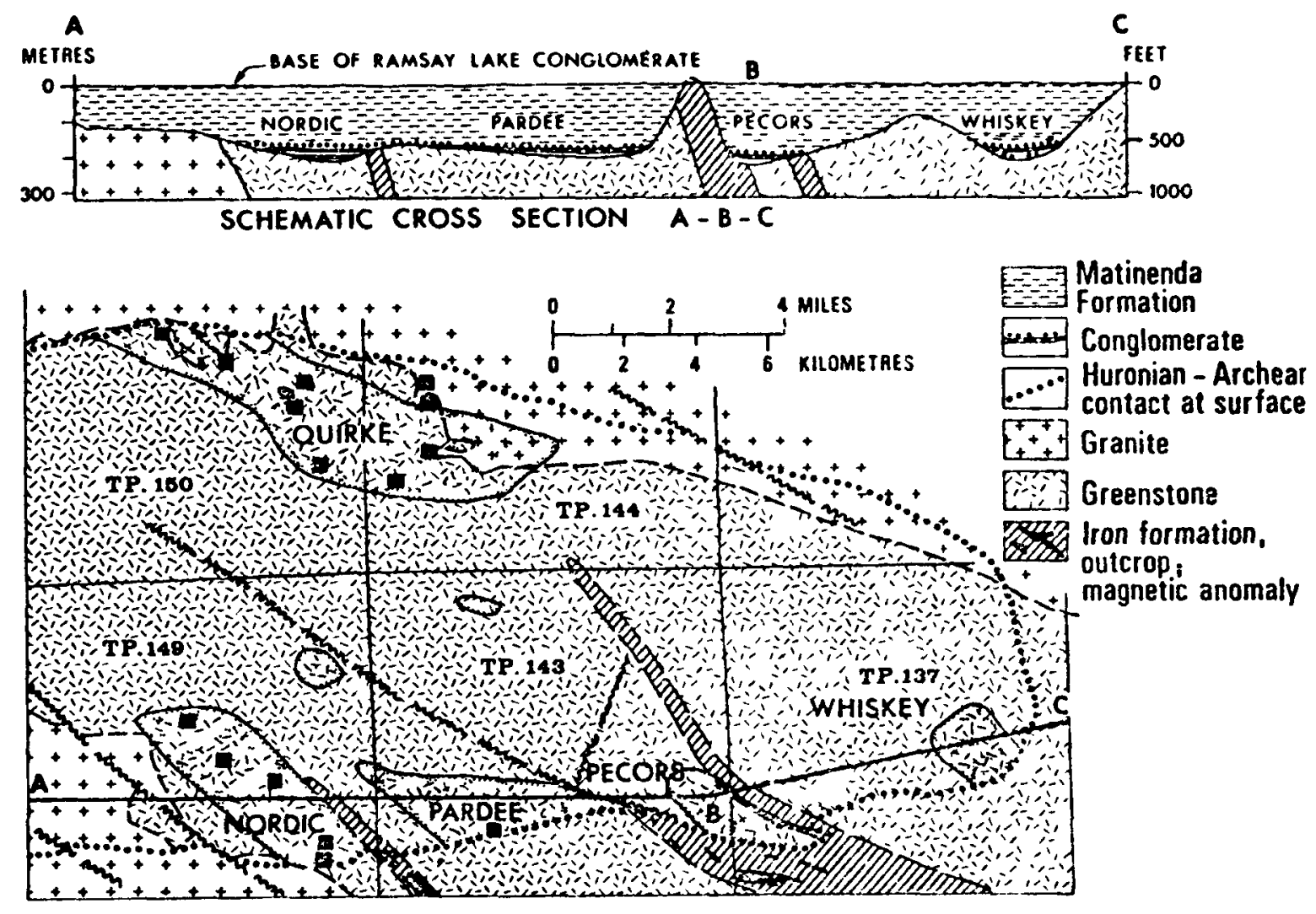

Figure 23. Detailed pre-Huronian geology of the Quirke Syncline, showing the development of the major orebodies (Quirke and Nordic) and subsidiary mineralized areas in paleovalleys cut on greenstone basalts (from J.A. Robertson, 1976).

\section{Differential Erosion on 01der Sedimentary Basins}

Ancient land surfaces developed on Archean and early Proterozoic basins have been studied in detail during mining and exploration activities associated with uraniferous-auriferous conglomerates. The best examples are in South Africa and include the unconformities developed between:

(1) the Mozaan and Insuzi subgroups of the 3,000-m.y.-old Pongola Group;

(2) the upper and lower divisions of the Witwatersrand Supergroup;

(3) Ventersdorp volcanics and the upper division of the Witwatersrand Supergroup; and, 
(4) the Transvaal Supergroup and the upper division of the Witwatersrand Supergroup.

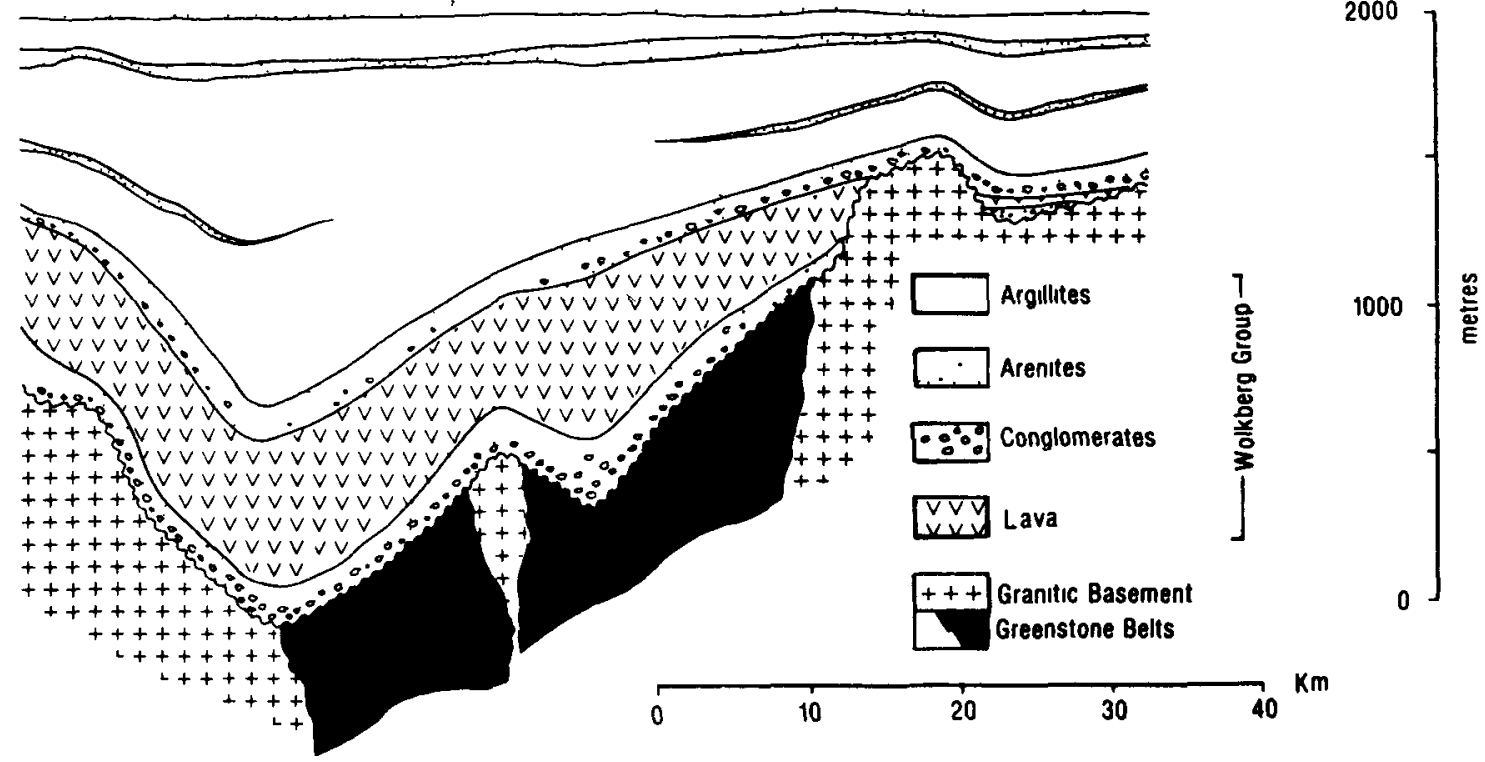

Figure 24. Cross section through basal units of the Wolkberg Group, Transvaal Supergroup, in the northeastern Transvaal, South Africa. Basal units are restricted to a broad paleovalley cut on an Archean greenstone belt (from Button and Tyler, 1979).

In all of these examples, the underlying stratified rocks (including shales, arenites, conglomerates, basalts, and some intrusive basic dykes) had been tilted gently before erosion commenced. Differential erosion of the gently dipping beds usually resulted in a series of cuesta ridges separated by strike valleys (Button and Tyler, 1979). In most instances, the ridges can be shown to have been composed of arenaceous formations, while the valleys were carved from shales, basalts, and basic intrusives. In plan view, the drainage patterns on such unconformities were trellis-like. Since the mineralized conglomerates tend to be confined to these paleovalleys and wedge out against the intervening cuesta ridges, the distribution of mineralization also has a trellis-1ike pattern (Figure 25A). In the example figured here (the unconformity between the base of the Transvaal Supergroup and the underlying Witwatersrand Supergroup in the West Rand area), older conglomerates outcropped along the cuesta ridges and supplied pebbles and heavy minerals to the fluvial gravels accumulating in the strike valleys.

Where the sediment below the unconformity is relatively uniform, differential erosion is unimportant and a dendritic drainage pattern becomes established. This is believed to be the situation in parts of the East Rand Basin, where the base of the Transvaal Supergroup rests on a monotonous alternation of 
sha1low-dipping beds of conglomerate and arenite of the upper Witwatersrand (Figure 25B). Mineralized conglomerates resting on the erosion surface are restricted to paleovalleys which, in plan view, taper and bifurcate upstream in a pattern reminiscent of dendritic drainage basins.

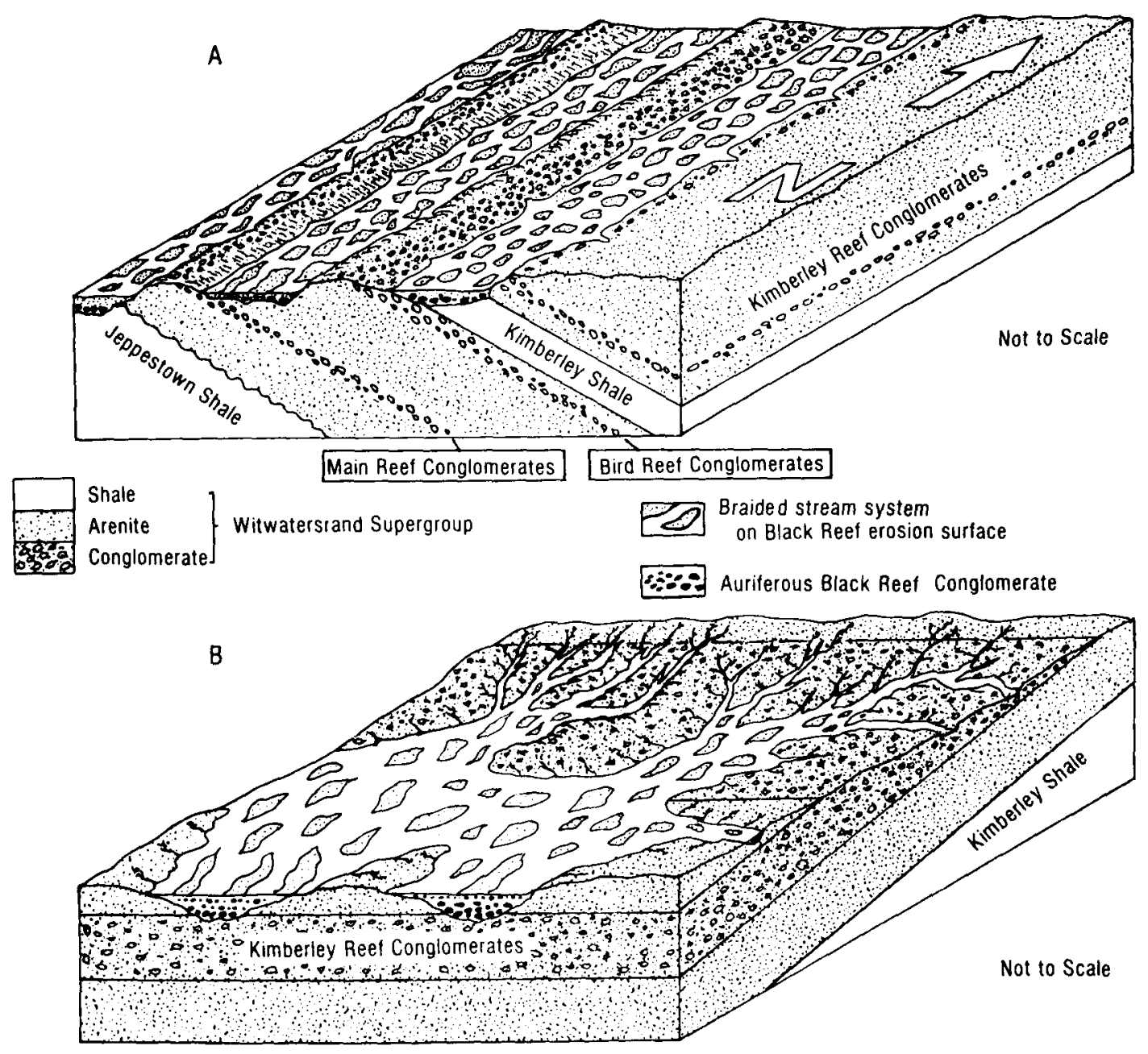

Figure 25. Schematic block diagrams showing trellis (A) and dendritic (B) paleodrainage patterns on the pre-Transvaal unconformity. Strata below the unconformity are units of the Witwatersrand Supergroup (from Button and Tyler, 1979; based on information given by Papenfus, 1964). 
The topography of unconformities in late Archean and early Proterozoic basins has a very marked influence on the distribution of uraniferous conglomerates. These are largely confined to paleovalleys, which range in scale from erosion etches a few meters across to basins hundreds of kilometers long and wide. Folding synchronous with sedimentation influenced paleotopography, uparched areas forming paleohighs and vice versa. Gravity faulting formed depositories ranging in scale from that of the Witwatersrand Basin to the graben troughs adjacent to the 45-km-long horst in the West Rand area. Paleovalleys were also formed by differential weathering both across the Archean basement and across older sedimentary and volcanic basins. In general, paleovalleys tend to be carved on greenstones and shaly formations while uplands were formed by rocks such as granites, quartzites, cherts, iron-formations, rhyolites, massive basalts, and serpentinites. The trends of paleoridges and paleovalleys can be predicted from a study of the structure of the layered rocks below the unconformities.

\section{Stratigraphic-Sedimentologic Setting of Uraniferous Conglomerates}

An important early step in the search for Precambrian uraniferous conglomerates is the recognition of favorable stratigraphic and sedimentologic environments. In this section, the importance of the unconformity to the development of mineralized conglomerates is reviewed. Several different types of unconformity are recognized. The depositional paleoenvironments in which the conglomerates and associated sediments are inferred to have been deposited are discussed.

\section{Unconformity Control on Uraniferous Conglomerates}

\section{Scale of Unconformity}

The unconformities associated with uraniferous conglomerates can be convenient1y classified on the basis of their lateral extent and the magnitude of the time break they represent:

(1) Fundamental Unconformities/Nonconformities can usually be traced laterally over an area on the order of $10^{4}$ to $10^{5}$ square kilometers. The rocks above and below the unconformity vary in age by time periods on the order of $10^{6}$ to $10^{8}$ years.

(2) Intraformational Unconformities/Disconformities usually have an areal extent on the order of $10^{2}$ to $10^{3}$ square kilometers. In the non-fossiliferous Precambrian sediments in question, the time break represented cannot be quantified. Geologic evidence suggests a time break on the order of $10^{3}$ to $10^{5}$ years. Evidence of such lengths of time includes the development of paleosols along unconformity surfaces (Button and Tyler, 1979) and the inclusion of indurated clasts of the underlying formation in conglomerates above the unconformity. 
The major subdivision is made on the basis of the scale of the unconformity and the time break it represents. A second criterion applied in the classification (Table 6) is the character of the rock type directly overlying the conglomerate developed on the unconformity. The rock type overlying the conglomerate plays a purely passive role in many instances, merely covering it and protecting it from subsequent erosive events. In other cases, however, the depositional processes responsible for deposition of the rock above the conglomerates can rework and modify the underlying conglomerate sheet.

Table 6. Classification of unconformities associated with Precambrian uraniferous conglomerates.

UNCONFORMITY TYPE

TYPE 1 - Fundamenta1 Unconformity/ Nonconformity
SUBTYPE

Overlain by fluvial sediments ( $1 \mathrm{f}$ ) Overlain by marine sediments ( $1 \mathrm{~m}$ ) Overlain by volcanic rocks ( $1 \mathrm{v}$ )

TYPE 2 - Intraformational Unconformity/ Overlain by fluvial sediments (2 f) Disconformity

Overlain by marine sediments $(2 \mathrm{~m})$

Overlain by volcanic rocks ( $2 \mathrm{v}$ )

Fundamental Unconformities/Nonconformities (Type 1)

Most erosional surfaces included in this category are cut across an Archean basement, comprising greenstone belts and granitoid rocks, including trondhjemitic, tonalitic, and granodioritic gneisses as well as granitic intrusives. Examples include the erosion surface below the Matinenda Formation, Elliot Lake district, Ontario, Canada (Roscoe, 1969), and the nonconformity below the Dominion Reef Group, South Africa (Von Backström, 1976).

Other fundamental unconformities are cut across sedimentary/volcanic sequences which themselves rest on an older granite-greenstone basement. Examples include the unconformity separating the upper from the lower division of the Witwatersrand Supergroup, which can be traced for a few hundred kilometers in the eastern part of the Witwatersrand Basin (Button and Tyler, 1979).

In addition to their areal scale and geochronologic characteristics, fundamental unconformities/nonconformities are almost always underlain by paleosols. Descriptions and recognition criteria for paleosols have been provided elsewhere in this report. Despite their wide ranges in age and starting rock types, paleosols of the late Archean and early Proterozoic are remarkably similar worldwide (Button and Tyler, 1979).

A very important control on the development of uraniferous conglomerates along fundamental unconformities/nonconformities is the paleotopographic configuration of the erosion surface. These controls have been described in a preceding section of this report.

Fundamental Unconformity/Nonconformity Overlain by Fluvial Sediments (Type $1 \mathrm{f}$ ). The best examples of uraniferous conglomerates formed in this stratigraphic setting are the Matinenda conglomerates of the Elliot Lake district and the 
Dominion Reef conglomerates in South Africa. Since little published information exists for the latter, the focus will be on the Elliot Lake deposits.

The pre-Huronian erosion surface has been shown to have sloped gently to the south-southeast (Pienaar, 1963; Roscoe, 1969; J.A. Robertson, 1976, 1978). The inclination of the erosion surface is indicated by the wedge-out of the Matinenda Formation to the north (J.A. Robertson, 1976) and by the wedge-out of the individual members within this formation in the same direction (Figure 26). On the south limb of the Quirke Syncline, the Ryan Member (a very coarse-grained, granule-bearing arenite) is in contact with the basement. It is overlain by the Stinson Member, a better sorted, relatively fine-grained unit. As the Ryan Member wedges out against the sloping unconformity, it is overstepped by the Stinson Member. Further north the Stinson wedges out, and the Manfred Member rests on the basement. Over large parts of the northern limb of the Quirke Syncline, the Manfred Member has wedged out, and the overlying Hough Lake Group rests directly on the Archean (Figure 26).

Onlap and wedge-out relations operate on a more local scale as well. Uraniferous conglomerates tend to be developed in paleovalleys and wedge out against basement highs (Figure 23). For example, The1s (1979) has published a diagram showing the wedge-out of a series of conglomerates and intervening arenites against a local basement hill (Figure 27).

In South Africa, the basal sediments of the Dominion Reef Group were deposited on an undulating surface cut across Archean granitic rocks. A "lower reef" occupies depressions on the erosion surface and is the main source of the gold previously mined in this district. An "upper reef" occurs some $18 \mathrm{~m}$ higher in the succession. It is a small pebble conglomerate which varies in thickness from 0.05 to $1.2 \mathrm{~m}$, and is laterally continuous over distances of up to $1 \mathrm{~km}$ (Von Backström, 1976). This reef $1 \mathrm{~s}$ very rich in uranium, espectally where thin, containing up to 1 percent $U$ over 2 to $5 \mathrm{~cm}$. It also carries significant concentrations of gold.

From the exploration standpoint, the relationships described above are of major importance. Uraniferous conglomerates may not outcrop due to wedge-out relations, such as those shown in Figure 26. They may also be missing locally within an area of high potential due to wedge-outs against basement hills (Figure 27).

Fundamental Unconformity/Nonconformity Overlain by Marine Sediments (Type $1 \mathrm{~m}$ ). Several examples of uraniferous conglomerate in this type of stratigraphic setting are known but none are presently producing uranium. Conglomerates are restricted to paleovalleys on the erosion surface. The plan-view distribution of conglomerates on such surfaces varies from dendritic (over homogeneous substrates) to trellis (over inclined layered rocks). The conglomerates occur in one or more layers in the paleovalleys and wedge out against channel margins. An excellent example of this setting is the mineralized conglomerate of the Black Reef Quartzite, at the base of the Transvaal Supergroup in the East Rand Goldfield (Papenfus, 1964; see Figure 25 of this report). Some of the channel-fill probably represents fluvial deposits in the paleovalley, while the upper units were probably reworked by the marine transgression that progressed across this unconformity. 

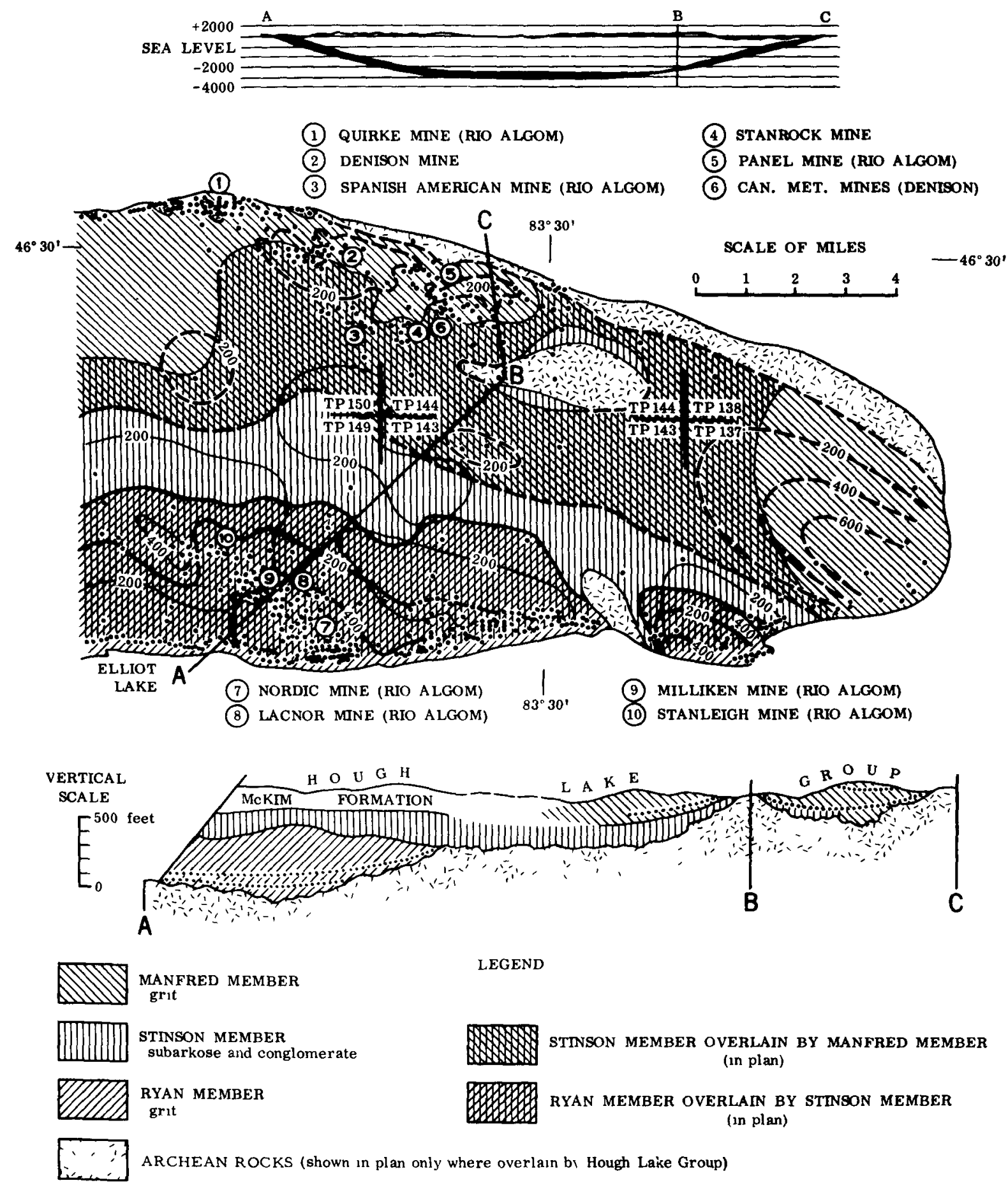

MANFRED MEMBER

LEGEND

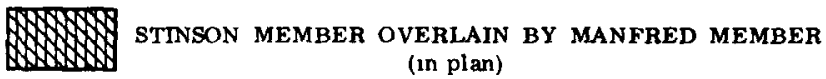

subarkose and conglomerate

RYAN MEMBER

grit

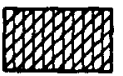

RYAN MEMBER OVERLAIN BY STTNSON MEMBER

(1n plan)

THICKNESS OF MEMBERS (FEET)

RYAN $-400-\quad$ STINSON $-400-\quad$ MANFRED $-400=-$

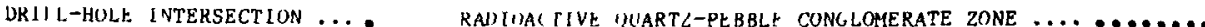

il lustrated schematically in section

Figure 26. Stratigraphic relations within the Matinenda Formation in the Quirke Syncline, Elliot Lake district (from Roscoe, 1969). 
Recognition of a marine sequence covering the conglomerates is usually based on several criteria, including the following:

(1) the textural and compositional maturity of the quartz a renites above the paleosurface;
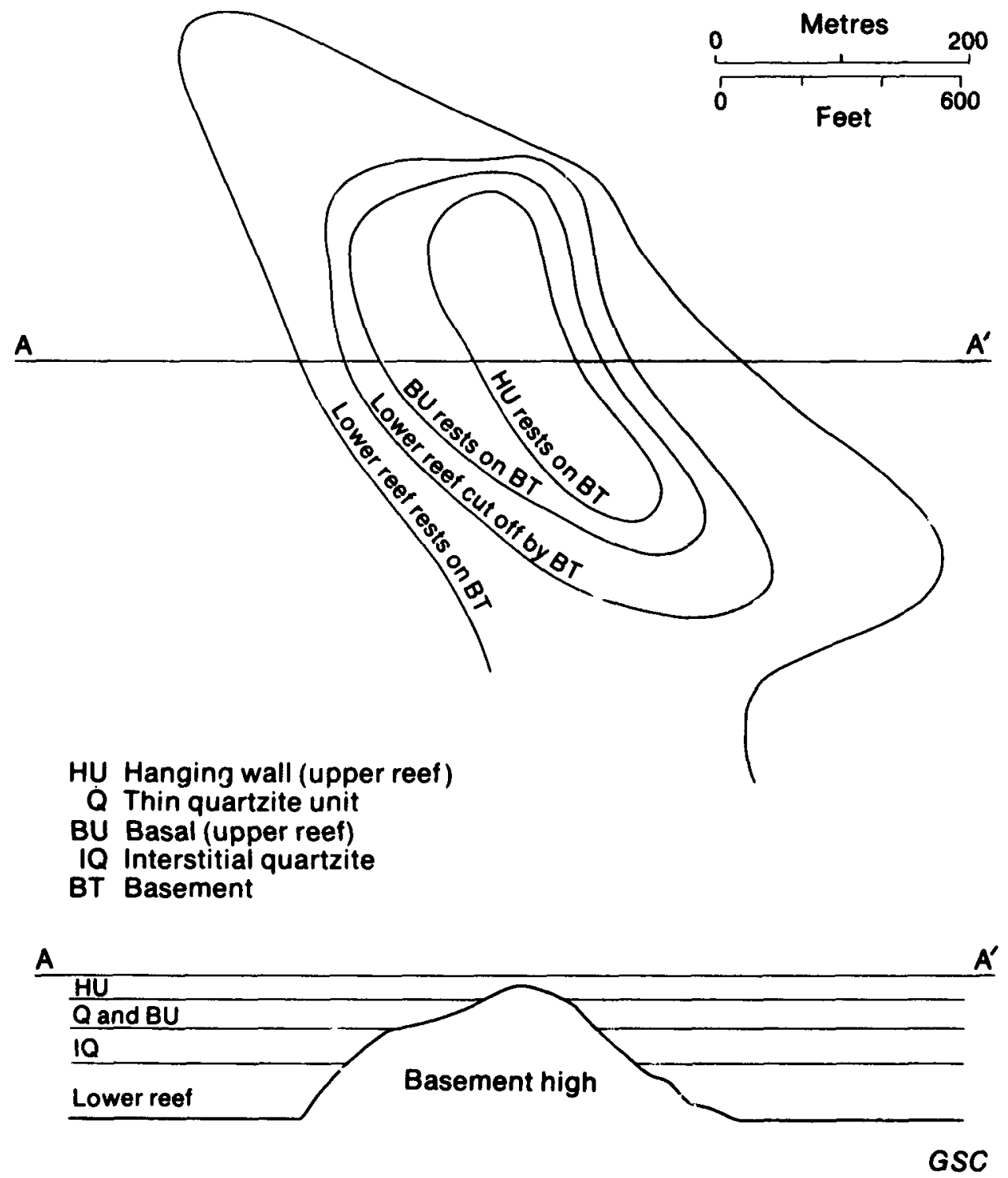

Figure 27. Wedge-out of units of the Rio Algom-Denison ore reef against a basement paleohil1 (from Theis, 1979). 
(3) the sedimentary structures and sediment dispersal patterns in the arenites; and,

(4) the upward gradation of the quartz arenites to finer grained clastic rocks or to chemical sediments.

Common gradations are of quartz arenite to shale to iron-formation and quartz arenite to shale to dolomite. The former sequence is seen at the base of the Mozaan Group of the Pongola Basin (gradation over tens of meters) and at the base of the lower division of the Witwatersrand Supergroup (gradation occurs over hundreds of meters). The latter sequence is seen in the transition from the Black Reef Quartzite to the Malmani Dolomite over a stratigraphic interval that varies from a few meters to a few hundred meters (Figure 28).

The marine-transgressed fundamental unconformity or nonconformity appears to have moderate-to-low potential for economic concentrations of uranium based on our present knowledge of producing districts. The basal Mozaan conglomerates of the Pongola Basin, South Africa, have produced a small amount of gold and are currently being pattern drilled to evaluate their gold and uranium potential. The basal conglomerate of the Black Reef Quartzite has been mined locally for gold, pyrite and platinoids (Papenfus, 1964). Though it is uraniferous (De Waal and Herzberg, 1969), no uranium has been commercially extracted from this unit, even when it rests unconformably on uraniumbearing Witwatersrand strata, as in parts of the East Rand area (Papenfus, 1964).

The reasons for this apparent low uranium potential are probably the thorough and repeated reworking of the sediments along the unconformity by weakly oxygenated fluvial or marine waters over the $10^{6}$ to $10^{8}$ year time spans associated with the regional unconformities. Under such conditions, dissolution of uranium is expected. This uranium is likely to have been redeposited (by reduction) in the fine-grained sediments above the marine quartz arenites. An example of this type could be the uranium found along the contact of an oxidized iron-formation and its slaty footwall at the Sherman Mine in northern Michigan (Vickers, 1956, quoted by Langford, 1977). Vickers demonstrated that the slate contained enough easily leachable uranium to have formed the deposits.

Fundamental Unconformity/Nonconformity Overlain by a Volcanic Sequence (Type 1 v). A well-studied example of this type is the Ventersdorp Contact Reef, developed at the unconformity separating the Ventersdorp volcanics from the underlying Witwatersrand beds (Figure 28). The conglomerate has been mined for gold in parts of the West Rand, Carletonville, and Klerksdorp Goldfields (Minter, 1970, 1978; Krapez, 1980).

The Ventersdorp Contact Reef is uraniferous. Though it rests on and was in part derived from uraniferous Witwatersrand conglomerates such as the Bird Reefs (in the West Rand) and the Carbon Leader (in the Carletonville Goldfield), the Ventersdorp Contact Reef has thus $f$ ar not been mined for uranium (Whiteside, 1970). Relatively small areas of this conglomerate may be mined for uranium in the future (W.E.L. Minter, written communication, 1980). 

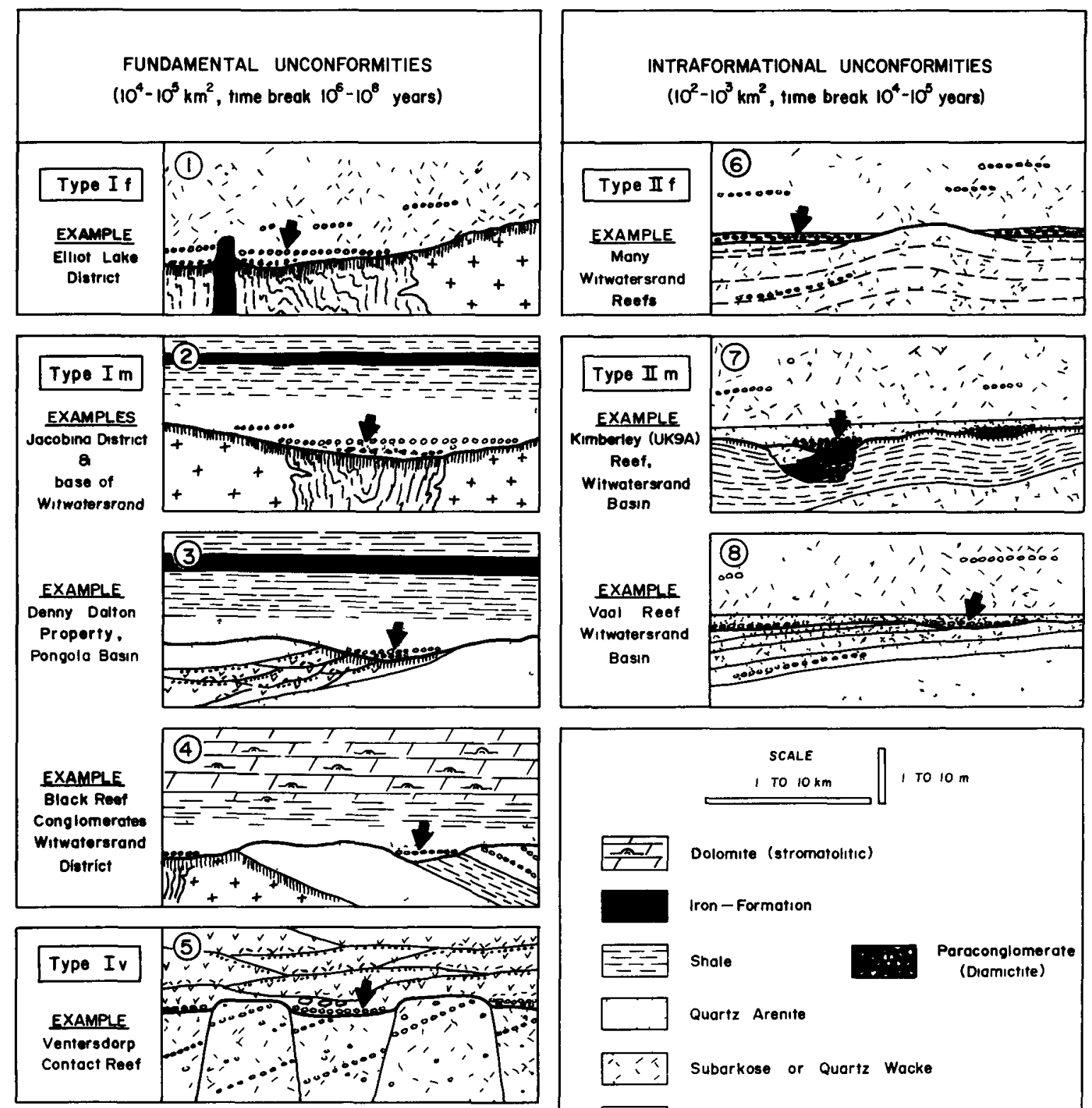

SCALE
Dolomite (stromatolitic)
Iron-Formation
Suartz Arenite

Figure 28. Geologic sketches showing the development of uraniferous conglomerates along or close to unconformities of varying types. 
The Ventersdorp Contact Reef is thought by some geologists to be a pediment gravel formed by erosion and deflation of a paleosurface cut across Witwatersrand sediments (Turner, 1979). Removal of much of the uranium from the gravel was probably due to exposure to ground water over periods of time on the order of $10^{6}$ to $10^{7}$ years.

Intraformational Unconformities/Disconformities (Type 2)

Uraniferous conglomerates associated with intraformational unconformities are well developed in the Witwatersrand Basin. The conglomerates are located on erosion surfaces cut across Witwatersrand sediments, usually quartz-wacke arenites. They are overlain by either fluvial quartz wackes or by marine quartzites.

Recognition of intraformational unconformities is of ten not possible on the level of study associated with outcrop mapping exercises. Most intraformational unconformities are only definitely recognized after mining commences and systematic mapping of the conglomerate footwall stratigraphy gets under way. Detailed study of conglomerate footwall stratigraphy from cored boreholes during exploration has allowed delineation of some intraformational unconformities (Button, 1968).

The angular differences between beds above and below the intraformational unconformities are usually too small to observe in the field or even in underground exposures. In the Central Rand, Cousins (1965) has shown that the Main Reef Leader conglomerate sheet truncates its footwall at a rate equivalent to $8 \mathrm{~m} / \mathrm{km}$ (Figure 29). In the Vaal Reef of the Klerksdorp Goldfield, the truncation occurs at $8.2 \mathrm{~m} / \mathrm{km}$ (Figure 30; Minter, 1976).

Locally, more dramatic unconformities within Witwatersrand formations have been noted. For example, in the uppermost Witwatersrand beds of the Welkom Goldfield, strata were repeatedly uplifted and eroded to form a series of intraformational unconformities (0livier, 1965). Some of these unconformities are shown in Figure 19. Angular discordances as high as 90 degrees are developed. These unconformities were probably formed by repeated upward movements of the western margin of the Witwatersrand Basin along the north to south-trending Border Fault zone. Conglomerates developed on these unconformities are mineralized. Some attain ore grade in gold. In general, however, rapid repetition of uplift episodes apparently did not allow enough time for the development of payable conglomerate sheets.

Where intraformational unconformities rest on chemically reactive rock types, such as shale or basalt, some paleoweathering effects can be noted. For example, in the eastern sectors of the Witwatersrand Basin, the Kimberley Reef rests with a gentle angular unconformity on the Kimberley Shale (Pretorius, 1964b; Tweedie, 1968). The dark gray shale is altered to a khaki color for a few centimeters below the unconformity. Such a thin alteration horizon is unlikely to be recognized in surface outcrops during exploration.

Intraformational Unconformities Overlain by Fluvial Sediments (Type $2 \mathrm{f}$ ). The Basal/Steyn conglomerate sheets of the Welkom Goldfield are economically mineralized by gold and uranium over an area of about $200 \mathrm{~km}^{2}$ (Minter, 1978). The conglomerates are overlain by "muds and muddy sands" (Minter, 


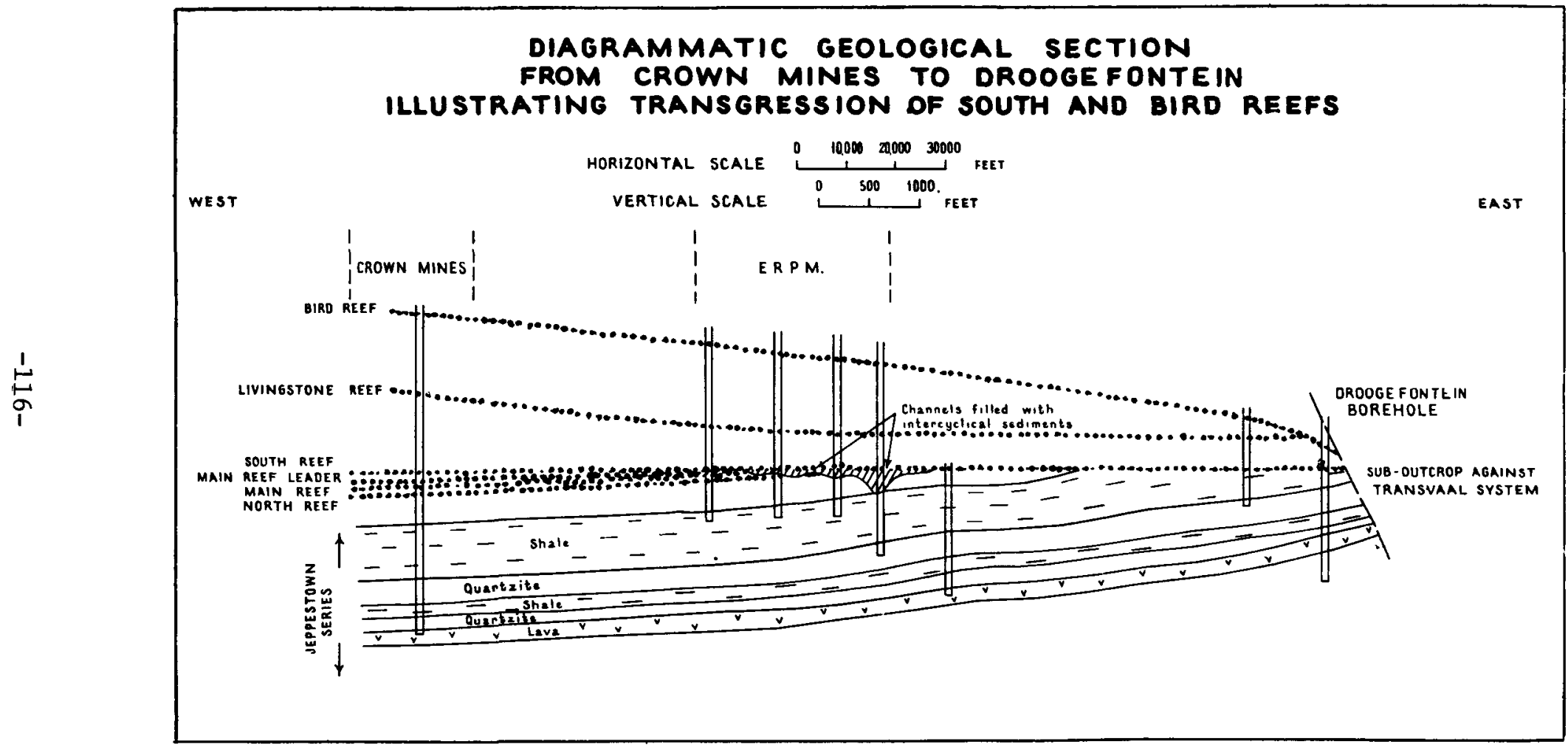

Figure 29. Restored stratigraphic cross section in the Central and East Rand areas showing the low-angle unconformity between the Main Reef Leader and its footwall units (from Cousins, 1965). 
1978). Minter was of the opinion that these sediments were deposited under standing water. Their impure nature suggests that the body of water was not related to an epeiric sea and may have been a lake in a fluvial environment.

The numerous conglomerates of the central Witwatersrand such as the Main Reef and Main Reef Leader are overlain by coarse- and very coarse-grained quartz wackes. While not studied in detail, these sediments are very similar to braided fluvial arenites of the East Rand area (Button, in press).

Intraformational Unconformities Overlain by Marine Arenites (Type $2 \mathrm{~m}$ ). Many well-mineralized uraniferous conglomerates of the Witwatersrand belong in this category. A well-studied example is the Vaal Reef in the Klerksdorp Goldfield (Minter, 1976). The conglomerate has an average thickness of $30 \mathrm{~cm}$ and is found over an area of about 250 square kilometers. It rests with gentle, angular unconformity on coarse-grained (sometimes pebbly) arenites (Figure 30). The erosion surface is etched by shallow, wide, braided erosion channels (up to $1.5 \mathrm{~m}$ deep, width/depth ratios of up to $1,000)$ which flowed from northwest to southeast down the paleoslope. The upper surface of the conglomerate is overlain disconformably (Minter, 1976, p. 173) by a "gray siliceous coarse-grained quartzite" up to $3 \mathrm{~m}$ thick, and, in the eastern part of the goldfield, by coarse-grained, sometimes pebbly "argillaceous quartzite". Paleocurrent studies have shown that the latter quartzite was transported consistently from southwest to northeast along the contour of the paleoslope. Minter (1976) believed that the Vaal Reef "was buried beneath sediments transported by a longshore current".
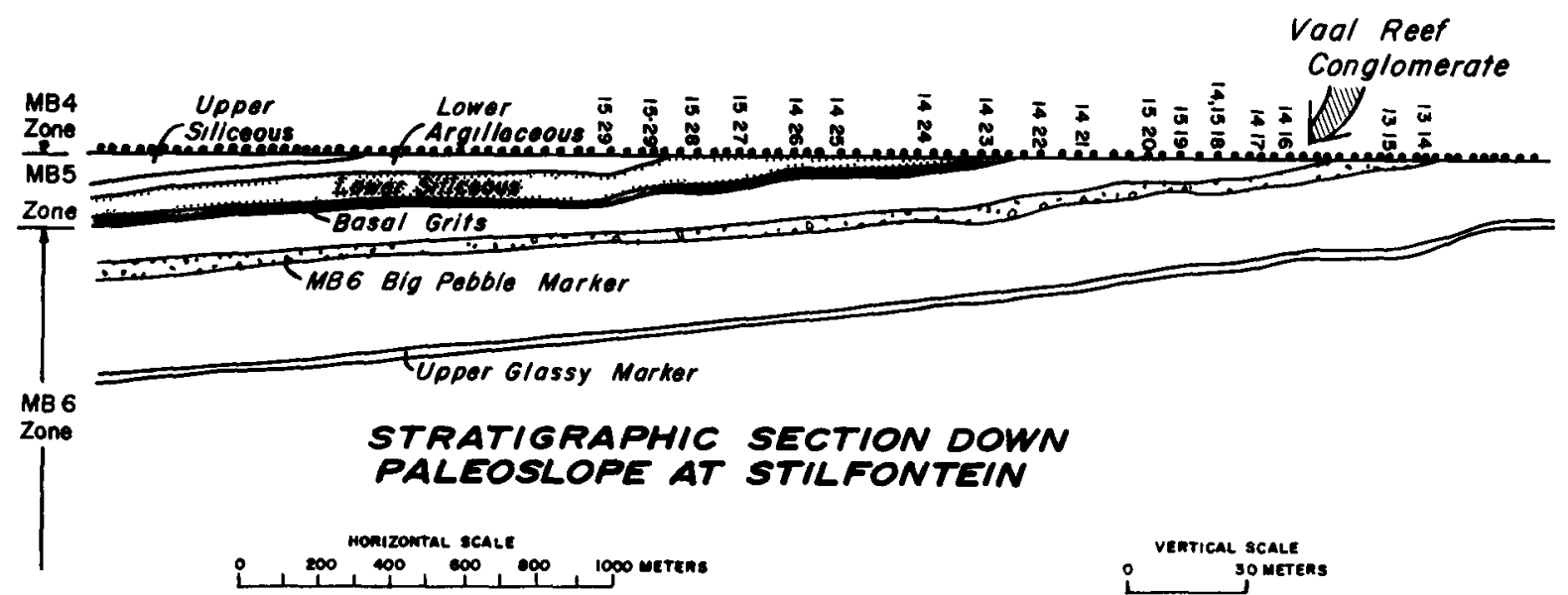

Figure 30. Restored stratigraphic cross section of the Klerksdorp area, showing the low-angle unconformity below the Vaal Reef (after Minter, 1976). 
Another uraniferous conglomerate that may be overlain by marginal marine arenites is the Kimberley Reef of the East Rand area. The conglomerate was deposited in a braided network of channels up to $2 \mathrm{~m}$ deep on an erosion surface inclined towards the south-southeast (Armstrong, 1968). The conglomerate is directly overlain by a pure quartzite known as the UK9A Marker. This sheet of quartzite is up to $4 \mathrm{~m}$ thick. Cross-beds within it give complex patterns of distribution of azimuths, including unimodal, bimodal, and polymodal patterns (Armstrong, 1968). The quartzite is also ripple marked. "Ladderback" ripples, formed by flow of water parallel to the crests of major ripples, are figured in Armstrong's report. Such ripples are common on contemporary tidal sandflats (Reineck and Singh, 1973). Shale drapes within the UK9A Marker are prominently mud cracked. Although Armstrong (1968) was of the opinion that the UK9A Marker was a fluvial deposit, reinterpretation of his data, in the light of tidal depositional models such as those presented by Klein (1975), indicates that it is probably a lower tidal-flat sandstone.

In summary, several important uraniferous conglomerates are overlain by thin (usually less than $5 \mathrm{~m}$ ), of ten clean, quartz arenites with depositional structures suggestive of marine or marginal marine paleoenvironments. The compositionally and texturally mature quartz arenites are contained within a much thicker succession of impure arenites and conglomerates. They are of ten conspicuous markers, both in the field and underground.

\section{Unconformity Control on Heavy Mineral Concentration}

In the foregoing section, the control by unconformities on the concentration of gold, uranium, and other heavy minerals has been stressed. In this section, the geologic factors responsible for this control are analysed in a "processresponse mode1" (Figure 31).

Unconformities and disconformities result from either tectonic or geomorphological processes. Tectonic factors include either an uplift of a depositional area or the cessation of uplift of a source area. Geomorphological factors include such processes as drainage basin modifications, brought about by stream capture, for example.

The responses to these processes include a reduction in the amount of clastic sediment entering a basin and a lowering of the local or regional base level of deposition (Figure 31). Under these conditions, the sediment moving over a surface is "bypassed" and is not permanent1y deposited on that surface. Furthermore, the erosion rate exceeds the sedimentation rate, so that a subaerial surface becomes established.

At this point, the process-response net splits into two circuits (Figure 31), the one relating to blological/chemical processes, the other to physical sorting processes. The former circuit commences with the establishment of local colonies of primitive algal or bacterlal organisms and the development of a hydrologic system. There is some evidence that leathery mats of a primitive plant colony may have acted as "corduroy"-type traps for heavy minerals. There is also evidence that, at least locally, the paleo-ground water became charged with the organic decomposition products of the primitive plants. 


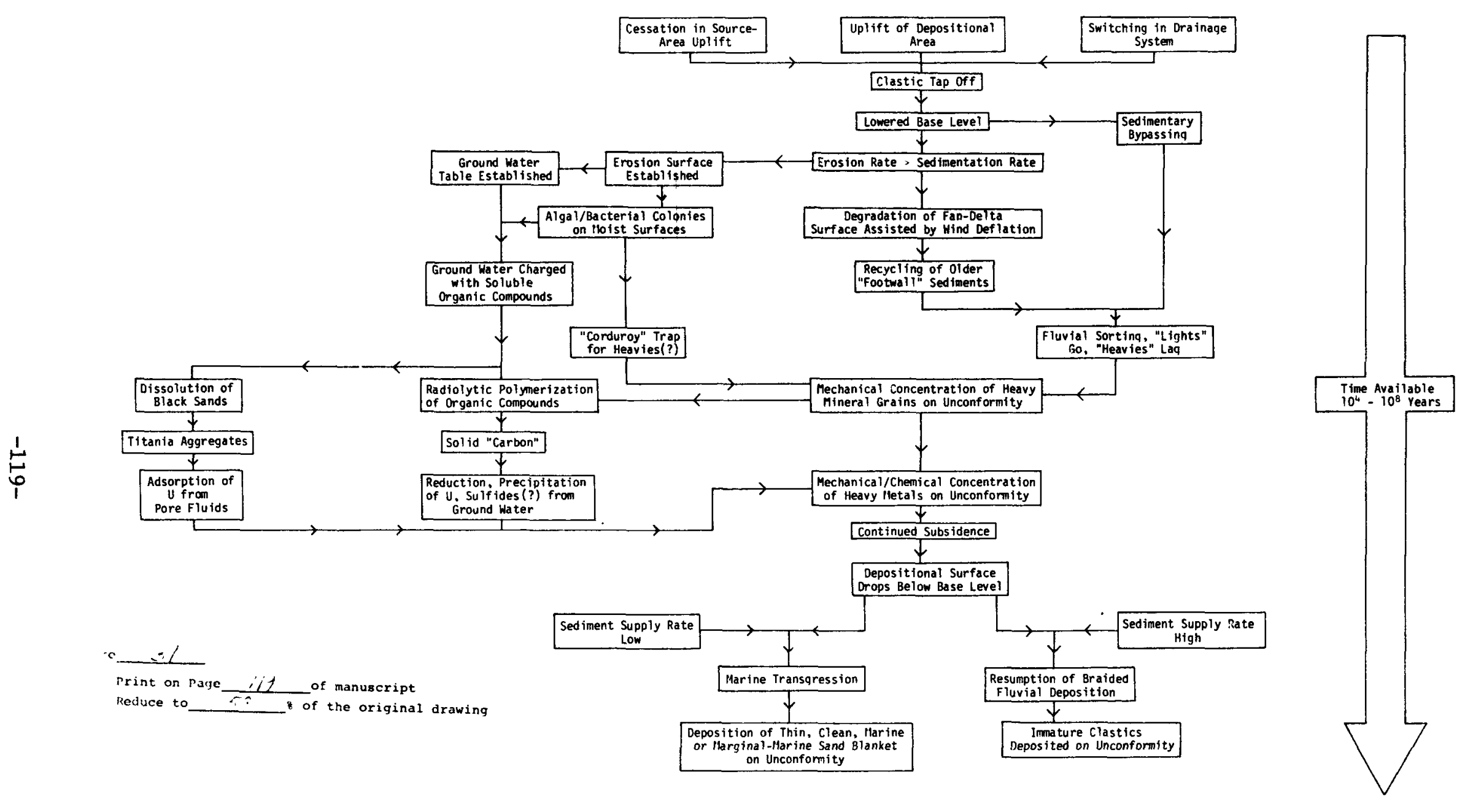

Figure 31. Schematic process-response model illustrating the control of the unconformity (or nonconformity) on the development of mechanical and chemical concentrations of uranium. 
At this point we must pick up the second circuit. Erosion of the paleosurface, assisted by wind deflation (as evidenced by ventifacts in some conglomerates, Minter, 1976), resulted in the recycling of older footwall sediments, some of which were uraniferous conglomerates. Fluvial (and eolian) sorting processes on this surface resulted in the "lagging" of heavy mineral grains on the surface of unconformity. This effect, combined with the "corduroy" trap and bypassing mechanisms, resulted in a mechanical concentration of heavy mineral grains and resistant pebbles on or near to the surface of unconformity.

At this point, the stage is set for the interaction of the two circuits. Ground waters charged with organic molecules fluxed through porous-permeable uraniferous conglomerates. The ionizing radiation emanating from uraninite grains generated a large number of free radicals in organic molecules, which then tended to polymerize in the immediate vicinity of the source of radiation. The resulting solid polymer, known as "carbon" (or thucholite) could then have acted as a powerful reductant. Any hexavalent uranium (or other soluble metallic ions in their higher valence states) in solution in paleo-ground water could then be reduced and fixed in or close to the carbon.

The reducing, organic-molecule-charged paleo-ground water was also probably responsible for the dissolution of black sand grains, such as ilmenite and ilmeno-magnetite. The removal of iron from these minerals, possibly promoted by organic complexation, resulted in the formation of titania "skeletons" with very large surface areas relative to their volume. These "titania aggregates" are powerful adsorbents of uranium in solution as will be shown in a subsequent section of this report. They are inferred to have collected uranium. Subsequently, the titania-uranium mixture underwent low-grade metamorphism to produce "brannerite", an important uranium mineral in many uraniferous conglomerates.

The net result of the merging of the two circuits is a conglomerate layer in which metals have been concentrated by both mechanical and chemical processes. The relative importance of these two components is bound to vary and will depend largely on the availability of organic molecules and of black sand components.

U1timately, the tendency for the basin to sink will result in a drop of the erosion surface below base level. At this point (see Figure 31), two alternatives are possible. If the sediment supply rate is low, the unconformity will probably be transgressed by a shallow sea, and the conglomerate covered by blanket deposits of marine arenite. If the sediment supply rate is high, the unconformity is likely to be covered by a prograding wedge of braided fluvial sediments. Both situations are known in the geologic record, the former being exemplified by such units as the Vaal Reef and the Black Reef, the latter by the Matinenda conglomerates.

An important contributing factor is the availability of great periods of time for these factors to operate. The unconformities in question represent spans of time on the order of $10^{4}$ to $10^{8}$ years. Given this time span, geologic processes, operating in their slow but thorough manner, can be highly effective in concentrating heavy metals on or close to unconformities. 


\section{Paleoenvironments of Deposition}

The following paragraphs are intended to be a general introduction to the topic of depositional paleoenvironments in basins containing Precambrian uraniferous conglomerates. Further details are given in the subsequent chapters in which the host rocks and the conglomerates themselves are described in detail.

In the 94 years since the discovery of the Witwatersrand deposits, the deposition of the conglomerates and the associated sediments has been ascribed to nearly every clastic depositional environment, with the exception of the deep-sea fan system. Pretorius (1975) has reviewed the subject and noted that environments postulated included the sea floor, beaches, deltas, rivers, lakes, and glacial environments. More specifically, shoreline deltas, shoreline fluvial fans, coastal fluvial systems, interior fluvial systems, and interior deserts have been proposed as the depositional environments within which deposition took place.

Some of the early work was not based on a logical analysis of contemporary depositional systems. The last two decades have seen the publication of numerous studies in which quantitative sedimentological and stratigraphic information has been used to refine the sedimentological models applicable to the Witwatersrand (Knowles, 1966; Armstrong, 1968; Minter, 1976, 1978; Smith and Minter, 1980; Krapez, 1980). The present consensus is that the conglomerates and associated sediments of the Witwatersrand were deposited in a series of fan deltas (Pretorius, 1976). The modification of the fluvial sediments by transgressive marine events has been documented by Minter (1976) and by Button (in press).

The present focus of sedimentological effort in basins such as the Witwatersrand is the application of refined models of braided stream systems, such as those proposed by Miall (1977). For example, Smith and Minter (1980) used models of contemporary braided stream systems to explain the concentration of gold and uranium in two Witwatersrand conglomerates.

The general acceptance of the braided fluvial models in Witwatersrand sedimentological studies should not be allowed to cloud objectivity in other occurrences. Other depositional systems can be important. For example, Turner (1979) has presented evidence for the argument that the Ventersdorp Contact Reef in the Carletonville area is a pediment gravel which was buried and preserved by voluminous basalt flows.

In contrast to the situation in the Witwatersrand, there has been agreement among most Canadian geologists that the Matinenda conglomerates and the associated subarkoses were fluvial sediments. Modern braided fluvial models have apparently not been applied to this formation. ${ }^{1}$ Relations described by Pienaar (1963) and illustrated in Figure 56 leave little doubt that such models could be applied successfully.

\footnotetext{
${ }^{1}$ According to J.A. Robertson (written communication, 1980), a sedimentological study of parts of the Matinenda Formation is currently being undertaken by A.D. Miall.
} 
Blark

$-122$. 
Recognition of the characteristics of the rocks enclosing uraniferous conglomerates is an important first step in exploration. Uranium-bearing conglomerates are relatively minor components within much thicker piles of sediments and volcanics. In this section, the petrology, geochemistry, and sedimentology of host rocks are reviewed.

Petrology, Mineralogy, and Chemistry of Host Rocks

In this report, three important petrological associations are recognized, a subarkose-quartz wacke association, a quartz-arenite association and a basalt association. The first-mentioned is by far the most important since it is the dominant association of the Witwatersrand and Elliot Lake districts. The quartz-arenite association is of potential economic importance in basins such as the Pongola (in South Africa) and Jacobina (in Brazil). The basalt association is exemplified by the Ventersdorp Contact Reef in South Africa, which contains important concentrations of gold, but (in most cases) subeconomic quantities of uranium.

\section{Subarkose-Quartz Wacke Association}

In addition to the Elliot Lake and Witwatersrand, this association is dominant in the Dominion Reef (South Africa), the Fortescue Group of the Hamersley Basin (personal observation, A.B., 1974), and the subeconomic occurrences of the Canadian Shield (D.S. Robertson, 1974). It is also a characteristic host rock of the uranfferous conglomerates in the Sierra Madre, Medicine Bow Mountains, and the Black Hills, U.S.A.

Color

The subarkoses and quartz wackes associated with uraniferous conglomerates are drab colored, usually shades of gray, green, olive, and khaki, of ten with a yellow cast. Descriptions of color are notoriously inconsistent and subject to observer bias. In a study of a representative sample of Witwatersrand cores (Button, 1968), rock colors were determined using a rock color chart prepared for the Geological Society of America (Goddard, 1963). Color was found to depend primarily on the sericite and chlorite content of arenites. The most sericitic arenites are dusky green-yellow (5 GY 5/2) or grayish olive ( $5 \mathrm{GY} 4 / 2$ ). Other common colors are greenish gray (5 G $6 / 1$ and $5 \mathrm{G}$ $5 / 1$ ) and dark and light greenish gray ( $5 \mathrm{G} 4 / 1$ and $5 \mathrm{G} 8 / 1$, respectively). It is believed that these colors span the range of descriptive terms given in the numerous papers on the Witwatersrand and Elliot Lake districts.

On weathering, the color of the subarkose-quartz wacke association sediments can change drastically depending on the composition of the arenite and the climate. In exposed parts of the Witwatersrand Basin, the pyritic quartz wackes weather with a rusty red crust. Where more strongly weathered, they are reduced to powdery rocks with pastel shades in cream, pink, and yellow. 
Mineralogical Composition

A thorough petrological examination of Witwatersrand arenites was published by Fuller (1958). He sampled the entire upper division of the Witwatersrand Supergroup and determined mineralogical composition by point count analyses. Fuller found that quartz comprises between 51 and 97 percent of the arenites studied and averages 79.6 percent through the entire column. Sericite and pyrophyllite make up 18 percent, on average, and range from 1 to 47 percent (Figure 32). Chlorite, chloritold, and chert grains make up the balance, averaging 2.1 percent (range 0 to 7 percent). Fuller's findings agree with those of other investigators. For example, Minter (1976) found that the "MB4 Quartzite", which is immediately above the principal hanging-wall formation of the uraniferous Vaal Reef (Klerksdorp Goldfield, Witwatersrand Basin), comprises 62 percent quartz, 26 percent sericite, 8 percent chlorite, and 4 percent rock fragments.

In an independent petrological study of Witwatersrand cores, Kent (1961) confirmed Fuller's findings. Kent studied 17 samples from 2 boreholes in the upper division of the Witwatersrand Supergroup in the Carletonville area. His results are reproduced in Table 7.

Table 7. Mineralogical composition of arenites of the upper division of the Witwatersrand Supergroup in the Carletonville area, South Africa (after Kent, 1961).

Mineral or Rock Fragment

detrital quartz

quartzite

recrystallized and authigenic quartz

sericite and pyrophylite

chlorite

chloritoid

opaques

$\begin{array}{ccc}\begin{array}{c}\text { Average } \\ \text { (percent) }\end{array} & & \begin{array}{c}\text { Range } \\ \text { (percent) }\end{array} \\ 60.7 & & 48-71.5 \\ 0.2 & .5-2 \\ 17.3 & 9.5-25 \\ 13.8 & 7-28 \\ 6.6 & 0-14 \\ 0.9 & 0-3.5 \\ 0.5 & \text { Trace }-1\end{array}$

Green-colored chrome mica (fuchsite) is a frequently identified component in Witwatersrand arenites (see, for example, Antrobus and Whiteside, 1964; De Jager, 1964).

Preserved feldspar grains are usually extremely rare in the upper division of the Witwatersrand Supergroup. Fuller's study did not reveal a single detrital grain of feldspar. W.E.L. Minter (written communication, 1980) has observed up to 15 percent of a "white altered feldspar" in some upper Witwatersrand 
sediments. According to classification schemes presented in Pettijohn (1975), most of the host arenites to Witwatersrand uraniferous conglomerates are best termed quartz wackes.

In the Canadian 1iterature, the uranium-bearing Matinenda Formation is usua1ly referred to as an "arkose", a "subarkose", or as a "quartzite" (Plenaar, 1963; Roscoe, 1969; J.A. Robertson, 1976). Roscoe stressed that the uraniferous conglomerates are associated with and contained in an arenite "composed mainly of poorly rounded quartz and potash feldspar clasts in a sericitic matrix, that imparts a characteristic greenish to yellowish color to the rock."

The most detailed petrological study of the Matinenda Formation was published by Pienaar (1963). Matinenda arenites contain from 5 to 23 percent sericitic matrix and from 8 to 26 percent feldspar (dominantly $\mathrm{K}$ feldspar). The sericite-poor arenites are appropriately termed sericitic subarkoses (Figure 32). The feldspar- and sericite-rich arenites are probably best described as quartz-feldspar wackes, arkosic wackes, or as feldspathic quartz wackes.

In the Witwatersrand quartz wackes, 80 percent of the quartz grains are single, untwinned crystals. The remainder are twinned or are aggregates of two or more grains (Fuller, 1958). Most quartz grains are strained, and those in the purer quartz arenites show deformation lamellae. Sericite is the dominant phyllosilicate in Witwatersrand arenites. Pyrophyllite, chlorite (iron rich), and chloritoid are quantitatively important constituents. Chloritoid is clearly of metamorphic origin and occurs as small lathlike crystals in arenites and argillites with the correct concentrations of alumina and iron (Kent, 1961). Fuller (1958) was of the opinion that both sericite and pyrophyllite were formed by post-depositional "hydrothermal" alteration of feldspar grains in Witwatersrand sediments. This explanation is rejected for several reasons. First, the alteration would have to have been extremely widespread (pervading $3,000 \mathrm{~m}$ of sediment over an area of over $10,000 \mathrm{~km}^{2}$ ). Preserved feldspar is extremely rare in the upper Witwatersrand, so the alteration would have to have been extremely uniform. Second, detrital feldspars are fairly common in the lower (non-economic) division of the Witwatersrand. It is difficult to see how these feldspars escaped the effects of a supposedly very widespread hydrothermal event. Finally, Archean and early Proterozolc paleosols are abundant in southern Africa and are mineralogically very similar to Witwatersrand quartz wackes (Button and Tyler, 1979). It is concluded that pyrophyllite and sericite in the upper Witwatersrand arenttes were introduced as aggregates of clay mineral. Such aggregates could have been composed of illite and kaolinite and could subsequently have been transformed metamorphically to sericite and pyrophyllite. Alternately, the sericite precursor could have been introduced as montmorillonite or mixed-layer montmorillonite-illite, which was then diagenetically transformed to 1111te (Perry and Hower, 1972) and subsequently metamorphically transformed to sericite.

In the Elliot Lake district, the source of sericite and of $\mathrm{K}$ feldspar clasts has long been regarded as being a weathered regolith developed on the granitic basement (Roscoe, 1969). The petrologic similarity and stratigraphic juxtaposition of Matinenda arenites on pre-Huronian paleosols is strong evidence in favor of this conclusion. 
Mineralogically, the Matinenda arenites are composed of quartz, chert, microcline, and minor amounts of altered plagloclase in a sericitic groundmass (Pienaar, 1963). The ratio of $\mathrm{K}$ feldspar to altered plagioclase ranges from 6:1 to 8:1. Plagioclase grains are almost always strongly sericitized; microcline and other clastic grains are less strongly altered. Quartz grains

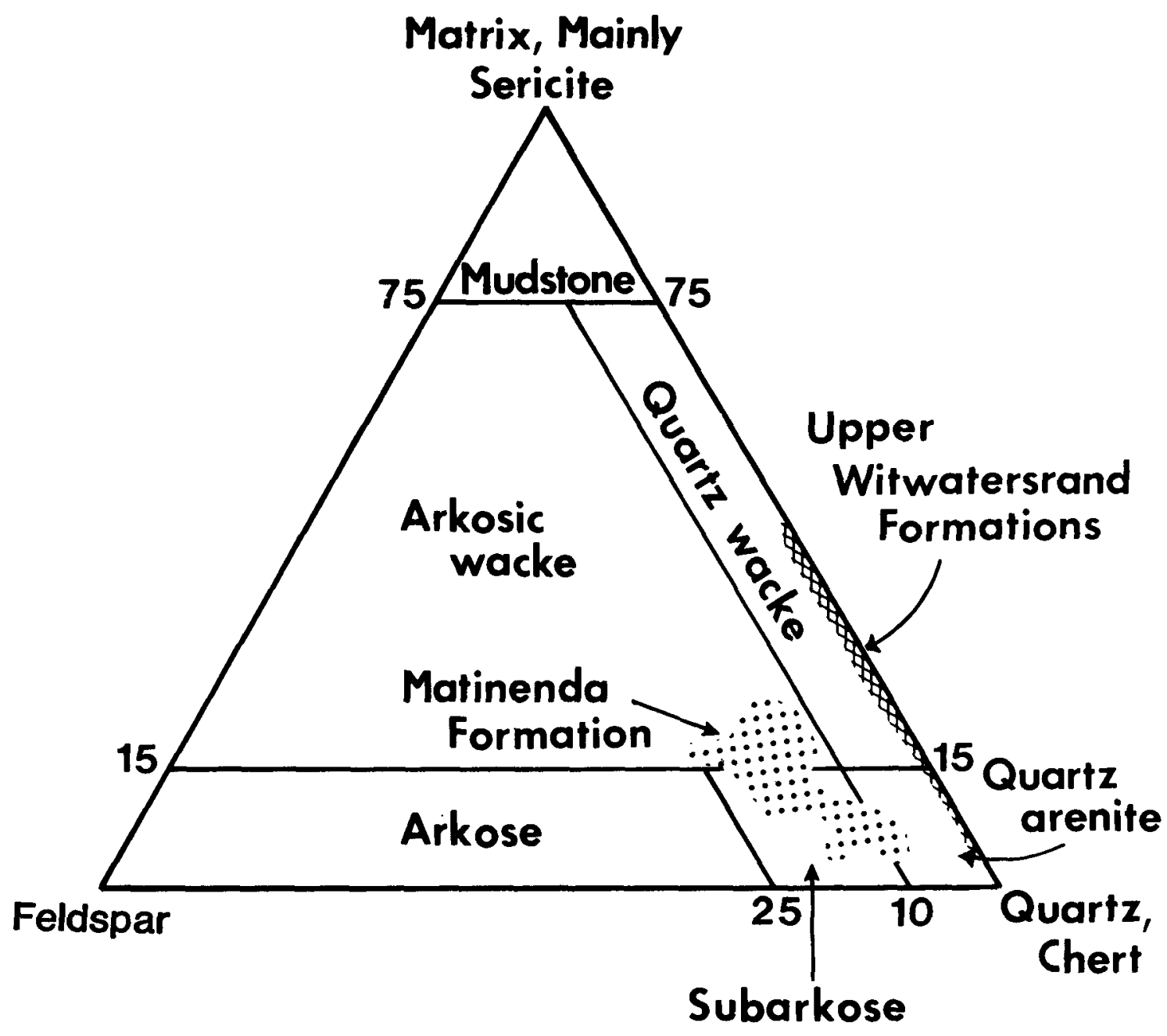

Figure 32. Triangular diagram showing compositional variations of arenites in the Matinenda Formation and in formations of the upper Witwatersrand succession (from Information in Pienaar, 1963; Fuller, 1958; Kent, 1961). 
are strained and cataclastically deformed in some instances. These strain phenomena may be due to post-depositional deformation of the arenites (J.A. Robertson, written communication, 1980).

Subordinate constituents in Matinenda arenites include pyrite, calcite, zircon, sphene, "black iron oxides", and, rarely, monazite and "leucoxenecoated black iron oxides". Pienaar remarked on the absence of cementing material and of overgrowths and inferred that the Matinenda arenites must have been relatively impermeable throughout their history.

A comparison of the mineralogy of Witwatersrand and Matinenda arenites is provided in the triangular diagram of Figure 32. The major difference is in the abundance of feldspar. Witwatersrand arenites are usually free of detrital feldspar, and plot on the quartz-sericite join. By contrast, the Matinenda arenites contain from about 8 to 26 percent feldspar. A second difference is that the Witwatersrand arenites have a wider range in composition; the quartz content varies from 51 to 97 percent. Third, Witwatersrand arenites contain an appreciable amount of quartz cement. Kent's study (of 17 samples) determined a range of 9.5 to 25 percent in the amount of "recrystallized and authigenic quartz" (Table 7).

Texture

Fuller's (1958) study provided quantitative information on the textural attributes of Witwatersrand quartz wackes. In this study, grain sizes were determined in thin sections and then corrected for the bias introduced by this method of measurement. Mean grain sizes determined for 31 samples range from 0.27 to $4.35 \mathrm{~mm}$. The average of the mean grain sizes is $1.35 \mathrm{~mm}$ (standard deviation from this mean is $0.95 \mathrm{~mm}$ ). The average Witwatersrand quartz wacke is thus very coarse grained. Fuller's study showed that 16 percent of the samples he analysed are fine gravels, 42 percent are very coarse grained, 35 percent are coarse grained, and the remaining 5 percent are medium grained.

Qualitative descriptions of the Matinenda arenites indicate that they are most of ten coarse- to medium-grained, coarse-grained or "gritty" (Roscoe, 1969). In addition to these adjectives, Pienaar (1963) uses the term "finegrained sugary subarkose" for a unit near the base of the Matinenda Formation. The term is probably only a relative one, indicating a finer grain size than in most of the Matinenda Formation.

Quantitative determinations of grain shape were made by Fuller (1958), who determined that the average short/long axis ratio of witwatersrand quartz grains was 0.64. He found that quartz grains are generally angular and show irregular outlines. In addition, Fuller determined that quartz grains show a preferred orientation, parallel to that of muscovite in the arenite matrix. He concluded (tentatively) that the fabric was due to tectonic rather than depositional forces.

Fuller noted that sericite in Witwatersrand quartz wackes was commonly found in "aggregates", similar in slze to quartz grains. He was of the opinion that the aggregates were originally feldspar grains which were altered to sericite by hydrothermal "soaking" of the upper division of the Witwatersrand 
Supergroup. Though the aggregates may well have been original feldspar grains, it is now believed that the alteration took place during paleoweathering and that the aggregates were transported as such.

Fine-grained Components of the Subarkose-Quartz Wacke Association

A small volume of silty or shaly material is usually found in arenites of the subarkose-quartz wacke association. The fine-grained fraction is developed in various forms. In the Matinenda Formation, lithified clay flakes are termed "silt scraps". Very similar clasts are common in many Witwatersrand arenites. Pienaar (1963) noted that many arenite beds "are outlined by thin green siltstone partings". The equivalent features in the Witwatersrand are usually termed "shale partings".

In a study of Witwatersrand lithology from drill-hole cores, Button (1968) determined that such partings are common in nearly all units. The color of the partings was determined quantitatively by comparison to a rock color chart. Colors are normally shades of olive (olive gray 5Y3/2; grayish olive 10Y4/2; 1ight olive 10Y5/4; grayish olive green 5GY3/2; 1ight olive brown $5 Y 5 / 6$ ) and green (dark green-gray 5GY4/1; dusky yellow green 5GY5/2; greenish yellow 10Y7/4; dark greenish gray 5G4/1). The partings are composed main1y of phyllosilicate minerals, including sericite, chlorite, chloritoid, and pyrophyllite (Wiebols, 1961). The present interpretation of the partings and mud clasts is that they represent "drapes" of muddy material deposited between major flood events. Some of the drapes were subsequently eroded and incorporated into arenites as mud clasts. Button (1968) showed that the partings are often directly overlain by concentrations of heavy minerals, including pyrite, leucoxene, chromite, and zircon. The sticky, muddy surfaces may have acted to trap heavy minerals carried by streams during subsequent flood events.

A second type of argillaceous rock that is fairly common in parts of the Witwatersrand occurs in thicker accumulations of ten in channels immediately below the major conglomerate sheets. The channels are filled by a heterogeneous assemblage of sediments ranging from conglomerates through quartzites, banded pyritic quartzites, puddingstones, and mudstones. The finer grained components are alumina-rich shales (16-35.8 percent $\left.\mathrm{Al}_{2} \mathrm{O}_{3}\right)$, containing chloritoid, pyrophyllite, sericite, quartz, chlorite, and some kaolinite (Wiebols, 1961). Wiebols inferred that the aluminous minerals were related to weathering concomitant with glacial epochs, which he believed were also responsible for the formation of payable conglomerate sheets in the Witwatersrand. Since weathering proceeds faster and to greater depths under tropical conditions, Wiebols' conclusions are questioned. It is believed that the alumina-rich sediments below the major conglomerate sheets were derived from regoliths formed by intense weathering in a warm, humid climate.

\section{Chemica1 Composition}

Available chemical analyses of rocks of the subarkose-quartz wacke association indicate $\mathrm{SiO}_{2}$ concentrations of 81.28 to 96.57 percent (Tables 8 and 9). The $\mathrm{Al}_{2} \mathrm{O}_{3}$ and $\mathrm{K}_{2} \mathrm{O}$ concentrations are relatively high (up to 10.4 and 5.4 percent, respectively) and confirm the importance of potassic minerals (sericite and $\mathrm{K}$ feldspar) in the arenites. With the exception of two very 
old analyses from the Witwatersrand (see Table 8), the arenites are strongly depleted in $\mathrm{CaO}$ and $\mathrm{Na}_{2} \mathrm{O}$, and, in most cases, $\mathrm{MgO}$.

Table 8. Chemical analyses of Witwatersrand arenites (after Fuller, 1958). Sample 1 is a Kimberley-Elsburg arenite from the East Rand. Samples 2 and 3 are arenites from the upper Witwatersrand of the East Rand area and were analysed prior to 1910.

\begin{tabular}{lrrr} 
& \multicolumn{1}{c}{1} & 2 & 3 \\
$\mathrm{SiO}_{2}$ & 90.14 & 96.57 & 87.60 \\
$\mathrm{Al}_{2} \mathrm{O}_{3}$ & 6.03 & trace & 8.20 \\
$\mathrm{Fe}_{2} \mathrm{O}_{3}$ & .11 & 1.72 & 0.99 \\
$\mathrm{FeO}$ & .70 & & 1.00 \\
$\mathrm{MgO}$ & .31 & trace & trace \\
$\mathrm{CaO}$ & .04 & & 1.10 \\
$\mathrm{Na}_{2} \mathrm{O}$ & .11 & 0.82 & 0.98 \\
$\mathrm{~K}_{2} \mathrm{O}$ & 1.37 & 0.67 & \\
$\mathrm{H}_{2} \mathrm{O}+$ & .83 & & \\
$\mathrm{H}_{2} \mathrm{O}-$ & .03 & & \\
$\mathrm{TiO} 2$ & .10 & & \\
$\mathrm{P}_{2} \mathrm{O} 5$ & .01 & & \\
$\mathrm{MnO}$ & .02 & & \\
$\mathrm{CrO}$ & $\mathrm{n.d.}$ & & \\
$\mathrm{S}$ & .02 & trace & \\
$\mathrm{CO} 2$ & .01 & & 99.87
\end{tabular}

Kimberley and others (in press) present graphs showing geochemical variations through granitic rocks, paleosols, Matinenda conglomerates, and arenites of the Elliot Lake area and of the Agnew Lake area. The graphic representation of analyses makes it difficult to generalize their results. In the samples from the Pronto Mine and Agnew Lake areas, the conglomerates are enriched in a wide range of elements ( $\mathrm{U}, \mathrm{Th}, \mathrm{Fe}, \mathrm{Ta}, \mathrm{Co}, \mathrm{Ti}, \mathrm{As}, \mathrm{Zr}, \mathrm{Ba}, \mathrm{Hf}, \mathrm{Tb}, \mathrm{Yb}, \mathrm{La}$, $\mathrm{Ce}, \mathrm{Sm}, \mathrm{Eu}, \mathrm{Dy}, \mathrm{Lu})$ relative to the enclosing arenites. The $\mathrm{K}$ and $\mathrm{Al}$ levels of the arenites are relatively high, while $\mathrm{Na}$ levels are low, and confirm this widely observed attribute of the host arenites of uraniferous conglomerates.

Trace element analyses given in Pienaar (1963) are unfortunately of little use, since the concentrations of $\mathrm{Cr}, \mathrm{V}, \mathrm{Ni}$, and $\mathrm{Co}$ were in most cases lower than the detection limits (see Table 10). Copper, however, was consistently above detection 1imit, ranging from 0.0008 to 0.0029 percent.

Pienaar also presented the results of what are presumed to be spectrographic analyses of a series of 10 elements $(\mathrm{B}, \mathrm{Pb}, \mathrm{Ga}, \mathrm{V}, \mathrm{Cu}, \mathrm{Ag}, \mathrm{Ni}, \mathrm{Co}, \mathrm{Cr}$, and Mo). $\mathrm{Ga}, \mathrm{Cu}$, and $\mathrm{Cr}$ are usually present at a spectrographic level rated as medium through very strong. Vanadium and lead were detectable in most samples. 
Table 9. Chemical analyses of Matinenda Formation arenites from the lower and upper members from both the north and south limbs of the Quirke Syncline (after Pienaar, 1963).

Lower Member

Upper Member

\begin{tabular}{|c|c|c|c|c|c|c|c|}
\hline & \multicolumn{3}{|c|}{ North Limb } & \multicolumn{2}{|c|}{ South Limb } & \multicolumn{2}{|c|}{ South Limb } \\
\hline & RF-641 & $\mathrm{RF}-1146$ & $\mathrm{RF}-760$ & $\mathrm{RF}-250$ & $\mathrm{RF}-786$ & $55-81$ & $55-71$ \\
\hline $\mathrm{SIO}_{2}$ & 89.31 & 91.44 & 81.28 & 81.82 & 83.62 & 89.36 & 93.72 \\
\hline $\mathrm{Al}_{2} \mathrm{O}_{3}$ & 7.40 & 5.20 & 10.40 & 10.00 & 9.70 & 3.92 & 3.69 \\
\hline $\mathrm{Fe}_{2} \mathrm{O}_{3}$ & 0.41 & 0.45 & 0.27 & 0.79 & 0.66 & 0.76 & 0.24 \\
\hline FeO & 0.09 & 0.00 & 0.18 & 0.00 & 0.00 & 0.13 & 0.13 \\
\hline MgO & 0.06 & 0.07 & 0.10 & 0.14 & 0.15 & 0.37 & $<0.01$ \\
\hline $\mathrm{CaO}$ & 0.050 & 0.018 & $<0.018$ & 0.037 & $<0.018$ & 0.66 & 0.15 \\
\hline $\mathrm{Na}_{2} \mathrm{O}$ & $<0.050$ & $<0.050$ & $<0.050$ & 0.15 & 0.205 & $<0.050$ & $<0.050$ \\
\hline $\mathrm{K}_{2} \mathrm{O}$ & 2.19 & 2.05 & 3.95 & 5.40 & 4.90 & 2.18 & 1.75 \\
\hline $\mathrm{H}_{2} \mathrm{O}\left(100^{\circ}\right)$ & 0.06 & 0.03 & 0.03 & 0.05 & 0.02 & 0.06 & 0.04 \\
\hline $\mathrm{H}_{2} \mathrm{O}\left(900^{\circ}\right)$ & 0.99 & 0.60 & 1.34 & 1.05 & 0.92 & 0.40 & 0.24 \\
\hline $\mathrm{TiO}_{2}$ & 0.18 & 0.21 & 0.11 & 0.16 & 0.18 & 0.14 & 0.10 \\
\hline $\mathrm{ZrO}_{2}$ & 0.0064 & 0.0112 & 0.0036 & 0.064 & 0.0039 & 0.0168 & 0.0072 \\
\hline Mno & $<0.001$ & $<0.001$ & $<0.001$ & $<0.0020$ & $<0.001$ & 0.0030 & 0.021 \\
\hline
\end{tabular}

\begin{tabular}{llllllll}
\hline Total & 100.75 & 100.06 & 97.76 & 99.56 & 100.36 & 98.00 & 100.09 \\
\hline
\end{tabular}

All samples from drill core except RF-786, which is from underground workings. RF-641 Subarkose--Consolidated Denison Mine.

RF-1146 Winnowed subarkose--northeast of Can Met Mine.

RF-760 Basal fine-grained subarkose--southeast of Stanrock Mine.

RF-250 Subarkose--Milliken Lake Mine.

RF-786 Subarkose--Nordic Mine.

55-81 Subarkose--northwest of Stinson Lake.

55-71 Quartzite--west of Stanleigh Mine.

Analyses by G. MacDonald, Miller Research Laboratory, Queen's University. 
$\mathrm{Ni}$ and Co were detected in some samples. B, Ag, and Mo are developed erratically; Mo and $\mathrm{Ag}$ could be related to altered zones adjacent to basic dykes intrusive into Matinenda arenites.

Table 10. Trace element analyses of arenites from the Matinenda Formation (after Pienaar, 1963). The sample locations are given in Table 9.

\begin{tabular}{rccccc}
\hline Sample & Cr & V & Ni & Co & Cu \\
\hline $55-71$ & 0.0017 & $<0.0015$ & $<0.0007$ & $<0.0010$ & 0.0008 \\
$55-81$ & $<0.0009$ & $<0.0015$ & $<0.0007$ & $<0.0010$ & 0.0017 \\
$R F-250$ & $<0.0009$ & 0.0023 & $<0.0007$ & $<0.0010$ & 0.0014 \\
$R F-760$ & $<0.0009$ & $<0.0015$ & $<0.0007$ & $<0.0010$ & 0.0029 \\
$R F-1146$ & $<0.0009$ & $<0.0015$ & $<0.0007$ & $<0.0010$ & 0.0017 \\
$R F-641$ & $<0.0009$ & $<0.0015$ & $<0.0007$ & $<0.0010$ & 0.0029 \\
\hline
\end{tabular}

Pienaar was of the opinton that much of the lead was contained in $\mathrm{K}$ feldspar, and that $\mathrm{Ga}$ was contained in "aluminous minerals", presumably mainly sericite.

The results of a neutron activation analytical study of Witwatersrand arenites are summarized by Pretorius (1976) and are reproduced in Table 11.

Table 11. Trace element analyses of Witwatersrand arenites from the East Rand area (after Pretorius, 1976).

\begin{tabular}{llllllllllllll}
\hline & $\begin{array}{r}\mathrm{Na} \\
\%\end{array}$ & $\begin{array}{r}\mathrm{Sc} \\
\mathrm{ppm}\end{array}$ & $\begin{array}{r}\mathrm{Co} \\
\mathrm{ppm}\end{array}$ & $\begin{array}{r}\mathrm{Cs} \\
\mathrm{ppm}\end{array}$ & $\begin{array}{r}\mathrm{Ba} \\
\mathrm{ppm}\end{array}$ & $\begin{array}{r}\mathrm{La} \\
\mathrm{ppm}\end{array}$ & $\begin{array}{r}\mathrm{Ce} \\
\mathrm{ppm}\end{array}$ & $\begin{array}{r}\mathrm{Eu} \\
\mathrm{ppm}\end{array}$ & $\begin{array}{r}\mathrm{Yb} \\
\mathrm{ppm}\end{array}$ & $\begin{array}{r}\mathrm{Lu} \\
\mathrm{ppm}\end{array}$ & $\begin{array}{r}\mathrm{H} f \\
\mathrm{ppm}\end{array}$ & $\begin{array}{r}\mathrm{Ta} \\
\mathrm{ppm}\end{array}$ \\
\hline $\begin{array}{c}\text { Bird } \\
\text { "Quartzite" }\end{array}$ & 0.03 & 3.10 & 6.00 & 0.66 & - & 6.93 & 25.7 & 0.56 & 0.42 & 0.05 & 1.34 & 0.26 \\
$\begin{array}{c}\text { Livingstone } \\
\text { "Quartzite" }\end{array}$ & 0.02 & 6.56 & 10.80 & - & -11.13 & 51.7 & 0.80 & 0.51 & 0.08 & 2.42 & 0.70 \\
$\begin{array}{c}\text { South } \\
\text { "Quartzite" }\end{array}$ & 0.05 & 6.35 & 32.90 & 0.90 & 309 & 9.01 & 38.5 & 0.76 & 0.46 & 0.10 & 2.53 & 0.59 \\
\hline
\end{tabular}


A comparison of Table 11 with the graphs of Kimberley and others (in press) indicates a wide variation in the trace and rare earth elemental patterns of Witwatersrand and Matinenda arenites. Matinenda arenites tend to be significantly richer in $\mathrm{La}, \mathrm{Ce}, \mathrm{Yb}, \mathrm{Hf}$, and $\mathrm{Ta}$ than their Witwatersand counterparts. While the number of analyses is rather small, and may not be representative of either unit, it is suggested that the higher Ce and La levels of the Matinenda reflect the relative abundance of detrital monazite in that formation (Roscoe, 1969) and its rarity in the Witwatersrand (Feather and Koen, 1975).

Redden (1980) has recently published the results of a study on the uraniferous conglomerates and assoclated sediments of the Nemo area, South Dakota. The conglomerates are hosted by very coarse-grained, granule-bearing quartz wacke arenites. We have selected a subsample of 19 such arenites from Redden's data and present the relevant geochemical data in Table 12. Like quartz wackes of other quartz-pebble conglomerate districts, they contaln very low concentrations of $\mathrm{Na}$ and $\mathrm{Ca}$. Other notable features include the relatively high concentrations of $\mathrm{Al}, \mathrm{K}$ (presumably in muscovite), $\mathrm{Ce}, \mathrm{Cr}$, and $\mathrm{T} 1$.

Table 12. Geochemistry of 19 pebble-free arenites from the Nemo area, South Dakota (from Redden, 1980).

\begin{tabular}{|c|c|c|c|c|c|}
\hline ELEMENT & AVERAGE & RANGE & ELEMENT & AVERAGE & RANGE \\
\hline $\mathrm{A} 1(\%)$ & 3.4 & $2.4-4.7$ & $\mathrm{Na}(\%)$ & 0.06 & $<0.05-0.08$ \\
\hline $\mathrm{Ba}(\mathrm{ppm})$ & 77 & $44-240$ & $\mathrm{Ni}$ (ppm) & 42 & $20-86$ \\
\hline $\mathrm{Ca}(\%)$ & $<0.05$ & $<0.05-0.33$ & $\mathrm{P}(\mathrm{ppm})$ & 82 & $44-180$ \\
\hline $\mathrm{Ce}(\mathrm{ppm})$ & 101 & $60-140$ & $\mathrm{Sc}(\mathrm{ppm})$ & 4.6 & $3-7$ \\
\hline Co (ppm) & 12 & $6-22$ & $\operatorname{Th}(\mathrm{ppm})$ & 35 & $12-99$ \\
\hline $\operatorname{Cr}(\mathrm{ppm})$ & 457 & $290-800$ & $\mathrm{~T} 1$ (ppm) & 812 & $230-1,900$ \\
\hline $\mathrm{Cu}(\mathrm{ppm})$ & 51 & $19-120$ & $\mathrm{U}(\mathrm{ppm})$ & 15 & $3.3-45$ \\
\hline $\mathrm{Fe}(\%)$ & 2.6 & $1.2-4.8$ & $Y(p p m)$ & 12 & $4-22$ \\
\hline $\mathrm{K}(\%)$ & 1.13 & $0.68-1.90$ & $\mathrm{Zn}(\mathrm{ppm})$ & 16 & $8-31$ \\
\hline $\operatorname{Mg}(\%)$ & 0.37 & $0.08-0.89$ & $\mathrm{Zr}(\mathrm{ppm})$ & 94 & $45-140$ \\
\hline
\end{tabular}

Summary

The dominant 1ithology of host arenites of uraniferous conglomerates in both the Witwatersrand and Elliot Lake districts $1 \mathrm{~s}$ a drab-colored, coarse- and very coarse-grained sericitic subarkose or quartz wacke. The arenites are characterized by a high $\mathrm{K} / \mathrm{Na}$ ratio and very 1 ittle $\mathrm{Ca}$. They contain the same suite of heavy minerals as the associated conglomerates, including pyrite, chromite, zircon, and leucoxene.

Small amounts of shaly rock are usually associated with the arenttes, occurring as partings, shale-clasts and as one component of the fill of scour channels. The shaly rocks are usually alumina-rich, and of ten contain authigenic chloritoid in addition to sericite, pyrophyllite, and chlorite. They probably represent the clay fraction of the paleosols developed both within and outside the limits of the sedimentary basins in question. 


\section{Quartz-Arenite Association}

Several occurrences of uraniferous conglomerate are found in association with relatively pure quartz arenites. This association owes its origin to the stratigraphic and sedimentologic history of the sediments in question, a subject addressed elsewhere in this report. At this point, it is adequate to restate only the facts that uraniferous conglomerates of the quartzarenite association tend to be developed on fundamental unconformities (or nonconformities) which were subsequently transgressed by shallow epeiric seas. The intense reworking by the epeiric seas is thought to be responsible for the development of the relatively pure quartz arenites.

\section{Witwatersrand Basin}

Within the Witwatersrand Basin, several uraniferous conglomerate sheets can possibly be related to the quartz-arenite association. The Vaal Reef, in the Klerksdorp area, rests on a gentle angular unconformity cut on a paleosurface sloping to the southeast (Minter, 1976). Vaal Reef conglomerates were deposited in shallow braided channels etched on the sloping paleosurface. After deposition of the conglomerate, a sheet of "siliceous coarse-grained quartzite", varying from 0 to $3 \mathrm{~m}$ in thickness, was deposited. This is in turn overlain by quartz wacke arenites, some of them pebble-bearing.

In a sense, then, the Vaal Reef exhibits elements of both the quartz-wacke and quartz-arenite associations. However, as $f$ ar as exploration is concerned, it should be emphasized that the siliceous hanging-wall quartzite of the Vaal Reef is a very minor component of the much thicker quartz-wacke association.

A second Witwatersrand occurrence is the Kimberley ("UK9A" or "May") conglomerate of the East Rand Goldfield. Here, gold and uranium have been extracted from a conglomerate developed in braided channels cut into an erosion surface inclined to the southeast (Armstrong, 1968). The UK9A Reef is overlain by up to $4 \mathrm{~m}$ of a siliceous quartzite sheet known as the "UK9A Marker". The UK9A Marker exhibits unimodal, polymodal, and bipolar-bimodal cross-bed foreset orientations. In addition, it is abundantly ripple marked and interference ripple marked. Shale drapes within it are mud cracked. It is inferred to represent a tidal deposit formed by destructive reworking of a lobe of a Witwatersrand fan delta. Again, the relative insignificance (in terms of regional exploration) of a $4 \mathrm{~m}$ quartz arenite in the 3,000 m thick upper division of the Witwatersrand Supergroup (dominated by quartz wacke) is stressed.

Thin, economically relatively unimportant conglomerates are developed at several levels through the lower division of the Witwatersrand Supergroup. The conglomerates rest on unconformities and are overlain by pure quartz arenites, grading upwards to shales, and, in some cases, to iron-formations. Paleoweathering of material below the conglomerates has been noted.

A good example of such a situation is the basal formation of the Witwatersrand Supergroup in the central Witwatersrand (Button, 1968). Here, the Orange Grove Quartzite has a locally developed basal conglomerate which contains both gold and uranium. The conglomerate is overlain by the extremely pure Orange Grove Quartzite, which passes upwards, in turn, to shales and eventually to an iron-formation locally termed the "Contorted Bed". 
Fuller (1958) determined that the Orange Grove Quartzite was a pure quartz arenite comprising 99 percent quartz (and some chert) grains with the balance being sericite. The grains are well sorted with a median grain size of about $1 \mathrm{~mm}$. They were originally well rounded but have been somewhat modified by pressure point solution effects.

\section{Pongola Basin}

The Pongola Group, which crops out in the area of the southeastern Transvaal, the northern parts of Natal and Swaziland, has been dated radiometrically at approximately $3,000 \mathrm{~m} . \mathrm{y}$. It is subdivided stratigraphically into two units, the Insuzi Subgroup, a succession of basalts with subordinate quartzites; and the overlying Mozaan Subgroup, dominated by quartzites and shales with some iron-formation. The two subgroups are separated by a gentle angular unconformity cut across both basalts and quartzites of the lower subgroup.

Paleovalleys on this unconformity are the sites of preservation of some gold- and uranium-bearing pyritic conglomerates (Figure 28.3). The conglomerates produced a modest amount of gold in the past and are currently being re-evaluated as possible sources of both gold and uranium.

The conglomerates are directly overlain by mature, compositionally pure quartz arenites, which grade upward, over an interval of several tens of meters, to shales, and eventually, to iron-formation (personal observation, A.B., 1977; verbal communications, C. Greathead, 1977).

While no detalled sedimentological studies on this part of the Pongola succession have been published, it is probable, from the nature of the sediments, that the arenites represent sands deposited in an epeiric sea which transgressed across the unconformity.

The auriferous and uraniferous conglomerates probably represent fluvial channel deposits on the unconformity, which were reworked to varying degrees during the marine transgression.

Jacobina, Bahia, Brazil

At the Canavieiras Mine, near Jacobina, Brazil, the uranium- and goldbearing conglomerates are found within the Serra do Corrego Formation between 350 and 550 meters above the older Archean basement (Gross, 1968). White (1961) referred to the host rocks as "white quartzite". D.S. Robertson (1974) described the quartzites as "clean, well washed and recrystallized to a high degree". White stated that both conglomerates and quartzites are "fresh, hard, well compacted, and highly silicified". He does, however, allude to "sericitization", and mentions the "characteristic green and brown color of the sericitized, pyritic uraniferous gold-bearing rock".

Certainly the bulk of the Serra do Corrego Formation is a white, texturally and compositionally mature quartz arenite (personal observation, A.B., 1976), so that this occurrence is justiflably considered as belonging to the quartz arenite association. Available descriptions indicate increasing proportions of a sericitic component towards the base of the formation. The relationships 
suggest a sericitic, possibly fluvial facies near the base of the formation, overlapped by a marine shelf facies comprising mature quartz arenites.

Belo Horizonte, Brazil

In the Belo Horizonte district of Minas Gerais, Brazil, the early Proterozoic Minas Series rests with a prominent angular unconformity on an Archean basement. The basal Caraca Group of the Minas commences with the Moeda Formation (Dorr, 1969) comprising clean quartz arenites and conglomerates. These arenites grade upwards to siltstones, shales, and carbonaceous shales of the Batata1 Formation, which grade in turn to banded iron-formations of the Caue Itabirite.

In parts of the Moeda Formation, uranium- and gold-bearing conglomerates are developed (D.S. Robertson, 1974; McNeil, 1980). No details on the petrology of the conglomerates or arenites are available. The Moeda Formation is certainly composed of relatively pure quartz arenites (personal observation, A.B., 1976). Its upward gradation through shales to iron-formation suggests a marine transgressive environment such as has been described in other locations.

\section{Black Reef Quartzite}

The Black Reef Quartzite is the basal formation of the Transvaal Supergroup. It rests unconformably on a wide variety of older formations (including the Witwatersrand) and grades upwards, through a transitional zone, to stromatolitic carbonates and cherts of the Malmani Dolomite. The quartzite is usually relatively thin $(<10 \mathrm{~m})$ and is a pure quartz arenite. In places it includes basal conglomeratic layers in channel-like scours into underlying formations. Where it lies across older Witwatersrand conglomerates, the Black Reef conglomerates are mineralized, containing pyrite with gold, platinoids, and uraninite. The conglomerates have been extensively exploited for their gold, platinoids, and pyrite, but not, thus far, for their uranium content.

Summarý

Unconformities which subsequently become transgressed by a marine shelf are frequently mantled by pure quartz arenites. Conglomerates are locally developed below such quartz arenite sheets usually in channels scoured into the rock below the unconformity. Of all the known occurrences, only a few (such as the Kimberley Reef of the Witwatersrand) have actually produced significant quantities of uranium. The Kimberley Reef occurrence probably reflects a minor period of marine reworking of a lobe of a prograding Witwatersrand fan delta. In this example, the pure quartz arenite is usually only a few meters thick and is over- and underlain by rocks of the quartz wacke association.

The remaining occurrences usually involve thicker quartz arenites (tens to hundreds of meters) which grade upward to marine rocks including shales, stromatolitic dolomites, and iron-formations. Thus far, only relatively minor uranium reserves have been found in this association. 
A few examples of basaltic volcanic rocks directly overlying uraniferous conglomeratic rocks are known. For example, outside of the Elliot Lake area, the basal Huronian succession is of ten dominated by basaltic volcanic rocks, such as those of the Thessalon and Stobie formations (Roscoe, 1969). Radioactive conglomerates occur at the base of, or interlayered with, these volcanicdominated formations in some areas, but none have been economically exploited. For example, Roscoe (1969) described a uraniferous pyritic quartz-pebble conglomerate occurrence interbedded with lava of the Thessalon Formation. Even though some samples analysed up to 0.1 percent $\mathrm{U}_{3} \mathrm{O}_{8}$, this conglomerate was characterized by submarginal overall grades and thicknesses.

The basalt association is exemplified by the Ventersdorp Contact Reef in the Witwatersrand district of South Africa. In parts of this area, the Ventersdorp volcanic succession rests unconformably on a base of tectonically tilted Witwatersrand sediments. Here, a conglomerate, known as the Ventersdorp Contact Reef, is locally developed and is being exploited for gold in parts of the West Rand region and in the Carletonville and Klerksdorp areas. The conglomerate is directly overlain by several hundred to a few thousand meters of volcanic rock, dominated by basaltic lava.

The lavas are mainly subaerial flows, characterized by massive or porphyritic flow bases and by amygdaloidal flow tops. Very locally, pillowed basalts are developed and probably indicate the presence of lakes. The basalts are typically of a high silica (55 percent) and high total iron (about 10 percent, as $\mathrm{Fe}_{2} \mathrm{O}_{3}$ ) type which is very typical of the early Proterozoic and late Archean basins of southern Africa (Wyatt, 1976).

Though uraniferous, the Ventersdorp Contact Reef is seldom rich enough in uranium to be mined for this element (Whiteside, 1970). The U/Au ratio of the conglomerate is usually less than 5, but increases up to 34 down the paleoslope (Minter, 1978).

\author{
Sedimentology of Host Rocks
}

Sedimentological observations are made daily on many mining properties, especially in the Witwatersrand. Nearly all the observations are focused on the ore conglomerate and its immediate foot-and hanging-wall units. Very little systematic work has been done on the sedimentological character of the host rocks themselves.

In this section, a short account is given of the sedimentological characteristics of some of the host units that have been studied using modern methods of paleoenvironmental analysis. 


\section{Subarkose-Quartz Wacke Association}

Matinenda Formation

McDowe11 (1957) and Pienaar (1963) undertook paleocurrent investigations of Huronian formations in the Elliot Lake district. Pienaar found that the average initial inclination of cross-beds was 21 degrees. He noted that 17 percent of the observations exceeded 33 degrees, the supposed angle of repose of sand in water. The anomalously high inclinations were ascribed to slumping.

Rose diagrams of cross-bed foresets for both the Matinenda and Mississagi Formations indicate sediment transport essentially towards the southeast. Most rose diagrams indicated unimodal current patterns. In a few instances, bimodal patterns were detected with modes separated by 30 to 60 degrees.

Both trough and planar cross-beds are developed in the Matinenda arenites. McDowell noted three types of grading in this formation. In the first, tabu1 ar beds fine upwards in the normal fashion. In the second, the grain size increases towards the toe of each tabular-planar cross stratum. In the third, each tabular-planar cross stratum is internally graded, fining upwards from pebble- or granule-bearing to coarse- or medium-grained arenite. The average thickness of cross-bed sets was found to decrease down the paleoslope (McDowe11, 1957).

Pienaar (1963) interpreted paleocurrent and other sedimentological data as being indicative of fluvial deposition of the Matinenda Formation. He pointed specifically to the predominant unimodal cross-bed patterns and to the uniformity of the sediment transport directions over distances of several tens of kilometers.

McDowel1 (1957) stressed the economic significance of paleocurrent studies in the Matinenda Formation. He showed that the cross-bed vectoral mean directions lie close to the elongation directions of the main orebodies of the Quirke and Nordic zones.

Given the stratigraphic setting of the Matinenda Formation (in pre-Huronian paleovalleys) and its lithology (coarse-grained subarkose and quartz wacke), the formation is probably best interpreted as a braided stream valley-fill deposit. Such an interpretation is consistent with the unimodal cross-bed foreset orientation, the consistency of sediment transport directions, the lithologic immaturity of the arenites, and the negligible amounts of shale or siltstone in the formation.

Witwatersrand Formations

Considering the large volume of sedimentological data on Witwatersrand conglomerates, the very small amount of published data on the enclosing arenites is striking. In a pioneer study, Hargraves (1962) studied cross-bedding and ripple marking in the East Rand area of the Witwatersrand Basin. He found that the Main-Bird arenites were structured predominantly by tabular-planar cross-bed sets, with the average initial angle of foresets having been 21 degrees (range from 7 to 36 degrees). As in the Matinenda Formation, he found that the average thickness of the cross-bed sets decreased from about $64 \mathrm{~cm}$ to 
$38 \mathrm{~cm}$ down the paleoslope over a distance of about $60 \mathrm{~km}$. Cross-bed vectors show the same divergent radial pattern as payshoots in the underlying Main Reef Leader conglomerate sheet (see Figure 49).

In a more detailed study of the same area, Button (in press) documented the vertical sequence of sedimentary structures and the orientation of cross-beds and other structures. The dominant motif in the quartz wacke arenites is a series of erosive-based sedimentary cycles (Figure 33). The cycles range in thickness up to $2 \mathrm{~m}$. The relief on the erosive bases of the cycles is up to $0.4 \mathrm{~m}$. A lag, composed of coarse- and very coarse-grained arenite with scattered quartz granules, is developed on the erosive surfaces. Massive or vaguely plane-bedded, granule-bearing arenites occur near the base of others. Most often, these units are overlain by medium-, coarse-, or very coarse-grained quartz wacke arenites, structured by one or more tabular-planar cross-bed sets measuring up to $1.4 \mathrm{~m}$ in thickness (see Figure 33). The cross-bed sets are usually 0.2 to $1.0 \mathrm{~m}$ thick. Individual foresets are graded, showing a progressive fining upwards both across and up (away from the toe) foreset beds.

The upper parts of many cycles are dominated by plane bedding and by trough cross-bedded intervals, frequently deformed to produce convoluted bedding. Some of the plane beds contain concentrations of heavy minerals, including pyrite. The finest grained material is developed in thin beds (up to $2 \mathrm{~cm}$ thick) near the tops of some cycles. This matrix-rich silty arenite is sometimes structured by centimeter-scale ripple cross-laminae.

Paleocurrent vectors are concentrated such that some 80 percent of the observations fall within a 120-degree arc. The vector mean direction of sediment transport is in general agreement with that of mineralized payshoots in the underlying Main Reef Leader conglomerate.

The features observed in these immature arenites were interpreted to have been formed by braided stream deposition on a low-gradient fan delta. The erosive, lag-covered surfaces represent deeper channels where flow was confined between banks or braid bars. The tabular-planar cross-bed sets were formed by the avalanche fronts of migrating transverse or linguoid sand bars. The planebedded and trough cross-bedded intervals were probably formed by sedimentation on the tops of the bars in very shallow and in somewhat deeper water, respectively. It was concluded that deposition was in a "Platte type" braided stream system. Miall (1977) stated that Platte type braided stream systems occur in low-gradient areas. They are characterized by little relief and by very shallow water. The dominant bed forms are linguoid and transverse bars.

Minter (1972) has published a comparable study of some 50 meters of the MB.5 zone (footwall of the Vaal Reef, Klerksdorp Goldfield). The arenites are structured largely by trough cross-beds in sets 10 to $25 \mathrm{~cm}$ in thickness. Cosets are frequently separated by mud drapes. Tabular-planar cross-bed sets are extremely rare (one $25-\mathrm{cm}$ set in 50 meters). Minter (written communication, 1980) is of the opinion that this trough cross-bed dominated unit represents a more proximal facies than the package of sediments illustrated in Figure 33. 

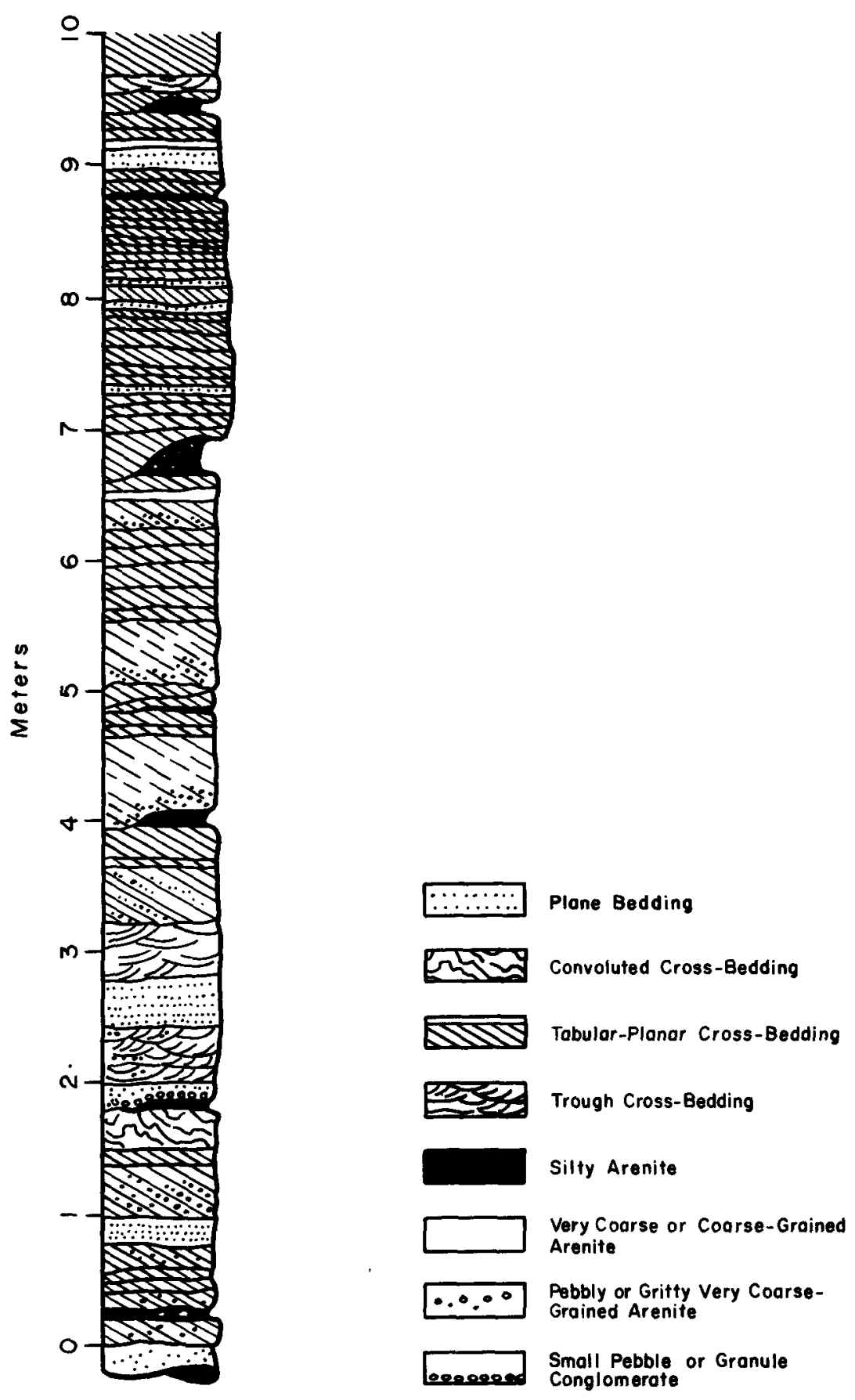

Figure 33. Detailed stratigraphic section showing vertical sequence of sedimentary structures in Witwatersrand quartz wackes from the Heidelberg area, East Rand district, Witwatersrand Basin (from Button, in press). 
The examples given above are representative of much, but certainly not all, of the immature arenite intervals of the Witwatersrand. Future work will hopefully be aimed at documenting other depositional sub-environments of the Witwatersrand.

Quartz-Arenite Association

There are only a limited number of examples of the quartz-arenite association that have been studied sedimentologically. One such unit is the quartzite which lies immediately on the uraniferous Vaal Reef of the Klerksdorp area, Witwatersrand Basin. In this area, Minter (1976) established that the Vaal Reef was deposited by shallow braided streams which flowed down a paleoslope inclined to the southeast. The Vaal Reef conglomerate sheet is overlain over most of its extent by a thin (up to $3 \mathrm{~m}$ ) blanket of clean quartz arenite. The quartz arenite is structured by trough cross-beds.

Armstrong (1968) studied the Kimberley Reef and its hanging-wall quartzite in parts of the East Rand area, Witwatersrand Basin. The Kimberley conglomerate, which was exploited for both gold and uranium, was deposited in a braided channel network on a paleoslope inclined towards the southeast. The conglomerate is overlain by pure quartz arenite as thick as $4.5 \mathrm{~m}$. This quartzite is structured by both trough and tabular-planar cross-bed foresets with unimodal, bimodal, and polymodal patterns of sediment dispersal. It is also megarippled, ripple marked, and contains desiccation-cracked shaly drapes. In addition, Armstrong's publication illustrates very convincing examples of ladderback ripples. Such structures are common in contemporary tidal flats where a falling water level exposes the crests of ripples. The water isolated between the large ripples is then forced to drain parallel to the ripple crests producing a set of smaller ripples with axes perpendicular to those of the major ripples. All of the sedimentary structures described by Armstrong can be formed on the lower, sand-dominated reaches of a tidal flat (Button, in press).

The examples cited are both of minor tongues of quartz arenite in much thicker successions of immature quartz wacke. The quartz-arenite association also occurs over fundamental unconformities or disconformities, as blanket deposits covering areas on the order of $10^{5}$ square kilometers. Such arenites are almost certainly of shallow-marine or marginal-marine origin. They characteristically grade upward into rocks of undoubted marine origin, including thick sequences of shale, carbonate, and iron-formation (Figure 28). No detailed descriptions of the sedimentological features of such pure quartz arenites (where they overlie uraniferous conglomerates) were found. In general terms, the quartz arenites, such as those of the Black Reef at the base of the Transval Supergroup, are structured by both trough and tabularplanar cross-bed sets, by plane bedding and by various types of ripple mark (Button, 1973). They have been interpreted as the products of sedimentation on very extensive, sand-dominated epeiric marine shelves.

\section{$\underline{\text { Basalt Association }}$}

Probably the best studied uraniferous conglomerate of the basalt association is the Ventersdorp Contact Reef of the Witwatersrand Basin. The conglomerate is overlain by hundreds to thousands of meters of dominantly basaltic volcanic 
rocks. The basalts appear to have been extruded subaerially in all but a few instances. They comprise numerous massive- or porphyritic-based, amygdaloidaltopped flows (Wyatt, 1976). Pillow structures are only locally developed immediately above the Ventersdorp Contact Reef (Knowles, 1966) and indicate the development of local volcanic lakes.

J.A. Robertson (1976) has summarized the character of the basalts of the Elliot Lake Group. They are locally amygdaloidal and porphyritic. Ropy structure and flow-top breccias have been recognized, while pillows are extremely rare, indicating a subaerial environment of extrusion. Robertson has stated that known uranium orebodies are marginal to some of the basaltic volcanic centers. He suggests that basalt centers may have been paleotopographic highs and could have influenced the courses of paleovalleys in which uraniferous conglomerates were deposited. 
Blark

$-142$. 


\section{CONGLOMERATE CHARACTERIZATION}

Geologists familiar with the conglomerates of the Witwatersrand and Blind River-Elliot Lake districts can make shrewd judgements as to the likely uranium (or gold) content of a particular "reef", based on the lithologic character of the conglomerate. This ability is very important in the early stages of exploration and allows the explorationist to focus his efforts on those conglomerates with greatest promise. Consequently, the composition and texture of uraniferous conglomerates from these districts are described in the following paragraphs.

According to Pretorius (1976), a "normal conglomerate" consists of 80 percent (by weight) of pebbles set in a matrix composed of recrystallized quartz, phyllosilicates (sericite, chlorite, sometimes pyrophyllite), sulfides, and heavy minerals. It must be emphasized that not all payable uraniferous "reefs" are conglomerates. For example, Minter (1978) has shown that the Vaal paleoplacer is a pebbly arenite and that the Steyn paleoplacer changes from conglomerate to quartz arenite down the paleoslope over a distance of $20 \mathrm{~km}$.

\section{Pebble Fraction}

\section{Composition}

Conglomerates are usually categorized as oligomictic or polymictic, based on the composition of their pebble fraction. Friedman and Sanders (1978, p. 191) define oligomictic types as those "conglomerates consisting of pebbles, cobbles and/or boulders of a single kind of rock". Polymictic conglomerates are composed of clasts of various rock types.

Geologic practice in the Witwatersrand and similar basins has been to use the term "oligomictic" to refer to conglomerates composed predominantly of highly resistant clasts, such as chert and vein quartz. For example, Minter (1978) categorizes the Vaal Reef pebble assemblage as oligomictic, even though it contains 12 percent chert clasts, 2.6 percent quartzite, 0.2 percent quartz porphyry, and 0.2 percent of shaly and schistose clasts, in addition to 85 percent vein-quartz clasts. In this report, the Witwatersrand usage of the term is adhered to since it has been found that the percentage of resistant clasts is one of the most important parameters in gauging the economic potential of a conglomerate. Thus those conglomerates containing over 90 percent of resistant clasts (quartz, chert, quartz porphyry) are considered "oligomictic", whereas those with a considerable proportion of clasts of shale, schist and the like are "polymictic".

Sims (1969) studied the pebble assemblage of several conglomerate sheets in the Welkom Goldfield of the Witwatersrand Basin. He distinguished durable pebbles from non-durable pebbles (see Table 13). The inclusion of quartzite clasts in the non-durable category is based on the supposition that these were weakly lithified sandstone clasts at the time of deposition. Since "quartz porphyry" clasts are of ten composed of highly silicified porphyritic rhyolitic lava, their inclusion in the non-durable category is questioned. 
Table 13. Composition of pebbles in Upper Witwatersrand strata in the Welkom fluvial fan (after Sims, 1969).

DURABLE PEBBLES

White quartz

Smoky quartz

Opalescent blue quartz

Dark gray massive chert

Gray banded chert

Green banded chert

Red banded chert
NON-DURABLE PEBBLES

Yellow silicified shale

Gray silicified shale

Gray quartzite

Yellow quartzite

Green quartzite

Quartz porphyry

Serpentinite

Talc schist

Chlorite schist

Many Witwatersrand conglomerates can be distinguished from one another in drill core (or other small exposures) by their lithologic character. The ability to distinguish conglomerates by their clast makeup is very useful during exploration and mining. Table 14 (Sims, 1969, quoted by Pretorius, 1976) illustrates the wide range in composition of several conglomerates of the Welkom Goldfield. The conglomerates cited can be distinguished by their content of distinctive clast types such as black, green, and yellow chert.

Table 14. Variations in composition and size of pebbles in different reefs in the Western Holdings Mine, Welkom fluvial fan (after Sims, 1969; quoted by Pretorius, 1976).

\begin{tabular}{lrrrrrr}
\hline PEBBLES & 1 & 2 & 3 & 4 & 5 & 6 \\
\hline & & & & & & \\
Quartz (\%) & 3 & 50 & 45 & 47 & 10 & 10 \\
Green chert (\%) & 5 & 0 & 0 & 0 & 60 & 50 \\
Yellow chert (\%) & 85 & 2 & 14 & 40 & 11 & 10 \\
Black chert (\%) & 2 & 46 & 32 & 5 & 15 & 20 \\
Quartzite (\%) & 5 & 2 & 7 & 3 & 1 & 5 \\
Quartz porphyry (\%) & 0 & 0 & 2 & 5 & 3 & 5 \\
Quartz (mm) (mm) & 30 & 30 & 15 & 135 & 210 & 150 \\
Green chert (mm) & 15 & - & - & - & 90 & 50 \\
Yellow chert (mm) & 40 & - & 10 & 75 & 15 & 40 \\
Black chert (mm) & 15 & 15 & 15 & 10 & 25 & 75 \\
Quartzite (mm) & 40 & - & 10 & 10 & - & 150 \\
Quartz porphyry (mm) & - & - & - & 100 & 150 & 135 \\
\end{tabular}

1 = UF-2 Reef, Livingstone Group; 2 = Middle Reef, Bird Group; 3 = Leader Reef, Bird Group; 4 = B Reef, Kimberley Group; 5 = Lower Reef, Elsburg Group; 6 = Upper Reef, Elsburg Group. 
The assemblage of clasts in uraniferous and auriferous conglomerates is summarized in the triangular plot of Figure 34. The plot shows the pebble makeup of uraniferous-auriferous, auriferous, and sub- or non-economic conglomerates in the Witwatersrand and Elliot Lake districts.

The majority of the pebble assemblages studied in these basins are oligomictic, 90 percent or more of the clasts being vein quartz and chert. The auriferous conglomerates of the Witwatersrand contain up to 60 percent chert clasts. Those conglomerates containing mineable concentrations of golduranium or of uranium tend to be composed predominantly of quartz clasts. The uraniferous Vaal Reef contains up to 12 percent chert, while many of the other uraniferous conglomerates contain over 95 percent quartz clasts.

Clast composition is thus a good indicator of the uranium potential of a conglomerate sheet. Those composed predominantly of quartz clasts have the highest potential for uranium, while those containing significant quantities of chert (over 20 percent) usually are not mined for uranium but may be mineralized by gold. As a general rule, the conglomerates which contain high proportions of non-durable clasts (such as schist and phyllite) are not mineralized to an economic degree.

The proportion of non-durable clasts has been shown to decrease down the paleoslope in several cases. For example, Sims (1969) showed that the percentage of non-durable pebbles decreased from 77 to 34 percent in the B Reef of the Welkom Goldfield from the "upper mid fan" to the "lower mid fan".

It has also been shown that the percentage of non-durable clasts decreases where a pebble-bearing "footwall formation" is reworked along an intraformational unconformity. Button (1968) showed that the Kimberley Reef of the Delmas area in the Witwatersrand Basin was derived by reworking of the under1ying pebbly arenite. The maturity index (ratio of durable to non-durable clasts) increases from 12.9 in the pebbly arenite to 16.5 in the conglomerate derived from it. Concomitant changes included a slight diminution in median pebble size $(9.8$ to $8.8 \mathrm{~mm}$ ) and an improved sorting (graphic standard deviation of $0.84 \phi$ in the pebbly arenite to $0.68 \phi$ in the conglomerate).

While these guidelines have proved to be very useful in the Witwatersrand and Blind River-Elliot Lake districts, they are not inviolate. An important exception is the presence of locally derived shaly clasts. In the Elliot Lake district, these are referred to as "silt scraps", while in the Witwatersrand, they are usually termed "silicified shale fragments". These clasts tend to have disc-like shapes. They are usually yellow, khaki, or olive in color. They represent the disrupted remains of shale drapes commonly found interbedded in the arenites and conglomerates. The drapes probably formed by suspension settling of silty and clay-sized material from standing bodies of water in ephemeral pools and ponds on the surface of a braided fluvial plain. Their presence in a conglomerate is not regarded as an indication of poor fluvial sorting and working, but rather as an indication of local reworking of previously deposited fluvial sediments. Some uraniferous conglomerates contain an appreciable proportion of these clasts. These include the extensive and we11-mineralized Steyn paleoplacer, which Minter (1978) categorized as a polymictic conglomerate on account of the abundant shale and quartz-porphyry clasts contained in it. 


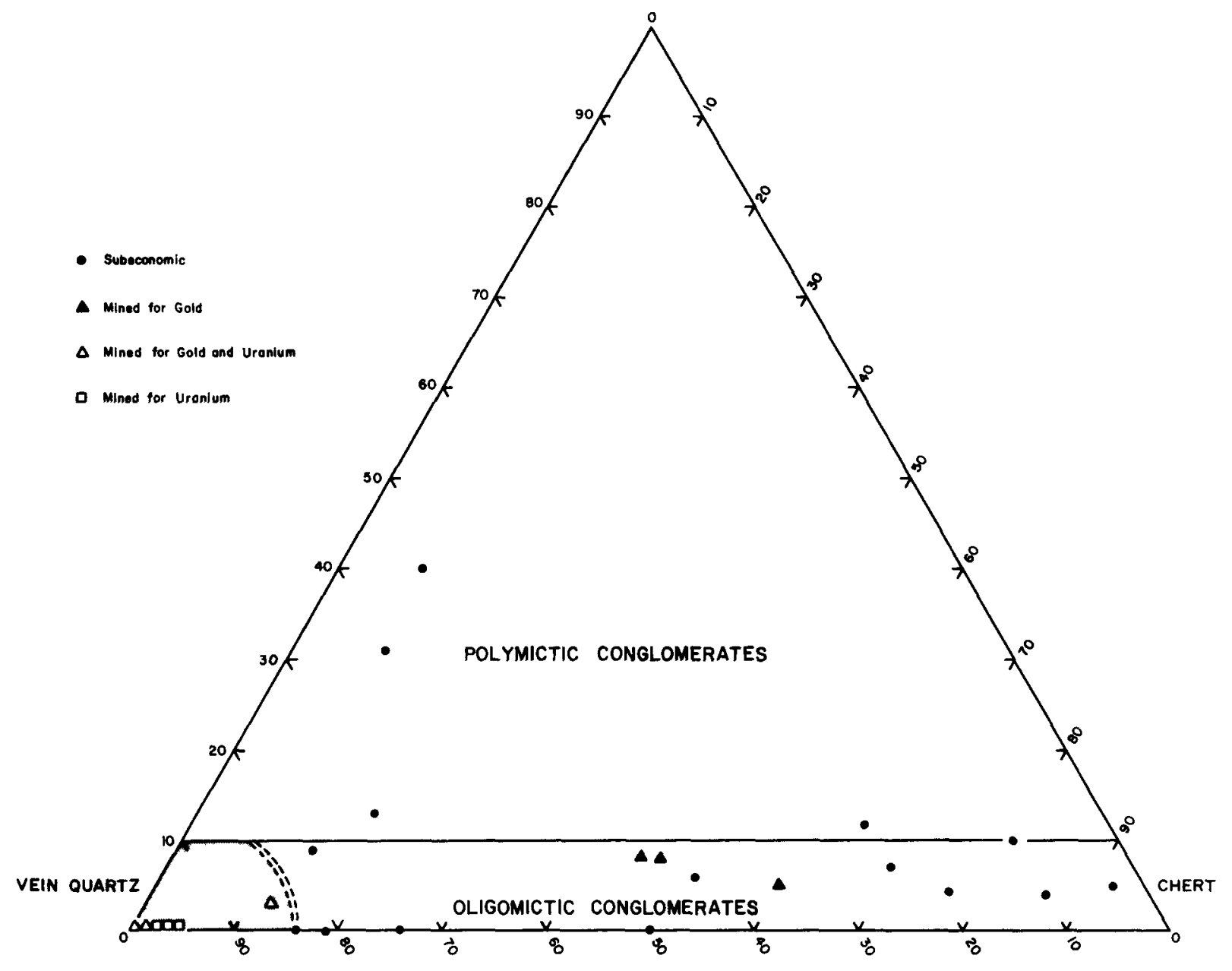

Figure 34. Triangular plot illustrating the composition of clasts in payable and unpayable uraniferous conglomerates (from information in Pienaar, 1963; Button, 1968; Armstrong, 1968; Minter, 1976, 1978; Pretorius, 1976). 
The relation of uranium and gold content to clast type is probably a reflection of source area control. It is widely believed that the gold and the chert pebbles were derived from Archean greenstone belts, while the uraninite and some of the quartz clasts were derived from late-Archean uraniferous granites and quartz monzonites.

\section{Fluid Inclusions in Quartz Pebbles}

Shepherd (1977) found that uraniferous conglomerates of the Witwatersrand are characterized by vein-quartz clasts with primary fluid inclusions rich in $\mathrm{CO}_{2}$. He was of the opinion that the uraninite grains and these quartz clasts had a common origin, both being derived from quartz-uraninite-bearing vein systems which formed from $\mathrm{CO}_{2}$-charged hydrothermal systems. He cited uraniumbearing vein systems in the U.S.S.R. and Europe which formed at temperatures from 50 to $350^{\circ} \mathrm{C}$ and at pressures from 400 to 2,000 bars from ore fluids enriched in $\mathrm{CO}_{2}$. He speculated that the vein systems from which witwatersrand uraninites were derived were formed by mobilization of uranium from the basement by supercritical $\mathrm{H}_{2} \mathrm{O}-\mathrm{CO}_{2}$ fluids generated during high-grade metamorphism and migmatization. We question Shepherd's conclusion, since the hydrothermal veins of this type usually contain low-thorium uraninites.

Shepherd's findings have not been applied to the Elliot Lake district. If they are shown to be valid in that area, fluid inclusion studies of quartz pebbles in Precambrian conglomerates may prove to be a useful discriminating tool in exploration programs.

\section{Pebble Packing}

Quantitative determinations of pebble packing in uraniferous conglomerates are rare. Pretorius' (1976) statement that the "normal conglomerate" consists of 80 percent (by weight) pebbles implies a well-packed, clast-supported conglomerate.

Pienaar (1963) recognized three packing classes in his study of the Matinenda conglomerates. Those comprising less than 15 percent pebbles were termed conglomeratic subarkoses; those with 15 to 40 percent pebbles were called loosely packed conglomerates while those with over 40 percent pebbles were referred to as well-packed conglomerates. He noted that packing changed laterally, so that conglomerates finger out into conglomeratic subarkoses and eventually to pebble-free subarkoses.

Theis (1979) is one of the few investigators to have studied packing in a quantitative way. He determined packing by placing a centimeter grid over a smoothed surface and counting the number of pebbles at grid intersections. He found that packing (in Matinenda conglomerates) measured in this way varied from 27.7 to 65.3 percent and averaged 53 percent. Theis admits that his sample is biased, since he selected for study the relatively well packed conglomerate facies. He found a weak correlation of packing with pebble size; the coarser grained conglomerates tend to be better packed (Figure 35). He explained the correlation as due to "the more efficient flushing of the finer grain components in the higher energy environments". Since pebble sizes correlate with the $\mathrm{U}_{3} \mathrm{O}_{8}$ content of the conglomerates, it follows that the better packed, coarser grained conglomerates will carry the highest 
concentrations of uranium. Pienaar (1963) stressed that a visual estimate of packing was a valid method of judging the probable uranium content of a Matinenda conglomerate.

Theis also documented the change in packing down the fluvial paleoslope in the Quirke area of the Elliot Lake district. The ore zone is comprised of over 90 percent "we11-packed conglomerate" along parts of the northern section of the southeast-trending ore zone. Some 5 to $7 \mathrm{~km}$ down the paleoslope, we11packed conglomerate usually comprises less than 50 percent of the ore zone.

Minter (written communication, 1980) has made the point that pebble-packing determinations are routinely made when evaluating the potential of Witwatersrand conglomerates. He gives as an example the Kimberley reefs at the South Roodepoort Mine which are never economically mineralized where the pebble packing falls below 40 percent.

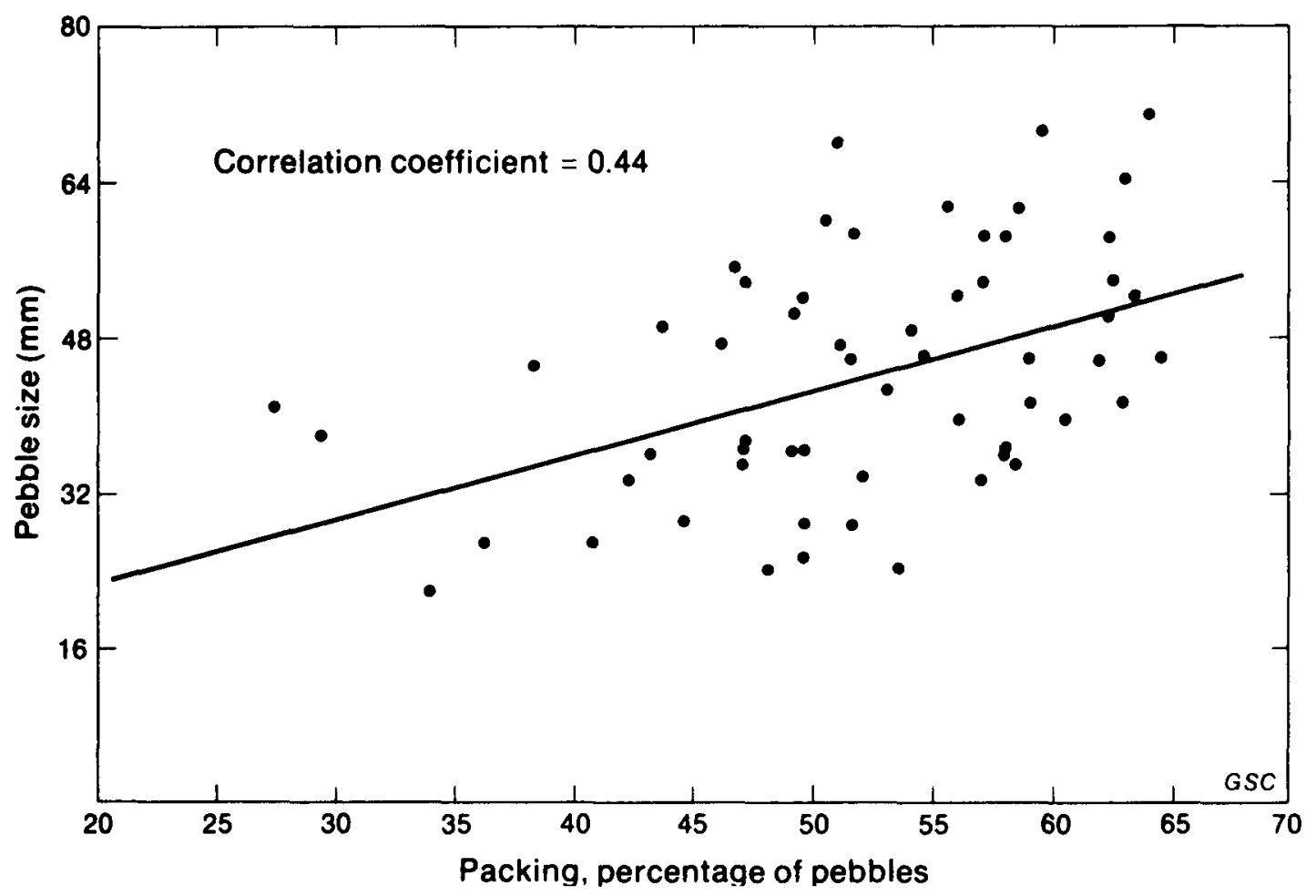

Figure 35. Scatter diagram showing pebble packing plotted against pebble size for samples of the Rio Algom-Denison ore reef, Quirke area of the E1liot Lake district (from The1s, 1979). 
Not all economic conglomerates in the Witwatersrand are well packed. For example, the uraniferous-auriferous Vaal Reef is a "pebbly siliceous quartzite" with an average packing density of pebbles of 20 percent (Minter, 1976). According to Minter, pebble-supported conglomerates are rare in the Vaal Reef, being restricted to lag deposits in some channels. A second example is the distal portion of the Steyn Reef in the Welkom Goldfield. According to Minter (1978), this paleoplacer changes down the paleoslope from interbedded clast-supported conglomerate and quartzite to a quartz arenite with mudstone veneers and scattered small pebbles on scour surfaces. This example is particularly relevant to the relation of uranium content to packing. Minter has shown that the highest U/Au ratio occurs relatively far down the paleoslope where the packing density of pebbles decreases.

In summary, packing density is usually a valid indication of the uranium potential of a conglomerate, particularly in the "proximal" parts of placer systems. Clast-supported conglomerates tend to be better mineralized than associated matrix-supported conglomerates. However, the distal parts of some Witwatersrand placer sheets are sometimes well mineralized, despite the fact that they comprise clean quartz arenite with pebbles being found only as lags on scour surfaces. Such placers can be recognized if account is taken of the underlying intraformational unconformity, the maturity of the quartz arenite, the abundance of pyrite and other heavy minerals, and the presence of resistant clasts (such as quartz and chert) on scour surfaces.

\section{Sorting}

There are several measures of sorting which have been applied to the pebble assemblages of uraniferous conglomerates. Comparisons between districts are difficult to make because of the lack of uniformity in the sorting parameters used. In many studies, the measure of pebble size used is an average of the ten largest clast diameters per unit area. For example, Theis (1979) based his study on the mean of the maximum-apparent diameter of the ten largest quartz pebbles per $1,000 \mathrm{~cm}^{2}$ of rock face. Studies of this type cannot provide insights into the sorting of clasts and the relationship of mineralization to pebble sorting.

A second problem with many pebble-sorting studies is the arbitrary definition of pebbles as clasts larger than $4 \mathrm{~mm}$. Most investigators have restricted their measurements to this size fraction. The results are thus biased by exclusion of grain-size data in the smaller than $4 \mathrm{~mm}$ fraction.

Since grain-size measurements are usually converted to phi units (where diameter in $\phi$ units $=-\log _{2}$ diameter in millimeters; Friedman and Sanders, 1978), sorting measures are usually also quoted in this unit. Several authors have used the graphic standard deviation $(\sigma g)$ as a measure of pebble sorting in Witwatersrand conglomerates.

The graphic standard deviation is defined as:

$$
\sigma g=\frac{\phi 84-\phi 16}{2}
$$


where $\phi 84$ and $\phi 16$ are the phi grain sizes at the 84 th and 16 th percentiles on a cumulative frequency plot of pebble sizes.

Armstrong (1968) determined that the pebble sorting of the Kimberley Reef of the East Rand area in the Witwatersrand Basin is $0.53 \phi$ (average of sorting values at 12 different locations). The Kimberley Reef was fairly extensively mined for both gold and uranium in the East Rand. Button (1968) calculated $\sigma g$ for several conglomerates from the Delmas area, east of the East Rand Basin. Several mineralized but sub-economic conglomerates were shown to have $\sigma g$ values ranging from 0.84 to $0.96 \phi$ units. The marginally sub-economic Kimberley Reef in this area has a $\sigma \mathrm{g}$ value of $0.68 \phi$. This unit rests on the same unconformity as the Kimberley Reef of the East Rand, which is economically mineralized, and which has a significantly better average sorting (0.53ф, Armstrong, 1968). In this instance, pebble sorting is a valued indication of the economic potential of a conglomerate sheet.

Other pebble sorting determinations include those for the uraniferous-auriferous Vaal Reef, where Minter (1976) recorded a standard deviation of $0.447 \phi$. In the Witwatersrand, the uraniferous conglomerates for which data exist appear to be well sorted or moderately well sorted with graphic standard deviations on the order of $0.5 \phi$ units. Limited data indicate that conglomerates with graphic standard deviations greater than about $0.8 \phi$ tend to contain sub-economic concentrations of uranium and gold. It must be stressed that these values are not absolute and probably vary from one district to the next. The important conclusion is that, within a given district, the better sorted conglomerates are likely to contain higher proportions of uranium and gold.

\section{Shape, Sphericity, and Roundness}

Sphericity is the degree to which a particle approaches a sphere. Sphericity determinations require three-dimensional exposure of clasts and are thus seldom measurable in highly lithified Precambrian conglomerates. In some areas, recent weathering has resulted in disintegration of the conglomerate matrix and release of pebbles. In such cases, sphericity can be measured.

Pienaar (1963) studied the shapes of two samples of pebbles from uraniferous conglomerates of the Elliot Lake district. Shape was determined by measuring the long, intermediate, and short axes for each pebble, and by plotting the axial ratios as shown in Figure 36. In both samples, spherical shapes were the most common. Disc, blade, and roller shapes were found and were the basis for Pienaar's study of preferred orientation of clasts.

Steyn (1964) studied pebble shapes in the Livingstone Reef of the West Rand area and determined that 51 percent of the pebbles are spheroidal, 24 percent are disc shaped, 20 percent are roller shaped, and 5 percent are blade shaped.

In his study of the Vaal Reef, Minter (1972, 1976) stated that disc-, roller-, and blade-shaped pebbles are common, comprising 75, 12.5, and 12.5 percent, respectively, of the pebble population. He also documented ventifact clasts, some of them apparently modified by subsequent fluvial transport. The ventifacts are dreikanters, comprising "perfect pyramidal tops . . - on sma11 (20 mm) pebbles previously rounded by fluvial cycles". 
NORDIC AND BUCKLES MINE

120 PEBBLES

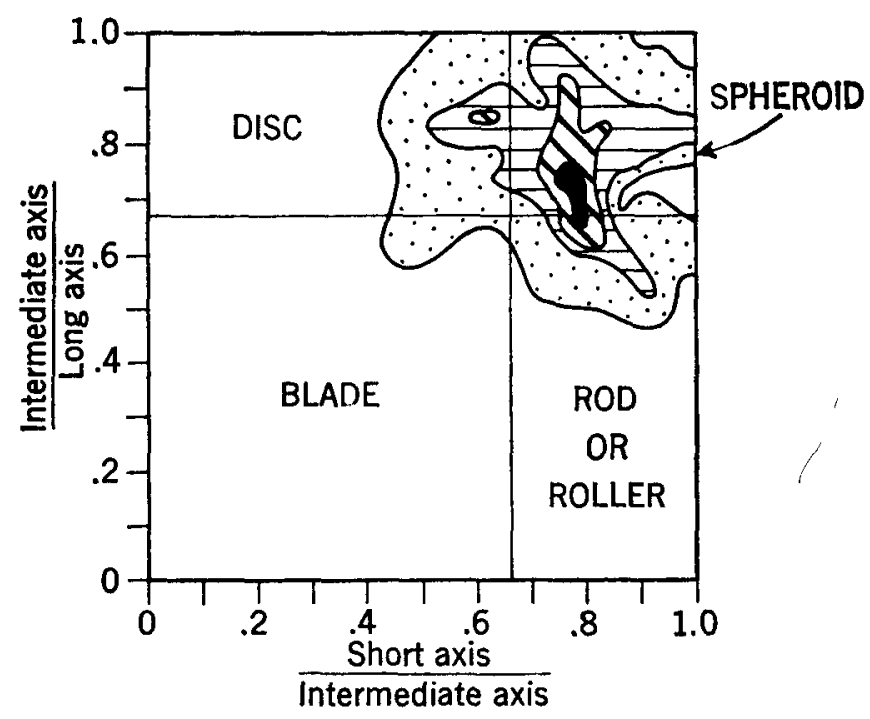

LE GEN D

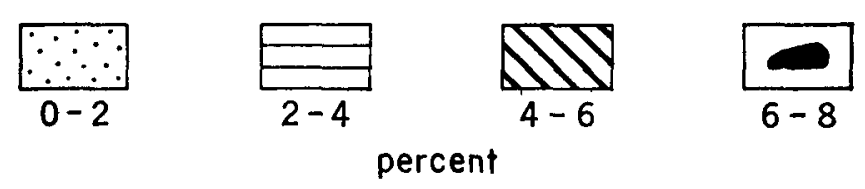

QUIRKE MINE

105 PEBBLES

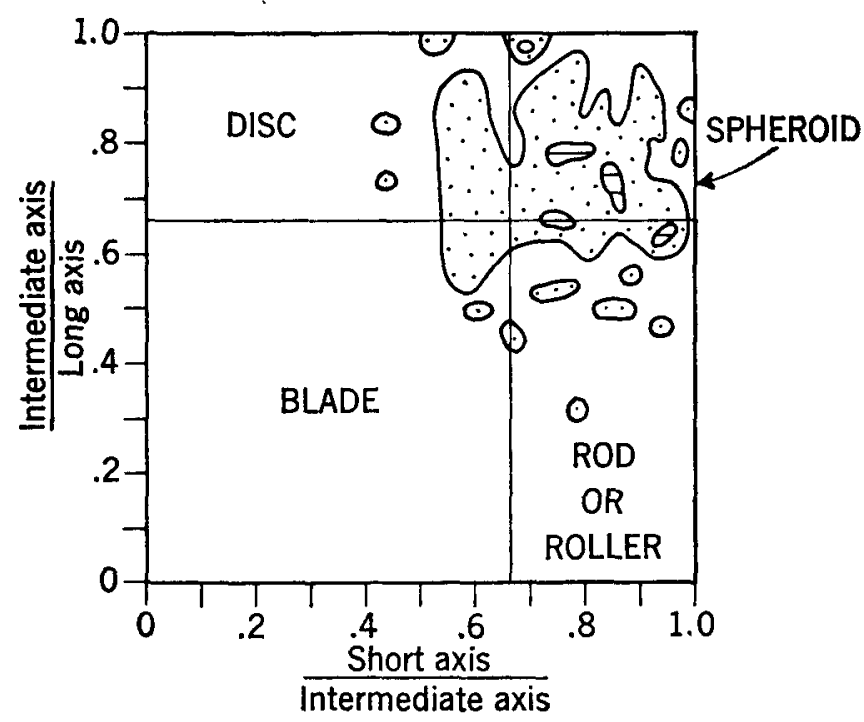

Figure 36. Plots of pebble:axial ratios, illustrating clast shape in Matinenda conglomerates (from Pienaar, 1963). 
Roundness is an attribute of the form of a particle that is related to the sharpness or curvature of edges and of corners (Friedman and Sanders, 1978). It is determined in two dimensions; thus roundness determinations can be easily made on outcrops or underground faces of Precambrian conglomerates. A practice in certain studies in the Witwatersrand was to determine roundness on polished surfaces cut through conglomerate slabs.

Roundness is defined mathematically as the ratio of the average radius of circles inscribed in individual edges and corners of a clast to the radius of the largest circle that can be inscribed in the profile of the clast. In practice, this technique is slow, and roundness determinations are usually made by visual estimation using a chart.

The rounding of clasts improves with distance of transport. Thus, rounding studies are potentially useful in Precambrian conglomerates, since they allow one to determine sediment transport and paleoslope directions, which can in turn be related to the uranium and gold potential of an area. However, rounding occurs relatively slowly, so that a long reach of a stream system must be available for study before roundness relationships become established. Thus, Sneed and Folk's (1958) study of rounding in the Colorado River was done over a reach measuring over $400 \mathrm{~km}$ in 1ength. By contrast, most Precambrian fluvial systems can be sampled over distances of a few tens of kilometers at most. Over these relatively small distances, increases in the degree of rounding will be small. Pebble-size changes are much more noticeable over the few tens of kilometers available for study and are thus much more useful in determining the paleoflow patterns.

In general, pebbles in auriferous and/or uraniferous Precambrian conglomerates are well rounded or very well rounded. For example, Pretorius (1976) categorizes the Vaal Reef pebbles as having "a high degree of rounding". Minter (1976) gave the average rounding of Vaal Reef pebbles as 94 percent. Photographs of Matinenda conglomerates (Roscoe, 1969; Theis, 1979) show that clasts are dominantly rounded or well rounded.

Rounding is an important criterion for the recognition of potentially uraniferous conglomerates. With the exception of locally derived shale clasts, the pebbles in conglomerates which contain economic concentrations of uranium and/or gold are dominantly well rounded or very well rounded. A high proportion of angular or subangular clasts is an indication of an immature conglomerate with a relatively low potential for economic concentrations of heavy metals.

\section{Orientation}

In fluvial systems, platy or disc-shaped pebbles, cobbles, and boulders are often shingled, dipping upstream at a low angle (Friedman and Sanders, 1978). If such a preferred orientation can be determined, it can, potentially, be used as a paleocurrent indicator in fluvial conglomerates.

Armstrong (1968) determined that those Kimberley Reef conglomerates deposited near a channel axis showed upstream imbrication with mean angles of inclination of 26 to 30 degrees. Conglomerates deposited along the same paleosurface, away from the channel axis, showed no imbrication. In this instance, 
pebble orientation not only indicated the paleocurrent direction but also provided some indication of location of samples relative to the axis of a channel.

Pienaar (1963) undertook a study of the preferred orientation of clasts in Matinenda conglomerates. He was not able to detect an upstream-inclined shingling. He found that most of the disc-shaped clasts were oriented paralle1 to cross-bed foresets, and thus inclined in a downstream direction.

Studies of preferred orientation of clasts in Precambrian conglomerates are potentially useful paleocurrent indicators. They have not been widely applied in exploration or in mine development due to the time-consuming measurements needed for such exercises, the difficulties in interpretation (illustrated by the two studies cited above), and due to the ease with which cross-bed orientations can be determined and interpreted.

\section{Size-Distribution Patterns}

Numerous studies have shown that size-distribution patterns in Precambrian conglomerates are extremely important in deciphering the paleoslope and sediment dispersal patterns. The technique most commonly used is to measure the 10 largest pebbles in a standard area. It has been shown (Pettijohn, 1956) that the mean of the maximum-diameter of the largest clasts is some function of the mean clast diameter. Theis (1979) used the average of the 10 largest clasts per $1,000 \mathrm{~cm}^{2}$ as the measure of pebble size in his study of Matinenda conglomerates. This method is quick and produces useful results. However, other grain-size parameters (such as sorting) cannot be determined f rom the data. Consequently, many other investigators have used the slower technique of measuring the diameters of all clasts greater than $4 \mathrm{~mm}$ in diameter in a sample (for example, Armstrong, 1968). This method usually requires removal of a block of conglomerate from the outcrop followed by slabbing and measurement on a smoothed surface.

A classic study of the relationship of pebble size to economic parameters (such as uranium and gold distribution) was published by Minter (1978). His study of the Basal and Steyn paleoplacers of the We1kom area showed that the mean of the ten largest pebbles decreased from $40 \mathrm{~mm}$ to less than $20 \mathrm{~mm}$ down a $20 \mathrm{~km}$ long paleoslope (Figure 37A). The highest concentrations of gold are found in the proximal parts of the paleoslope; the highest concentrations of uranium are found further down the paleoslope. The most distal fringes of the paleoslope are characterized by the highest U/Au ratio (between 5 and 20).

Theis (1979) studied pebble size variations and correlations in the Quirke area of the Elliot Lake district. He found an excellent correlation (0.93) between pyrite grain size and pebble size (average of 10 largest clasts/ $\left.1,000 \mathrm{~cm}^{2}\right)$. Pebble sizes are larger, on average, than those in Minter's (1978) study, ranging from some $20 \mathrm{~mm}$ to over $60 \mathrm{~mm}$ (Figure 38).

Theis also found that there was a weak positive correlation between pebble size and the $\mathrm{U}_{3} \mathrm{O}_{8}$ content of the conglomerate, the coarser conglomerates coinciding with the highest uranium contents (Figure 39 ). 

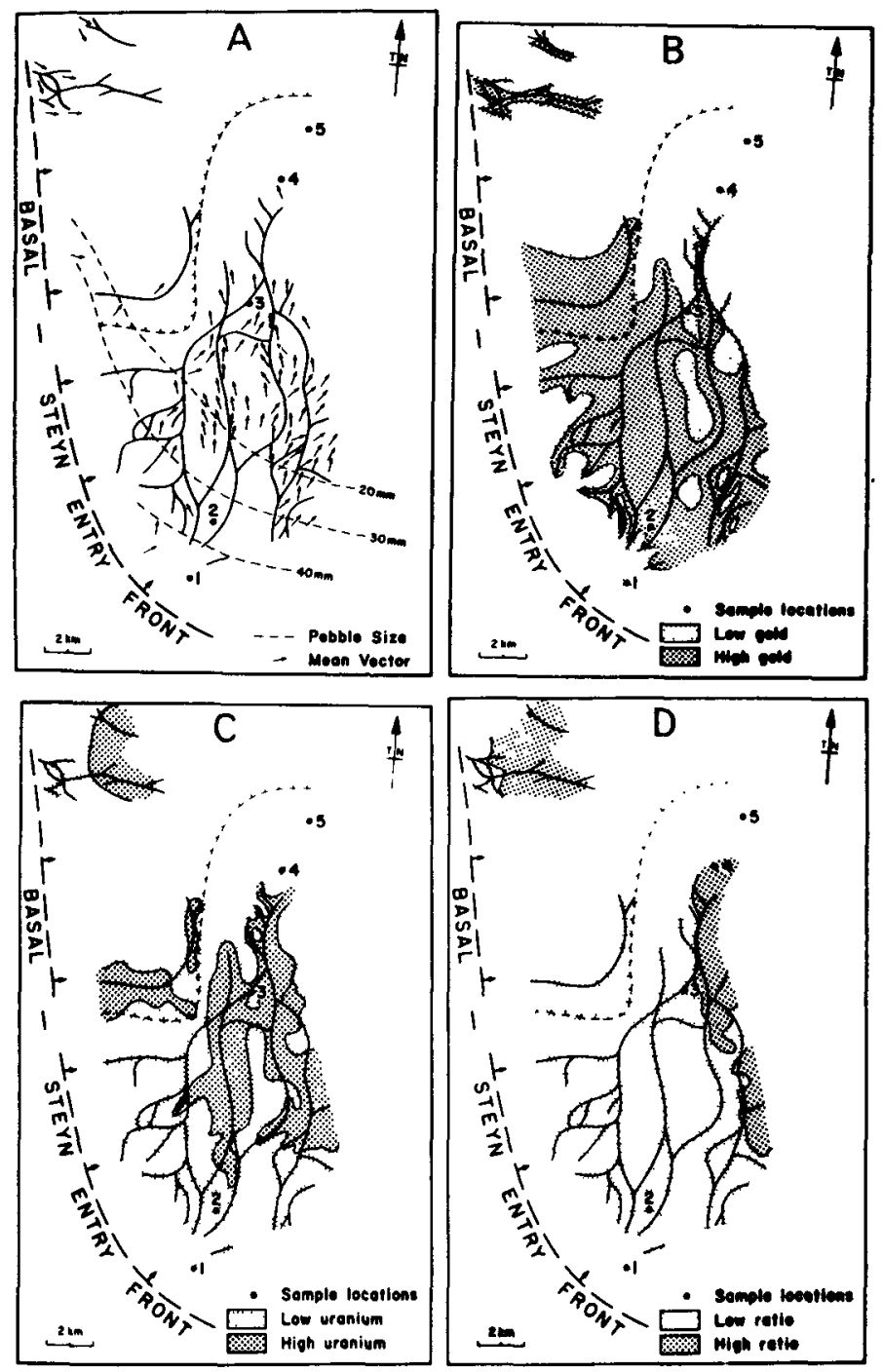

A. Main trends of mineralization (solid braided lines), paleocurrent vectoral means (arrows), contours of pebble size (average of 10 largest clasts per location; broken lines) and junction of the Steyn and Basal "facies" of the placer ( $T$ pattern).

B. Gold distribution pattern (high-gold areas have an average concentration of $15-60 \mathrm{ppm} \mathrm{Au}$ ).

C. Uranium distribution pattern (high-uranium areas have an average concentration of $150-500 \mathrm{ppm} \mathrm{U}$ ).

D. Uranium/gold ratio (high ratio is over 20; 1ow ratio ranges from 5 to 20).

Figure 37. Maps of the Basal/Steyn paleoplacer, Welkom area (from Minter, (1978). 


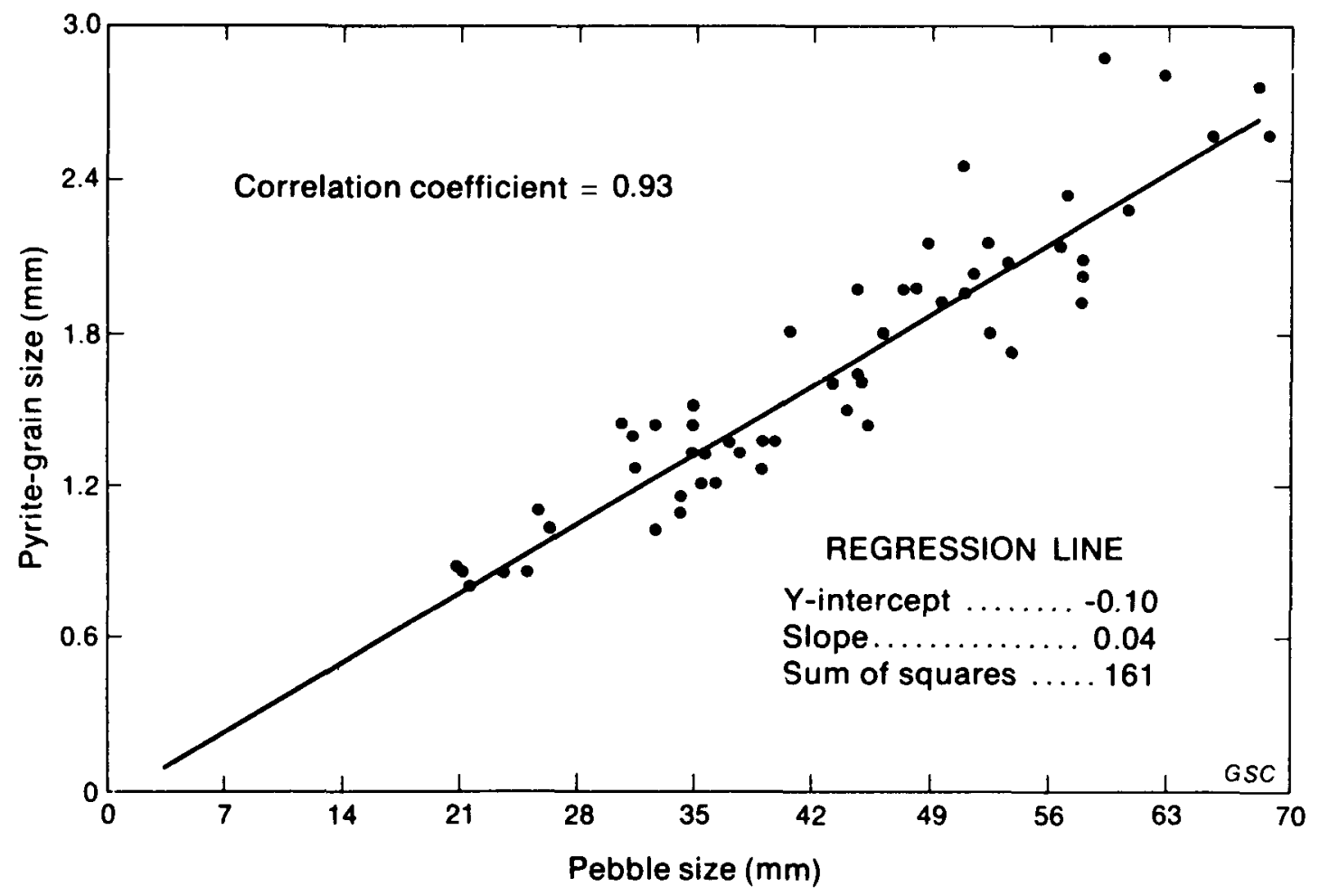

Figure 38. Scatter diagram showing pebble size plotted against pyrite grain size, Rio Algom-Denison ore reef (from Theis, 1979).

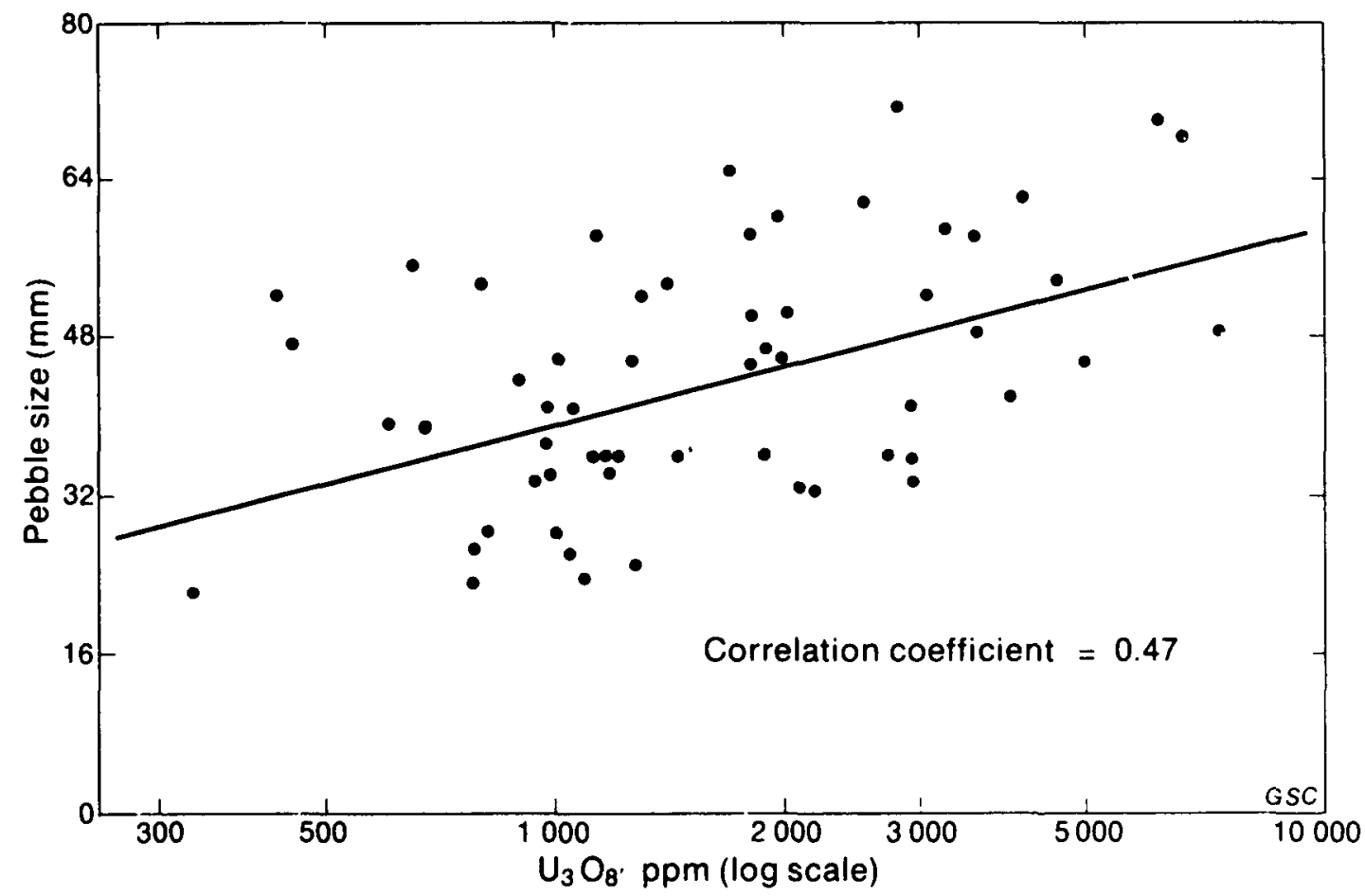

Figure 39. Scatter diagram showing weak correlation of pebble sizes and $\mathrm{U}_{3} 0_{\mathrm{a}}$ content (after Theis, 1979). 
In his study of the uraniferous-auriferous Kimberley Reef of the East Rand, Armstrong (1968) found that pebble sizes ranged from 18 to $48 \mathrm{~mm}$. The mean pebble size in the pebbly arenite which comprises the auriferous-uraniferous Vaal Reef is $7.5 \mathrm{~mm}$ (Minter, 1976). The 10 largest pebbles (in a population of 600 pebbles) range from just less than $20 \mathrm{~mm}$ to $35 \mathrm{~mm}$. One area of large pebbles was shown to be located where the Vaal Reef truncated an underlying pebbly quartzite containing relatively large clasts.

The average pebble diameter in the Kimberley Reef of the Evander Goldfield is 9-10 mm (Tweedie, 1978). The conglomerate on the same horizon in the Delmas area (to the northwest) has a median pebble diameter of $8.8 \mathrm{~mm}$.

Pretorius (1976) tabulated data from a study (by Sims, 1969) of severa1 conglomerates in the Welkom Goldfield (see Table 14). Columns 4, 5, and 6 indicate that some of the conglomerates contain cobbles of quartzite and "quartz porphyry". These conglomerates are poorly sorted and are not nearly as important as sources of gold and uranium as the better sorted Basal and Steyn placers.

In summary, studies of uraniferous and/or auriferous conglomerates in the Witwatersrand and Elliot Lake districts have shown that economic concentrations of metals tend to be associated with those conglomerates with pebble sizes (expressed by the mean of the 10 largest pebbles in a relatively small area) ranging from about 20 to $70 \mathrm{~mm}$. The median pebble diameters are much smaller, frequently being on the order of $10 \mathrm{~mm}$. Smaller grain sizes do not necessarily indicate absence of economic mineralization, since Minter (1978) has shown that the Vaal Reef and the distal parts of the Basal/Steyn Reef are dominated by material of sand size. Coarser cobble- and boulder-bearing conglomerates are mineralized in places, but seldom carry economic concentrations of either uranium or gold.

A puzzling aspect of uranium distribution relative to pebble size is illustrated by some of the examples cited above. Studies on the Elliot Lake district (Theis, 1979) indicate maximum uranium concentration with coarsest conglomerate phases. By contrast, Minter's (1978) synthesis on Witwatersrand conglomerates indicates the inverse relation, uranium being preferentially concentrated in the distal parts of some of the paleoplacer systems. The most logical explanation is that uraninite grain size is smaller, on average, in the Witwatersrand than in the Elliot lake district. While systematic comparisons of uraninite grain size in the two districts have not been made, this supposition is consistent with available data, which indicate larger uraninite grain sizes in the Elliot Lake district.

Finally, studies of a few Witwatersrand conglomerate sheets have indicated no systematic variations in pebble size (Minter, 1978). Examples include the Vaal Reef (Klerksdorp area) and the Carbon Leader (Carletonville area). Minter terms such conglomerates "transgressive placers". Pebble-size studies in such conglomerates would be of little help in establishing sediment dispersal systems and patterns of uranium (or gold) distribution. 


\section{Composition and Texture}

The matrices of uraniferous-auriferous conglomerates are composed main $1 \mathrm{y}$ of silicate minerals, predominantly quartz, sericite, and chlorite with some pyrophyllite and chloritoid.

For example, in the Vaal Reef of the Klerksdorp area, the conglomerate matrix comprises 95 percent quartz, 1 percent rock fragments, 3 percent sericite, and 1 percent chlorite (Table 15). Minter $(1976,1978)$ has stressed that the matrices of mineralized conglomerates tend to be much cleaner than the enclosing arenites. Thus, the MB4 "quartzite", which occurs a few meters above the Vaal Reef, comprises 34 percent phyllosilicates (Table 15).

Table 15. Percentage mineral composition of conglomerate matrix and arenite in Klerksdorp fluvial fan (after Pretorius, 1976).

\section{MINERAL}

Quartz

Rock fragments

Sericite

Chlorite
VAAL REEF MATRIX

95

1

3

1
MB4 ARENITE

62

4

26

8

\section{Allogenic Quartz}

Viljoen (1967, 1968) undertook a detailed examination of the Main Reef and Main Reef Leader conglomerates in the Central and East Rand areas. He found that allogenic (detrital) quartz (sand and silt size-grades) comprises some 80 percent of the conglomerate matrix. The quartz grains were thought to have been derived from veins. They are strained and contain aligned inclusions. Where original grain boundaries are visible, the quartz grains are seen to have been rounded to subangular.

\section{Authigenic Quartz}

Lithification of Precambrian conglomerates is largely a result of filling of pore spaces with a silica cement. Much of the silica was deposited as overgrowths on detrital quartz grains (Viljoen, 1967). The overgrowths are often in optical continuity with the detrital grains, the original boundaries of which are demarcated by inclusions. The quartz was probably derived by diagenesis of clay minerals in the conglomerates and enclosing rocks. Columnar or fibrous quartz is a minor constituent of the conglomerate matrix, tending to form in pressure shadows associated with grains of pyrite, 
pyrrhotite, chromite, and quartz. Some chlorite, sericite, and pyrrhotite have been found along with columnar quartz in pressure shadows (Viljoen, 1967).

\section{Sericite}

After quartz, sericite is usually the most common mineral in the matrices of Precambrian auriferous-uraniferous conglomerates. It occurs as minute flakes and in "large compact masses up to $1 \mathrm{~mm}$ in length" (Viljoen, 1967). Sericite also apparently replaces detrital quartz grains along grain boundaries and cracks. In relatively strongly metamorphosed conglomerates, the sericite is represented by muscovite (see, for example, Redden, 1980).

\section{Chlorite}

Chlorite group minerals (largely penninite) occur in varying amounts in conglomerate matrices. They are found as individual flakes, as aggregates of flakes, as radiating bunches of crystals, and as oval aggregates containing sulfides. Some chlorite is clearly pseudomorphous after detrital grains of amphibole (Koen, 1962). Chlorite also fills fractures in some detrital grains. The intimate association of much of the chlorite with sericite could suggest that they were derived from a common precursor clay, such as a mixedlayer illite-montmorillorite clay mineral.

Adjacent to basic dykes and sills, the matrices of conglomerates are frequently chloritized (Viljoen, 1967).

\section{Chloritoid}

Chloritoid occurs in amounts of up to several percent in numerous Witwatersrand conglomerates. It occurs as unoriented laths (from 0.5 to $0.1 \mathrm{~mm}$ long) and as rosette-like aggregates. Textural evidence suggests that the chloritoid is a mineral formed during low-grade (greenschist) metamorphism to which much of the Witwatersrand was subjected. Its growth implies relatively high $\mathrm{Al}_{2} \mathrm{O}_{3}$ and $\mathrm{FeO}$ contents in conglomerate matrices.

\section{Pyrophy11ite}

The matrices of Witwatersrand conglomerates are known to contain some pyrophyllite (Feather and Koen, 1975). The Identification of this mineral relies on $\mathrm{X}$-ray techniques. In thin section it cannot be distinguished from muscovite. It is probably present in greater amounts than is normally appreciated. The Vaal Reef contains 0.1 percent pyrophyllite while the Ventersdorp Contact Reef contains an estimated 0.2 percent of this mineral (Feather and Koen, 1975). Pyrophyllite was probably formed by diagenetic reconstitution of an aluminous clay mineral in the original matrices of conglomerates.

\section{Other Minerals}

Very small amounts of several other minerals have been detected in the matrices of auriferous-uraniferous conglomerates. Calcite and dolomite have been observed in Witwatersrand and Elliot Lake conglomerate matrices (Pienaar, 1963; Feather and Koen, 1975). In the former area, they have been observed 
filling pore spaces and replacing matrix constituents. Dominion Reef conglomerates contain some unaltered light-brown pyroxene, lathlike epidote crystals, and greenish, chromium-bearing biotite (Hiemstra, 1968a). Matinenda Formation conglomerates contain some highly altered microcline, epidote, phlogopite, biotite, zoisite, and iron-silicates such as greenalite, chamosite, and grunerite (Pienaar, 1963; Roscoe, 1969). The iron silicates are thought to have been derived from a ridge of Archean iron-formation which lies near some of the conglomeratic orebodies. Kaolinite is a trace constituent of some Witwatersrand conglomerates.

\section{Latera1 Variations in Matrix Composition}

The lateral variation in matrix components of a Witwatersrand conglomerate was investigated by Lenthall (1970). He studied the chlorite-to-sericite ratio in the Main Reef Leader conglomerate of the East Rand. A pattern of increasing chlorite concentration down the paleoslope was determined (Figure 40). The chlorite/sericite ratio ranges from $1 / 16$ in the proximal parts of the gravel sheet, to over 4 (and in places to 32 ) in the distal parts of the system. Lenthall interpreted the pattern as a reflection of the preferential flocculation of illitic clays where fluvial waters (entering the Witwatersrand Basin) encountered saline basinal waters. This interpretation is questioned, since no evidence of a marine basin exists for the time span in which the Main Reef Leader was deposited. A more likely explanation is that the sericite precursor was introduced into the basin as relatively coarse-grained clay mineral aggregates and was thus concentrated in the proximal parts of the fluvial system. Whatever the explanation, the relationships are potentially useful, since the more proximal facies, with a higher potential for gold and uranium, are characterized by a matrix rich in sericite relative to chlorite.

\section{Lateral Variation in Matrix Texture}

\section{Grain Size}

Viljoen (1968) and Lenthal1 (1970) studied the variation in the grain size of matrix quartz in the Main Reef Leader of the East Rand. Both authors found a systematic decrease in quartz median grain size down the paleoslope. Their work documented a change from a quartz median grain size of $0.75 \mathrm{~mm}$ to $0.3 \mathrm{~mm}$ over distances on the order of 10 to $30 \mathrm{~km}$. The larger grain sizes are coincident with areas of greater overall payability of the conglomerate sheet. Within a sedimentologic entity such as the Main Reef Leader conglomerate of the East Rand, quartz grain size is a useful indicator of position on the fluvial fan, and thus, of economic potential.

\section{Sorting}

Viljoen (1968) and Lenthal1 (1970) also determined that the sorting of quartz grains in the matrix of the Main Reef Leader improves down the paleoslope. Lenthall's data showed that the standard deviation decreased from $0.9 \phi$ units to $0.6 \phi$ units down the paleoslope, indicating improved sorting with distance of transport. 


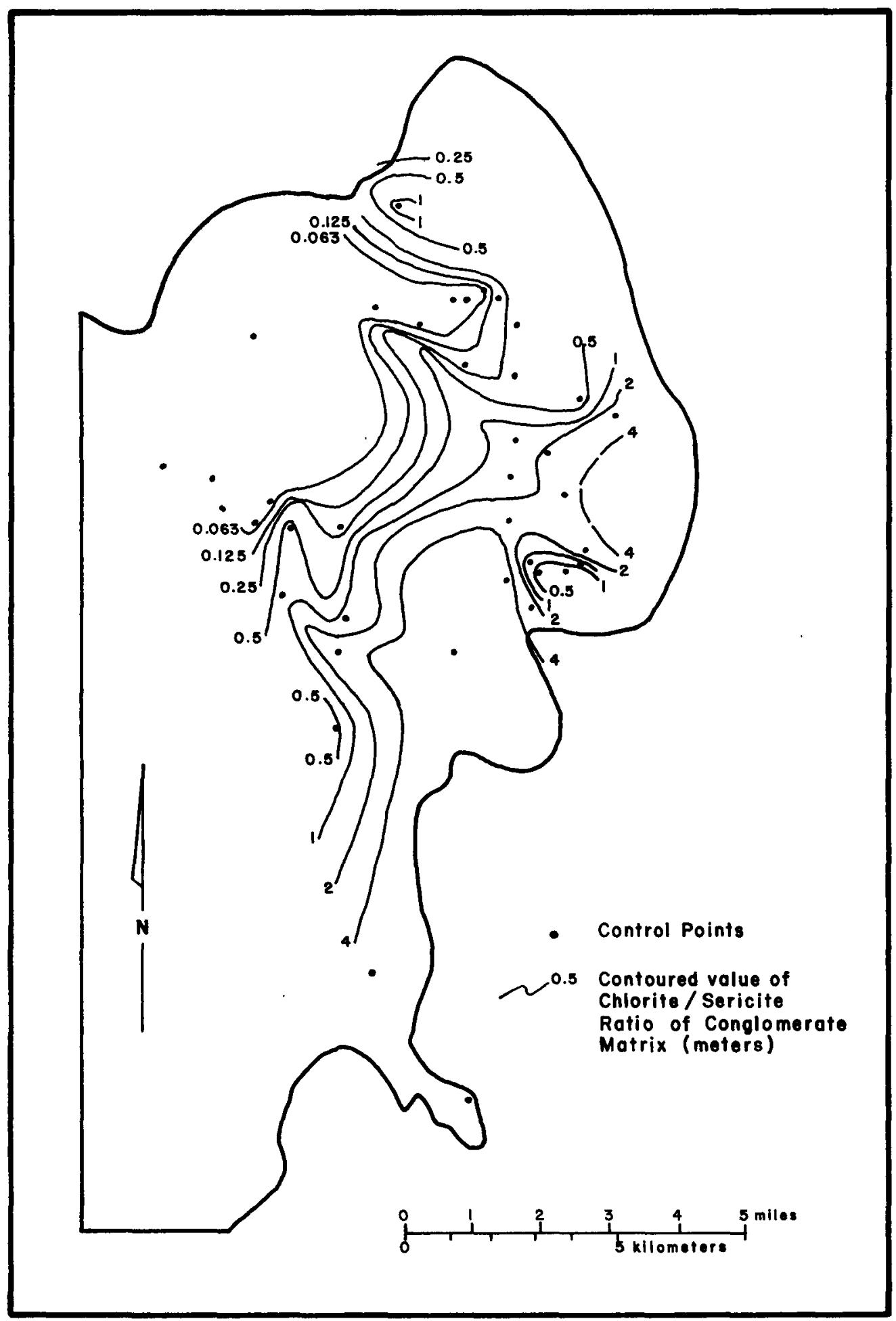

Figure 40. Contour map showing the variation of the chlorite/sericite ratio in the matrix of the Main Reef Leader, East Rand area (after Lentha11, 1970). Proximal facies (in the northwest) is sericiterich, probably because the sericite precursor was transported as relatively coarse-grained clay aggregates. 
The silicate fraction of the matrices of mineralized quartz-pebble conglomerates is composed dominantly of quartz, with lesser amounts of sericite, chlorite, and chloritoid and very small quantities of minerals such as pyrophyllite, epidote, biotite, phlogopite, carbonates, kaolinite, and iron silicates. Quartz occurs both as detrital grains and as the major cementing material in the conglomerate. Feldspar grains are relatively rare while phyllosilicates are fairly common. This suggests weathering of basement rocks prior to their transport and deposition in the basins. The high alumina content of the original clays in the matrix (indicated by such phases as pyrophyllite and chloritoid) suggests intense chemical weathering of the source area and implies that deposition took place under humid, tropical, or subtropical conditions.

Detailed studies of matrix constituents have shown that the median grain size of detrital quartz grains decreases down the paleoslope, and that there is a parallel improvement in sorting. In one example, clay mineral fractionation during deposition resulted in a sericite-rich matrix in the proximal parts of a fluvial fan, and a chlorite-rich matrix along the outer fringes of the fan. These parameters (quartz size and sorting, and sericite/chlorite ratio) are potentially useful tools in exploration, allowing the determination of the paleogeography of a braided fluvial system, and thus the areas of anticipated concentration of uranium and gold.

\section{Matrix Fraction (Heavy Minerals Excluding Uraniferous Phases)}

Precambrian uraniferous-auriferous conglomerates are characterized by matrices containing an exceptionally wide variety of minerals. According to Feather and Koen (1975), over 70 ore minerals have been recognized in Witwatersrand conglomerates. In his 1976 review of the nature of Witwatersrand conglomerates, Pretorius lists 78 minerals, 11 of which have been previously mentioned as comprising the light mineral fraction of the conglomerates. Pretorius classified the minerals as economic minerals, sulfides, oxides, silicates, and others. Feather and Koen modified and added to Pretorius' table, listing not only the minerals present, but their paragenetic sequence (Figure 41). They recognized three stages of mineralization, comprising the original detrital minerals, minerals formed in the matrix during the "main period of pyrite mineralization," and minerals emplaced during the "main period of gold remobilization and secondary sulfide mineralization". The first group was referred to as "allogenic" by earlier workers (Young, 1909, 1917; Viljoen, 1967); the latter groups were classed as "authigenic constituents".

In contrast to the Witwatersrand conglomerates, those of other districts (such as the E1liot Lake) are mineralogically relatively simple. It must be emphasized that even in the Witwatersrand, the vast majority of the ore minerals occur in extreme1y small amounts. This is indicated in Figure 41, where the relatively important heavy minerals are indicated in a heavy typeface. 
STAGE 1: Detrital mineralization

STAGE 2: Main period of pyrite mineralization

STAGE 3: Main period of gold remobilization and secondary sulphide mineralization.

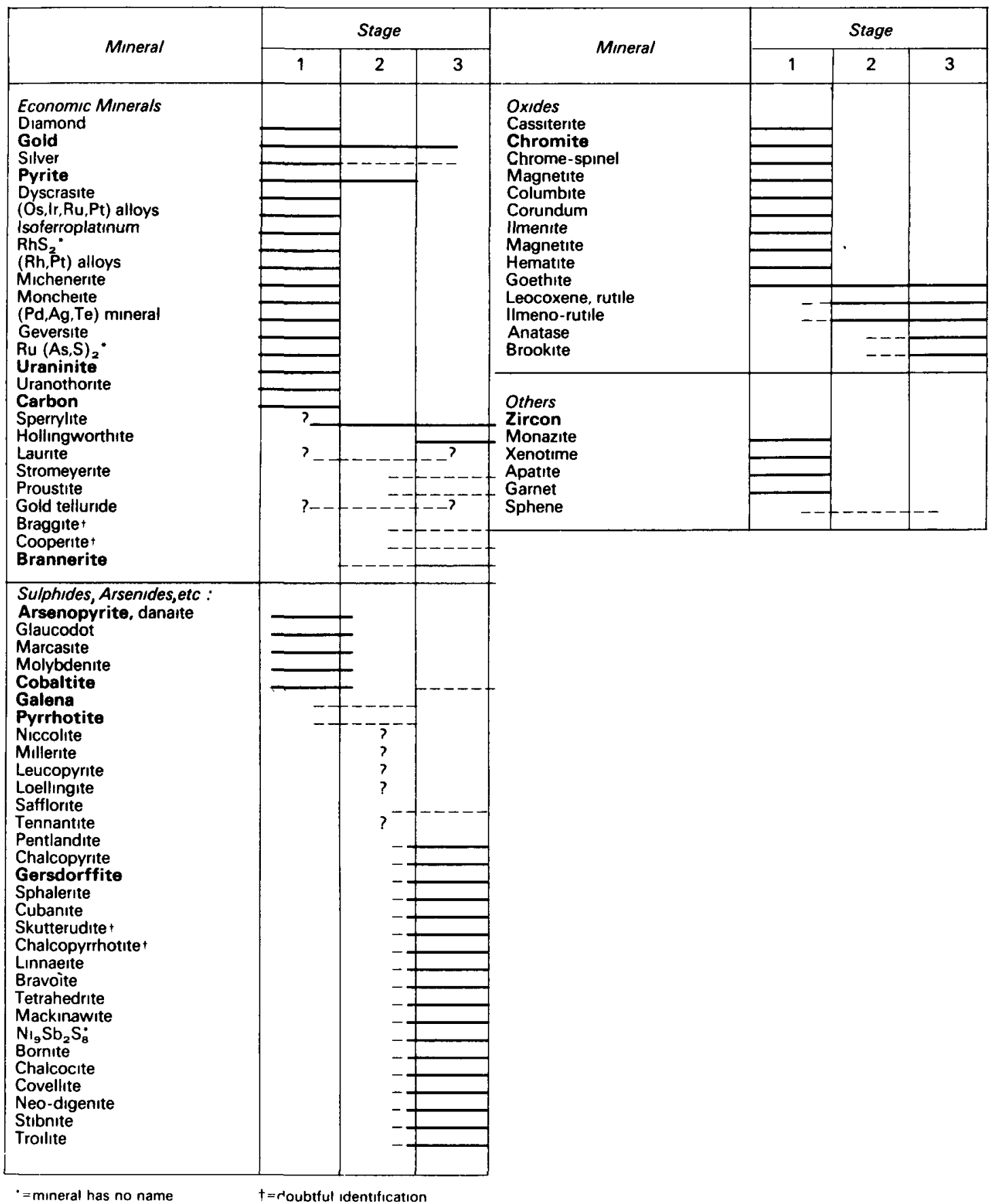

Figure 41. Chart showing mineralogy and paragenesis of the matrices of Witwatersrand conglomerates (from Feather and Koen, 1975). The most abundant (or economically important) minerals are shown in heavy typeface. 
In the discussion which follows, an attempt is made to discuss the minerals under the headings of detrital (allogenic) constituents and authigenic constituents, starting in each case with the most abundant minerals.

\section{Detrita1 (Allogenic) Constituents}

There are a significant number of minerals in the matrices of Precambrian uraniferous conglomerates which are known to be detrital in origin. These include zircon, chromite, cassiterite, and garnet. Several others are thought to be detrital based on their textural characteristics. These include some types of pyrite and other sulfides (such as arsenopyrite).

\section{Pyrite}

The majority of geologists in the Witwatersrand and Elliot Lake districts have long believed in the detrital origin of some types of pyrite. This belief was based on many lines of evidence. Pyrite grains are of ten rounded (Figure 42.1) and are distributed through the sediment in layers and along foresets which are also rich in zircon and chromite. More sophisticated observations have supported the contention that some of the pyrite is indeed detrital. For example, Hoefs, Nielsen, and Schidlowski (1968) and Roscoe (1969) showed that Witwatersrand and Matinenda pyrites have a very narrow range of sulfur isotopic compositions $\left(\delta^{34} S\right.$ of $+1 \%$ to $+4 \%$ ) and were probably derived (as detrital grains) from a magmatic pyrite source. Schidlowski (1967a) described a composite detrital grain composed of smaller grains of pyrite, zircon, chromite, rutile, and quartz (Figure 42.2). The composite grain comprises an older Witwatersrand heavy mineral layer that was cemented by pyrite then eroded and transported as a detrital grain. Simpson and Bowles (1977) described a pyrite grain partially enclosed in a detrital quartz grain. The pyrite "displays euhedral grain boundaries towards the host quartz, but has a sub-rounded and abraded margin where it forms the exterior of the composite grain". A cubic zonation is shown by etching of some compact pyrite grains (Coetzee, 1965, Plate Va). The grain figured by Coetzee must have been a detrital pyrite grain since the grain surface truncates the zoning.

Köppel and Saager (1974) noted that the $\mathrm{Pb}$ isotopic composition of Witwatersrand pyrite is similar to that of sulfides from primary gold lodes in Archean greenstone belts. They concluded that the pyrite (and gold) in the Witwatersrand conglomerates were derived from such a source.

The objection to the concept of detrital pyrite grains has largely disappeared due to the evidence quoted above, plus the increasing number of descriptions of detrital pyrite in contemporary streams. Zeschke (1960) and Simpson and Bowles (1977) have described detrital sulfides (including pyrite) in the Indus River and some of its tributaries in Pakistan. Detrital pyrite is known from gravels in Nova Scotia and the Yukon Territory (McLeod, 1959; Gleeson, 1963), and also from streams and beaches of the Atacama Desert (H. Clemmey, persona1 communication, 1980).

The consensus of recent research is that pyrite is stable in fluvial systems under some conditions. The abundance of pyrite in Precambrian paleoplacers 
requires specialized conditions, which would be met by a relatively low atmospheric oxygen content.

Pyrite is by far the most common sulfide in the Witwatersrand and Elliot Lake conglomerates. In the Witwatersrand, pyrite is said to constitute 3 percent of the average conglomerate or about 15 percent of the matrix. It constitutes about 90 percent of the sulfides present (Pretorius, 1976; Feather and Koen, 1975). Elliot Lake conglomerates are even richer in pyrite, containing, on the average, some 15 percent of that sulfide (J.A. Robertson, 1976).

The most detailed research work to date has been done on Witwatersrand pyrite and has resulted in the recognition of three main types of pyrite, namely rounded "compact" pyrite, rounded "concretionary" pyrite (often porous), and "authigenic" pyrite. The first two are believed to be detrital components and are described here.

Compact Pyrite. In the Witwatersrand, compact pyrite (Figure 42.1) occurs in rounded grains 0.5 to $2 \mathrm{~mm}$ in size (Feather and Koen, 1975). The original cubic cleavage is still visible in some grains. Rounded pyrite grains of this type are frequently overgrown by secondary pyrite and assume a euhedral form (Ramdohr, 1958). The original rounded cores may be difficult to distinguish unless the polished surface of the pyrite is etched.

Primary inclusions in compact pyrite include pale-colored, silver-rich gold, pyrrhotite, pentlandite, and chalcopyrite with exsolution discs of mackinawite (Feather and Koen, 1975). According to Simpson and Bowles (1977), the most abundant inclusions in pyrite are exsolution blebs of galena. Köppel and Saager (1974) noted that these inclusions are "essentially the same as in the pyrite of the primary deposits of the . . . greenstone belts". These authors also showed that the $\mathrm{Pb}$-isotopic composition of some compact pyrite is identical to that in some pyrite in gold deposits of Archean greenstone belts. They were of the opinion that Witwatersrand compact pyrite was derived from older pyritic rocks in greenstone belts.

Unfortunately, Hoefs and others (1968) did not distinguish between "compact" and "porous" pyrite in their study of the isotopic composition of Witwatersrand pyrite. They grouped these types together as "detrital" pyrite and showed that they have $\delta^{34} \mathrm{~S}$ values of +2.9 to $+4.0 \%$. They were of the opinion that the narrow isotopic composition range was indicative of a "magmatic" source of pyrite.

Utter (1977) studied the surface textures of compact pyrite grains and found that they are smooth and abraded with oriented lineations. In his samples from the Klerksdorp area, the compact pyrite was found to contain an average of $257 \mathrm{ppm} \mathrm{Au}$, as inclusions 10-80 micrometers in size.

Some of the compact pyrite was probably formed by pyritization of "black sand" constituents of the conglomerate matrix, either before or after their inclusion in the conglomerate in which they now 1le (Ramdohr, 1958; Saager, 1968). Rare remnants of both magnetite and hematite in compact pyrite grains have been documented, while pyritization of banded iron-formation and titaniferous magnetite grains occurred more frequently. The former are indicated by the layering inherited by the pyrite (Figure 42.5). Replacement of titaniferous magnetite is indicated by aligned rutile inclusions, the remants 
of the ilmenite exsolution discs in magnetite or hematite (Figures 42.3 and 42.4). The replacement of these "black sand" phases would explain their anomalous scarcity in the pyritic conglomerates of the Witwatersrand and Elliot Lake districts.

Some authors (Coetzee, 1965; Viljoen, 1968) were of the opinion that pyritization of "black sand" grains was not an important process in the Witwatersrand. Their arguments are based largely on the grain-size distributions of pyrite in conglomerate matrices. They showed that some pyrite grains are in hydraulic equilibrium with undoubted detrital grains (such as chromite and zircon). They concluded that the pyrite grains were deposited as pyrite grains and were not sulfidized in place. However, if sulfidized "black sand" grains were eroded out of previously deposited sediments and transported and deposited as pyrite grains, the objections of these authors are largely overcome.

In summary, compact rounded pyrite grains are probably detrital in origin. Some were derived from pyritic mineral deposits in Archean greenstone belts; others were formed by diagenetic sulfidization of "black sand" grains. Pyrite grains often formed the nuclei about which diagenetic pyrite crystallized to give the euhedral and subhedral pyrite crystals so common in the conglomerates in question.

Concretionary Pyrite. A number of pyrite types are grouped under this heading, including porous concretionary pyrite and pyrite nodules.

In the original work of Saager (1970), "porous rounded pyrite" grains are said to be relatively rare and relatively small (less than $2 \mathrm{~mm}$ in diameter). The pores are filled with pyrrhotite, chalcopyrite, sometimes by pentlandite and galena. Saager was of the opinion that these grains were a variety of the previously described compact pyrite with a far greater number of pores and inclusions. He thought that they were derived from primary sulfide deposits in the Archean basement.

The large (several $\mathrm{mm}$ to a few $\mathrm{cm}$ ), rounded pyrite grains termed "buckshot" pyrite are usually "concretionary pyrite", originally having formed as concretions in the sediment (Saager, 1970). They have rounded outlines and are generally loosely knit and give the impression of having been very delicate at the time of their formation and transportation. They frequently show a "skeletal" type of structure, composed of a very open framework of pyrite crystallites on the order of 10 micrometers in size (Figures 43.1, 43.2, 43.3). In most cases, the voids in the skeletal framework were filled in later to produce more compact varieties.

Saager and Mihalik (1967) showed that some of these concretionary pyrite grains are composed of two intergrown pyrite phases distinguished on the basis of hardness, reflectivity, and anisotropy. The phases differ in their content of $\mathrm{Co}, \mathrm{Ni}$, and As; the anisotropic phase being relatively rich in these elements.

The pores in concretionary pyrite acted as traps for elements transported in solution during diagenesis or metamorphism. Gold and base metal sulfides are commonly found in the pore spaces in the concretionary pyrite. Simpson and 
Figure 42. 1. (top left); Rounded compact pyrite grains, some of which have suffered pressure point solution and crushing, Basal Reef, Loraine Gold Mines, Welkom Goldfield (170x, from Schidlowski and Trurnit, 1966).

2. (top right): Major part of a spherical composite grain composed largely of rounded compact pyrite cemented by secondary pyrite, Elsburg A-1 Reef, Loraine Gold Mines, Welkom Goldfield (from Schidlowski, 1967a).

3. (center left): Rounded pyrite grain, pseudomorphous after titaniferous magnetite. Exsolution lamellae of ilmenite show triangular grid pattern and are now composed of rutile (dark gray). The magnetite part of the original grain is totally pyritized; Basal Reef, Welkom Goldfield (310x, from Saager, 1970).

4. (center right): Pseudomorph after a hematite-ilmenite grain; now composed of pyrite (white) and rutile (dark gray), "basal conglomerate", East Rand area (106x, from Ramdohr, 1958).

5. (lower left): Pyrite pseudomorph after a colloform limonite grain, showing delicate rhythmic layering, Black Reef, East Rand area (106x, from Ramdohr, 1958). Saager (1970, Plate II, Figure 11) interpreted similar grains as having been derived by sulfidization of banded iron-formation.

6. (lower right): Rounded pisolith of pyrite, Ventersdorp Contact Reef, Venterspost Mine, Carletonville area (33x, from Schweigart and Von Rahden, 1964). Ramdohr (1958) interpreted similar pisolites to be the sulfidized remains of concentrically layered iron oxide grains. 

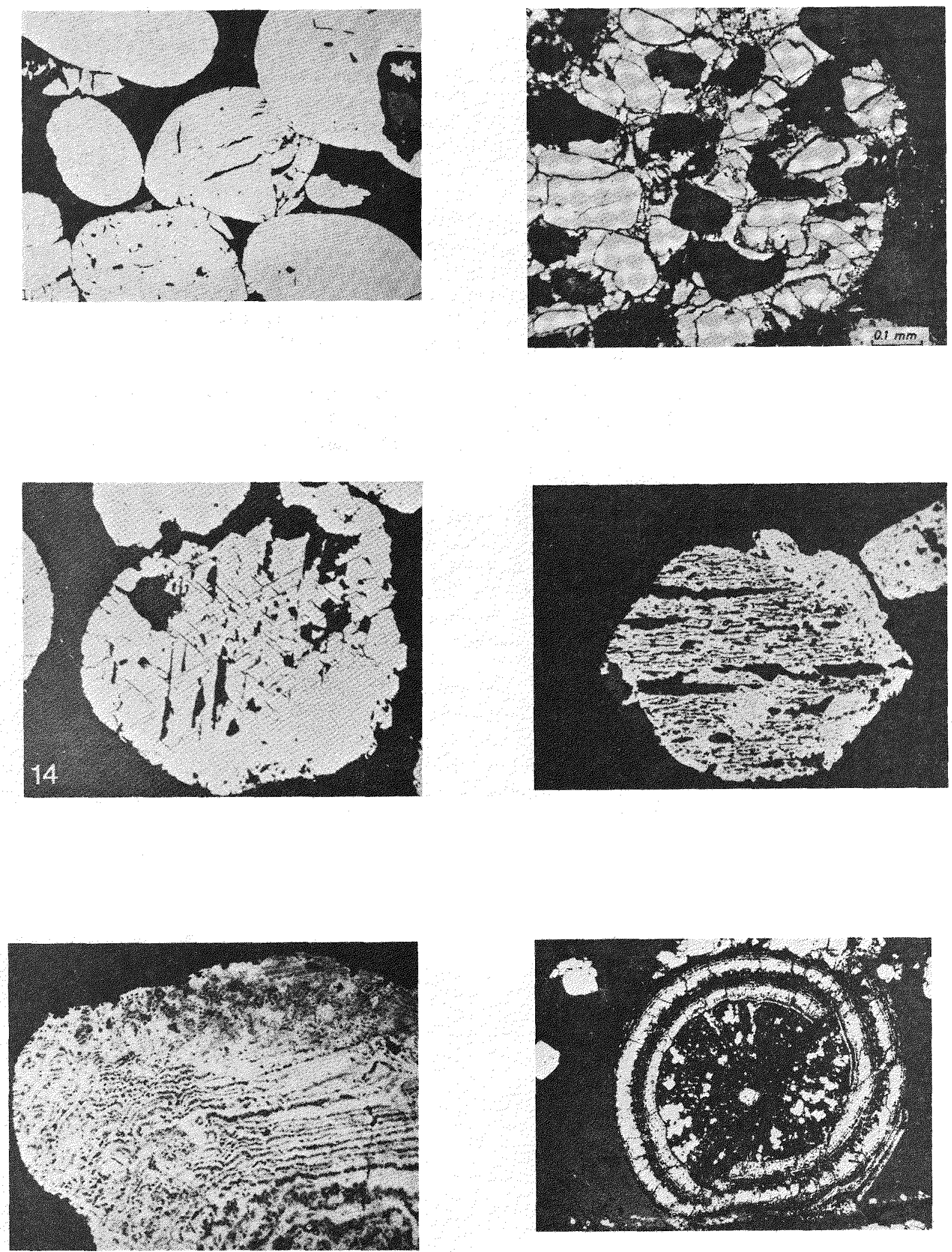
Figure 43: 1\&2: (top left and right): "Porous" concretionary pyrite, etched with nitric acid in right hand diagram, Basal Reef, Welkom Goldfield (44x, from Saager, 1970).

3. (center left): Part of a "porous" concretionary pyrite grain composed of pyrite crystallites, preferentially pyrite-cemented near outer margin (top in photomicrograph) of grain, Kimberley Reef, East Rand area (182x, from Ramdohr, 1958).

4. (center right): Part of a pyrite grain showing microspherical structures likened to "mineralized bacteria", Elsburg A-1 Reef, Loraine Gold Mines, Welkom Goldfield (630x, Schidlowski, 1966b).

5. (lower left): Scanning electron photomicrograph of a pyrite "mudball", showing indentation (top) and cracks (side) due to compaction by a neighboring clast while still in a plastic state, Elsburg Reef, Loraine Gold Mines, Welkom area (from Hallbauer and Utter, 1976).

6. (lower right): Detrital chromite grain with reflective margin (iron-rich, depleted in $\mathrm{Al}$ and $\mathrm{Mg}$ ), cut by pyritefilled fractures, Basal Reef, Welkom area (no magnification specified; from Saager, 1970). 

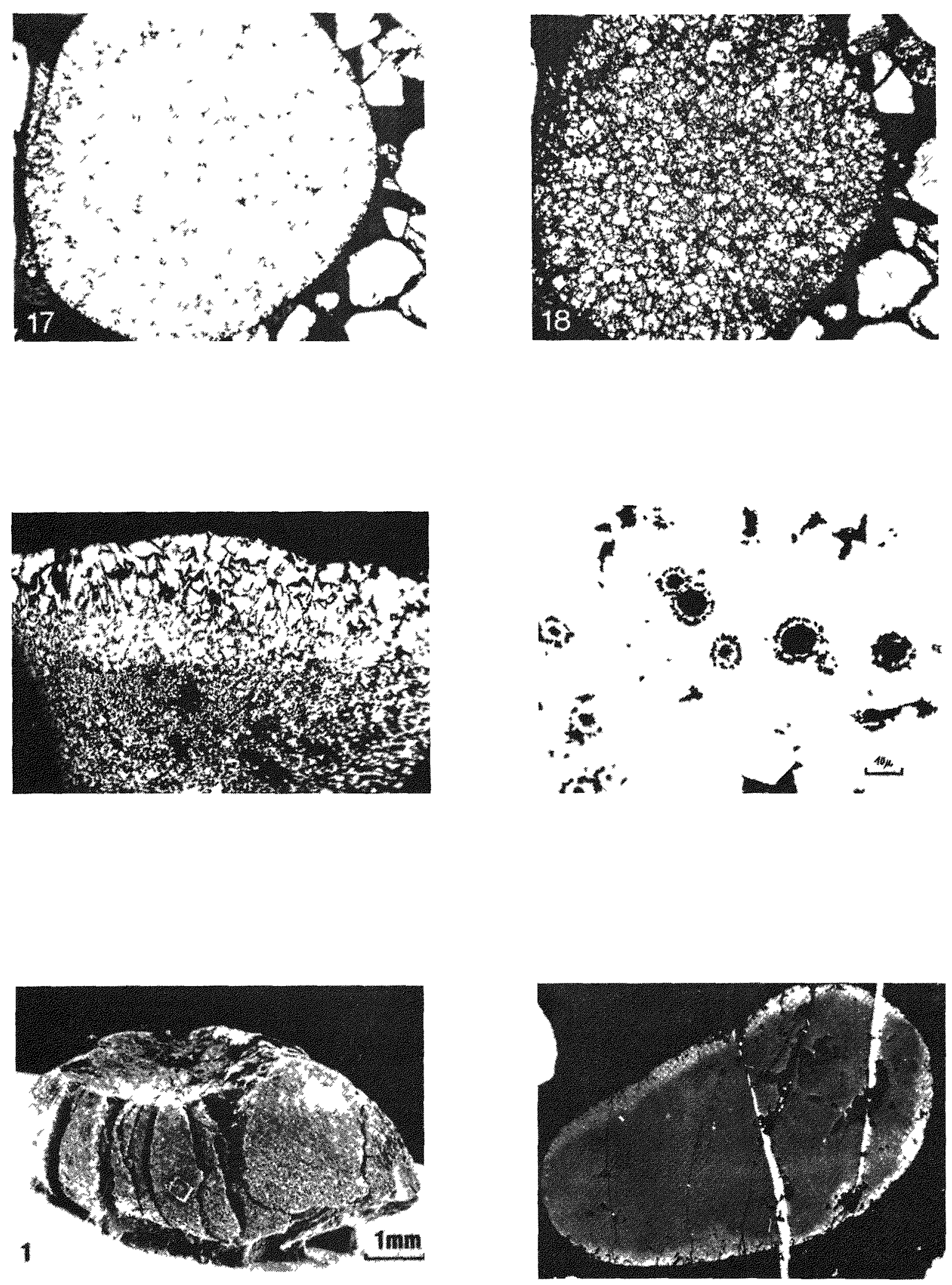
Bowles (1977) noted that the pore spaces (which usually make up about 10 percent of the grains) also contain quartz and a 7-angstrom clay mineral. They believe that pore-filling preceded transportation, and that the porous pyrite grains may have been well able to withstand transport. Steyn (1977) noted that some such pyrite grains contain up to $200 \mathrm{ppm}$ gold.

Utter (1977) studied surface textures and trace element contents of various pyrite types, including porous concretionary types. The porous types have dull porous surfaces and are composed of "cryptocrystalline pyrite-particles". They contain inclusions (2-8 micrometers in size) of quartz, "brannerite", galena, and titanium- and copper-bearing minerals. In addition, they carry inclusions of gold (up to 5 micrometers in size) and contain, on the average, $245 \mathrm{ppm}$ of this element.

The surface textures of porous pyrites, as revealed by scanning electron microscopy, indicate that they were formed as plastic, possibly gel-like bodies. These textures include indentation and cracking due to deformation by loading during sedimentation (Figure 43.5) and polygonal cracking on the surfaces of the concretions. The latter resemble synaeresis cracks developed on the surfaces of bodies composed of a dehydrated gel or pyritic mud. A gel origin for porous pyrite had been previously proposed by Saager (1970) and is supported by the work of Utter (1977).

A third type of porous pyrite contains microspherical structures, usually 10 to 15 microns in diameter (Figure 43.4). Both Ramdohr (1958) and Saager (1970) noted that some of the microspherical forms could represent "mineralized bacteria". However, identical microspherical structures are present in pyrite from undoubted hydrothermal deposits (Saager, 1970). Furthermore, sulfur isotopic studies of Witwatersrand pyrite indicate no significant isotopic fractionation, which is evidence against a biologic sulfate reduction origin of the $S$ in the pyrite.

Finally, Ramdohr (1958) and Schweigart and Von Rahden (1964) described pyrite grains with oölitic textures (Figure 42.6). These pyrite types are particularly common in the conglomerates of the Ventersdorp Contact Reef and Black Reef. Ramdohr was of the opinion that they represented limonitic oölites which had been pyritized before deposition in the conglomerate matrix.

Dimroth (1979) published the results of a study of the macroscopic features of relatively large pyrite bodies in Witwatersrand sediments. He recognized nine textural types, some of them showing radial and concentric structures reminiscent of marcasite nodules formed diagenetically in sediments. He was of the opinion that six of the textural types recognized were formed diagenetically within the sediments by bacterial reduction of sulfate ions. The remaining types represent the eroded and redeposited clasts derived from pre-existing diagenetic bodies. Some geologists working on the Witwatersrand are critical of Dimroth's conclusions. They point to the concentration of many kinds of pyrite, with chromite and zircon along cross-bed foresets, as indicating a detrital (rather than diagenetic) origin (W.E.L. Minter, written communication, 1980). 
In summary, concretionary pyrite comprises many different pyrite subtypes that have in common a rounded form and a porous, open structure. There is evidence that these pyrite grains were formed within the basin, possibly as pyritic muds and gels. After their formation, they were eroded and transported short distances before being deposited along with other heavy minerals. Loading of the plastic pyrite clasts caused bending and cracking, while dehydration of the gel-like material resulted in polygonal surface cracks.

Chemistry of Pyrite. Several authors have attempted to determine the origin of pyrite grains through geochemical studies. Roscoe (1969) presented a table in which the $\mathrm{Se}, \mathrm{Ti}, \mathrm{Co}$, and $\mathrm{Ni}$ contents of Matinenda Formation pyrites are given. He showed that pyrite grains from different types of conglomerate (ore conglomerate, less radioactive conglomerate, and conglomerate interbedded in volcanic rocks) are geochemically different. Roscoe concluded that some pyrite grains were detrital while others were formed diagenetically within the conglomerate.

Kimberley and others (in press) have analysed selected elements in pyrite concentrates from samples of uraniferous conglomerate. The elements determined are $\mathrm{U}, \mathrm{La}, \mathrm{Ti}, \mathrm{Co}, \mathrm{Ni}$, and Se (Table 16).

Table 16. Composition of pyrite concentrates from the Elliot Lake and Agnew Lake uraniferous conglomerates (after Kimberley and others, in press).

\begin{tabular}{lccc} 
& Average (ppm) & \multicolumn{2}{c}{ Range (ppm) } \\
\cline { 2 - 3 } $\mathrm{U}$ & 13.7 & $1.2-46.6$ \\
$\mathrm{La}$ & 56.6 & $0 *-158$ \\
$\mathrm{Ti}$ & 2363 & $39-9050$ \\
$\mathrm{Co}$ & 668 & $226-1275$ \\
$\mathrm{Ni}$ & 47 & $0 *-200$ \\
$\mathrm{Se}$ & 36.2 & $14.2-57.3$
\end{tabular}

*Not detected in significant amounts.

$\mathrm{U}$, La, and $\mathrm{Ti}$ were considered to be minor contaminants in the pyrite concentrates. U correlates strongly with La (correlation coefficient of 0.90 ) and moderately strongly with $\mathrm{Ti}(0.59)$ but shows no significant correlation with $\mathrm{Co}, \mathrm{Ni}$, or Se. Kimberley and his co-workers were of the opinion that the Co, $\mathrm{Ni}$, and $\mathrm{Se}$ were indigenous to the pyrite.

They attempted to draw conclusions regarding the origin of the pyrite based on $\mathrm{Se}$, Co, and $\mathrm{Ni}$ concentrations. The S/Se ratio was found to lie at the boundary between the ratios usually associated with magmatic and sedimentary pyrites. The Co/Ni ratios range from 5.6 to 47.8 . Kimberley and others (in press) noted that such ratios were consistent with "a volcanic origin for most of the pyrite". Their analyses of concentrates, rather than of individual grains, were a severe hindrance to the interpretation of results. Roscoe (1969) has stressed the textural variations in the types of pyrite in 
Matinenda conglomerates. The pyrite concentrates analysed by Kimberley and co-workers are mixtures of varying types of pyrite, some probably detrital in origin, others undoubtedly diagenetic.

In a similar study of Witwatersrand pyrite, Saager (1976) avoided this difficulty by analysing specific textural types of pyrite. He compared the analyses with pyrite contained in gold deposits in Archean greenstone belts of the Kaapvaal Craton. He showed statistically that, with respect to the trace elements analysed ( $\mathrm{Co}, \mathrm{Ni}, \mathrm{Cu}, \mathrm{Zn}, \mathrm{Pb}$, and $\mathrm{Ag}$ ), compact detrital pyrite grains (allogenic pyrite) belong to the same population as pyrite contained in Archean gold deposits. The concretionary, porous pyrites formed within the Witwatersrand Basin (authigenic pyrite) are geochemically distinct from both the previously mentioned types, being characterized by "remarkably homogeneous trace-element values and conspicuously high $\mathrm{Pb}-, \mathrm{Ni}-$ and $\mathrm{Co}-$ contents" (see Table 17). This geochemical study supports the results of a previous investigation into the $\mathrm{Pb}$-isotopic composition of pyrite in greenstone belts and in the Witwatersrand (Köppel and Saager, 1974), which showed that the source of compact detrital pyrite grains was probably sulfidic deposits in greenstone belts.

Summary. The detrital pyrite in uraniferous conglomerates was formed in several different ways. Some grains were almost certainly derived from preexisting sulfidic veins or stockworks in the Archean basement, most likely in Archean greenstone belts. A second major class was formed by various processes within the basin. These pyrite types were probably formed diagenetically within sediments and were subsequently exhumed, transported and abraded, and finally deposited as detrital grains. Several mechanisms of diagenetic pyrite production are suggested by textural variation in grains. Some were almost certainly produced by diagenetic sulfidization of hematite, magnetite, and iron-formation clasts. Others are thought to have formed as concretions and nodules. Such types are characterized by a variety of textures including radial and concentric structure (suggestive of a marcasite precursor), microspherical structure (1ikened to mineralized bacteria by many investigators), and a skeletal structure (characterized by pyrite crystallites in an open, porous arrangement). The most logical explanation for the origin of such pyrite types is that they formed by bacterial sulfate reduction within unconsolidated sediments. This origin is not, however, supported by sulfur isotopic studies since all pyrite types have a "magmatic" sulfur isotopic pattern.

\section{Pyrrhotite}

Allogenic pyrrhotite is a minor phase in many compact pyrite grains (Ramdohr, 1958). It occurs as "roundish inclusions", sometimes along with inclusions of chalcopyrite, sphalerite, and cubanite. Some allogenic pyrrhotite also occurs as inclusions in quartz grains.

Secondary pyrrhotite is far more common than allogenic pyrrhotite and will be discussed, along with the secondary sulfides, in a subsequent section. 
Table 17. Grouped results of trace element analyses (after Saager, 1976). $\bar{x}=$ mean; s = standard deviation; $C=$ coefficient of variation.

Co

$\mathrm{Ni}$

Group 1: 8 samples

Authigenic Witwatersrand Pyrite

$\begin{array}{lrrrrrr}\overline{\mathrm{x}}(\mathrm{ppm}) & 1301 & 1347 & 251 & 56 & 963 & \text { range } \\ \mathrm{s}(\mathrm{ppm}) & 932 & 490 & 109 & 30 & 1029 & 0-390 \mathrm{ppm} \\ \mathrm{C} & 0.71 & 0.36 & 0.43 & 0.54 & 1.07\end{array}$

$\stackrel{⿱}{\omega} \quad$ Group 2: 5 samples

Allogenic Witwatersrand Pyrite

$\begin{array}{lrrrrrr}\overline{\mathrm{x}}(\mathrm{ppm}) & 216 & 450 & 118 & 64 & 135 & \text { range } \\ \mathrm{s}(\mathrm{ppm}) & 88 & 112 & 63 & 21 & 69 & 0-10 \mathrm{ppm} \\ \mathrm{C} & 0.41 & 0.25 & 0.53 & 0.31 & 0.51\end{array}$

Group 3: 44 samples

Greenstone Belt Pyrite

$\begin{array}{lrrrrrr}\overline{\mathrm{x}}(\mathrm{ppm}) & 198 & 514 & 341 & 151 & 123 & \text { range } \\ \mathrm{s}(\mathrm{ppm}) & 195 & 532 & 456 & 379 & 73 & 0-380 \mathrm{ppm} \\ \mathrm{C} & 0.98 & 1.04 & 1.13 & 2.51 & 0.59\end{array}$




\section{Marcasite}

Small inclusions of marcasite are known from pyrite grains in the Dominion Reef Group (Hiemstra, 1968a). Marcasite is also developed as a secondary sulfide.

Chromite

Chromite is a minor (but very widely distributed) detrital heavy mineral in Witwatersrand conglomerates and arenites. It is also commonly developed in other uraniferous pebble conglomerate districts, for example, the Jacobina of Brazil (Gross, 1968) and the conglomerates of the Nemo district, South Dakota (Kim, 1979; Redden, 1980).

Chromite grains are rounded to varying degrees. They are commonly fractured, the fractures being filled with sericite, chlorite, or pyrite. Chromite grains are commonly zoned. Hiemstra (1968a) noted magnetite rims on some chromite grains from the Dominion Reef conglomerates. Mihalik and Saager (1968) described chromite grains with relatively high1y reflective rims from the Basal Reef of the Welkom Goldfield (Figure 43.6). Their research showed that the rims were enriched in $\mathrm{Fe}$ and $\mathrm{Cr}$ and depleted in $\mathrm{Al}$ and $\mathrm{Mg}$. They suggested that the rims were formed diagenetically, the alteration being promoted by radioactive bombardment and partial destruction of the chromite crystal structure. These authors also noted a wide range in composition in the unaltered cores of chromite grains. Ramdohr (1958) suggested that some of the chromites are actually chrome spinels.

Ramdohr also recorded more reflective margins on chromite grains and stated that such rims have been seen in primary chromitite deposits.

Reaction between detrital chromite grains and sericitic mica has produced the fuchsite so commonly associated with auriferous-uraniferous conglomerates. This reaction has been observed in the Witwatersrand (Button, 1968) and in the uraniferous conglomerates of the Black Hills, South Dakota (Kim, 1979; Redden, 1980).

\section{Zircon}

Zircon is almost always present in uraniferous conglomerates (Feather and Koen, 1975; Roscoe, 1969). Grains vary from well-rounded to prismatic. They are often zoned. Common colors include pink, purple, and colorless. Despite their well-known resistance to alteration, zircon grains in the conglomerates are altered to varying degrees. They are frequently enlarged by zircon overgrowths. In a study of zircons from the Dominion Reef conglomerates, Hendricks (1964) showed that the median grain size of zircon in some samples was reduced by 76 percent by a combination of solution and replacement effects. This author was of the opinion that the most altered zircons contained the highest concentrations of radioactive elements and that zircon breakdown was due to radiation damage to the crystal structure (metamictization). Evidence of radioactive decay in the zircons is provided by minute specks of radiogenic galena. 
A hydrated alteration product of zircon, known as cyrtolite, has been described from a sample of uraniferous conglomerate from the Nemo area of the Black Hills, South Dakota (Kim, 1979).

Despite modification of zircon sizes by these processes, many researchers believe that careful measurement of zircon grain sizes yields valid information on hydraulic parameters. This aspect of zircon study is dealt with in a subsequent section of this report.

\section{Arsenopyrite}

Arsenopyrite is a relatively common detrital sulfide in Witwatersrand conglomerates (Ramdohr, 1958; Viljoen, 1967). The grains are variable in composition; some exhibit the mimetic twin lamellae and weak anisotropism of the monoclinic variety known as danaite. Feather and Duggan (1974) (quoted in Feather and Koen, 1975) found no more than 3 percent Co and/or Ni in over 50 arsenopyrite grains analysed.

In contrast to pyrite grains, arsenopyrite grains are only rarely overgrown to form idiomorphic grains (Ramdohr, 1958; Viljoen, 1967). The 1atter author noted that some wel1-developed rhombohedra of arsenopyrite are developed in quartz pebbles.

Researchers on Witwatersrand mineralogy are unanimous that the arsenopyrite is a detrital component of the ore. Support for their conclusion comes from the observation of apparently unaltered detrital arsenopyrite in heavy mineral concentrates from the Indus River in Pakistan (Zeschke, 1960). In addition, Coetzee (1965) noted that arsenopyrite grains are probably in hydraulic equilibrium with other minerals in the conglomerate matrix. The probable sources for the Witwatersrand arsenopyrite are Archean greenstone belts, which commonly contain arsenopyrite-bearing vein systems (Viljoen, 1967).

\section{$\underline{\text { Garnet }}$}

Garnet is rarely developed as a detrital mineral in Witwatersrand conglomerates (Ramdohr, 1958). It has been observed as a detrital component in the Dominion Reef where it is cracked and chloritized along grain boundaries and fractures (Hiemstra, 1968a). Two types of garnet are developed, a bright yellow type (60 percent almandite, 40 percent andradite) and a rose-colored type (76 percent almandite, 20 percent pyrope, 4 percent grossularite).

Diamond

Several hundred small diamonds were recovered in the early days of Witwatersrand mining when the weathered conglomerates were being worked (Feather and Koen, 1975). Most of the diamonds weighed less than 1 carat, although at least one stone weighed 8 carats. The stones were colored various shades of green, presumably due to radiation damage. Diamonds are no longer recovered from Witwatersrand conglomerates since the ore is very finely milled before the gold and uranium are extracted. 
Allogenic grains of apatite occur rarely in the matrices of Witwatersrand and Matinenda conglomerates (Viljoen, 1967; J.A. Robertson, 1976). The grains are often fractured, the openings being filled with phyllosilicates and some sulfides.

\section{Ilmenite}

Ilmenite is rarely preserved in Witwatersrand and Matinenda conglomerates. According to Ramdohr (1958), ilmenite is "in most cases so decomposed that the remaining rutile skeletons are Fe-free". This author and Saager (1970) published several photomicrographs of sulfidized grains originally composed of hematite with exsolved ilmenite lamellae. The hematite is now composed of pyrite, the ilmenite lamellae of rutile (Figure 42.4).

Liebenberg (1955) recorded some detrital grains of ilmenite in the Dominion Reef conglomerate, while Hiemstra (1968a) noted that ilmenite in this conglomerate was also formed by recrystallization of pre-existing leucoxene.

\section{Magnetite}

Like ilmenite, magnetite is very rarely preserved in the Elliot Lake and Witwatersrand conglomerates. Ramdohr (1958) photographed a grain of magnetite enclosed by a thin rim of pyrrhotite in a pyrite grain. Jacob (1966; quoted in Feather and Koen, 1975) recorded a single grain of magnetite in the Vaal Reef. Saager (1970) figures a small magnetite remnant in a compact pyrite grain.

The former presence of titaniferous magnetite can be inferred from two types of pseudomorphs presently seen in Witwatersrand conglomerates. In one kind, the magnetite fraction is completely pyritized, the exsolution lamellae of ilmenite being preserved as rutile. The rutile in the pyrite occurs as lamellae oriented along what were octahedral parting planes in the original magnetite (Figure 42.3). The second type is composed of a rutile skeleton from which all the iron has been leached (Ramdohr, 1958). Again, the rutile often occurs in lamellae pseudomorphous after the original octahedral parting in the titaniferous magnetite predecessor (Figure 68.1).

Kimberley and others (in press) undertook a study of the magnetic-mineral content of uraniferous conglomerates and associated rocks from the Matinenda Formation. The abundance of each magnetic mineral was estimated from the decrease in magnetic susceptibility upon heating above the Curie point for that mineral. They found that the average magnetite content of conglomerate samples was 0.006 percent. The associated rocks (non-uraniferous conglomerate, arkose, granite, and granitic paleosol) contained somewhat greater proportions of magnetite.

\section{Hematite}

Hematite is an extremely rare component of Precambrian uraniferous conglomerates. Saager (1968) recognized hematite in only one instance. It occurs intergrown with magnetite in a rounded pyrite grain. Saager was of the 
opinion that the extreme rarity of pure hematite and magnetite is due to the thorough sulfidization of these components. It is only where the original hematite contained exsolved laths of ilmenite that its former presence can be confidently inferred by the preservation of rutile laths in pyrite (Figure 42.4 , Ramdohr, 1958; Saager, 1970).

\section{Cobaltite}

Ramdohr (1958) recorded a single rounded grain of cobaltite in an arsenopyriterich sample. Viljoen (1967) noted several rounded, spherical grains of cobaltite. Some had undergone relatively little rounding, so that the original cubic crystal outlines are preserved. Cobaltite also occurs as inclusions within some quartz pebbles.

Viljoen noted that cobaltite was also present as a diagenetic phase, presumably having been mobilized by, and deposited from, pore fluids in the sediment. Some of this cobaltite is porous and contains abundant gold in the pore spaces.

\section{Molybdenite}

Saager (1968) identified molybdentte in three polished sections from the Basal Reef of the Welkom Goldfield. It occurs as idlomorphic flakes in compact, rounded pyrite grains. A few rounded aggregates of molybdenite, presumably of detrital origin, have been found in conglomerates of the auriferous and weakly uraniferous Uitkyk Formation in South Africa (Saager and Muff, 1978).

\section{Dyscrasite}

Saager (1968) found a few inclusions of dyscrasite in detrital cobaltite and pyrite grains. The dyscrasite inclusions are assoclated with pyrrhotite and chalcopyrite inclusions.

\section{Tourmaline}

Viljoen (1967). noted a few water-worn grains of schorlite tourmaline in Witwatersrand conglomerates. Some of these are overgrown by diagenetic tourmaline. This mineral also occurs in some quartz grains and pebbles.

$\underline{\text { Rutile }}$

Ramdohr (1958) recognized a few grains of detrital rutile in Witwatersrand conglomerates. According to this author, detrital rutile is "fairly coarse, roughly corresponding in size to the chromites, and is always very markedly twin-laminated . . . "

Spine1

Ramdohr (1958) identified spinel grains in polished section by their "olive brown internal reflections" and weaker reflectivity compared to chromite and chrome spinel. 
Ramdohr (1958) mentioned the presence of detrital grains of kyanite and corundum in Witwatersrand conglomerates. Hiemstra (1968a) noted a few rounded, presumably detrital, grains of cassiterite and sphene in the Dominion Reef conglomerates. Hallbauer and Utter (1976) claim to have seen detrital grains of gersdorffite, chalcopyrite, and of a gold-gersdorffite intergrowth.

Go1d

Despite its economic importance, gold is a very minor component of Witwatersrand conglomerates. It is present in amounts varying from less than $1 \mathrm{ppm}$ to a few hundred ppm. On account of its economic importance, the gold fraction of the conglomerates has been intensely studied. Since emphasis is placed on the uranium content of the conglomerates in this report, the characteristics of gold distribution are described briefly.

Feather and Koen (1975) reviewed the subject thorough1y in their paper on the mineralogy of Witwatersrand conglomerates. Although it is widely held that the gold was originally a detrital component of the conglomerate, all researchers agree that the metal has been redistributed to varying degrees during diagenesis and low-grade metamorphism. For the sake of simplicity, gold is discussed here under the heading of detrital minerals.

Minor amounts of gold are found in quartz veins and dykes where they cut mineralized conglomerates. The metal is also found in banded pyritic quartzites, and sometimes on a shale "footwall" where such a horizon marks a pebble-free disconformity or unconformity (Pretorius, 1976). Notwithstanding these modes of occurrence, by far the greatest part of the gold has been won from the matrix fraction of conglomerates, which range from we11-packed to matrix-supported, and in some instances to quartzites with pebble concentrations on scour surfaces (Minter, 1978).

The grain size of gold has been established by hydrofluoric acid digestion of conglomerate samples followed by direct measurement of gold grains (Hallbauer and Joughin, 1973). No gold grains were found to exceed $2.4 \mathrm{~mm}$ in size. The majority of the grains are between 0.005 and $0.5 \mathrm{~mm}$ in size. These authors found that the shapes of gold particles varied with their size (plate-like shapes predominate in the smaller size-grades) and with their mineralogical association ( $p$ late-1ike, euhedral, spongy, or porous when associated with quartz and phyllosilicates; micronuggets and fibrous when associated with carbon).

Minter (1979) undertook a settling velocity experiment on gold and pyrite grains extracted from a we11-mineralized sample of Carbon Leader conglomerate (Carletonville Goldfield). He found that, despite the disparity in their grain sizes, the gold and pyrite are in hydraulic equilibrium. He concluded that these minerals were transported along with matrix quartz grains in the traction load of the paleostream responsible for Carbon Leader deposition. 
Some of the gold in conglomerates is thought to be "primary", that is essentially unaltered since its deposition. Such gold includes nugget-like particles in the conglomerates, as well as inclusions in detrital grains of compact pyrite. Hallbauer and Utter (1976) present several scanning electron photomicrographs of Witwatersrand gold particles, supposedly of this type. They recognized particles that had been transported only short distances by randomly oriented surface scratches and plastic deformation of protruding parts of the micronuggets. Grains of gold that had been transported for greater distances are "flattened and completely deformed". Based on this study, Hallbauer and Utter were of the opinion that much of the gold was transported for relatively short distances, on the order of 10 to $30 \mathrm{~km}$. Their results are questioned since they do not take into account the possible effects of grain modification due to compaction and mechanical deformation of the conglomerates.

The major part of the gold in the Witwatersrand is "secondary", having been subjected to dissolution and reprecipitation almost in situ. The mobilization of the gold is usually attributed to "metamorphism". The possible role of diagenetic pore fluids is usually not considered.

Secondary or redistributed gold occurs in association with many different phases of the conglomerate. Much of it occurs in association with (sometimes replacing) fine-grained matrix constituents, particularly phyllosilicates. Gold fills fractures in minerals such as pyrite, uraninite, zircon, chromite, arsenopyrite, cobaltite, monazite, tourmaline, iridosmine, and other minerals. Secondary gold replaces and fills pore spaces in pyrite of the concretionary type (Utter, 1977). Gold is frequently associated with, and sometimes replaces, secondary sulfides and arsenosulfides. This association is particularly common with pyrrhotite. Finally, the association of gold with carbonaceous matter has been stressed by many researchers. Carbon concentrates contain up to 3,000 ppm gold (Liebenberg, 1955). Hallbauer (1975) has published several photomicrographs showing that gold occurs both as a fibrous network within carbon and as "micronuggets" between carbon columns.

The presumed placer origin of gold in Witwatersrand conglomerates led several authors to try to establish a relationship between the silver content of the conglomerate (and of gold particles) and distance of sedimentary transport (as inferred from the established paleogeography in individual goldfields).

Several analyses of individual gold particles have been undertaken using electron microprobe techniques. The results of these studies are summarized by Feather and Koen (1975). Saager (1969) found that the silver content of individual gold particles (from the Basal Reef, Welkom Goldfield) varies from 6.53 to 9.37 percent. Schidlowski (1968) found that this parameter varies from 9.9 to 12.4 percent for samples in the Welkom Goldfield. Viljoen (1971; quoted by Feather and Koen, 1975) determined a range of 0.3 to 32.1 percent silver and noted a considerable range within individual particles. In particular, he found that many grains had silver-enriched peripheries.

Several other metals are present in Witwatersrand gold, including $F e$, and trace amounts of $\mathrm{Cu}, \mathrm{Mo}, \mathrm{Co}, \mathrm{Bi}, \mathrm{Pb}, \mathrm{Sn}, \mathrm{As}, \mathrm{Hg}, \mathrm{Ta}, \mathrm{V}, \mathrm{Ni}, \mathrm{Mn}, \mathrm{Sb}$, and $\mathrm{Te}$ (Feather and Koen, 1975). Numerous attempts have been made to correlate the gold concentration of Witwatersrand conglomerates with geochemical parameters (for 
example, with uranium concentration) and with mineralogical parameters (for example, with pyrite concentration or with zircon median grain size). The results of these attempts are given in the section dealing with the geochemistry of the uraniferous conglomerates.

\section{Platinoids}

Platinoid grains are a very minor component of most Witwatersrand conglomerates but have been recovered commercially as byproducts in most of the mines. The gold to platinoid group elements (P.G.E) ratio varies from 8,000 to 100 (Feather and Koen, 1975). Most investigators believe that the platinoid minerals are detrital but have undergone alteration and, in cases, remobilization.

Cousins (1973) noted that Witwatersrand platinoids tend to be enriched in Os and $\mathrm{Ir}$ relative to $\mathrm{Ru}, \mathrm{Pt}, \mathrm{Rh}$, and $\mathrm{Pd}$. Since the latter group are relatively soluble, Cousins concluded that the Witwatersrand platinoids were very mature, having suffered prolonged transportation and intense leaching. The essential elements in Witwatersrand P.G.E. mineral assemblages are a1loys of Os, Ir, and $\mathrm{Ru}$. Grains are often zoned, for example, Os-rich cores are surrounded by Ir-rich alloy with exsolution lamellae of Pt-Fe alloy. Secondary coatings of P.G.E. sulfides and arsenides on detrital platinoid grains are fairly common.

\section{Non-Detrital (Authigenic) Constituents}

Uraniferous conglomerates contain a significant number of non-detrital ore minerals. It has already been shown that much of the gold in witwatersrand conglomerates occurs with a non-detrital habit interpreted to be the result of post-depositional remobilization of gold. Several uranium-bearing phases are also non-detrital and will be described under the section dealing with uraniferous minerals.

\section{$\underline{\text { Authigenic Pyrite }}$}

A11 mineralogical accounts of Witwatersrand ores recognize an authigenic pyrite phase deposited after burial of the conglomerates. These grains tend to be idiomorphic or hypidiomorphic and show cubic outlines. They vary from porous to compact, and in size from $10 \mathrm{microns}$ to $2 \mathrm{~mm}$. Ramdohr (1958) termed this phase "hydrothermal pyrite". In some cases, the pyrite is demonstrably magmatic hydrothermal (being developed adjacent to intrusive dykes and sills, for example). In most cases, the pyrites are believed to have formed under metamorphic hydrothermal conditions which affected the basin as a whole (Saager, 1970).

Saager (1970) stated that authigenic pyrites are relatively free of inclusions of both gold and base metal sulfides. However, Simpson and Bowles (1977) noted abundant gold inclusions in some euhedral pyrite grains. Utter (1977) found that, in the Klerksdorp Goldfield, this type of pyrite contains an average of $166 \mathrm{ppm} \mathrm{Au}$. 
Idiomorphic pyrite is particularly abundant near intrusive dykes in the Witwatersrand (Saager, 1970) and is of ten associated with, and partially replaced by, galena, chalcopyrite, sphalerite, and other base metal sulfides.

Encrustations or overgrowths of pyrite on older pyrite grains are common in uraniferous Precambrian conglomerates. The encrustations are either compact or porous and are thought to have been deposited from heated pore fluids during the diagenetic or low-grade metamorphic events which followed deposition of the conglomerates.

Some pyrite has been formed in veinlets and fractures. These vein-fillings were probably also formed from pyrite precipitated from interstitial fluids during diagenesis or low-grade metamorphism.

Hoefs and others (1968) showed that sulfur in "recrystallized" pyrite in the Witwatersrand is between 1 and $2 \%$ lighter than that in detrital pyrite. The fractionation was explained as due to "preferential mobilization of the lighter sulfur isotope during the recrystallization process".

The pyrite types described above are all believed to have formed under advanced diagenetic or low-grade metamorphic conditions. There is a second important type of non-detrital pyrite in uraniferous conglomerates which appears to have formed within a sedimentary host under very early diagenetic conditions (Dimroth, 1979). Such pyrites usually occur as concretions or nodules within a sedimentary host. They frequently show concentric and radial structures suggestive of derivation from marcasite. It is this kind of pyrite that is believed to have been the source of the "concretionary" detrital pyrite grains which are so abundantly developed in many uraniferous conglomerates.

Strictly speaking, pyritized magnetite, ilmenite, and hematite grains should also be regarded as non-detrital types, though they can be exhumed after pyritization and be transported as heavy mineral grains. Pyritization most probably occurred under the influence of sulfidic reducing paleo-ground water.

\section{Pyrrhotite}

Non-detrital pyrrhotite is developed sporadically in uraniferous conglomerates, particularly near intrusives (Feather and Koen, 1975). The pyrrhotite was probably derived by desulfurization of pre-existing pyrite. Ramdohr (1958) suggested that the large inner surface area of porous pyrite would make it particularly susceptible to pyrrhotitization.

Textural studies have revealed several generations of pyrrhotite, which are generally late in the paragenetic sequence, being closely associated with the period in which gold was mobilized. In pyrrhotite-rich areas, gold tends to be locked in this sulfide (Feather and Koen, 1975).

Pyrrhotite tends to be xenomorphic. It contains exsolution lamellae of pentlandite in some cases. Pyrrhotite is either monoclinic or hexagonal, which suggests a fairly high temperature of pyrrhotitization (Ramdohr, 1958). It tends to be associated with other late sulfides and arsenosulfides, including galena, sphalerite, cubanite, and gersdorffite. Pyrrhotite frequently 
envelops and partially replaces pre-existing minerals, including pyrite and uraninite.

$\underline{\text { Galena }}$

This mineral occurs in several different ways. It is frequently associated with secondary sulfides (for example, intergrown with gersdorffite, Feather and Koen, 1975). Galena also occurs as inclusions in detrital pyrite grains.

A very characteristic occurrence of galena is in association with radioactive phases. This galena is thought to be radiogenic in origin. It occurs in association with uraninite, brannerite, and uranothorite, in veinlets, small inclusions, and cracks.

Galena veins are found crosscutting conglomerate reefs, often in the vicinity of basic dykes. The lead in such galena is believed to have been derived by mobilization of radiogenic lead (Roscoe, 1969).

\section{Cobaltite and Gersdorffite}

While detrital Co-Ni arsenosulfides are mainly cobaltite (Co $>\mathrm{Ni}$ ), authigenic phases are mainly gersdorffite ( $\mathrm{Ni}>\mathrm{Co}$ ). The latter are usually associated with other authigenic components of Witwatersrand reefs (Feather and Koen, 1975). Gersdorffite is intergrown with gold and sometimes replaces it. Feather and Duggan (1974) have studied lattice characteristics and the composition of the Co-Ni arsenosulfides. They concluded that these authigenic phases may have formed at temperatures of over $300^{\circ} \mathrm{C}$ and of up to $600^{\circ} \mathrm{C}$.

\section{Sphalerite}

Sphalerite is a fairly common component of uraniferous conglomerates of the Witwatersrand. It tends to be xenomorphic and was deposited during the main period of gold mobilization and deposition. It is associated with other authigenic sulfides, including chalcopyrite, galena, pyrrhotite, and pentlandite. The iron content of sphalerite has been used to obtain an estimate of the temperature of formation of this mineral. Estimates vary from 400 to $450^{\circ} \mathrm{C}$ (Feather and Koen, 1975). However, Feather (1975) has shown that the Fe content of Witwatersrand sphalerite grains is variable, ranging from less than 1 to 10 percent in the presence of abundant Fe (in pyrite and pyrrhotite). Given this range in iron contents, little faith can be placed in the sphalerite geothermometer in Witwatersrand deposits.

\section{Pentlandite}

This mineral is usually associated with pyrrhotite forming exsolution lamellae or exsolution intergrowths with pyrrhotite. The nickel is thought to have been derived from millerite or linnaeite, being introduced into pyrrhotite under diagenetic or metamorphic conditions and exsolving from it as temperatures decreased (Feather and Koen, 1975). It is an extremely rare mineral. 


\section{Millerite}

Ramdohr (1958, p. 39) recognized rare millerite concentrations in porous concretionary pyrite. The millerite forms near the outer portions of the pyrite concretions. Ramdohr was of the opinion that the millerite formed by $\mathrm{Ni}$ infiltration into the porous pyrite.

\section{Bravoite}

Saager (1968) 1ists bravoite as a mineral phase in the uraniferous conglomerates of the Welkom Goldfield. According to information presented by Feather and Koen (1975), bravoite is a widespread minor component of conglomerate reefs and is the main nickel-bearing mineral in some samples.

\section{Linnaeite and Skutterudite}

The mineralogic studies of Ramdohr (1958) and Viljoen (1967) revealed that linnaeite and skutterudite are developed as late-stage secondary sulfides, often associated with gold. Subsequent investigations, using the electron microprobe, suggest that the minerals identified as linnaeite and skutterudite are nickel-rich gersdorffites (Feather and Duggan, 1974).

\section{Chalcopyrite}

Chalcopyrite is associated with late-stage sulfides in the Witwatersrand. It replaces and penetrates porous and fractured pyrite. Chalcopyrite also replaces galena in uraninite and is often closely associated with gersdorffite (Feather and Koen, 1975). Cubanite inclusions in chalcopyrite have been noted.

\section{Cubanite}

This is an extremely rare mineral in uraniferous conglomerates. It has been described as inclusions in chalcopyrite and also occurs, along with other sulfides, in druses in quartz veins that cut Witwatersrand conglomerates (Feather and Koen, 1975).

Stibnite

Sporadic occurrences of stibnite have been reported from Witwatersrand conglomerates. This fact may account for the anomalously high $\mathrm{Sb}$ concentrations detected in some conglomerates by Simpson and Bowles (1977).

\section{Tucekite}

Just and Feather (1978) described tucekite $\left(\mathrm{Ni}_{9} \mathrm{Sb}_{2} \mathrm{~S}_{8}\right)$ from several witwatersrand uraniferous conglomerates. The mineral is frequently intergrown with gold and with gersdorffite.

\section{Silver-Bearing Phases}

In their review of Witwatersrand mineralogy, Feather and Koen (1975) mention several silver-bearing phases. Some native silver is known from Witwatersrand conglomerates. Saager (1968) identified rare silver sulfosalts from the 
Basal Reef of the Welkom Goldfield. These include stromeyerite and proustite, which occur in association with galena, sphalerite, and chalcopyrite near a dyke contact. Saager also noted a concentration of tennantite $\left(3 \mathrm{Cu}_{2} \mathrm{SAs}_{2} \mathrm{~S}_{3}\right)$ in association with these minerals. Tennantite also occurs with galena as inclusions in porous concretionary pyrite.

Mackinawite

Mackinawite is a rare authigenic mineral in Witwatersrand conglomerates. Its presence may imply a paleotemperature on the order of 210 to $250^{\circ} \mathrm{C}$ (Schidlowski and Ottemann, 1966).

$\underline{\text { Rutile, Anatase, and Leucoxene }}$

Titanium-bearing minerals are a small but widespread component of Witwatersrand and Elliot Lake conglomerates. While some detrital rutile is present, authigenic rutile is present in much greater quantities.

Rutile occurs in several distinct ways in the conglomerates under discussion. One mode is in prismatic-to-acicular crystals in chlorite and sericite and as fine needles in quartz, pyrite, uraninite, and "brannerite". The needles in quartz impart an opalescent bluish color (Feather and Koen, 1975). In some cases, rutile is associated with pyrrhotite, which could represent the iron fraction of sulfidized ilmenite or titaniferous magnetite.

A second mode of occurrence of rutile is in pyrite grains. Ramdohr (1958) and Saager (1970) have shown examples of sulfidized grains of hematite with exsolved ilmenite (Figure 42.4) and magnetite with exsolved ilmenite (Figure 42.3). In both cases, the ilmenite is now seen as rutile, while the iron-rich phase is completely replaced by pyrite.

A third mode of occurrence of rutile is in rounded grains of "leucoxene". Ramdohr (1958) has shown several examples in which the parent grain was undoubtedly titaniferous magnetite with exsolved ilmenite along octahedral cleavages. The ilmenite is now represented by rutile (and possibly some anatase) which forms pseudomorphs after the octahedrally distributed ilmenite.

Porous leucoxene grains are of ten filled by secondary minerals, including pyrite, gold, quartz, and uraninite (Viljoen, 1967, p. 8). Viljoen also noted wedge-shaped rutile pseudomorphs in quartz grains and suggested that some leucoxene could be derived by diagenetic alteration of original sphene. Roscoe (1969) noted that Elliot Lake titania-rich grains or aggregates comprise rutile, anatase, and brannerite intergrown with sericite, carbonate, chlorite, pyrite, and pyrrhotite.

Several investigators have studied the grain-size distribution of leucoxene grains in an attempt to identify the parent mineral. Coetzee (1965) noted that the grain-size distribution of this phase was similar to that of zircon and chromite and concluded that the parent mineral must have had a density similar to these minerals. Since the density of ilmenite $\left(4.6 \mathrm{gm} / \mathrm{cm}^{3}\right)$ is similar to that of zircon and chromite $\left(4.7 \mathrm{gm} / \mathrm{cm}^{3}\right)$, he concluded that ilmenite was the most likely precursor. In a similar study on different 
material, Viljoen (1968) found that the median grain size of leucoxene was always larger than that of zircon and chromite. He concluded that the parent mineral was of a lower density and suggested sphene as the most likely mineral. Neither author considered possible volume changes in grains undergoing alteration to rutile aggregates (leucoxene grains).

Based on textural evidence presented by Ramdohr (1958), a significant fraction of all the leucoxene grains was derived from pre-existing ilmeno-magnetite. The conditions under which the destruction of this mineral occurred are discussed in a subsequent section dealing with the origin of brannerite.

Roscoe (1969) noted several types of titania-rich grain aggregates in Matinenda conglomerates. The larger ones contain a relatively low proportion of $\mathrm{TiO}_{2}$ and were probably derived from detrital sphene, biotite, amphibole, or pyroxene. Smaller grains are composed of a greater concentration of rutile and were probably derived from detrital ilmenite or titaniferous magnetite.

Very Rare Authigenic Minerals

Feather and Koen (1975) list several rare authigenic minerals in Witwatersrand conglomerates. These have been described only once or twice during the numerous mineralogic studies of the conglomerates. They include bornite, brookite, chalcocite, chalcopyrite, covellite, dyscrasite, goethite (alteration of pyrite), leucopyrite, loellingite, neodigenite, niccolite, safflorite, tetrahedrite, and troilite.

Variations in Matrix Composition

There has been relatively little quantitative work done on the variations in the mineralogical composition of conglomerate matrices, either laterally (within one conglomerate) or vertically (from one conglomerate to others higher or lower in the succession). Systematic lateral variations can be useful in determining paleogeographical parameters, such as paleoslope and sediment dispersal patterns. Vertical variations are useful in conglomerate correlations and can provide an idea of changing source-area geology through time.

\section{Comparison of Conglomerate Matrix to Host Sediment}

If uraniferous-auriferous conglomerates are indeed paleoplacers, they should be enriched in heavy minerals relative to their host arenites. Coetzee (1965) investigated the quantitative variations in the quartz, pyrite, chromite, leucoxene, and zircon contents of a number of Witwatersrand samples. He found that the foot- and hanging-wallarenites contained no more than about 13 percent combined heavy minerals and averaged about 5 percent. By contrast, the matrix fraction of the associated conglomerates studied contained from 10 to 60 percent pyrite and from 2 to 13 percent combined chromite, zircon, and leucoxene (Figure 44). Clearly, conglomerate matrices are far richer in heavy minerals than the enclosing arenites. 
The relationship between gold and heavy mineral content was also established on a much smaller scale. Coetzee (1965) studied the distribution of grains of gold, pyrite, and other heavy minerals in banded pyritic quartzite from the Witwatersrand. It was shown that the pyritic foresets are richer in both gold and other heavy minerals than the non-pyritic fraction.

\section{Comparison of Matrix Compositions of Different Conglomerates}

The abundance and proportions of heavy minerals are not constant from one conglomerate to the next. Coetzee (1965) determined the heavy mineral contents of several Witwatersrand conglomerates. The results are shown in triangular diagrams (Figures 45 and 46). Conglomerates of the Main Reef group are shown to be leucoxene rich, while the Kimberley-Elsburg conglomerates plot nearer the chromite apex of the triangular diagram. The heavy mineral assemblage of the Carbon Leader is intermediate between those of the Main Reef group and the Kimberley-Elsburg conglomerates (Figure 46).

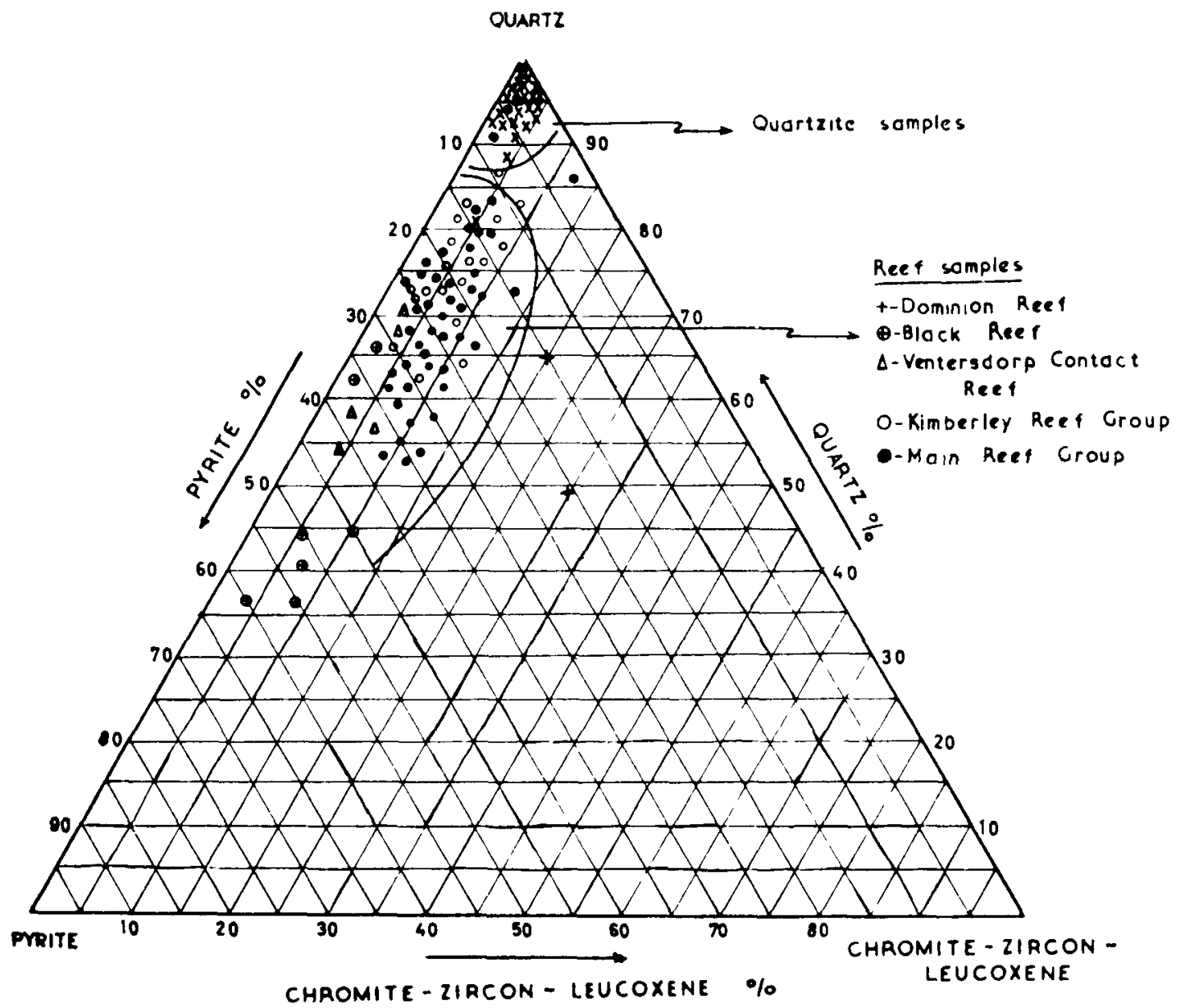

Figure 44. Triangular plot showing the relative enrichment in heavy minerals of conglomerate matrices ("reef samples") relative to associated host arenites ("quartzite samples"), Witwatersrand area (from Coetzee, 1965). 


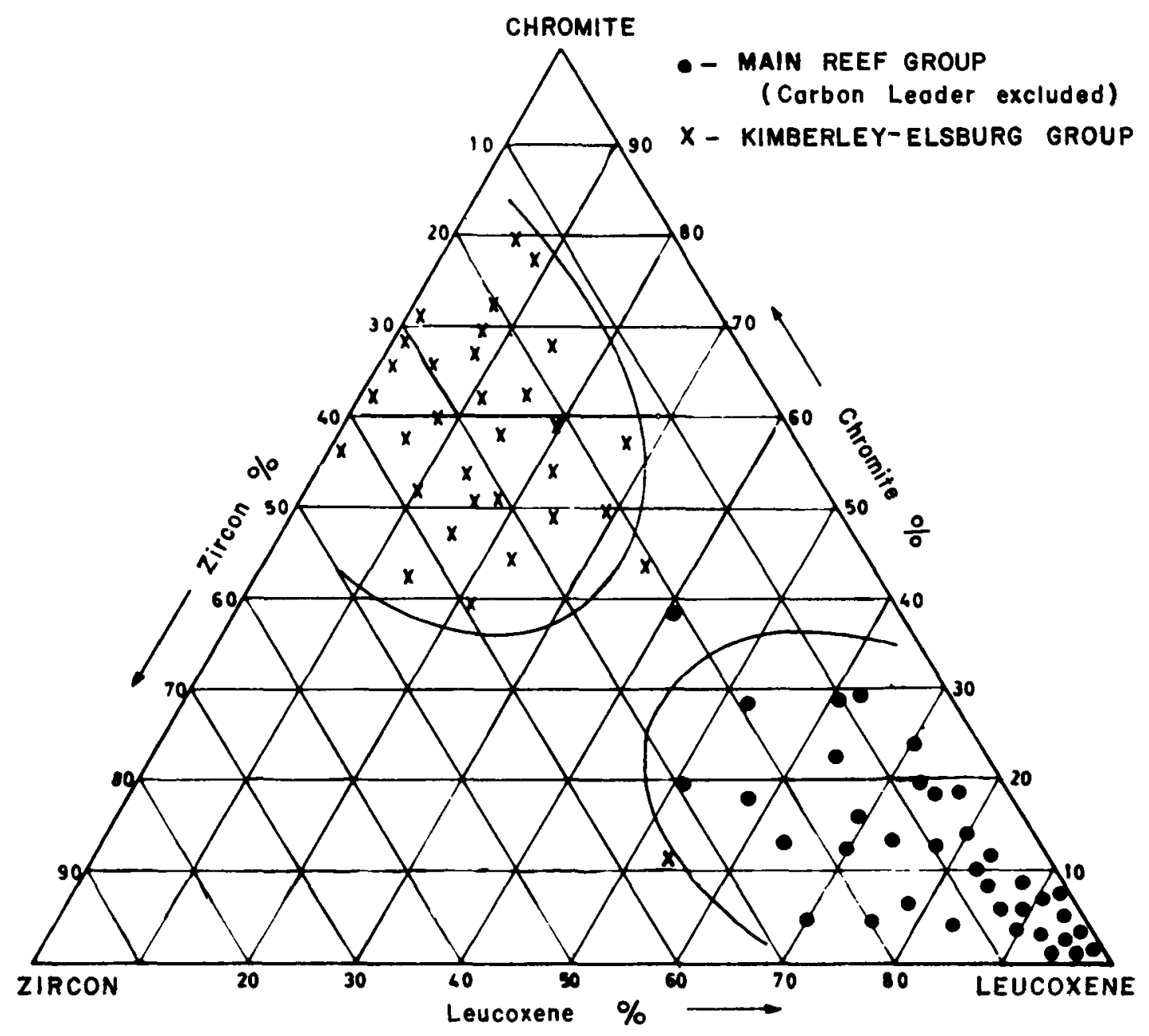

Figure 45. Triangular plot showing the relative concentrations of zircon, chromite, and leucoxene in matrices of conglomerates of the Main Reef and Kimberley-Elsburg groups (from Coetzee, 1965).

Pretorius (1976) has compiled a table from Coetzee's data showing the relative abundances of chromite, zircon, and leucoxene through the major conglomerate units of the Witwatersrand district in South Africa. Table 18, which is arranged in stratigraphic sequence, shows that, on the average, the upper units are richer in chromite, while the lower units tend to contain more leucoxene. The chromite/zircon ratio appears to increase upwards in the stratigraphic section. Pretorius has pointed out that the chromite/zircon ratio is probably a reflection of the relative abundance of basic and ultrabasic rock in the provenance areas of these conglomerates. 


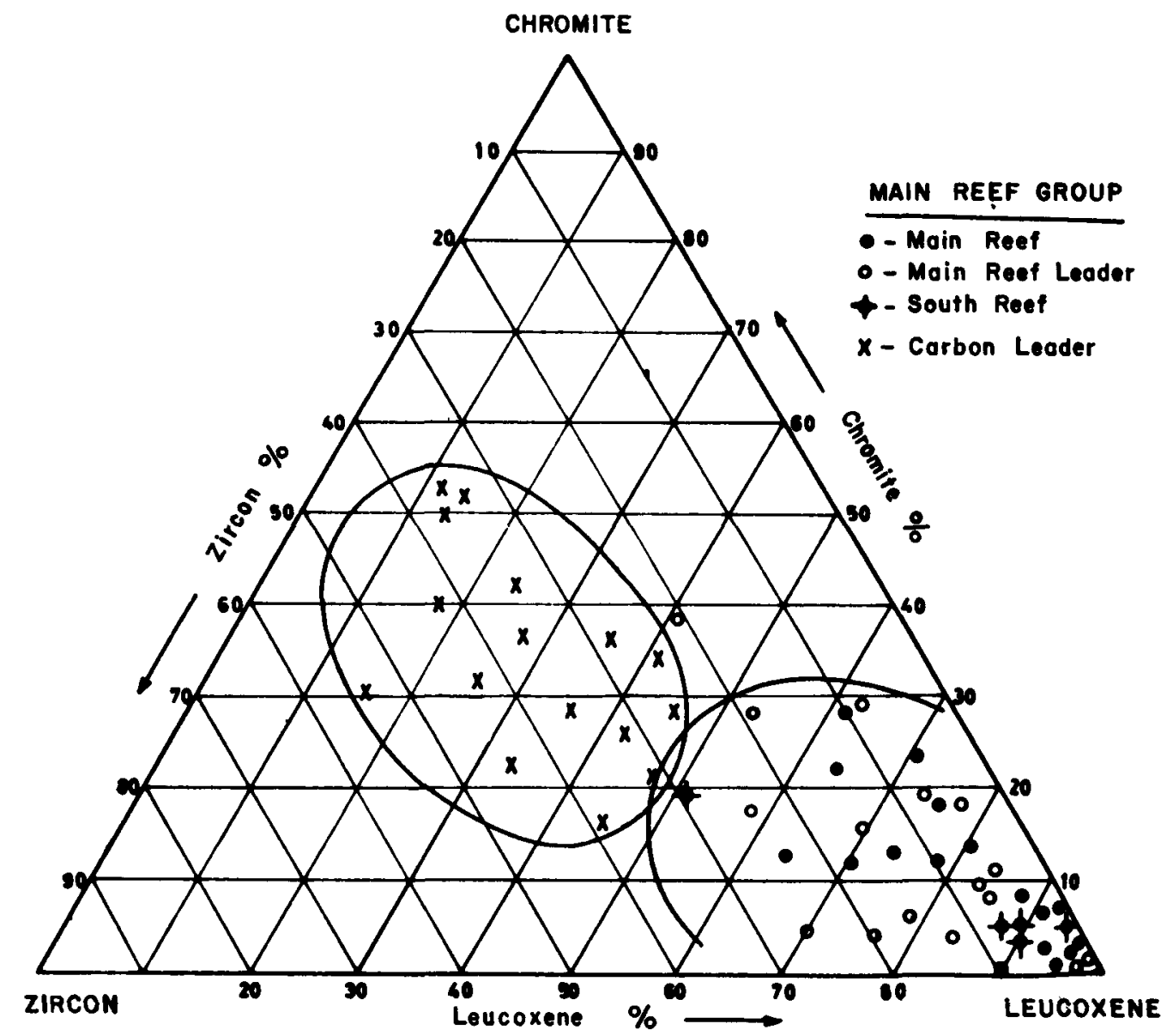

Figure 46. Triangular plot showing the relative concentrations of zircon, chromite, and leucoxene in matrices of the Carbon Leader and other conglomerates of the Main Reef group, Witwatersrand Basin (from Coetzee, 1965).

Table 18. Percentages of chromite, zircon, and leucoxene in major Witwatersrand conglomerate reefs (after Pretorius, 1976; data originally from Coetzee, 1965).

\begin{tabular}{lrrrr}
\hline REEF HORIZON & CHROMITE & ZIRCON & LEUCOXENE & CHROMITE/ZIRCON RATIO \\
\hline & 58 & 14 & 28 & 4.14 \\
Black & 34 & 25 & 41 & 1.36 \\
Ventersdorp & 64 & 34 & 2 & 1.88 \\
Elsburg & 59 & 26 & 15 & 2.27 \\
Kimberley & 38 & 36 & 26 & 1.06 \\
Bird & 6 & 7 & 87 & 0.86 \\
South & 11 & 12 & 77 & 0.92 \\
Leader & 14 & 8 & 78 & 1.75 \\
Main & 34 & 39 & 27 & 0.87 \\
Carbon Leader & 13 & 9 & 78 & 1.44 \\
Dominion & & & & \\
\hline
\end{tabular}


Experience in basins such as the Witwatersrand has shown that the gold and uranium content of conglomerates varies greatly over short distances. Consequently, individual assays of a conglomerate are not necessarily representative of the economic potential of the block of ground around an assay point. A possible approach to determining the true potential at one location is to measure a variable in the conglomerate that is less erratic than the gold or uranium content. One approach has been to measure pebble parameters (such as median size, packing, sorting, and sphericity). Another approach is to measure the grain size of matrix heavy minerals, including pyrite, zircon, chromite, and leucoxene. In this method, the apparent diameters of grains are measured on smoothed surfaces. A binocular microscope is used if the grains are smaller than about $1 \mathrm{~mm}$. The grain-size distributions so determined are obviously biased due to the "sectioning" effect (a random section will cut most spherical grains in such a way that the exposed diameter is less than the true diameter). The sectioning effect can be corrected mathematically or can be ignored, since, in most studies, all the data collected have the same bias and are thus internally consistent.

Once a statistically valid number of grain measurements is made, the median grain size can be determined from a cumulative frequency versus grain size plot. The median grain diameters can then be plotted on two-dimensional graphs (for example, median grain size against distance down paleoslope or median grain size against a geochemical variable such as gold and uranium content) or can be contoured to provide a picture of the areal variation in grain size.

\section{Two-Dimensional Plots}

Two-dimensional plots have been used to demonstrate the sympathetic grain-size changes of different components of a conglomerate. For example, Theis (1979) plotted pyrite grain size (average of 100 largest grains per slab) against pebble size (mean of maximum-apparent diameter of the 10 largest pebbles per $1,000 \mathrm{~cm}^{2}$ ). This plot (Figure 38 ) shows a straight-1ine relation with a correlation coefficient of 0.93 and suggests that both pebbles and pyrite sizes are controlled by the same depositional mechanisms.

In another type of plot, the median grain sizes of various heavy mineral types are plotted as a function of distance down a fluvial paleoslope. For example, Minter (1978) has determined the median grain sizes of pyrite and zircon at 5 locations down a $20 \mathrm{~km}$ paleoslope in the Basal/Steyn placer of the Welkom Goldfield. The median grain size of both minerals decreases down the paleoslope (Figure 47).

The zircons are smaller than would be expected if they were in strict hydraulic equilibrium with the pyrite. This probably reflects the absence of coarse zircon grains in the source area. The two minerals achieve a state of hydraulic equilibrium only in the distalmost parts of the system, where both pyrite and zircon grains average about $3 \phi$ in diameter (Figure 47). 
Contoured maps showing the median (or mean) grain size of heavy minerals are far more informative than two-dimensional plots but require much more data. In particular, these maps give an indication of the dispersal pattern of sediments within a single conglomerate sheet. This is particularly useful during exploration drilling programs, since conventional paleocurrent
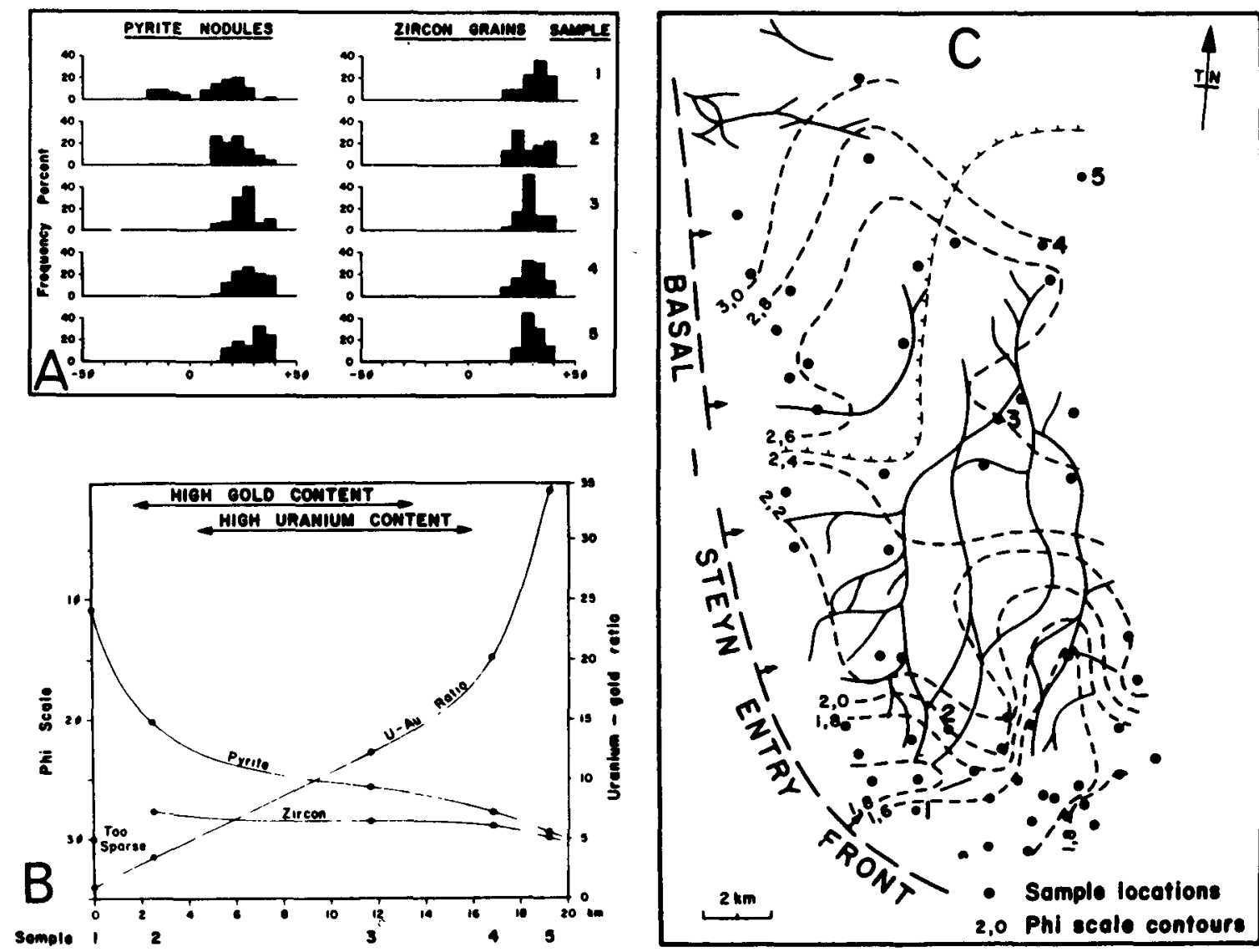

Figure 47. A. Pyrite and zircon grain-size histograms at locations 1 through 5 (see map, Figure 47C).

B. Changes in pyrite and zircon grain size and of U/Au ratio at locations 1 through 5 .

C. Map of Basal/Steyn paleoplacer, Welkom Goldfield, showing main mineralized channels (solid braided lines) and contoured pyrite grain size ( $\phi$ units, broken lines). From Minter, 1978. 
parameters (such as cross-bedding) cannot normally be determined from borehole core unless oriented cores are taken. Studies of this type have been undertaken in the East Rand area (Viljoen, 1967, 1968; Lenthal1, 1970), in the Klerksdorp area (McLachlan, 1968), and in the Welkom area (Minter, 1978). The East Rand and Welkom studies were the most informative and are described below.

In Minter's study of the Basa1/Steyn paleoplacer, the "mean size of compact pyrite nodules" was contoured (Figure 47). The mean sizes are in phi units and decrease from $1.6 \phi(0.33 \mathrm{~mm})$ to $3 \phi(0.125 \mathrm{~mm})$ over the goldfield. If this pattern is compared with the overall patterns of distribution of gold and uranium (Figure 37), it can be seen that:

(1) highest gold potential coincides with fairly large pyrite sizes (1.6 to about 2.6申);

(2) highest uranium potential coincides with somewhat lower pyrite sizes $(2.4$ to $2.6 \phi)$; and

(3) the lowest overall payability, at the north end of the goldfield, occurs where pyrite sizes are smallest ( 2.6 to smaller than $3 \phi)$.

The potential for gold and/or uranium within this paleoplacer could thus be gauged by determining mean pyrite sizes. Large pyrite sizes translate into a high potential, even if individual assays were to give low values.

In the study of the Main Reef Leader in the East Rand (Viljoen, 1968; Lenthall, 1970), the median grain sizes of several minerals were determined. In Figure 48, the contoured grain sizes of zircon and chromite are shown. The maps are similar, with largest grain sizes developed in the northern parts of the area and decreasing radially away from this point. Zircon sizes decrease from $2.5 \phi$ to smaller than $3.5 \phi$. Chromite grains are somewhat larger than zircons, varying from $1.5 \phi$ to smaller than $3 \phi$. The area of largest grain sizes coincides with the position of the East Rand "entry point", as established by several other criteria. The area enclosed by the $2.5 \phi$ zircon contour coincides well with the area of maximum development of payable conglomerate within the East Rand (see Figure 49). The economic potential of areas within the East Rand sedimentary system can thus be gauged by zircon and chromite mean grain size, as well as some other parameters (previously discussed), including quartz grain size and the sericite/chlorite ratio of the conglomerate matrix.

\section{Sorting Patterns of Heavy Minera1 Grains}

In the studies of the East Rand area mentioned above (Viljoen, 1968; Lenthall, 1970), sorting parameters of heavy mineral grain-size distributions were calculated, plotted, and contoured. Both studies showed that the sorting improves down the fluvial paleoslope. The area of highest payability is characterized by relatively poorly sorted zircons (standard deviation $0.7 \phi$ ), while further down the paleoslope, in a largely unpay area, sorting has improved (standard deviation of $0.5 \phi$ ). 


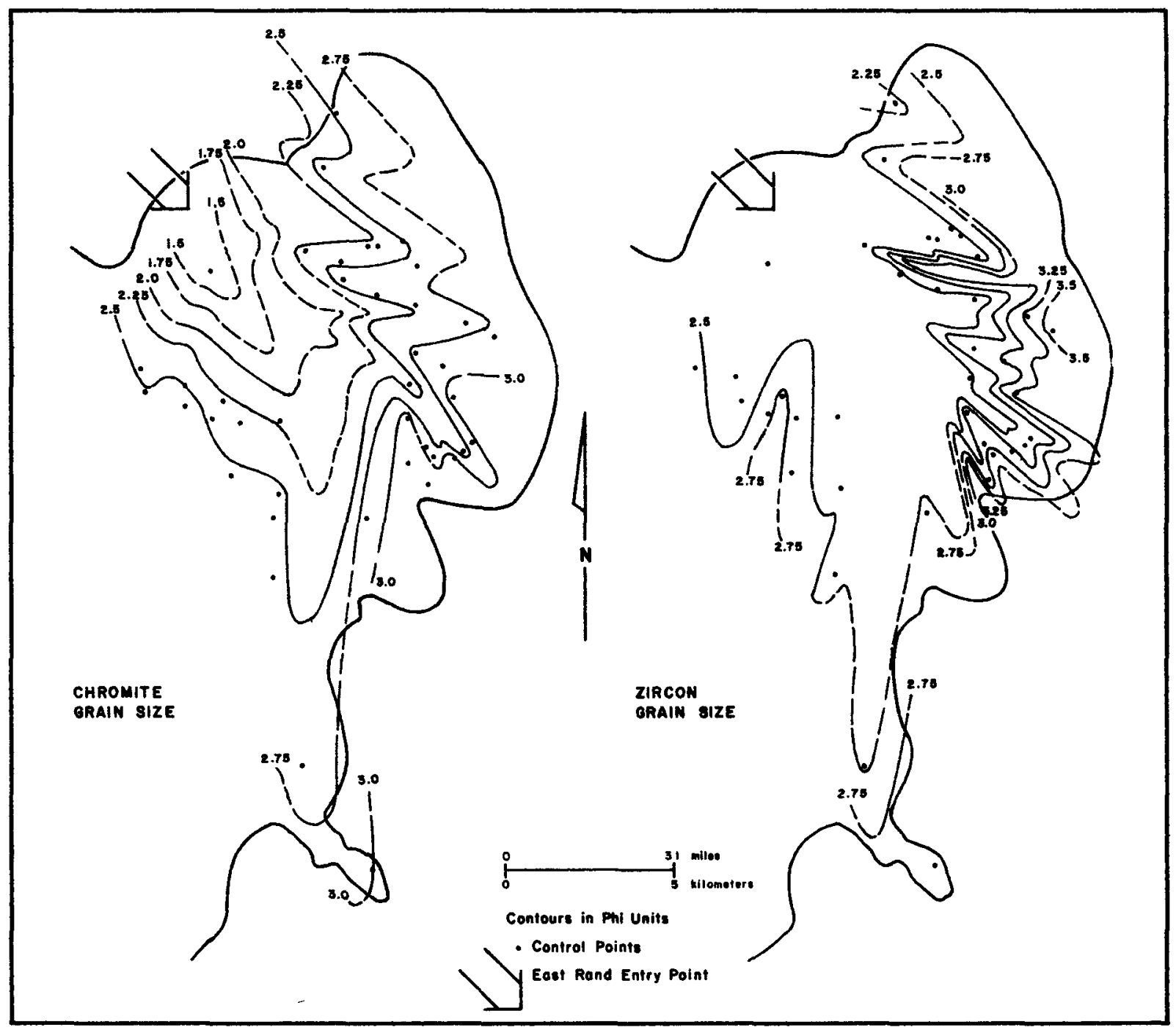

Figure 48. Maps showing chromite and zircon mean grain-size variations in the Main Reef Leader over the East Rand Goldfield (from Lenthall, 1970). 
A limited number of systematic geochemical Investigations have been undertaken on uraniferous conglomerates. The number of whole-rock, full silicate analyses is small, as is the number of trace element analyses. By contrast, the number of geochemical determinations of gold and uranium is very large, numbering several million in basins such as the Witwatersrand.

\section{Whole-Rock Ful1 Silicate Analyses}

Table 19, after Pretorius (1976), shows the chemistry of several conglomerates from the West Rand area. The conglomerates are siliceous, most of them containing over 85 percent $\mathrm{S}_{2} \mathrm{O}_{2}$. The high silica values are due to the nature of the clasts (mainly quartz and chert) and the matrix (mainly quartz). The low $\mathrm{MgO}, \mathrm{CaO}$, and $\mathrm{Na}_{2} \mathrm{O}$ values in most are consistent with their derivation from a deeply weathered and leached source terrane in which these elements were largely removed in solution.

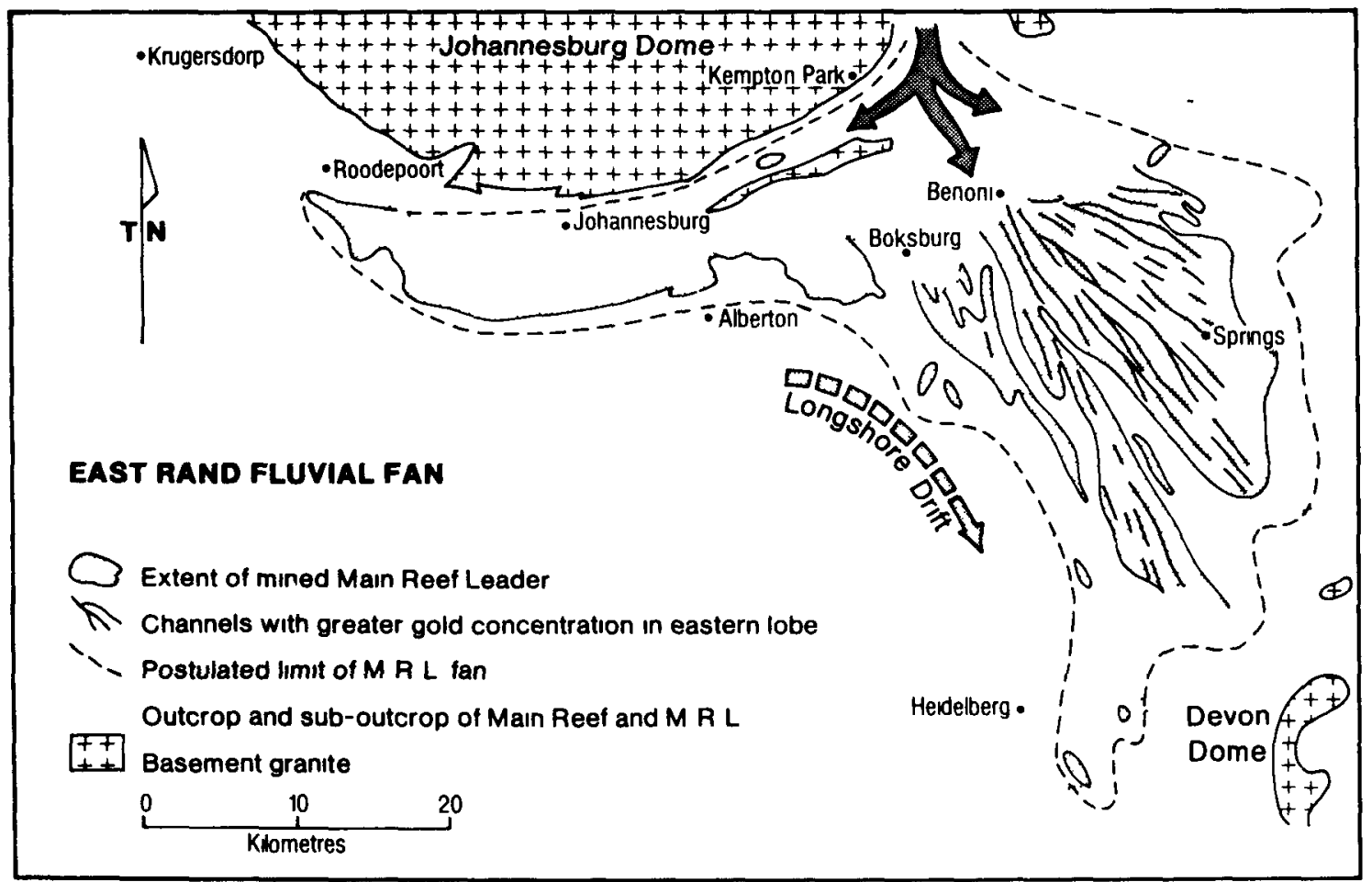

Figure 49. Map of the East Ran fluvial fan, showing paystreaks and the extent of the mined Main Reef Leader (from Pretorius, 1976). 
Table 19. Chemical analyses of conglomerates from the West Rand Consolidated Mine (after Pretorius, 1976):

\begin{tabular}{|c|c|c|c|c|c|c|c|c|}
\hline & NR & MR & BPQ & $\mathrm{SR}$ & LLR & ULR & WR & $\mathrm{BR}$ \\
\hline $\mathrm{SiO}_{2}$ & 89.26 & 93.14 & 62.08 & 94.06 & 86.38 & 88.18 & 87.19 & 88.32 \\
\hline $\mathrm{Al}_{2} \mathrm{O}_{3}$ & 2.31 & 1.69 & 1.92 & 2.51 & 5.13 & 4.42 & 3.97 & 1.77 \\
\hline $\mathrm{Fe}_{2} \mathrm{O}_{3}$ & 1.01 & 0.48 & 10.72 & 0.30 & 1.63 & 1.03 & 1.11 & 3.01 \\
\hline $\mathrm{FeO}$ & 3.05 & 1.36 & 2.07 & 0.79 & 0.78 & 1.07 & 0.87 & 0.79 \\
\hline $\mathrm{FeS}_{2}$ & 1.26 & 1.24 & 14.88 & 0.73 & 1.98 & 1.72 & 1.16 & 3.60 \\
\hline $\mathrm{MgO}$ & 0.45 & $<0.02$ & 1.07 & $<0.02$ & $<0.02$ & $<0.02$ & 0.05 & $<0.02$ \\
\hline $\mathrm{CaO}$ & $<0.02$ & $<0.02$ & $<0.02$ & $<0.02$ & 0.03 & $<0.02$ & 0.02 & $<0.02$ \\
\hline $\mathrm{Na}_{2} \mathrm{O}$ & 0.04 & 0.03 & 0.02 & 0.10 & 0.61 & 0.12 & 0.04 & 0.10 \\
\hline $\mathrm{K}_{2} \mathrm{O}$ & 0.01 & 0.02 & 0.01 & 0.12 & 0.35 & 0.14 & 0.27 & 0.18 \\
\hline $\mathrm{TiO}_{2}$ & 0.10 & 0.12 & 0.25 & 0.15 & 0.53 & 0.28 & 0.22 & 0.09 \\
\hline $\mathrm{P}_{2} \mathrm{O}_{5}$ & 0.03 & 0.04 & 0.02 & 0.03 & 0.03 & 0.02 & 0.04 & 0.02 \\
\hline MnO & 0.02 & 0.01 & 0.03 & 0.02 & 0.02 & 0.01 & 0.02 & 0.01 \\
\hline Loss & 1.43 & 1.07 & 6.36 & 0.99 & 1.91 & 2.15 & 2.15 & 2.27 \\
\hline Th* & $<5$ & 223 & 12 & 15 & 14 & 23 & 228 & 8 \\
\hline $\mathrm{La*}$ & 5 & 38 & 18 & 8 & 38 & 23 & 26 & 15 \\
\hline $\mathrm{C1*}$ & 137 & 179 & 67 & 78 & 124 & 83 & 84 & 56 \\
\hline Total & 98.98 & 99.24 & 99.44 & 99.81 & 99.40 & 99.15 & 97.14 & 99.17 \\
\hline
\end{tabular}

$\mathrm{NR}=$ North Reef; $\mathrm{MR}=$ Main Reef; $\mathrm{BPQ}=$ Banded Pyritic Quartzites; $\mathrm{SR}=$ South Reef; LLR = Livingstone Reef (Lower Band); ULR = Livingstone Reef (Upper Band); WR = White Reef; $\mathrm{BR}=$ Boulder Reef; Loss = corrected loss on ignition; * in p pm. 
Pienaar (1963) presented full silicate analyses of the matrices of several Matinenda conglomerates (Table 20). Elimination of the pebble fraction resulted in more meaningful information. Unfortunately, the results cannot be directly compared with those quoted above.

Table 20. Chemical analyses of matrices of Matinenda Formation conglomerates ${ }^{1}$ (after Pienaar, 1963).

\begin{tabular}{lcccc}
\hline & $\mathrm{PH}-478$ & $\mathrm{PH}-479$ & $\mathrm{PH}-281$ & $\mathrm{PH}-282$ \\
\hline $\mathrm{SiO}_{2}$ & 84.99 & 75.04 & 78.67 & 75.44 \\
$\mathrm{Al}_{2} \mathrm{O}_{3}$ & 7.40 & 7.60 & 9.80 & 8.80 \\
$\mathrm{Fe}_{2} \mathrm{O}_{3}$ & $3.01^{2}$ & $10.86^{2}$ & $3.07^{2}$ & $11.31^{2}$ \\
$\mathrm{MgO}$ & 0.01 & 0.10 & 0.14 & 0.28 \\
$\mathrm{CaO}$ & $<.018$ & 0.29 & $<0.018$ & $<0.018$ \\
$\mathrm{Na}_{2} \mathrm{O}$ & 0.050 & $<0.050$ & $<0.050$ & $<0.050$ \\
$\mathrm{~K}_{2} \mathrm{O}$ & 1.90 & 2.45 & 4.10 & 3.31 \\
$\mathrm{H}_{2} \mathrm{O}\left(110^{\circ}\right)$ & 0.05 & 0.04 & 0.05 & 0.05 \\
$\mathrm{H}_{2} \mathrm{O}\left(900^{\circ}\right)$ & 0.57 & 1.84 & 1.10 & 1.89 \\
$\mathrm{TiO}_{2}$ & 0.36 & 1.42 & 0.46 & 0.60 \\
$\mathrm{ZrO}$ & 0.0159 & 0.0265 & 0.0235 & 0.0946 \\
$\mathrm{MnO}_{\mathrm{SrO}}$ & 0.001 & $<0.001$ & $<0.001$ & 0.001 \\
$\mathrm{Rb}_{2} \mathrm{O}$ & 0.005 & 0.005 & 0.006 & 0.006 \\
& 0.0078 & 0.014 & 0.0115 & 0.0108
\end{tabular}

\begin{tabular}{lcccc}
\hline Total & 98.31 & 99.70 & 97.44 & 101.79 \\
\hline $\begin{array}{c}\text { Weight percent of } \\
\text { pebbles removed }\end{array}$ & 25.7 & 44.8 & 19.9 & 39.1 \\
\hline
\end{tabular}

${ }^{1}$ Al1 samples selected from ore-bearing oligomictic conglomerates.

${ }^{2}$ Total iron determined by $\mathrm{X}$-ray spectrographic means. Samples heat treated and $\mathrm{FeO}$ oxidized to $\mathrm{Fe}_{2} \mathrm{O}_{3}$.

$\mathrm{PH}-478$-Loosely packed conglomerate-4Dr. E. Quirke Mine.

PH-479-Wel1-packed conglomerate-3 feet below PH-478.

$\mathrm{PH}-281$-Loosely packed conglomerate-2W10 Stope-Nordic Mine.

PH-282-Well-packed conglomerate-1 foot below PH-281.

The conglomerate matrices are very similar in composition to the Matinenda arenites. They contain 75 to 85 percent $\mathrm{SiO} 2$, over 7 percent $\mathrm{Al}_{20} \mathrm{O}_{3}$ and over 1.9 percent $\mathrm{K}_{2} \mathrm{O}$ (see Table 20), reflecting their dominant 1ithology (quartz sericite, minor $\mathrm{K}$ feldspar). The conglomerate matrices are strongly depleted in $\mathrm{MgO}, \mathrm{CaO}$, and $\mathrm{Na}_{2} \mathrm{O}$, which reflects their derivation from a very deep1y weathered source terrane, similar to that developed in pre-Matinenda paleosols.

In summary, the most distinctive chemical characteristic of uraniferous conglomerates is their depletion in $\mathrm{Na}_{2} \mathrm{O}, \mathrm{CaO}$, and $\mathrm{MgO}$ relative to the granitic basement from which they were derived. Another obvious feature is the relatively high sulfur content. In Table 19, the conglomerate samples 
from the West Rand are shown to contain between 0.73 and 14.88 percent $\mathrm{FeS}_{2}$. The concentration of $\mathrm{TiO}_{2}$ in the Matinenda samples (Table 20) is relatively high, presumably reflecting the abundance of "brannerite" in the conglomerates.

\section{Trace-Element Analyses}

The available trace-element analyses of uraniferous conglomerates are unfortunately non-systematic, involving various elements and a relatively small number of samples. For example, Table 21 shows the results of analyses of a wide range of elements on a conglomerate and an associated arenite from the West Rand. The usefulness of the data is severely decreased by the small number of samples.

Table 21. Trace (and some major) element analyses of Kimberley conglomerate and associated arenite from the Durban Roodepoort Deep Mine, West Rand area (after Pretorius, 1976).

\begin{tabular}{lcc}
\hline ELEMENT & CONGLOMERATES & QUARTZITES \\
\hline Antimony (ppm) & 0.30 & 0.30 \\
Arsenic (ppm) & 30 & 30 \\
Barium (ppm) & 60 & 50 \\
Caesium (ppm) & 0.60 & 0.50 \\
Cerium (ppm) & 35 & 30 \\
Chromium (ppm) & 90 & 90 \\
Cobalt (ppm) & 30 & 6 \\
Europium (ppm) & 0.50 & 0.50 \\
Ga1lium (ppm) & 5 & 5 \\
Gold (ppm) & 1.00 & 0.03 \\
Hafnium (ppm) & 3.50 & 3.50 \\
Iron (\%) & 1.30 & 0.20 \\
Lanthanum (ppm) & 15 & 15 \\
Lutetium (ppm) & 0.20 & 0.10 \\
Neodymium (ppm) & 20 & 10 \\
Nicke1 (ppm) & 45 & 25 \\
Potassium (\%) & 0.08 & 0.10 \\
Rubidium (ppm) & 10 & 7 \\
Scandium (ppm) & 4 & 3 \\
Sodium (\%) & 0.04 & 0.05 \\
Tantalum (ppm) & 0.50 & 0.50 \\
Terbium (ppm) & 0.20 & 0.20 \\
Thorium (ppm) & 7 & 5 \\
Titanium (\%) & 0.15 & 0.08 \\
Tungsten (\%) & 0.50 & 0.60 \\
Uranium (p pm) & 10 & 1.00 \\
Ytterbium (ppm) & 1.20 & 130 \\
Zirconium (ppm) & 160 & \\
& & \\
\hline
\end{tabular}


Minter (1978) published the results of a spectroscopic scan of sediments associated with the $B$ placer in the Welkom area (Table 22). The placer is seen to be strongly enriched in $\mathrm{Ag}, \mathrm{As}, \mathrm{Au}, \mathrm{Bl}, \mathrm{Co}, \mathrm{Cu}, \mathrm{Mg}, \mathrm{Pb}, \mathrm{U}, \mathrm{Y}, \mathrm{Zn}$, and $\mathrm{Zr}$ relative to the enclosing arenites. Most of the elements enriched in the conglomerate are either sulfophile or are associated with heavy mineral grains such as chromite and zircon.

Table 22. Spectrographic analysis of the B placer and 1 ts foot- and hanging-wall sediments (after Minter, 1978).

\begin{tabular}{|c|c|c|c|}
\hline ELEMENT & $\begin{array}{c}\text { BELOW B PLACER } \\
\text { ppm }\end{array}$ & $\begin{array}{c}\text { WITHIN B PLACER } \\
\mathrm{ppm}\end{array}$ & $\begin{array}{c}\text { ABOVE } \\
\text { B PLACER } \\
\end{array}$ \\
\hline $\begin{array}{l}\mathrm{Ag} \\
\mathrm{As} \\
\mathrm{Au}\end{array}$ & $\begin{array}{c}<\quad 0.1 \\
<100 \\
0.2\end{array}$ & $\begin{array}{r}36 \\
237 \\
358\end{array}$ & $<\begin{array}{l}0.1 \\
<-\infty\end{array}$ \\
\hline $\begin{array}{l}\mathrm{Ba} \\
\mathrm{Be} \\
\mathrm{BI}\end{array}$ & $\begin{array}{r}650 \\
3 \\
<\quad 1.0\end{array}$ & $\begin{array}{c}200 \\
0.5 \\
45\end{array}$ & $\begin{array}{r}300 \\
1 \\
<\quad 1.0\end{array}$ \\
\hline $\begin{array}{l}\mathrm{Ca} \\
\mathrm{Co} \\
\mathrm{Cr}\end{array}$ & $\begin{array}{r}2125 \\
<\quad 10 \\
192\end{array}$ & $\begin{array}{l}300 \\
312 \\
209\end{array}$ & $\begin{array}{r}475 \\
22 \\
139\end{array}$ \\
\hline $\begin{array}{l}\mathrm{Cu} \\
\mathrm{Fe} \\
\mathrm{La}\end{array}$ & $\begin{array}{r}6 \\
>3000 \\
100\end{array}$ & $\begin{array}{r}1325 \\
>3000 \\
100\end{array}$ & $\begin{array}{r}57 \\
>3000 \\
100\end{array}$ \\
\hline $\begin{array}{l}\mathrm{Mg} \\
\mathrm{Na} \\
\mathrm{N1}\end{array}$ & $\begin{array}{r}1750 \\
>3000 \\
57\end{array}$ & $\begin{array}{r}>3000 \\
2375 \\
925\end{array}$ & $\begin{array}{r}1250 \\
1750 \\
50\end{array}$ \\
\hline $\begin{array}{l}P b \\
S b \\
S n\end{array}$ & $\begin{array}{r}12 \\
<\quad 50 \\
12\end{array}$ & $\begin{array}{r}650 \\
57 \\
8\end{array}$ & $\begin{array}{r}27 \\
<\quad 50 \\
11\end{array}$ \\
\hline $\begin{array}{l}\text { U } \\
Y \\
\mathrm{Zn} \\
\mathrm{Zr}\end{array}$ & $\begin{array}{l}-- \\
70 \\
12 \\
75\end{array}$ & $\begin{array}{r}260 \\
60 \\
132 \\
300\end{array}$ & $\begin{array}{r}-- \\
50 \\
32 \\
87\end{array}$ \\
\hline
\end{tabular}

One of the few systematic, published, geochemical studies of Witwatersrand conglomerates is that by Saager and Esselaar (1969), who analysed 109 samples from the Basal/Steyn placer of the Welkom Goldfield. A statistical summary of their data is given in Table 23. By comparison to an average conglomerate, the placer is clearly enriched in all of the nine elements analysed. 
Table 23. Statistical parameters of nine elements analysed from 109 samples of the Basal/Steyn placer, Welkom area (after Saager and Esselaar, 1969).

\begin{tabular}{|c|c|c|c|c|c|c|c|c|c|}
\hline & $\begin{array}{l}\mathrm{Co} \\
\mathrm{ppm}\end{array}$ & $\begin{array}{l}\mathrm{Zn} \\
\mathrm{ppm}\end{array}$ & $\begin{array}{l}\mathrm{Cu} \\
\mathrm{ppm}\end{array}$ & $\begin{array}{l}\mathrm{Au} \\
\mathrm{ppm}\end{array}$ & $\begin{array}{l}\mathrm{Ag} \\
\mathrm{ppm}\end{array}$ & $\begin{array}{c}\mathrm{U} \\
\mathrm{ppm}\end{array}$ & $\begin{array}{l}\mathrm{S} \\
\% \\
\end{array}$ & $\begin{array}{l}\mathbf{i} \\
\mathrm{ppm}\end{array}$ & $\begin{array}{l}\mathrm{Pb} \\
\mathrm{ppm}\end{array}$ \\
\hline $\begin{array}{l}\bar{x} \\
s\end{array}$ & $\begin{array}{r}155.9 \\
98.2\end{array}$ & $\begin{array}{r}98.8 \\
111.0\end{array}$ & $\begin{array}{l}211.6 \\
611.9\end{array}$ & $\begin{array}{l}375 \\
841\end{array}$ & $\begin{array}{l}36 \\
80\end{array}$ & $\begin{array}{r}937 \\
1205\end{array}$ & $\begin{array}{l}6.32 \\
5.36\end{array}$ & $\begin{array}{l}252.7 \\
165.0\end{array}$ & $\begin{array}{l}447.8 \\
693.1\end{array}$ \\
\hline $\mathbf{v}$ & 0.63 & 1.12 & 2.89 & 2.25 & 2.24 & 1.27 & 0.85 & 0.65 & 1.55 \\
\hline
\end{tabular}

$$
\bar{x}=\text { mean } \quad s=\text { standard deviation } \quad v=\text { coefficient of variation }
$$

Saager and Esselaar further treated these data by seeking statistical correlations and by subjecting it to a factor analysis program. The strongest correlations found were between $\mathrm{Au}$ and $\mathrm{Ag}(0.994)$, between $\mathrm{S}$ and both Co and $\mathrm{Ni}(0.870$ and 0.856 , respectively). Co correlates strongly with $\mathrm{Ni}(0.865)$. of particular interest in this report is the correlation of $\mathrm{U}$ with $\mathrm{Pb}(0.696)$, $\mathrm{Au}(0.605)$, and $\mathrm{Ag}(0.631)$. The correlations are easily interpreted by simple mineralogical relations. $\mathrm{Au}$ and $\mathrm{Ag}$ are alloyed and are thus highly correlated. Co and $\mathrm{Ni}$ are enriched in pyrite and other sulfides and thus correlate strongly with one another and with $\mathrm{S}$. $\mathrm{Pb}$ is formed by the radioactive decay of uranium and is thus correlated with $U$. The correlation of $U$ with Au and Ag suggests that these elements were deposited in the conglomerate by the same set of controls. The most logical control under the circumstances is the aqueous sorting of detrital minerals according to specific gravity.

The factor analysis to which these data were subjected confirms the association of $\mathrm{Co}$ and $\mathrm{Ni}$ with $\mathrm{S}$ and of $\mathrm{U}$ with $\mathrm{Au}$ and $\mathrm{Ag}$. It also suggests that $\mathrm{Cu}$ was not.associated with any of these elements and was probably deposited from solution after the conglomerate was deposited.

In a similar study of a larger variety of conglomerates from the Witwatersrand, Liebenberg (1973) found a "close" correlation of $U$ and $A u$ and of $U$ and Ag (Table 24). Statistically "significant" correlations were found between $U$ and $\mathrm{Zr}$ and between $\mathrm{U}$ and $\mathrm{Cr}$. The tendency for uranium to be concentrated along with heavy minerals is confirmed, since, in Witwatersrand conglomerates, $\mathrm{Zr}$ is contained largely in zircon and $\mathrm{Cr}$ in detrital chromite grains.

Turning now to North American examples, Pienaar (1963) published a table (Table XIV, p. 72, in Pienaar, 1963) showing the concentrations of selected trace elements in four samples of Matinenda conglomerate. His table shows that we11-packed conglomerates contain more $\mathrm{Co}, \mathrm{N} 1, \mathrm{Cr}, \mathrm{Cu}, \mathrm{V}, \mathrm{Th}$, and $\mathrm{U}$ than their poorly packed counterparts.

Kimberley and others (in press) have studied the behavior of certaln elements in uraniferous conglomerates and associated arenites and paleosols from the Matinenda Formation. Their study confirms the very strong depletion of $\mathrm{Na}$ relative to $\mathrm{K}$ in conglomerates (and associated arenite and paleosols). The 
$\mathrm{K} / \mathrm{Na}$ ratio in these rocks is consistently over 20 and commonly on the order of 50. By contrast, the average $\mathrm{K} / \mathrm{Na}$ ratio of arkosic sandstones is about 2 (Kimberley and others, in press).

Table 24. Correlation of selected elements in Witwatersrand conglomerates (after Pretorius, 1976; from data in Liebenberg, 1973).

\begin{tabular}{ll}
\hline COMPONENTS & CORRELATION \\
\hline Gold/silver & very close \\
Gold/silver/uranium & close \\
Gold/zirconium & significant \\
Gold/chromium & significant \\
Uranium/zirconium & significant \\
Uranium/chromium & significant \\
Gold/titanium/iron & inconclusive \\
Gold/uranium/potassium & none \\
\hline
\end{tabular}

Kimberley and co-authors also determined that there is a "strong correlation" of U with Th, Fe, Ta, Co, Ti, and rare earth elements (La, Ce, Sm, Eu, Dy, and $\mathrm{Lu}$ ) in rocks from the Denison Mine area. Further east, in the Agnew Lake area, they determined that zones of uranium concentration are also enriched in $\mathrm{Th}, \mathrm{Zr}, \mathrm{Ba}, \mathrm{Ti}, \mathrm{Fe}, \mathrm{Co}$, $\mathrm{Hf}, \mathrm{Ta}$, and $\mathrm{As}$, as well as the analysed rare earth elements ( $\mathrm{La}, \mathrm{Ce}, \mathrm{Sm}, \mathrm{Eu}, \mathrm{Tb}, \mathrm{Dy}, \mathrm{Yb}$, and $\mathrm{Lu}$ ). They concluded that these concentrations are "possibly indicative of heavy-mineral concentration".

Theis (1979) determined the concentrations of selected trace elements from 57 samples of Matinenda conglomerate. The only strong correlation of $\mathrm{U}_{3} \mathrm{O}_{3}$ was found to be with $\mathrm{Pb}$ (correlation coefficient 0.92). As in the Witwatersrand, this merely confirms the radiogenic origin of much of the lead. By contrast, $\mathrm{ThO}_{2}$ correlates strongly with $\mathrm{Ce}(0.84)$, La $(0.81), \mathrm{Y}(0.85)$, and $\mathrm{TiO}_{2}(0.73)$ and less strongly with $\mathrm{Zr}(0.64)$. The correlation of $\mathrm{Th}$ with $\mathrm{Ce}$ and $\mathrm{La}$ is readily explained by the fact that these elements are the principal cations in monazite, an abundant detrital phase in the conglomerates. This is confirmed by the very strong positive correlation of Ce with La (0.99, Figure 50). The correlation of $\mathrm{ThO}_{2}$ with $\mathrm{TiO}_{2}$ and $\mathrm{Zr}$ suggests a placer concentration mechanism, since monazite, zircon, and ilmenite have similar densities.

Kim (1979), in a study of a rather small number of conglomerate specimens (16) from the Nemo area of the Black Hills, South Dakota, determined that U correlated with $\mathrm{Y}(0.66), \mathrm{Au}+\mathrm{Ag}(0.60)$, and $\mathrm{Th}(0.53)$. Furthermore, $\mathrm{Au}+\mathrm{Ag}$ was found to correlate with $S(0.59)$. These correlations suggest, once again, the detrital origin of $\mathrm{U}$ and the association of $\mathrm{Au}$ and $\mathrm{Ag}$ with pyrite.

More recently, Redden (1980) published the results of a geochemical study of 95 borehole samples from the Nemo area of the Black Hills, South Dakota. The samples (which included conglomerates and arenites) were analyzed for 29 
elements (Table 25). A correlation matrix and a cluster variable dendogram were generated for 24 of the elements (Table 5 and Figure 22 of Redden, 1980).

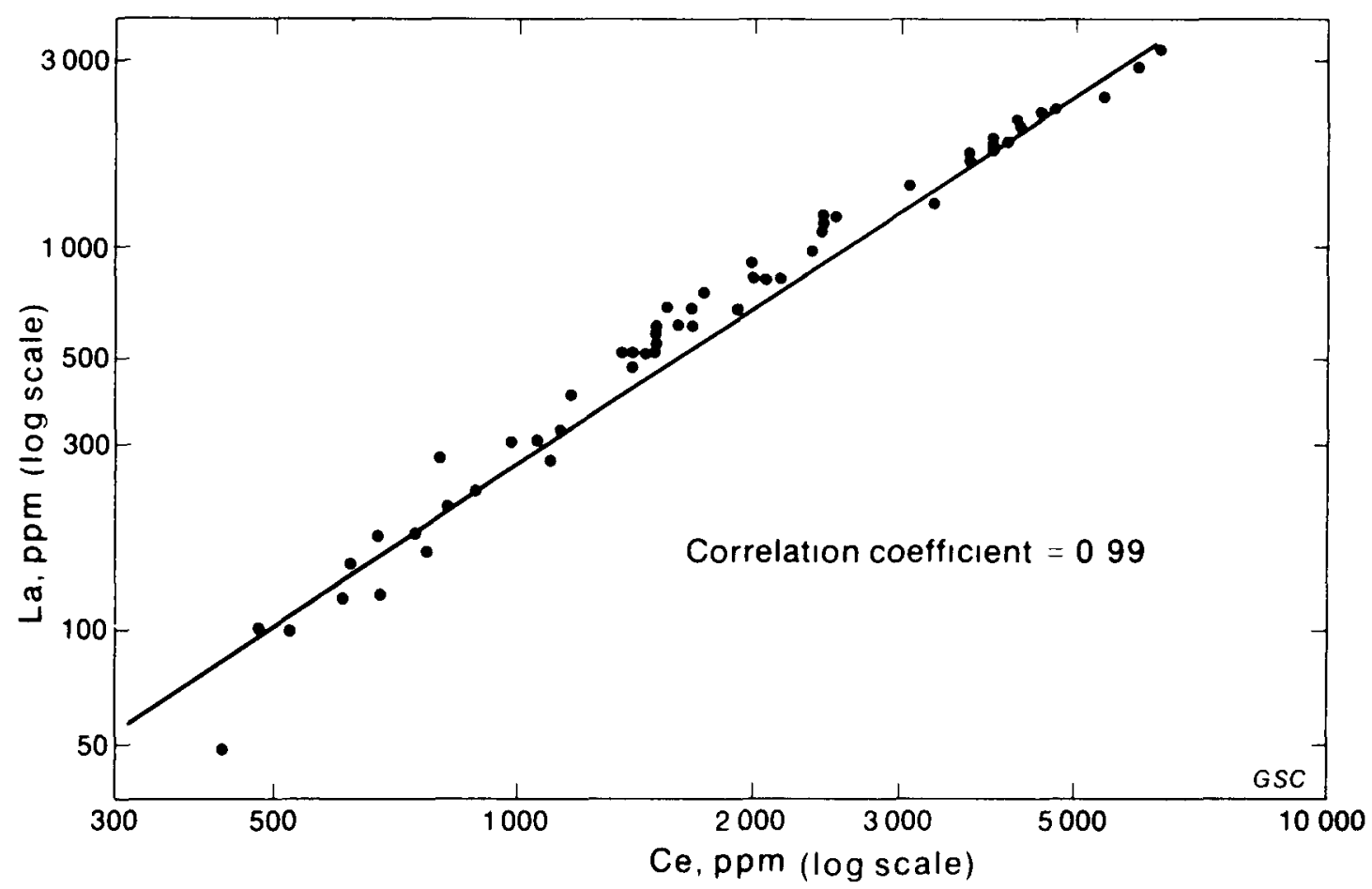

Figure 50. Scatter diagram showing Ce concentration plotted against La concentration in samples from the Rio Algom-Denison ore reef (from Theis, 1979).

Redden's data is not directly comparable with that of the other studies cited previously, since his statistical analyses were based on both conglomerates and on the host arenites. Of the samples analyzed, slightly over half were described as conglomerates, while the remainder included very coarse-grained and granule-bearing arenites, some of which contained scattered pebbles or conglomeratic layers.

Table 25 confirms many of the geochemical fingerprints we have established for uraniferous conglomerates and their host arenites. For example, the mean $\mathrm{Na}$ and $\mathrm{Ca}$ concentrations are low; the mean $\mathrm{K}$ and $\mathrm{Al}$ concentrations are relatively high. Other notable features include average $U$ and Th concentrations of 29 and $66 \mathrm{ppm}$, respectively. Redden estimated that, if the effects of surface leaching of uranium were excluded, the average $T h / U$ ratio of his samples would be 3.0 or slightly less. 
Table 25. Statistical summary for drill-core samples, Nemo area, South Dakota (modified from Redden, 1980).

\begin{tabular}{|c|c|c|c|c|c|c|c|c|}
\hline ELEMENT & $\begin{array}{c}\text { DETECTION } \\
\text { LIMIT }\end{array}$ & $\begin{array}{l}\text { MINIMUM } \\
\text { VALUE } \\
\end{array}$ & $\begin{array}{l}\text { MAXIMUM } \\
\text { VALUE }\end{array}$ & MEAN & MEDIAN & MODE & $\begin{array}{l}\text { STANDARD } \\
\text { DEVIATION }\end{array}$ & $\begin{array}{c}\text { COEFFICIENT OF } \\
\text { VARIATION }\end{array}$ \\
\hline $\mathrm{Ag}$ & $<2$ & $<2$ & 29 & 11 & $<2$ & $<2$ & 15.6 & 1.4 \\
\hline $\mathrm{A} 1$ & $<0.05$ & $<0.05$ & 6.11 & 3.17 & 3.09 & 3.16 & 0.706 & 0.222 \\
\hline B & $<10$ & $<10$ & 39 & 15 & $<10$ & $<10$ & 5.7 & 0.4 \\
\hline $\mathrm{Ba}$ & $<2$ & $<2$ & 161 & 71 & 60 & 55 & 31.4 & 0.4 \\
\hline $\mathrm{Be}$ & $<1$ & $<1$ & 4 & 1 & $<1$ & $<1$ & 0.4 & 0.3 \\
\hline $\mathrm{Ca}$ & $<0.05$ & $<0.05$ & 5.25 & 0.38 & $<0.05$ & $<0.05$ & 0.852 & 2.215 \\
\hline $\mathrm{Ce}$ & $<10$ & $<10$ & 265 & 118 & 111 & 85 & 48.1 & 0.4 \\
\hline Co & $<4$ & $<4$ & 47 & 20 & 19 & 22 & 9.9 & 0.5 \\
\hline $\mathrm{Cr}$ & $<1$ & $<1$ & 1188 & 542 & 523 & 598 & 181.1 & 0.3 \\
\hline $\mathrm{Cu}$ & $<2$ & $<2$ & 201 & 60 & 51 & 48 & 34.9 & 0.6 \\
\hline $\mathrm{Fe}$ & $<0.05$ & $<0.05$ & 6.78 & 3.28 & 3.15 & 3.59 & 1.184 & 0.360 \\
\hline $\mathrm{K}$ & & 0.08 & 1.71 & 0.90 & 0.88 & 0.87 & 0.263 & 0.293 \\
\hline $\mathrm{Li}$ & & 1 & 32 & 9 & 7 & 5 & 6.1 & 0.6 \\
\hline $\mathrm{Mg}$ & $<0.05$ & $<0.05$ & 3.01 & 0.54 & 0.44 & 0.42 & 0.409 & 0.763 \\
\hline $\mathrm{Mn}$ & $<4$ & $<4$ & 1588 & 213 & 157 & 154 & 196.3 & 0.9 \\
\hline Mo & $<4$ & $<4$ & 29 & 5 & $<4$ & $<4$ & 4.2 & 0.7 \\
\hline $\mathrm{Na}$ & $<0.05$ & $<0.05$ & 3.02 & 0.14 & 0.05 & 0.05 & 0.445 & 3.277 \\
\hline $\mathrm{Nb}$ & $<4$ & $<4$ & 30 & 15 & $<$ & $<$ & 12.7 & 0.8 \\
\hline $\mathrm{Ni}$ & $<2$ & $<2$ & 121 & 60 & 56 & 53 & 23.4 & 0.4 \\
\hline $\mathbf{P}$ & & 18 & 374 & 117 & 106 & 104 & 56.3 & 0.5 \\
\hline Sc & $<1$ & $<1$ & 11 & 5 & 5 & 4 & 1.4 & 0.3 \\
\hline $\mathrm{Sr}$ & $<1$ & $<1$ & 48 & 10 & 8 & 7 & 7.5 & 0.7 \\
\hline Th & & 2 & 504 & 66 & 59 & 60 & 57.8 & 0.9 \\
\hline $\mathrm{Ti}$ & $<10$ & $<10$ & 2081 & 707 & 533 & 238 & 519.8 & 0.7 \\
\hline$U$ & & 3.35 & 292.60 & 29.43 & 19.57 & 12.37 & 35.366 & 1.202 \\
\hline $\mathrm{V}$ & & 2 & 56 & 31 & 29 & 26 & 11.0 & 0.3 \\
\hline $\mathrm{Y}$ & $<1$ & $<1$ & 49 & 13 & 12 & 11 & 6.1 & 0.5 \\
\hline $\mathrm{Zn}$ & $<2$ & $<2$ & 114 & 20 & 17 & 15 & 13.5 & 0.6 \\
\hline $\mathrm{Zr}$ & $<2$ & $<2$ & 483 & 96 & 79 & 67 & 56.0 & 0.6 \\
\hline
\end{tabular}

NOTE: U equals total uranium as determined by neutron activation. All values in ppm except for $\mathrm{Al}, \mathrm{Ca}, \mathrm{Fe}, \mathrm{Mg}, \mathrm{Na}$, and $\mathrm{K}$ which are in weight percent. 
If we compare data from the Witwatersrand (Table 23) with the figures from the Nemo area (Table 25), it is apparent that the latter are nowhere near as rich in base metals ( $\mathrm{Co}, \mathrm{Zn}, \mathrm{Cu}$, and $\mathrm{Ni}$ ) as the former.

Redden noted relatively strong correlations between $\mathrm{K}$ and $\mathrm{A} 1$ ( 0.77 , associated in muscovite), $\mathrm{U}$ and $\mathrm{Th}(0.62), \mathrm{Ce}$ and $\mathrm{Zr}(0.79)$, and $\mathrm{Y}$ and $\mathrm{Zr}(0.72) .^{1}$ Redden was not able to substantiate Kim's (1979) finding that there is a significant correlation of $U$ and $Y$ in the Nemo conglomerates. He ascribed the lack of correlation of Th with $\mathrm{Cr}, \mathrm{Zr}$, and $\mathrm{Ti}$ to factors such as the differing source areas for some of these elements.

\section{Lateral Variations in Conglomerate Chemistry}

As in the case of lateral changes in heavy mineral grain size, geochemical plots can be presented as two-dimensional graphs or as contoured maps. Selected examples of both types are presented below.

Two-Dimensional Plots

Theis (1979) has determined statistical correlations of several geochemical and sedimentological parameters in Matinenda conglomerates. The sedimentological parameter used in most of the correlations is pebble size, which is an appropriate choice since pebble size is a measure of distance down the paleoslope.

Theis found positive correlations of pebble size with $\mathrm{U}_{3} \mathrm{O}_{8}$ concentration, and of pebble size with the $\mathrm{U}_{3} \mathrm{O}_{8} / \mathrm{ThO}_{2}$ ratio (Figures 39 and 51). As pebble size decreases down the paleoslope in the Matinenda Formation, the concentration of $\mathrm{U}_{3} \mathrm{O}_{3}$ can be expected to decrease relative to that of $\mathrm{ThO}_{2}$.

Several geochemical variables were found to increase with decreasing pebble size. These include $\mathrm{Zr}, \mathrm{Y}, \mathrm{Ce}, \mathrm{TiO}_{2}$, and $\mathrm{ThO}_{2}$ (Figures 52 and 53). The increasing concentrations of these elements with decreasing pebble size are thought to be due to considerations of hydraulic equilibrium. The uraninite grains have a density almost double that of monazite, zircon, ilmenite, and titaniferous magnetite. Uranium is thus concentrated along with larger pebbles, while zircon, monazite, titaniferous magnetite, and ilmenite were concentrated further down the paleoslope, with smaller pebbles. It must be emphasized that Theis' data are representative of only a few kilometers of fluvial paleoslope in one ore horizon of the Quirke ore zone. At points further down the paleoslope, the concentrations of thorium, titanium, and related elements will inevitably decrease as yet-lighter minerals are deposited in hydraulic equilibrium with ever-decreasing pebble sizes.

Similar relations have been detected in the Welkom area of the Witwatersrand. Here, however, uraninite is the relatively light mineral, while gold, being much heavier, is deposited along with larger pebbles higher up the paleoslope (Minter, 1978). The U/Au ratio increases from 1 or 2 to 35 over a $20 \mathrm{~km}$

\footnotetext{
${ }^{1}$ The Pearson correlation coefficients of the natural logarithms of the variables are quoted here. Redden (1980) also gave Spearman correlation coefficients, which differ very little from the Pearson parameter.
} 
distance down the paleoslope (Figure 37). Over this same interval, mean pebble sizes decrease from over $40 \mathrm{~mm}$ to less than $20 \mathrm{~mm}$ (Figure 47), while mean pyrite size decreases from $1 \phi(0.5 \mathrm{~mm})$ to $3 \phi(0.125 \mathrm{~mm})$.

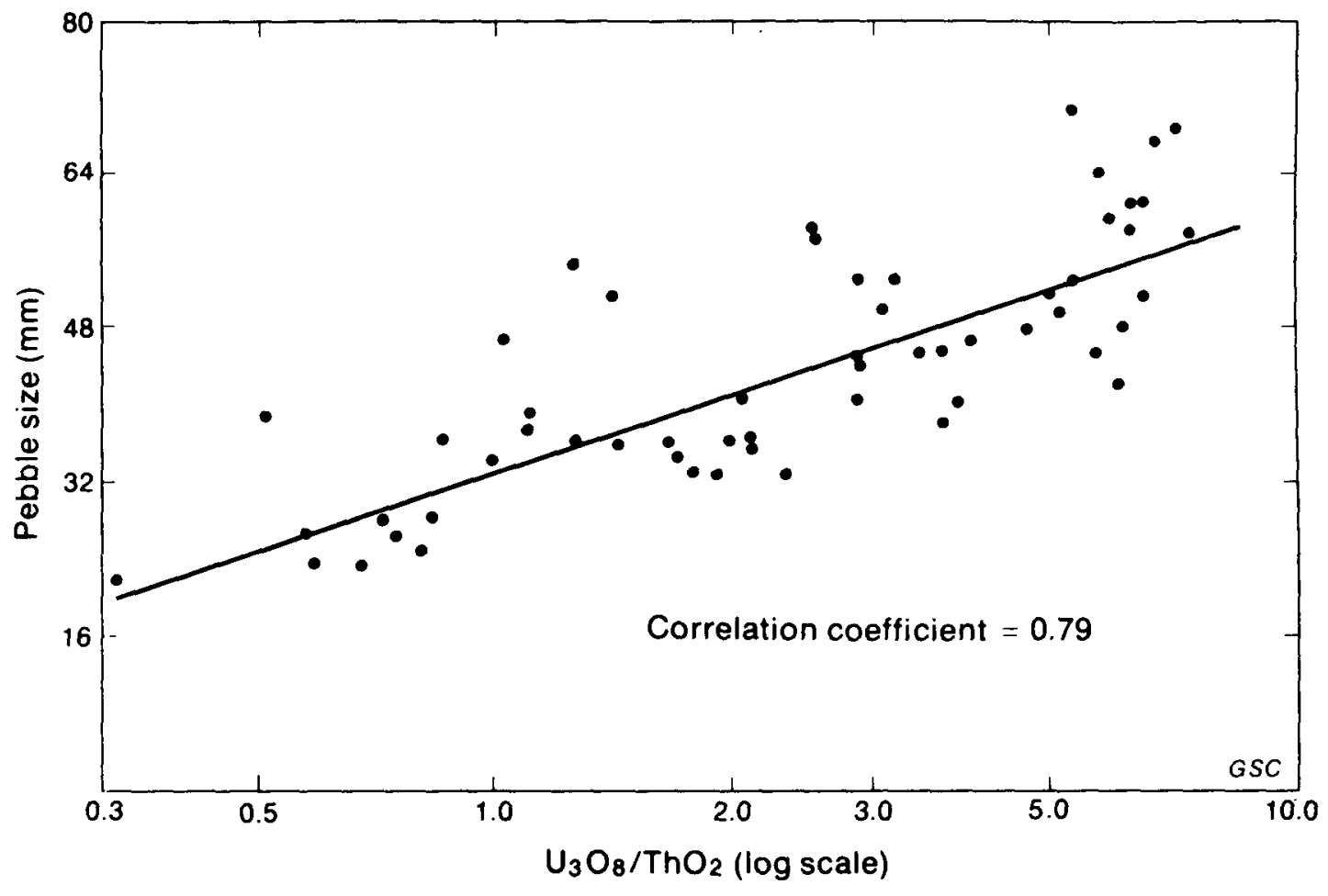

Figure 51. Scatter diagram showing the $\mathrm{U}_{3} \mathrm{O}_{8} / \mathrm{ThO}_{2}$ ratio plotted against pebble size of the Rio Algom-Denison ore reef (from Theis, 1979).

In summary, geochemical patterns can be related to sediment dispersal patterns, since successively lighter (or finer grained) minerals will shift into hydraulic equilibrium as one moves down the paleoslope, and thus be deposited. The overall pattern of element-zoning is likely to be gold (highest up the paleoslope), uranium, and thorium (lowest down the paleoslope). These considerations are of real economic importance since they offer the possibility of tracing thorium-rich conglomerates to uranium- and even gold-rich types.

\section{Contoured Geochemical Maps}

Gold and uranium distribution maps of several Precambrian conglomerate sheets have been presented by Minter (1978). Given the great local variations in gold and uranium concentrations, it is practically impossible to contour on the basis of each assay point. Minter has used moving average techniques to give a generalized picture of the gold distribution pattern. 


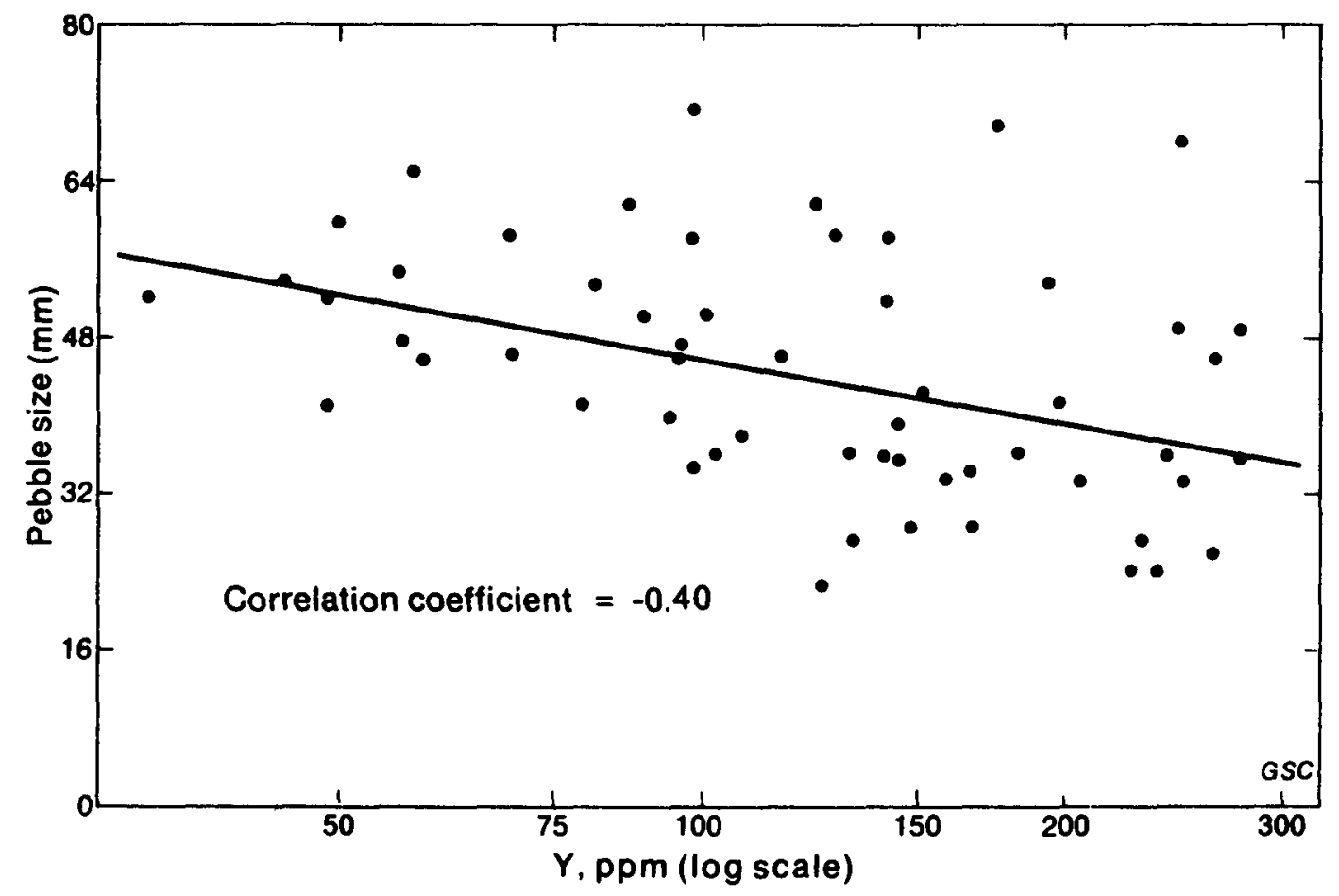

Figure 52. Scatter diagram showing $Y$ concentration plotted against pebble size of the Rio Algom-Denison ore reef (from Theis, 1979).

A set of geochemical maps for the Basal/Steyn placer of the Welkom area is shown in Figure 37 and is based on some 360,000 sample points. A "high gold" area (15 to $60 \mathrm{ppm}$ ) is shown to lie relatively high up the paleoslope, close to the structural "edge" of the basin. The "high uranium" area (150 to $500 \mathrm{ppm}$ $U$ ) is displaced down the paleoslope relative to the gold-rich area. The highest U/Au ratio areas are found in the most distal exposed parts of the paleosurface.

Minter (1978) presented a similar series of maps for the Vaal Reef in the Klerksdorp area (F1gure 54). The placer thickness, gold content (average $15 \mathrm{ppm} \mathrm{Au}$ ), and uranium content (average $500 \mathrm{ppm} U$ ) vary sympathetically across the goldfield. The gold and uranium patterns seem to be "telescoped" here, so that no obvious separation of the elements is seen down the paleoslope.

A geochemical map of sorts was presented for the Matinenda Formation conglomerates by Lang and others (1976). The map (Figure 55) shows that the uraniferous conglomerate orebodies grade down paleoslope into areas of "uranium ore with high thorium content", which grade in turn to "radioactive conglomerate, typically thorium-rich, with some marginal uranium ore". 


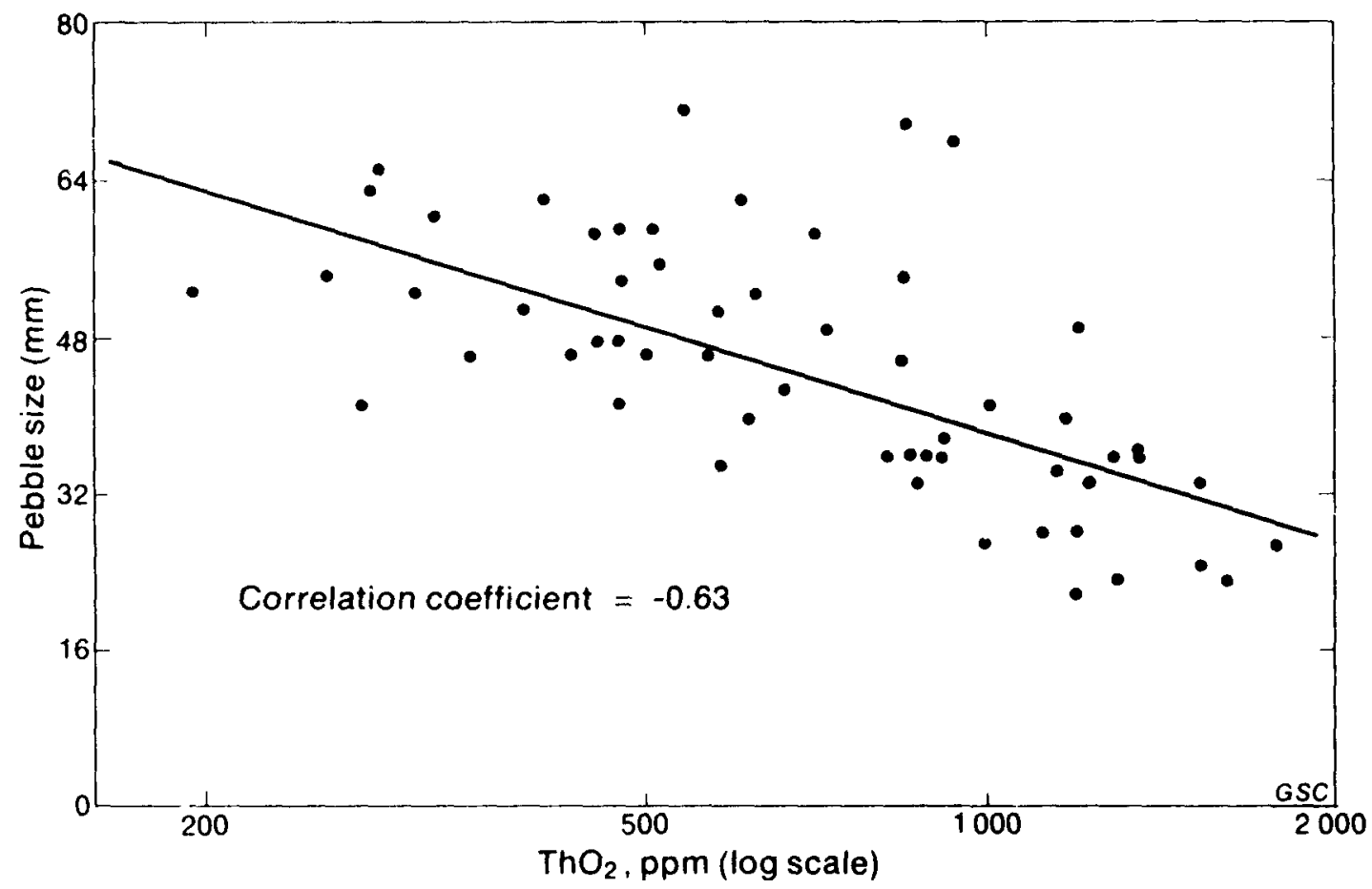

Figure 53. Scatter diagram showing $\mathrm{ThO}_{2}$ concentration plotted against pebble size of the Rio Algom-Denison ore reef (from Theis, 1979).

The contoured maps confirm that conglomerates are zoned with regard to their metal content. The economically important metals are concentrated (in many paleoplacers) in order of decreasing densities of their respective minerals as one moves down the paleoslope.

\section{Post-Depositional Modification of Conglomerate Matrix}

The conglomerates of the Witwatersrand and Elliot Lake districts can confidently be said to have undergone significant post-depositional modifications. If Mesozoic and Cenozoic sedimentary systems are used as hydrologic models, it is probable that the porous conglomerates acted as aquifers for periods on the order of $10^{7}$ to $10^{8}$ years after they were deposited. Given the fact that the conglomerates were buried under a cover of at least $10 \mathrm{~km}$ in parts of the Witwatersrand, the water in the aquifers and in sediment pore-spaces can be inferred to have been heated to some $200^{\circ} \mathrm{C}$. If one takes into account the fact that the conglomeratic sequence is overlain by several kilometers of a 

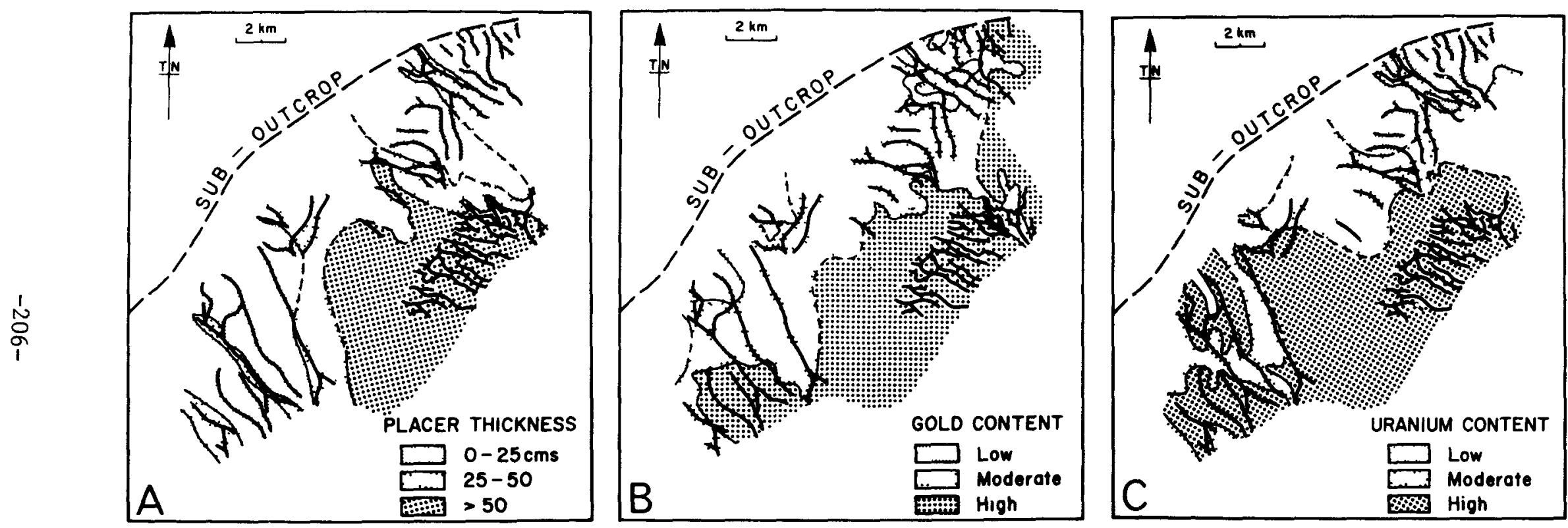

Figure 54. Moving average maps of the Vaal Reef, Klerksdorp area, showing:

A. placer thickness;

B. gold distribution pattern (average gold content is $15 \mathrm{ppm} \mathrm{Au}$ ); and

C. uranium distribution pattern (average uranium content is $500 \mathrm{ppm} \mathrm{U}$ ). From Minter, 1978. 
basaltic succession, a geothermal gradient of higher than the continental average of $20^{\circ} \mathrm{C} / \mathrm{km}$ can be inferred. Temperatures may well have risen to $300^{\circ} \mathrm{C}$ or even higher.

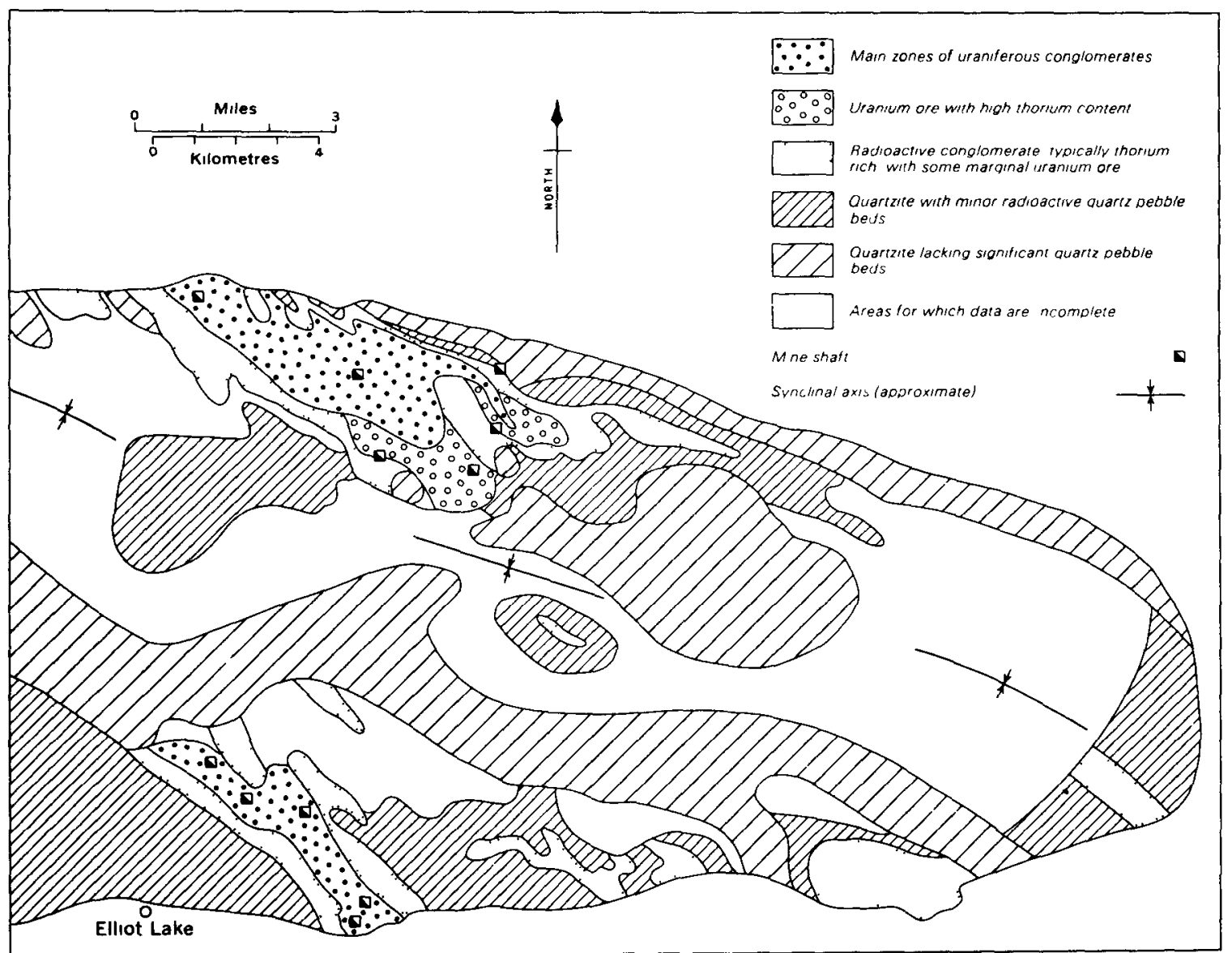

Figure 55. Map of the Quirke Syncline, showing the distribution of uranium and thorium in Matinenda conglomerates. Note that main orebodies grade down paleoslope to areas of Th-rich uranium ores, and that these are fringed by thorium-rich conglomerate with some marginal uranium ore (from Lang and others, 1976).

Thus, from a time that commenced shortly after the conglomerates were buried, the potential existed for their textural and mineralogical modification. There is abundant evidence of this modification in the Witwatersrand and, to a lesser extent, in the Elliot Lake district. In many cases, it is all but impossible to decide which changes are to be regarded as diagenetic and which 
metamorphic. This uncertainty is reflected in the paragraphs which follow. Most of the changes mentioned below were described in the sections dealing with the mineralogy of the conglomerate matrices. The diagenetic and metamorphic effects will only be briefly summarized here.

\section{Low-Temperature Modification}

Several of the mineralogical and textural changes seen in uraniferous conglomerates could have occurred at low temperatures $\left(100^{\circ} \mathrm{C}\right.$ or less). In fact, some could have occurred at ambient surface temperatures. In terms of economic geologic changes, the generation of concretionary pyrite and titania skeletons is probably the most important.

\section{Dissolution of Iron-Titanium Minerals}

Dimanche and Bartholome (1976) and Adams and others (1974) have reviewed the conditions under which iron-titanium minerals, such as ilmenite and ilmenomagnetite, are altered in sedimentary rocks. Under reducing conditions and near-normal $\mathrm{pH}$, the iron in such minerals is dissolved, leaving a framework of $\mathrm{TiO}_{2}$ (usually rutile) pseudomorphous after the original mineral. Thus the triangular "treillis" and rectangular "cloth" textures of ilmeno-magnetite are frequently preserved in the remaining titania aggregates.

In the Precambrian sediments in question, such alterations probably took place shortly after deposition at temperatures typical of shallow ground water. Given the low or very low oxygen concentrations suggested for the Precambrian atmosphere prior to $2,200 \mathrm{~m} . \mathrm{y}$. ago, any small amount of dissolved oxygen in meteoric water would be rapidly consumed by oxidation reactions at shallow levels in the hydrologic system. Below this level, ground waters were probably strongly reducing. Adams and others (1974) suggested that complexation of iron by organic molecules may have been a contributing factor in the removal of iron in Fe-Ti minerals in Mesozoic sandstones of the Grants mineral belt, New Mexico. In basins such as the Witwatersrand, Zumberge and others (1978) have shown that organic decomposition products were fluxed through witwatersrand sediments and gave rise to the "carbon" seams and granules associated with loci of uranium concentration. These organic molecules may we11 have contributed to the dissolution of Fe-Ti minerals in the way suggested by Adams and co-workers.

\section{Sulfidization of Black Sands}

Dimanche and Bartholomé have shown that ilmenite (and, by inference, ilmenomagnetite) can be pyritized "at surface temperatures in suitable environments". The principal requirements are a relatively low th and a source of $\mathrm{s}$. In organic-rich sediments, the source of $\mathrm{S}$ usually proposed is $\mathrm{H}_{2} \mathrm{~S}$, derived by bacterial reduction of sulfate ions. Such a $S$ source, on the face of it, appears to be inappropriate in the system in question, since the sulfur isotopic ratios of Witwatersrand and Matinenda pyrites do not show the characteristic enrichment in the lighter isotope. However, Krauskopf (1979) has alluded to recent advances in the area of $S$ isotope geology, which suggest that biologic sulfate reduction does not always cause an isotopic shift. Thus, biologically produced $\mathrm{H}_{2} \mathrm{~S}$ could still be the pyritizing agent. Other possibilities include volcanic $\mathrm{H}_{2} \mathrm{~S}$ (J.A. Robertson, 1976) or, as has been suggested 
by Houston and Kar1strom (1979), $\mathrm{HS}^{-}$in pore solutions. The latter could have been produced by decomposition of primitive plants in the sediments in question.

The timing of sulfidization is difficult to establish. In that the dissolution of $\mathrm{Fe}-\mathrm{Ti}$ oxides that gave rise to the $\mathrm{TiO}_{2}$ skeletons (alluded to in the previous section) was almost certainly a post-burial phenomenon, it seems likely that the related process of sulfidization must also have occurred within the sedimentary pile. Once sulfidized, some grains were possibly exhumed one or more times and transported as detrital pyrite grains before their final burial.

\section{Formation of Concretionary Pyrite}

In their present form, most concretionary pyrite grains show rounded and abraded outlines typical of detrital clasts. They were thus probably formed diagenetically within a sediment, exhumed, transported, and abraded before being finally deposited.

The extreme fragility of skeletons composed of pyrite crystallites (Figure 43.3) led some investigators to state that such grains could not have been transported as sedimentary particles. This argument is no longer considered valid, since the pore spaces may well have been filled prior to transportation, resulting in a fairly durable clast.

Dimroth (1979), on the basis of pyrite textural studies, believed that some pyrite types in Witwatersrand sediments grew in situ during diagenesis. He called on sulfate-reducing bacteria to supply the necessary sulfur. He did not address the problem that would then arise relative to the sulfur isotopic composition of the resulting pyrite grains.

\section{Formation of Brannerite}

The only definite fact concerning the time of formation of brannerite was that it postdates the period of diagenetic dissolution of Fe-Ti minerals. Uranium adsorption on the $\mathrm{TiO}_{2}$ skeletons could have occurred shortly after their formation. The fact that brannerite normally contains a few percent of $\mathrm{ThO}_{2}$ could be taken as evidence of a higher temperature environment of formation of this mineral, since low-temperature systems usually carry little or no $\mathrm{ThO}_{2}$ in solution (Frondel, 1958). However, the effects of organic complexing agents (which may well have been present in the ground-water system in question) on thorium solubility remain to be evaluated.

\section{Intermediate- and High-Temperature Modification}

A corollary to the "modified placer" hypothesis for the origin of Precambrian uranium- and gold-bearing conglomerates is that "metamorphic" conditions caused significant local redistribution of elements. The precise temperature ranges over which these redistributions took place are difficult to fix. A very brief summary of the effects of redistribution is given below. 
Sulfide Minerals and Gold

A host of "secondary" sulfide minerals, with or without gold, show indisputable evidence of having been deposited after lithification of the conglomerates had commenced. The sulfides in question include pyrrhotite, chalcopyrite, sphalerite, galena, and gersdorffite. They frequently fill cracks in brittle detrital grains, such as quartz, chromite, and compact pyrite. They are also seen to replace certain constituents, including matrix phyllosilicates.

Gold, in particular, shows striking evidence of "late" movement. In Figure 70.6, for example, gold is shown filling pressure shadows around compact pyrite grains in a carbon seam. Gold and metallic ions could well have been carried as organic or bisulfide complexes.

The sphalerite geothermometer, as applied in the Witwatersrand, has been largely discredited (Feather, in press). This author has used the gersdorffite-cobaltite geothermometer to suggest that Witwatersrand conglomerates were metamorphosed at "minimum temperatures in the region of 400 to $600^{\circ} \mathrm{C}$." He concedes, however, that this geothermometer has not been widely tested and could be in error.

\section{Uraninite}

There is some evidence that uranium minerals, particularly uraninite, react with silicate minerals under conditions of elevated temperature, to form uranothorite, $\mathrm{Th}>\mathrm{U}\left(\mathrm{SiO}_{4}\right)$. Ortlepp (1962) noted that the replacement of Dominion Reef uraninite by uranothorite started at the periphery of a grain and proceeded inward. The alteration advanced preferentially along cracks in the uraninite grains. Ortlepp noted that the reaction of thorian uraninite with silica to form uranothorite would involve liberation, and possible 1oss, of some uranium.

Another area of uranothorite development is in the Agnew Lake area, east of Elliot Lake in Ontario. Here Huronian sediments have been strongly deformed, and presumably more strongly metamorphosed than at Elliot Lake (J.A. Robertson, 1976). Although there is no published textural evidence for the origin of uranothorite in this deposit, it could have formed by the reaction described from the Dominion Reef. A third possible example is in the Medicine Bow Mountains of Wyoming, where uranium is present in silicate phases, including coffinite and thorite (Houston and others, 1979). The conglomerates of this area have been subjected to amphibolite-grade metamorphic conditions.

There is some evidence of uranium mobilization in uraniferous conglomerates in the Jacobina area, Brazil. Cox (1967) and Gross (1968) stressed that both gold and uraninite had, to some extent, been mobilized into small fracture systems associated with the conglomerates. The metamorphic grade in this area is probably at the amphibolite stage with the development of mineral suites in pelitic rocks which include garnet, andalusite, staurolite, biotite, and muscovite (in the north) and garnet, cordierite, anthophyllite, and sillimanite further south (Cox, 1967).

The probable fate of uranium under amphibolite or granulite conditions is outlined by Gabelman (1977). Radioelements, including uranium and thorium, are likely to be fractionated into the first-formed partial melts, unless 
they are locked in refractory minerals. According to this author ( $p$. 45), the "more readily mobilized, simple uranium silicates and oxides may be among the first constituents fractionated". Nishimori and others (1977) concur, noting that there is some evidence that $\mathrm{Th} / \mathrm{U}$ ratios increase with metamorphic grade, due to selective mobilization of uranium.

\section{Silicate Minerals}

Silicate minerals were no doubt modified within uraniferous conglomerates over a wide range of temperature. Some minerals, such as chloritoid, indicate widespread development of greenschist-grade conditions through the Witwatersrand Basin.

The timing of the development of the pervasive quartz cement in the conglomerates is difficult to determine. This cementation event would have had a marked effect on the conglomerates, drastically reducing their porosity and the ease with which elements had formerly been redistributed within them. Viljoen (1967) noted that the quartz cement formed "relatively late" in the history of the conglomerate, since, in places, it was seen to replace minerals such as chlorite and chloritoid. If this observation is generally applicable, the conglomerates may have been fairly porous through to the onset of greenschist-grade metamorphic conditions.

\section{Conglomerate Sedimentology}

The sedimentological characteristics of uraniferous conglomerates have been studied in great detail, particularly in the Witwatersrand Basin. Scores of theses and several published papers have been devoted to the topic. In the following paragraphs, the results of some of the better documented relations are presented.

\section{Matinenda Conglomerates}

Pienaar (1963) published a series of observations relevant to conglomerate sedimentology in the Elliot Lake district.

Conglomerate Fabric

Pienaar studied the preferred orientation of pebbles in Matinenda conglomerates. He showed that the long axes of pebbles are either parallel to or normal to the direction of stream flow determined from cross-beds. He suggested that pebble shape was a controlling factor, rod or ellipsoidal pebbles coming to rest with long axes parallel to flow, disc-shaped pebbles being oriented perpendicular to flow. In addition, a downstream imbrication of some pebbles was established. Pienaar suggested that this imbrication was an expression of downstream-dipping cross-stratification in the conglomerates, the clasts lying with long and intermediate axes in the plane of the crossstrata. 
Examples of the internal structures of oligomictic uraniferous conglomerates were provided by Pienaar (1963). Individual conglomerate beds are from one pebble to about $3 \mathrm{~m}$ thick. Zones of alternating conglomerate, conglomeratic subarkose, and pebble-free subarkose are up to $15 \mathrm{~m}$ thick. These zones are fairly persistent, according to Pienaar, being traceable for "considerable distances". Orebodies constitute all or part of such zones and are from 2.5 to $10 \mathrm{~m}$ thick.

Pienaar noted that ore zones tend to comprise multiple sedimentary units that are generally lenticular and intimately interlayered. Individual sedimentary units in ore zones comprise we11-packed conglomerate, loose1y packed conglomerate, conglomeratic subarkose and pebble-free subarkose. Figure 56 illustrates typical lateral and vertical relations in Matinenda conglomerates, including lenses and "feathering out" of massive conglomerates into several thin pebble layers.

Sediments of the ore zone are commonly cross-bedded (both trough and tabularplanar types). Foresets are frequently marked by scattered pebbles and by pyrite concentrations. The latter are up to $5 \mathrm{~cm}$ thick and are highly radioactive, containing black uranium minerals. In some cases, according to Plenaar, "seams" of black uranium minerals commonly contain as much as 40 percent $\mathrm{U}_{3} \mathrm{O}_{8}$.

The basal contacts of conglomerates are frequently erosive surfaces with depths of scour reaching about $25 \mathrm{~cm}$. The distribution of uranium can usually be related to sedimentary features. The best packed conglomerates, even if they do not occur at the base of a conglomeratic zone, tend to carry the highest grades of uranium. Though most pyrite-rich conglomerates are uraniferous, Pienaar stresses that this need not always be the case. Some pyritic conglomerates are only weakly mineralized by uranium, and some highly radioactive conglomerates contain relatively little pyrite.

McDowell (1957) and Pienaar (1963) agree that the internal structures of the conglomerates are typical of those formed in fluviatile systems. In terms of modern studies of fluvial systems, the conglomerates and conglomeratic subarkoses probably represent longitudinal gravel bars (Mial1, 1977) in braided stream complexes.

\section{Witwatersrand Conglomerates}

In the Witwatersrand, so much detailed sedimentological work has been done on conglomerates that it is necessary to select a few modern examples for further discussion. The studies of Minter (1978) and of Smith and Minter (1980) are used in that they interpret structures and the vertical sequences of sediment types in terms of modern models of fluvial sedimentation.

It is necessary to stress that Witwatersrand conglomerates show a highly varied set of characteristics. They vary from a single layer of scattered pebbles to well-packed conglomerates, several meters thick. Thicker conglomerates (those over about $1 \mathrm{~m}$ thick) almost always contain lenticular partings of pyritic arenite or of pebbly pyritic arenite. This variation is true even 
of single conglomerate sheets. Minter (1976) stressed that the Vaal Reef of the Klerksdorp area is usually a light gray "pebbly siliceous quartzite", but that nearly every conceivable combination of sand and pebble layers is present, specifically:

(1) a few $\mathrm{cm}$ to several tens of $\mathrm{cm}$ of quartz arenite;

(2) a single row of scattered small pebbles with or without quartz arenite;

(3) a double or treble layer of pebbles with interstitial quartz arenite;

(4) a thin layer of quartz arenite overlain by a single layer of pebbles;

(5) a 10 to $45 \mathrm{~cm}$ thick layer of pebble-supported conglomerate (rare);

(6) a multilayered sequence of single pebble layers with intercalated quartz arenite layers (usually confined to channels); and

(7) consecutive layers of conglomerate, pebbly quartz arenite, conglomerate, quartz arenite, and pebbly quartz arenite.

\section{Lateral Variation}

Minter (1978) has stressed the lateral variations in the character of Witwatersrand paleoplacers. One of the best examples is the Steyn paleoplacer of the Welkom area, which can be studied and sampled for $20 \mathrm{~km}$ down the paleoslope. In the proximal areas, the placer comprises multiple overlapping scour channels with a mean quartz pebble size of $-4.5 \phi$.

Some 20 kilometers down the paleoslope, the placer is essentially a quartz arenite built by "shallow sandbars and dunes". Yellow mudstone veneers up to $1 \mathrm{~mm}$ thick mark periods of suspended sediment settling. Small pebbles (average quartz-pebble diameter is $-2.5 \phi$ ) lie at the base of trough cross-beds or form lag veneers on scour surfaces, particularly the basal scalloped erosion surface of the placer. Multiple periods of sediment reworking within this facies of the Steyn placer are indicated by balls and flakes of yellow mudstone. These shaly clasts are found scattered in trough cross-bedded quartz arenite above erosive surfaces. According to Minter (1978), these features indicate that this facies of the Steyn placer was produced in a fluvial environment by the "unconfined flow of continuously shifting shallow braided streams".

Minter (1978) has used nomenclature developed by Miall (1977) to express the variation of sediment type within Witwatersrand placers. Seven components are recognized, three of them gravels (massive, trough cross-bedded, and planar cross-bedded), three of them sands (trough cross-bedded, planar crossbedded, and horizontal or plane-bedded), and one comprised of fine-grained sediment which settled out of suspension during periods of water stagnation (Table 26). This approach is a particularly useful one in that it allows a direct comparison of Witwatersrand conglomerates and various types of braided 
stream deposit. For example, if the sediment types suggest that a particular placer was formed under conditions of the "Platte type", then the plan-view distribution of sediments (and of heavy minerals) is likely to follow that of the Platte model.

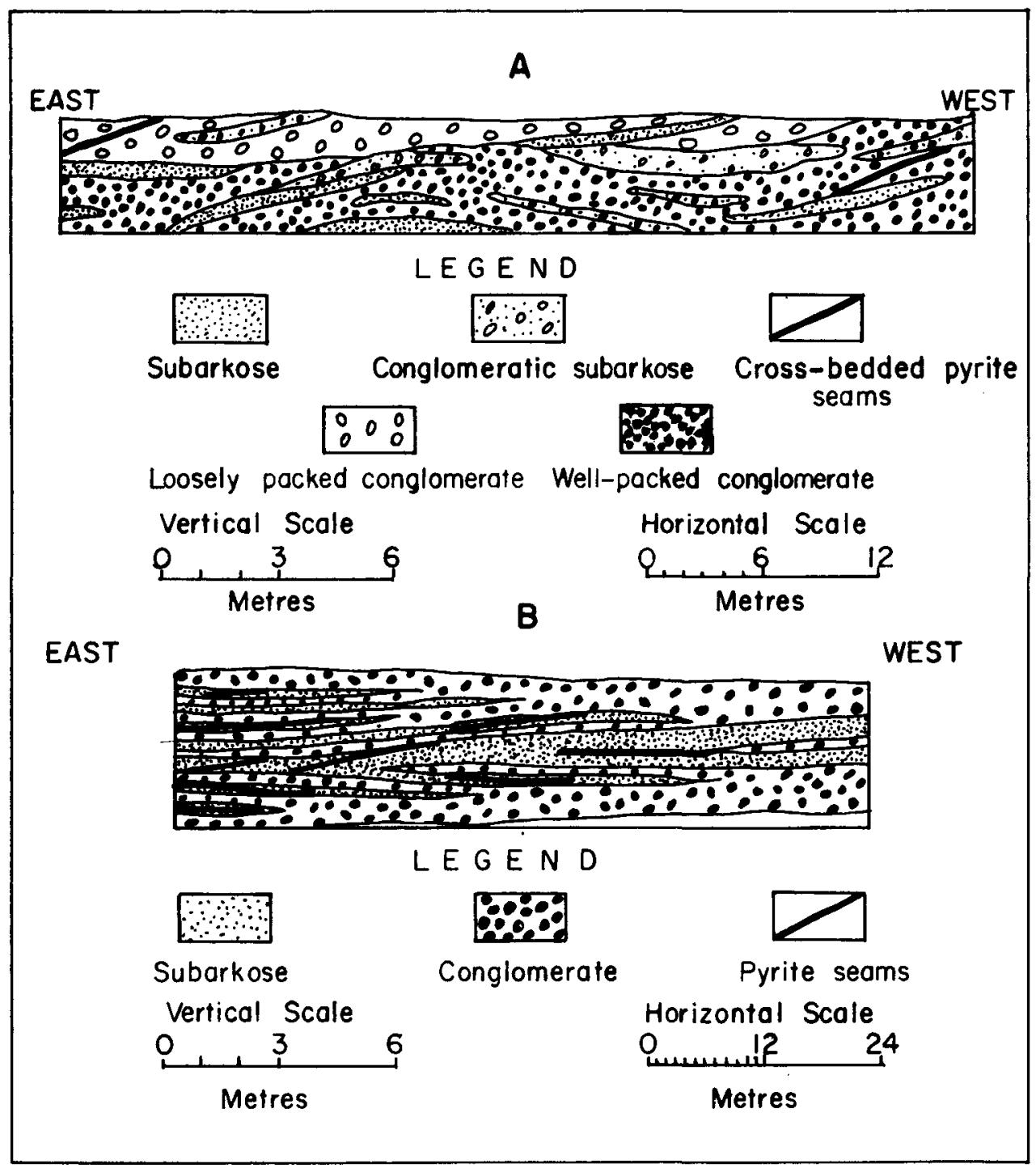

Figure 56. Vertical cross section through Matinenda conglomerates showing lensing and feathering out of well-packed and loosely packed conglomerates with subarkose and conglomeratic subarkose (after Pienaar, 1963). 
Table 26. Sedimentary features of several precambrian placers expressed in terms of common stratification types in modern braided stream systems (after Minter, 1978).

\begin{tabular}{|c|c|c|c|c|c|}
\hline PLACER & $\begin{array}{r}\text { MAJOR } \\
\text { FACIES } \\
\end{array}$ & $\begin{array}{r}\text { MINOR } \\
\text { FACIES } \\
\end{array}$ & $\begin{array}{c}\text { MEAN } \\
\text { PEBBLE } \\
\text { SIZE } \\
\end{array}$ & $\begin{array}{l}\text { URANIUM/ } \\
\text { GOLD RATIO } \\
\end{array}$ & MODEL \\
\hline $\begin{array}{l}\text { Steyn (proximal) } \\
\text { Steyn (distal) }\end{array}$ & $\begin{array}{l}\mathrm{Gt}, \mathrm{Gm} \\
\mathrm{St}, \mathrm{Sp}\end{array}$ & $\begin{array}{c}\mathrm{Gp}, \mathrm{St} \\
\mathrm{Gt}, \mathrm{Sh}, \mathrm{Fm}\end{array}$ & $\begin{array}{l}-4.5 \phi \\
-2.5 \phi\end{array}$ & $\begin{array}{l}<5 \\
40\end{array}$ & $\begin{array}{l}\text { Donjek } \\
\text { Platte }\end{array}$ \\
\hline $\begin{array}{l}\text { B (proximal) } \\
\text { B (distal) }\end{array}$ & $\begin{array}{l}\text { Gt, } \mathrm{Gm} \\
\mathrm{St}\end{array}$ & $\begin{array}{l}S t, S p \\
G t, S p\end{array}$ & $\begin{array}{l}-4.7 \phi \\
-2.5 \phi\end{array}$ & $\begin{array}{l}4-10 \\
>25\end{array}$ & $\begin{array}{l}\text { Donjek } \\
\text { Platte }\end{array}$ \\
\hline Vaa1 & St & Gt & $-3.2 \phi$ & $10-30$ & Platte \\
\hline $\begin{array}{l}\text { Ventersdorp Contact (proximal) } \\
\text { Ventersdorp Contact (distal) }\end{array}$ & $\underset{\mathrm{Gt}}{\mathrm{Gm}, \mathrm{Gt}}$ & St, Fm & $\begin{array}{c}\operatorname{Max} 40 \mathrm{~cm} \\
-3.4 \phi\end{array}$ & $\begin{array}{c}<5 \\
10-34\end{array}$ & $\begin{array}{r}\text { Scott } \\
\text { Donjek }\end{array}$ \\
\hline
\end{tabular}

$\mathrm{Gm}=$ massive grave1; $\mathrm{Gt}=\mathrm{trough}$ cross-bedded gravel; $\mathrm{Gp}=$ planar cross-bedded gravel; St $=\mathrm{trough}$ cross-bedded sand; $\mathrm{Sp}=$ planar cross-bedded sand; $\mathrm{Sh}=$ horizontally bedded sand; $\mathrm{Fm}=\mathrm{mud} \mathrm{drape}$. Nomenclature and abbreviations after Miall, 1977. 
Thus, in the B Placer of the Welkom area, proximal parts of the placer are dominated by massive and trough cross-bedded gravel with some trough and planar cross-bedded arenite. The assemblage is typical of Donjek-type braided stream systems. By contrast, distal parts of the same placer are dominated by trough cross-bedded arenite with some trough cross-bedded gravel and planar cross-bedded sand in an assemblage characteristic of Platte-type streams. According to Miall (1977), Donjek types frequently grade downstream to Platte types.

In unexplored or underexplored areas, the relations shown in Table 26 could prove to be useful indicators of the economic potential of certain conglomerates. In particular, the table shows that, relative to gold, uranium tends to be concentrated in the relatively distal parts of the braided fluvial system. ${ }^{1}$

\section{Uranium and Gold Distribution}

Smith and Minter (1980) have shown that gold and uranium concentrations in conglomerates and associated arenites are relatively strongly correlated (Figure 57). This figure shows that there is an overlap in values but that the heavy minerals are preferentially concentrated in the conglomerate relative to the arenite.

In a second diagram, it is shown that arenites and conglomerates with pyritic foresets are enriched in $U$ and $A u$ relative to conglomerates without pyritic foresets, and that arenites without pyritic foresets contain the lowest concentrations of these metals (Figure 58). In a third illustration of the sedimentary controls, it is shown that those conglomerates with significant carbon contain the highest grades of gold and uranium (Figure 59).

These relations suggest that a qualitative assessment of the uranium potential of a conglomerate could be made by a study of its structural and mineralogical attributes. Those conglomerates with the best packing, most resistant clasts, and the greatest concentration of pyritic foresets and of carbon are 1ikely to contain the most gold and uranium.

The physical processes responsible for the concentration of gold and uranium were almost certainly related to the stream velocity and turbulence distributions. Smith and Minter (1980) have given some convincing examples of the controls on the concentration of both uranium and gold in Witwatersrand paleoplacers. In one example, in the Leader Reef of the Welkom area, their underground mapping delineated a channel system, composed of a basal conglomerate overlain by interbedded arenite and conglomerate. The arenites on the left side of the channel (Figure 60) are planar cross-bedded with foresets dipping to the left (that is, towards the channel margin). The concentration

${ }^{1}$ It must be emphasized that the gold-uranium relations given in Table 26 are based on the Witwatersrand in general, where uraninite grains are relatively sma11. Where uraninite grains are larger, this mineral would be concentrated in the more proximal facies. 
of placer minerals (gold in this case) was found to be highest in conglomerates on the left-hand margin of the channel. Smith and Minter (1980) suggested that the concentration of gold was due to encroachment of a "bank-hugger" bar (see Figure 60) towards a channel margin. Under these conditions, water flow is concentrated in the narrow channel between bar and bank. Lighter minerals moved into this channel are flushed out, while heavier minerals are concentrated, along with pebbles, on the channel floor.

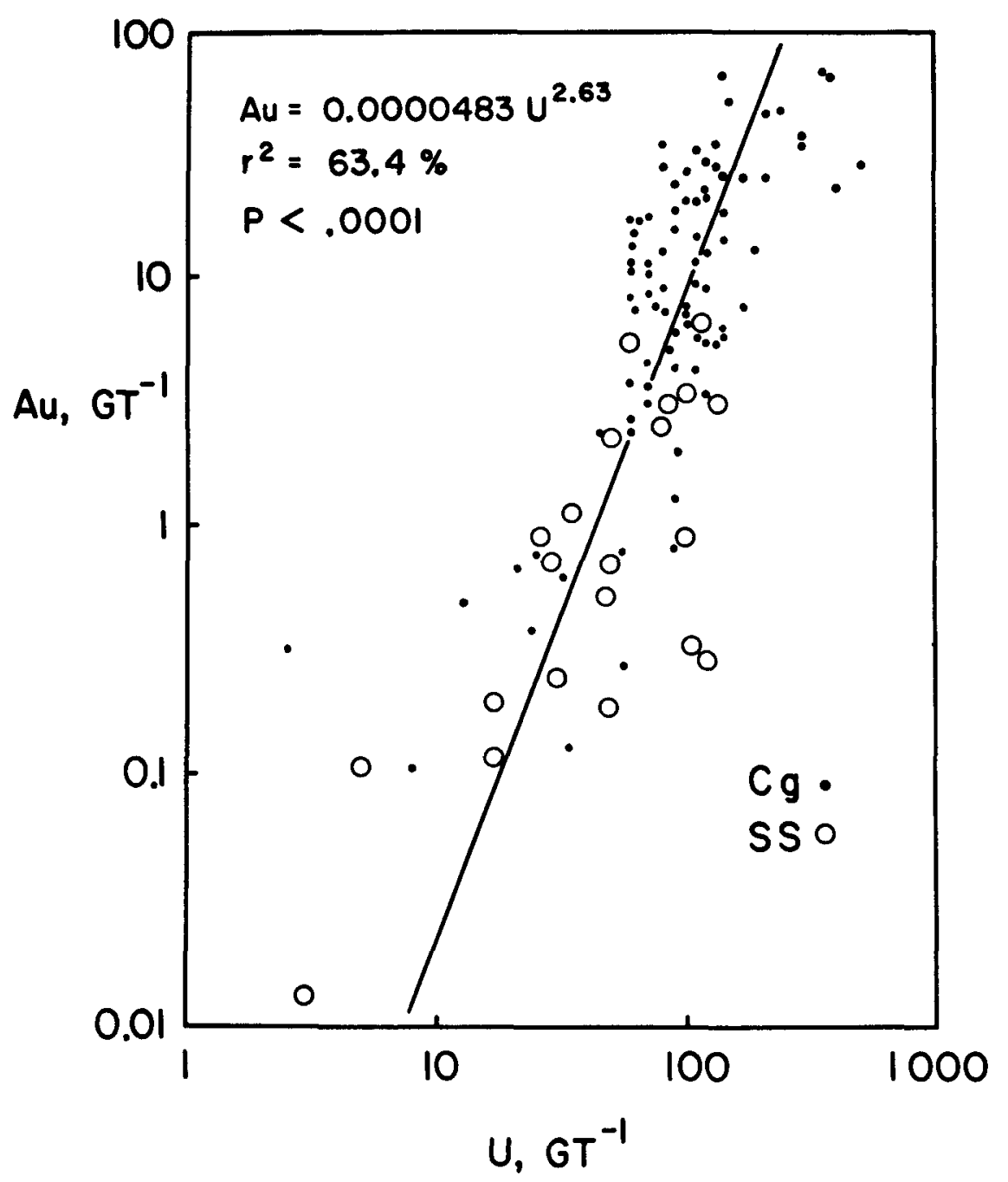

Figure 57. Scatter diagram showing gold and uranium concentrations in conglomerates and associated arenites of the Elsburg No. 5 Reef, Klerksdorp area (from Smith and Minter, 1980).

A second example is shown in Figure 61. Here, a longitudinal bar, composed of well-sorted gravel, is overlain by a thin layer of planar cross-bedded pyritic arenite. The highest uranium and gold values are located in the arenite, rather than the gravel bar. Smith and Minter suggested that this occurrence probably represents the downstream end of a tapering channel bar, 
where flows on both sides of the bar merge, with water flow moving over the bar surface. Such zones of flow convergence are areas in which heavy minerals tend to be concentrated.

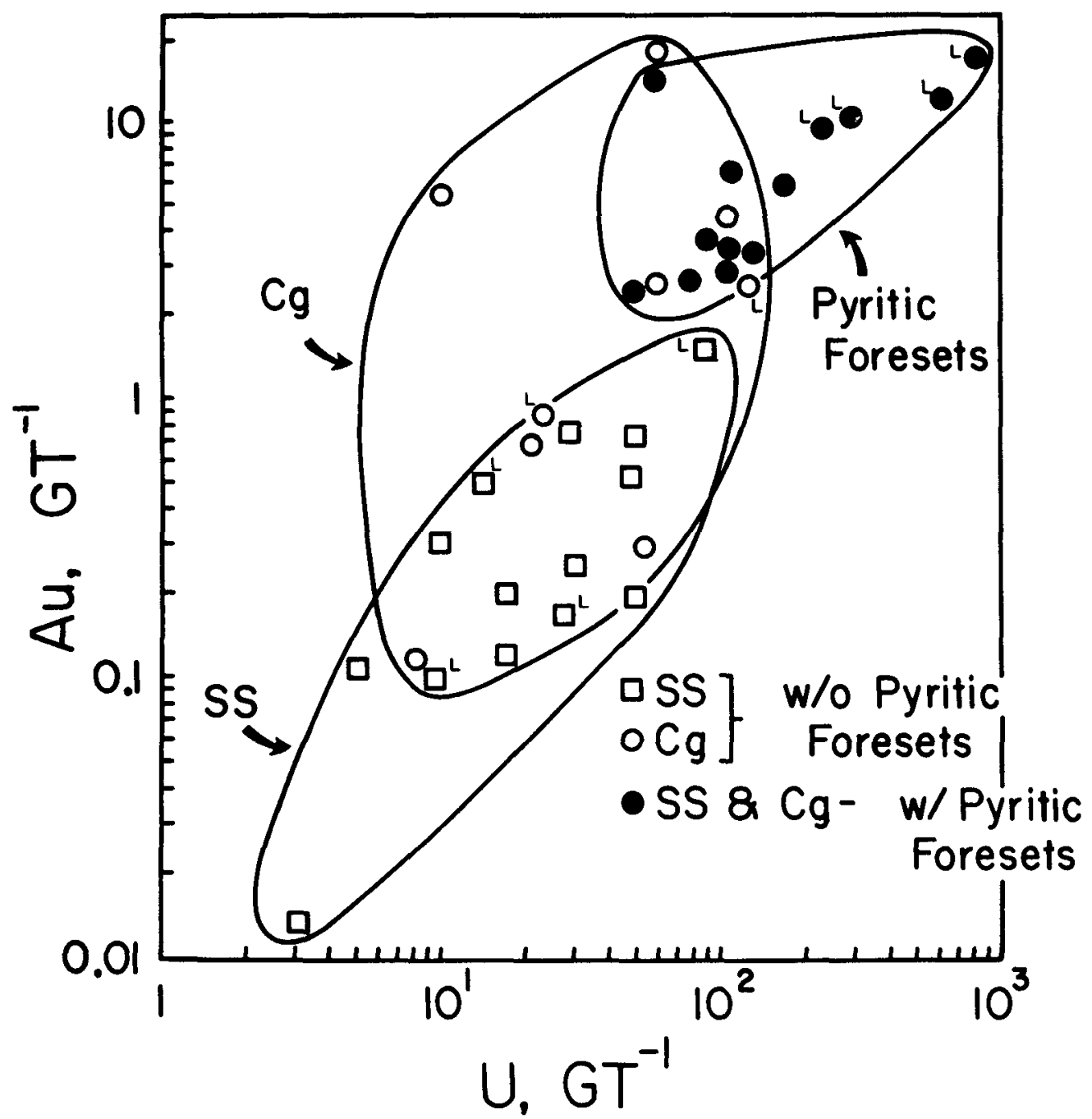

Figure 58. Scatter diagram of gold and uranium concentrations in arenites (SS), conglomerates ( $\mathrm{Cg}$ ) with and without pyritic foresets for the E1sburg No. 5 Reef and Leader Reef (points marked L), Klerksdorp and Welkom Goldfields, respectively (from Smith and Minter, 1980).

\section{Relation of Uranium and Carbon}

De Kock (1964) noted that a feature which nearly all Witwatersrand conglomerates had in common was the presence of "carbon". It is widely believed that the presence of carbon in a conglomerate is an indication of high uranium and gold values. This reasoning is logical, given the probable origin 
of the carbon. It is shown in a subsequent section that there is good evidence that the carbon was formed by radiolytic polymerization of the water-soluble decomposition products of primitive plants in the basin. Polymerization is thought to be largely due to the generation of free radicals in organic compounds by ionizing radiation. Given this relation, the presence of carbon in the conglomerate should depend only on the availability of suitable organic molecules and the presence of a high flux of ionizing radiation. Thus, carbon should be found intimately associated with radioactive minerals in the conglomerate, principally uraninite.

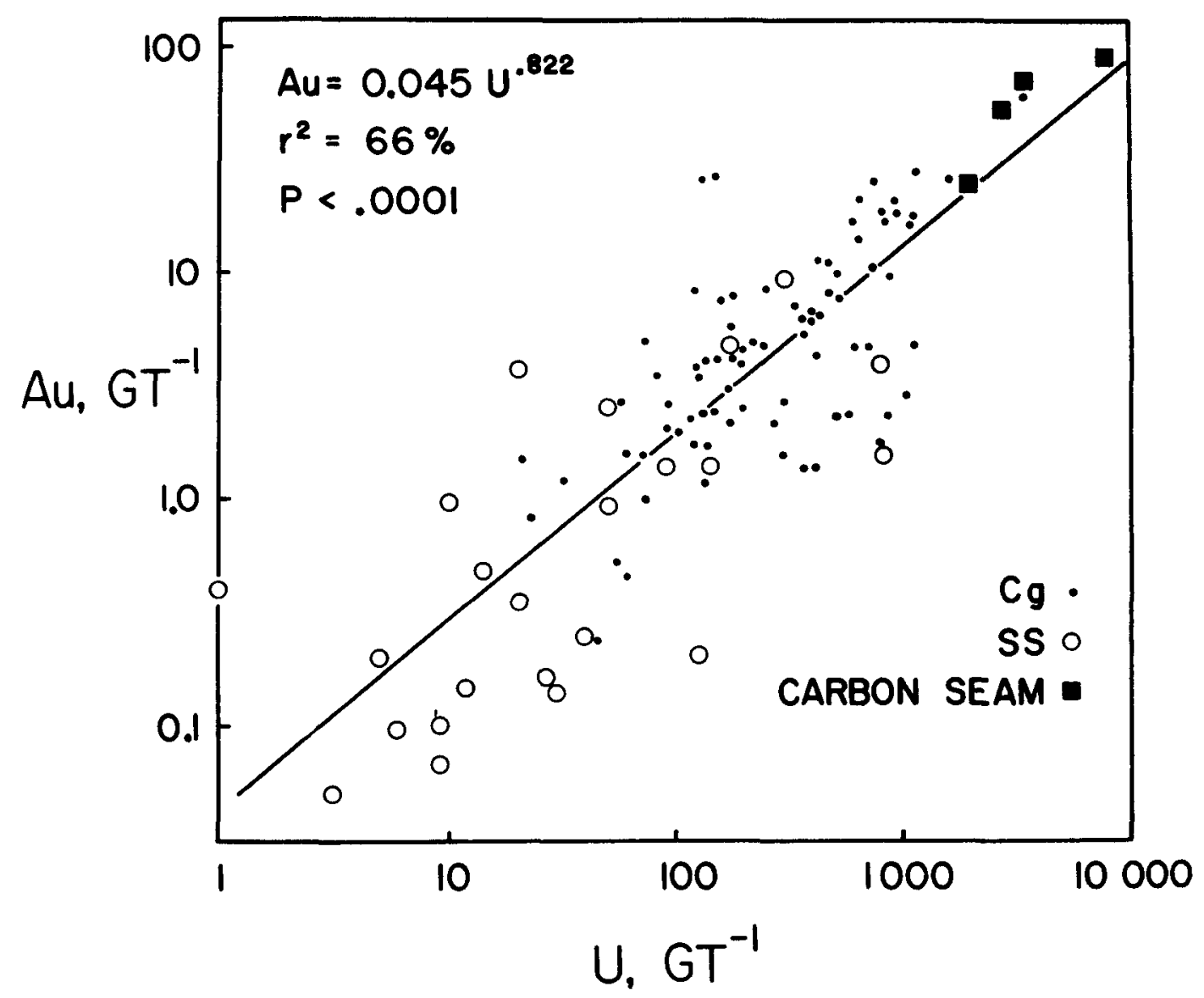

Figure 59. Scatter diagram of gold versus uranium concentration in the Leader Reef, Welkom area, showing variations for arenites (SS), conglomerates $(\mathrm{Cg})$ and carbon-rich facies of the placer (from Smith and Minter, 1980).

Minter (1978) noted that high uranium concentrations are associated with carbonaceous seams but that the areal distribution patterns of uranium and carbon do not necessarily coincide. Such a relation could possibly be explained by the distribution of the primitive plants which are thought to have 


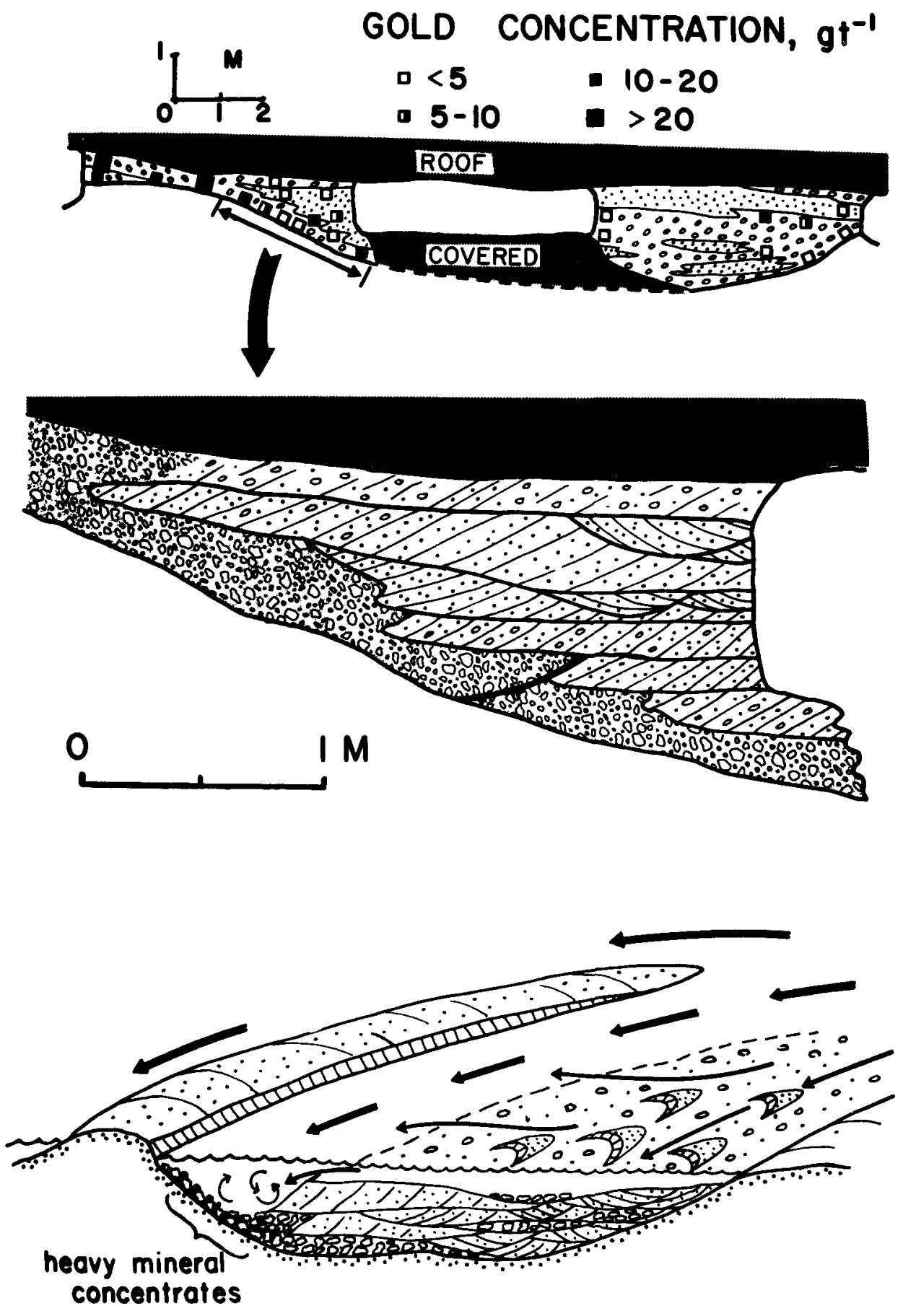

Figure 60. Distribution of gold on the basal scoured surface of a channel, Leader Reef, Welkom Goldfield. Foresets in the associated arenite are inclined towards the channel margin that contains the highest gold concentrations. The sketch above shows the probable mechanism of formation of the basal gravel lag, the foresets, and the heavy mineral concentrations (from Smith and Minter, 1980). 
decomposed to form the organic molecules. Some areas of uranium concentration might not have coincided with areas of abundant primitive plant life. Alternatively, if the decomposition products were supplied in aqueous solution, the distribution of carbon would depend not only on the presence of uraninite, but also on the paleohydrologic system operative in the conglomerate.

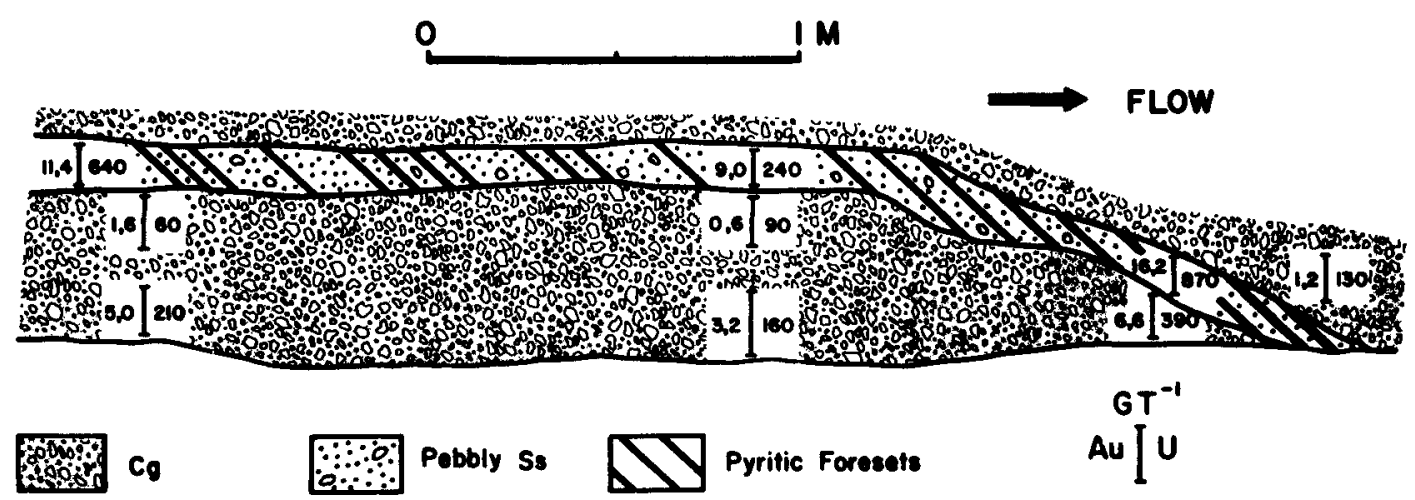

Figure 61. Longitudinal cross section of the downstream end of a longitudinal gravel bar, Leader Reef, Welkom Goldfield. The bar is overlain by pebbly arenite containing pyritic foresets. This phase carries the highest concentrations of gold and uranium, probably due to convergence of two threads of the braided stream at the downstream end of the longitudinal bar (from Smith and Minter, 1980).

\section{Sediment Dispersal Patterns}

Mining operations, combined with detailed stratigraphic-sedimentologic studies, have succeeded in determining the sediment dispersal patterns associated with many uranium-bearing conglomerates. Several different types of sediment dispersal are recognized and are described below.

\section{Diverging Radial Braided Distributary Pattern}

The best example of this pattern is provided by the Main Reef Leader conglomerate sheet of the East Rand area (Figure 49). This conglomerate was mined over an area of several hundred square kilometers. The radial drainage pattern is indicated by the distribution of mined areas (Reinecke, 1927); the orientation of payshoots (areas of richer conglomerate); the pebble orientation (Reinecke, 1927); the orientation of cross-bed foresets (Hargraves, 1962); and by maps showing the variation in size and sorting parameters of matrix constituents (Vi1joen, 1968; Lentha11, 1970).

The diverging dispersal pattern suggests entry of the sediment into the basin through a relatively narrow, confined valley or canyon (Figure 62). Projection of the payshoots suggests that the apex of this fan-like body was situated several kilometers north of the present outcrop limit. 


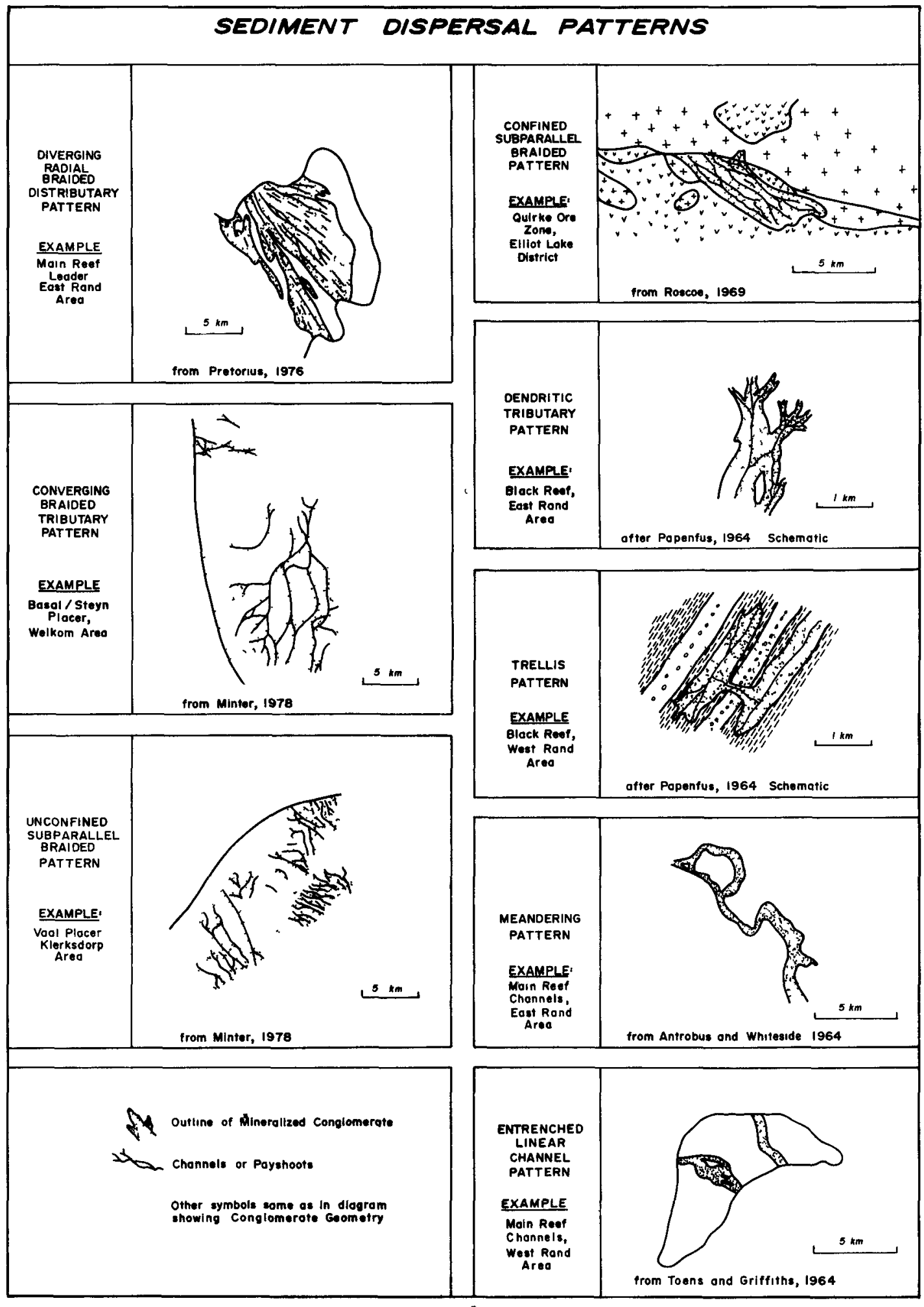

Figure 62. Diagram showing the different types of sediment dispersal patterns recognized in uranium-bearing conglomerates. 
Geologic studies in the Welkom area of the Witwatersrand Basin (Minter, 1978) have resulted in the recognition of what is here termed a converging braided tributary pattern (Figure 62). In this area, the streams entered the Witwatersrand Basin along a curved "entry front", concave to the northeast. Streams entering the basin appear to have been focused towards a common center, located north and east of the entry front. ${ }^{1}$ The term "tributary" is used in that (despite braiding) the number of drainage channels appears to decrease in a down-current direction.

The converging pattern of sediment dispersal was probably a function of paleogeography. The mountainous "entry front", from which the conglomerates were derived, was curved, forming a topographic amphitheatre facing towards the northeast.

\section{Unconfined Subparallel Braided Pattern}

An excellent example of this pattern is given by the Vaal Reef of the Klerksdorp area (Minter, 1976, 1978). The pattern is said to be unconfined in the sense that the braided streams were free to move laterally over a fluvial plain some $20 \mathrm{~km}$ wide (Figure 62). Cross-bed foresets and the traces of wide, shallow braided erosion channels have shown that sediment transport was to the southeast. There is no detectable tendency for the braided streams either to converge or to diverge. They maintain a subparallel arrangement down a paleoslope distance of about $10 \mathrm{~km}$.

\section{Confined Subparallel Braided Pattern}

In situations where a braided stream system flows on or close to a bedrock surface, the streams are likely to be confined within paleovalleys located between bedrock hills and ridges. This situation can be confidently applied to the Matinenda Formation, Elliot Lake district. Here, the arenites and conglomerates were deposited by streams (McDowe11, 1957; Pienaar, 1963; J.A. Robertson, 1960, 1976, 1978) confined to flow in paleovalleys between basement hills and ridges composed of iron-formation, massive greenstone, and granite (Figure 62). Although Pienaar and other Canadian geologists did not specify the character of the streams, the nature of the Matinenda Formation leaves very little doubt that they were coarse-bedload braided streams.

\section{Dendritic Tributary Pattern}

The clearest indication of a dendritic drainage pattern found during this review was outlined by the mining operations on the Black Reef conglomerates

\footnotetext{
${ }^{1}$ W.E.L. Minter (written communication, 1980) has commented that the impression of convergence is largely a function of the superimposition of two placers in the area in question. The slightly older Basal placer (in the north) had a drainage pattern to the east. The Steyn placer overlaps the Basal placer and had a drainage pattern to the north and northeast.
} 
in parts of the East Rand. In this area, the Black Reef rests unconformably on an erosion surface cut across a rather monotonous, shallow-dipping sequence of Witwatersrand conglomerates and arenites (Papenfus, 1964). Mining operations in the Black Reef conglomerate clearly established the location and geometry of the channels on the erosion surface (Figure 62). The pattern is interpreted to represent a dendritic drainage basin, the valleys of which became filled by fluvial sediments. Similar patterns can be anticipated wherever conglomerates rest on a relatively homogeneous, relatively soft substrate.

\section{Trellis Pattern}

Mining operations in the Black Reef conglomerate in parts of the West Rand established some of the elements of a trellis fluvial pattern (Papenfus, 1964). In this area, the Black Reef rests unconformably on inclined Witwatersrand formations, including units such as the Jeppestown and Kimberley shales. Linear paleovalleys were cut along the strike of softer formations (such as the shales mentioned above) and were subsequently filled with auriferous-uraniferous conglomerates.

Similar relations are to be expected wherever an unconformity is cut across older inclined formations of varying erosion resistance. In the 3,000 m.y. old Pongola Basin, the Denny Dalton conglomerate was deposited in a paleovalley which initially cuts across the strike of older Pongola rocks, then swings parallel to strike in a paleovalley cut on a softer formation (C. Greathead, personal communication, 1978).

\section{Meandering Pattern}

Meandering dispersa1 patterns are extremely rare in the Precambrian basins in question. Such systems have been locally established where rather specialized conditions exist. Antrobus and Whiteside (1964) have documented the presence of a meandering fluvial channel system in the "footwall beds", below the Main Reef Leader conglomerate sheet of the East Rand (Figure 62). The meandering channel was cut on a surface composed of Jeppestown Shale, a formation developed at the top of the lower division of the Witwatersrand Supergroup in this area. The channel contains a variety of sediments, some of which are uraniferous and auriferous.

\section{Entrenched Linear Channel Pattern}

Entrenched linear channels are known from several areas of the Witwatersrand Basin (Cousins, 1965). They tend to occur on erosion surfaces. They are up to several hundred meters deep, up to nearly $1 \mathrm{~km}$ wide, and extend down the paleoslope for distances of up to nearly $8 \mathrm{~km}$. They contain economically important conglomerates. The channels formed preferentially in or near to "fanhead" areas and could have formed in response to oversteepening of the fanhead area (Schumm, 1977). 
The striking finding of this review of sediment dispersal patterns is the resemblance of stream patterns to those presently found on the Earth's surface. A rather elementary application of the fundamentals of geomorphology is all that is necessary to understand, and in many cases predict, the fluvial dispersal systems operative on a given unconformity.

\section{Geometry of Conglomerate Occurrences}

The geometry of uraniferous conglomerates is a topic related to the sediment dispersal patterns in conglomerates, discussed in the previous section. A summary of the important controls on conglomerate geometry is provided here.

The geometry of uranium-bearing Precambrian conglomerates depends primarily on two factors:

(1) the character (particularly paleotopography) of the unconformity on which the conglomerate is developed; and

(2) the depositional processes operative on the unconformity surface.

In summary, ancient erosion surfaces with pronounced paleotopography are likely to be characterized by discontinuous conglomerate developments, mainly in paleovalleys. Conversely, unconformities that are relatively smooth (usually of the intraformational type) are often covered by widespread sheet gravels. For this reason, the geometry of the uraniferous conglomerate sheets will be analysed in terms of intraformational and fundamental unconformities, as defined in a previous section of this report.

\section{Fundamental Unconformities/Nonconformities}

Fundamental unconformities and nonconformities have been previously defined as those unconformities with areas on the order of $10^{4}$ to $10^{5}$ square kilometers or greater, and time breaks on the order of $10^{6}$ to $10^{8}$ years.

\section{Nonconformity on Archean Basement}

Nonconformities cut across Archean basement rocks (Figure 66) are normally sculptured into hills, ridges, and valleys, the configuration of which is usually controlled by the outline of greenstone belts in the basement. Total paleotopographic relief is frequently on the order of several hundred meters.

The geometry of conglomerates which occur on such nonconformities is controlled largely by valley shape. In the Elliot Lake district, "thick grit zones" and uranium orebodies are located in southeast-trending paleovalleys (Figure 63) coincident with underlying greenstone basalts.

The "typical" orebody in the Matinenda Formation is an elongate sheet with a long to short axis ratio of about $3: 1$ (D.S. Robertson, 1962). The mineralized sheets usually have blunt up-current ends and "fingered" down-current terminations (Figure 64). The dimensions of the orebodies are variable. 
J.A. Robertson (1976) and Roscoe (1969) gave the following statistics for the principal orebodies of the Elliot Lake area:

Quirke Zone: $9,700 \mathrm{~m}$ long; 1,800 to $2,700 \mathrm{~m}$ wide; area about 20 square kilometers.

Nordic Zone: $5,800 \mathrm{~m}$ long; 1,340 to $1,800 \mathrm{~m}$ wide; area about 9 square kilometers.

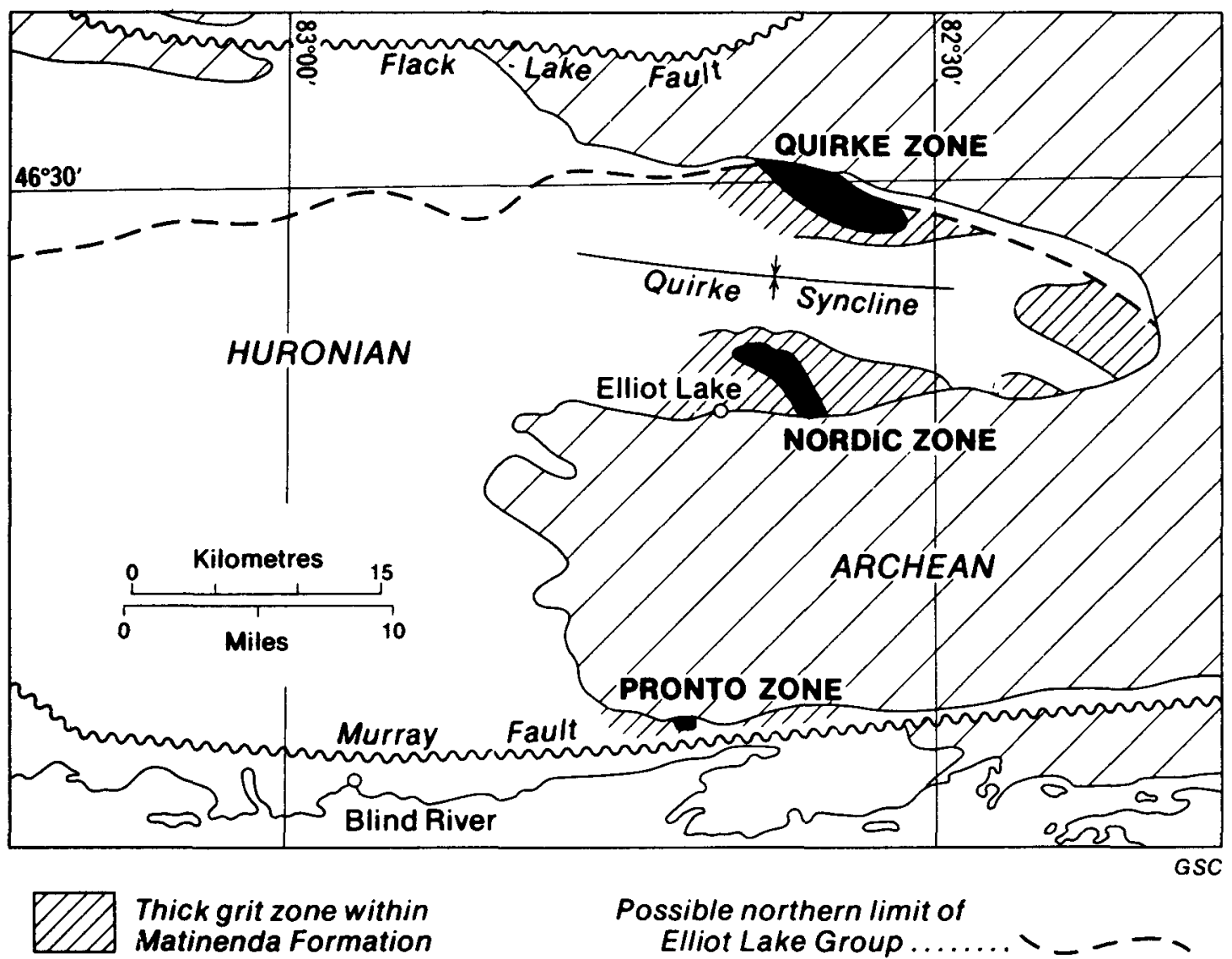

Figure 63. Development of uranium orebodies and thick "grits" within paleovalleys along the basal Huronian nonconformity (from Theis, 1979). The cross-hatched areas east of the Nordic Zone are, respectively, the Pecors and Whiskey Zones.

D.S. Robertson and others (1978) have estimated that the orebodies of the Elliot Lake district contain on the order of $0.5 \times 10^{9}$ tons of ore with $10^{9}$ pounds of recoverable $U$. The average grade is thus approximately 2 pounds $\mathrm{U} /$ ton $(1,000 \mathrm{ppm})$. 


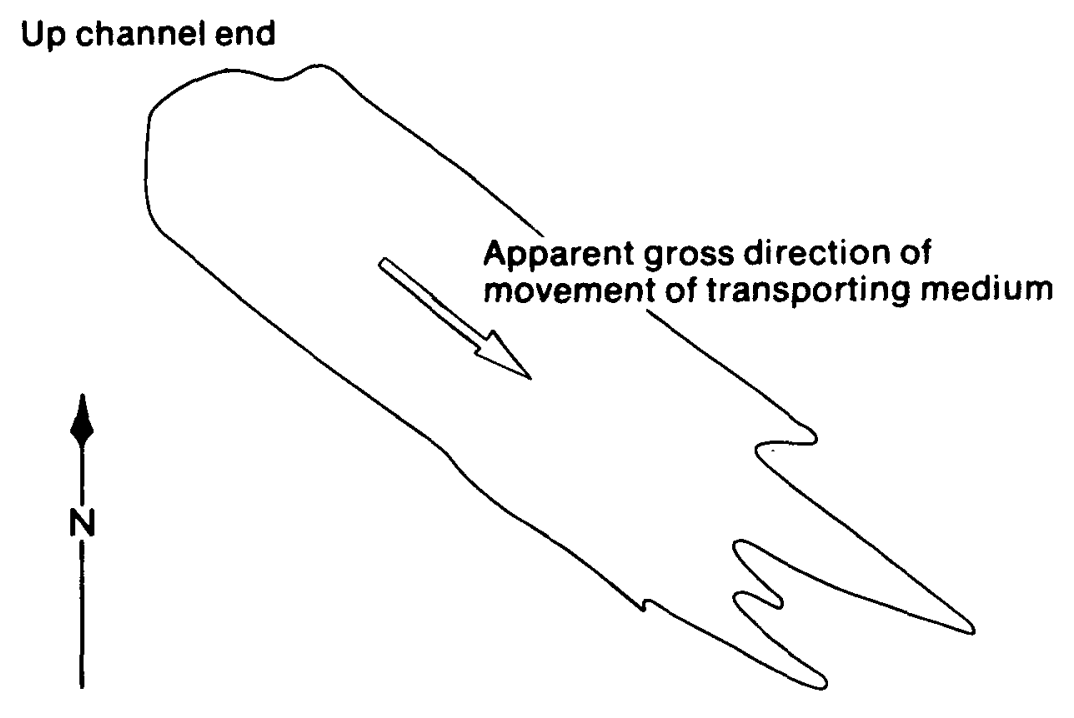

Down channel end

GSC

Figure 64. Typical plan-view configuration of a Matinenda Formation orebody, with a blunt, up-channel termination and a fingering down-current end. Based on relations in the Quirke Zone (from Theis, 1979).

The orebodies are terminated by boundaries of several different types, including outcrop edges; wedge-outs against local or regional basement highs; lateral fingering of conglomerates into arenites; erosional truncations beneath younger formations; and fault, fracture, or dyke terminations (J.A. Robertson, 1976, 1978).

Matinenda orebodies are composed of "layers of braided, interfingering channels and beds" (D.S. Robertson, 1962) or "sheet-like packages of conglomeratic units or lenses" (Theis, 1979). Individual conglomerate layers or lenses are not continuous over distances on the order of a few kilometers. However, the "packages" of conglomerate with arenite partings can be traced from one mining property to the next within the Quirke or Nordic ore zones.

In the Quirke area, the main ore zone is found in the Manfred Member of the Matinenda Formation (Figure 65). J.A. Robertson (1978) has published a detailed correlation table for conglomerates of the Quirke Zone. At the Quirke No. 1 Mine, the principal-conglomerate is $3.5 \mathrm{~m}$ thick and is developed $30 \mathrm{~m}$ above the basement. Further south and east, at the Quirke No. 2 and Denison Mines, the best ore occurs in the Denison Reef, some $30 \mathrm{~m}$ below the Quirke Reef (J.A. Robertson, 1976). The Denison conglomerate is of ten a composite body, being composed of several conglomerates separated by arkosic 
wackes (Theis, 1979). The two main conglomerates are 1.8 to $3.6 \mathrm{~m}$ thick and are separated by up to $2.4 \mathrm{~m}$ of "barren arkose". The uranium content is such that the composite unit $(10 \mathrm{~m}$ thick in places) was mined over much of the Denison property using large-scale equipment and trackless haulage.

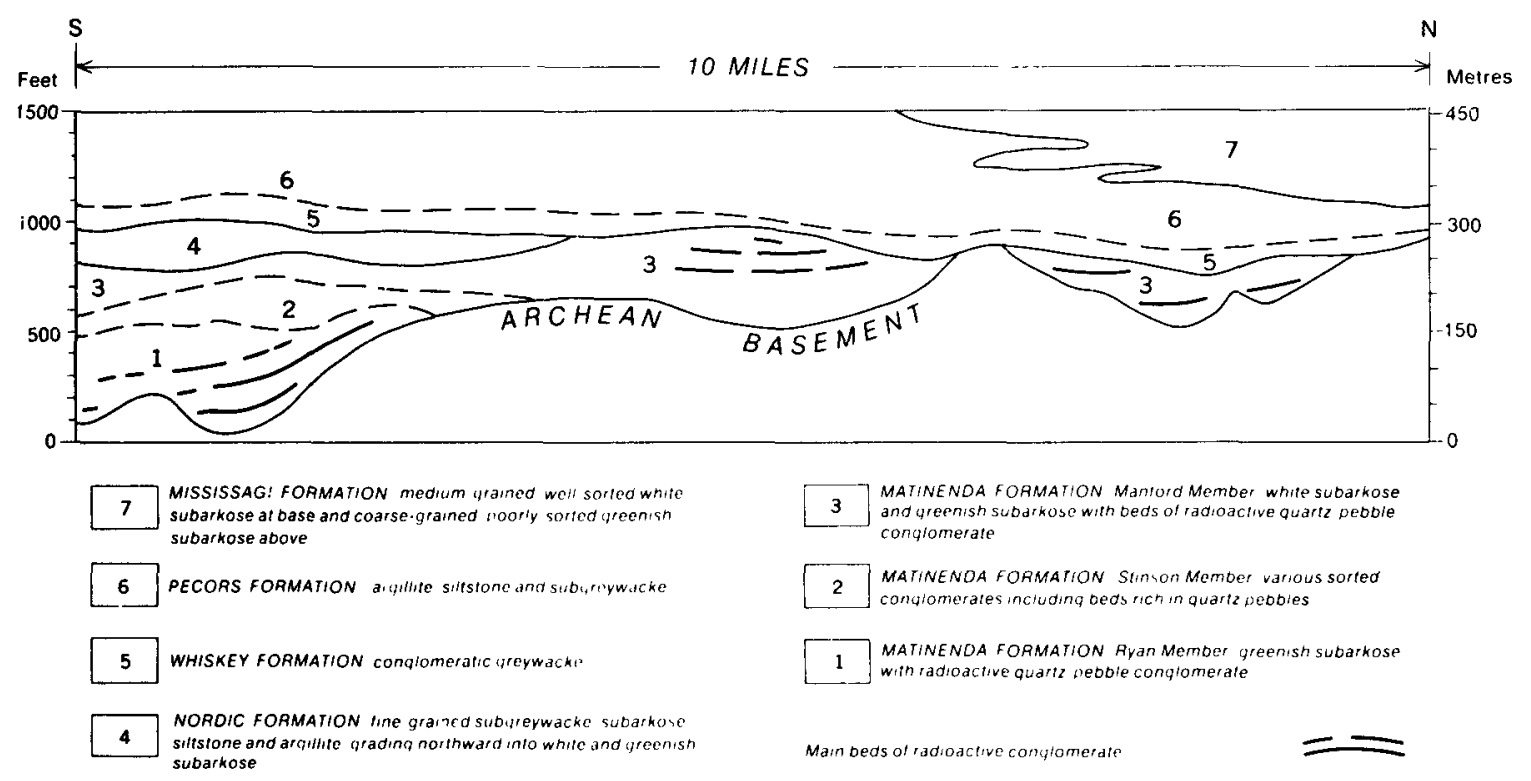

Figure 65. Relations of basal formations of the Huronian Supergroup in the Quirke Syncline (from Lang and others, 1976). Onlap and wedgeout relations against an inclined paleosurface result in uraniferous conglomerates being developed at higher stratigraphic levels towards the north. Note that stratigraphic unit 4 is now termed the McKim Formation; 5 is the Ramsay Lake Formation (J.A. Robertson, 1976).

In the Nordic area, the main ore zone occurs in the Ryan Member of the Matinenda Formation (Figure 65). It is up to about $3 \mathrm{~m}$ thick. A lower conglomerate was mined locally in this area. An upper conglomerate occurs in the eastern part of the Nordic Mine and can be traced to the east into the Pardee and Pecors areas, where it is up to $1.5 \mathrm{~m}$ thick.

\section{Unconformity on 01der Sediments or Volcanics}

Where an unconformity is cut across older stratified rocks, the paleotopography of that surface is controlled largely by the dip angle of the beds below the unconformity (at the time of their deposition) and by the variation in the resistance to weathering of beds below the unconformity. In summary, where the angular difference across the unconformity is small, a single stratigraphic unit can be expected to suboutcrop beneath the unconformity over a relatively large area. Under these conditions, a widespread conglomerate sheet is frequently developed on a fairly flat erosion surface. 
Conversely, where the dip on the underlying beds is appreciable, and these beds varied significantly in their resistance to erosion, the conglomerate beds are restricted in their development to paleovalleys. The anticipated geometry of the conglomerates in these two cases is discussed below.

Smal1 Angular Difference Across Unconformity. A good example of a low-angle fundamental unconformity is found in the East Rand area. Here the upper division of the Witwatersrand Supergroup rests unconformably on the lower division. The unconformity is overlain by the Main Reef Leader conglomerate sheet, one of the most extensive single placer sheets ever mined (Figure 49, Figure 66). The conglomerate was developed over an area of over $1,300 \mathrm{~km}^{2}$ (Pretorius, 1976) and was mined for gold over an area in excess of $400 \mathrm{~km}^{2}$. The conglomerate is, at most, a few meters thick and thins to a few centimeters on the margins of the fluvial fan. The local relief on the surface is usually on the order of a few tens of centimeters. The placer is composed dominantly of conglomerate, but interbeds of arenite are developed within it.

Limits of the mineralization are of several types, including outcrop and suboutcrop limits, wedge-outs against gentle paleotopographic highs, assay boundaries, and fault terminations.

One of the factors contributing to the great lateral extent of the Main Reef Leader sheet of the East Rand is the nature of the "footwa11". The underlying rocks are shaly sediments which provided a remarkably uniform base of deposition over a large area.

Large Angular Difference Across Unconformity. Where there is a large angular difference between beds above and below an unconformity, there is a high probability that beds of differing erosion-resistance will be developed at different places below the unconformity. Under these conditions, a paleorelief, varying from a few meters to a few hundred meters, is frequently developed along the unconformity surface. Given a layered structure in rocks below the unconformity, a trellis drainage pattern is typically developed. Paleovalleys tend to be developed over the relatively rapidly weathered rock types, such as shale, impure arenite, or basalt. On such surfaces, conglomerates are likely to be developed in relatively long, relatively narrow paleovalleys coincident with the suboutcrop trace, beneath the unconformity, of the softer formations.

An excellent example of this situation is in the West Rand area where the Black Reef conglomerates (base of Transvaal Supergroup) rest unconformably on inclined Witwatersrand beds, including shale, arenite, and conglomerate (Figure 66). The Black Reef conglomerates are largely restricted to paleovalleys located over softer Witwatersrand formations. They are uraniferous but have only been exploited for their gold content (Papenfus, 1964).

Another example of this type occurs where the Denny Dalton conglomerate rests unconformably on Insuzi Subgroup strata of the Pongola Basin in eastern South Africa. These examples have in common the fact that the conglomerates do not occur in extensive sheets but are restricted to linear paleovalleys. In exploration programs where these relations are anticipated, a primary task would be to try to establish the locations where softer formations could be expected to suboutcrop beneath the unconformity. 


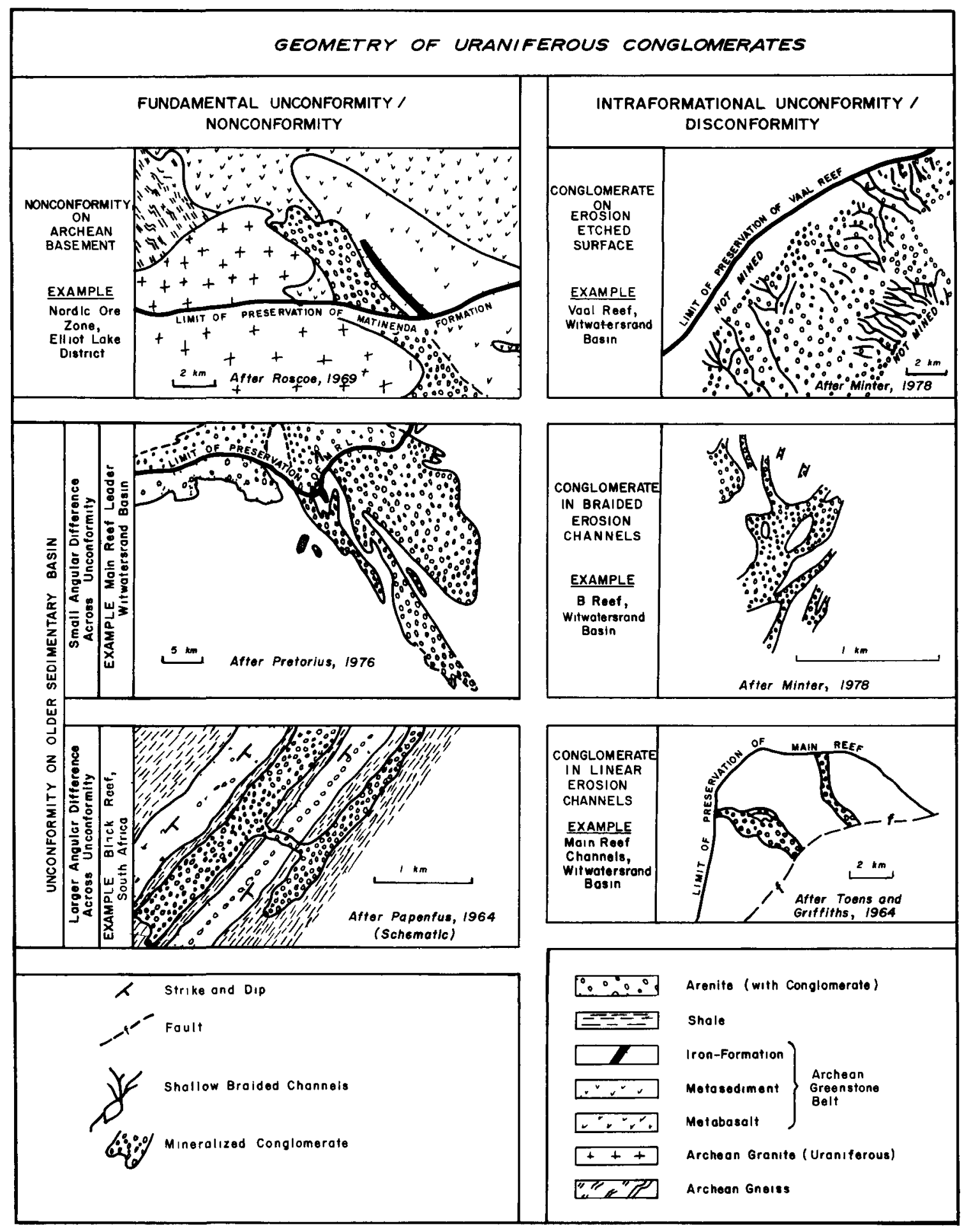

Figure 66. Schematic diagram showing the typical plan-view shapes of uranfferous conglomerates developed on fundamental and intraformational unconformities. 


\section{Intraformational Unconformities}

Intraformational unconformities ${ }^{1}$ are usually cut across sedimentary materials, which were in an unlithified or weakly lithifled state at the time of erosion. Under these conditions, the effects of differential erosion are minimal, the configuration of paleovalleys being controlled largely by geomorphological parameters.

Intraformational unconformities are exceptionally important in the Witwatersrand Basin, where all the major uranium-producing conglomerates rest on such surfaces. Several different styles of erosion can be recognized on such surfaces and are described below.

Erosion-Etched Surfaces

The term "erosion etching" is used to denote gentle eroston on a plane of intraformational unconformity. Under these conditions, the thickest conglomerate accumulations are developed in the etched "channels", usually no more than a meter or two deep. The important fact is that the conglomerates are not restricted to the channels but are developed in a more-or-less continuous sheet.

Excellent examples of erosion-etched intraformational unconformities are afforded by the Vaal and Basal/Steyn placers of the Witwatersrand Basin, both important uranium producers. The Basal and Steyn placers cover the same erosion surface, being differentiated on the basis of the pebble assemblage (Minter, 1978). They cover a combined area of some $400 \mathrm{~km}^{2}$. Erosional etches are usually shallow but are locally $4 \mathrm{~m}$ deep in the Steyn placer.

The Vaal placer of the Klerksdorp area (Figure 66) covers some $260 \mathrm{~km}^{2}$ and has an average thickness of some $30 \mathrm{~cm}$ (range 0 to $1 \mathrm{~m}$, Minter, 1976, 1978). The braided channels are usually no more than about $1 \mathrm{~m}$ deep.

In summary, the braided-etched intraformational erosion surfaces are economically attractive, due to their continuity and relatively large areas. The Basal/Steyn placer, with an area of some $400 \mathrm{~km}^{2}$, must contain on the order of $10^{9}$ metric tons of conglomerate if a $1 \mathrm{~m}$ average thickness is assigned to the placer sheet. The Vaal placer, with an area of $260 \mathrm{~km}^{2}$ and an average thickness of $0.3 \mathrm{~m}$, is calculated to contain on the order of $0.2 \times 10^{9}$ metric tons of uraniferous-auriferous sediment.

Braided Erosion-Channeled Surfaces

Some intraformational unconformities are ornamented by somewhat deeper, narrower braided scour channels than in the examples cited above. Under

${ }^{1}$ Since many of these unconformities separate genetic packages, some of which have been called formations, W. E.L. Minter (written communication, 1980) would prefer to see such stratigraphic breaks referred to as "interformational unconformities". 


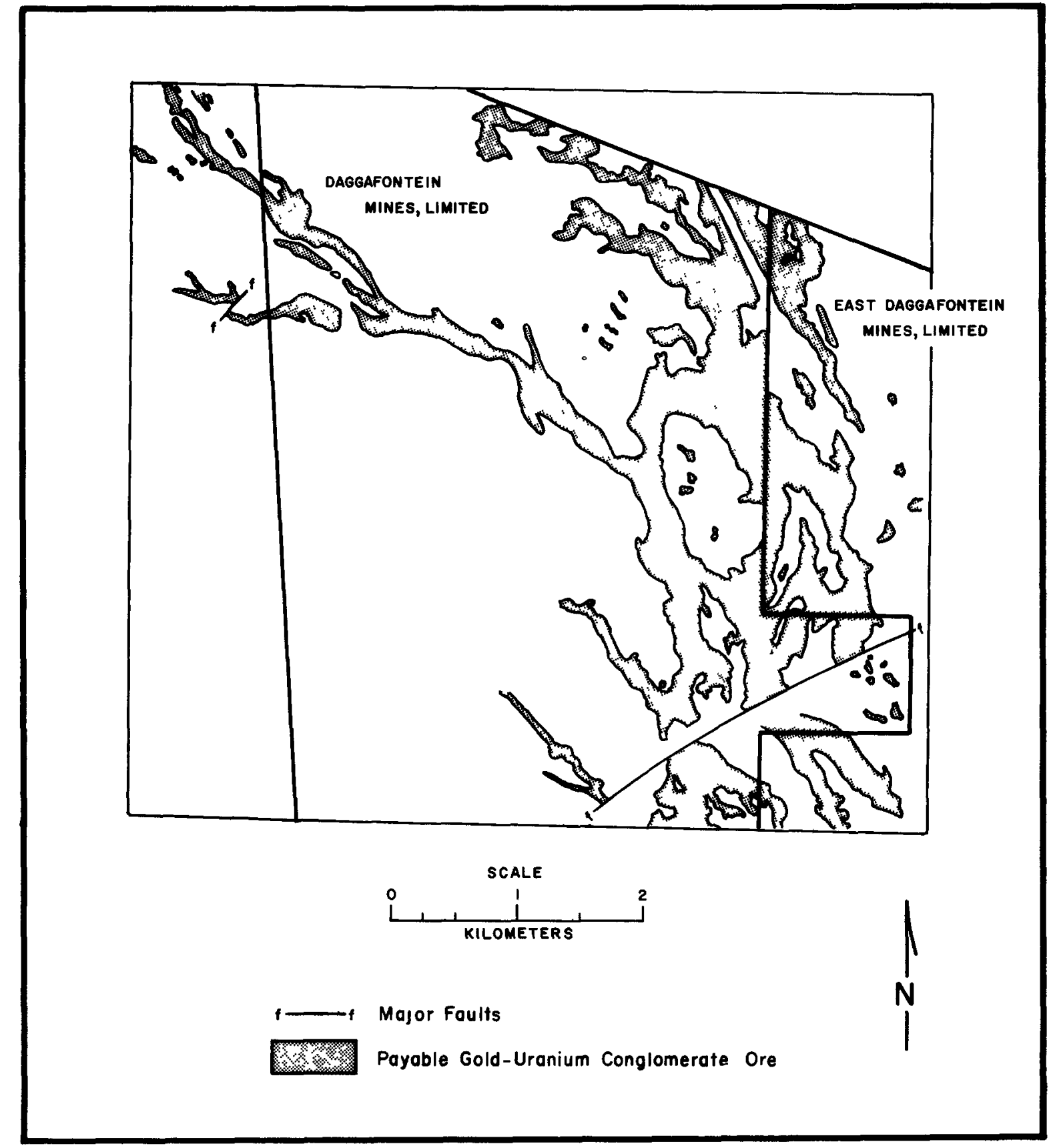

Figure 67. Plan view of the braided channel network of the UK9A (Kimberley) Reef of the East Rand area (after Armstrong, 1968). 
these conditions, the conglomerates developed along the surface of unconformity are frequent1y more or less restricted to the channels and do not form a laterally continuous sheet. Such conglomerates are relatively difficult to locate during exploration. There are, however, several valuable orebodies of this type in the Witwatersrand Basin.

The B Reef of the Welkom area is developed on an intraformational unconformity with an area of some $400 \mathrm{~km}^{2}$. Over this area, Minter (1978) estimated that conglomerate-filled channels occupy less than 35 percent of the erosion surface. Channels are from 1 to $200 \mathrm{~m}$ wide and are up to about $2 \mathrm{~m}$ deep. The channels are sinuous; their trends fall within an arc of about 110 degrees (Figure 66).

The uraniferous-auriferous Kimberley Reef of the East Rand area is a similar occurrence. It rests on a paleosurface which covers several hundred square kilometers. Economic mineralization is confined to braided channels on this surface. The channels are up to 500 to $600 \mathrm{~m}$ wide and are seldom deeper than about $2 \mathrm{~m}$ (see Figure 67).

Linear Erosion-Channeled Surfaces

Mining operations in the West and East Rand areas outlined several 1inear erosion channels associated with unconformities. A notable example is one of the channels developed in the West Rand area (Figure 66; Cousins, 1965; Toens and Griffiths, 1964). It trends east-southeast over a distance of $4.3 \mathrm{~km}$, widening from some $200 \mathrm{~m}$ near its apex to near $1 \mathrm{y} 1,000 \mathrm{~m}$ at its downstream 1imit. Such channels can be up to $200 \mathrm{~m}$ deep. Other examples, up to $8 \mathrm{~km}$ long, were noted in the mines of the Johannesburg area (Pretorius, 1964a).

The channels are filled by a variety of sedimentary rock types, including boulder conglomerates, "puddingstones" (pebbly mudstones), mudstones, quartz arenites, conglomerates, and banded pyritic quartzites. The channels are uranium-bearing, but have only been exploited for gold up to the present time. On some mines, the channels contributed as much as 6 percent of the total tonnage milled.

\section{Summary}

The geometry of uraniferous conglomerate orebodies is highly variable and depends on the paleotopography of the surface on which the conglomerates were deposited, as well as the geomorphological parameters relating to the surface. An intelligent prediction of the geometry of a conglomerate can be made by studying the character of the unconformity on which it rests. In particular, those unconformities cut on older bedrock surfaces are unlikely to have associated conglomerate sheets with areas measuring from 200 to $400 \mathrm{~km}^{2}$. The large-area sheets are more characteristic of intraformational unconformities, which were typified by a very low paleorelief. 
Blank

$-234-$ 
In this chapter, the details of uranium mineralization in Precambrian conglomerates are discussed. It is shown that uranium occurs in a wide variety of minerals but that only uraninite, "brannerite", and, to a lesser extent, monazite and uranothorite, are important sources of the metal in mined conglomerates.

Background Uranium Content of Mineralized Formations

A valid question in exploration is whether the uranium content of a late Archean or early Proterozoic succession of fluvial sediments is a measure of the uranium potential of the conglomerates contained within that succession. Unfortunately, the answer to this question will have to await geochemical studies specifically designed in this direction. The existing information has been collected "in passing", and the lack of uniformity in analytical techniques prevents confident comparisons between different areas of uraniferous conglomerate.

Roscoe (1969) presented three analyses of Matinenda Formation arenite, which contained 6,8 and $18 \mathrm{ppm} \mathrm{U}_{3} \mathrm{O}_{8}$. The overlying McKim Formation argillites

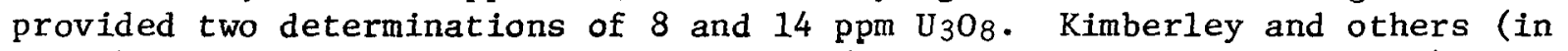
press) analysed a wide variety of rocks (including Matinenda arenites) for a wide variety of elements (including uranium). The analyses were done using the neutron activation analytical technique. The results were presented in graphs, so that absolute values cannot be determined. In general, it appears that the Matinenda arenites contain from 2 to $17 \mathrm{ppm} U$ in drill core from the Denison Mine area. The average appears to be between 5 and $10 \mathrm{ppm} U$.

Pretorius' (1976) review on the Witwatersrand district mentioned a single determination of $6 \mathrm{ppm} U$ in an arenite.

In his study of the uraniferous conglomerates of the Nemo area in South Dakota, Redden (1980) determined the uranium (and thorium) content of conglomerates and arenites. We calculated the average $U$ content of the arenites (many of them granule-bearing types) at $15 \mathrm{ppm}$, with a range of 3.3 to $45 \mathrm{ppm}$ (Table 12).

In summary, there is little useful published data on the uranium content of Witwatersrand, Matinenda, or other comparable arenites. The trace-element characterization of arenaceous units hosting uraniferous conglomerates could prove to be a valid method of ranking formations as exploration targets for this type of deposit.

Uranium Minerals in Quartz-Pebble Conglomerates

There are a large number of uranium-bearing minerals in uraniferous conglomerates. Some are undoubtedly of detrital origin, while others appear to have 
been formed after conglomerate deposition. Table 27 1ists the major uraniumbearing phases described to date.

Of the nineteen phases listed, only six are quantitatively important as sources of uranium in Precambrian conglomerates. In the paragraphs that follow, these phases are described in greater detail.

\section{Brannerite and Uraniferous Leucoxene}

Uranium-titanium aggregates are an extremely important source of uranium in the Matinenda and in certain Witwatersrand conglomerates. These uraniumtitanium aggregates are known by a number of names. Pienaar (1963) referred to them as "two-phase uranium-titanium compound", while Roscoe (1969) called them titania-rich grains or aggregates. In the Witwatersrand, the material is usually called "uraniferous leucoxene" and has been shown to be composed of an admixture of rutile and anatase with tiny needles of brannerite (Feather and Koen, 1975). Much of the "secondary uraninite" of the Witwatersrand (Liebenberg, 1955) has now been shown to be brannerite.

The Matinenda conglomerates have long been known to contain an important uranium-titanium phase (Nuffield, 1954; Trail, 1954). This material, 1ike its counterpart in the Witwatersrand, is metamict and must be heated before a characteristic X-ray diffraction pattern is produced. In that the heating may actually synthesize brannerite from uranium and titanium oxides, there has always been some uncertainty as to whether brannerite was actually present in the ores. This uncertainty is usually reflected by placing "brannerite" in quotation marks (Theis, 1979). To avoid repetition, insertion of the quotation marks for "brannerite" will be omitted through the remainder of this report.

Studies by Theis (1979) and by Feather (in press) have revealed a homogeneous phase with the optical and chemical properties of brannerite. The authors differ in their opinion on the character of the uranium-titanium phase. Theis was of the opinion that it is an amorphous U-Ti oxide mixture "analogous with wad or limonite", while Feather believed that the mineral was crystalline brannerite which has lost its ordered structure due to metamictization. Theis' argument rests largely on stoichiometry. The E1liot Lake brannerites are deficient in $\mathrm{U}$ relative to $\mathrm{Ti}$.

Habit

The habit of brannerite varies greatly from conglomerate to conglomerate, and within conglomerate units. The material occurs in fairly well-defined grains, as well as in diffuse "clouds" in the conglomerate matrix.

Crack Fillings. Feather (in press) has noted that brannerite fills cracks, pores, and cleavages in such minerals as quartz, leucoxene, sericite, and sulfide grains (Figure 68.2). The inclusions are of ten very small (less than $5 \mu)$ and account for a large part of the uranium lost to the mill tailings in certain South African mines (Feather and Snegg, 1978).

Wisps and Clouds. Roscoe (1969) noted that rutile- and anatase-rich phases containing brannerite occur as "wispy streaks" in the conglomerate matrix. 
Table 27. Uranium-bearing phases in Precambrian quartz-pebble conglomerates.

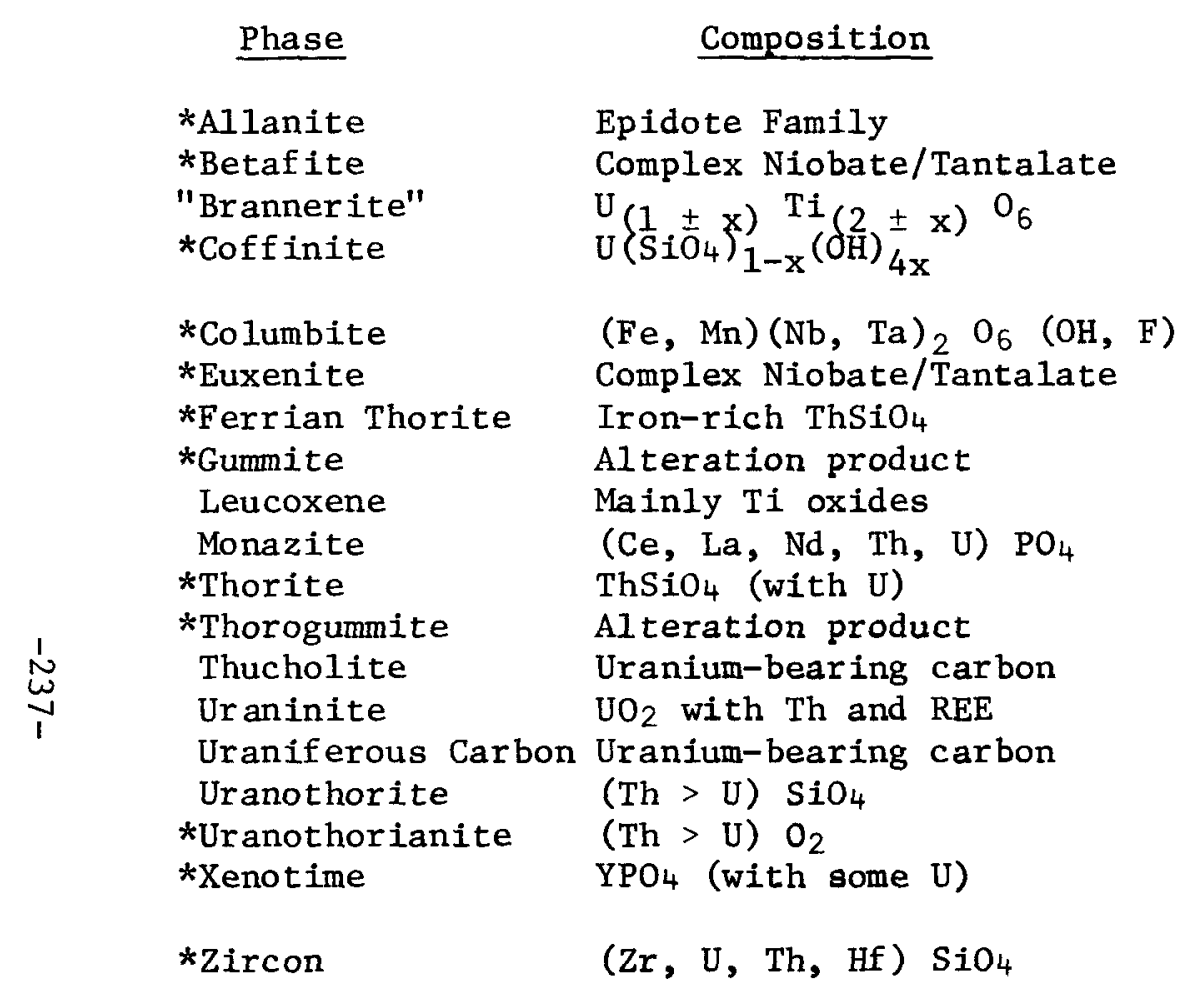

\section{Remarks}

E11iot Lake district (Roscoe, 1969)

Rare, alteration product (Hiemstra, 1968a)

Important, Witwatersrand and Elliot Lake districts

Rare (De Waal and Herzberg, 1969; Desborough and Sharp, 1979; Patchett, 1960)

Rare, in Dominion Reef (Hiemstra, 1968a)

Rare, alteration product (Hiemstra, 1968a)

Rare, in Dominion Reef (Hiemstra, 1968a)

Rare, in oxidized conglomerate (De Waal and Herzberg, 1969)

Carries uranium in Witwatersrand (Feather and Koen, 1975)

Uranium ore mineral in Matinenda conglomerate (Roscoe, 1969)

Very rare, in Witwatersrand (Feather and Koen, 1975)

Very rare, in pre-Huronian paleosol (Roscoe, 1969)

See uraniferous carbon

Important, Witwatersrand and Elliot Lake districts

Important in Witwatersrand (Feather and Koen, 1975)

Uranium ore mineral (Hiemstra, 1968a; Roscoe, 1969)

Rare, in Elliot Lake conglomerates (Roscoe, 1969)

In Witwatersrand and Elliot Lake (Feather and Koen, 1975; Roscoe, 1969)

Very common heavy mineral

* Not important sources of uranium in conglomerates. 
Theis (1979) described its occurrence in "occasional cloudy areas throughout the matrix of the conglomerate".

Overgrowths and "Ghosts". Investigators of Witwatersrand brannerite describe instances where this phase occurs as overgrowths around uraninite grains. In some cases, the uraninite is partly replaced by brannerite. In that the shape of the parent uraninite grain can often be seen in the replacing material, Ramdohr (1958) termed them "uraninite ghosts" (Figure 72.1). The central parts of such "ghost" grains are often filled by secondary minerals including chalcopyrite, pyrrhotite, and galena (Figure 72.2).

Grains and Grain Aggregates. Theis (1979) and earlier workers such as Pienaar (1963) and Roscoe (1969) noted that brannerite frequently occurs in titania-rich grains, composed largely of rutile and anatase. The grains are rounded or ovoid, and are up to $1.5 \mathrm{~mm}$ in size (Roscoe, 1969). They are extremely variable in their composition. In many, pore spaces within the grains are filled by a range of secondary minerals, chief1y quartz and pyrrhotite. The shapes and sizes of the grains and the arrangement of the titanium oxide phases suggest a varied parentage for the grains, including sphene, biotite, amphibole, pyroxene, ilmenite, and titaniferous magnetite (Roscoe, 1969).

Theis (1979) recognized three types of brannerite grain from samples of the Rio Algom-Denison ore reef of the Matinenda Formation. "Type I" grains are the most abundant and are described as "composite grain aggregates". The grains are rounded; some appear to have been slightly flattened by compaction. They are usually composed of a framework of optically continuous rutile laths, often arranged in a triangular grid pattern suggestive of derivation from titaniferous magnetite. The pore spaces that previously existed within the framework have become filled by a variety of minerals, including quartz, pyrrhotite, radiogenic galena, and brannerite (Figures 68.4 and 68.5). Grains of this sort in the Witwatersrand contain up to 18 percent $\mathrm{SiO}_{2}$ (Feather, in press).

Within composite grains of this type, brannerite (along with galena and pyrrhotite) normally occurs as finely disseminated phases around the margins of the grains. The proportion of brannerite in the grain aggregates varies great1y. Theis (1979) noted that the amount of brannerite in the aggregates decreases down the paleoslope.

"Type II" grains are less abundant than those of "Type I" and are somewhat smaller. They occur as rounded, unzoned grains with a "cheesy texture due to numerous pits and holes in the polished surface" (Figure 68.3). This type is chemically distinctive, containing up to 5 weight percent $\mathrm{CaO}$ and 1 ow $\mathrm{SiO}_{2}$ values. "Type III" grains are very rare, show a "patchy, irregular, concentric zoning", and have a high niobium content (Theis, 1979).

\section{Chemistry}

J.A. Robertson (1976) summarized the results of earlier chemical analyses of brannerites from the Matinenda conglomerates (Table 28). The $\mathrm{U}_{3} \mathrm{O}_{8}$ content varies from 6 to 41 percent, the $\mathrm{ThO}_{2}$ from 1.14 to 6.1 percent, and the $\mathrm{TiO}_{2}$ from 20 to 37 percent. The uranium-thorium ratio (expressed as $\mathrm{U}_{3} 08 / \mathrm{ThO}_{2}$ ) varies from 5.0 to 20.0 . 
Table 28. Geochemistry of brannerite from the Matinenda conglomerates, Elliot Lake district, Canada (after J.A. Robertson, 1976).

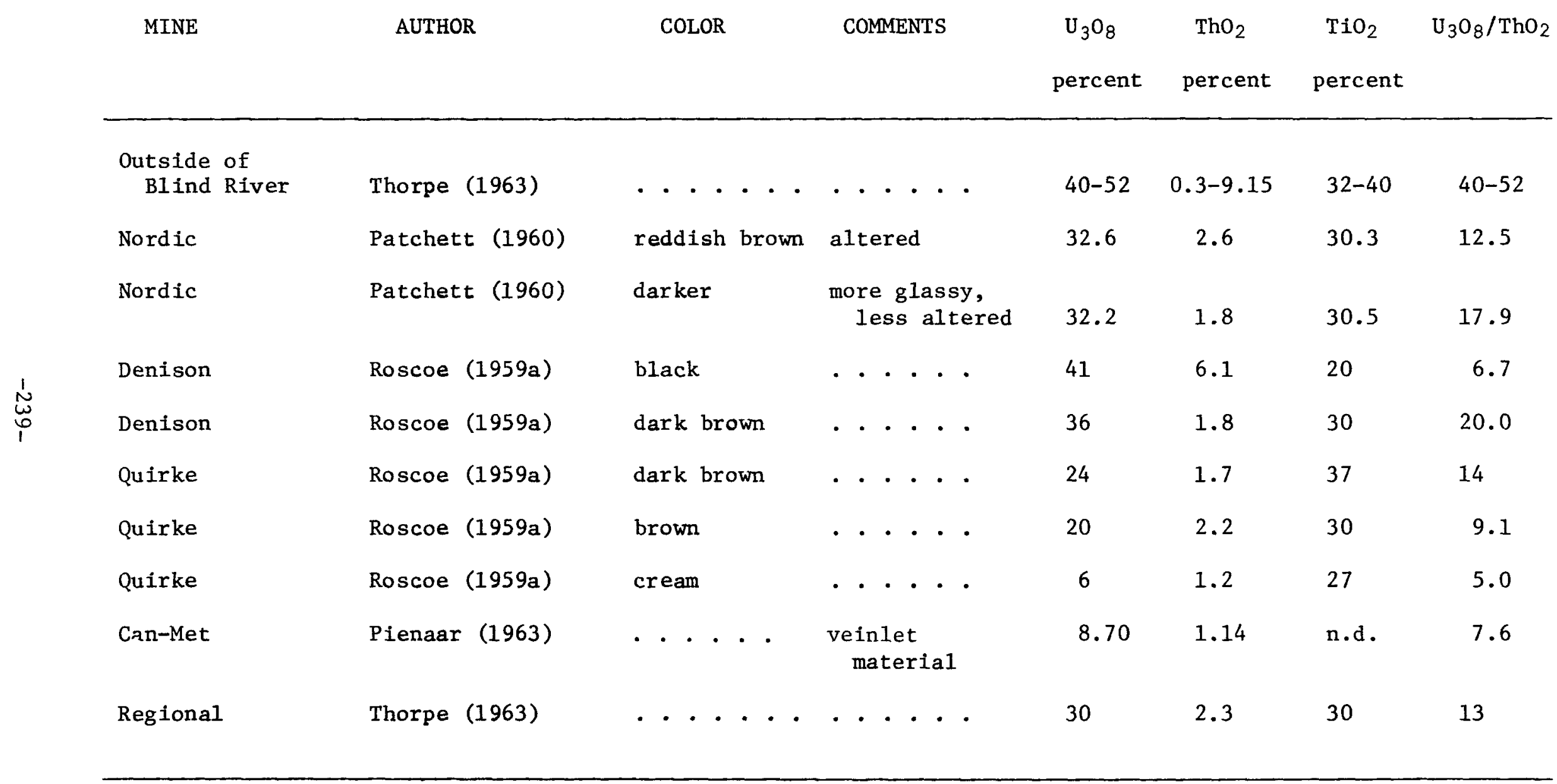


Figure 68. 1. (top left): Rutile pseudomorph after titaniferous magnetite. The original ilmenite exsolution lamellae of the magnetite are now composed of rutile. The magnetite fraction was entirely destroyed by diagenetic dissolution. "Bastard Reef", East Rand area (365x, from Ramdohr, 1958).

2. (top right): Brannerite (white) lining pore-spaces in leucoxene from a Witwatersrand conglomerate (214x, from Feather and Snegg, 1978).

3. (center): Grain of "Type II" brannerite with grains of uraninite (small, angular grains, upper right) and pyrite (large grain on left) in a quartz and sericite matrix, Rio Algom-Denison ore reef (54x, from Theis, 1979).

4. (lower left): Composite grain composed of oriented rutile laths in a skeletal arrangement with internal pores filled by silicate minerals. Brannerite is developed in very small grains around the margin of the grain aggregate, Rio Algom-Denison ore reef (144x, from Theis, 1979).

5. (lower right): Composite grain aggregate comprising quartz in original pores (darkest gray), brannerite (medium gray), rutile (1ightest gray), and galena (small white apecks) (84x, "A" reef of Quirke No. 1 Mine, from Theis, 1979). 

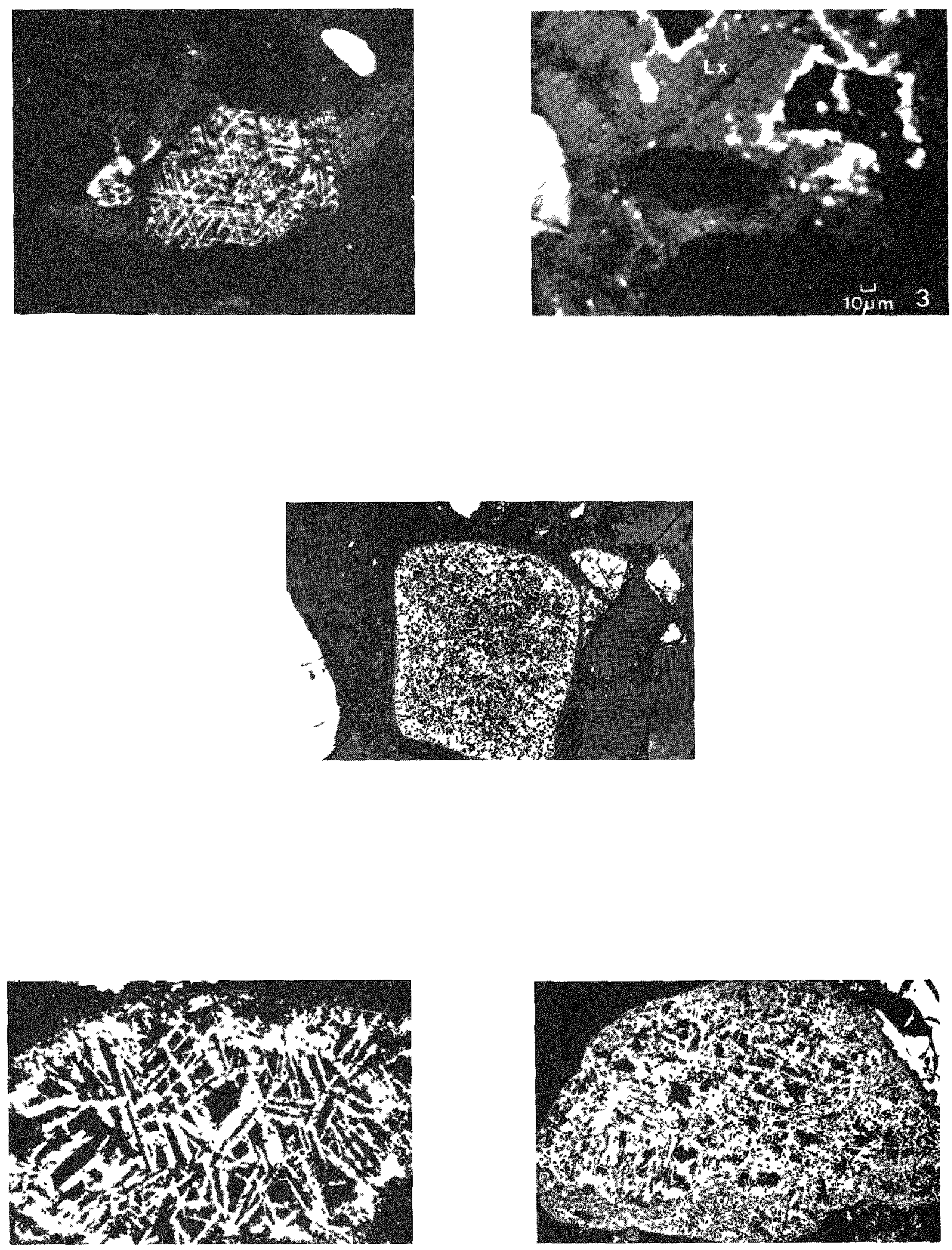
Ferris and Ruud (1971) studied a wide variety of brannerites using microprobe techniques. They found that Blind River and Witwatersrand brannerites are geochemically distinct. They contain variable and generally relatively low concentrations of both uranium and thorium. Given the expected stoichiometry of brannerite, they found that the Blind River samples are deficient in uranium relative to titanium.

Feather (in press) analysed 29 brannerite grains from Witwatersrand conglomerates using electron microprobe techniques. He found that the grains contain from 1 to 18 percent $\mathrm{SiO}_{2}$. A summary of his data is presented in Table 29. The overall average composition of 29 grains is 36 percent $\mathrm{UO}_{2}$, 2.7 percent $\mathrm{ThO}_{2}, 11.7$ percent $\mathrm{PbO}_{2}, 4.1$ percent $\mathrm{Fe}, 31.9$ percent $\mathrm{TiO}_{2}, 0.5$ percent $\mathrm{CaO}$, and 8 percent $\mathrm{SiO}_{2}$. The low totals (see Table 29) could be due to the omission of such phases as $\mathrm{H}_{2} \mathrm{O}$ and $\mathrm{S}$. The latter is present in the galena and pyrrhotite usually associated with the brannerite. The average $\mathrm{U} / \mathrm{Ti}$ ratio is much lower than the theoretical ratio of 2.48 (based on a chemical formula of $\mathrm{UO}_{2} \cdot 2 \mathrm{TiO}_{2}$ ).

In another microprobe study, Theis (1979) analysed 45 areas within brannerite grains from the Matinenda conglomerates. In addition to the elements analysed by Feather, he determined $\mathrm{Al}_{2} \mathrm{O}_{3}, \mathrm{Y}_{2} \mathrm{O}_{3}, \mathrm{Nb}_{2} \mathrm{O}_{5}, \mathrm{~S}$, and $\mathrm{Ce}_{2} \mathrm{O}_{3} . \mathrm{Al}_{2} \mathrm{O}_{3}$ contents vary from 0.12 to 2.16 percent, $\mathrm{Y}_{2} \mathrm{O}_{3}$ from 0 to 2.92 percent, $\mathrm{Nb}_{2} \mathrm{O}_{5}$ from 0 to 2.94 percent, $\mathrm{S}$ from 0 to 0.63 percent, and $\mathrm{Ce}_{2} \mathrm{O}_{3}$ from 0 to 2.98 percent. He showed an inverse relation between the $\mathrm{U}$ and $\mathrm{Ti}$ contents of the brannerite phase and confirmed the non-stoichiometric behavior of the phase. The variability in composition is consistent with the probable origin of the brannerite. If this material was originally a porous $\mathrm{TiO}_{2}$ aggregate, it can be expected to have adsorbed variable concentrations of metals.

\section{Area1 Distribution}

Theis (1979) showed that there is a strong negative correlation of pebble size and the $\mathrm{TiO}_{2}, \mathrm{Ce}$, and $\mathrm{Zr}$ content of the Rio Algom-Denison ore conglomerate. Apparently the minerals containing these elements are associated with rather small pebble sizes. The $\mathrm{Ce}$ and $\mathrm{Zr}$ are largely contained in monazite and zircon, respectively. The sympathetic behavior of $\mathrm{TiO}_{2}$ with $\mathrm{Ce}$ and $\mathrm{Zr}$ (correlation coefficients are 0.95 and 0.88 , respectively) suggests that the $\mathrm{TiO}_{2}$ was originally contained in a mineral with a density of about $5 \mathrm{gm} / \mathrm{cm}^{3}$. Possibilities include ilmenite and titaniferous magnetite.

Theis noted that the total content of brannerite-bearing grain aggregates in conglomerates increases in sympathy with $\mathrm{TiO}_{2}$. Thus, grain aggregates are most abundant in areas of conglomerate with rather sma11 pebbles. Conversely, the brannerite content of the aggregates was found to increase with increasing pebble size (Figure 69). If pebble size is equated with distance down a paleoslope, it is apparent that the brannerite content of the grain aggregates would increase in an upstream direction.

Origin

Many of the early investigators believed that the brannerite in conglomerates of the Elliot Lake area was a detrital mineral, derived by weathering and erosion of a granitic source area. At present, the consensus of opinion is that the mineral was formed after deposition of the conglomerate. 
Table 29. Results of electron microprobe analyses of Witwatersrand brannerite grains (after Feather, in press). Note that ideal brannerite $\mathrm{UO}_{2} \cdot 2 \mathrm{TiO}_{2}$ would give $\mathrm{UO}_{2} / \mathrm{TiO}_{2}=1.69$ and $\mathrm{U} / \mathrm{Ti}$ of 2.48 .

Sample $\quad \underline{\mathrm{UO}_{2}} \quad \underline{\mathrm{ThO}_{2}} \quad \underline{\mathrm{PbO}_{2}} \quad \underline{\mathrm{FeO}} \quad \underline{\mathrm{TiO}_{2}} \quad \underline{\mathrm{CaO}} \quad \underline{\mathrm{SiO}_{2}} \underline{\mathrm{Total}_{\mathrm{UO}} / \mathrm{TiO}_{2}} \quad \underline{\mathrm{U} / \mathrm{Ti}} \quad \underline{\mathrm{UO}}{ }_{2} / \mathrm{ThO}_{2}$

\begin{tabular}{|c|c|c|c|c|c|c|c|c|c|c|c|}
\hline 4 Grains) & 36.5 & 3.6 & 2.4 & 1.2 & 39.5 & 0.5 & 10.5 & 94.2 & 0.92 & 1.4 & 10.1 \\
\hline $\begin{array}{l}\text { Leader Reef (Average } \\
\text { of } 6 \text { Grains) }\end{array}$ & 35.8 & 3.0 & 8.2 & 1.3 & 32.0 & 0.3 & 8.5 & 89.1 & 1.12 & 1.7 & 11.9 \\
\hline $\begin{array}{l}\text { Vaal Reef (Average } \\
\text { of } 5 \text { Grains) }\end{array}$ & 28.6 & 2.4 & 22.7 & 3.8 & 28.3 & 0.6 & 7.7 & 94.1 & 1.01 & 1.5 & 11.9 \\
\hline $\begin{array}{l}\text { Vaal Reef (Average } \\
\text { of } 5 \text { Grains) }\end{array}$ & 34.0 & 2.9 & 21.5 & 12.7 & 25.9 & 0.3 & n.d. & 97.3 & 1.31 & 2.0 & 11.7 \\
\hline $\begin{array}{l}\text { Carbon Leader } \\
\text { (Average of } \\
4 \text { Grains) }\end{array}$ & 45.0 & 2.3 & 8.9 & 5.4 & 31.9 & 0.7 & n.d. & 94.2 & 1.41 & 2.2 & 19.6 \\
\hline $\begin{array}{l}\text { Main Reef (Average } \\
\text { of } 5 \text { Grains) }\end{array}$ & 38.4 & 1.5 & 4.2 & 0.9 & 34.8 & 0.7 & 6.1 & 86.6 & 1.10 & 1.7 & 25.6 \\
\hline Dverall Average & 36.0 & 2.7 & 11.7 & 4.1 & 31.9 & 0.5 & 8.0 & 94.9 & 1.13 & 1.7 & 13. \\
\hline
\end{tabular}



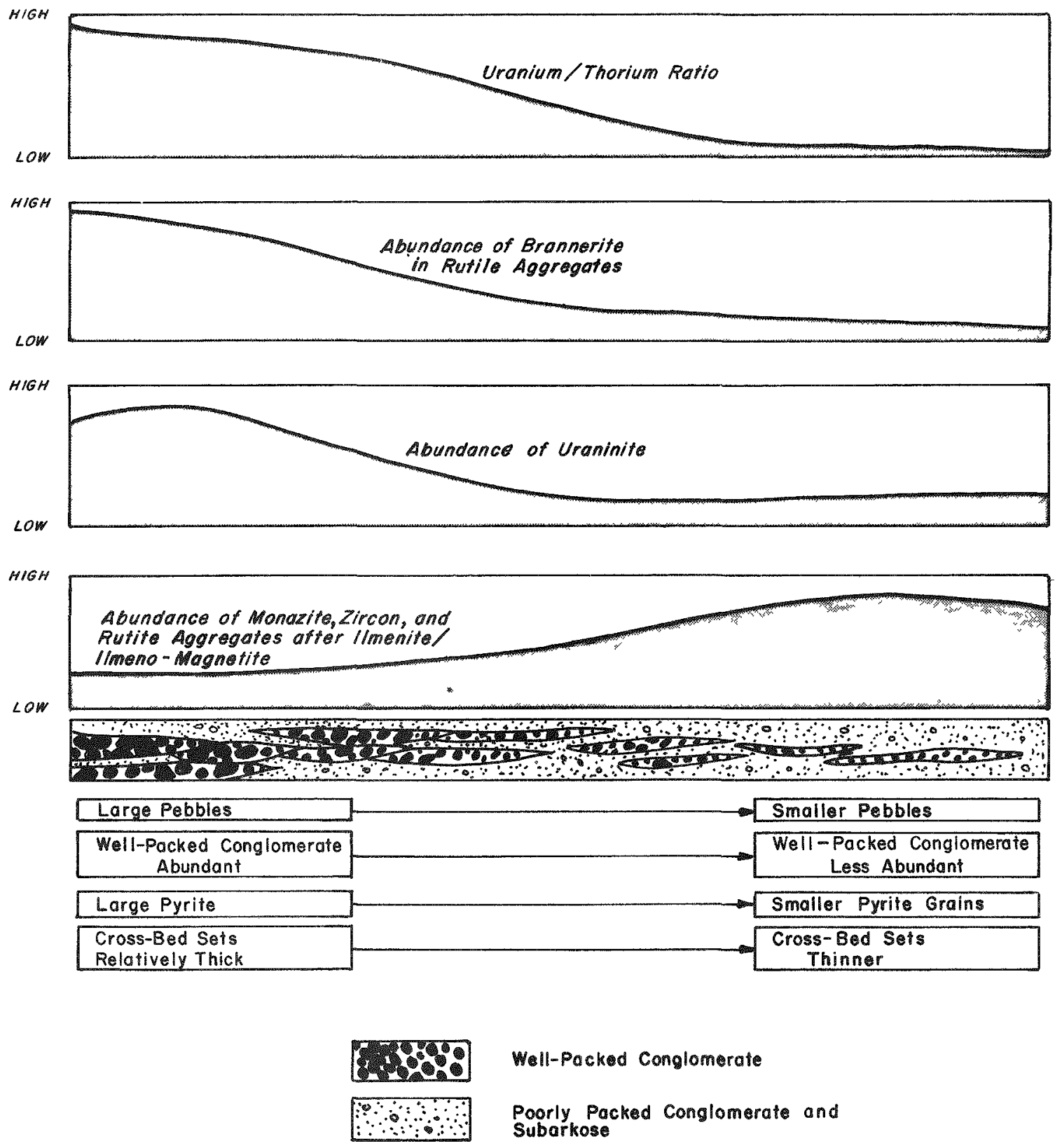

Figure 69. Schematic diagrams showing downstream changes in a Matinenda Formation orebody (compiled from information in Theis, 1979). 
Ramdohr (1957) was one of the first investigators to observe the internal textures of brannerite-bearing aggregates. He noted that remnant rutile laths in the aggregates were frequently found in triangular grid patterns reminiscent of the pattern of exsolved ilmenite in magnetite. He theorized that the brannerite was formed by the "Pronto Reaction". It was suggested that $\mathrm{UO}_{2}$ reacted with $\mathrm{TiO}_{2}$ to form $\mathrm{UTi}_{2} \mathrm{O}_{6}$ (brannerite). In this reaction, either $\mathrm{UO}_{2}$ or $\mathrm{TiO}_{2}$ could be the mobile phase. The reaction was thought to occur under low-grade metamorphic conditions, the $\mathrm{UO}_{2}$ being supplied by uraninite, the $\mathrm{TiO}_{2}$ by sulfidized grains of ilmenite or titaniferous magnetite.

The formation of brannerite is now believed to be a multi-stage process. The first step involves the generation of reactive $\mathrm{TiO}_{2}$ frameworks. Adams and others (1974) have shown that diagenetic dissolution of ilmenite and titaniferous magnetite results in the formation of clots composed of very finely divided $\mathrm{TIO}_{2}$ minerals. Dissolution is promoted by a low $\mathrm{Eh}$ and neutral to weakly acid ground water. The resulting $\mathrm{TiO}_{2}$ skeletons can be expected to have been very efficlent collectors of any uranium in solution in formation waters (Loskorin and others, 1958). Diagenesis or low-grade metamorphism can be expected to have converted the $\mathrm{U}-\mathrm{TiO}_{2}$ complex to the mixtures of rutile, anatase, and brannerite found in many grain aggregates.

This theory explains several commonly observed attributes of brannerite in Precambrian conglomerates.

(1) Brannerite occurs in grain aggregates, some of which were almost certainly formed by dissolution of titaniferous magnetite.

(2) The finest grained rutile/anatase aggregates contain the highest concentrations of uranium (Theis, 1979). This is consistent with chemical kinetics, whereby reactions take place at greater rates on particles which have the highest surface area per unit volume.

(3) The greatest concentration of brannerite is around the rims of titania aggregates, suggesting addition of uranium to a titania aggregate rather than dissolution of detrital brannerite, as had previously been suggested.

(4) The low and variable concentration of brannerite in grain aggregates was probably controlled by the local availability of uranium in solution.

(5) The relatively low thorium content of the brannerite is consistent with the low solubility of this element in aqueous systems.

(6) The quartz- and sulfide-filled internal pores in the titania grain aggregates are consistent with the idea that the aggregates were porous skeletons derived by dissolution of iron from iron-titanium minerals.

(7) The apparent hydraulic equivalence of brannerite with minerals such as pyrite, zircon, and monazite (Theis, 1979) suggests a precursor mineral with a density of about $5 \mathrm{gm} / \mathrm{cm}^{3}$ and is consistent with a magnetite $\left(5.18 \mathrm{gm} / \mathrm{cm}^{3}\right)$ or ilmenite $\left(4.72 \mathrm{gm} / \mathrm{cm}^{3}\right)$ precursor. 
(8) The titania grain aggregates are richest in brannerite in uraniniterich phases of the Matinenda conglomerates. Theis (1979) suggested that ragged-edged, partly dissolved uraninite grains were the probable sources of uranium and stated that the brannerite content of grain aggregates was a function of their proximity to uraninite grains.

Schidlowski (in press), Ramdohr (1958), and Liebenberg (1955) have stressed the occurrence of brannerite as overgrowths on, and partial replacements of, detrital uraninite grains. In such cases, it appears that an immobile uranium phase has reacted with a mobile titanium-rich pore solution.

A question that has been largely ignored in the discussion on the origin of this type of brannerite is the transport mechanism of uranium. Most previous authors have stated or implied that the uranium migrated during diagenesis or low-grade metamorphic conditions in (presumably reducing) pore fluids.

Langmuir (1978) has shown that uranous complexes are only stable under rather specialized conditions in low-temperature systems. Uranous fluoride complexes are stable under $\mathrm{pH}$ conditions of less than 3 , while a $\mathrm{pH}$ of greater than 8 is necessary to transport $\mathrm{U}^{4+}$ as the $\mathrm{U}(\mathrm{OH})_{5}{ }^{-}$complex. It is extremely doubtful that a $\mathrm{pH}$ of 3 or less could be maintained in the system in question, since hydrolysis of silicate minerals would buffer the $\mathrm{pH}$ by production of $\mathrm{OH}^{-}$ions. A $\mathrm{pH}$ of 8 could conceivably have developed in diagenetic pore fluids in the conglomerates and could have caused dissolution of some uraninite. The proximity of brannerite and ragged, partially dissolved uraninite grains could have originated in this way.

A second source of uranium could be the leachate from paleosols during Archean and early Proterozoic paleoweathering. Ferric iron-rich weathering crusts on these profiles (Gay and Grandstaff, in press) suggest a modest concentration of oxidant in the paleoatmosphere or paleo-ground water. Under these conditions, shallow ground waters could have carried some uranium in urany $1\left(U^{6+}\right)$ complexes. As the ground waters moved into paleoaquifers (such as the conglomerate units), they might be expected to have lost their uranium to reactive species such as $\mathrm{TiO}_{2}$ skeletoins. The chemically adsorbed uranium might then be expected to have reacted with the titania to form brannerite under the higher temperatures imposed during diagenesis and lowgrade metamorphism.

\section{Summary}

Brannerite is an extremely important uranium ore mineral in Precambrian quartz-pebble conglomerates. With the possible exception of "Type II" brannerite grains (Theis, 1979), the "mineral" formed in the conglomerates after their deposition. Leaching by reducing paleo-ground water resulted in the destruction of iron-titanium phases such as ilmenite and titaniferous magnetite. The remaining titania skeletons adsorbed uranium (and some other metals) from pore fluids in the conglomerates. Some uranium may have moved as a $\mathrm{U}(\mathrm{OH})_{5}^{-}$complex under alkaline, reducing conditions associated with later diagenesis or low-grade metamorphism. In addition, some uranium could have been carried as uranyl complexes in shallow, weakly oxidizing ground waters. 
The brannerites formed in this way involved an immobile $\mathrm{TiO}_{2}$ phase and a mobile, uraniferous solution. Some brannerites apparently formed by reaction of a mobile $\mathrm{TiO}_{2}$ phase with uraninite grains. In these cases, the brannerite occurs as overgrowths on, and replacements of, uraninite grains. A dissolved $\mathrm{TiO}_{2}$ phase requires a powerful solubilizing agent, possibly an organic complexing molecule.

\section{Coffinite}

Coffinite, which has the generalized formula $U\left(\mathrm{SiO}_{4}\right)_{1-\mathrm{X}}(\mathrm{OH})_{4 \mathrm{X}}$, is a minor source of uranium in quartz-pebble conglomerates. It has been identified in Elliot Lake conglomerates (Patchett, 1960; Robertson, 1976, p. 26). Coffinite is not mentioned in review articles on Witwatersrand mineralogy (Pretorius, 1976; Feather and Koen, 1975). It is developed in small amounts in the Black Reef conglomerates (base of Transvaal Supergroup) in the eastern Transvaal. Here, De Waal and Herzberg (1969) found that coffinite was developed in submicroscopic granules (up to 80 microns in size) in carbonaceous material. It also occurs as botryoidal masses and as crack-fillings in a carbonaceous host. They were of the opinion that the coffinite was formed by the organic reduction of solutions containing hexavalent uranium ions or ionic complexes.

Desborough and Sharp (1979) mention the presence of coffinite granules in conglomerates of the Medicine Bow Mountains, Wyoming.

\section{Columbite}

Columbite is not a significant uranium-bearing mineral in Precambrian uraniferous conglomerates. It has been found as "grains of fairly low roundness and sphericity" in the Dominion Reef conglomerates of South Africa (Hiemstra, 1968a). Some of the grains are well preserved, others are largely metamict.

\section{Euxenite}

Euxenite, a complex hydrated niobate, tantalate, and titanate of uranium, thorium, and rare earth metals, has tentatively been identified in very minor amounts in Dominion Reef conglomerates. A metamict alteration product of columbite, when heated, gave the X-ray diffraction pattern of heated euxenite (Hiemstra, 1968a, p. 12).

\section{Ferrian Thorite}

Thorite is composed of $\mathrm{ThSiO}_{4}$, with variable concentrations of uranium. An $\mathrm{Fe}^{2+}$ rich thorite occurs as detrital grains in the Dominion Reef conglomerates as "fairly large reddish-brown grains which contain inclusions of galena" (Hiemstra, 1968a, p. 12). The material is metamict. After heating, it gives the diffraction pattern of uranoan thorianite.

Gummite and Thorogummite

Gummite is a "generic term for alteration products of uraninite and pitchblende" (Steacy and Kaiman, 1978). It comprises a dense gummy mass of brightly colored uranium silicates and oxides. Roscoe (1969) mentioned gummite in Matinenda conglomerates, presumably as a surficial alteration product of one of the primary uranium minerals. According to Robertson 
(1976), who quoted Rice (1958), gummite (comprising the minerals soddyite and uranophane) was a significant ore mineral at the Spanish American Mine in the Elliot Lake district. De Waal and Herzberg (1969) mentioned gummite in cracks associated with near-surface samples of uraniferous Black Reef conglomerate in the eastern Transvaal, South Africa.

A single occurrence of "thorogummite" has been mentioned. It occurs in a granitic paleosol of the Elliot Lake area (Roscoe, 1969).

Monazite

Monazite is a complex phosphate mineral with the general formula (Ce, La, Nd, $\mathrm{Th}, \mathrm{U}) \mathrm{PO}_{4}$. In the Witwatersrand Supergroup (sensu stricto), monazite is a very rare mineral, occurring as minute euhedral grains in detrital uraninite (Feather and Koen, 1975). It also occurs in veinlets in conglomerates in parts of the Witwatersrand Basin (Liebenberg, 1955).

Monazite is one of the most abundant heavy mineral grains in the Dominion Reef conglomerates. It occurs as cracked, of ten we11-rounded, sometimes zoned grains averaging about $0.1 \mathrm{~mm}$ in diameter (Hiemstra, 1968a, p. 13). The grains have suffered minor metamictization. Selected grains from this source contain 4.47 percent $\mathrm{ThO}_{2}$ and 0.32 percent $\mathrm{U}_{3} \mathrm{O}_{8}$.

Monazite is an abundant detrital heavy mineral in conglomerates of the Matinenda Formation, Elliot Lake area (Roscoe, 1969). Rounded grains some $0.3 \mathrm{~mm}$ in diameter are abundant in most ores. They vary in color in a single sample, from red, through orange, yellow, and gray. Gray monazites are significant sources of uranium in this area (Roscoe, 1959b). They contain finely disseminated pyrite, plus inclusions of a radioactive mineral tentatively identified as uranothorite. These grains have a higher thorium and a much higher uranium content than other monazites. Some of the uranium in these grains is leached and recovered during metallurglcal treatment of the ore.

J.A. Robertson (1976) has summarized the chemistry of monazites from the Matinenda conglomerates. ThO ${ }_{2}$ contents range from 3.9 to 6.7 percent, and $\mathrm{U}_{3} \mathrm{O}_{8}$ from 0.31 to 2.9 percent (Table 30 ).

Theis (1979) studied monazite grains from the Elliot Lake conglomerates. He found that the monazites are generally larger than associated zircons and range in size from 0.2 to $0.4 \mathrm{~mm}$. In his study, he found a strong correlation between $\mathrm{Ce}$ and $\mathrm{La}(0.99)$ and between these elements and $\mathrm{ThO}_{2}(0.84$ and 0.81 , respectively). These correlations confirm that monazite is the major source of $\mathrm{Ce}, \mathrm{La}$, and $\mathrm{ThO}_{2}$ in the Matinenda conglomerates. Each of these elements shows a strong negative correlation with pebble size. Apparently, there were few monazite grains large enough to be deposited in hydraulic equilibrium with the larger pebbles.

\section{Thorite and Uranothorite}

Thorite ( $\mathrm{ThSiO}_{4}$ ) usually contains some uranium. With a significant uranium content, it is referred to as "uranothorite". 
Table 30. Analyses of monazites from Matinenda uraniferous conglomerates (after J.A. Robertson, 1976).

\begin{tabular}{|c|c|c|c|c|c|c|}
\hline & & $\mathrm{SCOE}$ & & & THORP & 53) \\
\hline & 1 & 2 & 3 & 4 & Range & Average \\
\hline Color & orange & yellow & gray & gray & & \\
\hline $\mathrm{ThO}_{2}$ & 5.9 & 3.9 & 6.7 & 5.9 & $5.6-6.2$ & 5.6 \\
\hline $\mathrm{U}_{3} \mathrm{O}_{8}$ & 0.31 & 0.95 & 1.65 & 2.9 & $1-2$ & 1.4 \\
\hline $\mathrm{U}_{3} \mathrm{O}_{8} / \mathrm{ThO}_{2}$ & 0.0525 & 0.244 & 0.246 & 0.492 & $0.18-0.32$ & 0.25 \\
\hline
\end{tabular}

Thorite is an extremely rare mineral in the Witwatersrand (sensu stricto). A single occurrence, in association with zircon, has been noted (Feather and Koen, 1975).

Metamict uranothorite is an important source of acid-soluble thorium in Dominion Reef conglomerates. The mineral contains 34.9 percent $\mathrm{ThO}_{2}, 9.5$ percent $\mathrm{U}_{3} \mathrm{O}_{8}$, and 13.9 percent $\mathrm{Pb}$ (as specks of radiogenic galena). According to 0rtlepp (1962), the uranothorite originated through "the replacement in situ of relatively thorium-rich grains of uraninite by siliceous solutions".

Thorite grains are present in granitic rocks (and their paleoweathered equivalents) in the Elliot Lake area. The grains measure 0.2 to $0.5 \mathrm{~mm}$ in diameter (Roscoe, 1969).

Small quantities of uranothorite occur in Matinenda conglomerates of the Elliot Lake region (Roscoe, 1969; Theis, 1979). Uranothorite is the major uranium ore mineral in the relatively strongly metamorphosed Agnew Lake area, east of the E11iot Lake district.

In the Medicine Bow uraniferous conglomerate occurrences of Wyoming, Desborough and Sharp (1979) have noted the presence of thorite grains. The grains contain 30-45 weight percent $\mathrm{Th}$, and up to several percent of $\mathrm{U}, \mathrm{Pb}$, and $\mathrm{Y}$.

\section{Uraninite}

Uraninite (theoretically $\mathrm{UO}_{2}$ ) is the most important ore mineral of uranium in most Witwatersrand conglomerates and is a very important source of uranium in E11iot Lake ores. It has been more extensively studied than any other uranium mineral in Precambrian uraniferous conglomerates. In that uraninite is inherently unstable under present atmospheric conditions, its presence in large quantities in Precambrian conglomerates has excited interest beyond that due to its economic importance. Its presence has been widely cited as evidence of an anoxic or reducing paleoatmosphere during the early Proterozoic and Archean (see, for example, D.S. Robertson, 1974). 
Uraninite occurs in the matrices of the conglomerates under discussion and in arenite partings and lenses associated with the conglomerates. In the Witwatersrand and Elliot Lake districts, uraninite grains are said to be concentrated at the basal contacts of uraniferous conglomerates, along with gold and other heavy minerals (Schidlowski, in press; Roscoe, 1969). Occasionally, concentrations are found higher in the conglomerates, along what have been termed "false footwalls". These probably represent local erosion surfaces within the conglomerate sequence. Roscoe (1969) has described a uraninite grain that was pressed down into an underlying argillite by an overlying quartz pebble.

Extremely rich concentrations of uraninite are found along bedding and crossbedding surfaces in arenite partings within Matinenda conglomerates (Roscoe, 1969). Some of these layers are over $1 \mathrm{~cm}$ thick and were observed to contain size-graded uraninite grains in places, varying from about $0.2 \mathrm{~mm}$ at the bases of the layers to $0.1 \mathrm{~mm}$ at their tops (Figures 70.2 and 70.3).

Several authors have noted that uraninite grains tend to form clusters in the matrices of uraniferous conglomerates. The clusters vary in size from about 1 to $3 \mathrm{~mm}$ and have the appearance of gray metallic specks. Some of the clusters are composed essentially of uraninite grains. Others include heavy minerals such as zircon (Feather and Koen, 1975).

In some conglomerates, there is a well-defined relationship between pebble size and the development of uraninite. In the Denison area of the Elliot Lake district, conglomerates with pebbles over $40 \mathrm{~mm}$ in size contain appreciable uraninite. Those with pebbles 35 to $40 \mathrm{~mm}$ in diameter contain some uraninite, while this mineral is very rare where pebbles are smaller than $35 \mathrm{~mm}$ and essentially absent where pebbles are smaller than $30 \mathrm{~mm}$ (Theis, 1979).

\section{Grain Size}

The sizes of uraninite grains vary within very small limits. Roscoe (1969) and Theis (1979) noted a size range of 0.05 to $0.2 \mathrm{~mm}$ for Matinenda conglomerates. Witwatersrand uraninites tend to be somewhat smaller. Liebenberg (1955) determined the range in uraninite grain sizes from several Witwatersrand conglomerates at 0.02 to $0.18 \mathrm{~mm}$. Size distribution histograms show that the modal size-class is usually between 0.04 and $0.10 \mathrm{~mm}$.

Detailed studies of uraninite grain-size distributions were undertaken by Koen (1961) and Coetzee (1965). They showed that the slopes and shapes of uraninite grain-size cumulative frequency curves were almost identical to those of undoubted detrital minerals such as zircon and chromite. Koen found that uraninite median grain size varied from 0.091 to $0.294 \mathrm{~mm}$. The ratio of the median grain size of uraninite to that of zircon and chromite in the same samples was found to be nearly constant and to range from 0.413 to 0.598 . These authors showed that uraninite grains are very slightly smaller than would have been predicted by a strict application of the principle of hydraulic equivalence. Coetzee (1965) suggested that this reflected the availability of various size-grades in the parent rock. 
Simpson and Bowles (1977) found that uraninite grains from the Dominion Reef are in hydraulic equilibrium with pyrite and quartz grains. By contrast, they assert that associated gold grains are too small to be in equilibrium with the uraninite, quartz, and pyrite.

Grain Shape

Uraninite grains are usually equidimensional. Their degree of rounding varies greatly. Grains from Matinenda conglomerates are usually angular to subrounded (Figure 70.3), but can vary from euhedral to well rounded (Roscoe, 1969; Theis, 1979). Witwatersrand uraninites are, on the average, better rounded. They are most of ten rounded to well rounded and are oval or "muffinshaped" (see Figure 71.1). The latter grains are bounded by one falrly flat side, with the opposite side forming a bulge (Schidlowski, in press).

Feather and Koen (1975) noted that euhedral and subhedral uraninite grains are more common in the Witwatersrand than had been previously implied. They believe that some of the crystal faces on grains represent overgrowths caused by recrystallization of uraninite.

Primary Inclusions

Hiemstra (1968a) illustrated a well-preserved primary inclusion of zircon in a Dominion Reef uraninite grain. Other inclusions which could be primary include small bodies of quartz and monazite (Feather and Koen, 1975).

\section{Secondary Inclusions}

The most common secondary inclusions in the uraninite grains in quartz-pebble conglomerates are minute specks of galena. The galena was almost certainly formed by sulfidization of radiogenic lead and implies a mobile sulfur-bearing phase in the conglomerates over a great length of time. Some of the radiogenic galena has been mobilized and now fills cracks within the uraninite grains or forms halos around them (Figure 72.3).

Other minerals that form inclusions within uraninite grains include gold, gersdorffite, pyrite, pyrrhotite, and chalcopyrite. These minerals usually occur as crack fillings, sometimes along octahedral parting planes in the uraninite (Feather and Koen, 1975).

The interiors of some uraninite grains appear to have been dissolved to leave what are, in effect, negative crystals. The open spaces in the grains become filled by a variety of secondary minerals, including quartz, pyrrhotite, and gold. The leaching of the interior of the grains implies compositional variations within grains. It seems probable that the less soluble rims are richer in a phase such as $\mathrm{ThO}_{2}$.

Uraninite Zoning and Cleavage

Zoned uraninite crystals are very rare in Precambrian quartz-pebble conglomerates. Ramdohr (1958) alluded to a rectilinear cubic zonal structure in a few grains of uraninite from the Witwatersrand. Grains showing octahedral cleavage are more common. In some of these grains, the octahedral cleavage planes have become filled by some of the secondary phases described above. 
Figure 70: 1 . (top left): Zoned uraninite grain from a panned heavy mineral concentrate from the Indus River, Chilas, Gilgit, Pakistan (163x, from Zeschke, 1960).

2. (top right): X-ray photomicrograph of thin section showing flat-based, sometimes cross-laminated, uraninite microlayers in a subarkose lens within an ore conglomerate from the Quirke Mine, Elliot Lake district (from Roscoe, 1969).

3. (center left): Photomicrograph of a uraninite microlayer showing angular nature of grains and fining-up sizegrading; sample as in Figure 70.2 (from Roscoe, 1969).

4. (center right): Scanning electron photomicrograph of bundles of microcolumns in a Witwatersrand carbon seam (from Hallbauer, 1975).

5. (lower left): Scanning electron photomicrograph of a "fly speck" carbon granule, Basal Reef, St. Helena Gold Mine, Welkom Goldfield (from Hallbauer, 1975).

6. (lower right): Gold (showing scratches) in a pressure shadow of a rounded compact pyrite grain in a mass of carbon, B Reef, Loraine Gold Mines, Welkom Goldfield (96x, from Schidlowski, 1966a). 

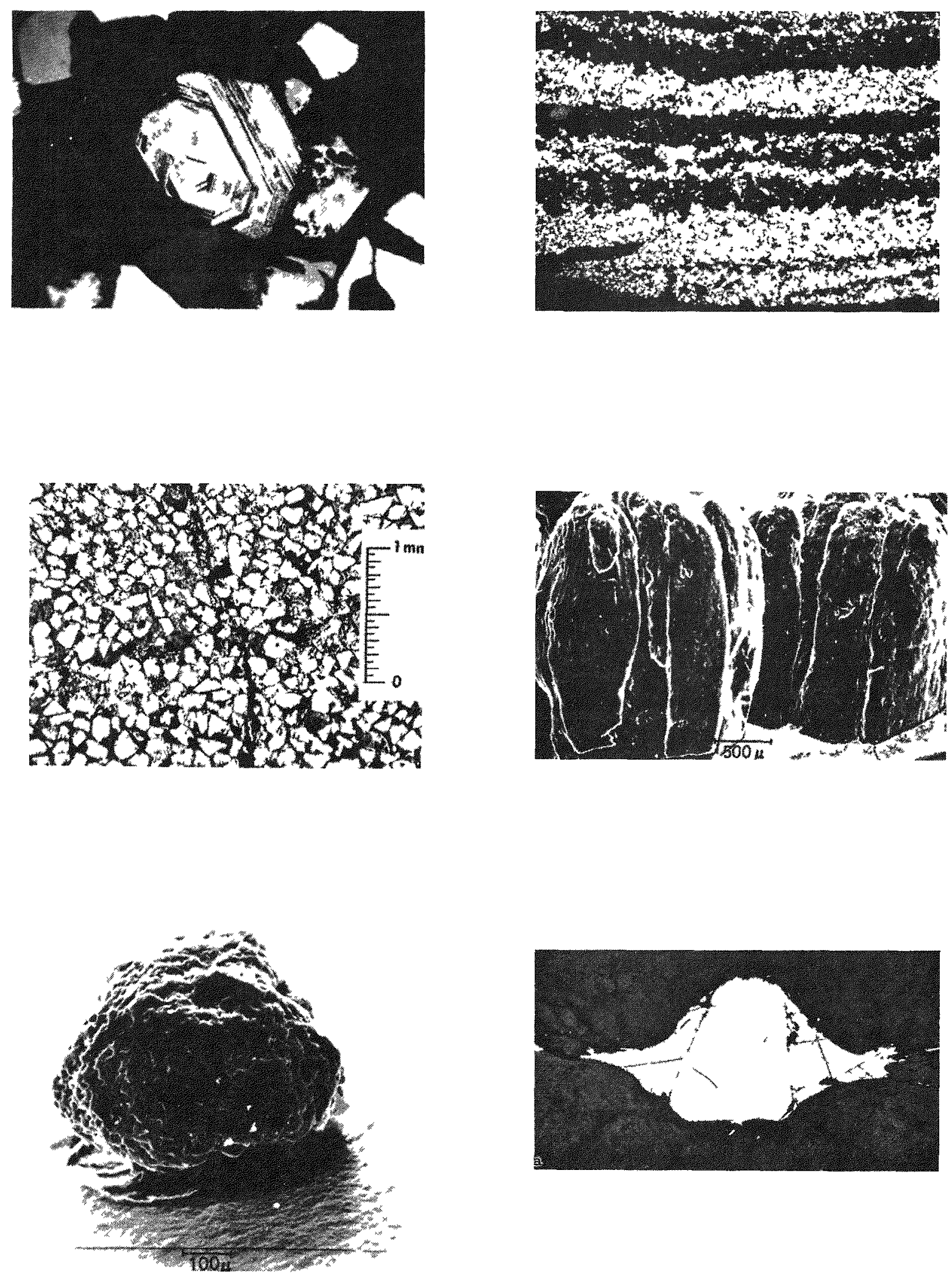
Figure 71: 1. (top left): Rounded gralns of uraninite (some of them "muffin-shaped") with a very fine-grained dusting of

galena, Basal Reef, Loralne Gold Mines, Welkom Goldfleld (198x, from Schidlowski, 1966c).

2. (top right): Uraninite grains in early stages of disintegration. Carbon fills cracks in, and forms a halo around, the uraninite grains. A halo of pyrite grains occurs around the carbon, B Reef, Loraine Gold Mines, Welkom Goldfield (173x, from Schidlowsk1, 1966d).

3. (center left): Uraninite grain in a more advanced stage of disintegration in carbon. Note higher reflectivity of carbon near the uraninite. White specks in uraninite are radiogenic galena. From the B Reef, Loraine Gold Mines, Welkom Goldfield (249x, from Schidlowsk1, 1966a).

4. (center right): Granule of carbon which has "digested" much of the original uraninite grain, leaving small angular uraninite remnants. Note pyrite halo around granule. B Reef, Loraine Gold Mines, Welkom area (173x, from Schidlowski, 1966d).

5. (lower center): Polished section cut perpendicular to carbon columns. Note streamlined "flow" effects and small angular uranintte remnants surrounded by more reflective carbon. B Reef, Loraine Gold Mines, Welkom Goldfield (77x, from Schidlowski, 1966a). 

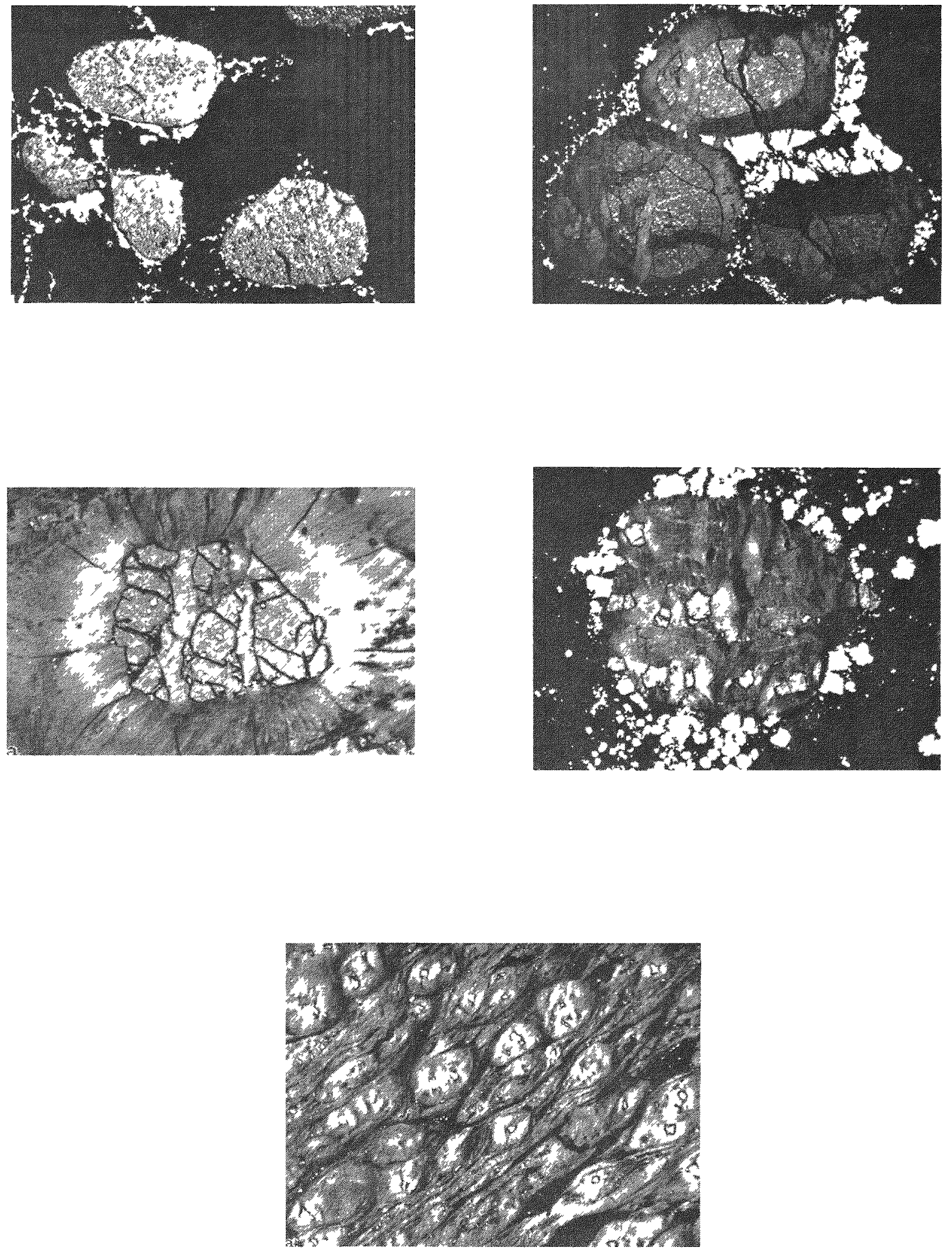
Figure 72: 1. (top left): Uraninite "ghosts", the shapes of which are preserved by rims of brannerite. Basal Reef, Free State Geduld Mine, Welkom Goldfield (no magnification given; Thiel and others, 1979).

2. (top right): Uraninite "ghost" composed of brannerite surrounded by pyrrhotite laths and filled by chalcopyrite, pyrrhotite, and some galena. Elsburg A-1 Reef, Loraine Gold Mines, Welkom Goldfield (265x, Schidlowski, 1966e).

3. (center): Uraninite grain, with dusting of galena, and cut by veins of carbon, enclosed in a mantle of pyrite. The pyrite is cracked due to radioactive "blasting". Elsburg A-3 Reef, Loraine Gold Mines, Welkom Goldfield (244x, Schidlowski, 1966f).

4\&5: (lower left and right): Porous pyrite grains with leucoxene (Lx) and chloritoid laths (gray). The right-hand photograph shows the fission tracks (due to ${ }^{235} \mathrm{U}$ disintegration) on a mica detector and indicates the concentration of uranium in a discontinuous coating around the pyrite. B Reef, Free State Geduld Gold Mine, Welkom Goldfield (Thiel and others, 1979). 

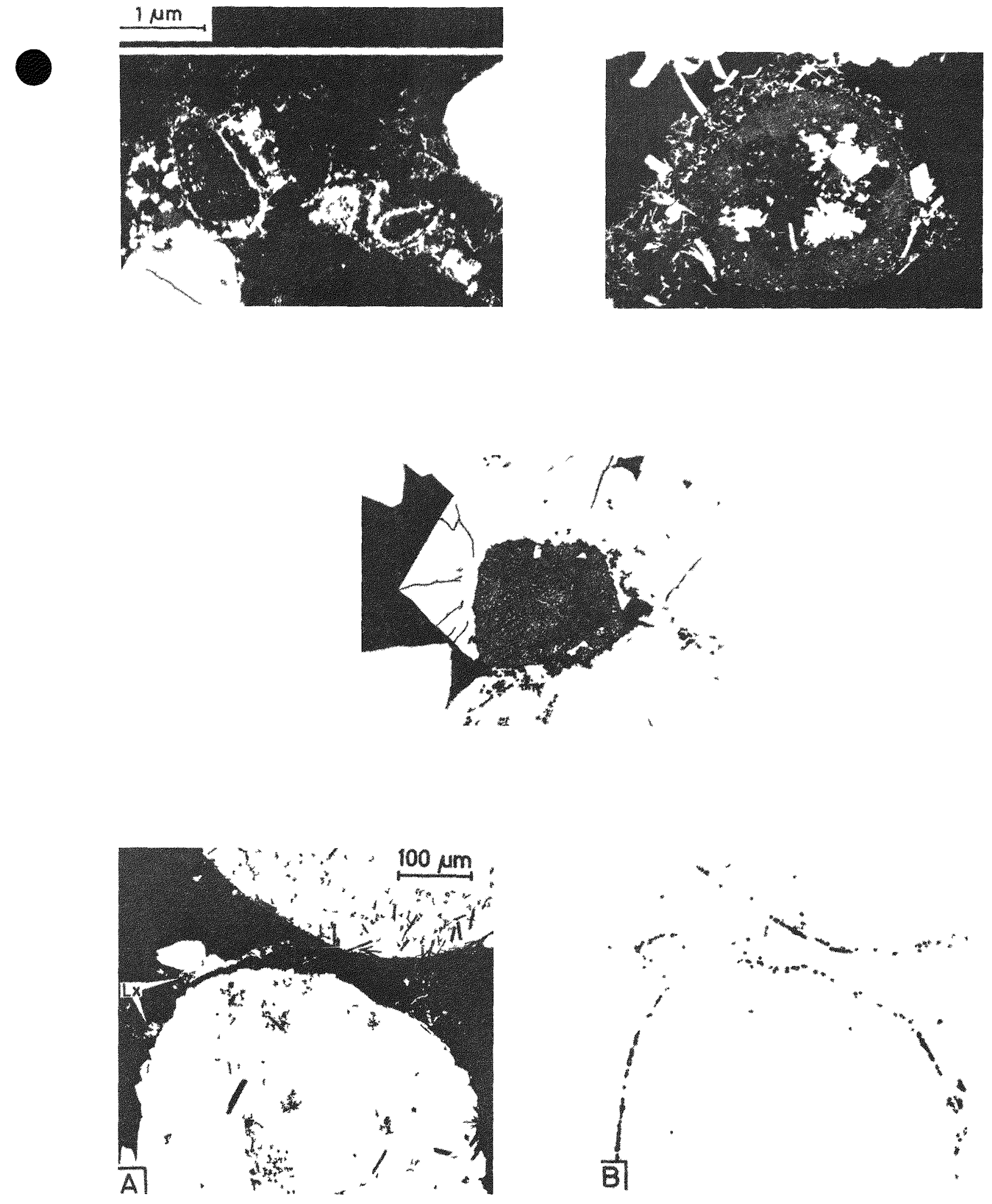
The uraninite grains contained in Precambrian conglomerates are frequently altered to varying degrees. Numerous authors (for example, Liebenberg, 1955; Ramdohr, 1958) have shown various stages in the alteration of uraninite grains. In many cases, the alteration is seen as a partial replacement of uraninite by what was called "secondary uraninite" by Liebenberg and Ramdohr. It is now known that the secondary uraninite is a U-Ti phase, which has been identified as brannerite by Feather and Koen (1975). Such brannerite also occurs as overgrowths around uraninite grains. In certain cases, the entire grain has become replaced by brannerite. Ramdohr (1958) referred to such grains as "ghosts". Thiel and others (1979) figure yet another replacement style in which the original uraninite grains are represented by shells of brannerite coinciding with the original outer margin of the grains. The interiors of the grains were completely leached and are now filled by some of the secondary minerals mentioned above (Figure 72.1).

Feather (in press) and Feather and Koen (1975) have noted that some of the rounding of uraninite grains is probably due to post-depositional dissolution of uraninite. They base this conclusion on the fact that rounded grains are invariably found to be surrounded "by traces of minute crystals of an alteration product".

Another style of alteration of uraninite grains involves the introduction of solid hydrocarbon along cracks in the grains (Schidlowski, in press). All stages in this process have been noted, from relatively thin crack-fillings in grains to the complete disruption of grains into very small, angular fragments (Figures 71.2 and 71.3 ).

\section{Composition of Uraninite Concentrates}

Prior to the development of techniques capable of analysing single grains, the composition of uraninite was determined by analysing concentrates. Roscoe (1969) and J.A. Robertson (1976) have summarized the results of analytical work on uraninites from the Matinenda Formation (Table 31). The uraninites contain between 39 and 60 percent $\mathrm{U}_{3} \mathrm{O}_{8}$, approximately 4 to 7 percent $\mathrm{ThO}_{2}$ and approximately 3 to 8 percent rare earth oxides. In order of abundance, the rare earth elements determined were Y, Nd, Ce, Dy, Gd, Sm, Er, Pr, and La (Roscoe, 1969). This order of abundance was shown to be identical with that of uraninites from the pegmatite-related deposits of the Bancroft area in Ontario, Canada.

Liebenberg (1955) presented the results of chemical analyses of Witwatersrand uraninites (Table 32). The concentrates contain on the order of 70 percent $\mathrm{U}_{3} \mathrm{O}_{8}, 2$. percent $\mathrm{ThO}_{2}, 1-2$ percent rare earths, and measurable concentrations of $\mathrm{ZrO}_{2}, \mathrm{TiO}_{2}, \mathrm{SiO}_{2}, \mathrm{MgO}, \mathrm{CaO}, \mathrm{Fe}_{2} \mathrm{O}_{3}$, and $\mathrm{Al}_{2} \mathrm{O}_{3}$. Hiemstra (1968a) determined that Dominion Reef uraninite contains 17.1 percent $\mathrm{UO}_{2}, 46.19$ percent $\mathrm{UO}_{3}$, 6.52 percent $\mathrm{ThO}_{2}$, and 3.43 percent rare earth elements. 
Table 31. The composition of uraninites from Blind River/Elliot Lake conglomerates (after J.A. Robertson, 1976).

\begin{tabular}{llccc}
\hline \multicolumn{1}{c}{ MINE } & AUTHOR & $\begin{array}{c}\mathrm{U}_{3} \mathrm{O}_{8} \\
\text { percent }\end{array}$ & $\begin{array}{c}\mathrm{ThO}_{2} \\
\text { percent }\end{array}$ & $\mathrm{U}_{3} \mathrm{O}_{8} / \mathrm{ThO}_{2}$ \\
\hline Denison & Pienaar (1963) & 48.4 & 5.6 & 8.65 \\
Denison & Pienaar (1963) & 39.0 & 7.2 & 5.4 \\
Denison & Pienaar (1963) & 55.5 & 5.4 & 10.3 \\
Nordic & Patchet (1960) & 55.25 & 6.25 & 8.85 \\
Quirke & Wanless and Trail1 (1956) & 51.7 & 4.1 & 12.6 \\
Pronto & Wanless and Trail1 (1956) & 57.0 & 5.12 & 11.1 \\
Nordic & Roscoe (1959a) & 64.0 & 6.3 & 10.15 \\
Denison & Roscoe (1959a) & 60.0 & 5.9 & 10.2 \\
Regional & Thorpe (1963) & 60.0 & 6.0 & 10.0 \\
& & & & \\
\hline
\end{tabular}

Table 32. Chemical analyses of uraninite concentrates from Witwatersrand conglomerates (after Liebenberg, 1955).

\begin{tabular}{|c|c|c|}
\hline \multirow{2}{*}{ CONSTITUENT } & BLYVOORUITZICHT & SUB NIGEL \\
\hline & (CARBON LEADER) & (MAIN REEF LEADER) \\
\hline $\mathrm{U}_{3} \mathrm{O}_{\mathrm{g}}$ & 74.10 & 66.65 \\
\hline $\mathrm{Pb}$ & 15.50 & 18.05 \\
\hline $\mathrm{ThO}_{2}$ & 270 & 1.63 \\
\hline Rare Earths & 1.00 & 2.13 \\
\hline $\mathrm{ZrO}_{2}+\mathrm{TiO}_{2}$ & 1.40 & 1.01 \\
\hline $\mathrm{SiO}_{2}$ & 1.78 & 2.07 \\
\hline $\mathrm{MgO}$ & 0.16 & 0.30 \\
\hline $\mathrm{CaO}$ & 0.81 & 1.54 \\
\hline $\mathrm{Fe}_{2} \mathrm{O}_{3}$ & 0.84 & 1.81 \\
\hline $\mathrm{Al}_{2} \mathrm{O}_{3}$ & 1.33 & 0.99 \\
\hline TOTAL & 96.62 & 96.21 \\
\hline
\end{tabular}

\section{Single-Grain Analyses of Uraninite}

In the last ten years, the development of the electron microprobe has resulted in a number of studies on the compositions of individual grains of uraninite. Grandstaff (1974b) studied the $\mathrm{UO}_{2}$ and $\mathrm{ThO}_{2}$ contents of several uraninite grains from the Witwatersrand and Matinenda conglomerates. Step scans showed no coherent pattern of zoning within individual grains. Determination of the $\mathrm{UO}_{2}$ and $\mathrm{ThO}_{2}$ contents of uraninite grains showed a wide scatter within single samples. The Elliot Lake samples contained from 58 to 69 percent $\mathrm{UO}_{2}$ and 4 to 9 percent $\mathrm{ThO}_{2}$. The Witwatersrand samples (from the Vaal Reef West Mine, Klerksdorp area) analysed 55 to 77 percent $\mathrm{UO}_{2}$ and 0.8 to 11 percent $\mathrm{ThO}_{2}$ (Figure 73). 


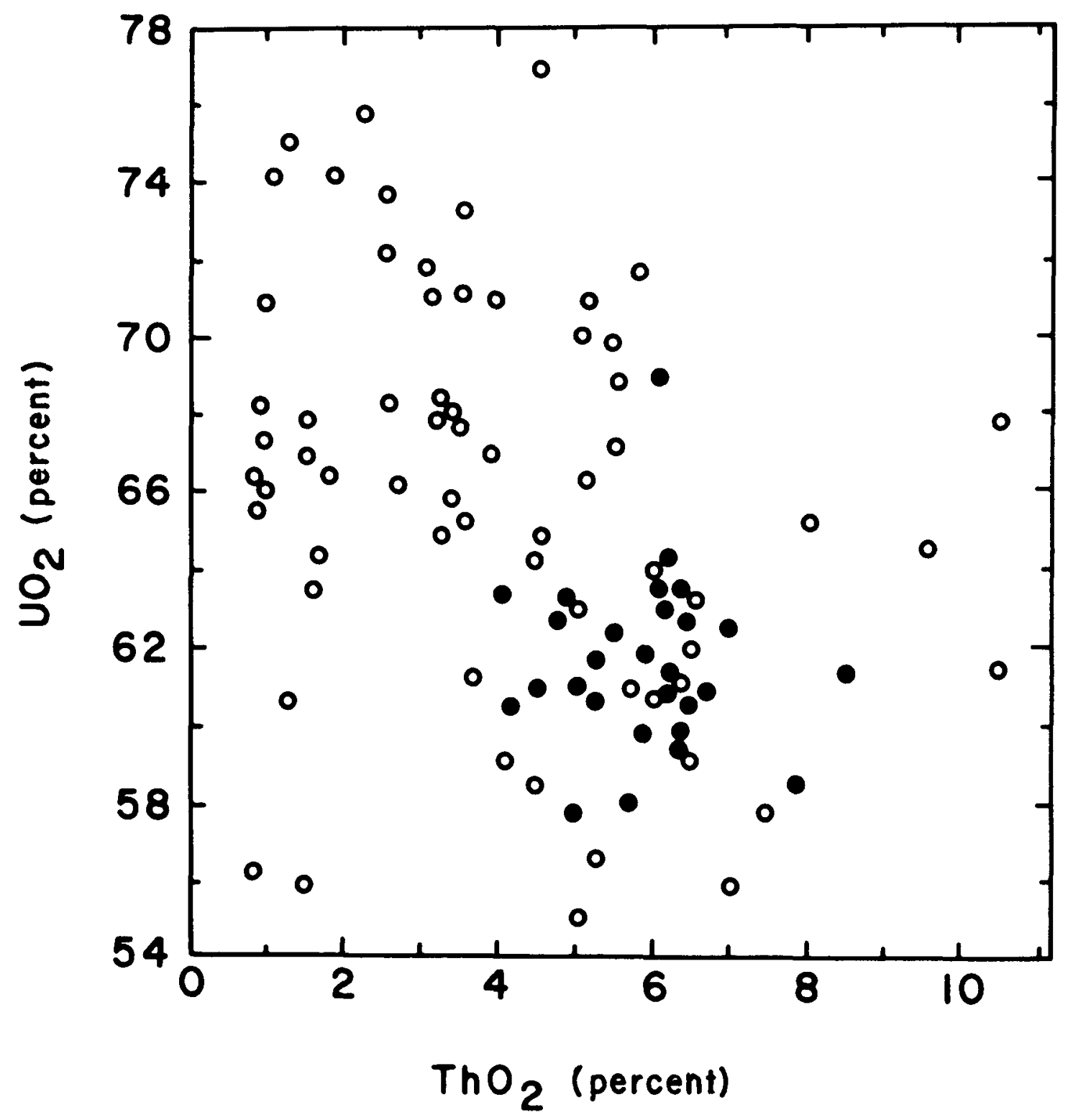

Figure 73. $\mathrm{ThO}_{2}$ and $\mathrm{UO}_{2}$ content of individual uraninite grains from the Rio Algom Nordic Mine, Elliot Lake district, Ontario (closed circles), and from the Vaal Reef West Mine, Witwatersrand, South Africa (open circles). From Grandstaff, $1974 \mathrm{~b}$.

Similar studies have been carried out by several authors, incIuding Feather (in press), Simpson and Bowles (1977), and Theis (1979). Their results are summarized in Table 33. In addition to $\mathrm{UO}_{2}$ and $\mathrm{ThO}_{2}$, Feather determined that the average Witwatersrand uraninite (33 grains) contained 22.8 percent $\mathrm{PbO}_{2}$, 
Table 33. $\mathrm{UO}_{2}$ and $\mathrm{ThO}_{2}$ characteristics of individual uraninite grains from the Witwatersrand, Dominion Reef, and Matinenda conglomerates.

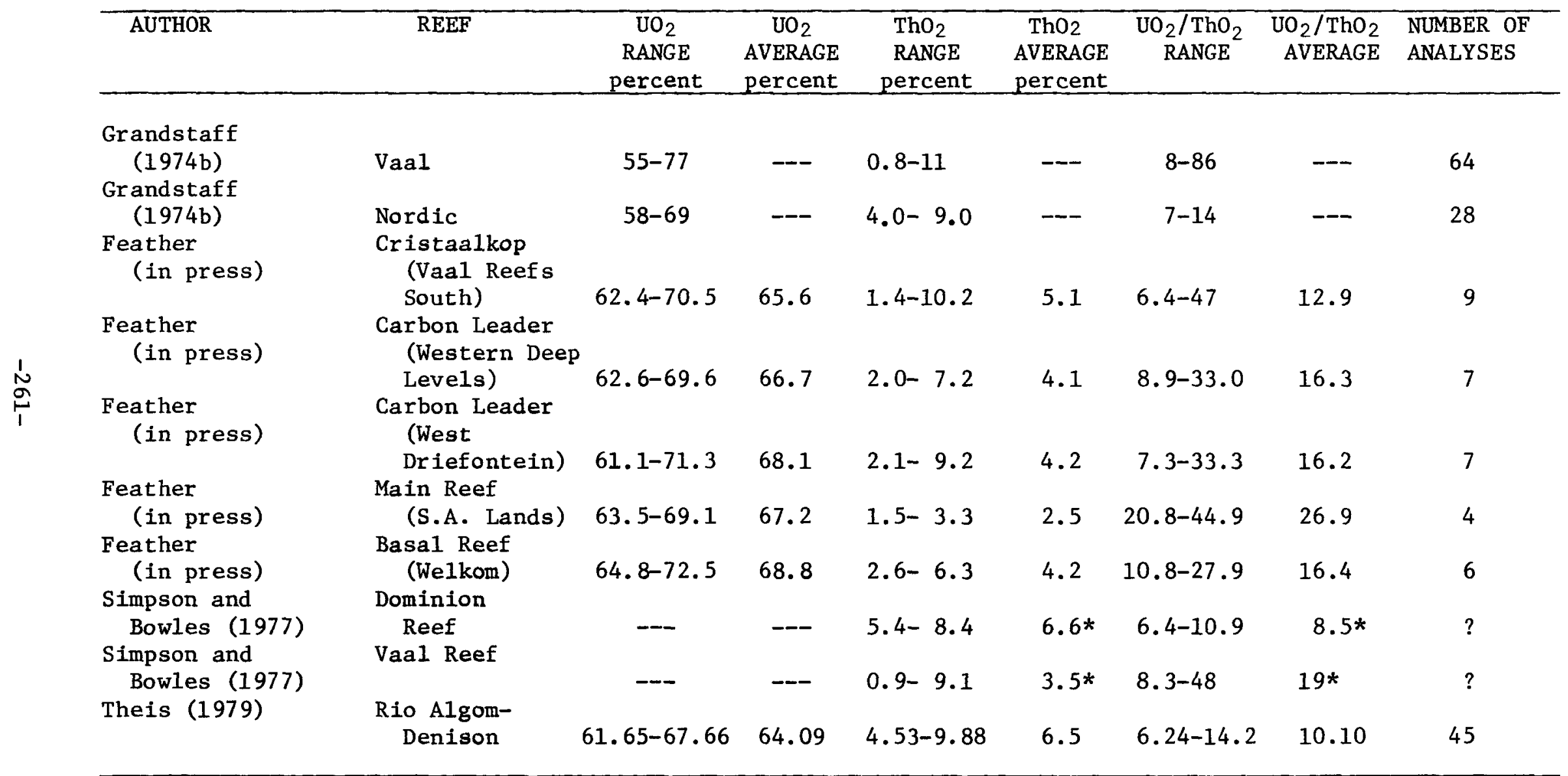

*Median Values, Not Average 
0.5 percent $\mathrm{FeO}, 0.2$ percent $\mathrm{TiO}_{2}$, and 0.7 percent $\mathrm{CaO}$. The overall average $\mathrm{UO}_{2} / \mathrm{ThO}_{2}$ ratio for the Witwatersrand grains was determined at 17.2 .

Theis (1979) studied the compositions of 45 uraninite grains from the Matinenda conglomerates of the Elliot Lake area. He determined $\mathrm{Al}_{2} \mathrm{O}_{3}, \mathrm{SiO}_{2}, \mathrm{Y}_{2} \mathrm{O}_{3}, \mathrm{~S}$, $\mathrm{P}_{2} \mathrm{O}_{5}, \mathrm{PbO}, \mathrm{CaO}, \mathrm{TiO}_{2}, \mathrm{Ce}_{2} \mathrm{O}_{3}$, and $\mathrm{FeO}$, in addition to $\mathrm{UO}_{2}$ and $\mathrm{ThO}_{2}$. The $\mathrm{Y}_{2} \mathrm{O}_{3}$ concentration was found to be as high as 4.42 percent, the $\mathrm{Ce}_{2} \mathrm{O}_{3}$ as high as 1.10 percent.

The relatively high $\mathrm{ThO}_{2}$ content of Witwatersrand and Matinenda uraninites suggests a "pyrogenetic" source, such as a granite or granitic pegmatite (Grandstaff, 1974b). The compositional variability of uraninite grains is greatest for Witwatersrand samples and is somewhat less for Matinenda and Dominion Reef material. Grandstaff stressed that the great compositional variabllity of grains from within small volumes of conglomerate suggests derivation of uraninite grains from several different granitic or pegmatitic sources.

The results provided in Table 33 are strong evidence against the hydrothermal introduction of uranium into the conglomerates to form uraninite, an idea championed by C.F. Davidson and published in a series of papers in the 1950s (see, for example, Davidson, 1957). Hydrothermal uraninites contain very 1ittle thorium, usually less than 0.1 percent $\mathrm{ThO}_{2}$ (Frondel, 1958). Furthermore, the extreme variation in uraninite grain composition over very small distances and the lack of zoning cannot be reconciled with a hydrothermal origin of uraninite.

A scrutiny of the analyses presented in Table 33 suggests that two geochemical types of uraninite grain can be distinguished. In those stratigraphic situations where it can be inferred that the uraninite was derived from a nearby granitic source (Matinenda and Dominion Reef conglomerates), the thorium contents are relatively high (average about 6.5 percent $\mathrm{ThO}_{2}$ ), and the $\mathrm{UO}_{2} / \mathrm{ThO}_{2}$ ratios are relatively consistent and relatively low (average 8.5 to 10). In stratigraphic situations where the uraninite can be inferred to have been derived from a more distant source (and possibly have been recycled several times), the thorium contents are relatively low (about 2.5 to 4 percent) and the $\mathrm{UO}_{2} / \mathrm{ThO}_{2}$ ratios are highly variable (usually between 6 and 50) and relatively high (average 13 to 27 ).

Origin of the Uraninite

There have been several ideas on the origin of uraninite grains in Witwatersrand and Matinenda conglomerates. Some investigators have proposed a hydrothermal origin. Chief among these was C.F. Davidson, whose principal argument against the placer hypothesis was the very low uranium content (and high thorium content) of modern placers (Davidson, 1957). The paleoplacers in question have high uranium to thorium ratios. A second objection involved the supposed chemical and mechanical instability of uraninite grains. Davidson was of the opinion that uraninite would not be able to withstand significant distances of fluvial transport. These objections are examined in the paragraphs below. 
A novel idea for the origin of Elliot Lake uraninite was presented by Kimberley (1978) and by Kimberley and others (in press). They pointed to the development of stratiform pyrite-uranium-thorium deposits in permeable diatomite beds in a volcanogenic sedimentary pile in central Italy. The deposits formed where chemically active ground waters, charged with volcanic gases, leached $U$ and Th from volcanic rocks and deposited these elements, along with pyrite, in porouspermeable sedimentary layers. Subsequent erosion of such beds might be expected to have supplied pyrite and uranium-thorium aggregates to a nearby sedimentary basin. Kimberley suggested that this process may have supplied these constituents to basins such as the Huronian and the Dominion Reef. The low-grade metamorphism which was superimposed on sediments in these basins was called on to homogenize uranium-thorium aggregates to thorian uraninites. In support of their idea, they pointed to the association of many uraniferous conglomerates with volcanic rocks.

This theory has not been developed to the extent that it can be considered as a satisfactory explanation for the origin of detrital uraninites. Major problems are the lack of a volcanic association in many areas and the lack of any textural evidence of an inhomogeneous, U-Th precursor to thorian uraninites. The major uraniferous conglomerates of the Witwatersrand, located in the western half of the basin, are not associated with volcanic rocks. The nearest volcanic rocks are those of the Jeppestown Basalt (in the lower Witwatersrand) and the Ventersdorp lavas, above the Witwatersrand. These volcanic units are separated in time (by major unconformities) from the uraniferous sections of the Witwatersrand. Furthermore, they are basalt dominated and do not have the high $U$ and Th background concentrations of the Quaternary volcanics in the area of central Italy.

Physical Durability of Uraninite. The attrition resistance of uraninite was investigated by Koen (1958). It was found that, where uraninite particles equivalent in size to those in uraniferous conglomerates were tested in attrition cells, they were slightly more resistant than monazite. In that monazite is a very common detrital heavy mineral in both contemporary- and paleoplacers, Koen concluded that uraninite was physically durable enough to survive protracted periods of aqueous transport.

Chemical Stability of Uraninite. The abundance of rounded, detrital-looking uraninite grains in witwatersrand conglomerates has been a puzzle since, under present atmospheric conditions, uraninite tends to dissolve as tetravalent ions are oxidized to their hexavalent form. This has led many investigators (Louw, 1954; Liebenberg, 1955; Roscoe, 1969) to propose that the uraninite grains were stable because of the anoxic character of the Archean and early Proterozoic paleoatmosphere. A strictly anoxic atmosphere no longer seems to be necessary for the preservation of detrital uraninite. First, several instances of detrital uraninite in contemporary stream systems are known (Figure 70.1). Zeschke (1960) and Simpson and Bowles (1977) have documented such grains in the Indus River and its tributaries in Pakistan. Several other occurrences have been reviewed by Schidlowski (in press), who stated that they are "quantitatively unimportant and mostly restricted to cold climates, where chemical weathering is retarded as a result of low temperature means". 
A major advance in the knowledge of the dissolution characteristics of uraninite was made by Grandstaff (1974a, 1976, in press). Grandstaff studied the effects of several variables (surface area, composition, oxygen partial pressure, hydrogen ion concentration, interaction of hydrogen ion and carbonate species, temperature, and the presence of organic and inorganic ions) on the dissolution rates of uraninite grains. The concentration of non-uranium metals (largely thorium) in the uraninite was found to be an important control on the dissolution rate of uraninite. Grandstaff has shown that the thoriumbearing uraninites in the Elliot Lake and Witwatersrand conglomerates could have survived as detrital heavy minerals at oxygen pressures as high as 0.01 of the present atmospheric leve1. Thus, an oxygen-deficient paleoatmosphere (rather than anoxic) may have been all that was required to ensure the survival of uraninite as a detrital mineral in the early Proterozoic and late Archean.

Given the fact that the ability of uraninite to survive as a detrital mineral is no longer in question, the following facts are in favor of a placer origin of uraninite in the Precambrian conglomerates under discussion.

Distribution. Uraninite distribution in conglomerates (at the base of conglomerate layers, along foresets and scour surfaces, in graded units, and in heavy mineral clusters) all suggest a placer origin. Descriptions of uraninite grains being pressed into a shaly footwall by an overlying pebble can hardly be explained in any other way.

Recycling. Numerous examples are known where uraninite is recycled where an older conglomerate is truncated and eroded by a younger conglomerate. In the Elliot Lake district, for example, the Ramsay Lake conglomerate is uraniferous where it truncates the Matinenda Formation uraniferous conglomerate ( $\mathrm{J} . \mathrm{A}$. Robertson, 1976). It is difficult to escape the conclusion that the Matinenda, complete with uranium, was in place before deposition of the Ramsay Lake conglomerate.

Grain Size. Careful measurements of uraninite grain-size distributions have shown that the grains are essentially in hydraulic equilibrium with heavy minerals of undoubted detrital origin.

Grain Shape. The variable, sometimes excellent, rounding of uraninite grains is best explained by fluvial transport and abrasion of the grains. Schidlowski (in press) has reviewed evidence to suggest that rounding of uraninite grains could occur down to a size limit of $0.06 \mathrm{~mm}$. Feather (in press) has suggested that rounding could be due to post-depositional chemical dissolution of the margins of uraninite grains. The crisp, sharp, and smooth grain margins figured by investigators such as Liebenberg (1955), Hiemstra (1968a), and others indicate that this was probably not a quantitatively important process.

Inclusions. Primary inclusions of zircon, such as those illustrated by Hiemstra (1968a), could only have formed during crystallization of the uraninite and zircon in a magmatic system.

Grain Structure. The absence of colloform banding and shrinkage cracks (typical of hydrothermal uraninite) has been stressed by several investigators. The presence of an octahedral cleavage in some grains is indicative of 
derivation from a crystalline uraninite source and not from amorphous pitchblende.

Development with Detrital Components. Several geochemical studies (for example, Hiemstra, 1968b; Theis, 1979) have shown statistically that the abundance of uraninite in a conglomerate correlates with other sedimentary parameters, such as the pebble size or the concentration of elements in known detrital minerals.

Composition. Uraninites from the conglomerates in question invariably carry significant (up to 11 or 12 percent) $\mathrm{ThO}_{2}$, as well as a percent or two of rare earth elements. This geochemical pattern is characteristic of pyrogenetic uraninites, such as those formed in granites and granite pegmatites. Hydrothermal and ground water-related uraninites usually contain no more than about 0.1 percent $\mathrm{ThO}_{2}$.

It is concluded that the overwhelming weight of evidence supports a detrital origin for the uraninite grains in quartz-pebble conglomerates. The source (or sources) of this uraninite is discussed elsewhere in this report.

\section{Uraniferous Carbon}

The carbon in Precambrian quartz-pebble conglomerates was first described in 1896, in the Witwatersrand Basin (Hallbauer, 1975). E11sworth (1928) was the first to describe thucholite, a radioactive, uraniferous hydrocarbon. The material originally described was found in a pegmatite near Parry Sound, Ontario. The substance is not a true mineral. It was named for the chemical symbols of the five main elements it contains, namely $\mathrm{Th}, \mathrm{U}, \mathrm{C}, \mathrm{H}$, and $\mathrm{O}$. It has subsequently been shown that the material frequently carries little or no thorium (Steacy and Kaiman, 1978). For this reason, modern investigators of the material refer to the substance as "carbon" or "kerogen" (Hallbauer, 1975; Zumberge and others, 1978).

Uraniferous carbon is known from numerous Archean and early Proterozoic pebble conglomerates. Some of the oldest occurrences (about 3,000 m.y.) are in the Archean Uitkyk Formation in South Africa (Saager and Muff, 1978) and in pyritic conglomerates of the Moodies Group in the Barberton Mountain Land (Thiel and others, 1979). The material is well developed in the Witwatersrand Supergroup and is also developed in the Ventersdorp Supergroup and at the base of the Transval Supergroup (about 2,300 m.y.). "Thucholite" has been described from the conglomerates of the Elliot Lake district in Ontario (Pienaar, 1963; Roscoe, 1969) and is also developed in conglomerates of the Fortescue Group, Australia, and of the Moeda Formation of the Caraca Group in Minas Gerais, Brazil (D.S. Robertson, 1974). Uraniferous carbon is thus a worldwide associate of the uranium-bearing quartz pebble conglomerates.

By far the best development of the material is in the Witwatersrand Basin of South Africa, and most of the research on the carbon has been done on Witwatersrand material. 


\section{Distribution in Conglomerates}

Uraniferous carbon occurs in many different ways in Witwatersrand sediments. Minter (1978) has documented "seams" of carbon up to $5 \mathrm{~cm}$ thick, which frequently rest on the basal, scoured surface of a widespread conglomerate sheet (Figure 74). Such "seams" frequently hold "entrapped" sand grains, pebbles (usually sma11), and placer minerals (such as zircon and chromite).

Several other modes of occurrence have been noted. Carbonaceous material occurs on scour surfaces within the conglomeratic placer unit, sometimes on a thin yellow mudstone veneer; on the scoured bases of trough cross-bedded sets; on the toes of foresets; wrapped around pebbles; as granular, probably detrital accumulations on the stoss sides of ripple marks; and on reactivation surfaces in transverse sandbars (Minter, 1978).

In coarse conglomerates, carbon is seldom found as "seams", but sometimes occurs as fragmentary clasts, presumably the disrupted remains of pre-existing seams. Very small clasts, on the order of $1 \mathrm{~mm}$ in size, occur in the matrices of conglomerates, as well as in mineralized arenites associated with such conglomerates. The small carbon particles are routinely logged in descriptions of Witwatersrand rocks, normally being referred to as "fly-speck" carbon (Figure 70.5). Schidlowski (1967b) has noted the presence of graphite flakes in some Witwatersrand conglomerates and believed that they formed at the expense of carbon granules.

\section{Structure of Carbon}

A number of techniques have been applied in determining the structural attributes of Witwatersrand carbon. Several investigators have employed standard coal petrographic techniques, using reflected light microscopy (Snyman, 1965; Schidlowski, 1969). Starting in the mid-1970s, other investigators have ashed the carbon by combustion in a furnace at $500^{\circ} \mathrm{C}$. The structure of the remaining inorganic material can then be studied using optical or scanning electron microscopy (Hallbauer, 1975). Another technique employed is the complete dissolution of samples in hydrofluoric acid, and optical or scanning electron microscopy of the insoluble product, which includes carbon, gold, and sulfide minerals.

Macroscopic studies have resulted in the recognition of three types of carbon. "Sooty" carbon is a very fine-grained, soft, dull black material which resembles fusinite in coals. "Massive" carbon occurs in seams and has the appearance and physical properties of vitrinite. "Columnar" carbon occurs as vitreous fibers normal to bedding, usually along the basal contact (Figure 74), but sometimes within a conglomerate and occasionally forming the matrix to the conglomerate (McKinney and others, 1964).

Snyman (1965) studied the structure of carbon using coal petrographic techniques. He noted microscopic features which he thought were very similar to algal and fungal structures in Phanerozolc sapropelic coals. Other features noted by Snyman include "incoalation-haloes", small areas of more reflective carbon around uraninite specks. The higher reflectivity is due to the radioactive bombardment of the carbon. Snyman (1965) and Schidlowski (1969) both noted "flow structures" in the carbon. Flow in a plastic state is indicated 
by several features, including linear concentrations of small inclusions (with elongate inclusions drawn out in this direction) and "streamline" and pressure shadow effects around relatively non-compressible grains included in the carbon. Gold and other secondary sulfide minerals frequently occur in these pressure shadows (Figure 70.6).

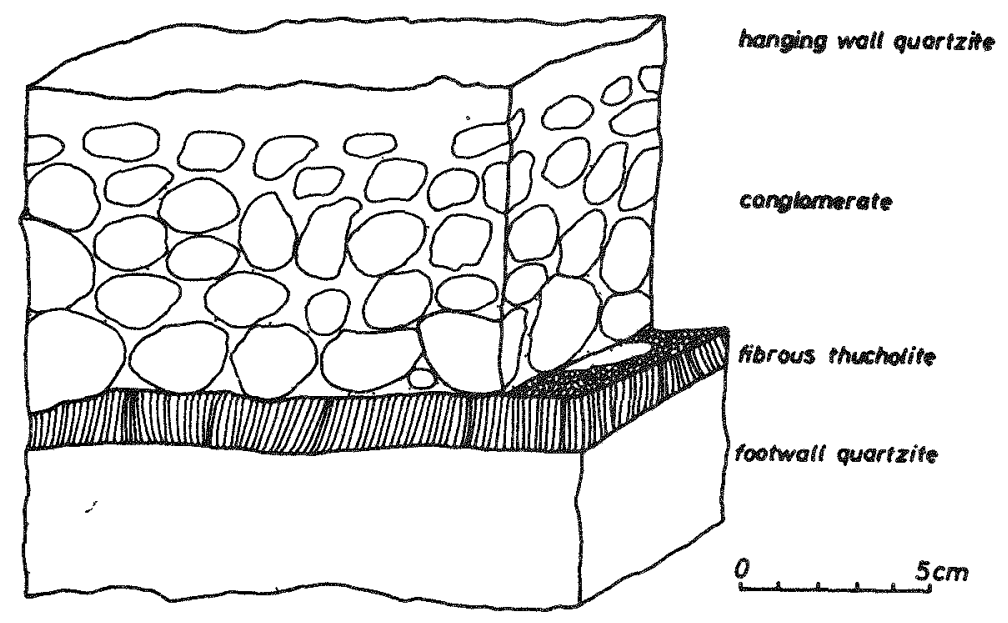

Figure 74. Fibrous "thucholite" seam at the base of a typical witwatersrand conglomerate (from Schidlowski, 1969).

Schidlowski (1969) showed that the supposed resemblance of Witwatersrand carbon to sapropelic coal was a fortuitous one. In the coal, the long axes of deformed (flattened) algae are roughly parallel to bedding, while in the carbon, the supposedly similar structures (Figure 71.5) are due to the lensshaped cross sections of carbon "fibres" which are usually perpendicular to bedding.

X radiographs and S.E.M. techniques were employed by Hallbauer (1975) to study the structure of carbon columns. The vertical columns are 0.5 to $5 \mathrm{~mm}$ 1ong and 0.2 to $0.5 \mathrm{~mm}$ in diameter (Figure 70.4). The columns sometimes occur in bundle-like aggregates with the upper ends of individual columns curving in towards a common center.

Hallbauer and Van Warmelo (1974) and Hallbauer (1975) published the results of the ashing technique for the investigation of the internal structure of the carbon. The ashed residues show a wide array of exceedingly delicate fibrous and mesh-like structures composed of oxides of uranium, thorium, lead, and titanium with silica. The authors concluded that the upright columns were the remains of a "carpet-like colony of columnar individuals" which extracted gold and other elements from solution and redeposited them inter- and intracellularly. They were of the opinion that the organism was a 
symbiotic colony, comprising an algal and a fungal partner, and that the isolated "fly-speck" material was the "reproductive mode" of this association.

The astounding lack of deformation in the material photographed by Hallbauer and Van Warmelo raises suspicions that the structures are not primary organic growth structures. Witwatersrand beds have been buried by several thousand meters of volcanic and sedimentary material. Metamorphic conditions certainly attained the greenschist grade with the widespread development of minerals such as chloritoid. Feather (in press) presented evidence that temperatures as high as $400-600^{\circ} \mathrm{C}$ were attained in the conglomerates. Deformation within Witwatersrand conglomerates is manifested by the shattering of quartz pebbles. The carbon itself shows signs of deformation, including the "flow structures" documented by Snyman (1965) and Schidlowski (1969; in press) and the slickensides mentioned by Hallbauer (1975). Furthermore, plant remains are compressed by factors of 10 or more as they are converted to coal. Hallbauer's argument that the framework of quartz pebbles prevented compression does not stand careful scrutiny, since, by his own admission, most of the material which has yielded "biogenic" structures "occurs as individual seams at the base of the reefs . . . with or without an overlying conglomerate" (Hallbauer, 1975 , p. 115). It is thus inconceivable, on geologic grounds, that the vertical carbon columns and their internal fibrous mineral framework could represent the original growth forms of a primitive land plant.

Further doubts as to the biologic origin of the structures were raised by Cloud (1976), who showed that fibrous forms, almost identical to those illustrated by Hallbauer (1975), could be produced by heating a mixture of powdered carbon with mineral matter (such as lead and zinc filings or zinc powder). Cloud concluded that the structures reported by Hallbauer "could be artifacts of preparation".

In summary, the studies of the structure of Witwatersrand carbon have not resulted in a definite conclusion as to the origin of the material. The columnar structures in the carbon and the associated flow structures and slickensides were probably produced by mechanical deformational forces within the plastic to semi-plastic material after its emplacement and burial. Schidlowski (1966a) compared the columnar structure in carbon to crystal growths at right angles to bedding in such substances as gypsum and calcite.

\section{Elemental Chemistry of Carbon}

Snyman (1965) compared the proximate and ultimate analyses of Witwatersrand carbon (Liebenberg, 1955) with equivalent figures for sapropelic coals from South Africa and Germany. He showed that the "thucholite" analyses were similar in most respects to those of "high-rank du11 coal", except that they contained significantly less hydrogen. He suggested that Witwatersrand carbon had been largely dehydrogenated by "alpha particle bombardment" from the uraninite.

Ruzicka and Steacy (1976) showed that the Elliot Lake carbon contained a significant amount of sulfur not associated with pyrite. Subsequent work on Vaal Reef carbon from the Witwatersrand showed that the material was composed largely of two intimately intergrown phases (Zumberge and others, 1978). The one phase consists mainly of kerogen, containing (non-pyrite) sulfur and 
occasionally some nitrogen, in addition to carbon. The second phase is composed mainly of silicates of iron and alumlnum, together with some sulfur (as pyrite) and gold. The silicates detected were probably septechlorite clay minerals. Gold particles usually occur near the clay-kerogen boundarles, either in the clay or the kerogen. Some of the gold occurs as filaments or as euhedral crystals (Zumberge and others, 1978), while much of it occurs as apparently water-worked micronuggets (Hallbauer, 1975).

Zumberge and co-workers analysed a number of carbon specimens (and associated host rock arenite) using the neutron activation analytical technique. They found that the carbon contains much more $\mathrm{Au}, \mathrm{Ag}, \mathrm{U}, \mathrm{Th}, \mathrm{V}, \mathrm{Sc}, \mathrm{Cs}, \mathrm{Sb}$, and rare earth elements than the host arenite. The silver content of the gold is from 3.4 to 11.5 percent (average of 6.1 percent). No correlation was found between the total carbon content and either Au or U. A tentative correlation of $U$ with $V$ was suggested by their data. The Sb content of the carbon is as high as $644 \mathrm{ppm}$. For comparison, the average $\mathrm{Sb}$ concentration in sedimentary rocks is 2.0 to $2.6 \mathrm{ppm}$.

They found that Vaal Reef carbon carries from 2 to 100 times higher rare earth element abundances than the average crustal rock. The rare earths are probably contained in zircon, clay minerals, and micas (Zumberge and others, 1978), but can also be held in uraninite (Theis, 1979; Feather, in press).

Organic Geochemistry of Carbon

Prashnowsky and Schidlowski (1967) and Oberlies and Prashnowsky (1968) examined the organic geochemistry of Witwatersrand carbon. They were able to determine that the carbon contained from 2 to $20 \mathrm{ppm}$ of amino acids and also contained some carbohydrates. Ten amino acids have been identified, most of them aliphatic types. Two sulfur-bearing amino acids were identified. An aromatic amino acid (tyrosine) was found to make up to 25 percent of the amino acid assemblage.

Carbohydrates in Witwatersrand carbon are of particular interest in that they are typically produced by photosynthetic organisms. Seven carbohydrates have been identified in amounts.ranging from 10-26 ppm. The ratio of pentoses to hexoses approaches $1: 1$, which is similar to the ratio for modern algae (Ha11bauer, 1975).

The presence of these organic species was considered to reflect the biologic origin of W1twatersrand carbon. Prashnowsky and Schidlowski (1967) concede that the amino acids could have formed abiologically (possibly through irradiation of traces of ammonia and methane). They were of the opinion that the monosaccharides could only have been formed biologically.

Zumberge and others (1978) have published a comprehensive account of the organic and inorganic geochemistry of carbon seams from the Vaal Reef in the Klerksdorp Goldfield, South Africa. They showed that the carbon seams consist of a complex, solid, solvent-insoluble, polymerlike substance containing mainly aromatic hydrocarbons and some organic sulfur and oxygen compounds. They suggested that the Witwatersrand "kerogen" was not formed as the result of polymerization of gaseous or liquid hydrocarbons, as had been suggested by $\mathrm{Du}$ Toit (1954) and Liebenberg (1955), but rather by polymerization of biochemicals from decayed, primitive Precambrian micro-organisms. 
The vacuum pyrolysis breakdown products of Witwatersrand kerogen are mainly alkyl-substituted aromatic hydrocarbons, low molecular weight aliphatic hydrocarbons, and some aromatic sulfur and aliphatic oxygen compounds. Polymerization was probably due to "free radical reactions". The Witwatersrand carbon was found to contain from ten to one hundred times more organicfree radicals than coal. The radiation emitted by uraninite (plus diagenetic heating) is thought to have produced many (or most) of the free radicals, and thus promoted the polymerization process. During the polymerization process, volatiles such as $\mathrm{H}_{2}, \mathrm{CH}_{4}, \mathrm{CO}_{2}$, and $\mathrm{NH}_{3}$ were 1 sest and can be inferred to have fluxed through the porous sediments, probably causing, in part, the reduction and solution of iron in such minerals as magnetite and ilmenite.

In summary, the work carried out by Zumberge and his co-workers requires the presence of an organic (algal or bacterial) precursor for the formation of Witwatersrand carbon. They favored the idea that the carbon seams were themselves "primitive microbial mats" and that the mats trapped heavy minerals (including uranium and gold). While this is an attractive and logical idea, there is probably no reason why water-soluble biochemicals might not have migrated through the sediment, becoming polymerized and solidified in the immediate vicinity of a strong flux of ionizing radiation. The aromatic centers in the polymer are stable to $450^{\circ} \mathrm{C}$ in a high vacuum, and it is thus to be expected that they would have survived the greenschist grade metamorphic conditions to which the Witwatersrand was subjected.

\section{Isotopic Character of Witwatersrand Carbon}

Investigations into the carbon isotopic composition of Witwatersrand "carbon" have indicated strongly negative values of $\delta^{13} \mathrm{C}$, between -22 and $-33 \% / 00$ (Hoefs and Schidlowski, 1967; Hoering, 1967). Samples from the Carbon Leader of the Carletonville Goldfield have given values as 1 ow as $-37 \%$ (Hoering, 1967). The average figure for Witwatersrand material is -29.5 $\%$. Carbon from the Elliot Lake district falls within the same range as determined for Witwatersrand material (Schidlowski, in press).

Coals generally have $\delta^{13} \mathrm{C}$ values of -21 to $-27 \%$, with an average of -24.2 $\%$. Since $\delta^{13} \mathrm{C}$ values are apparently largely unaffected by geologic age, Schidlowski (1969) suggested that the isotopic composition of the carbon indicates a likeness to oil and asphalt, rather than to isotopically heavier coal. According to this author, the strongly negative $\delta^{13} \mathrm{C}$ values suggest that the carbon was derived, at least in part, from the mobilized fractions of sedimentary organic material in which the light isotope $\left({ }^{12} \mathrm{C}\right)$ had been enriched as a result of the "chromatographic effect". This conclusion, which predated the work by Zumberge and others (1978), is in remarkable agreement with the general conclusions reached by these authors.

\section{Uranium in Carbon}

Uranium mineralization is intimately associated with carbon in the Witwatersrand and in the Elliot Lake conglomerates (Liebenberg, 1955; Ruzicka and Steacy, 1976). De Kock (1964) stressed that the one thing all economically important Witwatersrand conglomerates had in common was the presence of variable amounts of carbon. The association of uranium and carbon is particularly prevalent in the Witwatersrand. Most of the research done on the association is from this basin. 
The microscopic investigations of Liebenberg (1955) and of subsequent workers (for example, Schidlowski, 1969) have shown that uraninite occurs in carbon in grains which vary from rounded to angular. They have shown that rounded, presumably detrital grains of uraninite are often surrounded by a halo of carbon (Figure 71.2). Cracks within the rounded individuals are of ten penetrated by carbon, producing a jigsawlike effect (Figure 71.3). Taken a step further, the small uraninite fragments appear to have been forced apart, so that the ultimate result is a mass of very smal1, very angular uraninite clasts in large masses of carbon (Figure 71.4). Microprobe analyses by Simpson and Bowles (1977) have confirmed that these small angular particles are fragmented remains of detrital uraninite grains. They showed that the fragments occur in groups. Fragments within a group (remains of one detrital grain) have essentially the same $\mathrm{ThO}_{2}$ content. Fragments from neighboring groups often have markedly different $\mathrm{ThO}_{2}$ contents. Both Liebenberg and Schidlowski suggested that some of the uraninite is "replaced" or digested by the carbon. Liebenberg noted that this fragmentation/replacement process could continue until no visible uraninite was left. The ultimate product is carbon with a radioactive character and a very fine dusting of radiogenic galena.

In addition to uraninite, brannerite occurs in association with carbon, sometimes as minute specks and veinlets accompanying the remnants of detrital pyrite grains. Elsewhere, the brannerite occurs as minute veinlets between and within carbon granules.

Simpson and Bowles (1977) have studied the character of uranium mineralization in Witwatersrand carbon. They have used the term "pitchblende" to refer to "poorly crystallized" uraninite usually associated with carbon. This uranium phase contains, according to these authors, a relatively low thorium content. They found that specks of "pitchblende" in "fly-speck" carbon contained from 1.1 to 2.9 percent $\mathrm{ThO}_{2}$ with an average of 2.0 percent. The "pitchblende" has a median $\mathrm{UO}_{2} / \mathrm{ThO}_{2}$ ratio of 33 with a range from 25 to 69. Analysis of variance showed that this uraniferous material is significantly lower in its $\mathrm{ThO}_{2}$ content than all other Witwatersrand and Dominion Reef uraninites. For this (and other) reasons, Simpson and Bowles suggested that this "pitchblende" probably formed in situ during diagenesis and metamorphism.

This "pitchblende" has a relatively low lead content and may thus be younger than detrital uraninite. Simpson and Bowles suggested that this relatively low $\mathrm{ThO}_{2}$ uranium phase was "precipitated by absorption on decaying organic material". Some "pitchblende" occurs with brannerite, gold, and gersdorffite along sutures between carbon columns. These authors also noted the presence of "uraniferous silicates" occurring as complex intergrowths with gold and gersdorffite in internal pore spaces within carbonaceous matter.

A second type of "pitchblende" was recognized in samples studied by Simpson and Bowles (1977). This is a high-thorium variety (median 6.2 percent $\mathrm{ThO}_{2}$, range 3.17 to 6.9 percent $\mathrm{ThO}_{2}$ ), with a median $\mathrm{UO}_{2} / \mathrm{ThO}_{2}$ ratio of 9.0 (range 6.2 to 12.2 ). It occurs in association with partially replaced detrital uraninite grains in columnar carbon. Simpson and Bowles were of the opinion that the high thorium content is "attributable to solution and redeposition of both uranium and thorium from the allogenic uraninite undergoing attack by the carbonaceous matter". 
In addition to uraninite, brannerite, "pitchblende", and uranfferous silicates, Simpson and Bowles detected a mineral tentatively identified as churchite $\left(\mathrm{YPO}_{4} \cdot 2 \mathrm{H}_{2} \mathrm{O}\right)$. It occurs as a "tenuous phase" surrounding finegrained "pitchblende" in columnar carbon. This phase contains major Y and $P$, along with heavy rare earth elements $G d, T b, D y, E r$, and $Y b$.

Feather (in press) undertook a comparative study of uraninite grains in carbon and in carbon-free conglomerates in the Witwatersrand. Although he did not carry out a rigorous statistical analysis, he was of the opinion that the compositions of the two uraninite populations were "very similar", and that uraninite grains in carbon probably represented the fragmented remains of detrital uraninites.

\section{Summary}

Accumulated evidence suggests that the "carbon" or kerogen in uraniferous quartz-pebble conglomerates formed as a result of radiolytic polymerization of the decomposition products of primitive algal or bacterial remalns. The primary cause for the association of the carbon and uraninite is thought to be the generation of free radicals in the organic decomposition products where these mobile compounds moved into environments of high ionizing radiation. As polymerization of organic compounds proceeded in cracks in uraninite grains, the grains became fragmented into numerous very small, very angular clasts which retained the thorium content of their parent grains. In addition to fragmentation, most investigators see evidence of "digestion" of uraninite by the enclosing carbonaceous matter, possibly due to the formation of organometallic complexes. Some of the digested uraninite appears to have formed secondary phases such as brannerite and poorly crystallized "pitchblende" which are found associated with the carbon. Other secondary minerals, particularly gold and gersdorffite, appear to have been fixed within the already-solidified carbon.

\section{Xenotime}

Xenotime, ( $\mathrm{Y}, \mathrm{Th}, \mathrm{U}$ ) $\mathrm{PO}_{4}$, has been described as a rare, probably detrital, component of Witwatersrand and Matinenda conglomerates (Liebenber 8 : 3 ; ; Ramdohr, 1958; Roscoe, 1969). It is not a quantitatively importanc source of uranium.

\section{$\underline{\text { Zircon }}$}

Zircon is a consistent detrital heavy mineral in nearly all uraniferous conglomerates. Though uraniferous in most instances, zircons are insignificant contributors of uranium extracted from the conglomerates (Feather and Koen, 1975). The presence of radioactive elements within the zircons is indicated by minute specks of radiogenic galena.

"Dispersed" Uranium in Quartz-Pebble Conglomerates

The application of uranium micromapping techniques, using thermal neutrons, has provided a wealth of new information on the distribution of low concentrations of this element. Uranium distribution can be mapped at the part per billion level with a spatial resolution superior to common techniques, including electron-microprobe scanning. Simpson and Bowles (1977) and Thiel and 
others (1979) have applied this technique to a wide variety of uraniferous conglomerates and have detected minutely dispersed uranium in a large number of mineral phases.

\section{Phyllosilicates}

Extremely finely disseminated uranium has been found associated with phy1losilicates in a wide range of uraniferous conglomerates. The phyllosilicates include chlorite, sericite, muscovite, pyrophylitte, and, occasionally, biotite, kaolinite, and an unidentified $7 \AA$ clay mineral (Thiel and others, 1979). The uranium is apparently not associated with a specific mineral and is thought to have been deposited on the phyllosilicates by "adsorption of uranium from circulating hydrous solutions" (Thiel and others, 1979). These authors noted that chlorite developed in pressure shadows was a particularly favored site for the concentration of uranium.

\section{Detrital Pyrite}

Simpson and Bowles (1977) found that detrital "massive" pyrite grains carried essentially no uranium (less than $0.01 \mathrm{ppm}$ ). However, these pyrite grains are frequently coated by a clay-rich phase in which uranium is relatively abundant. Similar clay mineral phases, away from pyrite grains, do not carry uranium. Simpson and Bowles concluded that the pyrite played some part in the fixation of uranium in the surrounding clay phase.

Thiel and others (1979) showed that the uranium-rich rims around pyrite grains are discontinuous, being composed of discrete grains (Figures 72.4 and 72.5), some of them with crystalline outlines. They concluded that the minute grains represented discrete uranium minerals with uranium contents in the percent range. In contrast to Simpson and Bowles, they found that pore-free pyrite contains on the order of 5 ppm $U$.

\section{Concretionary Pyrite}

Simpson and Bowles (1977) found detectable concentrations of uranium associated with porous pyrite. In some, uranium occurs throughout the grains, in others it is concentrated around the periphery of the grains (but still in the pyrite). A $7 \AA$ clay mineral which occurs as inclusions in the porous pyrite concretions is enriched in uranium. They concluded that the uranium was adsorbed by the concretionary pyrite during its transport, or after its deposition, during diagenesis.

Thiel and others (1979) found that the pores in concretionary pyrite, filled by such phases as chlorite, sericite, quartz, pyrophyllite, and chloritoid, commonly contain uranium at concentrations of a $f e w$ hundred ppm. 0ccasionally, pores contain minute inclusions of what are believed to be uranium minerals such as brannerite and coffinite.

\section{Lithic Granules and Pebbles}

Simpson and Bowles (1977) found that granules and pebbles composed of quartz, pyrophylite, and other aluminous minerals (kaolinite, illite, kyanite) contain detectable concentrations of uranium. In one such clast, uranium was found to be concentrated in what appeared to be a leached, weathered margin of the clast. 
Other Minerals

Thiel and others (1979) determined the uranium concentrations in several other mineral phases in uraniferous conglomerates. The results of their analyses are presented in Table 34.

Table 34. Uranium content of mineral phases in uraniferous conglomerates from South Africa (after Thiel and others, 1979).

MINERAL

Quartz

Porous Pyrite ${ }^{+)}$

Compact Pyrite

Leucoxene ${ }^{+}$)

Clay Minerals

Zircon + )

Chromite ${ }^{++}$)

Carbonaceous Matter

\section{UITKYK-FORMATION}

$1 \mathrm{ppb}-6.3 \mathrm{ppm}$

$10^{2}$ ppm range

$1 \mathrm{ppb}-2 \mathrm{ppm}$

108 ppm - 557 ppm

$6.5 \mathrm{ppm}-0.90 \%$

$10^{2}$ ppm range

$10^{1}$ ppm range

$1.22 \%-1.90 \%$

\section{BASAL/"B"-REEF}

$1 \mathrm{ppb}-525 \mathrm{ppm}$

5 ppm - 320 ppm

$1 \mathrm{ppb}-1 \mathrm{ppm}$

256 ppm $-2.78 \%$

$0.55 \%-0.69 \%$

$0.11 \%-0.84 \%$

$8.8 \mathrm{ppm}-250 \mathrm{ppm}$

$1.56 \%-4.9 \%$
ANALYSES

\section{7}

5

4

23

8

5

5

11

+) Polished section

H) Polished thin section

Discussion

Simpson and Bowles (1977) were the first to introduce the concept of the "bimodal" nature of uranium mineralization in Precambrian conglomerates. two "modes" of uranium occurrence are the detrital mode (rounded thorian The uraninite) and a "precipitated mode". The latter category includes the dispersed uranium described above, as well as the poorly crystallized, lowthorium "pitchblende" associated with granular and columnar carbon. Brannerite grains of various types are also logically included under this heading.

Simpson and Bowles, noting the stability of high-thorium uraninites in contemporary fluvial sediments in the Indus River and some of its tributaries, were of the opinion that uraniferous conglomerates of the Precambrian formed under atmospheric conditions comparable to those prevalling today. Under such conditions, solution of uranium in the uranyl ion ( $\mathrm{UO}_{2}{ }^{2+}$ ) and in uranyl complexes should be anticipated. The "precipitated mode" is considered to be 
due to reduction or adsorption reactions which occurred in conglomerate paleoaquifers. A major criticism of this idea is the fact that many of the "precipitated phases", such as the "pitchblende" and "brannerite", contain one percent or more of $\mathrm{ThO}_{2}$. Uranium precipitated from solution in Mesozoic and Cenozoic sandstone-hosted deposits usually contains no more than a few tenths of a percent of $\mathrm{ThO}_{2}$ (Frondel, 1958), due to the relatively insoluble nature of this oxide under conditions normally encountered in ground water.

Notwithstanding this objection, it is difficult to argue that some uranium was not introduced into the conglomerate aquifers as soluble uranyl ions. Studies of paleoweathering profiles and of their uranium content suggest that $\mathrm{U}$ was dissolved and leached during paleoweathering by ground waters that were at least weakly oxidizing. This uranium would become fixed within the conglomerate by reduction or by adsorption on reactive phases such as clay minerals or titania skeletons.

Thiel and others (1979) stressed the evidence for later solution transport of uranium over relatively short distances during low-grade regional metamorphism. Some of their evidence is weak. For example, precipitated uranium occurs around euhedral pyrite grains of supposed "metamorphic" origin. Euhedral pyrite grains can form diagenetically, very soon after deposition of the host sediment, so that this relation could occur during low-temperature ground water fluxing of the conglomerate. Similarly, the association of brannerite (a supposed metamorphic mineral, according to Thiel and others) with leucoxene could be easily explained by metamorphism of a titania aggregate that contained adsorbed uranium. The association of uranium with chlorite in pressure shadows is more compelling evidence of metamorphic or post-metamorphic movement, as is the presence of dispersed uranium in cracks cutting low-grade metamorphic minerals.

The solution mechanism of uranium under reducing conditions was not discussed by Thiel and others. Under the correct conditions of high $\mathrm{pH}$, the uranium could have moved as the $\mathrm{U}(\mathrm{OH})_{5}{ }^{-}$complex. Unfortunately, the stability of this and similar ionic complexes under metamorphic conditions is not known.

Uranium Orebody Parameters

Since the question of orebody geometry has already been discussed in some detail in the section dealing with the geometry of uraniferous conglomerates, the relevant parameters are summarized here in Table 35. The table stresses the largest and best-mineralized orebodies and is not representative of the class of mineralized conglomerates as a whole. Smaller orebodies do exist and have been profitably mined in the past (example: the uraniferous-auriferous conglomerates of the Dominion Reef Group in South Africa, which

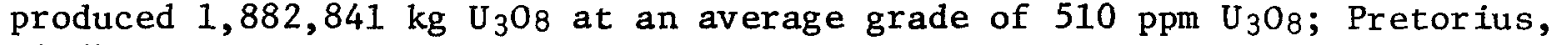
1976). The exclusion of the smaller orebodies is due to the lack of published information.

In general, the areas of orebodies vary from some 10 to $400 \mathrm{~km}^{2}$ with thicknesses of up to $10 \mathrm{~m}$. Most orebodies are less than $3 \mathrm{~m}$ thick, and many are on the order of 0.5 to $1.0 \mathrm{~m}$ thick. Tonnages of ore range from less than 10 
Table 35. Parameters for uranium orebodies in the Witwatersrand and E111ot Lake districts. Sources:

(1) from J.A. Robertson, 1976; (2) from Theis, 1979; (3) from D.S. Robertson and others, 1978;

(4) from Minter, 1978; (5) areas given by Minter (1978) are for the placer sheet as a whole, including some unpay ground; (6) figures calculated by, the authors; should be regarded as approximate; derived using area and thickness figures given by sources cited; (7) from Pretorius, 1976; (8) from Whiteside and others, 1976; and (9) grade estimate from tonnage and recoverable metal figures given by D.S. Robertson and others, 1978, in their Table 1.

* indicates long axis parallel to sediment transport direction

$\dagger$ indicates long axis perpendicular to mean sediment transport direction

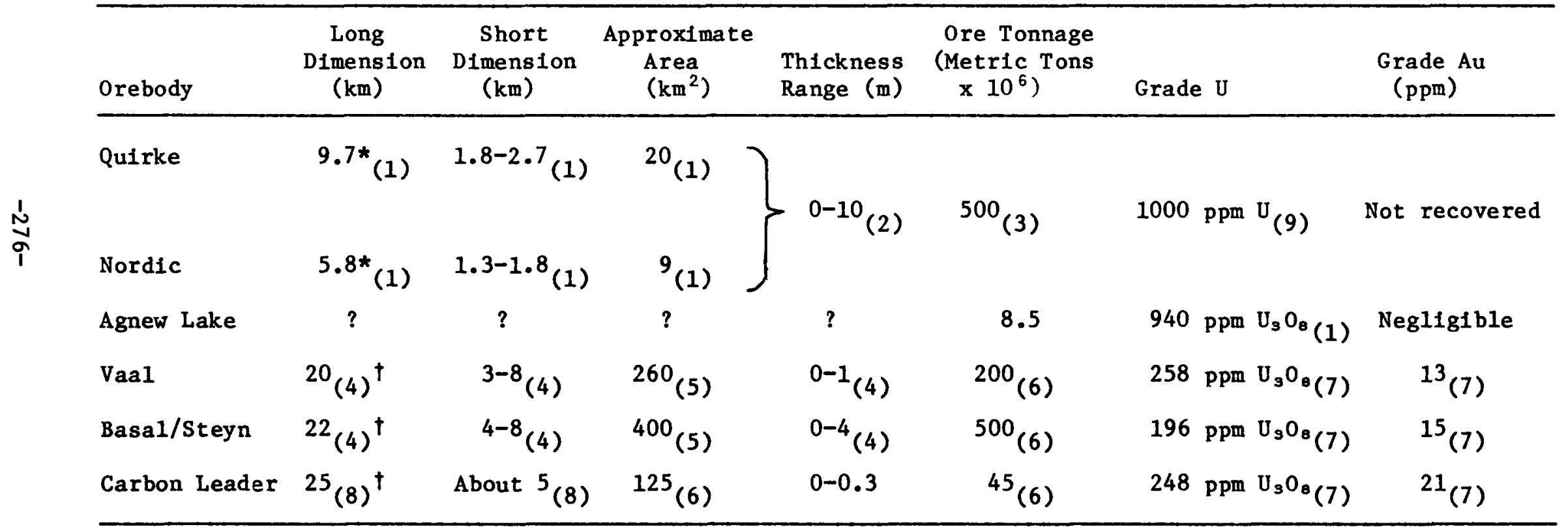


million tons to several hundred million tons. In deposits mined purely for their uranium, grades are usually on the order of $1,000 \mathrm{ppm} \mathrm{U}$. By contrast, in those conglomerates with $10-20 \mathrm{ppm} \mathrm{Au}$, uranium is a valuable by-product or co-product and is present at levels of 200 (or more) $\mathrm{ppm} \mathrm{U}_{9} \mathrm{O}_{\mathrm{B}}$. The importance of gold can obviously not be overemphasized. Only one or two Witwaters rand mines would be profitable as uranium producers in the absence of gold. Yet figures given by D.S. Robertson and others (1978) Indicate that the Witwatersrand contains on the order of $500 \times 10^{6}$ pounds of mineable urantum.

In summary, there is no longer any real doubt that the detrital uraninites of the Witwatersrand, Dominion Reef, and Matinenda conglomerates were derived from a magmatic parent rock, such as grante or granite pegmatite. There is also no argument about there having been substantial solution and redeposition of uranium within the conglomerate. While there is some evidence that this redistribution occurred syn- and post-metamorphically, some mineralogical relations could be equally well explained by deposition of uranium from paleoground water. 
Blank

$-278-$ 


\title{
RECOGNITION CRITERIA
}

\author{
Introduction
}

The geologic characteristics of important uraniferous conglomerate deposits have been reviewed and discussed in the context of ore-forming processes in the preceding sections of this report. We now proceed to identify those geologic characteristics related to these deposits that we feel are most diagnostic for the presence or absence of deposits in unexplored areas. The geologic characteristics selected, including geophysical and geochemical observations, are referred to as recognition criteria and have been shown to be related in some significant way to this type of deposit. These recognition criteria should be useful in resource studies and exploration for estimating the geologic favorability of an area of study for the occurrence of a conglomerate-hosted uranium deposit.

The selection, definition, and ranking of recognition criteria are routinely performed by the expert geologist "in his head". The material presented in this section, and in the Appendix, is not intended for the "expert" but for those geologists involved in exploration or resource studies who are still developing their data bases and interpretations. Nor is this material presented as a "cookbook" to be perfunctorily applied to prospective areas. Considerable geologic judgement is required in the use of the recognition criteria, and inexperienced geologists will encounter much difficulty. The criteria are merely guides to be used by trained geologists as they develop their evaluations of unexplored areas for purposes of exploration or resource studies.

To be useful in resource studies or exploration, recognition criteria are chosen so that: (a) when they are present or favorable, the chances of a deposit being present are significantly increased, i.e., they are important "good news"; or (b) when they are absent or unfavorable, the chances of a deposit being present are significantly decreased, i.e., the negative criteria are important "bad news". Some recognition criteria have both attributes and are thus particularly useful. By using only criteria that significantly affect the likelihood of a deposit being present or absent, one avoids the distraction of including geological observations which are too ubiquitous or undiagnostic to be useful guides to the favorability of an area.

Considerable subjectivity is involved in the selection, definition, and use of the recognition criteria. Because geologic observations do not lend themselves to rigorous numerical treatment, the use of such data unavoidably involves subjective judgement. In our opinion, it is far better to use the data and the judgements, carefully documenting where and how subjectivity has been used, than simply to leave the reader to make the most of geologic information such as was presented in the preceding sections of this report. In the following paragraphs, therefore, we subjectively select and define those criteria which, based upon our experiences and the data contained in the preceding sections of this report, we consider to be most useful for evaluating areas for conglomerate-hosted uranium deposits. We make no pretense that these are the only criteria and definitions that could have been 
chosen; they are simply the best ones we were able to devise. The reader may prefer other criteria and/or other definitions which, if they reflect geologic facts, may improve our 1ist. We acknowledge that such improvements will be needed and earnestly solicit constructive comments and contributions. Only through a consensus of careful observations and informed opinions will the criteria become reliable and useful.

The detail or scale of each recognition criterion deserves special mention. As exploration and resource studies are conducted on areas of vastly different size and degree of geologic definition, it is appropriate to include recognition criteria that range from regional in scale (i.e., "regional tectonic setting", "uranium content of basement rocks", etc.) to local (i.e., "conglomerate sorting", "conglomerate packing", etc.). We have attempted to do this in the accompanying criteria, but some readers may consider certain criteria too general or too detailed to be useful, or may wish to include criteria yet more general or more specific. These options, where supported by geologic data, may improve the list of recognition criteria.

In Figure 75, the criteria we have selected for the uraniferous conglomerate deposits are arranged by scale of observation, proceeding from the broadest and most regional on the left to the most local on the right. The reader will note that the criteria also are arranged in a hierarchical format. The more general criteria are progressively subdivided into more detailed "modifying" criteria. This format permits the lowest level criteria (terminal criteria), which are based on field observations, to be combined to evaluate the favorability of the higher level criteria. In the evaluation of an area, this combining process continues up through the recognition criteria net until the favorability of the area of study for a conglomerate-hosted uranium deposit is determined. A rigorous method for combining information on the criteria has been presented by Hart, Duda, and Einaudi (1978) and a specific application developed for roll-type deposits by Rackley (Gaschnig, 1980). In the Appendix, we present a much-simplified method for combining geologic observations to reach favorability estimates. The reader is cautioned that the individual criteria are used only to establish the favorability of intermediate-level criteria. The ultimate favorability estimate for a conglomerate-hosted deposit is the composite effect of many criteria, and it is not necessarily equivalent to the probability of a deposit being present as will be discussed in the Appendix.

With recognition criteria identified and organized as in Figure 75 , it is now possible to geologically define each criterion and establish its relative importance in determining the favorability of the criterion above it in the net. The selection and definition of criteria is subjective, as discussed earlier, but the estimation of the relative importance of criteria is even more so. The justification for assigning importance or weight is that intuitively we feel some criteria are more important than others. As with the criteria themselves, we have assigned the best set of weights we could develop, but they are entirely subjective, and the reader may be justified in modifying our estimates to reflect his data. Weights assigned are obviously only approximations to indicate the relatively encouraging or discouraging nature of a particular definition of a criterion. An estimate of +65 , for example, might as well have been +75 or +50 . We are simply attempting to capture the geologist's approximate estimate of the relative importance of 


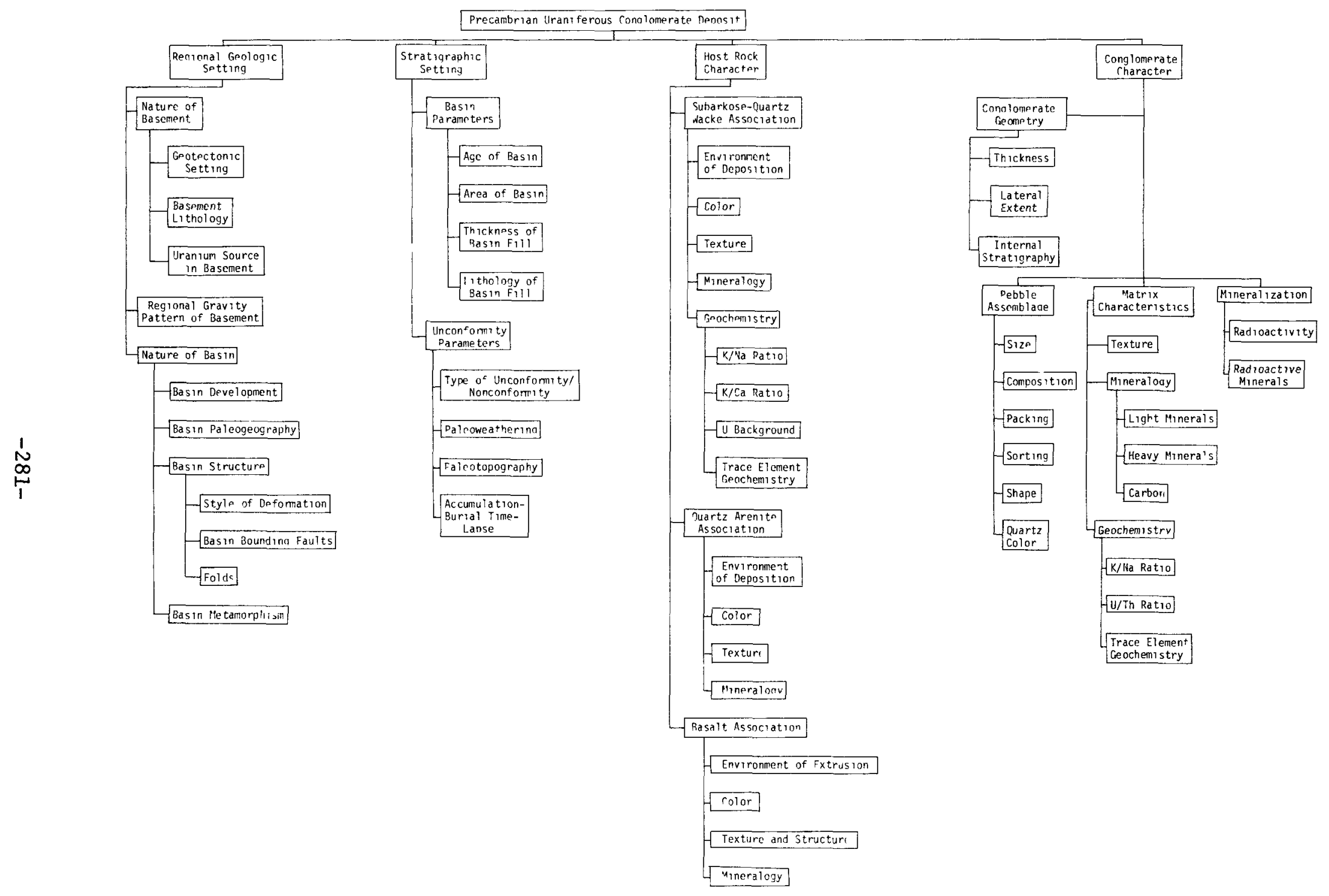

Figure 75. Structured net of recognition criteria for use in exploration for Precambrian uraniferous conglomerates. 
geologic observations as an additional aid in the evaluation of unexplored areas. The system is subjective and imprecise and likely to remain so, but the subjective information is useful if we can learn to collect and use it properly. It is toward that end that the subjective, relative importances are assigned to all criteria in the following section, and a simple method for accumulating this information is presented in the Appendix.

\title{
Evaluation of Recognition Criteria
}

The assignment of importance or weight to recognition criteria may be conveniently explained by referring to the three criteria at the left side of Figure 75 which evaluate the Nature of Basement. Each of the three criteria embodies, in the geologist's mind, numerous considerations which relate to geologic observations, the processes they reflect and, their importance to the presence or absence of a uranium deposit. With respect to evaluating Nature of Basement, which in turn will be used with other criteria to evaluate the likelihood of occurrence of a deposit, these are presumably the three most important criteria that could have been selected, and we assume no important criteria have been omitted.

In most cases, any three such criteria will have different importances in establishing the intermediate criterion above them. Therefore, importance or weight is assigned to each recognition criterion with the aid of the relation shown in Figure 76. Weights are assigned to each criterion independently of the others, based on how sufficient the presence of the criterion by itself is for establishing the presence of favorable basement, or how sufficient the absence of the criterion is by itself to establish the absence of favorable basement. For example, if one knows the geotectonic setting in some area under consideration, but knows nothing about the two other criteria, how favorable is the basement? The types of geotectonic settings one might consider include:

\author{
Archean craton \\ Proterozoic mobile belt \\ Phanerozoic suture zone \\ Cenozoic convergent plate margin
}

The favorability of the basement would decrease from Archean craton to Cenozoic convergent plate margin, reflecting decreased favorability of depositional and structural parameters. The likelihood of a favorable "basement" being present is highest in an Archean craton and is essentially nil in the Cenozoic plate marginal environment.

Suppose that a basin rests on part of an Archean craton. Since this is the geotectonic setting in which Precambrian uraniferous conglomerates occur, this is suggestive of "good news" for the presence of the proper basement, but how suggestive is it? In Figure 76, modifying expressions have been arranged along arbitrary scales from 0 to +100 and 0 to -100 as an aid to the geologist in estimating the importance or weight for a particular criterion. The positive scale is used when geologic observations regarding a criterion are encouraging or "good news" for the favorable occurrence of the higher level criterion, i.e., favorable "basement". The negative scale is used when 


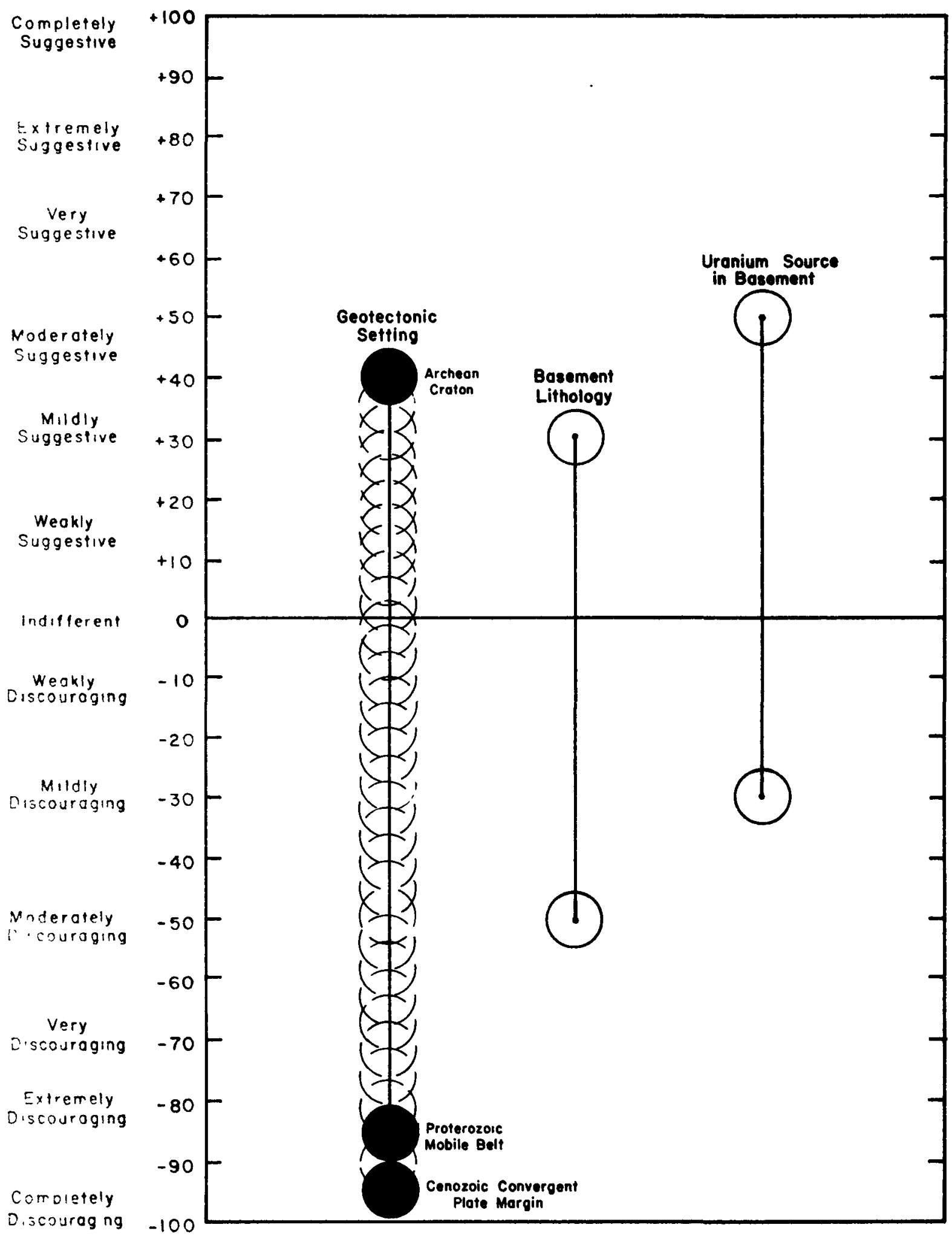

Figure 76. Schematic diagram showing the method of assigning importance (or weight) to a recognition criterion. 
the criteria are discouraging for the presence of favorable basement. Zero is used when the state of the criterion is unknown, i.e., no information, or it does not affect the favorability of basement. The scale ranges and modifying expressions might have been chosen quite differently, for example, 0 to 1.0 or 0 to 500 and with different words such as favorable and very favorable for the positive scale and unfavorable and extremely unfavorable for the negative scale.

To assign weights to a criterion, the geologist asks, "If the criterion is absolutely perfect, 1.e., if the area under evaluation is a 'perfect' Archean craton, how suggestive is it that favorable basement is present?" Since Archean cratons are internally rather varied, the mere presence of the craton does not assure us of a "perfect" basement for basins containing uraniferous conglomerate. Such a geotectonic setting is considered to be "moderately suggestive" of the perfect basement being present, and thus is assigned a score of +40 .

If, on the other hand, the tectonic setting was a Cenozoic plate boundary, it effectively rules out the probability of a proper basement. Such a setting is designated as almost completely insufficient and is assigned a value of -95. We might have assigned a value of -100 , but out of respect for the vagaries of the earth, we have left some room for surprises. Anyway, the result is essentially the same. The presence of a convergent plate marginal environment essentially destroys the potential for not only a favorable basement, but for a Precambrian uraniferous conglomerate deposit.

The geotectonic setting is not the only criterion for evaluating the basement. The presence of a uranium source in the basement is significant "good news", and is "moderately suggestive" of a favorable basement. If no such source is evident, this is only considered to be mildly discouraging $(-30)$, since the potential for burial or removal (by erosion) of that source over a period of 2 or $3 \times 10^{9}$ years is relatively high.

Once such values have been assigned for all the criteria which evaluate an intermediate-level criterion (which may be viewed as an intermediate hypothesis or conclusion), they are combined to yield a numerical estimate, in this case, the favorability of the basement terrane. The arithmetic procedures for combining recognition criteria scores are outlined in the Appendix.

\section{Description of Recognition Criteria}

In order to apply the recognition criteria net (Figure 75) to the evaluation of field areas, it now remains to (1) describe the recognition criteria so that they can be evaluated with field geologic observations, and (2) assign numerical value to various states of the criterla, depending on how suggestive or discouraging the states are for the intermediate criterion above them. To this end, a short description of each criterion is given in a series of elaborative paragraphs. These paragraphs should be read in conjunction with the series of tables listing the numerical weights of the various criteria (Tables 36 through 40). 
The first of these tables (Table 36) shows the maximum and minimum possible scores (on a scale of +100 to -100 ) for the four criteria that appear along the top line of the recognition criteria net (Figure 75). As will be shown later (see Appendix), the scores for all subsidiary criteria are combined to come up with a favorability number for each of the major criteria in Table 36. These favorability numbers then have to be normalized so that they do not fall outside the positive and negative limits set in Table 36.

Table 36. Relative importance of the major criteria in establishing the likelihood of finding (or not finding) a uranium-bearing conglomerate orebody.

CRITERION

Regional Geologic Setting

Stratigraphic Setting

Host Rock Character

Conglomerate Character
ESTIMATE OF SUGGESTIVITY WHEN PRESENT OR FAVORABLE
ESTIMATE OF DISCOURAGEMENT WHEN ABSENT OR UNFAVORABLE

$\begin{array}{lr}+40 & -90 \\ +50 & -90 \\ +50 & -90 \\ +70 & -90 \\ +210 & -360\end{array}$

\section{$\underline{\text { Regional Geologic Setting }}$}

There are two important aspects to the regional geologic setting of a prospective basin, namely the nature of the basement and of the basin itself (Table 37).

Nature of Basement $(+40,-95)$

Geotectonic Setting. Basins containing economic or sub-economic concentrations of uranium in Precambrian conglomerate are found exclusively within the confines of Archean cratons (+40) (also known as Archean "blocks" or "provinces"). Any other geotectonic setting is extremely discouraging (-95). Should such settings be encountered, they should be regarded as "killers", discouraging further work. Low positive scores (0-40) should be assigned on the basis of the degree of certainty that a basin rests on an Archean block.

Basement Lithology. Ideal basement $(+30)$ comprises a gneiss-granite-greenstone terrane or an older basin, itself resting on such a terrane. Granu1ite- and upper amphibolite-grade basement should score -50; lower amphibo1ite-grade basement scores 0 . Basement comprising very extensive greenstone belts scores -20 .

Uranium Source in Basement. The presence of local or more widespread uraniferous granites (with or without associated pegmatites) in a position where 
Table 37. Score sheet for regional geologic setting of basins targeted for uraniferous conglomerates.

$\underline{\text { Regional Geologic Setting }}$

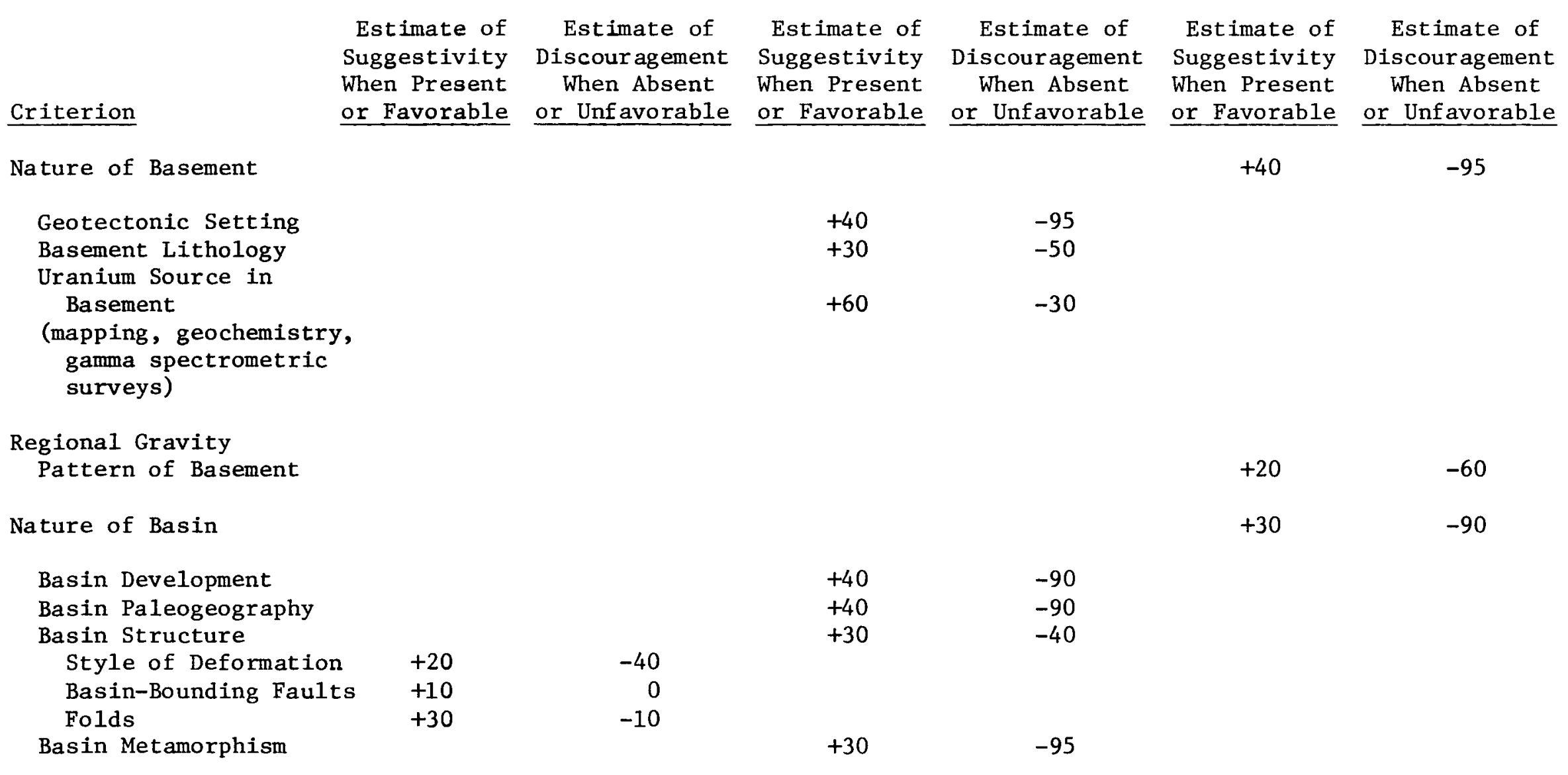


they could have shed material into the basin in question is suggestive of a favorable basement $(+60)$. The presence of such a uranium source will normally be determined by field mapping, combined with airborne gamma spectrometric surveys and regional geochemical studies. The apparent absence of anomalously uraniferous granites is only mildly discouraging $(-30)$, since such granites could be covered or could have been eroded in the 2.5 to $3.0 \mathrm{X}$ $10^{9}$ years since their emplacement.

Regional Gravity Pattern of Basement $(+20,-60)$

Archean granite-greenstone terrane, in the absence of complicating factors, normally exhibits a series of stubby $(10-100 \mathrm{~km})$ linear gravity highs coinciding with individual greenstone belts. Such a pattern is weakly suggestive $(+20)$ of a favorable regional geologic setting. By contrast, very long $\left(10^{2}\right.$ to $\left.10^{3} \mathrm{~km}\right)$ linear gravity highs are suggestive of Proterozoic or Archean high-grade metamorphic basement (a discouraging situation, -60 ).

Nature of Basin $(+30,-90)$

Basin Development. Economic concentrations of uranium in Precambrian conglomerates occur in well-preserved basins developed over areas of $10^{4}$ to $10^{5} \mathrm{~km}^{2}$. The basins appear to have been long lived ( $10^{6}$ to $10^{7}$ years). The presence of such a basin (or basins) is mildly suggestive of a favorable basin ( +40$)$. The complete absence of such basins within the confines of an Archean craton is a "killer". Such basins are extremely necessary $(-90)$.

Basin Paleogeography. Completely favorable basins were formed in continental settings close to paleo-sea level. Such basins contain continental and marginal-marine clastic successions, including fluvial, deltaic, neritic, and shallow-marine sediments $(+40)$. Basins dominated by thick $\left(>10^{4} \mathrm{~m}\right)$ deepwater turbidites and associated chemical sediments and pillow basalts are extremely discouraging ( -90$)$ and can be regarded as falling in the "killer" category.

Basin Structure $(+30,-40)$. There are several important aspects of basin structure:

(1) The style of deformation is considered to be important. Basins with high potential are usually gently deformed in open anticlines and synclines. While such a style of deformation is only weakly suggestive $(+20)$ of a favorable basin, the absence of this style (for example, an isoclinally deformed succession) is considered to be mildly discouraging $(-40)$.

(2) The presence of basin-bounding faults (which may have been active during deposition) is mildly suggestive of the development of a favorable basin $(+10)$. Uplift along such blocks supplies the adjacent basin with wedge-shaped bodies of fluvial sediment. The absence of such faults is an indifferent criterion ( 0 ).

(3) Fold structures have been shown to have been active both during and after sedimentation in the basins in question. Since both major orebodies and local payshoots often lie along synclinal axes, the 
presence of such structures is mildly suggestive $(+30)$ of a favorable location within a basin. The absence of such structures is weakly discouraging $(-10)$.

Basin Metamorphism. The major producing basins are relatively unmetamorphosed (greenschist grade). Such a low grade is mildly suggestive of a favorable basin $(+30)$. A lower amphibolite grade is considered to be weakly discouraging $(-20)$, an upper amphibolite grade discouraging $(-70)$, while a granulite grade is extremely discouraging ( -95$)$.

\section{Stratigraphic Setting}

The stratigraphic setting of prospective basins is an important factor in the evaluation of their potential. Two general topics are considered under this heading, the first dealing with the basin itself, the second with unconformities in the basinal succession (Table 38 ).

Basin Parameters $(+40,-95)$

Age of Basin. The most productive basins range in age from about 2,200 m.y. to $2,800 \mathrm{~m} \cdot \mathrm{y}$. Basins with ages in this range are mildly suggestive of the presence of economic deposits $(+30)$. Those basins from 2,000 to 2,200 and from 2,800 to $3,200 \mathrm{~m} \cdot \mathrm{y}$. in age are considered to be indifferent targets (i.e., 0 ). Those outside this range (younger than $2,000 \mathrm{~m} . \mathrm{y}$. or older than $3,200 \mathrm{m.y.})$ are extremely discouraging (-95).

Area of Basin. Depositional basins with original areas on the order of $10^{4}$ to $10^{5} \mathrm{~km}^{2}$ are weakly suggestive $(+10)$ of the most favorable situation. The presence of a basin with an inferred original area smaller than $10^{4} \mathrm{~km}^{2}$ is mildly discouraging $(-20)$.

Thickness of Basin Fill. The most productive basins are from 5,000 to 10,000 meters thick (+20). Basins with substantially thicker or thinner successions are mildly discouraging $(-30)$.

Lithology of Basin Fill. Terrestrial, marginal-marine and shallow-marine clastics and chemical sediments (including some carbonates and iron-formation) occur in favorable basins. The successions include variable proportions of subaerial basaltic and rhyolitic volcanic rocks. Such a lithic fill is only mildly suggestive of the development of uraniferous conglomerates $(+30)$. By contrast, the predominance of a turbidite-pillow basalt assemblage is extremely discouraging $(-80)$.

Unconformity Parameters $(+40,-60)$

Type of Unconformity/Nonconformity. The presence of nonconformities and unconformities (both fundamental and intraformational types) is mildly encouraging (+30). A stronger weighting could not be given, since the areal extent of orebodies is only a fraction of that of the associated unconformity. The absence of significant stratigraphic breaks is very discouraging $(-60)$. It should be recalled, however, that intraformational unconformities can often not be recognized during field mapping exercises. If there is a 
Table 38. Recognition criteria score sheet for establishing favorability of stratigraphic setting.

\section{Stratigraphic Setting}

Estimate of Estimate of Estimate of Suggestivity Discouragement Suggestivity When Present When Absent When Present or Favorable
Estimate of Discouragement

When Absent

Estimate of Suggestivity When Present or Unfavorable or Favorable
Estimate of Discouragement When Absent or Unfavorable

Basin Parameters

Age

Area

Thickness of Fill

Lithology of Fill

$\begin{array}{ll}+30 & -95 \\ +10 & -20 \\ +20 & -30 \\ +30 & -80\end{array}$

Unconformity Parameters

Type of Unconformity/ Nonconformity

Paleoweathering

Paleotopography

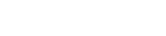

$+30$

$-90$

Accumulation-Burial

$+40-20$

Time-Lapse

$+30$

$-60$ 
reasonable chance that they might be present, a zero (rather than -60) could be assigned in this category.

Paleoweathering. Productive basins $(+30)$ are associated with unconformities and nonconformities with characteristic paleosols, composed of quartz-sericite \pm chlorite (over granitic rocks) and sericite \pm chlorite (over basaltic rocks). The paleosols are drab to cream colored. Signs of near-surface oxidation within them are subtle, being indicated, for example, by an increasing ferric/ferrous ratio. Where paleosols contain red-colored rocks with abundant specularite or hematite, the associated basins are considered to have essentially zero potential (extremely discouraging, -90). Such highly oxidized paleosols are normally found associated with basins younger than about $2,000 \mathrm{~m} \cdot \mathrm{y}$.

Paleotopography. Uraniferous conglomerates are preferentially developed in paleovalleys. The inferred presence of a paleovalley is moderately suggestive $(+40)$ of a favorable unconformity situation. Since paleovalleys are difficult to delineate during outcrop mapping exercises, their apparent absence is only mildly discouraging $(-20)$.

Accumulation-Burial Time-Lapse. Very rapid dumping and burial of fluvial sediment are unfavorable and are moderately discouraging (-60). A delicate balance of tectonics and sediment supply rate produces well-worked, oligomictic conglomerates, a mildly suggestive criterion (+30). Conglomerates that can be inferred to have remained unburied on an unconformity for periods of $10^{6}$ to $10^{8}$ years (pediment-like accumulations) are moderately discouraging $(-60)$. Even the slow rate of uraninite dissolution in the oxygen-deficient Archean and early Proterozoic paleoatmosphere can be shown to have destroyed much of the uraninite that was once contained in such conglomerates.

\section{Host Rock Character}

Characterization of the host rock containing uraniferous conglomerates is an important step. In exploration, this would allow the geologist to select favorable formations within the prospective basin. Three sets of recognition criteria are offered here, one for each host rock association. The three associations are not mutually exclusive. Some basins contain all three, others two, some only one. The positive criteria are additive; in other words, if two or more of the lithologic criteria are present, their scores are added, indicating the greater chances of success offered by the different lithologic associations. Conversely, if either (or both) the quartz-arenite or basalt association is missing, this is not considered to be very damaging, since by far the most important host rock is the subarkose-quartz wacke association.

Subarkose-Quartz Wacke Association $(+70,-70)$

Environment of Deposition. The subarkoses and quartz wackes of this association were deposited mainly in braided stream depositional environments ( +40$)$. Similar-looking sediments could conceivably be deposited by submarine turbidity currents, for example, a very discouraging situation $(-70)$. 
Color. The primary colors of sediments of this association are drab shades of olive, khaki, green, and gray $(+60)$. Primary reds, mauves, purples, or pinks are considered to be extremely discouraging $(-80)$. Two qualifications are necessary here. First, it is absolutely essential to determine the color in fresh, unweathered rock, since weathered quartz wackes are often rusty red, orange, or pink. Second, the words "primary color" are intended to refer to the preweathering color, not necessarily the color of the original sediment as it was deposited.

Texture. The arenites of this association are most often coarse- or very coarse-grained, relatively poorly sorted, and composed of relatively unrounded grains $(+40)$. However, their textural maturity can be somewhat higher under certain conditions, so that a local change in this parameter is not considered to be too damaging (0).

Mineralogy. The arenites in question are composed of quartz and sericite, with or without grains of $\mathrm{K}$ feldspar, and some chlorite, pyrophyllite, and, in the case of arenites in the greenschist grade, some chloritoid $(+60)$. Heavy mineral laminae are pyrite- and leucoxene-rich, and contain (at most) trace amounts of magnetite and ilmenite. The presence of hematite, ilmenite, and/or magnetite in amounts of over 0.1 percent is considered to be very discouraging $(-70)$.

Geochemistry $(+50,-30)$

(1) The subarkose-quartz wacke arenites are formed from leached basement rock, depleted in $\mathrm{Na}$. The $\mathrm{K} / \mathrm{Na}$ ratio in such host arenites is usually high to very high, ranging from 20 to nearly $100(+60)$. This ratio reflects the almost total destruction of plagioclase during paleoweathering. Arenites with a ratio significantly lower than the limit set above are considered to have formed under different conditions and are thus moderately discouraging $(-50)$.

(2) The leached basement rock is also depleted in $\mathrm{Ca}$, reflecting the almost total destruction of plagioclase feldspar. A high (>40) $\mathrm{K} / \mathrm{Ca}$ ratio is a favorable indication $(+50)$. A somewhat lower $\mathrm{K} / \mathrm{Ca}$ ratio (about 5-40) can be tolerated in arenites where a diagenetic calcite or dolomite cement is in evidence. Arenites with $\mathrm{K} / \mathrm{Ca}$ ratios lower than about 5 are moderately discouraging $(-50)$.

(3) The uranium content of arenites of the association under discussion is of the same order as that in the parent granites, about 5 to $15 \mathrm{ppm}$, with some samples containing up to $20 \mathrm{ppm} \mathrm{U}(+50)$. Consistently lower uranium contents (on the order of 1-3 ppm U, say) are moderately discouraging $(-50)$.

(4) The subarkose-quartz wacke arenites usually contain over $10 \mathrm{ppm}$ La and over $20 \mathrm{ppm} \mathrm{Ce} \mathrm{(0).} \mathrm{The} \mathrm{absence} \mathrm{of} \mathrm{such} \mathrm{concentrations} \mathrm{is} \mathrm{bad}$ news, being considered moderately discouraging $(-50)$. The presence of these elements is an indifferent criterion ( 0$)$, since these elements are to be expected in monazite-bearing arenites of all ages. This review has revealed a serious lack of trace element information on quartz wackes and associated sediments in mineralized and unmineralized basins. Application of trace element 
criteria may go far towards allowing us to discriminate between a reas of high and low potential in the same basin, or even within single formations.

Quartz-Arenite Association $(+20,0)$

Environment of Deposition. Quartz arenites intimately associated with uraniferous conglomerates appear to have been deposited in marginal marine (especially lower tidal flat) and shallow marine environments. This is a weak criterion $(+10)$, in that nearly all Precambrian quartz arenites were deposited in such environments.

Color. The primary colors of the quartz arenites are shades of gray, varying from very dark to very light gray $(+30)$. Other primary colors (red, mauve, pink, purple) are extremely discouraging (-80).

Texture. The arenites are texturally much more mature than their quartz wacke counterparts. They tend to be relatively well sorted, medium- or medium- to coarse-grained and are composed of relatively well-rounded grains (where grain margins have not been destroyed by pressure-point solution) $(+30)$. The absence of this mature texture is weakly discouraging $(-10)$, unless the quartz arenite grades to the subarkose-quartz wacke association.

Mineralogy. The arenites are composed of quartz grains (with or without chert grains) and a small (less than 5 percent) proportion of matrix constituents, such as sericite and chlorite. They frequently contain pyrite concentrations along erosive surfaces, cross-bed foresets, and set boundaries. Such a mineralogical makeup is mildly suggestive of a favorable arenite host rock $(+30)$. By contrast, arenites of the same general type that contain a primary red hematitic coloring are extremely discouraging $(-80)$.

Basa1t Association $(+15,0)$

Environment of Extrusion. Conglomerates interbedded with subaerial basalts are mildly suggestive of the possibility of development of uranium deposits $(+20)$. The consistent development of features indicating a submarine extrusive environment is a "killer" (-95).

Color. Basalts associated with uraniferous conglomerates are usually shades of gray and green in color $(+10)$. The development of large thicknesses of red or of maroon basalt is extremely discouraging $(-80)$, indicating the presence of oxidizing conditions during or after extrusion.

Texture and Structure. Uraniferous conglomerates are associated with basalts that occur in flows with highly amygdaloidal tops (originally scoriaceous) and massive, sometimes porphyritic, bases $(+20)$. Pillow structures are seen only on a scale commensurate with the development of local volcanic lakes. The large-scale development of pillowed basalts and of interflow pelagic sediments is extremely discouraging $(-80)$.

Mineralogy. Under greenschist conditions, the basalts are usually composed largely of albitic plagioclase, actinolitic amphibole, epidote, and chlorite. Development of this mineralogy is only weakly suggestive $(+20)$, since enormous volumes of such basalt occur without associated uraniferous conglomerate. A 
Table 39. Recognition criteria score sheet for establishing favorability of host rock character.

Host Rock Character

\begin{tabular}{|c|c|c|c|c|c|c|}
\hline Criterion & $\begin{array}{r}\text { Estimate of } \\
\text { Suggestivity } \\
\text { When Present } \\
\text { or Favorable } \\
\end{array}$ & $\begin{array}{c}\text { Estimate of } \\
\text { Discouragement } \\
\text { When Absent } \\
\text { or Unf avorable }\end{array}$ & $\begin{array}{l}\text { Estimate of } \\
\text { Suggestivity } \\
\text { When Present } \\
\text { or Favorable } \\
\end{array}$ & $\begin{array}{c}\text { Estimate of } \\
\text { Discouragement } \\
\text { When Absent } \\
\text { or Unf avorable }\end{array}$ & $\begin{array}{l}\text { Estimate of } \\
\text { Suggestivity } \\
\text { When Present } \\
\text { or Favorable } \\
\end{array}$ & $\begin{array}{r}\text { Estimate o } \\
\text { Discourageme } \\
\text { When Absen } \\
\text { or Unfavorab }\end{array}$ \\
\hline $\begin{array}{l}\text { Subarkose-Quartz Wacke } \\
\text { Association } \\
\text { Environment of } \\
\text { Deposition } \\
\text { Color } \\
\text { Texture } \\
\text { Mineralogy } \\
\text { Geochemistry } \\
\text { K/Na Ratio } \\
\text { K/Ca Ratio } \\
\text { U Background } \\
\text { Trace Element } \\
\text { Geochemistry }\end{array}$ & $\begin{array}{l}+60 \\
+50 \\
+50\end{array}$ & $\begin{array}{l}-50 \\
-50 \\
-50 \\
-50\end{array}$ & $\begin{array}{l}+40 \\
+60 \\
+40 \\
+60 \\
+50\end{array}$ & $\begin{array}{r}-70 \\
-80 \\
0 \\
-70 \\
-30\end{array}$ & +70 & -70 \\
\hline $\begin{array}{l}\text { Quartz-Arenite } \\
\text { Association } \\
\text { Environment of } \\
\text { Deposition } \\
\text { Color } \\
\text { Texture } \\
\text { Mineralogy }\end{array}$ & & & $\begin{array}{l}+10 \\
+30 \\
+30 \\
+30\end{array}$ & $\begin{array}{r}0 \\
-80 \\
-10 \\
-80\end{array}$ & +20 & 0 \\
\hline $\begin{array}{c}\text { Basalt Association } \\
\text { Environment of } \\
\text { Extrusion } \\
\text { Color } \\
\text { Texture and } \\
\text { Structure } \\
\text { Mineralogy }\end{array}$ & & & $\begin{array}{l}+20 \\
+10 \\
+20 \\
+20\end{array}$ & $\begin{array}{l}-95 \\
-80 \\
-80 \\
-80\end{array}$ & +15 & 0 \\
\hline
\end{tabular}


large proportion of hematitic pigment in the basalt is considered to be extreme1y discouraging $(-80)$.

\section{Conglomerate Character}

The ultimate step in the application of the recognition criteria net is in the evaluation of conglomerate characteristics (Table 40). This is particularly useful during the final stages of field mapping (prior to subsurface exploration) and during drilling programs. The criteria are also intuitively applied by most geologists in mining areas such as the Witwatersrand and Elliot Lake areas.

Conglomerate Geometry $(+30,-20)$

Thickness. Economically exploitable conglomerates range in thickness from a single pebble width to about 3 meters $(+30)$. The extremes are:

(1) scattered pebbles on an erosion surface; and

(2) conglomerates with interbedded arenites forming a mineable stratigraphic package up to 10 meters thick.

There are no known examples of development of mineable grades over larger thicknesses. Thus, conglomerates in excess of about 10 meters in thickness are considered to be moderately discouraging $(-50)$. Those from 3 to 10 meters thick should be rated with low positive numbers $(0$ to +30$)$. Those less than 3 meters thick should be rated as mildly suggestive $(+30)$, the highest rating in this category. A higher rating is not advisable, since numerous thin conglomerates contain little or no uranium.

Lateral Extent. The lateral extent of payable conglomerates varies enormously. Some composite grave1-sand sheets can be traced (and mined) over areas of up to $400 \mathrm{~km}^{2}$. Others, such as those in the Matinenda, can be traced (as composite packages of lenticular gravels with intervening arenites) over areas on the order of $20 \mathrm{~km}^{2}(+30)$. The economic potential of gravels that (despite careful prospecting) can be mapped over only a $f$ ew square kilometers is relatively low. Such a situation is considered to be mildly discouraging $(-30)$.

Internal Stratigraphy. Uraniferous conglomerates, especially those over a meter or so in thickness, are characterized by the presence of internal partings of pyrite-rich arenite and, in some cases, argillite. Arenite partings are lenticular and are structured by trough or tabular cross-bed sets. Argillite partings are usually thin ( $\mathrm{few}$ millimeters) and discontinuous. The conglomerate usually rests on a scoured, eroded surface. Internal erosive surfaces are also characteristically present. If present, these features are mildly suggestive of a favorable geometry $(+30)$. If absent, they are weakly discouraging $(-20)$.

Pebble Assemblage $(+50,-70)$

Size. Economic concentrations of uranium are usually associated with pebble conglomerates and not with cobble or boulder conglomerates. The ideal 
conglomerate should have a median (or mean) pebble size of less than about $7 \mathrm{~cm}$. If clast size is expressed in terms of the average diameter of the 10 largest clasts in an area, a somewhat larger limit to clast size should be allowed. Where clast sizes are consistently in the cobble or boulder size range, the situation is considered to be very discouraging $(-60)$. Within the pebble size range, no preference is expressed, and a mildly suggestive (+30) category is employed.

Composition. Uraniferous conglomerates are characteristically oligomictic, containing, at most, 10 to 20 percent chert pebbles and a few percent of less durable types. Such conglomerates are moderately suggestive of the ideal pebble assemblage $(+50)$. One type of polymictic conglomerate that should be similarly rated is one which contains not more than 20 or 30 percent of locally derived shaly clasts. All other polymictic conglomerates are regarded as "bad news" and should be awarded a negative rating varying from (say) 0 (15 percent non-durable clasts) to -80 (50 percent or more non-durable clasts).

Packing. As a general rule, the density of packing of pebbles can be taken as a measure of conglomerate potential. Clast-supported conglomerates almost always contain more uranium than associated matrix-supported types. However, some payable auriferous-uraniferous placers comprise no more than scattered pebbles along a scour surface overlain by a mature, pyritic quartz arenite with sporadic pebbles. Lack of favorable packing is only weakly discouraging $(-10)$. A well-packed arrangement can only be considered mildly suggestive $(+20)$ of a favorable situation, since by no means all such conglomerates are well mineralized.

Sorting. The uranium (or gold) potential normally increases with the degree of conglomerate sorting. No absolute sorting values can be set, as the parameter is sensitive to the size distribution of the original clasts. Most Witwatersrand placer sheets have graphic standard deviations of $0.5 \phi$ or less. If sorting is better than $1 \phi$, the parameter is considered to be mildly suggestive $(+30)$ of a favorable pebble assemblage. If sorting lies between 1 and $1.5 \phi$ units, a zero value should be assigned. If sorting is any worse than $1.5 \phi$, the parameter is moderately discouraging $(-50)$. This criterion needs to be fine-tuned on the basis of a comparative study of sorting between districts and between payable and non-payable conglomerates within districts.

Shape. The ideal conglomerate is composed of elliptical or spherical, rounded or well-rounded clasts. Since not all such conglomerates contain economic concentrations of uranium, the shape parameter is, at best, mild1y suggestive $(+20)$ of the ideal conglomerate being present. A large proportion of non-spherical, angular clasts is considered to be "bad news", being rated at the -70 leve1.

Quartz Color. It has been noted that uraniferous conglomerates usually contain a high proportion of gray "smoky quartz" pebbles (Pienaar, 1963, p. 67). The dark color has been ascribed to radiation damage to the crystal structure. The presence of a high proportion of such clasts is considered to be moderately encouraging $(+50)$. Where dark gray quartz clasts compose only a few percent of the clast population, the situation is considered to be moderately discouraging $(-50)$. 
Matrix Characteristics $(+70,-80)$

Texture. The matrices of uraniferous conglomerates are generally medium-, coarse-, or very coarse-grained $(+20)$ and tend to be somewhat better sorted than the associated arenites. A matrix dominated by grain sizes outside this range (that is, fine sand to clay or granule and larger) is "bad news" ( -50$)$.

Mineralogy. There are a number of mineralogical features associated with a favorable conglomerate matrix:

(1) The light minerals that dominate the matrix include quartz (both as a detrital mineral and as a cement) with a few percent of sericite, somewhat less chlorite with or without aluminous minerals such as pyrophyllite, and chloritoid ( +50$)$. Large proportions (over 15 or 20 percent) of phyllosilicates in the matrix are "bad news". A phyllosilicate-dominated matrix is a "killer" $(-90)$.

(2) Payable uraniferous conglomerates are dominated by a suite of heavy minerals, including pyrite of various types, leucoxene, zircon, chromite, monazite, and a host of lesser minerals. If abundant pyrite is present, a moderately suggestive score $(+50)$ is suggested. The score could be increased by 5 (to give a maximum of +70 ) for each of the minerals mentioned that is found in addition to pyrite. If none of the minerals mentioned is present in appreciable amounts, the score shifts to -50 (moderately discouraging). If greater than trace amounts of hematite, magnetite, and/or ilmenite are present, the score shifts to the "killer" category (-95).

(3) The presence of "carbon" in a conglomerate matrix is "very good news", ranking as very suggestive for "fly speck" carbon $(+60)$ to a maximum of +80 (extremely suggestive) for seams of carbon. Since by no means all payable conglomerates contain carbon, the absence of this material can only be considered to be weakly discouraging $(-15)$.

Geochemlstry. Several obvious geochemical parameters can be applied to the assessment of the favorability of the conglomerate matrix. These include:

(1) $\mathrm{K} / \mathrm{Na}$ (and $\mathrm{K} / \mathrm{Ca}$ ) ratios, which should be large, as in the case of the host arenites $(+40,-30)$.

(2) U/Th ratio, which 1s, 1deally, greater than 1 . Expressed as $\mathrm{UO}_{2} / \mathrm{ThO}_{2}$, the ratio has been shown to vary from 2.6 to 15 for selected Witwatersrand conglomerates (Feather, in press). Expressed as $\mathrm{U}_{3} \mathrm{O}_{8} / \mathrm{ThO}_{2}$, the ratio varies from 1.8 to 3.15 for selected Matinenda conglomerates (Plenaar, 1963). The ratio is less than 1 for most unpayable or non-mineralized conglomerates. A rating of +30 is suggested where the ratio is about 1.5 , and of +50 where the ratio exceeds 2 . At the other end of the scale, a ratio of 1 is inconclusive (0), while ratios approaching 0.1 are "bad news" and rated at -50 . 
Table 40. Recognition criteria score sheet for establishing favorability of conglomerate character.

\section{Conglomerate Character}

\section{Criterion}

Conglomerate Geometry Thickness

Lateral Extent

Internal

Stratigraphy

Pebble Assemblage Size

Composition

Packing

Sorting

Shape

Quartz Color

Matrix Characteristics

Texture

Mineralogy

Light Minerals

Heavy Minerals

Carbon

Geochemistry

$\mathrm{K} / \mathrm{Na}$ Ratio

U/Th Ratio

Trace Element

Geochemistry

$+50$

$+70$

$+80$

$+40$

$+50$

$+50$
Estimate of Suggestivity

When Present

or Favorable

Estimate of Estimate of Discouragement Suggestivity

When Absent When Present

or Unf avorable or Favorable
Estimate of Estimate of Discouragement Suggestivity When Absent When Present or Unf avorable or Favorable

Estimate of Discouragement

When Absent

or Unf avorable

$+30$

$-20$

$+30$

$+30$

$+30$

$-50$

$-30$

$-20$
$+50$

$-30$

$-50$

$-50$
$+30$

$+50$

$+20$

$+30$

$+20$

$+50$

$+20$

$+80$

$-90$

$-95$

$-15$

$-60$

$-80$

$-10$

$-50$

$-70$

$-50$

$+70$

$-80$

$-90$

$-50$
$-70$

Mineralization

Radioactivity

Uranium Minerals 
(3) The trace-element composition of uraniferous conglomerates is relatively high. Studies on a statistically valid number of samples have not been undertaken, so that absolute limfts are difficult to set. Conglomerates with a high potential should contain $S$ at the 1 percent level, $\mathrm{TiO}_{2}$ at the 0.1 to 2 percent level, and $\mathrm{Co}, \mathrm{Ni}, \mathrm{Cu}, \mathrm{As}, \mathrm{Zn}, \mathrm{Cr}, \mathrm{Zr}$, and $\mathrm{Pb}$ at the level of several tens to a few hundred ppm. $\mathrm{Au}, \mathrm{Ag}$, and rare earth elements are characteristically present at the $1 \mathrm{ppm}$ to $100 \mathrm{ppm}$ level in many uraniferous conglomerates. The presence of such levels of most of these elements is moderately suggestive $(+50)$ of a payable conglomerate matrix, while their absence is equally discouraging $(-50)$.

Mineralization $(+80,-70)$

Radioactivity. Conglomerates with significant potential should be markedly radioactive (at least $10 \mathrm{X}$ background). This is true even of fairly strongly weathered conglomerates, which retain radioactive thorium (out of uraninite, brannerite, and monazite). Radioactivity at this level is moderately suggestive $(+50)$ of a well-mineralized conglomerate while a background level of radioactivity suggests an extremely discouraging situation $(-90)$.

Uranium Minerals. The positive identification of significant concentrations of uraninite, brannerite, or uranothorite is "good news", being very suggestive $(+70)$ of a payable conglomerate. The presence of dispersed uranium with no identifiable uranium mineral phases is less encouraging $(+30)$. The absence of uranium, even in the dispersed form, is very discouraging $(-70)$. 
The enormous revenues generated by mining of uraniferous-auriferous conglomerates have resulted in a very large body of published data. There are, however, many problems, the answers to which will materially enhance our ability to predict the location of uraniferous conglomerates within target basins. In the paragraphs which follow, we enumerate what we see to be the most important avenues for future resource estimation and exploration-oriented research.

Source of Uraninite. To date, attempts at locating dispersed uraninite grains in what appear to be the source granites of particular basins have been unsuccessful. This is puzzling and has fueled some of the skepticism regarding the theory of a detrital origin of uraninite in Precambrian conglomerates. Recent studies of the distribution of uranium in the Granite Mountains of Wyoming (Stuckless and Nkomo, 1978) give hope that the uraninite source may yet be positively identified. Here, it was shown that 70 (or more) percent of the uranium in granitic rocks has been leached to depths of many tens of meters. It may well be that the Archean granitic source rocks studied were leached to similar depths by both present and past erosion cycles. Samples of unweathered rock from probable source rocks should be obtained from areas peripheral to basins such as the Huronian of the Elliot Lake area. Once source rocks have been positively identified, techniques for their routine recognition could be developed. In addition, a knowledge of the distribution, grain size, and chemistry of uraninite in such plutons might lead to the development of the types of exploration targets such as the vein deposits in granites in France.

Source Area Evaluation. Direct study of granitic source area is undoubtedly the best method of evaluating the uranium potential of superjacent Precambrian basins. Methods employed should include mapping, regional geochemical studies, and airborne gamma spectrometric surveys. Unfortunately, such studies are not always possible. First, as we mention above, uranium is often strongly leached from such granites. Second, the granites are often not exposed. Finally, the relations in the basement may be tectonically so complex that we cannot distinguish the source rock plutons from other less important granitoid bodies.

Faced with one or more of these problems, we may be forced to resort to indirect methods of evaluating the source rock character. One approach would be to study the uranium content of refractory igneous minerals either in their original granitic host or in the arenites and conglomerates of the basin itself. The obvious choice for this study would be zircon, which is ubiquitous in granitic rocks and in coarse-grained sediments. It seems entirely reasonable to expect that a study of the uranium content of the unaltered cores of zircon grains (in granites or in sediments derived therefrom) would be an excellent method of determining the uranium content of the provenance area.

Host Rock Evaluation. In nearly all of the areas reviewed, uraniferous conglomerates occur in waxy-looking, drab-colored subarkoses or quartz wackes. We have detected no obvious physical differences between the host arenites of the economic conglomerates and those of their poorly mineralized counterparts. We feel intuitively that significant differences must exist due to the favorable and unfavorable source areas of the host arenites of the respective 
deposits. The approach favored here is one of geochemical fingerprinting either of the whole rock or of selected mineral grains.

Geochemical study of conglomerates is plagued by sampling problems caused by the undue influence of large clasts on manageably large samples. The obvious approach is to study the finer grained fractions, either the arenites or the thin shaly drapes that are so common in the host arenites. Multi-element analyses of such samples, followed by statistical treatment of the data, should result in the recognition of several geochemical families, one or more of which could indicate favorable source terrane.

Zircon has been mentioned as one mineral holding obvious possibilities in host-rock assessment. Another would be the titania aggregates (leucoxene) that are so universally associated with the conglomerates and with their host arenites. The capacity of titania aggregates to adsorb uranium is apparent1y very high. It seems reasonable to expect that leucoxene grains in a favorable host arenite should be appreciably uraniferous, and vice versa. We suggest that research along these lines would be invaluable during exploration in allowing us to evaluate the uranium potential of two or more macroscopically identica1 target formations.

Metamorphic Destruction of Uraniferous Conglomerate Deposits. Our assembled data are consistent with other information on igneous and metamorphic rocks which suggest uranium loss at relatively high metamorphic grades. There seems to be no doubt that prograde metamorphic reactions ultimately result in mobilization and loss of uranium. It now needs to be determined at what metamorphic grade economically viable uranium concentrations in conglomerates become destroyed. Empirically it appears to lie somewhere in the amphibolite facies because all the large, high-grade deposits are of greenschist grade. of those deposits in amphibolite-grade host rocks, only Jacobina appears to be economic under present conditions, and this largely is due to its gold (rather than uranium) content. No granulite-grade deposits are known. We feel there is ample justification for downgrading the potential of conglomerates of amphibolite rank and have done so in our recognition criteria scheme. Our concern is that we may have been too lenient, and that amphibolite-grade metamorphism approaches "killer" status.

Solutior Transport of Uranium. There is general agreement that there has been very significant post-depositional migration of uranium in conglomerate systems. The timing and mechanism of uranium (and thorium) transport is in question. Previous investigators have favored transportation by metamorphic pore fluids during greenschist-grade metamorphism. We would argue that the porosity/permeability of the system was substantially reduced at such a metamorphic grade. Further, no satisfactory solution-transport mechanism (for U and $\mathrm{Th}$ ) has been proposed for fluids in the $200-300^{\circ} \mathrm{C}$ temperature range in question. Indeed, under the highly reducing conditions envisaged, it is difficult to see how uranium could be transported.

Uranium redistribution by paleo-ground water (possibly under cover of thousands of meters of sediment) seems to be an attractive alternative. First, the system would have been fairly porous and permeable. Second, it has been shown in at least one case that paleo-ground water was almost certainly significantly uraniferous. Third, there is textural evidence of early movement 
of uranium in its introduction into and concentration in porous titania aggregates before they were cemented by quartz. A problem for the paleoground water theory (and, for that matter, for the metamorphic transport concept) is the presence of significant (a few percent) thorium in phases such as brannerite. McLennan and Taylor (1979) have inferred significant transport of Th (and REEs) in Proterozoic rocks of the Northern Territory, Australia. They proposed that these elements were moved as carbonate complexes in a lowtemperature system. In the system under discussion, there is independent evidence of the presence of a flux of organic-rich solutions through the conglomerates. Research into the complexing capacity of molecules like those inferred to have fluxed through the conglomerates may well show that they had the capacity to transport not only uranium and thorium but also gold and other sulfophile elements commonly found in Witwatersrand carbon. If this were shown to be the case, paleohydrology would become an important exploration tool for uraniferous conglomerates.

Uraninite Destruction on Unconformities. As far as we know, this compilation is the first one in which the concept of uraninite destruction on a paleo-erosion surface is advanced. The evidence for destruction seems very strong. In the West Rand area, for example, Witwatersrand conglomerates are well mineralized by gold and uranium. Conglomerates on the overlying unconformities (at the base of the Ventersdorp and Transvaal successions) have been mined for gold, but not for uranium. There is textural evidence for uraninite dissolution in the younger conglomerates (Liebenberg, 1955).

A new negative element to exploration has emerged. Conglomerates that can be inferred to have lain on an unconformity for long periods of time (we cannot say exactly how long, but on the order of $10^{6}$ or more years) have a significantly lower potential than those that were buried and sealed shortly after their formation. This negative observation raises the possibility of a new exploration target. In the West Rand, for example, the uranium lost on the Black Reef erosion surface may well have become chemically fixed in the carbonaceous shales that overlie the basal conglomerates and arenites in a transgressive, fining-up cycle. 
Blank

$-302$. 


\author{
UNITED STATES POTENTIAL FOR \\ PRECAMBRIAN URANIFEROUS CONGLOMERATES
}

In this concluding chapter, an appraisal of the United States' potential for the development of uraniferous conglomerates is presented. The topic has been recently reviewed in a report by Houston and Karlstrom (1979). These authors gave an exhaustive account of the geologic environments within which such deposits might be found. In this report, the criteria relating to the development of uraniferous conglomerates are applied to these areas in an attempt to sharpen the focus on possible exploration targets. It is hoped that this approach will provide the stimulus for continued exploration in the prospective areas.

In the paragraphs that follow, we intend first to use the broadest possible filter, that of geotectonic setting. This will enable us to exclude much of the Precambrian terrane within the United States from further consideration. Thereafter, the general geology of the prospective areas will be described. Finally, the appropriate recognition criteria will be applied and will point to formations which are belleved to provide the best possible exploration targets within the United States.

Archean Provinces of the United States

It will be recalled that all significant Precambrian uraniferous quartz-pebble conglomerates are confined within the outlines of Archean provinces. This follows, of course, from the fact that the basins are efther late Archean or early Proterozoic in age and must rest on somewhat older basement rocks.

The general outline of the Archean areas of the United States has been established and is shown in Figure 77 . To the best of our present knowledge, Archean basement rocks are restricted to the area around the Great Lakes and to an area centered around the state of Wyoming. The former is part of the Superior Province, the latter of the Wyoming Province.

The Superior Province extends in a northeasterly direction from the Dakotas to beyond Hudson Bay, a distance of some $2,500 \mathrm{~km}$. That part of the province in the United States comprises only a small fraction of the total area of this immense geologic unit. Archean rocks of the Superior Province crop out in Minnesota and the northern parts of Wisconsin and Michigan. In the subsurface, these rocks have been traced westward into eastern North Dakota and northeastern South Dakota (Lidiak, 1971).

The outlines of the Wyoming Province are less well established since only a small fraction of the province is exposed in the cores of several Laramide uplifts. Houston and Karlstrom (1979) reviewed the information relevant to the extent of the province. They showed that it extends from the Black Hills (in the east) to the northwestern corner of Utah (in the west) and from the vicinity of the Wyoming-Colorado state line (in the south) to central Montana (in the north). 
The Wyoming and Superior Provinces are apparently separated by a Proterozolc mobile belt. According to information presented by Lidiak (1971), this may be the southern extension of the north to south-trending Churchill Province of west-central Canada.
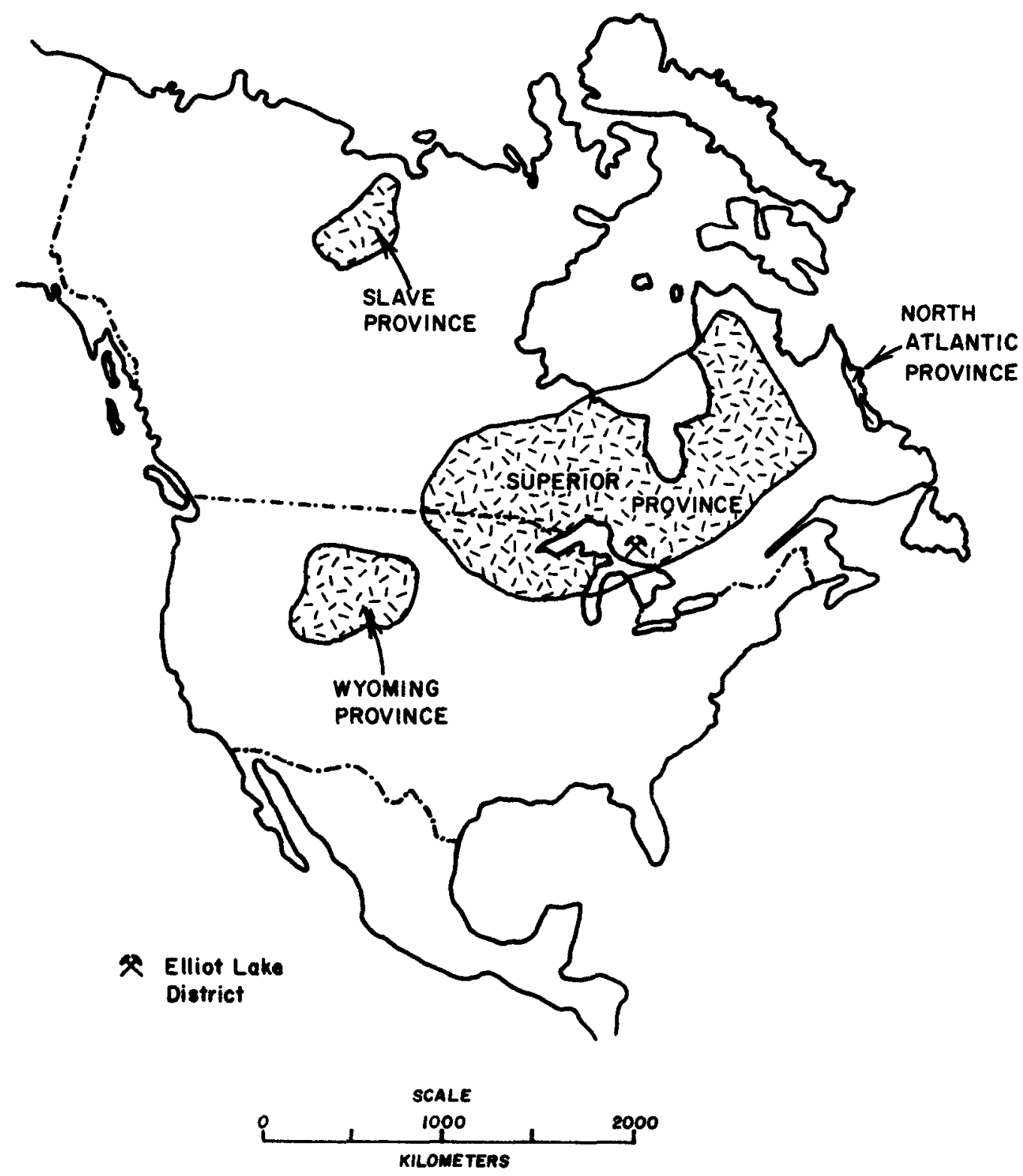

Figure 77. Distribution of Archean cratons in North America (modified after Van Schmus, 1976). 
The Superior Province

On the face of it, the United States sector of the Superior Province is an attractive area within which to explore for Precambrian uraniferous conglomerates. The world's largest conglomerate-hosted uranium reserve is situated in early Proterozoic sediments on the north shore of Lake Huron, in the Elliot Lake Group of the Huronian Supergroup. The Elliot Lake Group can be traced to the west to near Sault Ste. Marie. When last seen, the group is "alive and we11", and appears to be heading for the Upper Peninsula area of Michigan. Between Marquette, Michigan, and Sault Ste. Marie, Precambrian outcrops are obscured by Paleozoic sediments and by the waters of Lake Superior. It is encouraging to note that the general geology of the Marquette area and the Elliot Lake region are similar, comprising a basement of granitic rocks and greenstone belts unconformably overlain by lower Proterozolc rocks. Tillite-like sediments are even developed in the Proterozolc of the Marquette area and in the Menominee ranges to the south (Puffet, 1969; 1974; James and others, 1961). However, as we shall see, no simple correlation of stratigraphy between the Marquette and Elliot Lake areas can be made. Indeed, most geologists who have worked in the region are of the opinion that the Proterozoic rocks of the Lake Superior area are younger than the Huronian Supergroup (Van Schmus, 1976).

Lithology and Tectonic Level of the Archean Basement

In an extremely useful review, Sims (1976) has shown that the Archean basement of the Lake Superior area comprises two very different types of geologic terrane. An older high-grade gneiss belt lies south of a somewhat younger greenstone terrane (Figure 78). The boundary between these units trends more or less east-west, from the region of the common point on the borders of the Dakotas with the state of Minnesota, to near Duluth. Here, the relations are obscured by the Keweenawan rift zone, with its basalts, basic intrusives, and sediments.

The boundary between the two Archean terranes was apparently displaced about $160 \mathrm{~km}$ to the southeast, along a southeast-trending fault. From the vicinity of Mellen in northern Wisconsin, the geologic boundary continues to trend about $\mathrm{E} 20^{\circ} \mathrm{N}$ to a point just south of Marquette after which it is obscured by Phanerozoic cover formations.

The gneiss terrane is composed of a variety of migmatitic gneisses with mineral assemblages typical of granulite- and amphibolite-grade metamorphic conditions (Sims, 1976). The gneisses are relatively well-exposed in the Minnesota River valley where they have been intensively studied. They have been dated in the range from 3,500 to $3,800 \mathrm{~m} \cdot \mathrm{y}$. In northern Wisconsin and Michigan, attempts at dating what are believed to be the equivalents of these gneisses have been complicated by the resetting of isotopic ages during the Penokean orogeny, some $1,900 \mathrm{~m} \cdot \mathrm{y}$. ago.

In terms of the model of tectonic level within the Archean crust, the gneisses of the Minnesota River valley would represent low levels and are considered to be relatively unfavorable source rocks for uraniferous conglomerates. It is not certain that this status would apply to all the gneisses of this belt in the Wisconsin and north Michigan areas. A careful reading of some of the 


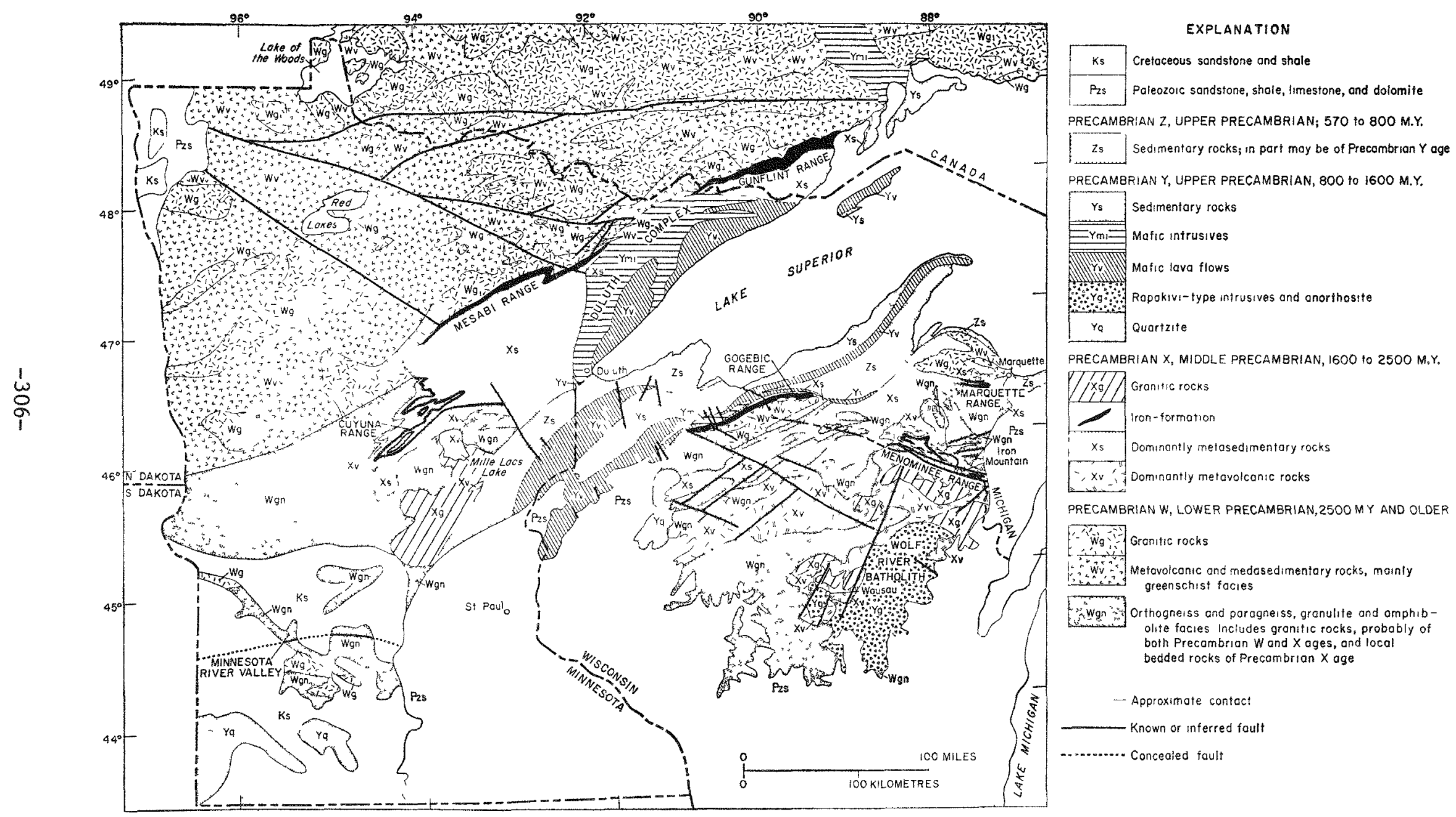

Figure 78. Generalized geology of the Lake Superior area (from Sims, 1976). 
descriptions of gneissic areas south of the Marquette region suggests that some of this country could be underlain by tonalitic gneisses such as those which separate many greenstone belts. For example, the Margeson Creek Gneiss, exposed in the "Amasa ova1" of the Menominee area, incorporates a "magnetic green schist" comprising sericitic and chloritic rocks of a slaty to schistose type (Gair and Weir, 1956). Further east, the Carney Gneiss comprises a granitoid mass with 10 percent inclusions of amphibolite, biotite schist, and metasediments (Bayley and others, 1966). The point is made that some greenschist- to amphibolite-grade material occurs in parts of this gneissic belt. Where such grades prevail, intermediate crustal levels are indicated. Granitic rocks associated with intermediate crustal levels could possibly have supplied uranium to the early Proterozoic basins of this area.

The greenstone terrane is exposed over much of northern Minnesota and along a narrow (less than $100 \mathrm{~km}$ wide) belt south of Lake Superior (Figure 79). The area is typical of greenstone terranes elsewhere, being composed of synclinal belts of greenschist-grade metavolcanics and metasediments, separated by granitic plutons of varying age and character. Both greenstone belts and the associated plutons appear to have formed during a short-lived volcanicplutonic cycle, some $2,700-2,750 \mathrm{~m} \cdot \mathrm{y}$. ago (Sims, 1976).

Morey and Sims (1976) have explained the relations described by suggesting that the gneiss terrane represented a "sialic protocontinent" and that the greenstone country was welded to this block in a manner akin to continental accretion. Together, the composite blocks formed a "large coherent continental crustal segment" some $2,600-2,700 \mathrm{~m} \cdot \mathrm{y}$. ago.

The relation of the gneissic and greenstone "blocks" could also be explained in terms of the layered crust concept, developed earlier in this report. The gneiss terrane could merely represent a more deeply eroded level of continental crust. The sharp boundary between the two terranes could then be explained as due to the upward movement of the southern block along a fault system. Indeed, Sims (1976) suggested that the boundary was a fault or fault system.

If we accept that "intermediate" tectonic levels represent the most favorable levels for the development of uranium source areas for basins of uraniferous conglomerate, we might decide to concentrate our search on the border zones of these two tectonic provinces.

Existing information on the evolution of the granitoid basement of the Lake Superior area is a patchwork of local detail and regional generalizations. It is difficult to obtain reliable information on the background uranium contents of granitic rocks. Kalliokoski (1976) mentions a few Archean granitic rocks that might be of the type that could act as a source of uranium in Proterozoic basins. The Red River Quartz Monzonite of northern Wisconsin, for example, is a pink porphyritic rock which is locally pegmatitic. Radiometric assays of up to $104.7 \mathrm{ppm}$ equivalent $\mathrm{U}_{3} \mathrm{O}_{8}$ in this body were mentioned by Kalliokoski. In general, the source rock recognition criterion (Figure 75) cannot be applied in this area for want of reliable uranium analyses. 


\section{Area}

If we exclude the greenstone belts, the Lake Superior region is dominated by two Precambrian basins, the Lower Proterozoic Marquette Range Supergroup and the Middle to Upper Proterozoic Keweenawan succession. The latter can be disregarded as a possible host for uraniferous conglomerates because of its age. The Marquette Range Supergroup and equivalents probably covered an area

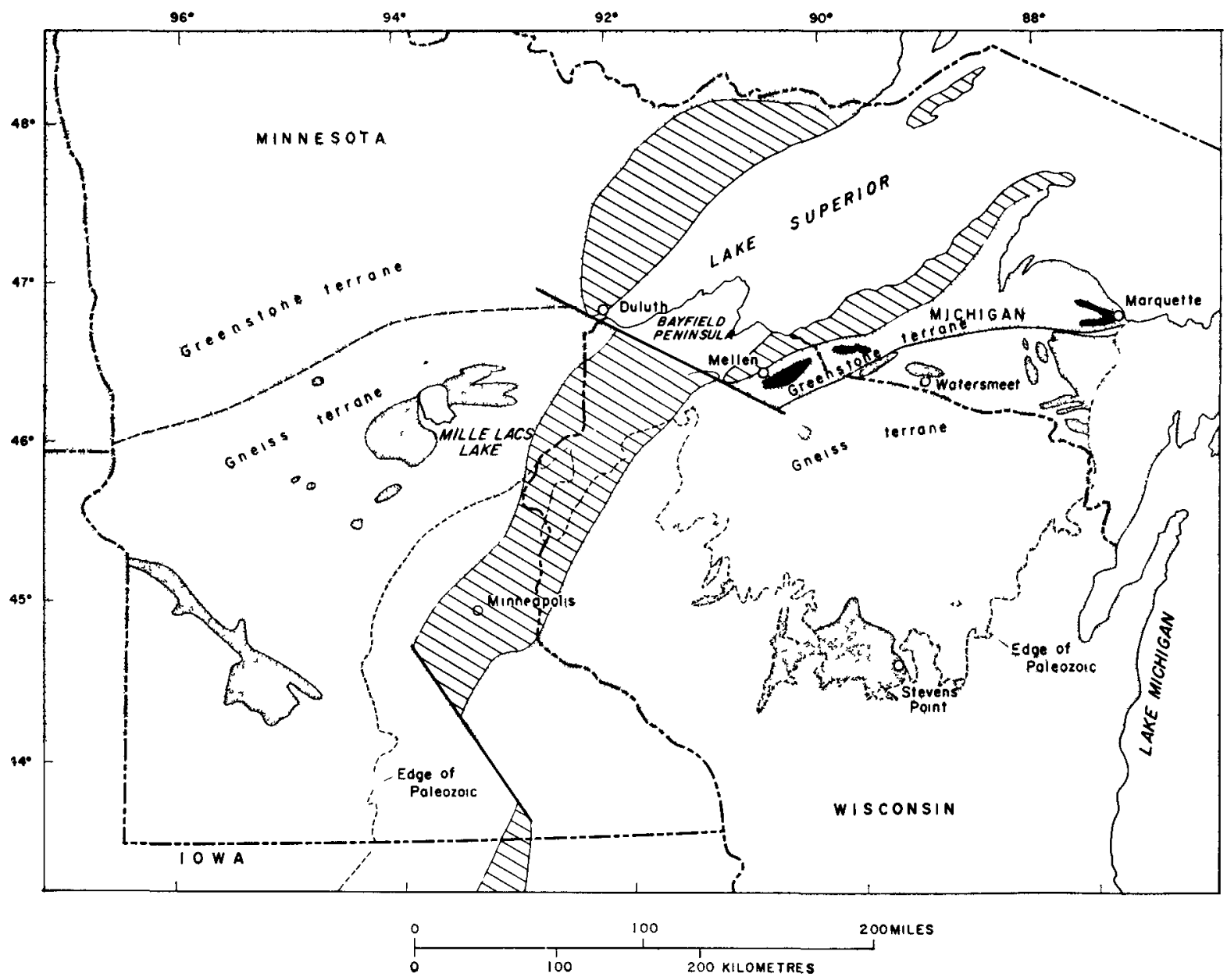

Figure 79. Simplified geological map of the Lake Superior area showing the distribution of gneiss and greenstone terrane. Individual greenstone belts are shown (in black) only in the area south of Lake Superior. The separation of the Archean terrane into two blocks by the Keweenawan rift system (cross-hatched) is emphasized (from Sims, 1976). 
of at least $100,000 \mathrm{~km}^{2}$. Remnants of the basin are exposed over an area measuring about $550 \mathrm{~km}$ (southwest to northeast) by 100 to $300 \mathrm{~km}$ (northwest to southeast) (Figure 80 ).

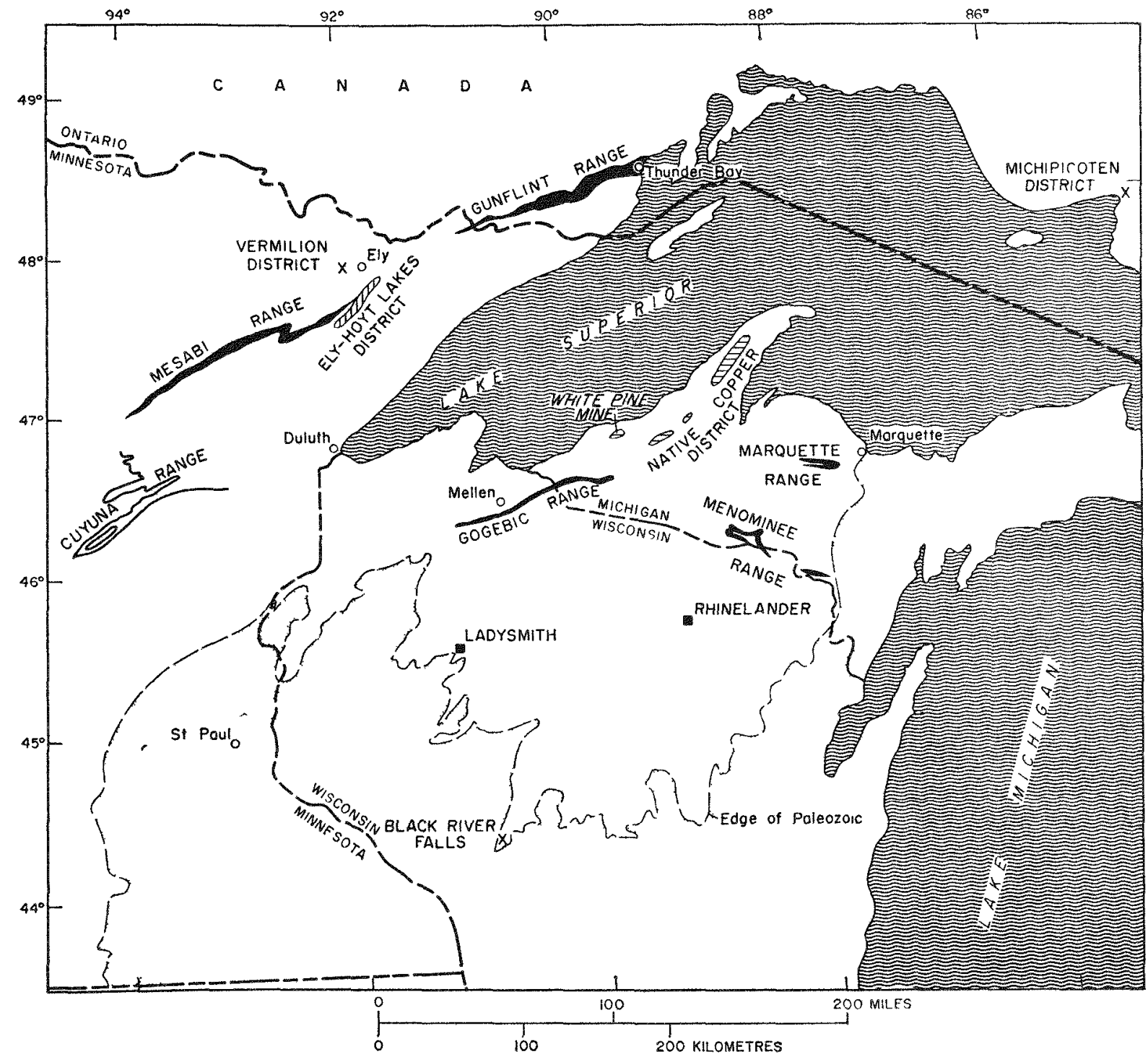

Figure 80 . Outcrop areas of lower Proterozoic basins (black) in the Lake Superior area (from Sims, 1976). 
Paleogeography

The paleogeography of the basin appears to have been controlled by the character of the Archean basement. The northern half of the basin (which rests on granite and greenstone terrane) is dominated by a relatively thin succession of "miogeosynclinal sediments", while the southern half comprises a much thicker "eugeosynclinal" assemblage comprising both sedimentary and volcanic rocks (Sims, 1976). The regional paleoslope was from north to south. The fluvial conditions typically responsible for the deposition of uraniferous conglomerates have the greatest chance of being developed in the northern part of the basin.

\section{Structure and Metámorphism}

The structural patterns tend to follow the paleogeographic situation which has been outlined above. Sediments of the northern part of the basin are gently deformed while the southern half of the basin is much more strongly deformed. Here, the cover rocks are complexly and tightly folded together with the basement gneisses (Sims, 1976).

The regional distribution of metamorphic effects follows the structural pattern, with the northern area being only weakly metamorphosed (pumpellyiteprehnite facies). Further south, the metamorphic grade is usually much higher. Several "nodes" of higher metamorphic grade are recognized, four of them being located in northern Michigan and adjacent parts of Wisconsin, another in east-central Minnesota (Sims, 1976).

Since economic deposits of uraniferous conglomerate tend to occur in weakly deformed and little-metamorphosed areas, the northern half of the early Proterozoic basin of the Lake Superior area appears to be the most encouraging for this type of deposit.

\section{Stratigraphic Setting}

Age

A firm limit to the age of the Marquette Range Supergroup (and the associated Animikie group) is set by the Archean basement on which it rests. The youngest elements of this basement appear to be some $2,700 \mathrm{~m} . \mathrm{y}$. old (Sims, 1976). The basin must be older than the magmatic and metamorphic events of the Penokean orogeny, which appear to have reached their maximum intensity about 1,800 to $1,900 \mathrm{~m} . \mathrm{y}$. ago. Thus, for example, Bayley and James (1973) stated that the age of the Marquette Range Supergroup and its partial equivalent, the Animikie Group of Minnesota, is bracketed between 1,900 and 2,700 m.y.

There is some evidence that the age of the basin lies near the $1,900 \mathrm{~m} \cdot \mathrm{y}$. limit. Banks and Van Schmus (1972) have dated acid volcanics from the Hemlock Formation of the Marquette Range Supergroup at 1,950 m.y. (U-Pb zircon). The same authors showed that pre-Marquette metamorphic rocks in northern Michigan were strongly metamorphosed some 2,100 to $2,000 \mathrm{~m} \cdot \mathrm{y}$. ago. In that the over1ying Marquette sediments apparently were not affected by this metamorphic event, they were of the opinion that the sediments are younger than 2,000 m.y. (Van Schmus, 1976). This reasoning is open to interpretation, since, as Houston and Karlstrom (1979) have pointed out, Sims (1976) believes that the basement was reactivated after deposition of the Marquette Range Supergroup. 
Since there is still some question about the interpretation of the relations described above, it would be rash to write the Marquette Range Supergroup off on the grounds that it is geologically too young. The basin must thus be evaluated using other criteria.

\section{Stratigraphy of the Lake Superior Area}

The stratigraphic succession of the lower Proterozolc of the Lake Superior area has been reviewed by Morey (1972a), Bayley and James (1973), and by Sims (1976). Lower Proterozoic sediments are developed in two areas separated by the Keweenawan rift of the Lake Superior area. That part of the basin to the northwest of the rift comprises the Animikie Group. The southern part of the basin comprises the Marquette Range Supergroup.

The overall pattern of development of the basin is similar to that of many basins of equivalent age around the globe. This pattern is one of repeated wedge-outs and overlaps as one proceeds from older to younger formations within the basin. The oldest formations (normally with the highest potential for uraniferous conglomerates) are often confined to relatively sma11 "protobasins", while successively younger units cover larger and larger areas.

In the Lake Superior area, such a "protobasin" is developed in the Marquette and Menominee areas, where the Chocolay Group attains its greatest development. Further west and north, this group wedges out against the Archean basement and is overlapped by the Menominee Group and the laterally equivalent basal formations of the Animikie Group (Figure 81 ).

The oldest formations of the Chocolay Group are confined to paleovalleys on the Archean basement. These formations are laterally discontinuous, and they are known by different names in different areas. In the Menominee Ranges, the basal formation is the Fern Creek Formation, and is up to $80 \mathrm{~m}$ in thickness (Bayley and others, 1966). Further north, in the area of the Marquette Ranges, the equivalent unit is the Enchantment Lake Formation, up to $150 \mathrm{~m}$ thick. In parts of this area, spectfically the Negaunee Quadrangle, a possible equivalent, known as the Reany Creek Formation, is developed and is up to $1,060 \mathrm{~m}$ thick (Puffet, 1969; 1974). The Reany Creek rests with marked unconformity on the Mona Schist, part of an Archean greenstone belt. Its relation to younger formations of the Marquette Range Supergroup cannot be determined since the formation is truncated by faults. Its structural, stratigraphic, and lithologic character led Puffet (1974) to believe that it is a locally developed basal unit of the Marquette Range Supergroup.

The locally developed formations described above are overlain by a sulte of arenaceous rocks. This sulte frequently rests directly on the older basement where the previously mentioned paleovalley-controlled formations are absent. The arenites comprise the Mesnard Quartzite in the Marquette area (60-150 m thick). Further south, in the Dickinson County area, it is known as the Sturgeon Quartzite and attains thicknesses of up to $600 \mathrm{~m}$ (Bayley and others, 1966). To the west, in the Gogebic Range, the correlative formation is known as the Sunday Quartzite (Sims, 1976). Yet, further west, in the Cuyana area, unnamed quartzites and slates rest unconformably on the Archean basement and could be the equivalent of the Sunday, Mesnard, and Sturgeon quartzites. 


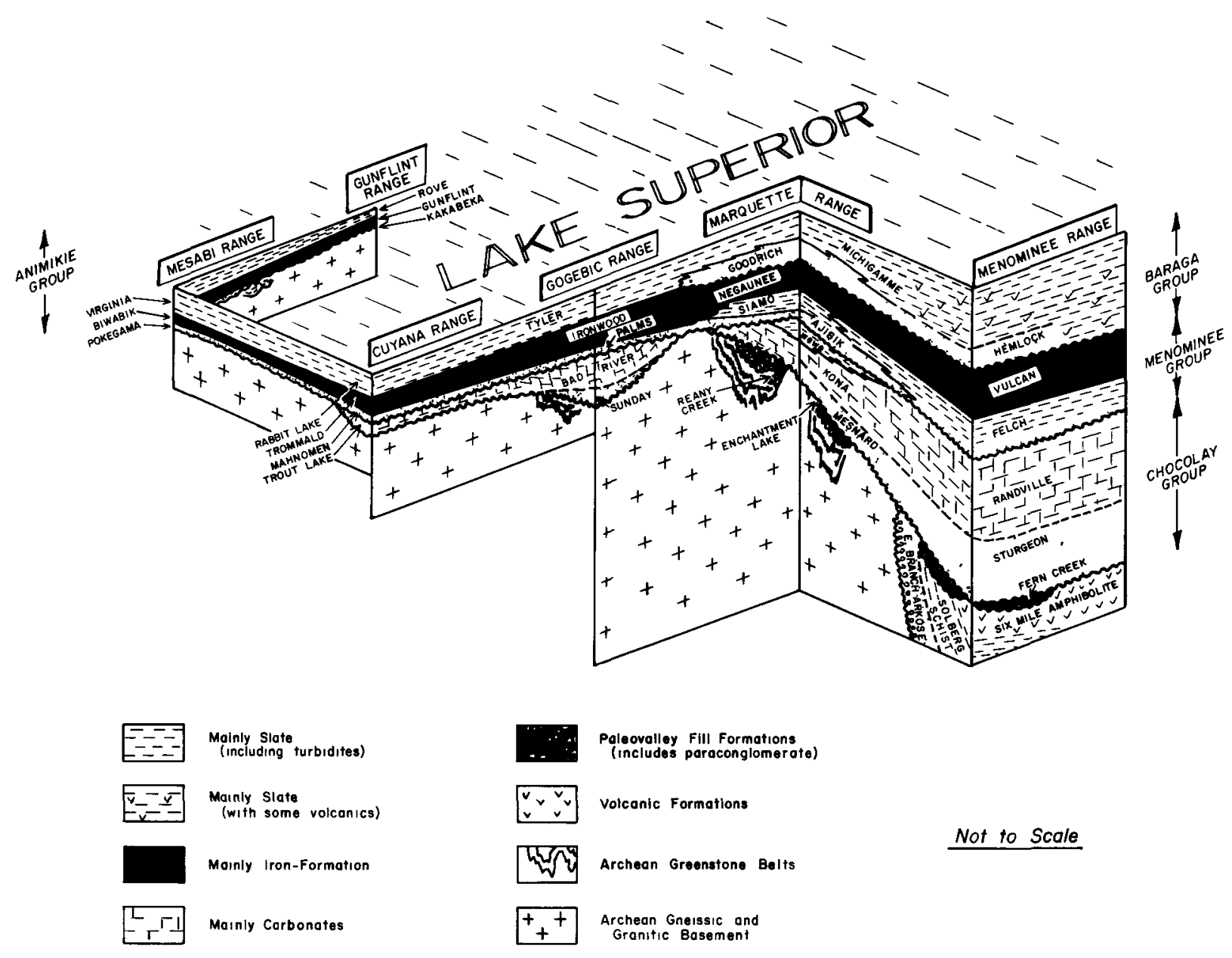

Figure 61 . Schematic fence diagram (not to scale) illustrating regional stratigraphic relations in the lower Proterozoic strata of the Lake Superior area. Compiled from descriptions in numerous sources, including Bayley and James (1973) and Sims (1976). 
These quartzite formations are conformably overlain by a carbonate unit, known as the Randville Dolomite (Menominee area), Kona Dolomite (Marquette area), Bad River Dolomite (Gogebic area), and the Trout Lake Formation (Cuyana area). The formation is up to $360 \mathrm{~m}$ thick in the Marquette area, and up to $600 \mathrm{~m}$ thick further south. The Wewe Slate (up to $450 \mathrm{~m}$ thick) overlies the Kona Dolomite of the Marquette region (Figure 81 ).

At this point, sedimentation in the basin was interrupted, a widespread erosion surface beling developed. A second cycle of sedimentation commenced with a quartzitic formation that extended over a much larger area, extending as far north as the basin is developed. The basal quartzite of this cycle is known by different names in each major outcrop area (Figure 81). It passes conformably upwards (often through an intervening shaly formation) to the major iron-formation units of the Lake Superior area, known variously as the Gunflint, Biwabik, Trommald, Ironwood, Negaunee, and Vulcan iron-formations (Figure 81). Younger units rest on the iron-formations but are not of concern to us here, since, on a worldwide basis, the development of the mega ironformations marks the stratigraphic level above which no uraniferous conglomerates are developed.

Now that we have set the regional stratigraphic framework of the Archean and lower Proterozoic of the Great Lakes area, we can turn our attention to the question of the potential of individual formations within this area. It is convenient to do this under several headings, commencing with late Archean formations, then focusing on early Proterozoic units.

\section{Archean Formations}

Knife Lake Group and Lake Vermilion Formation

These formations are units within greenstone belts of the Superior Province in northern Minnesota (0jakangas, 1972). Given the recent documentation of minor amounts of uranium in conglomerates of some South African greenstone belts (Saager and Muff, 1978; Thiel and others, 1979), these formations deserve mention. The units are dominated by greywacke but include smaller volumes of slate, conglomerate, dacitic tuff, and agglomerate; and mafic to felsic volcanic flows (0jakangas, 1972). The greywackes are turbidites and are largely volcaniclastic in origin. Neither their mineralogy nor their chemistry indicates any similarity to rocks of the subarkose-quartz wacke association. They contain plagioclase grains and have $\mathrm{K}_{2} \mathrm{O} / \mathrm{Na}_{2} \mathrm{O}$ ratios near unity. They are unattractive host rocks from every aspect.

The associated conglomerates are equally unattractive targets for uranium exploration, containing granitic clasts in addition to volcanic and sedimentary types (McLimans, 1972). The matrices contain abundant plagioclase grains, as well as numerous rock fragments (usually some 15 to 25 percent) (McLimans, 1972).

In summary, the Knife Lake and Lake Vermilion formations appear to be very poor target areas for the development of uraniferous conglomerates. Their source area (greenstone belts and the Saganaga tonalite) and depositional environment (subaqueous fans) provided neither the uranium nor the means of concentrating it. 
James and others (1961) recognized a previously unnamed succession of sediments and volcanics in central Dickinson County, in the Menominee Range district of northern Michigan. The succession is poorly exposed but was shown to postdate the basement gnelsses of this area and to be unconformably overlain by the Marquette Range Supergroup. The princlpal outcrops are located north of Felch in northern Michigan. James and his co-workers named this unit the Dickinson Group. The group is from 3,000 to 3,600 meters in total thickness and is composed of three stratigraphic units, the East Branch Arkose (base), the Solberg Schist, and the Six Mile Amphibolite (top; Figure 81).

The Dickinson Group is inferred to rest nonconformably on the granite-gneiss of the Norway Lake area. This is a red, follated, medium- to coarse-grained rock, with pink perthitic microcline phenocrysts. It is radioactive (2 to 3 $x$ background) and contains up to $40 \mathrm{ppm}$ equivalent uranium.

The basal formation, the East Branch Arkose (up to $760 \mathrm{~m}$ thick), is the obvious target formation for uraniferous conglomerate exploration. It comprises arkose, with beds of conglomerate ( 3 to $10 \mathrm{~m}$ thick) and some interbedded tuffs and subaerial basic volcanic flows. The host rock is composed of sutured quartz grains, with 5-10 percent $K$ feldspar grains and an estimated 10-15 percent muscovite matrix. It is metamorphosed to varying degrees, containing sillimanite locally, near the Peavy metamorphic node in the Felch trough area. In general, the formation is metamorphosed in the amphibolite grade and contains staurolite and garnet.

The conglomerates described by James and others (1961) are polymictic, containing clasts of vitreous quartzite (possibly meta-chert), granite gneiss, slate, schist, and vein quartz. Clasts are usually stretched, the ratio of long to short axis dimensions being $3: 1$.

In summary, the East Branch Arkose of the Dickinson Group presents some hope as a target formation for uranium exploration. Positive factors include its age (probably late Archean), its stratigraphic setting (above an unconformity), its source rock (a radioactive granite), and its lithology (feldspathic quartz wacke or subarkose). Negative factors include the strong deformation, metamorphism, and the predominance of polymict conglomerates. Exploration would be further hampered by problems of exposure, since much of the area is covered by glacial till.

Notwithstanding these difficulties, the Dickinson Group should be investigated for uraniferous conglomerates. Numerous basins containing uraniferous conglomerates contain some polymict conglomerate intervals. The main effort should be aimed at determining whether there are also some oligomictic conglomerates within the formation.

Magnetic surveys may well prove to be invaluable in tracking formations under glacial cover. James and others (1961) note that the interbedded basalt flows are moderately magnetic and give significant magnetic anomalies. We predict that the assoclated subarkoses will be characterized by a low magnetic susceptibility and may well be traceable at shallow depths due to this property. 


\section{Lower Proterozoic Formations}

Units Filling Paleovalleys on the Archean Basement

Stratigraphic studies in the area of northern Michigan have revealed at least three formations that are developed primarily in pre-Marquette Range Supergroup paleovalleys. These are the Fern Creek, Enchantment Lake, and Reany Creek formations. Their importance lies not only in the fact that they might contain uraniferous conglomerates, but that they indicate the presence of paleovalleys. In the Elliot Lake district, the stratigraphically lowest formations are located in paleovalleys and contain the principal uraniferous conglomerates of that district.

Fern Creek Formation. Pettijohn (1943) was the first to recognize this unit as a stratigraphic entity in the Menominee Range and neighboring areas. He noted that it contained a greywacke conglomerate (possibly tillite), as well as laminated argillite with rafted clasts. Bayley and others (1966) stated that the Fern Creek Formation is up to $80 \mathrm{~m}$ thick and is composed of conglom erate with arkose, arglilite, and sericite schist. The conglomerates described are polymictic, being composed of clasts of gnelss, granite, basic schist, and vein quartz in a matrix that varies from dark red to dark gray in color, and from quartzite to arkose to greywacke in composition. The reddish color of the conglomerate and of some of the associated arenites is due to the presence of pink or red feldspar grains.

The host arenites of these conglomerates have been described as arkoses or greywackes, of ten schistose in structure. They are said to contain magnetite, rutile, zircon, and rare epidote (Bayley and others, 1966).

Enchantment Lake Formation. This formation, up to $150 \mathrm{~m}$ thick, was first described from the Marquette and Sands Quadrangles (Gair and Thaden, 1968). In the type area, three units were noted, a lower conglomerate, a central unit of slate and greywacke, and an upper unit of wacke. It attains its maximum thickness over paleovalleys cut on Mona Schist (part of a greenstone belt) and tends to wedge out against basement paleohills composed of Compeau Creek Gneiss.

The basal conglomerate comprises angular to subrounded boulders of granite with pebbles of granite, greenstone, vein quartz, and feldspar. The matrix is composed mainly of chlorite, sericite, carbonate, and quartz with some feldspar, leucoxene, magnetite, biotite, sulfides, rutile, apatite, and "reddish iron oxide". It is not apparent from the description whether the iron oxide was primary or was the oxidation product of pyrite grains in the conglomerate matrix. Arkoses associated with the conglomerates range from salmon colored to brick red, due presumably to the presence of pink or red feldspars.

The middle unft is schistose to slaty, comprising dark gray to green-gray greywacke. The greywacke contains clasts of arkose up to $20 \mathrm{~cm}$ in size. This unit also comprises some subarkose, arkose, wacke, sericitic slate, conglom erate, and ferruginous quartzite.

The upper unit is a wacke, composed of detrital quartz grains (60-75 percent) with sericite, some chert grains, yellow-brown iron oxide, rutile, 
zircon, sphene, and leucoxene. The iron oxide could conceivably be due to decomposition of sulfides. The wacke contains interbeds of sericitic slate.

Further west, in the Negaunee Quadrangle, the formation is thinner (up to $60 \mathrm{~m}$ ) and comprises a basal conglomerate overlain by arenites and argillites (Puffet, 1974). The conglomerate is oligomictic, beling composed of white quartz pebbles, up to $12.5 \mathrm{~cm}$, but usually less than $5 \mathrm{~cm}$, in size. The matrix is composed of quartz and sericite with some microcline.

The remainder of the formation comprises feldspathic quartzite, arkose, and sericitic slate. A chemical analysis of the latter indicated a potassia- and alumina-rich sediment ( 6.19 percent $\mathrm{K}_{2} \mathrm{O} ; 21.11$ percent $\mathrm{Al}_{2} \mathrm{O}_{3} ; 0.32$ percent $\mathrm{Na}_{2} \mathrm{O} ; 0.14$ percent $\mathrm{CaO}$; and 0.19 percent $\mathrm{MgO}$ ). Such a composition is similar to that of aluminous argillites interbedded with the quartz wacke arenites of the Witwatersrand Basin.

Reany Creek Formation. The Reany Creek Formation (Figure 81 ) occurs in the Negaunee Quadrangle, to the west of Marquette (Puffet, 1969; 1974). It 1s much thicker than either the Enchantment Lake or Fern Creek Formations, attaining a thickness of some 900 to $1,050 \mathrm{~m}$. We interpret this unit as a local paleovalley-fill formation. Its development on the Mona Schist is no accident. The Mona Schist is a $7,000 \mathrm{~m}$ thick succession dominated by basic volcanics. Such units within Archean greenstone belts give rise to paleovalleys in the Elliot Lake area (J.A. Robertson, 1976) and in basins in South Africa and western Australla (Button, 1976).

The Reany Creek Formation rests unconformably on the volcanic rocks of the Mona Schist. Its strike is mainly east-west, and dips are to the south. The upper contact relations of the formation cannot be determined, since the formation is truncated by faults on the southern and eastern margins of its outcrop area.

Puffet has determined that the formation is composed of three members, a basal conglomerate (up to $600 \mathrm{~m}$ ), a slate and greywacke unit (up to $300 \mathrm{~m}$ thick), and an upper member composed of interbedded arkose, slate, greywacke, conglomerate, and quartzite. The latter formation is up to $120 \mathrm{~m}$ thick but may have been considerably thicker before being truncated by the fault which terminates the formation on its southern side.

The basal conglomerate is best developed in subsidiary paleovalleys notched in the floor of the main paleovalley containing the Reany Creek Formation. It is composed of rounded to angular clasts of granite, greenstone, and Iron formation in a matrix that varies from arkosic (in the east) to chloritic (in the west). Granitic boulders are up to $0.6 \mathrm{~m} \mathrm{in} \mathrm{size,} \mathrm{other} \mathrm{boulders} \mathrm{are} \mathrm{up} \mathrm{to}$ $3 \mathrm{~m}$ in size.

The middle member is composed of granitic boulders and arkose clasts widely dispersed in a green chloritic slate, with beds of greywacke and pinkish-gray arkose. Granitic clasts are up to $0.56 \mathrm{~m}$ in size.

The upper unit comprises mixed sediments, including conglomerate (in beds up to $0.9 \mathrm{~m}$ thick), interlayered with slate and greywacke. This member also contains large lenses of feldspathic quartzite and some arkose. 
Puffet suggested that the Reany Creek Formation was deposited in part by glacial agencies. The incised paleovalleys in which the basal conglomerates were deposited have a rounded, possibly U-shaped configuration. Tillite-1ike rocks are developed at several levels in the formation. The slates of the Reany Creek are geochemically similar to those of the Gowganda Formation in Canada, both being characterized by a low $\mathrm{CaO}$ content, a low $\mathrm{Fe}_{2} \mathrm{O}_{3} / \mathrm{FeO}$ ratio, and a relatively high $\mathrm{Na}_{2} \mathrm{O} / \mathrm{K}_{2} \mathrm{O}$ ratio.

Uranium Potential. With one exception, the conglomerates described in the paleovalley-fill formations appear to have little or no uranium potential. Most are polymictic and have chloritic slate matrices. They tend to be matrixsupported; many are paraconglomerates, thought by some geologists to be tillites.

The conglomerates developed in the upper part of the Enchantment Lake Formation in the Negaunee Quadrangle appear to offer some hope. They are oligomictic pebble conglomerates and occur within a subarkosic host formation. Conglomerates of this type may be more widely developed than is indicated in the literature. After all, a $0.5 \mathrm{~m}$ thick oligomictic conglomerate is not a very significant unit in a regional mapping exercise. It is thought that these formations should be re-examined with the specific objective of identifying favorable host arenites and oligomictic conglomerates.

Blanket Arenites on the Archean Basement

The paleovalley-fill formations outlined above are overlain by a very widespread blanket of quartz arenite (Figure 81). In that these formations of ten rest directly on the Archean basement, their economic potential is examined in the following paragraphs.

Sturgeon Quartz1te. This formation is developed in the Menominee and neighboring areas and is up to $600 \mathrm{~m}$ thick (Bayley and others, 1966; James and others, 1961). The formation is usually divisible into two members, a lower sericitic quartzite (up to $105 \mathrm{~m}$ thick) and an upper pure quartz arenite.

In the area under discussion, the Sturgeon Quartzite rests on a gneissic basement over very extensive areas. Under such conditions, we might expect to find a paleosol developed along the unconformity. We think that oblique references to paleosols may be contained in the reports cited above. James and others (1961) mention the development of $15 \mathrm{~m}$ (stratigraphic) of a schistose quartz-sericite rock at the appropriate stratigraphic level in the Pine Creek area of Dickinson County, Michigan. The original description of contact relations by Pettijohn (1943) documents the fact that the Sturgeon Quartzite and the basement gneiss are separated by a very coarse-grained "sericitic quartzite" that grades downward to the gneiss. Both descriptions are very suggestive of the presence of a paleosol along the basal unconformity. We are impressed with the similarity of the basal serictic zone of the Sturgeon Quartzite with the subarkose-quartz wacke association, previously documented. The basal Sturgeon is greenish in color and ranges in composition from "sericitic quartzite" to "quartz-sericite schist". It contains heavy mineral concentrations, including pyrite (altered to hematite) and what have been identified as euhedral martite crystals (after magnetite). 
The basal member of the Sturgeon Quartzite crops out relatively poorly, due to the fact that it is overlain by the much more resistant quartz arenite member of the formation. No conglomerates are mentioned (in the reports cited) in this phase of the Sturgeon. It would be very surprising if a basal conglomerate were not at least locally developed.

The remainder of the Sturgeon Quartzite is a pure ( 96 percent $\mathrm{SiO}_{2}$ ) vitreous rock composed of interlocking quartz grains with minor sericite. The rock is white to gray in color and is structured by cross-beds and ripple marks (coated by micaceous films). This facies is said to contain magnetite, pyrite, and zircon. Thin layers of pebble conglomerate are developed within this part of the formation (James and others, 1961).

Mesnard Quartzite. This formation is supposedly the lateral equivalent of the Sturgeon Quartzite and is developed in the Marquette area of Michigan. It is from 60 to $150 \mathrm{~m}$ thick and rests directly on the Archean basement or on the Enchantment Lake Formation (Figure 81).

The Mesnard is composed of massive vitreous quartzite with some slate, wacke, and quartz-pebble conglomerate (Gair and Thaden, 1968; Puffet, 1974). The quartzite varies in color from light gray to pink to red in places. It contains spots of specular hematite and is cut by veinlets of quartz with specular hematite.

The Mesnard Quartzite is a quartz arenite, composed of over 90 percent quartz with some sericite, chlorite, cherty quartz, and heavy minerals, including leucoxene, zircon, tourmaline, rutile, and a dusting of hematite that outlines original detrital grains.

Pebbly zones within the Mesnard contain clasts of vein quartz, cherty quartz, and quartzite from 2.5 to $7.5 \mathrm{~cm}$ in size, in a matrix of white to red quartzite.

Ajibik Quartzite. This formation norma1ly rests unconformably on the Chocolay Group of the Marquette Range Supergroup (Figure 81). To the west of Marquette, in the Negaunee Quadrangle, it unconformably truncates the Chocolay Group and comes to rest on the Archean basement.

The Ajibik is up to $60 \mathrm{~m}$ thick in the area in question. It is dominated by gray vitreous quartzite with some conglomerate, slate, and greywacke. It is said to be hematite-stained in places and is sometimes red with white specks. A $25 \mathrm{~cm}$ thick granule conglomerate bed within it is said to carry a few grains of gold with some pyrite, pyrrhotite, galena, and xenotime. The granule conglomerate is underlain by a fine-grained gray quartz-sericte arenite that contains some zircon, tourmaline, and leucoxene.

Other Quartzites. In the Gogebic area, the basal unconformity of the Marquette Range Supergroup is overlain by the Sunday Quartzite. Upsection, the Palms Quartzite rests unconformably on the Bad River Dolomite. In the absence of detailed descriptions of these units, it is suggested that their potential could be compared to that of their equivalents to the east.

In the Cuyana, Mesabi, and Gunflint areas, the basal formations of the Animikie Group are named the Mahnomen, Pokegama, and Kakabeka Formations, respectively. The Pokegama and Kakabeka are dominated by pure quartz arenites with 
some feldspathic quartzite, feldspathic greywacke, sandy argillite, and minor conglomerate (Morey, 1972b; 1972c). The Mahnomen of the Cuyana district is much thicker (some $600 \mathrm{~m}$ ) and comprises argillite, slate, siltstone, greywacke, and quartzite (Marsden, 1972). Pink- and red-colored arenites are described in some of these formations. The thin basal conglomerates, which are sporadically developed, are usually polymictic, comprising clasts of metavolcanic and granite, in addition to quartz.

Uranium Potential. Of the formations surveyed, all but one are considered to have essentially zero potential for the development of economic uraniferous conglomerates. Several factors were taken into account in reaching this conclusion. First, pink and red colors, due to disseminated hematite, are fairly common in the arenites and indicate deposition or diagenesis under oxidizing conditions. Second, the conglomerates described are, for the most part, polymictic. Third, the unconformities in question probably represent very long time breaks. The basal conglomerates on the unconformities may have been exposed to weathering processes for very long periods and may thus have been leached of their uranium content.

The exception is the basal phase of the Sturgeon Quartzite, which is a quartzsericite wacke, and contains some pyrite. The only negative aspects of this formation are the apparent paucity of conglomerates and the reported presence of magnetite (altering to martite) within it. Given the rather poor exposure of this part of the formation, some conglomerate may well be developed within it. The quantitative abundance of magnetite in the formation cannot be established from the reports quoted. Magnetite could be a rather locally developed mineral phase within the lower part of the formation. It is thought that there may well be some uraniferous conglomerates within this unit.

Unexposed Lower Proterozolc Formations

When dealing with formations deposited on an irregular erosion surface, there is always the possibility of a basal unit (or units) having no surface expression. To illustrate this, one need only look at the north limb of the Quirke Syncline in the Elliot Lake area (Figure 23). Here, over a distance of $24 \mathrm{~km}$, the al1-important Matinenda Formation is simply not exposed. It has wedged out against the paleovalley walls and has been overstepped by younger formations, such as the Ramsay Lake Formation. Thus, mapping along this 24-km outcrop belt would be extremely discouraging, since the essentially nonmineralized Ramsay Lake Formation would be found resting directly on the Archean basement. However, as we now know, the Matinenda Formation, with its enormous reserves of uranium, is preserved up to a kilometer or two south of the outcrop trace of the Archean-Proterozoic unconformity.

In foregoing sections, we have established that the pre-Marquette Range Supergroup unconformity was topographically sculptured and probably had a paleorelief of at least $1,000 \mathrm{~m}$ in places. Therefore, if we stand on the unconformity and find rather discouraging Proterozoic sediments in contact with Archean basement, are we justified in writing off such an area? The answer, based on the Elliot Lake district, is a defintte no. Paleovalleys, developed downdip in a given area, could have preserved within them several hundred (or more) meters of a highly favorable, Matinenda-like host arenite (Figure 82). How, one might ask, could one hope to locate such unexposed 


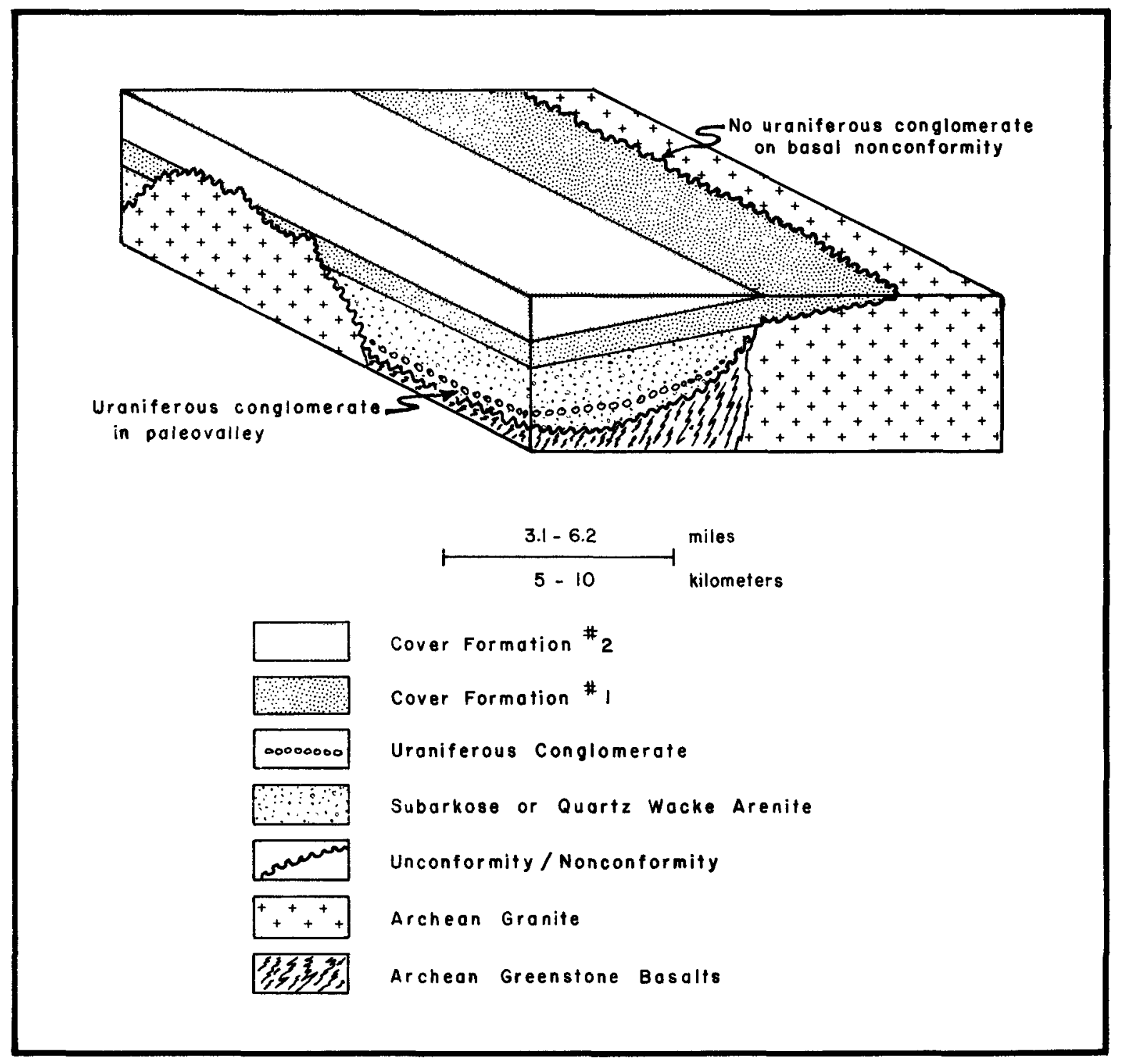

Figure 82. Schematic block diagram illustrating the fact that uraniferous conglomerates of Matinenda type need have no surface expression, being confined to non-outcropping paleovalleys. 
paleovalleys? There are two approaches, based on geological and geophysical techniques.

Geological Approach. Many (but not all) paleovalleys along Archean-Proterozoic unconformities are cut on softer greenstone basalt or greywacke/shale sedimentary assemblages. Geologic mapping may well point to areas where such units are likely to be present below a lower Proterozoic succession. By contrast, Archean granites, cherts, iron-formations, and rhyolites normally formed paleoridges. The trends of paleovalley-paleoridge systems can be predicted by a study of the structural patterns of the more- and less-erodible units of the Archean basement.

Geophysical Approach. The greenstone belts of Archean cratons give rise to distinct positive gravity anomalies. A gravity survey over a lower Proterozoic basin may well indicate the presence of greenstone belts under the younger formations. There is an excellent chance that paleovalleys will be developed over the greenstone belts. Whether or not such paleovalleys will contain uraniferous conglomerates will depend on other factors, such as the presence of a suitable source rock.

A magnetic survey may also be of assistance. Linear or "folded" magnetic anomalies may indicate the presence of Archean iron-formations. The ironformations, in turn, indicate the presence of greenstone belts and of paleovalleys. The configuration of such magnetic anomalies provides a picture of the structure of the underlying greenstone belt, which is useful in attempting to predict paleovalley configuration.

Application. The application of the techniques suggested above should be reserved for only the most geologically favorable situations. For example, where a basin, or part of a basin, makes a near-perfect score in the "regional geologic setting" and "stratigraphic setting" categories of the recognition criteria net (Figure 75), geophysical exploration, followed by drilling, would be warranted.

Subsurface Exploration for E1liot Lake Group Strata

The Elliot Lake Group is known to be present near the international boundary (Canada-U.S.A.) in the vicinity of Sault Ste. Marie (Figure 4; Roscoe, 1969; Frarey, 1977). West of this location, Precambrian rocks are covered by Phanerozoic strata and by the waters of Lake Superior. Given the fact that E1liot Lake Group strata extend east-west for over $250 \mathrm{~km}$, from Sudbury to Sault Ste. Marie, we find it inconceivable that these rocks would not extend under cover into United States territory. A simple projection suggests that the formations should be present (at depth) along the north shore of the Upper Peninsula of Michigan, from Whitefish (in the east) for an undetermined distance to the west, possibly as far as Grand Island.

Subsurface exploration in this area will certainly have its problems. First, an undetermined thickness of Paleozoic rocks will have to be penetrated. Second, the central parts of the area outlined may well be underlain by sediments, volcanics, and intrusives associated with the Keweenawan rift system. Finally, the structural and stratigraphic complications inherent in the Huronian strata themselves are bound to make exploration more difficult. 
On the positive side, subsurface exploration for mineralized conglomerates can be extremely successful. For example, the Welkom, Klerksdorp, Carletonville, and Evander districts in the Witwatersrand Basin were all discovered by subsurface exploration efforts under conditions every bit as difficult as those anticipated for the Upper Peninsula of Michigan.

It is thus recommended that a detailed study of the known surface and subsurface geology of the area be compiled with a view to selecting areas within the Upper Peninsula for subsurface exploration for uraniferous (and potentially auriferous) conglomerates.

\section{Summary}

It is believed that the potential for the development of uraniferous conglomerates in the Lake Superior area has in no way been fully evaluated. Specifically, the following possibilities need to be considered:

(1) The East Branch Arkose of the Dickinson Group comprises the correct host sediments in a favorable stratigraphic setting. It should be evaluated by surface mapping and sampling programs.

(2) The upper part of the Enchantment Lake Formation and the lower part of the Sturgeon Quartzite comprise quartz wackes of the type that host most uraniferous conglomerates. Their potential should be further tested.

(3) The possible development (in paleovalleys) of unexposed, Matinendalike formations at the base of the Marquette Range Supergroup should be considered.

(4) The possible subsurface extension of the Elliot Lake Group into the Upper Peninsula area of Michigan should be considered. The initial investigation should include the collection and compilation of all available geological and geophysical data from this area and the neighboring parts of Canada.

The Wyoming Province

The general geology of the Wyoming Province has been thoroughly reviewed by Houston and Karlstrom (1979). The outline of the province is only approximately known since the Precambrian is only sporadically exposed within Laramide uplifts. The Wyoming Province is also complicated by the overprinting of its peripheral areas by a "Hudsonian" (1,700-1,900 m.y.) metamorphic and magmatic event (Figure 83) and by thrust faulting in the IdahoWyoming overthrust belt.

\section{Tectonic Level in the Wyoming Province}

If the preservation of greenstone belts is accepted as a valid measure of tectonic level, then the central and south-central parts of Wyoming must represent the highest tectonic level within the province. Houston and 


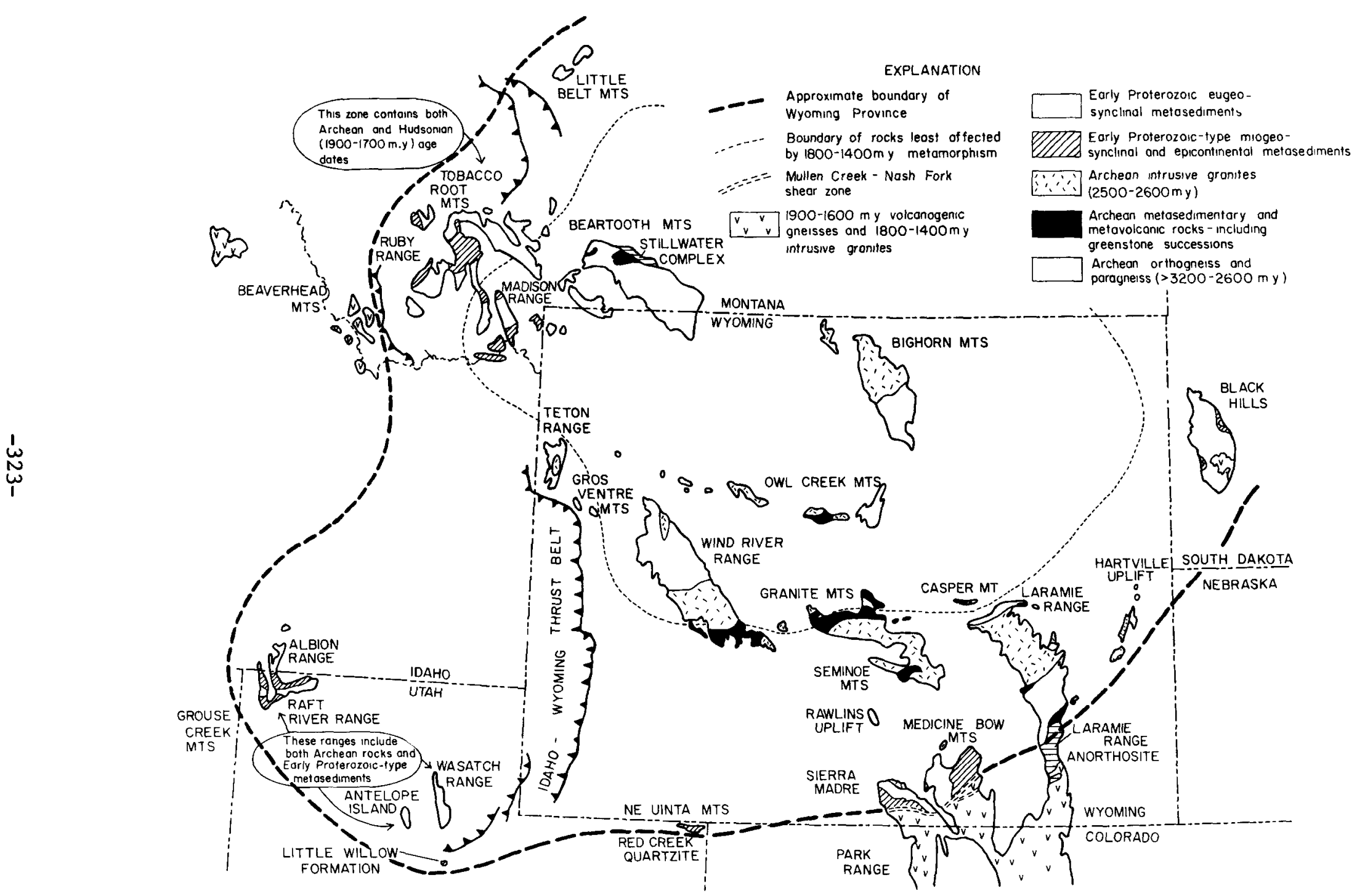

Figure 83. Generalized Precambrian geology of the Wyoming Province (from Houston and Karlstrom, 1979). 
Karlstrom (1979) have shown that remnants of greenstone belts are known from the Owl Creek Mountains, the southern Wind River Range, the Granite Mountains, the Seminoe Mountains, and Casper Mountain (Figure 83). Given this tectonic level, it is probably no coincidence that this area of Wyoming has been a uranium province since early Precambrian time (Stuckless, 1979). This province could thus have acted as a source of uranium in conglomerates in late Archean or early Proterozoic basins in this area.

\section{Archean Greenstone Belts}

The recent discovery of what appear to be minor and economically unimportant occurrences of uraniferous conglomerates in two Archean greenstone belts in South Africa has been mentioned previously. There is no reason why such occurrences could not be found in sedimentary units of the Wyoming greenstone belts if the correct conditions of source area, tectonics, and depositional environment were present.

In this connection, the "mildly radioactive" quartzite and conglomerates in the Slate Creek area of the central Laramie Range (just north of the Laramie Range anorthosite) are of interest (Houston and Karlstrom, 1979). These metasediments are interbedded with gneisses and amphibolites and have been interpreted as the metamorphic products of mafic and intermediate lavas and volcaniclastic sediments. Since the sediments and associated volcanics have been metamorphosed at "highest almandine amphibolite facies", their primary uranium content has probably been severely depleted. It is doubtful that economic concentrations of uranium were ever developed in this succession, but even if they were, there is a good chance that they were destroved by the advanced metamorphism.

\section{Supracrustal Sediments in Gneissic Terrane}

Late Archean or early Proterozoic metasediments are found in several of the Laramide uplifts of the Wyoming Province. In general, the sediments are strongly deformed and highly metamorphosed, often being interlayered with quartzo-feldspathic gneisses (Houston and Karlstrom, 1979). For this reason, we believe that they have low or very low potential for the preservation of economic concentrations of uranium in Precambrian conglomerates. For the sake of completeness, a summary of Houston and Karlstrom's review is presented here. The interested reader can consult this source for further details.

\section{Beartooth Mountains}

Archean-age metasediments are developed in the Beartooth Mountains in southern Montana. The sediments vary in character and include cordierite hornfels, quartzite, diamictite, marble, schist, and gneiss. Some of the quartzites are locally conglomeratic.

\section{Southwestern Montana}

Several ranges in this area contain metasedimentary remnants, frequently grouped in what has become known as the Cherry Creek Group. Some geologists believe that a sequence of gneisses, known as the Pony Series, constituted the original basement to this supracrustal assemblage. These supracrustal metamorphics are preserved in parts of the Tobacco Root Mountains and in the 
Ruby, Gravelly, and Madison Ranges. They include quartzite, marble, quartzofeldspathic gneiss, iron-formation, amphibolite, mica schist, and phyllite.

Northern Utah and Southern Idaho

Archean and early Proterozoic metasedimentary and metavolcanic rocks are preserved in several ranges in this area.

Albion and Raft River Ranges. Metamorphics in these ranges include quartzofeldspathic gneisses, schists, and amphibolites. Some of the schists were derived from shale, siltstone, and pebbly mudstone. The Elba Quartzite is developed within parts of the Raft River Range. It rests unconformably on the older schists and granitoid rocks and has a well-developed basal conglomerate with an underlying regolith. Houston and Karlstrom noted that the conglomerates contained primary hematite in the matrices. In addition, Elba quartz schists have been dated at $570 \pm 80 \mathrm{~m} \cdot \mathrm{y}$. ( $\mathrm{Rb} / \mathrm{Sr}$ whole rock). The rocks are thus probably upper Proterozoic in age.

Wasatch Range and Antelope Island. Three metamorphic sequences have been outlined in this area. The Farmington Canyon Complex comprises paraschists and paragneisses with some quartzite, quartz schist, arkosic quartzite, metagreywacke, and conglomerate. The metasedimentary pile is at least $3,600 \mathrm{~m}$ thick, predates 1,600-1,700 m.y. old felsic intrusives, and is metamorphosed at grades up to granulite facies.

The Little Willow Series is preserved in a small area near Salt Lake City. The succession is relatively unmetamorphosed. It comprises quartzite and quartz-muscovite schist (some with stretched pebbles) and is intruded by basic igneous rocks. Houston and Karlstrom recorded the presence within it of weakly radioactive quartzite and conglomerate. The quartzite is laminated, fine grained, and pyritic. The overlying conglomerate is polymictic and matrix-supported.

The "Formation of Facer Creek" occurs near Huntsville, Utah, and is composed of clean quartzite, fuchsitic quartzite, pelitic schist, amphibolite, mica schist, and pegmatite. The rocks are at least 1,600 to $1,700 \mathrm{~m} \cdot \mathrm{y}$. old.

The Red Creek Quartzite is preserved to the northeast of the Uinta Mountains. It is at least $2,320 \mathrm{~m} \cdot \mathrm{y}$. old and is composed of feldspathic quartzite, pure quartzite, quartz-mica schist, and meta limestone. Some of the metasediments contain chrome mica, while others are aluminous, containing kyanite.

Uranium Potential of Supracrustal Metasediments

Given the deformation and metamorphism that these successions have suffered, we are of the opinion that their uranium potential is relatively low. They certainly warrant lower priority than the less-metamorphosed sequences of the Black Hills, Medicine Bow Mountains, and Lake Superior area. Available descriptions of 1ithologies suggest that the Little Willow and Facer Creek successions offer the greatest incentive for further work. 
In the last five years or so, considerable interest has been aroused by the discovery of uranium-bearing quartz-pebble conglomerates in three areas within the Wyoming Province. These areas are the northern Black Hills of South Dakota and the Medicine Bow and Sierra Madre Ranges, both in southcentral Wyoming (Figure 83). The geology and potential of these areas are reviewed in the following sections.

The Black Hills

The Black Hills of South Dakota comprise a Laramide-aged uplift in which the Precambrian basement is exposed. The exposures occur within an oval area with a long axis trending north-northwest and measuring about $100 \mathrm{~km}$. The shorter (east-west) dimension of the oval area of Precambrian outcrops measures some $35 \mathrm{~km}$.

Age. The age of the Precambrian metasediments of the Black Hills is constrained by several dated igneous rocks. The Little Elk Granite, which crops out in a small inlier in the northeastern part of the hills, north of Nemo (Figure 84), has been dated at 2,560 m.y. (Zartman and Stern, 1967). This gneissic biotite granite is in fault contact with Precambrian metasediments but is widely believed to represent the basement on which the sediments were deposited.

Another Archean granite is exposed in the Bear Mountain Dome, along the western margin of the hills (Figure 84). Here, the granites (and associated pegmatites) occur as small intrusive bodies in a sequence of biotite schists which comprise the core of the dome. The granite and pegmatite have been dated at 2,500 m.y. (Ratté and Zartman, 1970).

The Precambrian sediments which comprise the bulk of the core area of the hills are intruded by a number of basic sills. Zircons separated from one such sill in the Nemo area gave a ${ }^{207} \mathrm{~Pb} /{ }^{206} \mathrm{~Pb}$ age of $2,090 \pm 10 \mathrm{~m} \cdot \mathrm{y}$. (Redden, 1980).

The Precambrian sediments are also intruded by the Harney Peak Granite, a suite of granitic (often pegmatitic) sill-like bodies located in the southcentral hills. These are dated at 1,740 m.y. (R1ley, 1970).

The age of the metasediments is thus bracketed between 2,090 and 2,500 m.y. Their age is highly favorable for the development of uraniferous conglomerates.

Structure. The structure of the Precambrian strata of the Black Hills is complex. In broadest outline, the structural pattern could be likened to a north to northwest-plunging synclinorium. Archean basement rocks are exposed in the domes of the Bear Mountain and Little Elk regions, mentioned above (Figure 84). According to J.A. Redden (personal communication, 1980), a similar domal structure is present in the south-central hills, around the Harney Peak area. The nature of this dome is obscured by the intrusion, in this area, of the Harney Peak Granite. 


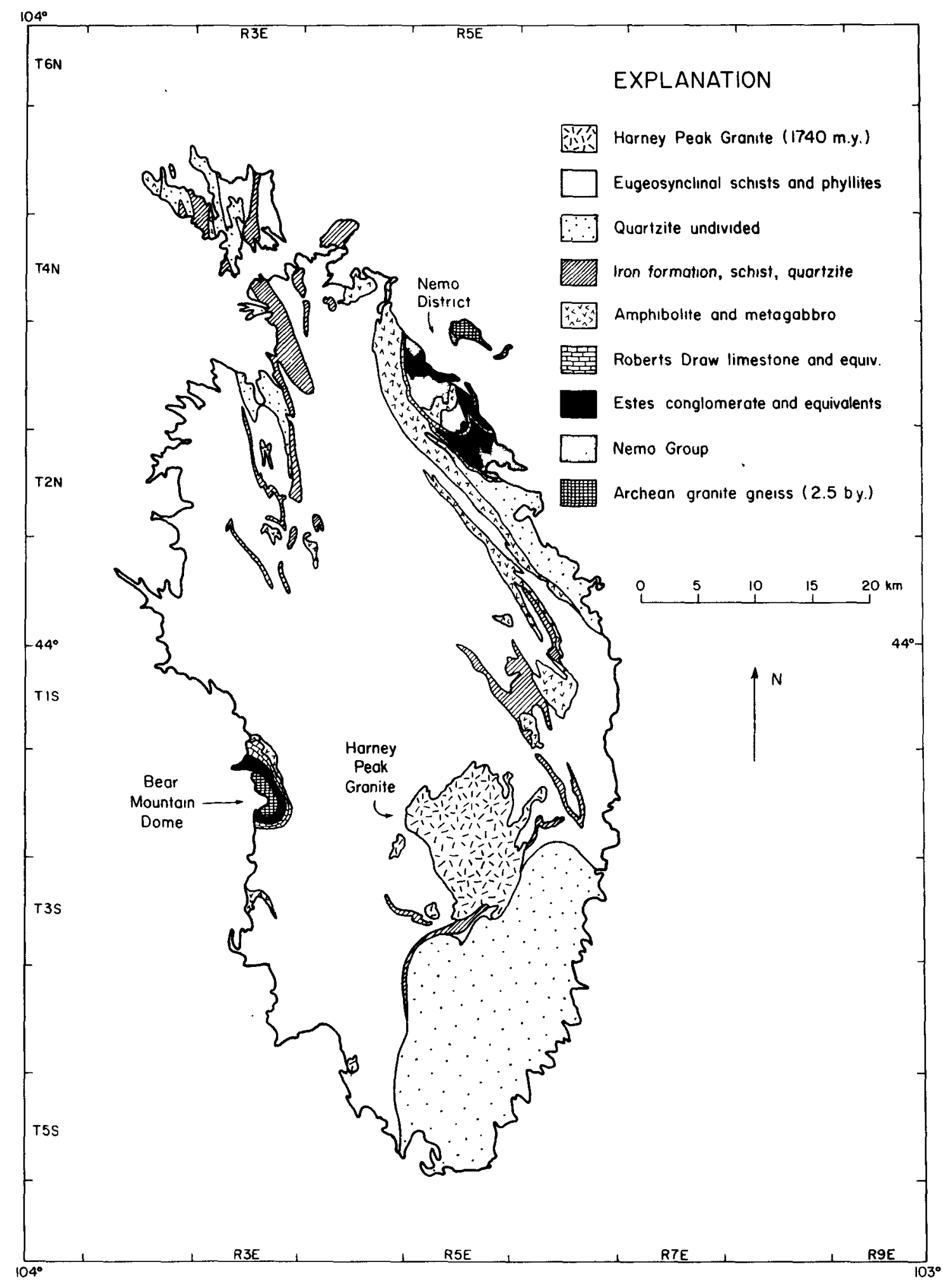

Figure 84. Generalized geology of the Black Hills, South Dakota (from Houston and Karlstrom, 1979). 
The structural fabric of the hills trends north-northwest. Longitudinal faults and the axes of folds (often isoclinal) have this trend. The metamorphic zonation, by contrast, trends east-west to northwest-southeast in most cases. The lowest metamorphic grades (biotite zone) are confined to a northwest to southeast-trending girdle in the north-central hills. The grades are highest in the southern hills, around the Harney Peak Granite, where sediments lie within the "sillimanite zone" (Redden and Norton, 1975).

Stratigraphy. No comprehensive account of the Precambrian stratigraphy of the Black Hills exists. This is largely due to the degree of structural deformation. New concepts of stratigraphic succession are currently emerging and will require a revision of the accepted stratigraphy in certain areas.

In broadest outline, the Precambrian strata are believed to be extremely thick $(18,000 \mathrm{~m})$. They commence with sediments typical of stable continental shelves, including quartzite, shale, iron-formation, and some carbonate and conglomerate. These shallow-water to continental sediments are overlaln by a much thicker sequence of deep-water "eugeosynclinal" sediments, including graphitic slates, cherts, iron-formation, greywacke, and pillow-basalt. Our attention will be focused on the former sequence, which is best developed in the Nemo area of the northeastern hills.

The Nemo succession is believed to be the lowest stratigraphic package of the Black Hills area. Bayley (1972) mapped the area and established what he believed to be the stratigraphic succession of the district. Subsequent work (Kim, 1979; Redden, 1980) has established that Bayley's stratigraphic succession is inverted. The succession described below is based on the revised column, as given by Redden and by Kim (Table 41).

The lowest unit is an iron-formation, at least $140 \mathrm{~m}$ thick. It is an oxide facies rock, comprising layers of chert and of hematite and magnetite. The iron-formation occurs in packages 10 to $30 \mathrm{~m}$ thick, separated by chloritic phyllite intervals (Kim, 1979). It should be stressed that the iron-formation is not in sedimentary contact with older rocks being faulted against the Little Elk Granite. The iron-formation may have been separated from the basement by hundreds, possibly thousands, of meters of stratigraphic section.

The basal member of the overlying Boxelder Formation is known as the Greenwood Tongue and is several hundred meters thick. The member comprises chloritic phyllite and some dolomite in its distal facies. Proximal facies comprise chlorite-rich arenite (with a few scattered clasts), paraconglomerate (chloritic arenite with 5 to 20 percent clasts, up to cobble size, and composed largely of iron-formation, quartzite, and phyllite), and conglomerate (clasts of chert, quartzite, and iron-formation). The facles are arranged in a coarsening-up cycle, suggestive of deposition by a prograding submarine fan.

The succeeding member (Tomahawk Tongue) contains al1 the important radioactive conglomerates in the Nemo area. It is some $120 \mathrm{~m}$ thick and comprises a "light greenish yellow" arenite composed of quartz (including opalescent blue quartz granules), sericite (or muscovite), some fuchsite, and pyrite (Kim, 1979). The arenite is planar and trough cross-bedded. Some beds contain scattered pebble- and cobble-sized clasts. 
Table 41. Revised stratigraphy of the Precambrian of the Nemo area, Black Hills, South Dakota (after Kim, 1979; Redden, 1980).

UNIT

Estes Conglomerate

Benchmark Iron

Formation

Boxelder Formation

Nemo Iron Formation

Little Elk Granite
DESCRIPTION

Boulder and cobble conglomerate (with clasts of iron-formation and quartzite), arkose, and mudstone. Close to $2,000 \mathrm{~m}$ thick in places.

Locally preserved in a syncline, at least $45 \mathrm{~m}$ thick.

Upper Member: comprises cross-bedded quartzite, probably at least $3,000 \mathrm{~m}$ thick. Green Phyllite: some 20 to $50 \mathrm{~m}$ thick. Conglomerate and Arenite: some $120 \mathrm{~m}$ thick, composed of beds of pebble and cobble conglomerate with very coarse-grained quartz wacke. Tomahawk Tongue of Redden (1980).

Lower Member: comprises a distal facies (chloritic phyllite, some dolomite) and a proximal facies (chloritic quartzite, paraconglomerate, conglomerate). Greenwood Tongue of Redden (1980).

Iron-formation with interlayered phyllite, over $140 \mathrm{~m}$ thick.

Fault Contact

Gneissic biotite granite with "blue quartz".

The radioactive conglomerates occur as lenses within the arenite. The lenses are from 1 to $20 \mathrm{~m}$ thick. The conglomerates comprise pebble- (and some cobble-) sized clasts of quartzite, chert, vein quartz, and minor phyllite. Quartzite clasts are the most common, and usually make up 60 percent of the pebble fraction. Further detalls will be given in a subsequent section dealing with mineralization.

The conglomerate-bearing suite is covered by 20 to $50 \mathrm{~m}$ of green phyllite, which passes upwards to several hundred meters of cross-bedded quartzite. This quartzite was intruded, some $2,090 \mathrm{~m} . \mathrm{y}$. ago, by a differentiated basic sill.

The local stratigraphic column is terminated by the Benchmark Iron Formation, which is preserved in the core of a syncline. This iron-formation supplied much of the detritus to the overlying Estes Conglomerate. J.A. Redden (personal communication, 1980) believes that the Estes is a fanglomerate, shed off an upfaulted block (or blocks) of older sediment, including the Benchmark iron-formation and the underlying quartzite. The boulder conglomerates interfinger upsection with finer grained sediments, including arkosic arenites and mudstones. 
The assemblage of relatively shallow-water sediments described above passes upward to deeper water strata, comprising argillites, greywacke arenites, some iron-formation, dolomite, graphitic phyllite, and pillow-basalt. These units are not relevant to our discussion and will not be described further.

Mineralization. Uranium and thorium mineralization in conglomerates of the Black Hills was discovered in 1976 by F.A. Hills and documented in two reports (Hills, 1977; 1979). Kim (1979), in a doctoral dissertation submitted to the South Dakota School of Mines and Technology, described the mineralized conglomerates in an area near Nemo. He had available core from several holes drilled by the Homestake Mining Company. Dr. J.A. Redden, of the same institution, has recently completed a comprehensive report on the results of his field and laboratory investigation of the occurrences (Redden, 1980).

Hills (1979) determined that the strongly leached surface samples of conglomerate contained from $10-122 \mathrm{ppm} \mathrm{U,} \mathrm{20-970} \mathrm{ppm} \mathrm{Th,} \mathrm{and} \mathrm{up} \mathrm{to} 1.39 \mathrm{ppm} \mathrm{Au}$. of the 26 samples analysed, 50 percent contained at least $0.05 \mathrm{ppm} \mathrm{Au}$. He noted that the conglomerate matrices contained up to 25 percent pyrite.

In a more detailed study of surface samples and drill cores, K1m (1979) determined that the conglomerates contain pyrite, chromite, rutile (and anatase), zircon (and its alteration product, cyrtolite), and some gold. No primary uranium-bearing minerals were positively identified. Other heavy minerals include tourmaline, apatite, xenotime, and monazite (the latter two are very rare) (Redden, 1980).

Kim noted that pyrite grains are of different types, including idiomorphic crystals and rounded grains. Some of the latter are composite grains, composed of smaller rounded pyrite grains cemented together by silica. Redden (1980) noted a positive correlation in the sizes of pebbles and of pyrite grains. Some pyrrhotite is developed in one sample. Anatase occurs in aggregates and clusters of small grains and contains "considerable amounts" of $\mathrm{Th}, \mathrm{U}$, and $\mathrm{Y}$.

The only possible primary uranium mineral noted was uranothorite. Kim tentatively identified this phase in a few thin sections. Its development would be logical (see section on metamorphic modification of uraniferous conglomerate) since the conglomerates and their enclosing sediments have been metamorphosed at just above the biotite isograd (Kim, 1979).

The conglomerate matrices contain a range of lighter minerals, principally quartz and muscovite, with minor fuchsite and some carbonates (dolomite, siderite, ankerite). The ankerite, which occurs in veins and as grain overgrowths, contains "appreciable" amounts of uranium and thorium, apparently in solid solution, replacing calcium ions in the carbonate structure (Kim, 1979).

In a geochemical study of 16 samples of conglomerate, Kim determined that there were significant positive correlations of $U$ with $Y(0.66)$, Th $(0.53)$, and $\mathrm{Au}+\mathrm{Ag}(0.60)$. Th/U ratios were found to vary from just less than 1 to over 4, averaging about 2 to 3 in subsurface samples. The surface samples are somewhat depleted in $\mathrm{U}$, having $\mathrm{Th} / \mathrm{U}$ ratios of 5 to 7 (Redden, 1980). 
Kim (1979) was of the opinion that uranium in the Nemo conglomerates was contained, to some extent, in the anatase aggregates and ankerite veins and grain overgrowths. It could also possibly be dispersed through the conglomerate in the fashion described by Thiel and others (1979).

Redden (1980) determined the average $\mathrm{Th} / \mathrm{U}$ ratio in cores at 3.2 . Redden's statistical treatment of geochemical data did not confirm the findings of Kim (1979) regarding correlation between elements. Redden found correlations between $\mathrm{K}$ and $\mathrm{A} 1, \mathrm{Zr}$ and $\mathrm{Ce}, \mathrm{Zr}$ and $\mathrm{Y}, \mathrm{Ce}$ and $\mathrm{Y}$, and $\mathrm{U}$ and $\mathrm{Th}$.

Source of Uranium. On the basis of the thickness and frequency of conglomeratic units, and from a study of cross-bedding, both $\mathrm{Kim}$ and Redden are of the opinion that the radioactive conglomerates were derived from the north or northeast. The Little Elk Granite lies in this direction relative to the conglomerates and could have been their source. Some support for this idea comes from the development of opalescent blue quartz grains in both the granite and the conglomerate. Furthermore, the granite contains up to $5 \mathrm{ppm}$ $U$ on surface and is inferred to contain up to twice this amount below the zone of surface weathering.

Other Areas in the Black Hills. The basal unconformity of the lower Proterozoic sequence in the Bear Mountain Dome area (Figure 84) is an obvious target for the development of uraniferous conglomerate. A meta-conglomerate is developed above what is thought to be the basal unconformity. It is overlain by quartzite, mica schist, amphibole schist, and dolohitic marble (Redden and Norton, 1975). Some exploration has been conducted in this area. Anomalous uranium and thorium values like those of the Nemo area are apparently not found in the conglomerates of the Bear Mountain Dome (J.A. Redden, personal communication, 1980).

The domical structure of the Harney Peak area exposes stratigraphically low formations (J.A. Redden, personal communication, 1980). Uraniferous conglomerates could concelvably be developed here. In this connection, the large area of quartzite exposed in the southeastern quadrant of the Precambrian core of the hills (Figure 84 ) is of interest. The quartzite occurs near the inferred domal structure of the Harney Peak area. It probably represents a relatively low stratigraphic level within the sequence, since higher levels are characterized by deeper water sediments. This area, which measures some $32 \mathrm{~km}$ (northeast-southwest) by up to $16 \mathrm{~km}$ (northwest-southeast), should be examined for favorable host lithologies and for uraniferous conglomerates. The potential of the area is diminished somewhat by the metamorphic grades in the area, which are high (above the sillimanite isograd) (Redden and Norton, 1975).

Potential of the Black Hills. The proven development of uraniferous conglomerates in the $B$ lack Hills makes it one of the most prospective areas presently known in the United States. The surface and subsurface exploration efforts to date have given disappointing results. The highest uranium values are on the order of $300 \mathrm{ppm} \mathrm{U}$, but most conglomerates contain no more than some 50$100 \mathrm{ppm} U$. This is approximately 10 to 20 times less than in the Elliot Lake district, where grades average some $1,000 \mathrm{ppm}$. It is also lower than in the Witwatersrand district, where uranium is mined as a by-product or co-product of gold. Here, uranium-producing areas have a range in concentrations from 
193 to $628 \mathrm{ppm} \mathrm{U} \mathrm{O}_{8}$ (Pretorius, 1976). Thus, despite large tonnages, the uraniferous conglomerates of the Nemo area contain an order of magnitude less uranium than the Blind River district. On the face of it, this would appear to be very discouraging. There are, however, several qualifying factors which suggest that the potential of the Black Hills area has not yet been fully evaluated.

First, we should recognize the relation of the areas of orebodies to the sizes of the enclosing basins. The largest of the Elliot Lake orebodies has an area of about $20 \mathrm{~km}^{2}$. It lies in a basin that stretches from Sault Ste. Marie to the Cobalt and Noranda areas, some $400 \mathrm{~km}$ to the northeast. Conservatively, this basin must have an area of well over $20,000 \mathrm{~km}^{2}$. If we relate these figures to the Black Hills, we realize that we are probably seeing only a very small portion of a much larger basin and that our chances of finding an exposed orebody are rather sma11. The question is how we can go about trying to increase our chances of discovering an orebody. Two approaches come to mind and are described below.

First, we must recognize that the conglomerates of the Nemo area could represent the distal fringes of a mineralized system. The associated proximal areas could contain higher uranium concentrations (Figure 85). If further detailed stratigraphic and paleocurrent data confirm that the source-area lay to the north or northeast, it might be worth the effort to attempt to explore in this direction. This would involve drilling through hundreds to thousands of meters of Paleozoic sediment and would ordinarily be out of the question, given the structural complexity of the Precambrian sediments. However, the presence of magnetic iron-formations in the stratigraphic pile (see Table 41) provides a method of arriving at a picture of pre-Paleozoic structure. A structural map of this sort should substantially increase our chances of intersecting the appropriate stratigraphic package at depth. Parenthetically, it should be pointed out that tracing of magnetic marker beds in the lower Witwatersrand, beneath cover formations well over $1,000 \mathrm{~m}$ in thickness, resulted in the discovery of fabulously wealthy Carletonville district.

One consideration might, however, point against this approach. If clast size can be taken as a measure of proximity to source area, the Nemo conglomerates represent both medial and proximal facies. Neither the pebble conglomerates (medial facies) nor the cobble conglomerates (proximal facies) of the Nemo area contain economic concentrations of uranium. It may be that this particular fluvial system was simply not supplied with the requisite quantities of uraninite to form an orebody in elther the proximal, medial, or distal situations.

The second approach involves attempting to locate the basal unconformity of the sedimentary pile of the Nemo area. In foregoing chapters of this report, we have made much of the importance of the unconformity to the localization of uranium orebodies. If uraniferous-auriferous conglomerates are developed hundreds (or possibly thousands) of meters above the basal unconformity (as at Nemo), we reason that those developed on or close to the basal unconformity may well be significantly richer in urantum (and possibly gold). The task of locating this unconformity beneath Paleozolc cover formations will not be an easy one (Figure 85). Once again, we would need to rely heavily on the structural picture generated by a study of magnetic patterns related to 
the iron-formations in the pile. An advantage here would be the anticipated magnetic contrast between the lowest iron-formation and an (anticipated) underlying quartz wacke, paleosol, and granite sequence.

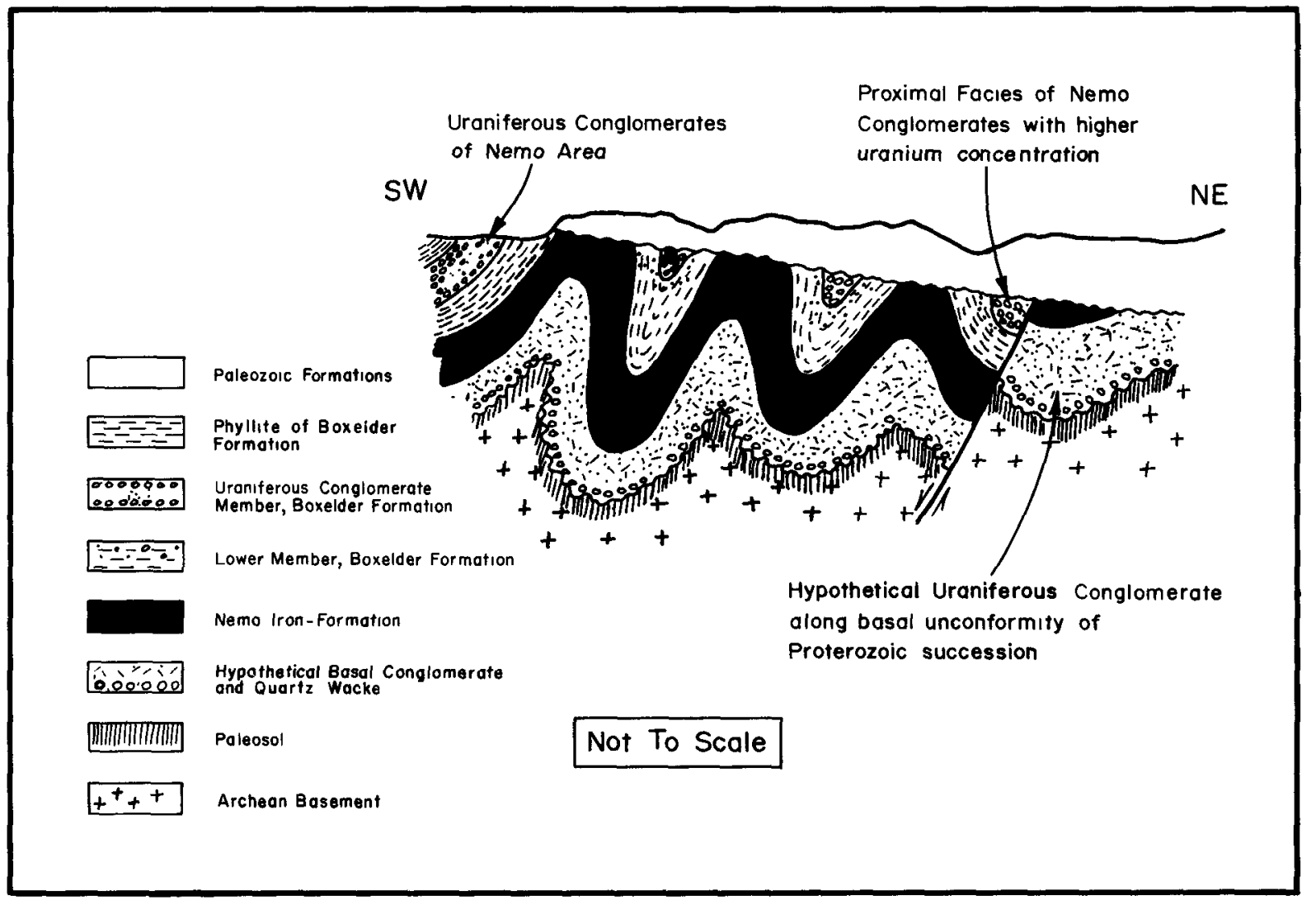

Figure 85. Schematic cross section of the Nemo area, illustrating possible subsurface uranium targets.

Summary. The potential of the Black Hills area should not be underestimated merely because of the initially discouraging uranium values. The succession is of the right age for the development of uraniferous conglomerates, and the right sort of host sediment (representing the right sort of depositional environment and source area) is present. Given the size of orebodies relative to the basins containing them, it would be almost too much to expect to discover an orebody on surface. The full potential of this district will never be determined by surface exploration alone. Imaginative and wellfounded paleogeographic and subsurface structural studies, backed by the 
money to drill several tens of holes to depths of at least $1,000 \mathrm{~m}$ in some cases, are needed to fully evaluate the Nemo district.

The Medicine Bow and Sierra Madre Ranges

The Medicine Bow and Sierra Madre Ranges are located in southeastern Wyoming (Figure 83). Like the Black Hills, they are Laramide-aged uplifts. The results of initial investigations into the geology of the area were published by Blackwelder (1926) and by Houston and others (1968). These studies

resulted in the recognition of the stratigraphic similarities of the Medicine Bow sequence and the Huronian Supergroup of Ontario. In turn, this similarity led to the search for, and discovery of, uraniferous conglomerates in the Medicine Bow Mountains and in the neighboring Sierra Madre Range.

Age. The Precambrian sediments of the Slerra Madre and Medicine Bow Ranges rest nonconformably on Archean granitic and gneissic rocks, dated at some $2,500 \mathrm{~m} \cdot \mathrm{y}$. (Karlstrom and Houston, 1979). The southern limit of the early Proterozoic and Archean rocks in these ranges is marked by the Mullen CreekNash Fork shear zone, a belt of mylonites and cataclastic gneisses (Houston and others, 1968). The shear zone trends more or less east-west through the Sierra Madre, then swings northeast through the Medicine Bows and continues with this trend through to the Laramie Range (Figure 83). The "eugeosynclinal" metasediments and volcanics south of the shear zone were probably deposited 1,800 to $2,000 \mathrm{~m} \cdot \mathrm{y}$. ago and were intruded by a suite of granitic igneous rocks some $1,700 \mathrm{~m} . \mathrm{y}$. ago.

The age of the Proterozoic sediments of the ranges in question is firmly constrained between 1,700 and $2,500 \mathrm{~m} . \mathrm{y}$. limits. In all probability, the strata will turn out to be between 2,100 and $2,500 \mathrm{~m} \cdot \mathrm{y}$. old, since they are intruded by a suite of basic sills similar to those in the Black Hills and in the Huronian Supergroup, which are between 2,100 and 2,200 m.y. old. Like the Black Hills sequence, the strata in these ranges have "ideal" ages for the development of uraniferous conglomerates.

Nature of Basement. In general terms, the basement to the early Proterozoic basin of the Sierra Madre comprises Archean gneiss and an Archean granite. According to Graff (1979), Archean metasediments and metavolcanics occur in the gneissic terrane and comprise quartzite, meta-agglomerate, and layered volcanic and amphibolitic gneisses. They are interlayered and infolded with 2,600-2,700 m.y. old gneisses. Whether or not these may be regarded as parts of a greenstone belt is not known. If they are, their metamorphic rank (amphibolite grade from Graff's description) indicates a relatively low tectonic level in the Archean craton.

The basement to the Medicine Bow succession is composed mainly of quartzofeldspathic gneiss and intrusive granite (Houston and Karlstrom, 1979). The foliation of the gneisses has been deformed during several periods of structural activity (Karlstrom and Houston, 1979b). No greenstone belt remnants have been mapped in the area (Houston and others, 1968), so that a relatively low tectonic level is inferred.

Structure. The structural geology of the Medicine Bow area has been reviewed in detail by Karlstrom and Houston (1979b). They recognized several structural domains in the area. The principal structural fabric of the area trends 
northeast-southwest (Figure 86). However, Karlstrom and Houston (1979b) have shown that the structural history of the Lower Proterozoic sediments is complex, involving at least four periods of folding. The most important, in terms of the distribution of sediments, appears to be their $F_{2}$ fold event, which produced northeast-trending isoclinal fold structures. The earliest period of folding $\left(F_{1}\right)$ influenced mainly the lowermost stratigraphic units (the Phantom Lake Metamorphic Suite and Deep Lake Group), $F_{3}$ folding, due to northeast-southwest compression, post-dated deposition of the youngest major unit (the Libby Creek Group), and is responsible for the refolding (about northwest-southeast axes) of $F_{1}$ and $F_{2}$ axial plane traces.

In addition to folds, northeast-trending southeast-dipping reverse faults cut upper Deep Lake and Libby Creek strata (Figure 86). Karlstrom and Houston (1979b) have suggested that this faulting may have been due to compression created by convergence along the margin of an Archean/Early Proterozoic plate boundary.

The early Proterozoic rocks of the Sierra Madre crop out in a westward-widening wedge which comprises the northern half of a major synclinorium (Figure 87). The southern limb of this structure is inferred to have been removed by faulting along the Mullen Creek-Nash Fork shear zone. The principal fold structures in the Sierra Madre outcrop area trend east-west, but subordinate folds trend both northeast and northwest (Houston and Karlstrom, 1979). Reverse or thrust faults, more or less paralle1 to the shear zone, have attenuated the stratigraphic section near the eastern end of the outcrop belt (Figure 87 ).

Stratigraphy. Three major stratigraphic packages are present in the Medicine Bow Mountains, the Phantom Lake Metamorphic Suite (base), the Deep Lake Group, and the Libby Creek Group (top). The uppermost of these units is missing from the Sierra Madre area and is presumed to have been removed by faulting along the reverse or thrust faults which parallel the shear zone.

The three units are separated by unconformities or disconformities. The presence of a pre-Libby Creek Group unconformity is suggested by the fact that it appears to lap onto the Archean basement towards the southwestern end of the outcrop belt in the Medicine Bow Range (Figure 86).

The sediments of the three stratigraphic packages are metamorphosed to varying degrees. In general, the oldest unit (Phantom Lake Metamorphic Suite) is the most metamorphosed (amphibolite grade). Greenschist grades prevail in the Libby Creek Group.

In the last few years, a number of reports have been written on the general geology and stratigraphy of these areas. These include reports by Graff (1979) on the Sierra Madre, by Kar1strom and Houston (1979a; 1979b) on the Medicine Bow area, and by Houston and Karlstrom (1979) and Houston and others (1979) on both ranges. We present a greatly summarized version dealing mainly with those units with potential for uraniferous conglomerates.

The Phantom Lake Metamorphic Suite has been divided into lower and upper assemblages. The lowest assemblage comprises feldspathic quartzite and phyllite with pebbly quartzite, marble, amygdaloidal basalt, and agglomerate. 


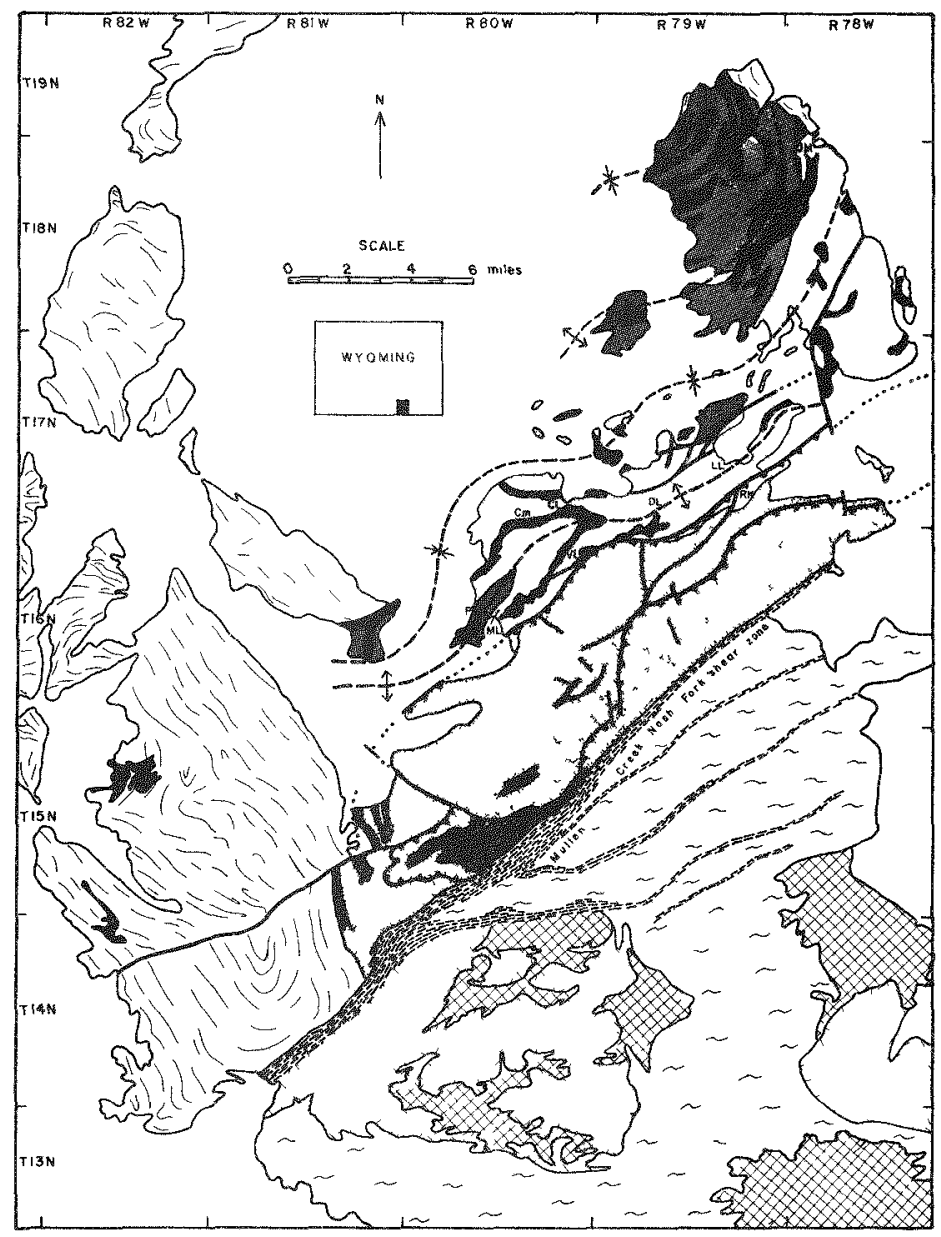

\section{EXPLANATION}
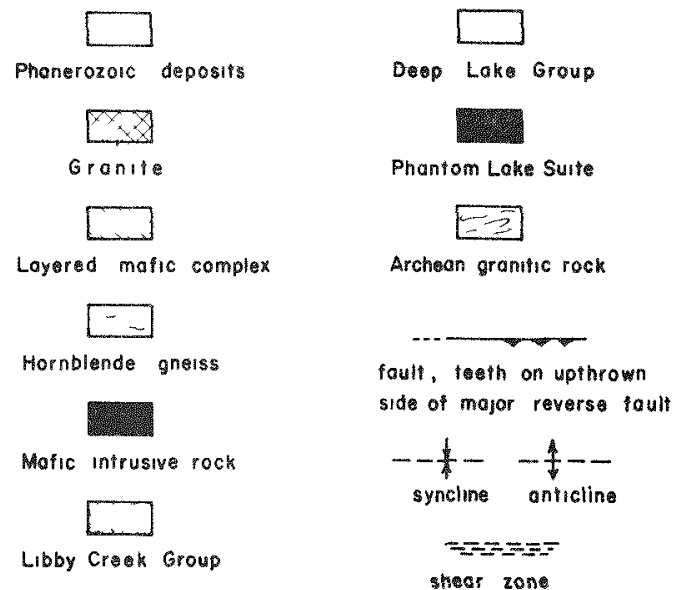

Figure 86. Generalized Precambrian geology of the Medicine Bow Mountains, Wyoming (from Houston and Karlstrom, 1979). 


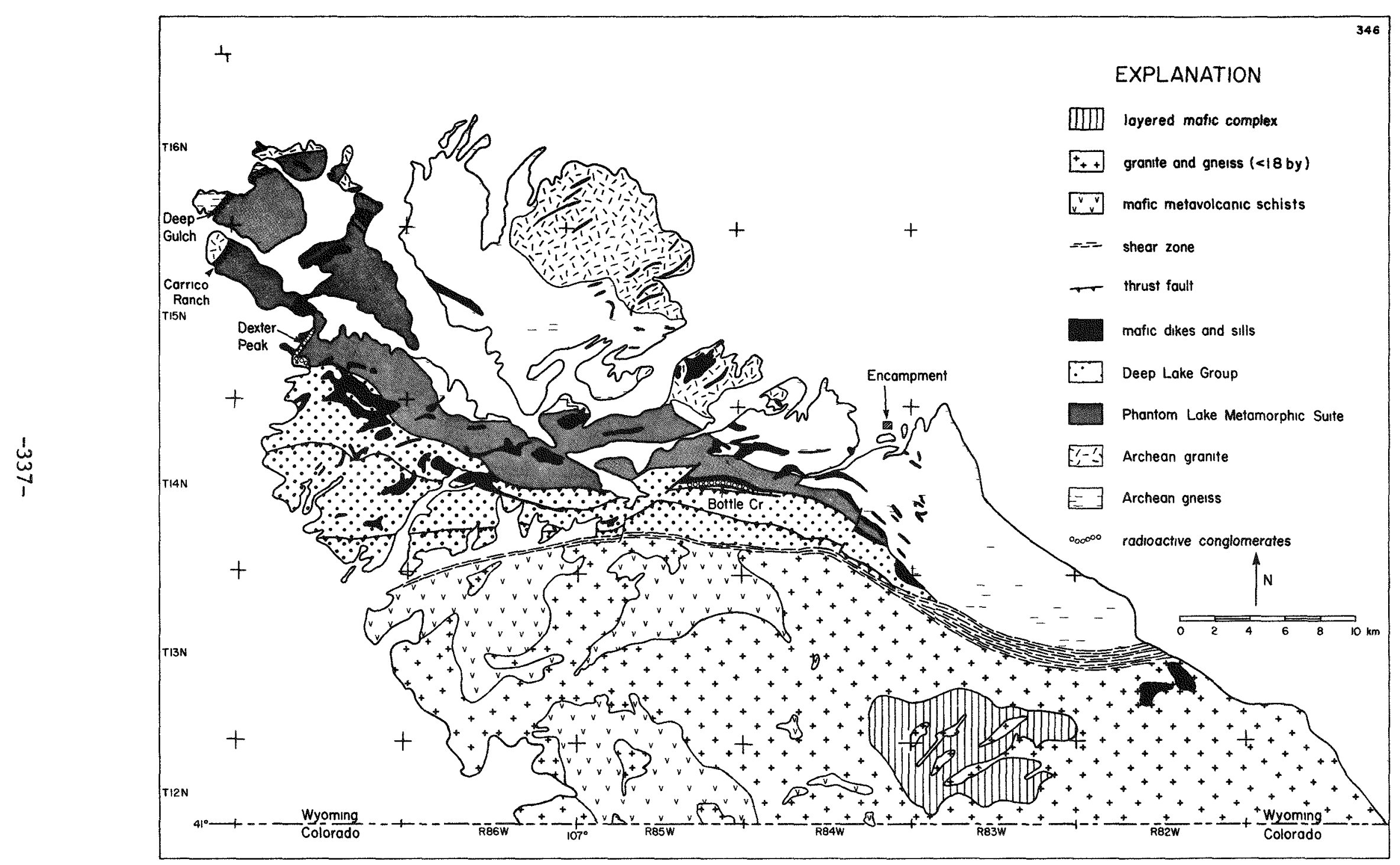

Figure 87. Generalized Precambrian geology of the Sierra Madre, Wyoming (from Houston and Karlstrom, 1979). 
Locally, the lower unit contains gneisses and amphibolites which resemble those in the Archean basement. Contact relations with the Archean basement are confusing, in places suggesting an unconformable relation, in others a gradational or cross-cutting relation. Weakly radioactive rocks $(2-3 \mathrm{x}$ background) include beds of conglomerate, paraconglomerate, and micaceous quartzite. Locally, in the northwesternmost outcrops of the Sierra Madre, a radioactive conglomerate is developed at or close to the contact of the stratified rocks with the Archean gneissic and granitic basement.

The upper part of the Phantom Lake Suite rests unconformably on the lower unit. It commences with a few hundred meters of fluvial sediment, including coarse-grained micaceous quartzite (originally probably quartz sericite wacke) with beds and lenses of radioactive conglomerate. The remainder of the unit is dominated by quartzites and phyllites, with some carbonates (stromatolitic in part), metavolcanics (including pillowed basalts), and paraconglomerate. The thickness of the upper half of the Phantom Lake Suite is estimated to be on the order of 5,000 meters (in the Sierra Madre) and 3,000 meters (in the northeastern Medicine Bow area). Some 30 percent of these thickness figures comprises basic sills.

In the Sierra Madre, Houston and others (1979) described a facies change in Phantom Lake rocks. The easternmost parts of the outcrop belt contain much more volcanics than elsewhere (up to 50 percent of the column).

The radioactive unit of the Phantom Lake Suite is best known in the northeastern part of the Medicine Bows, where it has been core drilled. It is at least $130 \mathrm{~m}$ thick and is a coarse-grained sericitic quartzite with compound zones, up to $3 \mathrm{~m}$ thick, of pyritic pebble conglomerate with coarser and finer grained pyritic quartzite. These sediments are inferred to have been deposited by fluvial agencies and to have been transported from a source area lying to the north or northeast. Other details on the mineralization w11l be given in a subsequent section.

The Deep Lake Group follows unconformably on the Phantom Lake succession. It is relatively unmetamorphosed so that primary depositional structures are well preserved. The Deep Lake succession has been subdivided into six units (Table 42), the lowest of which (the Magnolia Formation) is of special interest to us in this report.

The stratigraphic succession varies somewhat in the Sierra Madre, so that some stratigraphic units were assigned different names in that area (Table 42; Graff, 1979).

In general, the Magnolia Formation commences with a 150-200 m thick conglomeratic member, which passes upwards to an arenaceous member. In the Medicine Bow Mountains, the conglomeratic member comprises coarse-grained arkosic quartzite with conglomerate layers. In places, the conglomerate contains clasts up to $16 \mathrm{~cm}$ in size and is "strongly radioactive" (7-8 x background; Houston and others, 1979). In this case, the clasts are rounded and are composed of quartzite, micaceous quartzite, phyllite, metavolcanic rocks, and granite in a pyritic-arkosic matrix. This $3 \mathrm{~m}$ conglomerate is overlain by a pebble conglomerate with clasts of quartz, quartzite, fine-grained sericitic quartzite, phyllite, and altered volcanic rock in a sericitic, feldspathic 
Table 42. Stratigraphic succession of the Sierra Madre and Medicine Bow areas compared to that of the Huronian Supergroup in Ontario (from Houston and Karlstrom, 1979).

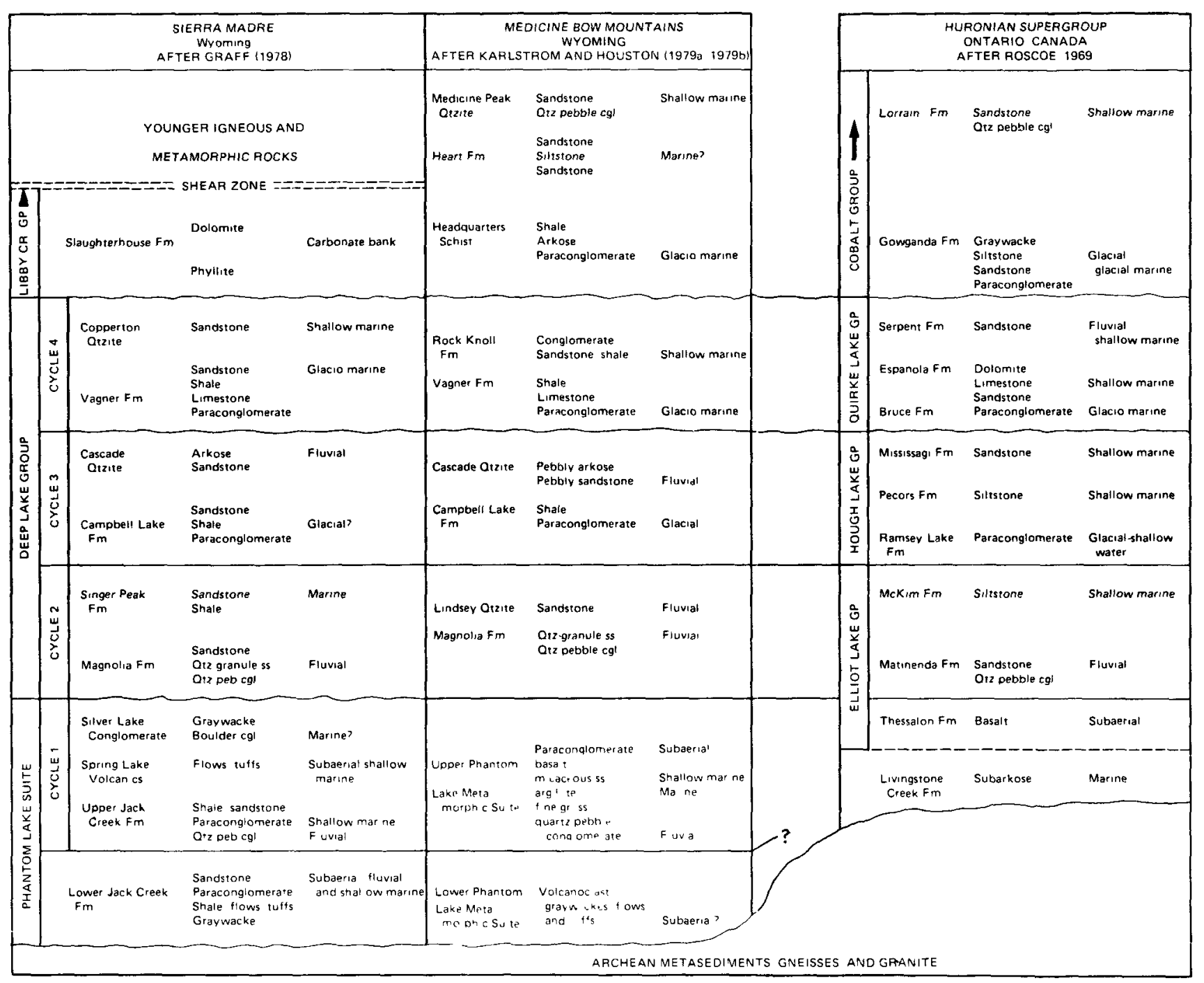


quartzite groundmass. In some areas, the basal conglomeratic member of the Magnolia is absent. In yet other areas (for example, the Dexter Peak area of the Sierra Madre), the conglomerate (which is radioactive) is composed mainly of vein quartz clasts in a pyritic, sericitic matrix.

The remainder of the Magnolia Formation comprises coarse-grained (sometimes pebbly) and better sorted feldspathic and sericitic quartzite. The quartzites are prominently trough cross-bedded and are characterized by fining upward stratification sequences on the order of several meters thick. This member of the Magnolia is some $425 \mathrm{~m}$ thick in the Medicine Bow Mountains (Karlstrom and Houston, 1979b).

The Magnolia Formation is conformably overlain by the Lindsey Quartzite, a $410 \mathrm{~m}$ thick sequence of white to light gray, medium-grained quartzite with lenses and layers of pebbles. Pebbles are concentrated along foresets and cross-bed set boundaries. They are composed predominantly of quartz and are mainly less than $1 \mathrm{~cm}$ in size. In the Sierra Madre, the lateral equivalent of the Lindsey Quartzite is the Singer Peak Formation, which comprises green phyllite with thin layers of quartzite (Graff, 1979).

Both the Singer Peak and Lindsey are overlain by the Campbell Lake Formation, a $65 \mathrm{~m}$ thick paraconglomerate-phyllite unit. The tillite-like paraconglomerate could have been deposited under glacio-marine conditions (Graff, 1979). The overlying Cascade Quartzite occurs in both the Sierra Madre and the Medicine Bow Ranges. It is over $1,450 \mathrm{~m}$ thick and is dominated by medium-grained quartzite with layers of pyritic, quartz, and chert-pebble conglomerate. The conglomerates are non-radioactive and vary in thickness from a single pebble layer to beds 15 to $20 \mathrm{~m}$ thick. The last unit that will be mentioned is the Vagner Formation, which comprises a basal paraconglomerate, followed by limestone and phyllite. The paraconglomerates may be tillites and are associated with phyllites carrying scattered dropstones.

Several younger formations are developed in both the Sierra Madre and the Medicine Bow Ranges. They are of little importance to this report and are not discussed further.

Correlation with the Huronian Supergroup. Houston and Karlstrom (1979) have noted that the stratigraphic assemblages in the areas under discussion can be subdivided into severa1 packages (or cycles). The three uppermost cycles (cycle 3, cycle 4, and the Libby Creek Group, Table 42) commence with tillitelike paraconglomerates, thought to have been formed by glacial agencies. These cycles are reminiscent of those of the Huronian Supergroup of Canada, which also commence with tillite-like paraconglomerate units. Other striking similarities in the stratigraphic sequences are brought out in Table 42. Whether or not the supposedly correlative formations formed at the same time in response to common climatic and/or tectonic controls remains a matter for debate. The important point, as stressed by Houston and Karlstrom, is the overall similarity in the geologic evolution of the two areas. If other factors (such as uranium source and metamorphism) could be shown to be comparable, one would have to conclude that the Medicine Bow-Sierra Madre areas would have a high to very high potential for the development of payable uraniferous conglomerates. 
Uranium Mineralization. The development of uraniferous conglomerate is restricted to two principal units in the area under discussion, the base of the upper unit of the Phantom Lake Suite and the base of the Magnolia Formation. The restriction of important uranium mineralization to these units is entirely predictable since both overlie unconformities and are composed of arenites of the subarkose-quartz wacke type.

The most detailed investigation of uraniferous conglomerates in the area was undertaken in the One Mile Creek locality, south of Arlington, at the northeastern termination of the Medicine Bow Mountains. There is apparently some question about the correlation of the unit containing the uraniferous conglomerate. In the report by Houston and Karlstrom (1979), the mineralized conglomerates of this area were correlated with the basal unit of the Magnolia Formation. In the more recently compiled report of Houston and others (1979), the same rocks are assigned to the basal part of the upper assemblage of the Phantom Lake Suite. The confusion reflects the lithologic similarity of the two uranium-bearing packages, their structural and metamorphic complexities, and the fact that the outcrop areas have not all been mapped in detail.

The conglomerates of the One Mile Creek area contain up to 20 percent pyrite, in rounded as well as euhedral grains. The conglomerate matrices are composed of quartz with some feldspar and sericite. The pebbles are largely of vein quartz, quartzite, and altered clasts, probably felsic volcanics and pegmatite-derived feldspar (Houston and Karlstrom, 1979).

Uranium is concentrated in the basal parts of conglomerate beds in 0.1 to $0.2 \mathrm{~mm}$ sized grains identified as coffinite and thorite (Desborough and Sharp, 1979). Associated minerals include galena (of probable radiogenic origin), $\mathrm{Ni}-\mathrm{Co}-\mathrm{Fe}$ sulfides, marcasite, chalcopyrite, zircon, garnet, monazite, ilmenorutile, columbite, and apatite. Minor magnetite, sphene, ilmenite, and spessertine were also recorded. The ilmenorutile comprises spongy rounded aggregates of crystals supported interstitially by quartz. Poorlycrystallized round grains of sulfur-bearing graphite are present and contain some coffinite inclusions. We believe that the morphological and chemical character of these grains suggests that they were derived from original "fly speck" carbon granules.

The coffinite and thorite occur in nondetrital blebs. Some $U$ and $T h$ are also contained within $\mathrm{Ni}$-Co sulfides, indicating their cogenetic development. Coffinite contains 45-61 percent $U$ and a few tenths to several weight percent $\mathrm{Pb}$ and $\mathrm{Th}$. The thorite contains 30-45 weight percent thorium and a few tenths to several weight percent $\mathrm{U}, \mathrm{Pb}$, and $\mathrm{Y}$.

Uranium Potential. The potential of the Medicine Bow and Sierra Madre areas for the development of economic deposits of uraniferous conglomerate can be gauged by weighing up positive and negative factors. The basin in question rests on part of an Archean craton and probably had the requisite original area. The basin fill is dominated by fluvial and shallow-marine sediments which is good news. It has the correct age. Its stratigraphic fill is separated into several packages by unconformities. Two of the unconformities are covered by fluvial sediments, which suggests the probability of a short time lapse between deposition of conglomerates and their final burial. 
The sericitic and arkosic arenites of the Phantom Lake and Deep Lake units are clearly of the subarkose-quartz wacke type, the most favorable type of host sediment. The conglomerates contained within these arenites carry the same sort of heavy mineral suite as mineralized conglomerates at (for example) Elliot Lake. Uranium minerals are present, at least locally, and radioactive conglomerates are widely developed.

Factors that are less favorab1e, even discouraging, are the apparent low tectonic level of the Archean basement below the basins, the relatively high grade of metamorphism, and the highly deformed nature of the sediments in many instances. Another such factor is the nature of the radioactive conglomerates, many of which are polymictic with clasts of granite, volcanic rock, quartzite, and phyllite. However, others apparently approach an oligomictic character.

A third set of factors remains unevaluated (to a greater or lesser degree) at this time. Such factors include:

(1) the presence and location of radioactive basement granites (within, say, 20 or $30 \mathrm{~km}$ of the basins);

(2) the paleotopographic configuration of the unconformities; and

(3) the paleotransport directions of sediment above the unconformities.

A full and final evaluation of the uranium potential of the Medicine Bow and Sierra Madre Ranges will require continued detailed geologic investigations. In particular, we need to know the locations (and uranium contents) of potential source granites. Second, very detailed mapping of the unconformities may reveal the presence of paleovalleys. Houston and others (1979) have shown that the principal unconformities are cut across a variety of rock types, including quartzites, phyllites, and metavolcanics. The situation envisaged is shown schematically in Figure 88. The key to subsurface exploration of conglomerates that appear hopeful from surface indications is to establish the locations and probable trends of paleovalleys. Given the fact that the unconformities in question are cut across different lithologies in the underlying units, it is entirely likely that the paleotopographic configuration of these ancient land surfaces comprised a system of cuesta paleoridges and strike paleovalleys, arranged in a trellis pattern. The elucidation of the paleotopographic relations associated with the unconformities of the Medicine Bow and Sierra Madre successions should enjoy a high priority once the basic field mapping has been completed. It is realized that this task is likely to be an extremely difficult one, given the degree of deformation and the sporadic nature of the outcrops. However, since these relations are crucial to exploration, even in gently deformed successions, we cannot fully evaluate the potential of the area in question without establishing the paleotopographic configuration of the unconformities.

The third aspect that should be examined is that of sediment transport directions. Karlstrom and Houston (1979) have published the results of a preliminary investigation into paleocurrent patterns in the Phantom Lake and Magnolia arenites. Transport directions appear to have been mainly to the south and southwest. The paleocurrent directions in these formations should be studied over a much wider area in an attempt to define the regional and 


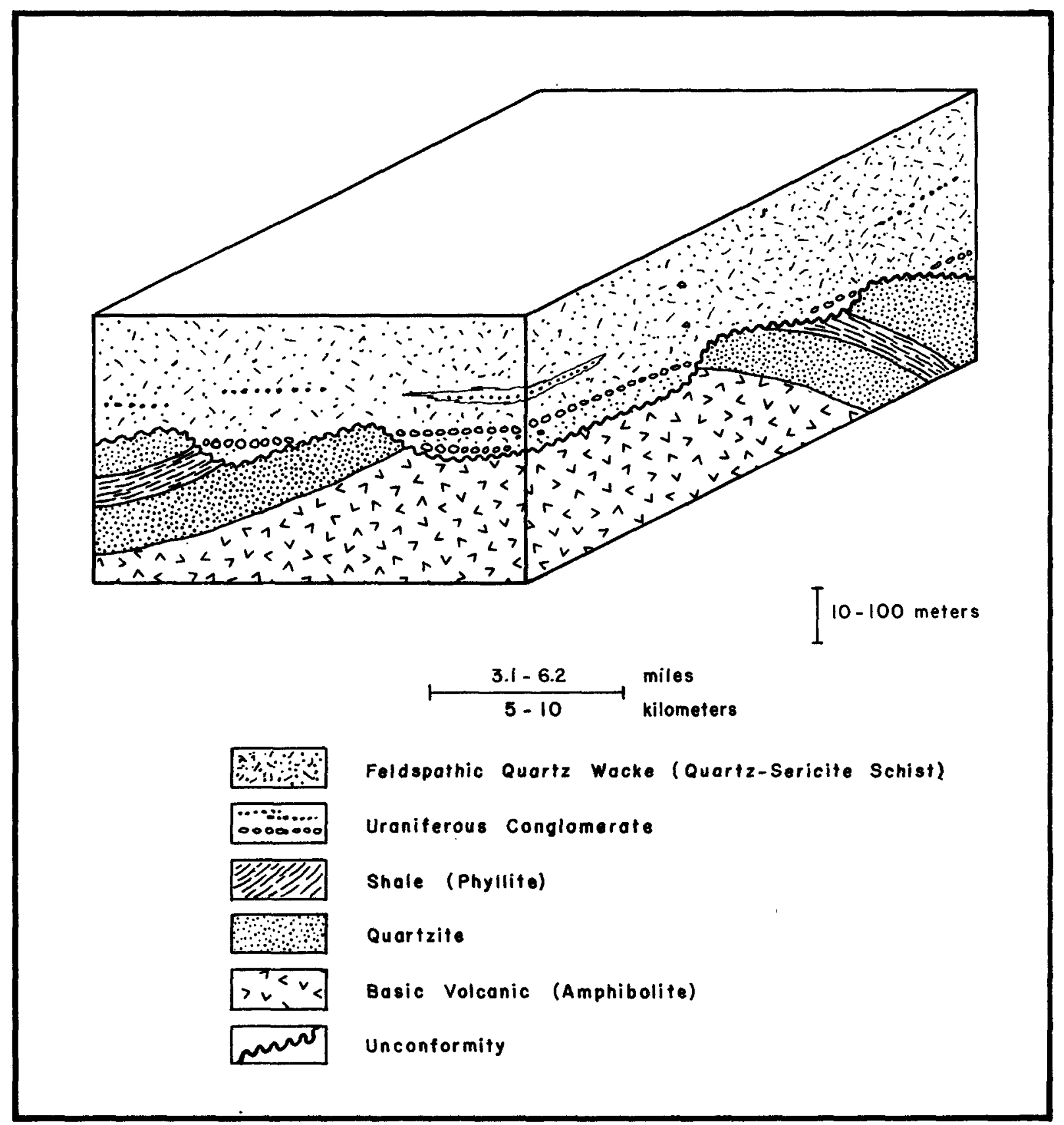

Figure 88. Schematic block diagram illustrating the possible preferential development of uraniferous conglomerates in paleovalleys associated with unconformities below the Magnolia Formation (Deep Lake Group) or below the upper assemblage of the Phantom Lake Suite. 
local sediment dispersal patterns. This information could then be integrated with studies on paleotopography and the location of uranium-rich Archean granites to focus prospecting effort on the areas with highest potential.

In summary, the Medicine Bow-Sierra Madre areas represent some of the most attractive rocks within the United States in which to explore for Precambrian uraniferous conglomerates. Given the deformation and the imperfect exposure (due to Tertiary outliers and glacial debris), exploration is bound to be difficult. The full potential of the area cannot be evaluated until detailed surface mapping is complete, stratigraphy and facies changes documented and understood, sediment dispersal patterns established, the location of uraniferous basement granites fixed, and the paleotopographic configuration of the major unconformities determined. Even then, the evaluation will be incomplete, since such a small proportion of the whole rock mass is seen on outcrop. Subsurface exploration of targets established by the studies mentioned above is bound to be required before evaluation efforts can be considered to be complete.

\section{Summary of United States Resource Potential}

The evaluation of exposed uraniferous conglomerates in the United States is incomplete at this stage. Significant potential exists in the Medicine BowSierra Madre, Black Hills, and Great Lakes areas. The subsurface potential of unexposed parts of known mineralized basins has not been evaluated in any meaningful way. If we bear in mind that all the presently producing goldand uranium-bearing conglomerates of the Witwatersrand were discovered by expensive exploration programs (including core drilling to depths of 4,500 m), it is evident that the expenditure to date within the United States has been totally inadequate. The potential of areas with known uraniferous conglomerates will not be fully evaluated before subsurface exploration targets are established and tested. Some such exploration will be for targets covered by a few hundred meters of glacial debris or Tertiary beds (in the Medicine Bows, for example). Other programs will involve targets below many hundred to several thousand meters (as in the northern Black Hills and Upper Peninsula of Michigan). A study of the subsurface geology of the latter area should definitely be initiated since there is a very strong probability that E11iot Lake Group strata will be found below Paleozoic cover in parts of this area. If one uses the Witwatersrand analogy once again, exploration proceeded from outcropping mineralization to areas where mineralized conglomerates occur at depths of thousands of meters. The subsurface rim of the basin was traced over hundreds of kilometers. A large part of the perimeter thus established was unmineralized. However, five major areas of mineralization were established. Without an expensive subsurface exploration program, we will never know whether a second Elliot Lake district lies buried beneath the Paleozoic formations of the Upper Peninsula of Michigan. 
ESTIMATION OF GEOLOGIC FAVORABILITY FOR THE OCCURRENCE OF URANIFEROUS CONGLOMERATE

Numerous methods have been used for estimating the geologic favorability or expected resource endowment of an area for various types of ore deposits (Cargill and Clark, 1978; Singer and Ovenshine, 1979; Voelker and others, 1979; Harris and Carrigan, 1980). In this section, we present a simplified method for estimating the favorability of an area for the occurrence of uraniferous conglomerate deposits using the recognition criteria net (Figure 75) and the welghts assigned to the recognition criteria (Tables 36 through 40). It must be emphasized that the favorability estimate reflects only the general geologic similarities between known deposits, as defined by the recognition criteria, and the geologic characteristics of an area in which similar deposits might occur. A higher degree of geologic similarity yields a higher favorability estimate, suggesting a greater likelihood that the type of deposit for which the recognition criteria were developed is present in the untested area. No attempt is made to estimate the number of deposits or their geologic size, grade, and continuity. These characteristics require information about the known deposits which, in many cases, is not yet available.

The use of this method presumes that sufficient geologic information is available for the area of study so that weights can be confidently assigned to the recognition criteria. In most cases, geologic data are incomplete and values cannot be assigned to all criteria. Using the method described below, the absence of a value for a criterion is analogous to assigning it a value of zero. This could introduce a significant error in the interpretation of the favorability estimate if the geologist fails to note where data were lacking. If the true favorability of the criterion is significantly higher than zero, the absent data lead to a fallaciously low estimate of the area's favorability. This is a common situation, particularly in resource evaluation of Federal lands where adequate geologic information is customarily unavailable for the systematic evaluation for all types of deposits. Geologic favorability simply cannot be estimated until an adequate data base is available. Where data are lacking, the large negative and positive welghts indicate those recognition criteria for which data must be acquired. The assignment of a weight of zero may also significantly overestimate favorability if that criterion is in fact very discouraging. There is no substitute for a sufficient data base.

Calculation of Estimated Favorability

The procedure for calculating an estimated favorability may be conveniently explained by returning to the discussion of "Nature of Basement", considered under Evaluation of Recognition Criteria. Weights were assigned to various favorable and unfavorable states of the three criteria that determine the favorability of basement. To evaluate the favorability of basement for field areas, favorability values, based on field observations, are assigned to the 
three criteria. Table 43 presents hypothetical results for four imaginary field areas. In accumulating the values of the recognition criteria, negative and positive values are accumulated separately, but in like fashion.

Table 43. Hypothetical results determined from four field areas for three criteria that determine "nature of basement".

Estimated Favorability Values (Fe) Area A Area B Area C Area D

Geotectonic Setting

Basement Lithology

Uranium Source

in Basement

Estimated

$+30$

$+40$

$+10$

$-95$
Favorability

Values

$\underline{(\mathrm{Fm}+) \quad(\mathrm{Fm}-)}$

$+40$

Favorability
$-50$

$+20 \quad+20$

$+10$

$-50$

( $\mathrm{Fe})+8$

$+30$

$+30$

$+50$

$+50$

$+30$

$-50$

$+90$

$+70$

$+50$

$-145$
$+120$

$-175$
$+50$

In test Area A, for example, the geotectonic setting has been assigned a value of +30. Basement lithology provides an additional +20. Similarly, uranium source in basement contributes an additional +30 , yielding an estimated favorability ( $\mathrm{Fe}$ ) of +80 . However, if all the criteria had been perfect and the maximum favorability values had been used, the sum of the three criteria would have been +120 (Table 43). It is necessary, therefore, to normalize the estimated favorability by dividing by the maximum (Fm) value to yield a normalized (Fn) value:

$$
\frac{F e}{F m}=F n \quad \text { or, } \frac{80}{120}=.67
$$

The favorability of nature of basement for Area A 1s 67, 1.e., very suggestive.

For Area $D$, the negative and positive criteria are combined in like manner, but separately, normalized and then summed:

$$
\begin{aligned}
& \text { Negative values-- } \\
& \text { Geotectonic } \\
& \text { Basement } \\
& \text { Setting } \\
& \text { Lithology } \\
& -95 \\
& + \\
& -50 \\
& =-145 \\
& \frac{F e}{F m}=F n \\
& \text { or, } \frac{145}{175}=-.83
\end{aligned}
$$




\section{Positive values-- \\ Uranium Source in Basement}

$$
\frac{\mathrm{Fe}}{\mathrm{Fm}}=\mathrm{Fn} \quad \text { or, } \quad \frac{50}{120}=.42
$$

Combining the normalized positive and negative values $(-83+42=-41)$, one determines that Area $D$ has a relatively large negative number, hence, a discouraging basement for a deposit. Area $D$ is thus not a very favorable one in which to prospect for uraniferous conglomerates. In fact, the large negative values for geotectonic setting and basement lithology would be sufficient in most geologists' minds to kill the potential of this area. The explorationist should thus not waste further time in collecting other detailed geological information from this area. This example shows that the geologist making the evaluation must always inspect individual negative numbers which, if sufficiently discouraging, can destroy the entire potential for the area, even though the accumulation of numerous positive observations may yield a net positive (or only slightly negative) answer.

It can be seen (Figure 75 and Table 37) that the "nature of basement" is merely one criterion that helps to define a higher level criterion, namely "regional geologic setting". Table 37 shows that, in defining "regional geologic setting", the "nature of basement" can contribute a maximum of 40 points. In our example for Area A, "nature of basement" contributes:

$$
0.67 \times 40=27=\text { Applied Normalized Favorability (Fna) }
$$

This value can then be used in calculating the value of the higher order criterion, namely, Regional Geologic Setting. In a similar manner, all other terminal criteria are combined to evaluate intermediate criteria until the favorability for a uraniferous conglomerate deposit has been evaluated. This favorability is not necessarily equivalent to the probability of a deposit being present as is discussed in a later paragraph.

\section{Completeness and Confidence of Geologic Data}

If the field geologist has complete geologic data and is equally and completely confident about all his field observations, he may evaluate the favorability according to the preceding paragraphs. In most cases, however, he w11l lack data and probably have various levels of confidence regarding the data that do exist. His confidence for different observations may range from completely certain that, for example, a uranium source rock is present, to no confidence (i.e., he does not know) that the age of the prospective basin sediments is late Archean or early Proterozoic. In such circumstances, methods can be devised to modify the favorability estimates, but no calculations can overcome the lack of data or confident observations. Such shortcomings must be carefully documented and the resulting favorability estimate interpreted accordingly. 


\section{Interpretation of Results}

Favorability estimates prepared by the methods described in the preceding paragraphs should be accepted and used only after review of four important parameters:

(1) the final favorability estimate itself;

(2) favorability estimates for intermediate level criteria;

(3) favorability values for individual criteria, particularly large negative values; and,

(4) completeness of data and certainty of observations.

Each of these is briefly discussed with reference to favorability estimates made for three areas in North America and presented in the next section.

The final favorability estimate reflects the net geologic favorability of an area when compared with type areas (i.e., Elliot Lake district, Witwaters rand, etc.) for which the recognition criteria net and maximum and minimum favorability values were selected. A score of 100 indicates a perfect geologic fit, i.e., virtual assurance that at least one deposit is present. A final score of zero indicates a very low level of favorability, provided the geologic data is complete, and the prospects of finding a deposit would be comparable to hitting a deposit with a dart thrown at a map of North America. A favorability of +50 , therefore, is only half as favorable as one of +100 . If the score is based on high confidence in the observations and complete data (i.e., no zeros assigned to criteria), the area may be sald to possess only half the favorable attributes necessary for a deposit. This does not mean the area has a 50 percent chance of a deposit being present. In our judgement, the likelihood is less, but how much less is difficult to estimate. At a favorability estimate of zero, the chances of a deposit being present are vanishingly small, and at negative favorabilities, the chances are even worse. Figure 89 is our subjective attempt to relate estimated favorability of an area to the chances of a deposit being present within that area. The relationship suggests that the chances of a deposit being present decrease more rapidly than the estimated favorability. At 75 percent favorability, for example, we believe there is about a 50 percent chance that a deposit is present.

The estimated favorability values for the second level criteria of the recognition criteria net (Figure 75) for the three areas considered in the next section are also useful for interpreting the favorability estimates. Inspection of these values, which are tabulated below, permits one to determine the contribution of each intermediate level criterion to the final estimated favorability.

Inspection of this table permits one to determine the contribution of each intermediate level criterion to the final estimated favorability. The favorability of the Nemo area relative to the Medicine Bow area, for example, is decreased significantly by stratigraphic setting and conglomerate character. By similar comparisons, one may pursue low favorability values through 


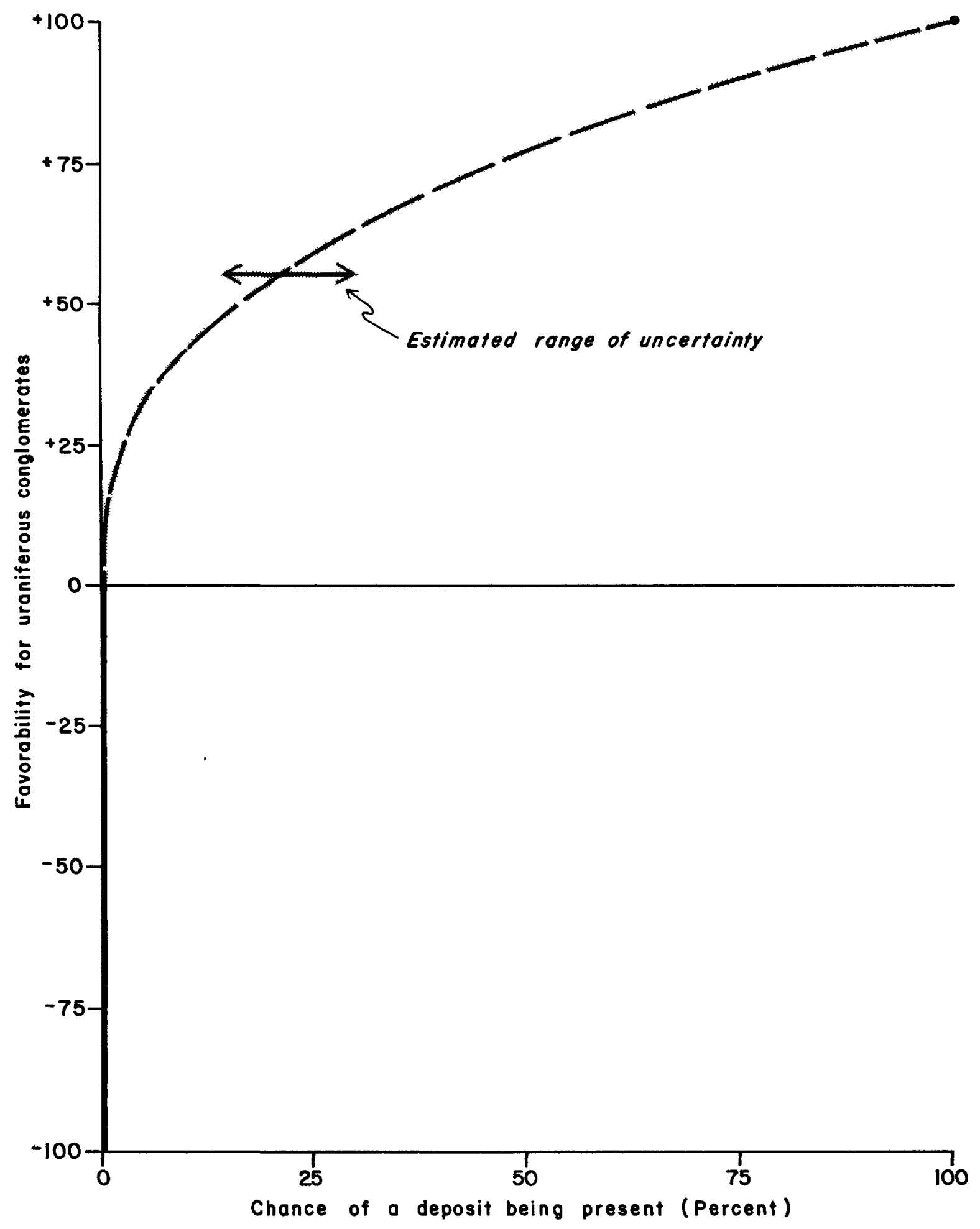

Figure 89. Schematic relation between calculated favorability for uraniferous conglomerate deposits and the chances of a deposit being present within the area evaluated. 
successively lower levels of the criteria net and ascertain exactly which observations are unfavorable or for which no data exist.

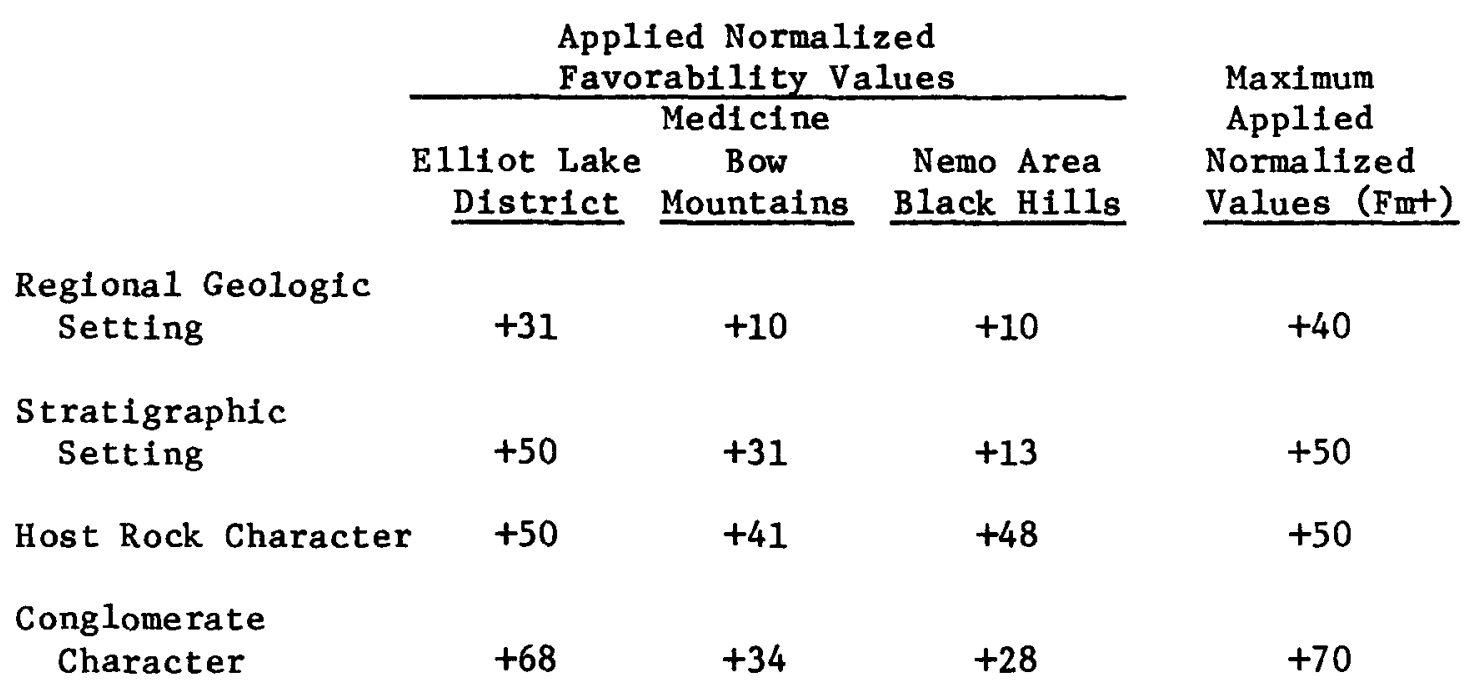

Strongly negative values for individual criteria are, in some cases, sufficient to essentially kill the potential of an area. In the final favorability estimate, a single large negative value may become lost in generally positive criteria values, hence, the geologist must inspect the values of individual criteria.

Finally, the completeness of the data, hence the number of zero values, may produce erroneous estimated favorability values. In exploration, low favorability values due to incomplete and uncertain data are not as unfavorable as low favorability values resulting from negative or low positive criteria values. In resource studies, however, the absence of data could yield an apparent favorability much lower (or higher) than the area warrants. Careful inspection must be made of incomplete and uncertain data and the resulting favorability estimate interpreted accordingly. Where new data or more certain observations are needed, the criteria welghts will indicate which observations are most important to obtain.

\section{Examples of Favorability Estimates for Three Areas}

In the following pages, recognition criteria are used to estimate the geologic favorability for uraniferous conglomerate deposits in three North American basins. In one case (Elliot Lake district), the favorability is already known, since deposits have been mined there for over 20 years. We have attempted to use data from this area that would be comparable in quality (and quantity) to that now available for the Nemo area and Medicine Bow Mountains.

The following abbreviations are used throughout:

$$
\text { ELD = Elliot Lake district, Ontario }
$$




$$
\begin{aligned}
& \mathrm{MBM}=\text { Medicine Bow Mountains, Wyoming } \\
& \mathrm{NABH}=\text { Nemo area, Black Hills, South Dakota } \\
& \mathrm{Fe}=\text { Estimated favorability value } \\
& \mathrm{Fm}=\text { Maximum favorability value } \\
& \mathrm{Fn}=\text { Normalized favorability value } \\
& \text { Fna }=\text { Normalized applied favorability value }
\end{aligned}
$$

Estimated Favorability (Fe) is simply the sum of the favorability values assigned to each of a group of criteria that determines the favorability of a higher intermediate level criterion, based upon field data.

Maximum Favorability (Fm) is the sum of the maximum values that could be assigned to those criteria.

Normalized Favorability (Fn) is equal to the estimated favorability divided by the maximum favorability. It may be interpreted, therefore, as a percentage of the total possible favorability of the criteria.

Normalized Applied Favorability (Fna) is the normalized favorability of a group of criteria which is then multiplied by the maximum possible weight assigned to the criterion above; the product is the weight for that higher level criterion that is then used with other criteria to calculate the favorability of the next higher level criterion.

The score sheet for reglonal geologic setting is presented in Table 37 . The favorability of the regional geologic setting of a basin is a function of the nature of the basement, the regional gravity pattern in the basement, and the nature of the basin in question.

\section{Nature of Basement}

\section{Geotectonic Setting}

ELD: 40 (basin lies on part of an Archean craton)

MBM: 40 (as above)

NABH: 40 (as above)

Basement Lithology

ELD: 30 (basement comprises granite, greenstone, and gneiss)

MBM: $\quad 0$ (basement at least lower amphibolite grade)

NABH: 0 (nature of basement unknown except in a sma11 window) 
Uranium Source in Basement

ELD: 60 (uraniferous quartz monzonites crop out around basin $\mathrm{rim}$ )

IIBM: $\quad 0$ (uranium distribution in basement not known)

NABH: 10 (Little Elk Grantte contalns on the order of 5-10 ppm U)

\section{Nature of Basement Score}

The reader should recall that the favorability estimate ( $\mathrm{Fe}$ ) is calculated by summing the Individual favorability numbers.

$$
\begin{aligned}
& \text { Fe ELD }=40+30+60=\underline{+130} \\
& \text { Fe MBM }=40+0+0=\underline{+40} \\
& \text { Fe NABH }=40+0+10=+50
\end{aligned}
$$

Reference to Table 37 indicates that a "perfect basement" is only mildly to moderately suggestive $(+40)$ of an economic deposit of uraniferous conglomerate being present. The Fe values must be normalized so as not to exceed 40, the maximum score in this category. The first step is to calculate the maximum score in the "nature of basement" class.

$$
\mathrm{Fm}=40+30+60=\underline{130}
$$

The normalized applied favorability for "nature of basement" (Fna) is given by

Fna $=\frac{F e}{F m} \times$ maximum permissible value for "nature of basement"

(40 in-this case; see Table 37 ). Thus,

Fna ELD $=\frac{130}{130} \times 40=40$ (a perfect score for nature of basement)

Fna MBM $=\frac{40}{130} \times 40=\underline{12}$ (out of a possible 40 )

Fna NABH $=\frac{50}{130} \times 40=\underline{15}$ (out of a possible 40 )

\section{Regional Gravity Pattern of Basement}

ELD: $\quad$ (writers unaware of reglonal gravity pattern)

MBM: $\underline{0}$ (as above)

NABH: $\underline{0}$ (as above) 
Basin Development

ELD: $\quad 40$ (basin large and long-lived)

MBM: $\quad 30$ (basin probably as large and as long-lived as above)

$\mathrm{NABH}$ : 30 (as above)

Basin Paleogeography

ELD: $\quad 40$ (basin was continental or shallow marine)

MBM: 40 (as above)

NABH: 10 (basin dominated by deeper marine sediments and volcanics)

Basin Structure

Style of Deformation. ELD: 20 (open, gentle folds)

MBM: $\quad-40$ (isoclinal folding)

NABH : $\quad-20$ (strongly deformed)

Basin-Bounding Faults. ELD: $\quad 0$ (role of basin-bounding faults unknown)

MBM: 0 (as above)

NABH: $\quad 0$ (as above)

Folds. ELD: 30 (lies in a regional syncline)

MBM: $\quad 10$ (parts lie in regional synclines)

NABH: $\quad 0$ (1ies near a regional dome)

Basin Structure Score. Fe ELD $=20+0+30=\underline{50}$

Fe MBM Pos $=0+10=10$

$\mathrm{Neg}=-40$

Fe $\mathrm{NABH}=-20+0+0=\underline{-20}$

$\mathrm{Fm}_{\mathrm{m}} \mathrm{Pos}=20+10+30=\underline{60}$

$\mathrm{Neg}=-40-0-10=\underline{-50}$

Fna ELD $=\frac{50}{60} \times 30=25$ (out of a possible 30 )

Fn MBM Pos $=\frac{10}{60}=0.17$

$$
\mathrm{Neg}=\frac{-40}{-50}=0.80
$$




$$
\begin{aligned}
\text { Net } & =0.17-0.80=-0.63 \\
\text { Fna MBM } & =-0.63 \times 40=-25 \text { (out of a possible -40) } \\
\text { Fna NABH } & =\frac{-20}{-50} \times-40=-16 \text { (out of a possible }-40 \text { ) }
\end{aligned}
$$

Basin Metamorphism

ELD: $\quad 30$ (greenschist grade)

MBM: -20 (basin metamorphosed at least to lower amphibolite grade)

NABH: 0 (metamorphosed at upper greenschist grade)

Nature of Basin Score

$$
\begin{aligned}
& \text { Fe ELD }=40+40+25+30=135 \\
& \text { Fe MBM Pos }=30+40=+70 \\
& \text { Neg }=-25-20=-45 \\
& \text { Fe NABH Pos }=30+10=40 \\
& \text { Neg }=-16 \\
& F_{m} \text { Pos }=40+40+30+30=140 \\
& \mathrm{Neg}=-90-90-40-95=-315 \\
& \text { Fna ELD }=\frac{135}{140} \times 30=29 \text { (out of a possible } 30 \text { ) } \\
& \text { Fn MBM Pos }=\frac{70}{140}=0.50 \\
& \begin{array}{l}
\text { Neg }=\frac{-45}{-315}=-0.14 \\
\text { Net }=0.50-0.14=+0.36
\end{array} \\
& \text { Fna MBM }=0.36 \times 30=11 \text { (out of a possible } 30 \text { ) } \\
& \text { Fn NABH Pos }=\frac{40}{140}=+0.29 \\
& \mathrm{Neg}=\frac{-16}{-315}=-0.05 \\
& \text { Net }=0.29-0.05=+0.24
\end{aligned}
$$




$$
\begin{aligned}
\text { Net } & =0.29-0.05=+0.24 \\
\text { Fna NABH } & =0.24 \times 30=7 \text { (out of a possible 30) }
\end{aligned}
$$

\section{$\underline{\text { Regional Geologic Setting Score }}$}

Having calculated the favorability scores for nature of basement, regional gravity pattern, and nature of basin, we are now in a position to start accumulating these numbers to arrive at a score for regional geologic setting for each of the basins. The reader should recall that we must use the applied normalized favorabilities in each case.

$$
\begin{aligned}
\text { Fe ELD } & =40+0+29=\underline{69} \\
\text { Fe MBM } & =12+0+11=\underline{23} \\
\text { Fe NABH } & =15+0+7=\underline{22} \\
\text { Fm } & =40+20+30=\underline{90}
\end{aligned}
$$

If we consult Table 36 , we see that basins with a perfect regional geologic setting are only mildly to moderately suggestive (+40) of an economic deposit being present. The final step is to calculate the applied normalized values for regional geologic setting in the usual way.

$$
\begin{aligned}
& \text { Fna ELD }=\frac{69}{90} \times 40=31 \text { (out of a possible 40) } \\
& \text { Fna MBM }=\frac{23}{90} \times 40=10 \text { (out of a possible 40) } \\
& \text { Fn NABH }=\frac{22}{90} \times 40=10 \text { (out of a possible 40) }
\end{aligned}
$$

Our conclusion is that the Elliot Lake district has a very favorable regional geologic setting ( 31 out of a possible 40 ). The regional geologic setting of both the Medicine Bow and Nemo areas is much less than perfect ( 10 out of a possible 40 for both areas). It is important to realize that part of the poor scores for these areas is due to a lack of data on, for example, the uranium content of source-area granitic rocks. In other cases, it is due to unfavorable scores (for example, negative scores for amphibolite-grade metamorphism).

\section{Stratigraphic Setting}

Having evaluated the regional geologic setting of the three basins in question, we can now turn our attention to their stratigraphic setting. In Table 38 , it is shown that stratigraphic setting is considered to be a function of basina 1 and of unconformity parameters. 
Age

ELD: $\quad 30$ (age of around $2,300 \mathrm{~m} \cdot \mathrm{y} \cdot$ lies in the ideal range)

MBM: 20 (age probably as above, but younger limit not established)

NABH: 30 (as for ELD)

Area

ELD: 10 (area on the order of $10^{5} \mathrm{~km}^{2}$ )

MBM: 10 (area almost certainly $>10^{4} \mathrm{~km}^{2}$ )

NABH: 10 (as above)

Thickness of Fill

ELD: $\quad 20$ (thickness of between 5,000 and $10,000 \mathrm{~m}$ )

MBM: 20 (as above)

NABH: $\quad 0$ (thickness not well established, may be $>10,000 \mathrm{~m}$ )

Lithology of Fill

ELD: 30 (dominated by terrestrial and marginal-marine rocks)

MBM: 30 (as above)

NABH: $\quad 0$ (marine rocks dominate section; deeper marine sediments and volcanics make up most of the upper part of the succession)

Basin Parameter Score

Fe ELD $=30+10+20+30=90$

$\mathrm{Fe}$ MBM $=20+10+20+30=80$

Fe NABH $=30+10+0+0=40$

$\mathrm{Fm}_{\mathrm{m}}=30+10+20+30=90$

Table 38 shows that the maximum score for basinal parameters is 40 . We shall normalize the scores for the three areas in the usual way.

Fna ELD $=\frac{90}{90} \times 40=40$ (out of a possible 40)

Fna MBM $=\frac{80}{90} \times 40=35$ (out of a possible 40 ) 


$$
\begin{aligned}
\text { Fna NABH }=\frac{40}{90} \times 40 & =18 \text { (out of a possible 40) } \\
& \text { Unconformity Parameters }
\end{aligned}
$$

Type of Unconformity/Nonconformity

ELD: $\quad 30$ (fundamental disconformity developed at base of succession)

MBM: $\quad 30$ (fundamental and intraformational unconformities present at appropriate stratigraphic levels)

NABH: 0 (unconformity not known to be developed at approprlate stratigraphic leve1)

Paleoweathering

ELD: 30 (paleosols very well developed along basal nonconformity)

MBM: $\quad 0$ (no paleosols known)

NABH: 0 (as above)

Paleotopography

ELD: 40 (presence of paleovalleys could be predicted, since greenstone basalts directly underlie the basin)

MBM: $\quad 0$ (no paleovalleys delineated, could be present)

NABH: 0 (as above)

Accumulation-Burial Time-Lapse

ELD: $\quad 30$ (ideal conditions indicated by olfgomictic conglomerates in a subarkosic host rock)

MBM: 20 (some oligomictic conglomerates in a quartz wacke host)

NABH: 10 (no true oligomictic conglomerates; host is quartz wacke) Unconformity Parameter Score

$$
\begin{aligned}
\text { Fe ELD } & =30+30+40+30=130 \\
\text { Fe MBM } & =30+0+0+20=50 \\
\text { Fe NABH } & =0+0+0+10=10 \\
\text { Fm } & =30+30+40+30=130 \\
\text { Fna ELD } & =\frac{130}{130} \times 40=40 \text { (out of a possible 40) }
\end{aligned}
$$




$$
\begin{aligned}
& \text { Fna MBM }=\frac{50}{130} \times 40=15 \text { (out of a possible 40) } \\
& \text { Fna NABH }=\frac{10}{130} \times 40=3 \text { (out of a possible 40) }
\end{aligned}
$$

\section{Stratigraphic Setting Score}

$$
\begin{aligned}
& \text { Fe ELD }=40+40=80 \\
& \text { Fe MBM }=35+15=50 \\
& \text { Fe NABH }=18+3=21 \\
& \text { Fm }=40+40=80 \\
& \text { Fna ELD }=\frac{80}{80} \times 50=50 \text { (Table } 36 \text { shows that the maximum permissible } \\
& \text { value for stratigraphic setting is 50) } \\
& \text { Fna MBM }=\frac{50}{80} \times 50=31 \text { (out of a possible 50) } \\
& \text { Fna NABH }=\frac{21}{80} \times 50=13 \text { (out of a possible 50) }
\end{aligned}
$$

A perusal of these results indicates a perfect situation (relative to stratigraphic setting) for the Elliot Lake district. With respect to the two U.S. basins analyzed, the Medicine Bow Mountains turn out to be significantly more favorable than the Nemo area of the Black Hills. In large part this is due to the fact that the basal nonconformity is not exposed at Nemo. If this nonconformity were to be found (by drilling, for example), the Nemo area would assume a favorability similar to that of the Medicine Bow area.

\section{Host Rock Character}

Table 39 shows that uraniferous conglomerates can occur in association with basalts, quartz arenites, and with impure arenites (subarkoses and quartz wackes). The basins in question all contain uraniferous conglomerates in association with impure arenites, so the other host rock associations will not be evaluated here.

\section{Environment of Deposition}

ELD: $\quad 40$ (braided stream deposition)

MBM: 30 (no detailed studies, but available evidence indicates deposition by braided streams)

NABH: 30 (as above) 


\section{Color}

ELD: 60 (host sediments are shades of green, olive, khaki)

MBM: $\quad 60$ (as above)

NABH: 60 (as above)

\section{Texture}

ELD: 40 (relatively poor1y sorted, grains not we11 rounded)

MBM: $\quad 40$ (as above)

NABH: 40 (as above)

\section{Mineralogy}

ELD: 60 (composed of quartz and sericite with some feldspar)

MBM: 60 (as above)

NABH: 60 (quartz-muscovite arenite)

Geochemistry

K/Na Ratio. $\quad$ ELD: 60 (high $\mathrm{K} / \mathrm{Na}$ ratio typical of arenites)

MBM: $\quad 30$ (assumed high from mineralogical descriptions)

NABH: 60 (as for ELD)

K/Ca Ratio. ELD: 50 (high $\mathrm{K} / \mathrm{Ca}$ ratio typical of arenites)

MBM: 25 (assumed high from mineralogical descriptions)

NABH: 50 (as for ELD)

U Background. ELD: 50 (uranium background high)

MBM: $\quad 0$ (uranium background not evaluated)

NABH: 50 (as for ELD)

Trace Element Geochemistry. ELD: 0 (rich in appropriate trace elements)

MBM: $\quad 0$ (not evaluated)

NABH: 0 (as for ELD)

Geochemistry Score

$$
\text { Fe ELD }=60+50+50+0=160
$$




$$
\begin{aligned}
\text { Fe MBM } & =30+25+0+0=55 \\
\text { Fe NABH } & =60+50+50+0=160 \\
\text { Fm } & =60+50+50+0=160 \\
\text { Fna ELD } & =\frac{160}{160} \times 50=50 \text { (out of a possible 50) } \\
\text { Fna MBM } & =\frac{55}{160} \times 50=17 \text { (out of a possible 50) } \\
\text { Fna NABH } & =\frac{160}{160} \times 50=50 \text { (out of a possible 50) }
\end{aligned}
$$

\section{Host Rock Character Score}

$$
\begin{aligned}
& \text { Fe ELD }=40+60+40+60+50=250 \\
& \text { Fe MBM }=30+60+40+60+17=207 \\
& \text { Fe NABH }=30+60+40+60+50=240 \\
& \text { Fm }=40+60+40+60+50=250 \\
& \text { Fna ELD }=\frac{250}{250} \times 50=50 \text { (maximum score for host rock character, } \\
& \text { Fna MBM }=\frac{207}{250} \times 50=41 \text { (out of a maximum of } 50 \text { ) } \\
& \text { Fna NABH }=\frac{240}{250} \times 50=48 \text { (out of a maximum of 50) } \\
& \text { Conglomerate Character }
\end{aligned}
$$

\section{Conglomerate Character}

The final aspect of the comparison of the three basins is the numerical ranking of conglomerates within them (Table 40). To some extent this is a function of detail of study. The Elliot lake conglomerates have been far better studied than their U.S. counterparts. The scores of the latter are depressed because of this lack of data.

\section{Conglome rate Geometry}

\section{Thickness}

ELD: $\quad 30$ (many conglomerates $<3 \mathrm{~m}$ thick)

MBM: 30 (as above)

NABH: 30 (as above) 


\section{Lateral Extent}

ELD: $\quad 30$ (conglomerate-arentte packages can be traced over areas of up to $20 \mathrm{~km}^{2}$ )

MBM: $\quad 0$ (areas of conglomerate bodies not evaluated)

NABH: $\quad 0$ (as above)

Interna1 Stratigraphy

ELD: $\quad 30$ (a11 aspects of favorable internal stratigraphy have been observed)

MBM: $\quad 15$ (some aspects of favorable internal stratigraphy have been observed, for example, pyritic arenite partings)

NABH: 15 (as above)

Conglomerate Geometry Score

Fe ELD $=30+30+30=90$

$\mathrm{Fe} M B M=30+0+15=45$

Fe NABH $=30+0+15=45$

$\mathrm{Fm}=30+30+30=90$

Fna ELD $=\frac{90}{90} \times 30=30\left(\begin{array}{c}\text { (maximum value for conglomerate geometry, } \\ \text { Table } 40 \text { ) }\end{array}\right.$

Fna MBM $=\frac{45}{90} \times 30=15$ (out of a possible 30 )

Fna $\mathrm{NABH}=\frac{45}{90} \times 30=15$ (out of a possible 30 )

Pebble Assemblage

Size

ELD: 30 (pebble conglomerates common)

MBM: 30 (pebble conglomerates present)

NABH: 30 (as above)

Composition

ELD: 50 (oligomictic quartz clast conglomerates common) 
MBM: $\quad 0$ (oligomictic quartz clast conglomerates present, not common)

NABH: -50 (conglomerates olfgomictic in many cases, but clasts largely of quartzite)

Packing

ELD: 20 (well-packed conglomerates common)

MBM: 15 (wel1-packed conglomerates present)

NABH: 15 (as above)

Sorting

ELD: $\quad 0$ (no systematic quantitative sorting determinations available)

MBM: 0 (as above)

NABH: 0 (as above)

Shape

ELD: 20 (well-rounded, spherical pebbles common)

MBM: 15 (well-rounded, spherical pebbles present)

NABH: 15 (as above)

Color

ELD: $\quad 50$ (dark vein quartz clasts common)

MBM: 20 (dark vein quartz clasts present)

NABH: 20 (as above)

Pebble Assemblage Score

Fe ELD $=30+50+20+0+20+50=170$

Fe MBM Pos $=30+0+15+0+15+20=80$

Fe NABH Pos $=30+15+15+20=80$

Neg $=-50$

Fm Pos $=30+50+20+30+20+50=200$

Neg $=-60-80-10-50-70-50=-320$

Fna ELD $=\frac{170}{200} \times 50=43$ (out of a possible 50) 
Fna MBM $=\frac{80}{200} \times 50=20$ (out of a possible 50)

Fn NABH Pos $=\frac{80}{200}=0.40$

$$
\begin{aligned}
& \text { Neg }=\frac{-50}{-320}=-0.16 \\
& \text { Net }=0.40-0.16=0.24
\end{aligned}
$$

Fna NABH $=0.24 \times 50=12$

\section{Matrix Characteristics}

$\underline{\text { Texture }}$

ELD: 20 (matrix is coarse- or very coarse-grained)

MBM: 20 (as above)

NABH: 20 (as above)

Mineralogy

Light Minerals. ELD: 50 (quartz with sericite and some chlorite)

MBM: 50 (as above)

NABH: 50 (as above)

Heavy Minerals. ELD: 70 (heavy minerals include very abundant pyrite plus leucoxene, zircon, chromite, monazite)

MBM: $\quad 60$ (abundant pyrite, some zircon and monazite)

NABH: 65 (abundant pyrite, some zircon, chromite, anatase)

Carbon. ELD: 80 (carbon present in seams)

MBM: 10 (some graphite, may be derived from carbon)

NABH : -15 (no carbon recorded)

Mineralogy Score. Fe ELD $=50+70+80=200$

Fe $M B M=50+60+10=120$

Fe NABH Pos $=50+65=115$

$\mathrm{Neg}=-15$

Fm Pos $=50+70+80=200$ 


$$
\begin{aligned}
& \begin{array}{l}
\text { Neg }=-90-95-15=-200 \\
\text { Fna ELD }=\frac{200}{200} \times 80=80 \text { (maximum score for matrix } \\
\text { mineralogy, see Table } 40)
\end{array} \\
& \text { Fna MBM }=\frac{120}{200} \times 80=48 \text { (out of a possible 80) } \\
& \text { Fn NABH Pos }=\frac{115}{200}=0.58 \\
& \qquad \text { Neg }=\frac{-15}{-200}=-0.07 \\
& \text { Net }=.58-.07=0.51 \\
& \text { Fna NABH }=0.51 \times 80=41 \text { (out of possible } 80 \text { ) }
\end{aligned}
$$

Geochemistry

K/Na Ratio. ELD: 40 (ratio high)

MBM: 20 (ratio inferred to be high from mineralogical descriptions)

NABH : 40 (as for ELD)

U/Th Ratio. ELD: 50 (ratio high)

MBM: 0 (analyses of fresh rock not available)

NABH: 0 (ratio usually less than 1)

Trace Element Geochemistry. ELD: 50 (high levels of trace elements)

MBM: $\quad 0$ (trace element geochemistry not systematically studied)

NABH: 20 (relatively high levels of trace elements present)

Geochemistry Score.

$$
\begin{aligned}
\text { Fe ELD }=40+50+50=140 \\
\text { Fe MBM }=20+0+0=20 \\
\text { Fe NABH }=40+0+20=60 \\
\text { Fm = }=40+50+50=140 \\
\text { Fna ELD = } \frac{140}{140} \times 50=50 \begin{array}{l}
\text { (maximum allowable value } \\
\text { for conglomerate } \\
\text { geochemistry) }
\end{array}
\end{aligned}
$$




$$
\begin{aligned}
& \text { Fna MBM }=\frac{20}{140} \times 50=7 \text { (out of a possible 50) } \\
& \text { Fna NABH }=\frac{60}{140} \times 50=21 \text { (out of a possible 50) }
\end{aligned}
$$

Score for Matrix Characteristics

$$
\begin{aligned}
& \text { Fe ELD }=20+80+50=150 \\
& \text { Fe MBM }=20+48+7=75 \\
& \text { Fe NABH }=20+41+21=82 \\
& \text { Fm }=20+80+50=150 \\
& \text { Fna ELD }=\frac{150}{150} \times 70=70 \text { (maximum score for matrix characteristics, } \\
& \text { Fna MBM }=\frac{75}{150} \times 70=35 \text { (out of a possible 70) } \\
& \text { Fna NABH }=\frac{82}{150} \times 70=38 \text { (out of a possible 70) } \\
& \text { Mineralization }
\end{aligned}
$$

Radioactivity

ELD: 50 (strongly radioactive, > $20 \times$ background)

MBM: $\quad 30$ (frequently $>10 x$ background)

NABH: 10 (moderately radioactive, usually 5-10 x background)

Uranium Minerals

ELD: 70 (abundant uraninite and brannerite)

MBM: 40 (minor coffinite and some uranium-bearing thorite)

NABH: 30 (no uranium minerals 1dentified, probably in dispersed form)

\section{Mineralization Score}

$$
\begin{aligned}
\text { Fe ELD } & =50+70=120 \\
\text { Fe MBM } & =30+40=70 \\
\text { Fe NABH } & =10+30=40 \\
\text { Fm } & =50+70=120
\end{aligned}
$$




$$
\begin{aligned}
& \text { Fna ELD }=\frac{120}{120} \times 80=80 \text { (maximum score for mineralization) } \\
& \text { Fna MBM }=\frac{70}{120} \times 80=47 \text { (out of a possible } 80 \text { ) } \\
& \text { Fna NABH }=\frac{40}{120} \times 80=27 \text { (out of a possible } 80 \text { ) }
\end{aligned}
$$

\section{Conglomerate Character Score}

$$
\begin{aligned}
& \text { Fe ELD }=30+43+70+80=223 \\
& \text { Fe MBM }=15+16+35+47=113 \\
& \text { Fe NABH }=15+12+38+27=92 \\
& \text { Fm }=30+50+70+80=230 \\
& \text { Fna ELD }= \frac{223}{230} \times 70=68 \text { (out of a possible 70, Table 34) } \\
& \text { Fna MBM }=\frac{113}{230} \times 70=34 \text { (out of a possible 70) } \\
& \text { Fna NABH }=\frac{92}{230} \times 70=28 \text { (out of a possible 70) } \\
& \text { Comparison of the Potential of the Basins }
\end{aligned}
$$

We have now gathered all the numbers needed to evaluate the favorability of the Medicine Bow and Nemo areas relative to the Elliot Lake district. To do this, we need to sum the values of the major criteria given in Table 36 . For clarity, the relevant information is tabulated below.

Table 44. Numerical favorability values for use in calculating the overall relative favorability of three North American basins.

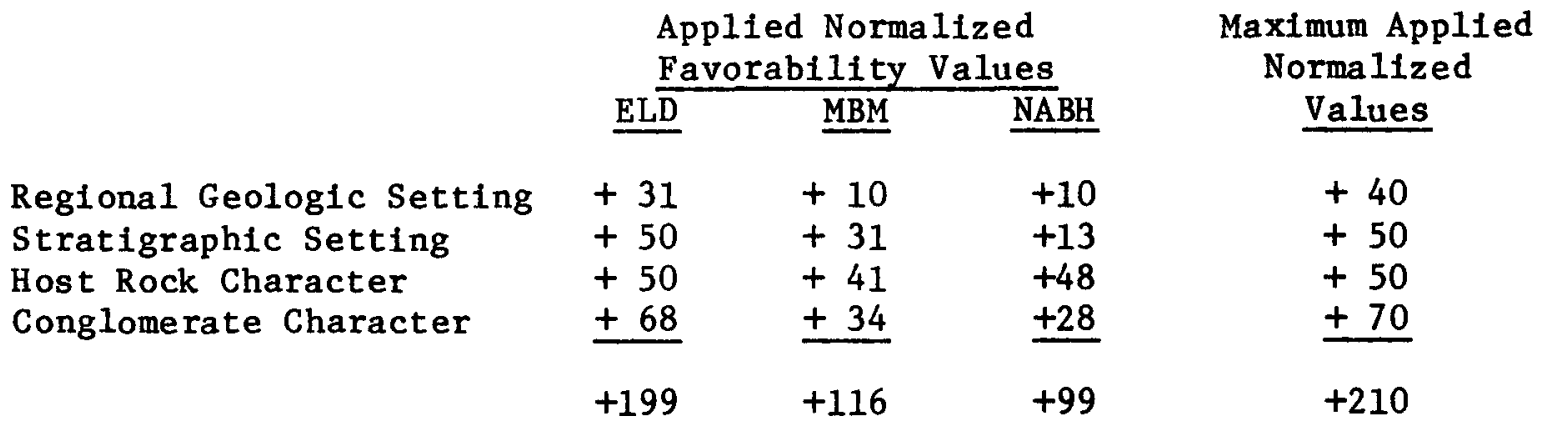




$$
\begin{aligned}
& \text { Fn ELD }=\frac{199}{210} \times 100=95 \% \\
& \text { Fn MBM }=\frac{116}{210} \times 100=55 \% \\
& \text { Fn NABH }=\frac{99}{210} \times 100=47 \%
\end{aligned}
$$

Application of the recognition criteria suggests that the Medicine Bow area has a somewhat higher potential for the development of economic uraniferous conglomerates than the Nemo area of the Black Hills. Neither area approaches the favorability of the Elliot Lake district. 
Blank

$-368-$ 
Adams, S.S., Curtis, H.S., and Hafen, P.L., 1974, Alteration of detrital magnetite-ilmenite in continental sandstones of the Morrison Formation, New Mexico, in Formation of uranium ore deposits: Vienna, Internationa1 Atomic Energy Agency, p. 219-253.

A11sopp, H.L., 1964, Rubidium/strontium ages from the western Transvaal: Nature, v. 204, p. 361-363.

Al1sopp, H.L., Roberts, H.R., Schreiner, G.D.L., and Hunter, D.R., 1962, Rb$\mathrm{Sr}$ age measurements on various Swaziland granites: Journal of Geophysical Research, v. 67, p. 5307-5313.

Almeida, F.F.M. de, Ameral, G., Cordani, U.G., and Kawashita, K., 1972, The Precambrian evolution of the South American cratonic margin south of the Amazon River, in Nairn, A.E.M., and Stehli, F.G., eds., The ocean basins and margins, v. 1: New York, Plenum Publishing Co., p. 411-446.

Anhaeusser, C.R., 1973, The evolution of the early Precambrian crust of southern Africa: Philosophical Transactions of the Royal Society of London, A273, p. 359-388.

Anhaeusser, C.R., 1975, Precambrian tectonic environments: Annual Review of Earth and Planetary Sciences, v. 3, p. 31-53.

Anhaeusser, C.R., 1976, The nature and distribution of Archaean gold mineralization in southern Africa: Minerals Science and Engineering, v. 8, p. 46-84.

Anhaeusser, C.R., Mason, R., Viljoen, M.J., and Viljoen, R.P., 1969, A reappraisal of some aspects of Precambrian shield geology: Geological Sóclety of America Bulletin, v. 80, p. 2175-2200.

Antrobus, E.S.A., and Whiteside, H.C.M., 1964, The geology of certain mines in the East Rand, in Haughton, S.H., ed., The geology of some ore deposits in southern Africa: Geological Society of South Africa, v. 1, p. 125-159.

Armstrong, G.C., 1968, Sedimentological control of gold mineralization in the Kimberley Reefs of the East Rand Goldfield: Johannesburg, University of the Witwatersrand Economic Geology Research Unit Information Circular $47,24 \mathrm{p}$.

Banks, P.0., and Van Schmus, W.R., 1972, Chronology of Precambrian rocks of Iron and Dickinson Counties, Michigan--part II (abs.): Houghton, Michigan, Institute on Lake Superior Geology, 18th Annual Abstracts and Field Guides, Paper 23.

Barton, J.M., Fripp, R.E.P., and Ryan, B., 1977, Rb/Sr ages and geologica1 setting of ancient dykes in the Sand River area, Limpopo Mobile Belt, South Africa: Nature, v. 267, p. 487-490. 
Baur, M.E., 1978, Thermodynamics of heterogeneous iron-carbon systems: Imp11cations for the terrestrial primitive reducing atmosphere: Chemical Geology, v. 22, p. 189-206.

Bayley, R.W., 1972, Preliminary geologic map of the Nemo district, Black Hills, South Dakota: U.S. Geological Survey Miscellaneous Geological Investigations, Map I-712.

Bayley, R.W., Dutton, C.E., and Lamey, C.A., 1966, Geology of the Menominee iron-bearing district, Dickinson County, Michigan, and Florence and Marinette Counties, Wisconsin: U.S. Geological Survey Professional Paper 513,96 p.

Bayley, R.W., and James, H.L., 1973, Precambrian iron-formation of the United States: Economic Geology, v. 68, p. 934-959.

Be11, R.T., 1970, The Hurwitz Group--a prototype for deposition on metastable cratons: Geological Survey of Canada Paper 70-40, p. 159-168.

Birkeland, P.W., 1974, Pedology, weathering and geomorphological research: New York, Oxford University Press, 285 p.

Blackwelder, E., 1926, Precambrian geology of the Medictne Bow Mountains: Geological Society of America Bulletin, v. 37, p. 615-658.

Brock, B.B., and Pretorius, D.A., 1964, Rand Basin sedimentation and tectonics, in Haughton, S.H., ed., The geology of some ore deposits in southern Africa: Geological Society of South Africa, v. 1, p. 549-600.

Burger, A.J., and Coertze, F.J., 1973, Radiometric age measurements on rocks from southern Africa to the end of 1971: Republic of South Africa Department of Mines, Geological Survey, Bulletin 58, 46 p.

Burger, A.J., Nicolaysen, L.O., and De Villiers, J.W.L., 1962, Lead isotopic compositions of galenas from the Witwatersrand and Orange Free State, and their relation to the Witwatersrand and Dominion Reef uraninites: Geochimica et Cosmochimica Acta, v. 26, p. 25-59.

Button, A., 1968, Subsurface stratigraphic analysis of the Witwatersrand and Transvaal sequences in the Irene-Delmas-Devon area, Transvaal: Johannesburg, University of the Witwatersrand unpublished M.Sc. thesis, $120 \mathrm{p}$.

Button, A., 1973, A regional study of the stratigraphy and development of the Transvaal Basin in the eastern and northeastern Transvaal: Johannesburg, University of the Witwatersrand unpublished Ph.D. dissertation, $352 \mathrm{p}$.

Button, A., 1976, Transvaal and Hamersley Basins--review of basin development and mineral deposits: Minerals Science and Englneering, v. 8, p. 262293.

Button, A., 1979, Early Proterozolc weathering profile on the 2,200 m.y. old Hekpoort Basalt, Pretoria Group, South Africa: Preliminary results: Johannesburg, University of the Witwatersrand Economic Geology Research Unit Information Circular 133, 37 p. 
Button, A., in press, Houtpoort Quartzite Member, marine-reworked facies of a Witwatersrand fan-delta: Johannesburg, University of the Witwatersrand Economic Geology Research Unit Information Circular.

Button, A., and Tyler, N., 1979, Precambrian paleoweathering and erosion surfaces in southern Africa: Review of their character and economic significance: Johannesburg, University of the Witwatersrand Economic Geology Research Untt Information Circular 135, 37 p.

Card, K.D., Church, W.R., Franklin, J.M., Frarey, M.J., Robertson, J.A., West, G.F., and Young, G.M., 1972, The Southern Province in Price, R.A., and Douglas, R.J.W., eds., Variation in tectonic styles in Canada: Geological Association of Canada Special Paper 11, p. 335-380.

Carg111, S.M., and Clark, A.L., eds., 1978, Standards for computer applications in resource studies--a conference held as part of the International Geological Correlation Program Project 98, Taita Hills, Kenya, November 815, 1979, published as Journal of the International Association for Mathematical Geology, v. 10, p. 405-642.

Cloud, P.E., 1976, Major features of crustal evolution: Alex L. du Tolt Memorial Lecture No. 14, Annexure to v. 79 of Transactions of the Geological Society of South Africa, 33 p.

Coertze, F.J., Burger, A.J., Walraven, F., Marlow, A.G., and MacCaskie, D.R., 1978, Field relations and age determinations in the Bushveld Complex: Transactions of the Geological Society of South Africa, v. 81, p. 1-12.

Coetzee, F., 1965, Distribution and grain-size of gold, uraninite, pyrite and certain other heavy minerals in gold-bearing reefs of the Witwatersrand Basin: Transactions of the Geological Soclety of South Africa, v. 68, p. $61-88$.

Cordani, U.G., Melcher, G.C., and Almeida, F.F.M. de, 1968, Outline of the Precambrian geochronology of South America: Canadian Journal of Earth Science, v. 5, p. 629-632.

Cousins, C.A., 1965, Disconformities in the Main Reef Zone of the Witwatersrand System, and their bearing on reef correlation, with particular reference to the east, central and west Witwatersrand: Transactions of the Geological Society of South Africa, v. 68, p. 121-142.

Cousins, C.A., 1973, Platinoids in the Witwatersrand System: Journa1 of the South African Institute of Mining and Metallurgy, v. 73, p. 184-199.

Cox, D.P., 1967, Regional environment of the Jacobina auriferous conglomerate, Brazil: Economic Geology, v. 62, p. 773-780.

Crawford, A.R., 1969, Reconnaissance $\mathrm{Rb}-\mathrm{Sr}$ dating of southern peninsular India: Journal of the Geological Society of India, v. 10, p. 117-160.

Davidson, C.F., 1957, On the occurrence of uranium in ancient conglomerates: Economic Geology, v. 52, p. 668-693. 
Davies, R.D., Allsopp, H.L., Erlank, A.J., and Manton, W.T., 1969, Sr-isotopic studies on various layered mafic intrusions in southern Africa: Geological Society of South Africa Special Publication 1, p. 576-593.

De Jager, F.S.J., 1964, The Witwatersrand System in the Springs-Nige1Heidelberg section of the East Rand Basin, in Haughton, S.H., ed., The geology of some ore deposits in southern Africa: Geological Society of South Africa, v. 1, p. 161-189.

De Kock, W.P., 1964, The geology and economic significance of the West Wits Line, in Haughton, S.H., ed., The geology of some ore deposits in southern Africa: Geological Society of South Africa, v. 1, p. 323-386.

De Laeter, J.R., and Blockley, J.G., 1972, Granite ages within the Archean Plibara Block, western Australia: Journal of the Geological Society of Australia, v. 19, p. 363-370.

De Laeter, J.R., and Trenda11, A.F., 1971, The age of the Gidley Granophyre: Geological Survey of West Australia Annual Report for 1970, p. 62-67.

De Sá, E.F.J., McReath, I., Neves, B.B. de B., Bartels, R.L., and Kawashita, K., 1976, Reconnaissance geochronology of the infrastructure of part of the Saõ Francisco Craton in the state of Bahla, Brazil: Nata1, Braz11, Federal University of R1o Grande do Norte unpublished manuscript.

Desborough, G.A., and Sharp, W.N., 1979, Uranium and thorium minerals in Precambrian metaconglomerates, Medicine Bow Mountains, south-central Wyoming, in Houston, R.S., Karlstrom, K.E., and Graff, P.J., Progress report on the study of radioactive quartz-pebble conglome rate of the Medicine Bow Mountains and Sierra Madre, southeastern Wyoming: U.S. Geological Survey Open-File Report 79-1131, p. 38-39.

De Waal, S.A., and Herzberg, W., 1969, Uranium and gold mineralization of the Black Reef Series in the Kaapsehoop area, Nelspruit district, eastern Transvaal: Annals, Republic of South Africa Department of Mines, Geological Survey, v. 7, p. 111-124.

Dimanche, F., and Bartholomé, P., 1976, The alteration of ilmentte in sediments: Minerals Science and Engineering, v. 8, p. 187-201.

Dimroth, E., 1979, Significance of diagenesis for the origin of Witwatersrandtype uraniferous conglomerates: Philosophical Transactions of the Royal Society of London, A291, p. 277-287.

Dimroth, E., 1980, Synopsis of sedimentological evidence suggesting high oxygen concentrations in the atmosphere and ocean since very early Precambrian time: Paper presented at the joint meeting of International Geologic Correlation Program project 157 and 160 working groups, Santa Barbara, California, April 1980.

Dimroth, E., and Lichtblau, A.P., 1978, 0xygen in the Archean ocean: Comparison of ferric oxide crusts on Archean and Calnozolc pillow basalts: Neues Jahrbuch für Mineralogie, Abhandlungen, v. 133, p. 1-22. 
Dorr, J. van N., 1969, Physiographic, stratigraphic, and structural development of the Quadrilatero Ferrifero, Minas Gerais, Brazi1: U.S. Geological Survey Professional Paper 641A, $110 \mathrm{p}$.

Du Toit, A.L., 1954, The geology of South Africa (3d ed.): New York, Hafner Publishing Co., 611 p.

Ellsworth, H.V., 1928, Thucholite, a remarkable primary carbon mineral from the vicinity of Parry Sound, Ontario: American Mineralogist, v. 13, p. 419-441.

Eriksson, K.A., 1979, Marginal marine depositional processes from the Archean Moodies Group, Barberton Mountain Land, South Africa: Evidence and significance: Precambrian Research, v. 8, p. 153-182.

Fairbairn, H.W., 1965, Re-examination of $\mathrm{Rb}-\mathrm{Sr}$ whole rock ages at SudburyBlind River, Ontario: Massachusetts Institute of Technology, Department of Geology and Geophysics, 13th Annual Report, 1381-13, p. 107.

Fairbairn, H.W., Hurley, P.M., Card, K.D., and Knight, C.J., 1969, Correlation of radiometric ages of Nipissing Diabase and Huronian meta sediments with Proterozoic orogenic events in Ontario: Canadian Journal of Earth Science, v. 6, p. 489-497.

Feather, C.E., 1975, Some aspects of the mineralogy of the Witwatersrand and related reefs: Rondebosch, South Africa, University of Cape Town unpublished $\mathrm{Ph} . \mathrm{D}$. dissertation.

Feather, C.E., in press, Some aspects of Witwatersrand mineralization with special reference to uranium minerals: U.S. Geological Survey Professional Paper.

Feather, C.E., and Duggan, L.W., 1974, Investigation of arsenosulphides in the Witwatersrand reefs: Proceedings Electron Microscopy South Africa, v. 4, p. 73-74.

Feather, C.E., and Koen, G.M., 1975, The mineralogy of the Witwatersrand reefs: Minerals Science and Engineering, v. 7, p. 189-224.

Feather, C.E., and Snegg, J.A., 1978, The role of brannerite in the recovery of uranium from Witwatersrand reefs: Transactions of the Geological Society of South Africa, v. 81, p. 255-260.

Ferris, C.S., and Ruud, C.0., 1971, Brannerite: Its occurrences and recognition by microprobe: Colorado School of Mines Quarterly, v. 66, p. 1-35.

Frarey, M.J., 1977, Geology of the Huronian belt between Sault Ste. Marie and Blind River, Ontario: Geological Survey of Canada Memoir 383, 87 p.

Friedman, G.M., and Sanders, J.E., 1978, Principles of sedimentology: New York, John Wiley and Sons, 792 p.

Fronde1, C., 1958, Systematic mineralogy of uranium and thorium: U.S. Geological Survey Bulletin 1064, 400 p. 
Fryer, B.J., 1977, Geochemistry of early Proterozoic paleosols, north of Lake Huron, Ontario: Geological Abstracts and Proceedings of the 25th annual meeting of the Lake Superior Conference.

Fuller, A.0., 1958, A contribution to the petrology of the Witwatersrand System: Transactions of the Geological Society of South Africa, v. 61 , p. $19-45$.

Gaál, G., Mikkola, A., and Söderholm, B., 1978, Evolution of the Archean crust in Finland: Precambrian Research, v. 6, p. 199-215.

Gabelman, J.W., 1977, Migration of uranium and thorium-exploration significance: American Association of Petroleum Geologists, 168 p.

Gair, J.E., and Thaden, R.E., 1968, Geology of the Marquette and Sands Quadrangles, Marquette County, Michigan: U.S. Geological Survey Professional Paper 397,77 p.

Gair, J.E., and Weir, K.L., 1956, Geology of the Kiernan Quadrangle, Iron County, Michigan: U.S. Geological Survey Bulletin 1044, 88 p.

Gashnig, J., 1980, Development of uranium exploration models for the Prospector consultant system: Menlo Park, California, S.R.I. International, Project $7856,603 \mathrm{p}$.

Gay, A.L., and Grandstaff, D.E., in press, Chemistry and mineralogy of Precambrian paleosols at Elliot Lake, Ontario, Canada: Precambrian Research.

Gee, R.D., 1979, Structure and tectonic style of the western Australian Shield: Tectonophysics, v. 58, p. 327-369.

Gleeson, C.F., 1963, Reconnalssance heavy mineral study in Northern Yukon Territory: Geological Survey of Canada Paper 63-32, 10 p.

Goddard, E.N., 1963, Rock-colour chart: The Netherlands, Huyskes-Enschede.

Graff, P., 1979, A review of the stratigraphy and uranium potential of Early Proterozolc (Precambrian X) metasediments in the Slerra Madre, Wyoming: University of Wyoming Contributions to Geology, v. 17, p. 149-157.

Grandstaff, D.E., 1974a, Uraninite oxidation and the Precambrian atmosphere (abs.): Transactions of the American Geophysical Union, v. 55, p. 457.

Grandstaff, D.E., 1974b, Microprobe analyses of uranium and thorium in uraninite from the Witwatersrand, South Africa, and Blind River, Ontario, Canada: Transactions of the Geological Society of South Africa, v. 77, p. 291-294.

Grandstaff, D.E., 1976, A kinetic study of the dissolution of uraninite: Economic Geology, v. 71, p. 1493-1505.

Grandstaff, D.E., in press, Origin of uraniferous conglomerates at Elliot Lake, Canada, and Witwatersrand, South Africa: Implications for oxygen in the Precambrian atmosphere: Precambrian Research. 
Gross, W.H., 1968, Evidence for a modified placer origin for auriferous conglomerates, Canavietras Mine, Jacobina, Brazil: Economic Geology, v. 63 , p. 271-276.

Hallbauer, D.K., 1975, The plant origin of the Witwatersrand "carbon": Minerals Science and Engineering, v. 7, p. 111-131.

Hallbauer, D.K., and Joughin, N.C., 1973, The size distribution and morphology of gold particles in Witwatersrand reefs and their crushed products: Journal of the South African Institute of Mining and Metallurgy, v. 73, p. 395-405.

Hallbauer, D.K., and Utter, T., 1976, Geochemical and morphological character1stics of gold particles from recent river deposits and the fossil placers of the Witwatersrand: Republic of South Africa unpublished Chamber of Mines Research Report, 18 p.

Hallbauer, D.K., and Utter, T., 1977, Geochemical and morphological characteristics of gold particles from recent river deposits and the fossil placers of the Witwatersrand: Mineralium Deposita, v. 12, p. 293-306.

Hallbauer, D.K., and Van Warmelo, K.T., 1974, Fossilized plants in thucholite from Precambrian rocks of the Witwatersrand, South Africa: Precambrian Research, v. 1, p. 199-212.

Hamilton, P.J,, 1976, Isotope and trace element studies of the Great Dyke and Bushveld mafic phase and their relation to early Proterozoic magma genesis in southern Africa: Journal of Petrology, v. 12, p. 24-52.

Hargraves, R.B., 1962, Cross-bedding and ripple-marking in the Main-Bird Series of the Witwatersrand System in the East Rand area: Transactions of the Geological Society of South Africa, v. 65, p. 263-275.

Harris, D.P., and Carrigan, F.J., 1980, A probabilistic endowment appraisal system based upon the formalization of geologic decisions, a general description: Grand Junction, Colorado, U.S. Department of Energy, 114 p.

Hart, P.E., Duda, R.0., and Elnaudi, M.T., 1978, Prospector--a computer-based consultation system for mineral exploration: Journal of the International Association for Mathematical Geology, v. 10, p. 589-610.

Hendricks, L.P., 1964, Quantitative evidence of the alteration of $z$ ircon grains in the Dominion Reef: Transactions of the Geological Society of South Africa, v. 67, p. 211-217.

Herz, N., 1970, Gneissic and igneous rocks of the Quadrilatero Ferrifero, Minas Gerais, Brazil: U.S. Geological Survey Professional Paper 641-B, $58 \mathrm{p}$.

Hiemstra, S.A., 1968a, The mineralogy and petrology of the uraniferous conglomerate of the Dominion Reefs mine, Klerksdorp area: Transactions of the Geological Society of South Africa, v. 71, p. 1-65. 
Hiemstra, S.A., 1968b, The geochemistry of the uraniferous conglomerate of the Dominion Reefs mine, Klerksdorp area: Transactions of the Geological Society of South Africa, v. 71, p. 67-100.

Hills, F.A., 1977, Uranium and thorium in the middle Precambrian Estes Conglomerate, Nemo district, Lawrence County, South Dakota--a preliminary report: U.S. Geological Survey Open-File Report 77-55, 27 p.

Hi11s, F.A., 1979, Uranium, thorium and gold in the lower Proterozoic (?) Estes Conglomerate, Nemo district, Lawrence County, South Dakota: University of Wyoming Contributions to Geology, v. 17, p. 159-172.

Hills, F.A., Gast, P.W., Houston, R.S., and Swainbank, I., 1968, Precambrian geochronology of the Medicine Bow Mountains of southeastern Wyoming: Geological Society of America Bulletin, v. 79, p. 1757-1784.

Hoefs, J., Nielsen, H., and Schidlowski, M., 1968, Sulfur isotope abundances in pyrite from the Witwatersrand conglomerates: Economic Geology, v. 63 , p. $975-977$.

Hoefs, J., and Schidlowski, M., 1967, Carbon isotope composition of carbonaceous matter from the Precambrian of the Witwatersrand System: Science, v. 155, p. 1096-1097.

Hoering, T.C., 1967, The organic geochemistry of Precambrian rocks, in Abelson, P.H., ed., Researches in geochemistry, a seminar series conducted at the Department of Geology, The Johns Hopkins University, v. 2: New York, John Wiley, p. 87-111.

Houston, R.S., and Karlstrom, K.E., 1979, Uranium-bearing quartz-pebble conglomerates: Exploration model and United States potential: Laramie, Wyoming, University of Wyoming, $510 \mathrm{p}$.

Houston, R.S., Karlstrom, K.E., and Graff, P.J., 1979, Progress report on the study of radioactive quartz-pebble conglomerates of the Medicine Bow Mountains and Sierra Madre, southeastern Wyoming: U.S. Geological Survey Open-File Report 79-1131.

Houston, R.S., and others, 1968, A regional study of rocks of Precambrian age in that part of the Medicine Bow Mountains lying in southeastern Wyoming, with a chapter on the relationship between Precambrian and Laramide structure: Geological Survey of Wyoming Memolr 1, 167 p.

Hunter, D.R., 1957, The geology, petrology and classification of the Swaziland grantes and gneisses: Transactions of the Geological Society of South Africa, v. 60 , p. 85-120.

Hunter, D.R., 1974, Crustal development in the Kaapvaal Craton: Precambrian Research, v. I, p. 259-326.

Jacob, R.E., 1966, The geology of the Vaal Reefs Mine: Grahamstown, Rhodes University unpublished M.Sc. thesis. 
James, H.L., Clark, L.D., Lamay, C.A., and Pettijohn, F.J., 1961, Geology of central Dickinson County, Michigan: U.S. Geological Survey Professional Paper 310, 176 p.

James, H.L., and Trenda11, A.F., in press, Banded iron-formation: Distribution in time and paleoenvironmental significance: Paper presented at Dahlem Workshop on Biospheric Evolution and Metallogeny, Berlin, September 1980 .

Jenny, H., 1935, The clay content of the soil as related to climatic factors, particularly temperature: Soil Science, v. 40, p. 111-128.

Jenny, H., 1941, Factors of soil formation: New York, McGraw-H111 Book Co., 281 p.

Just, J., and Feather, C.E., 1978, Tucekite, a new antimony analogue of hauchecornite: Mineralogical Magazine, v. 42, p. 278.

Kalliokoski, J., 1975, Chemistry and mineralogy of Precambrian paleosols in northern Michigan: Geological Society of America Bulletin, v. 86, p. $371-376$.

Kalliokoski, J., 1976, Uranium and thorium occurrences in Precambrian rocks, Upper Peninsula of Michigan and northern Wisconsin, with thoughts on other possible settings: U.S. Energy Research and Development Administration GJBX-48(76), 294 p.

Karlstrom, K.E., and Houston, R.S., 1979a, Stratigraphy and uranium potential of early Proterozoic metasedimentary rocks in the Medicine Bow Mountains, Wyoming: Geological Survey of Wyoming Report of Investigations No. 13, 45 p.

Karlstrom, K.E., and Houston, R.S., 1979b, Stratigraphy of the Phantom Lake Metamorphic Suite and Deep Lake Group and a review of the Precambrian tectonic history of the Medicine Bow Mountains: Untversity of Wyoming Contributions to Geology, v. 17, p. 111-133.

Kent, L.E., 1961, Note on chloritoid in the Witwatersrand System: Transactions of the Geological Society of South Africa, v. 64, p. 91-96.

Kim, J.D., 1979, Mineralogy and trace elements of the uraniferous conglom erates, Nemo district, Black Hills, South Dakota: Rapid City, South Dakota, South Dakota School of Mines and Technology unpublished Ph.D. dissertation, $125 \mathrm{p}$.

Kimberley, M.M., 1978, Origin of stratiform uranium deposits in sandstone, conglomerate, and pyroclastic rock, in Kimberley, M.M., ed., Short course in uranium deposits: Thelr mineralogy and origin: Mineralogical Association of Canada, p. 339-381.

Kimberley, M.M., Tanaka, R.T., and Farr, M.R., in press, Composition of Middle Precambrian uraniferous conglomerate in the E11iot Lake-Agnew Lake area of Canada: Precambrian Research. 
Klein, G. de V., 1975, Sandstone depositional models for the exploration for fossil fuels: Champaign, Illinols, Continuing Education Publishing Co., $109 \mathrm{p}$.

Knowles, A.G., 1966, A palaeocurrent study of the Ventersdorp Contact Reef at Western Deep Levels, Limited, on the Far West Rand: Johannesburg, University of the Witwatersrand unpublished M.Sc. thesis, 125 p.

Koen, G.M., 1958, The attrition of uraninite: Transactions of the Geological Society of South Africa, v. 61, p. 183-191.

Koen, G.M., 1961, The genetic significance of the size distribution of uraninite in Witwaters rand bankets: Transactions of the Geological Society of South Africa, v. 64, p. 23-46.

Koen, G.M., 1962, Note on chlorite pseudomorphs after detrital amphibole in Witwatersrand banket: Transactions of the Geological Soclety of South Africa, v. 65, p. 57-58.

Köppel, V.H., and Saager, R., 1974, Lead 1sotope evidence on the detrital origin of Witwatersrand pyrites and its bearing on the provenance of Witwatersrand gold: Economic Geology, v. 69, p. 318-331.

Krapez, B., 1980, A sedimentological study of the Ventersdorp Contact Reef at East Driefontein Gold Mine, Carletonville, South Africa: Johannesburg, University of the Witwatersrand unpublished M.Sc. thesis, 237 p.

Krauskopf, K.B., 1979, Introduction to geochemistry (2d ed.): New York, McGraw-Hill Book Co., 617 p.

Kröner, A., Anhaeusser, C.R., and Vajner, V., 1973, Neue Ergebnisse zur Evolution der präkambrischen Kruste im südlichen Afrika: Geologische Rundschau, v. 62, p. 281-309.

Lang, A.H., Goodwin, A.M., Mulligan, R., Whitmore, D.R.E., Gross, G.A., Boyle, R.W., Johnson, A.G., Chamberlain, J.A., and Rose, E.R., 1976, Economic minerals of the Canadian Shield, in Douglas, R.J.W., ed., Geology and economic minerals of Canada: Geological Survey of Canada Economic Geology Report, Part A, p. 151-226.

Langford, F.F., 1977, Surficial origin of North American pitchblende and related uranium deposits: Bulletin of the American Association of Petroleum Geologists, v. 61, p. 28-42.

Langmuir, D., 1978, Uranium solution-mineral equilibria at low temperatures with applications to sedimentary ore deposits, in Kimberley, M.M., ed., Short course in uranium deposits: Their mineralogy and origin: Mineralogical Association of Canada, v. 3, p. 17-55.

Lentha11, D.H., 1970, A micro-sedimentological study of the upper Witwatersrand sequence in the East Rand-Delmas area, Transvaal: Johannesburg, University of the Witwatersrand unpublished M.Sc. thesis, 105 p. 
Lidiak, E.G., 1971, Buried Precambrian rocks of South Dakota: Geological Society of America Bulletin, v. 82, p. 1411-1420.

Liebenberg, W.R., 1955, The occurrence and origin of gold and radioactive minerals in the Witwatersrand System, the Dominion Reef, the Ventersdorp Contact Reef and the Black Reef: Transactions of the Geological Society of South Africa, v. 58, p. 101-227.

Liebenberg, W.R., 1973, Mineralogical features of gold ores in South Africa, in Adamson, R.J., ed., Gold metallurgy in South Africa: Johannesburg, Chamber of Mines of South Africa, p. 352-446.

Loskorin, B.N., Metalnikov, S.S., and Terentiev, A.S., 1958, Extraction of uranium from natural water: Proceeding of the Second United Nations International Conference on the Peaceful Uses of Atomic Energy, v. 3, p. 211-215.

Louw, J.D., 1954, Geologica1 age determinations on Witwatersrand uraninites using the lead isotope method: Transactions of the Geological society of South Africa, v. 57, p. 209-227.

Louw, J.D., 1955, Geological ages of Witwatersrand uraninites: Nature, v. 175 , p. 349 .

Mair, J.A., Maynes, A.D., Patchett, J.E., and Russel, R.D., 1960, Isotopic evidence on the origin and age of the Blind River uranium deposits: Journal of Geophysical Research, v. 65, p. 341-348.

Marsden, R.W., 1972, Cuyana district, in Sims, P.K., and Morey, G.B., eds., Geology of Minnesota: Minnesota Geological Survey, p. 227-239.

Matthews, P.E., and Scharrer, R.H., 1968, A graded unconformity at the base of the early Precambrian Pongola System: Transactions of the Geological Society of South Africa, v. 71, p. 257-271.

McDowe11, J.P., 1957, The sedimentary petrology of the Mississagi Quartzite in the Blind River area: Ontario Department of Mines Geological Circular $6,31 \mathrm{p}$.

McKinney, J.S., and others, 1964, Geology of the Anglo American Group mines in the Welkom area, Orange Free State Goldfield, in Haughton, S.H., ed., The geology of some ore deposits in southern Africa: Geological Society of South Africa, v. 1, p. 451-506.

McLachlan, C., 1968, A grain study of zircon and chromite in the Vaal Reef of the Klerksdorp Goldfield, Transvaal: Johannesburg, University of the Witwatersrand unpublished M.Sc. thesis.

McLennan, S.M., and Tayler, S.R., 1979, Rare earth element mobility assoclated with uranium mineralization: Nature, v. 282, p. 247-249.

McLeod, C.R., 1959, Trial study of heavy mineral content of certain deposits of sand and gravel in New Brunswick, Nova Scotia and Prince Edward Island: Geological Survey of Canada Paper 59-7, 21 p. 
McLimans, R.K., 1972, Granite-bearing conglomerates in the Knife Lake Group, Vermilion district, in Sims, P.K., and Morey, G.B., eds., Geology of Minnesota: Minnesota Geological Survey, p. 91-101.

McNei1, M., 1980, Brazil's uranium/thorium deposits: San Francisco, Miller Freeman Publications, Inc., 125 p.

Mia11, A.D., 1977, A review of the braided river depositional environment: Earth-Science Reviews, v. 13, p. 1-62.

Mihalik, P., and Saager, R., 1968, Chromite grains showing altered borders from the Basal Reef, Witwatersrand System: Johannesburg, University of the Witwatersrand Economic Geology Research Unit Information Circular 43, 6 p.

Minter, W.E.L., 1970, Gold distribution related to sedimentology of a Precambrian Witwatersrand conglomerate, South Africa, as outlined by moving-average analysis: Economic Geology, v. 65, p. 963-969.

Minter, W.E.L., 1972, Sedimentology of the Vaal Reef in the Klerksdorp area: Johannesburg, University of the Witwatersrand unpublished Ph.D. dissertation, $170 \mathrm{p}$.

Minter, W.E.L., 1976, Detrital gold, uranium, and pyrite concentrations related to sedimentology in the Precambrian Vaal Reef placer, Witwatersrand, South Africa: Economic Geology, v. 71, p. 157-176.

Minter, W.E.L., 1978, A sedimentological synthesis of placer gold, uranium and pyrite concentrations in Proterozolc Witwatersrand sediments: Canadian Society of Petroleum Geologists Memoir 5, p. 801-829.

Minter, W.E.L., 1979, Hydraulic equivalence of gold and pyrite grains in the Carbon Leader Reef, Blyvooruitzicht, Carletonville goldfield: Anglo American Corporation, Welkom Office, Report 11/000/366/79/1146, 4 p.

Monster, J., Appe1, P.W.V., Thode, H.G., Schidlowski, M., Carmichael, C.M., and Bridgwater, D., 1979, Sulfur isotope studies in early Archean sediments from Isua, West Greenland: Implications for the antiquity of bacterial sulfate reduction: Geochimica et Cosmochimica Acta, v. 43, p. 405-413.

Moorbath, S., O'Nions, R.K., and Pankhurst, R.J., 1973, Early Archean age for the Isua iron formation, West Greenland: Nature, v. 245, p. 138-139.

Morey, G.B., 1972a, Middle Precambrian, general geologic setting, in Sims, P.K., and Morey, G.B., eds., Geology of Minnesota: Minnesota Geological Survey, p. 199-203.

Morey, G.B., 1972b, Mesabi Range, in Sims, P.K., and Morey, G.B., eds., Geology of Minnesota: Minnesota Geological Survey, p. 204-217.

Morey, G.B., 1972c, Gunflint Range, in Sims, P.K., and Morey, G.B., eds., Geology of Minnesota: Minnesota Geological Survey, p. 218-226. 
Morey, G.B., and Sims, P.K., 1976, Boundary between two Precambrian W terranes in Minnesota and its geologic significance: Geological Society of America Bulletin, v. 87, p. 141-152.

Nicolaysen, L.0., Burger, A.J., and Liebenberg, W.R., 1962, Evidence for the extreme age of certain minerals from the Dominion Reef conglomerates and the underlying granite in the western Transvaal: Geochimica et Cosmochimica Acta, v. 26, p. 15-23.

Nishimori, R.K., Ragland, P.C., Rogers, J.J.W., and Greenberg, J.K., 1977, Uranium deposits in granitic rocks: U.S. Energy Research and Development Administration Report GJBX-13(77), Grand Junction, Colorado, 93 p.

Nuffield, E.W., 1954, Brannerite from Ontario, Canada: American Mineralogist, v. 39 , p. 520-522.

Oberlies, F., and Prashnowsky, A.A., 1968, Biogeochemische und elektronenmikroskopische Untersuchung praekambrischer Gesteine: Naturwissenschaften, v. 55, p. 25-28.

0 jakangas, R.W., 1972, Graywackes and related rocks of Knife Lake Group and Lake Vermilion Formation, Vermilion district, in Sims, P.K., and Morey, G.B., eds., Geology of Minnesota: Minnesota Geological Survey, p. 82-90.

Olivier, H.J., 1965, The tectonics of the Upper Division of the Witwatersrand System in the Loraine area of the Orange Free State Gold-field: Transactions of the Geological Society of South Africa, v. 68, p. 143-175.

Oosthuyzen, E.J., 1970, The geochronology of a suite of rocks from granitic terrain surrounding the Barberton Mountain Land: Johannesburg, University of the Witwatersrand unpublished Ph.D. dissertation.

Oosthuyzen, E.J., and Burger, A.J., 1964, Radiometric dating of intrustves associated with the Waterberg System: Annals, Republic of South Africa Department of Mines, Geological Survey, v. 3, p. 87-106.

Ortlepp, R.J., 1962, On the occurrence of uranothorite in the Dominion Reef: Transactions of the Geological Society of South Africa, v. 65, p. 197-202.

Papenfus, J.A., 1964, The Black Reef Series with1n the Witwatersrand Basin with special reference to its occurrence at government gold mining areas, in Haughton, S.H., ed., The geology of some ore deposits in southern Africa: Geological Soclety of South Africa, v. 1, p. 189-218.

Patchett, J.E., 1960, A study of the radioactive minerals of the uraniferous conglomerate, Blind River area: University of Toronto unpublished Ph.D. dissertation, 220 p.

Perry, E.A., and Hower, J., 1972, Late-stage dehydration in deep1y burled pelitic sediments: American Association of Petroleum Geologists Bulletin, v. 56, p. 2013-2021.

Pettijohn, F.J., 1943, Archean sedimentation: Geological Society of America Bulletin, v. 54, p. 925-972. 
Pettijohn, F.J. 1956, Sedimentary rocks (2d ed.): New York, Harper and Bros., 718 p.

Pettijohn, F.J., 1975, Sedimentary rocks (3d ed.): New York, Harper and Row, $628 \mathrm{p}$.

Pienaar, P.J., 1963, Stratigraphy, petrology, and genesis of the Elliot Group, Blind River, Ontario, including the uraniferous conglome rate: Geological Survey of Canada Bulletin 83, 140 p.

Piper, J.D.A., 1976, Paleomagnetic evidence for a Proterozoic supercontinent: Philosophical Transactions of the Royal Society of London, A280, p. 469-490.

Prashnowsky, A.A., and Schidlowski, M., 1967, Investigation of Pre-Cambrian thucholite: Nature, v. 216, p. 560-563.

Pretorlus, D.A., 1964a, The geology of the Central Rand goldfield, in Haughton, S.H., ed., The geology of some ore deposits in southern Africa: Geological Society of South Africa, v. 1, p. 63-108.

Pretorius, D.A., 1964b, The geology of the South Rand goldfield, in Haughton, S.H., ed., The geology of some ore deposits in southern Africa: Geological Society of South Africa, v. 1, p. 219-282.

Pretorius, D.A., 1975, The depositional environment of the Witwatersrand goldfields: A chronological review of speculations and observations: Minerals Science and Engineering, v. 7, p. 18-47.

Pretorius, D.A., 1976, The nature of the Witwatersrand gold-uranium deposits, in Wolf, K.H., ed., Handbook of strata-bound and stratiform ore deposits: Amsterdam, Elsevier, p. 22-88.

Puffet, W.P., 1969, The Reany Creek Formation, Marquette County, Michigan: U.S. Geological Survey Bulletin 1274-F, 25 p.

Puffet, W.P., 1974, Geology of the Negaunee Quadrangle, Marquette County, Michigan: U.S. Geological Survey Professional Paper 788, 51 p.

Radhakrishna, B.P., and Vasudev, V.N., 1977, The early Precambrian of the southern Indian shield: Journal of the Geological Society of India, v. 18 , p. 525-541.

Ramdohr, P., 1957, Die "Pronto-Reaktion": Neues Jahrbuch für Mineralogie, Monatshefte, 1957, p. 217-222.

Ramdohr, P., 1958, New observations on the ores of the Witwatersrand in South Africa and their genetic significance: Transactions of the Geological Society of South Africa, Annexure to v. 61, 50 p.

Ratté, J.C., and Zartman, R.E., 1970, Bear Mountain gneiss dome, Black Hills, South Dakota--age and structure: Geological Soclety of America, Abstracts with Programs, v. 2 (5), p. 345. 
Redden, J.A., 1980, Geology and urantum resources in Precambrian conglomerates of the Nemo area, Black H11ls, South Dakota: U.S. Department of Energy, Bendix Field Engineering Corporation, Subcontract No. 79-311-E, 147 p.

Redden, J.A., and Norton, J.J., 1975, Precambrian geology of the Black Hills, in Mineral and water resources of South Dakota: U.S. Senate, Committee on Interior and Insular Affairs, Henry M. Jackson, Chairman, p. 21-28.

Reineck, H.E., and Singh, I.B., 1973, Depositional sedimentary environments: New York, Springer, 439 p.

Reinecke, L., 1927, The location of payable ore-bodies in the gold-bearing reefs of the Witwatersrand: Transactions of the Geological Society of South Africa, v. 30, p. 89-119.

Rice, R., 1958, Geology and ore deposits of the Elliot Lake district, Ontario: England, Emmanuel College unpublished Ph.D. dissertation.

Riley, G.H., 1970, Isotopic discrepancies in zoned pegmatites, Black Hills, South Dakota: Geochimica et Cosmochimica Acta, v. 34, p. 713-725.

Robb, L.J., 1978, A general geological description of the Archaean grantic terrane between Nelspruit and Bushbuckridge, eastern Transvaal: Transactions of the Geological Society of South Africa, v. 81, p. 331-338.

Robb, L.J., 1979, The distribution of granitophile elements in Archean granites of the eastern Transvaal and their bearing on geomorphological and geological features of the area: Transactions of the Geological Soclety of South Africa, v. 82, p. 169-178.

Robertson, D.S., 1962, Thorfum and uranium variations in the Blind River ores: Economic Geology, v. 57, p. 1175-1184.

Robertson, D.S., 1974, Basal Proterozoic unfts as fossil time markers and their use in uranium prospection: Vienna, International Atomic Energy Agency publication SM-183/35, p. 495-512.

Robertson, D.S., Tilsley, J.E., and Hogg, G.M., 1978, The time-bound character of uranium deposits: Economic Geology, v. 73, p. 1409-1419.

Robertson, J.A., 1960, The general geology of part of the Blind River area: Kingston, Ontario, Queen's University unpublished M.Sc. thesis, 433 p.

Robertson, J.A., 1976, The Blind River uranium deposits: The ores and their setting: Ontario Division of Mines Miscellaneous Paper 65, 45 p.

Robertson, J.A., 1978, Uranium deposits in Ontario, in Kimberley, M.M., ed., Short course in uranium deposits: Their mineralogy and origin: Mineralogical Association of Canada, 3, p. 229-280.

Roscoe, S.M., 1959a, On thorium-uranium ratios in conglomerate and associated rocks near Blind River, Ontario: Economic Geology, v. 54, p. 511-512. 
Roscoe, S.M., 1959b, Monazite as an ore mineral in Elliot Lake uranium ores: Canadian Mining Journal, July 1959, p. 65-66.

Roscoe, S.M., 1969, Huronian rocks and uraniferous conglomerates in the Canadian Shield: Geological Survey of Canada Paper 68-40, 205 p.

Roscoe, S.M., and Steacy, H.R., 1958, On the geology and radioactive deposits of Blind River region: Proceedings of Second International U.N. Conference on the Peaceful Uses of Atomic Energy, Geneva, v. 2, 222, p. 473-483.

Rundle, C.C., and Snelling, N.J., 1977, The geochronology of uraniferous minerals in the Witwatersrand triad; an interpretation of new and existing $\mathrm{U}-\mathrm{Pb}$ age data on rocks and minerals from the Dominion Reef, Witwatersrand and Ventersdorp Supergroups: Philosophical Transactions of the Royal Society of London, A286, p. 567-583.

Ruzicka, V., and Steacy, H.R., 1976, Some sedimentary features of conglomeratic uranium ore from Elliot Lake, Ontario: Geological Survey of Canada Paper 76-1A, p. 343-346.

Saager, R., 1968, Newly observed ore-minerals from the Basal Reef in the Orange Free State Goldfield in South Africa: Economic Geology, v. 63, p. 116-123.

Saager, R., 1969, The relationship of silver and gold in the Basal Reef of the Witwatersrand System, South Africa: Mineralium Deposita, v. 4, p. 93-113.

Saager, R., 1970, Structures in pyrite from the Basal Reef in the Orange Free State Gold-field: Transactions of the Geological Society of South Africa, v. 73, p. 29-46.

Saager, R., 1976, Geochemical aspects of the origin of detrital pyrite in Witwatersrand conglomerates: Johannesburg, University of the Witwatersrand Economic Geology Research Unit Information Circular 105, 21 p.

Saager, R., and Esselaar, P.A., 1969, The use of factor analysis in the processing of geochemical data from the Basal Reef, Orange Free State Goldfield, South Africa: Johannesburg, University of the Witwatersrand Economic Geology Research Unit Information Circular 53, 11 p.

Saager, R., and Mihâlik, P., 1967, Two varieties of pyrite from the basal reef of the Witwatersrand System: Economic Geology, v. 62, p. 719-731.

Saager, R., and Muff, R., 1978, Petrographic and mineragraphic investigations of the Archean gold placers at Mount Robert in the Pietersburg greenstone belt, northern Transval: Johannesburg, University of the Witwatersrand Economic Geology Research Unit Information Circular 114, 10 p.

Salop, L.J., 1977, Precambrian of the northern hemisphere: New York, Elsevier, 378 p. 
Schidlowski, M., 1966a, Mineralbestand und Gefügebilder in Faseraggregaten von kohliger Substanz ("Thucholith") aus den Witwatersrand-Konglomeraten: Contributions to Mineralogy and Petrology, v. 12, p. 365-380.

Schidlowski, M., 1966b, Zellular strukturierte Elemente aus dem Präkambrium des Witwatersrand-Systems (Südafrika): Zeitschrift der Deutschen Geologischen Gese11schaft, v. 115, p. 783-786.

Schidlowski, M., 1966c, Beiträge zur Kenntnis der radioaktiven Bestandteile der Witwatersrand-Konglomerate. I. Uranpecherz in den Konglomeraten des Oranje-Freistaat-Goldfeldes: Neues Jahrbuch für Mineralogie, Abhandlungen, v. 105, p. 183-202.

Schidlowski, M., 1966d, Beiträge zur Kenntnis der radioaktiven Bestandteile der Witwatersrand-Konglomerate. III. Kohlige Substanz ("Thucholith"): Neues Jahrbuch für Mineralogie, Abhandlungen, v. 106, p. 55-71.

Schidlowski, M., 1966e, Beiträge zur Kenntnis der radioaktiven Bestandtefle der Witwatersrand-Konglomerate. II. Brannerit und "Uranpecherzgeister": Neues Jahrbuch für Mineralogie, Abhandlungen, v. 105, p. 310-324.

Schidlowski, M., 1966f, Some observations on radioactive blasting haloes and radioactive corrosion phenomena in conglomerates from the orange Free State Goldfield: Transactions of the Geological Society of South Africa, v. 69 , p. 155-159.

Schidlowski, M., 1967a, A composite detrital grain from the Witwatersrand conglomerates (South Africa): Journal of Sedimentary Petrology, v. 37, p. 227-228.

Schidlowski, M., 1967b, Note on graphite in the Witwatersrand conglomerates: Transactions of the Geological Society of South Africa, v. 70, p. 65-66.

Schidlowski, M., 1968, The gold fraction of the Witwatersrand conglomerates from the Orange Free State Goldfield (South Africa): Mineralium Deposita, v. 3, p. 334-363.

Schidlowski, M., 1969, Critical remarks on a postulated genetic relationship between Precambrian thucholite and boghead coal, in Schenck, P.A., and Havenaar, I., eds., Advances in organic geochemistry: Oxford, Pergamon Press, p. 579-592.

Schidlowski, M., in press, Uraniferous constituents of the Witwatersrand conglomerates: Ore-microscopic observations and implications for the Witwatersrand metallogeny: U.S. Geological Survey Professional Paper.

Schidlowski, M., and Ottemann, J., 1966, Mackinawite from the Witwatersrand conglomerates: American Mineralogist, v. 51, p. 1535-1541.

Schidlowski, M., and Trurnit, P., 1966, Drucklösungser Scheinungen an Geröllpyriten aus den Witwatersrand-Konglomeraten. Ein Beitrag zur Frage des diagenetischen Verhaltens von Sulfiden: Schweizerische Mineralogische und Petrographische Mitteilungen, v. 46, p. 337-351. 
Schumm, S.A., 1977, The fluvial system: New York, Wiley-Interscience, 338 p.

Schweigart, H., and Von Rahden, H., 1964, Oolithische Strukturen in Pyriten des Ventersdorp-Contact-Reefs, Südafrika: Geologischen Rundschau, v. 54, p. 1143-1148.

Shegelski, R., 1980, Archean red beds in the Lake Shebandowan area and their implications for Archean oxygen levels: Paper presented at the joint meeting of International Geologic Correlation Program project 157 and 160 working groups, Santa Barbara, California, April 1980.

Shepherd, T.J., 1977, Fluid inclusion study of the Witwatersrand golduranium ores: Philosophical Transactions of the Royal Society of London, A286, p. 549-565.

Simpson, P.R., and Bowles, J.F.W., 1977, Uranlum mineralization of the Witwatersrand and Dominion Reef systems: Philosophical Transactions of the Royal Society of London, A286, p. 527-548.

Sims, J.F., 1969, The stratigraphy and paleocurrent history of the upper division of the Witwatersrand System on President Steyn Mine and adjacent areas in the Orange Free State Goldfield, with specific reference to the origin of the auriferous reefs: Johannesburg, University of the Witwatersrand unpublished Ph.D. dissertation, 181 p.

Sims, P.K., 1976, Precambrian tectonics and mineral deposits, Lake Superior region: Economic Geology, v. 71, p. 1092-1127.

Singer, D.A., and Ovenshine, A.T., 1979, Assessing Alaska's meta1 resources: American Scientist, v. 67 , p. 582-589.

Smith, N.D., and Minter, W.E.L., 1980, Sedimentological controls of gold and uranium in two Witwatersrand paleoplacers: Economic Geology, v. 75, p. 1-14.

Sneed, E.D., and Folk, R.L., 1958, Pebbles in the lower Colorado River, Texas, a study in particle morphogenesis: Journal of Geology, v. 66, p. $114-150$.

Snyman, C.P., 1965, Possible biogenetic structures in Witwatersrand thucho1ite: Transactions of the Geological Society of South Africa, v. 68, p. 225-235.

Steacy, H.R., and Kaiman, S., 1978, Uranium minerals in Canada: Their description, identification and field guides, in Kimberley, M.M., ed., Short course in uranium deposits: Their mineralogy and origin: Mineralogical Association of Canada, 3, p. 107-140.

Steyn, L.S., 1964, The sedimentology and gold distribution pattern of the Livingstone reefs on the West Rand: University of the Witwatersrand unpublished M.Sc. thesis, 132 p.

Steyn, P., 1977, The occurrence of gold in banded "buckshot" pyrite from the Witwaters rand auriferous conglomerates: Abstracts of Papers, 17 th Congress of the Geological Society of South Africa, p. 103-104. 
Stuckless, J.S., 1979, Uranium and thorium concentrations in Precambrian granites as indicators of a uranium province in central Wyoming: University of Wyoming Contributions to Geology, v. 17, p. 173-178.

Stuckless, J.S., and Nkomo, I.T., 1978, Uranium-lead isotope systematics in uraniferous alkali-rich granites from the Granite Mountains, Wyoming: Implications for uranium source rocks: Economic Geology, v. 73, p. 427-441.

Symons, D.T.A., and O'Leary, R.J., 1978, Huronian polar wander and paleomagnetism of the Thessalon Volcanics: Canadian Journal of Earth Science, v. 15 , p. $1141-1150$.

Theis, N.J., 1979, Uranium-bearing and associated minerals in their geochemical and sedimentological context, Elliot Lake, Ontario: Geological Survey of Canada Bulletin 304, 50 p.

Thiel, K., Saager, R., and Muff, R., 1979, Distribution of uranium in early Precambrian gold-bearing conglomerates of the Kaapvaal craton, South Africa: A review of a case study for the application of fission track micro-mapping of uranium: Minerals Science and Engineering, v. 11, p. 225-245.

Thorpe, R.I., 1963, The radioactive mineralogy of the ore conglomerate at Panel Mine, Blind River, Ontario: Kingston, Ontario, Queen's University unpublished M.Sc. thesis, $148 \mathrm{p}$.

Toens, P.D., and Griffiths, G.H., 1964, The geology of the West Rand, in Haughton, S.H., ed., The geology of some ore deposits in southern Africa: Geological Society of South Africa, v. 1, p. 283-321.

Tra111, R.J., 1954, A preliminary account of the mineralogy of radioactive conglomerates in the Blind River region, Ontario: Canadian Mining Journal, v. 75, p. 63-68.

Trow, J., 1977, Uraniferous quartz-pebble conglomerates and their chemical relation to $\mathrm{CO}_{2}$-deficient atmospheres synchronous with glaciations of almost any age: Abstract, Geological Society of America, Abstract with Programs, v. 9, p. 1205-1206.

Turner, P.A., 1979, The planar auriferous Witwatersrand conglomerates: Pediment mantles of the Proterozolc: Unpublished report presented at 18 th Congress of the Geological Society of South Africa, 10 p.

Tweedie, E.B., 1978, History, geology and value distribution of Evander goldfield, eastern Transvaal, South Africa: Institute of Mining and Metallurgy, Eleventh Commonwealth Mining and Metallurgical Congress, Hong Kong, Paper 23, 8 p.

Tweedie, K.A.M•, 1968, The stratigraphy and sedimentary structures of the Kimberley Shales in the Evander Gold-field, eastern Transvaal, South Africa: Transactions of the Geological Society of South Africa, v. 71 , p. 235-256. 
U.S. Department of Energy, 1980, Statistical data of the uranium industry: U.S. Department of Energy Report GJo-100(80), 94 p.

Utter, T., 1977, The morphology of different types of pyrite from the Witwatersrand System of the Klerksdorp Goldfield: Abstracts of Papers, 17th Congress of the Geological Society of South Africa, p. 120-122.

Van Neikerk, C.B., and Burger, A.J., 1964, The age of the Ventersdorp System: Annals, Republic of South Africa Department of Mines, Geological Survey, v. 3, p. 75-86.

Van Neikerk, C.B., and Burger, A.J., 1969, A note on the minimum age of the acid lava of the Onverwacht Serles of the Swazlland system: Transactions of the Geological Society of South Africa, v. 72, p. 9-21.

Van Neikerk, C.B., and Burger, A.J., 1978, A new age for the Ventersdorp acidic lavas: Transactions of the Geological Society of South Africa, v. 81 , p. 155-163.

Van Schmus, W.R., 1965, The geochronology of the Blind River-Bruce Mines area, Ontario, Canada: Journal of Geology, v. 73, p. 755-780.

Van Schmus, W.R., 1976, Early and middle Proterozoic history of the Great Lakes area, North America: Philosophical Transactions of the Royal Society of London, A280, p. 605-628.

Van Valkenburgh, T., 1979, Petrology of the pre-2,800 m.y. old paleosol below the Dominion Reef Group, South Africa: Campbell University, North Carolina, student research project, 7 p.

Venkatasubramanian, V.S., 1974, Geochronology of the Dharwar craton, a review: Journal of the Geological Society of India, v. 15, p. 463-468.

Vickers, R.C., 1956, Origin and occurrence of uranium in northern Michigan: University of Wisconsin unpublished Ph.D. dissertation.

Viljoen, E.A., 1971, An electron-microprobe analysis of gold in the Witwatersrand banket and in ores from the Barberton Mountain Land: National Institute for Metallurgy Research Report No. 1361, Johannesburg.

Viljoen, R.P., 1967, The composition of the Main Reef and Main Reef Leader conglomerate horizons in the northeastern part of the Witwatersrand Basin: Johannesburg, University of the Witwatersrand Economic Geology Research Unit Information Circular 40, 54 p.

Viljoen, R.P., 1968, The quantitative mineralogical properties of the Main Reef and Main Reef Leader of the Witwatersrand System: Johannesburg, University of the Witwatersrand Economic Geology Research Unit Information Circular 41, 63 p.

Visser, D.J.L., compller, 1956, The geology of the Barberton area: Republic of South Africa Department of Mines, Geological Survey, Special Publication $15,253 \mathrm{p}$. 
Visser, H.N., and Verwoerd, W.J., 1960, The geology of the country north of Nelspruit: Explanation sheet 22 (Nelspruit): Republic of South Africa Department of Mines, Geological Survey, 128 p.

Viswanatha, M.N., Ramakrishnan, M., Chayapathi, N., Seshadri, T.S., Devudu, G.R., and others, 1977, Geology of the greenstone-granite terrain of Karnataka craton, South India: International Geologic Correlation Program project 92, excursion guide.

Voelker, A.H., Wedow, H., Oakes, E., and Scheffler, P.K., 1979, A systematic method for resource rating with two applications to potential wilderness areas: Oak Ridge, Tennessee, Oak Ridge National Laboratory publication ORNL/TM-6739.

Von Bäckstrom, J.W., 1976, Uranium, in Coetzee, C.B., ed., Mineral resources of the Republic of South Africa: Republic of South Africa Department of Mines, Geological Survey, p. 233-239.

Walker, J.C.G., 1980, 0xygen content of the early atmosphere resulting from abiotic photochemical processes: Abstract, joint meeting of International Geologic Correlation Program project 157 and 160 working groups, Santa Barbara, California, April 1980.

Wanless, R.K., and Trai11, R.J., 1956, Age of uraninites from Blind River, Ontario: Nature, v. 178, p. 249-250.

Wanless, R.K., Stevens, R.D., Lachance, G.R., and Rimsaite, R.Y.H., 1965, Age determinations and geological studies, part 1--isotopic ages: Report 5, Geological Survey of Canada Paper 64-17, 126 p.

Wetherill, G.H., Kouvo, 0., Tilton, G.R., and Gast, P.W., 1962, Age measurements on rocks from the Finnish Precambrian: Journal of Geology, v. 70 , p. 74-88.

White, M.G., 1961, Origin of uranium and gold in the quartzite-conglomerate of the Serra de Jacobina, Brazil: U.S. Geological Survey Professional Paper 424-B, p. 88-89.

White, M.G., 1964, Uranium at Morro do Vento, Serra de Jacobina, Brazil: U.S. Geological Survey Bulletin 1185-A, p. A1-A18.

Whiteside, H.C.M., 1970, Uraniferous Precambrian conglomerates of South Africa, with discussion, in Uranium exploration geology: Vienna, International Atomic Energy Agency Panel Proceeding Series PL-391/14, p. 49-75.

Wiebols, J.H., 1961, Note on chloritoid in the Witwatersrand System: Transactions of the Geological Society of South Africa, v. 64, p. 85-90.

Windley, B.F., 1977, The evolving continents: New York, John Wiley and Sons, $385 \mathrm{p}$.

Wyatt, B.A., 1976, The geology and geochemistry of the Klipriviersberg volcanics, Ventersdorp Supergroup, south of Johannesburg: Johannesburg, University of the Witwatersrand unpublished M.Sc. thesis, $178 \mathrm{p}$. 
Yaalon, D.H., 1961, Weathering and soll development through geologic time: Proceedings of the Israel Geological Society, p. 149-150.

Young, R.B., 1909, Further notes on the auriferous conglomerates of the Witwatersrand with a discussion on the origin of gold: Transactions of the Geological Society of South Africa, v. 12, p. 82-100.

Young, R.B., 1917, The banket of the South African goldfields: London, Gurney and Jackson, 125 p.

Zartman, R.E., and Stern, T.W., 1967, Isotopic age and geologic relationships of the Little Elk Granite, northern Black Hills, South Dakota: U.S. Geological Survey Professional Paper 575-D, p. D157-D163.

Zeschke, G., 1960, Transportation of uraninite in the Indus River, Pakistan: Transactions of the Geological Society of South Africa, v. 63, p. 87-98.

Zumberge, J.E., Sigleo, A.C., and Nagy, B., 1978, Molecular and elementa1 analyses of the carbonaceous matter in the gold and uranium bearing Vaal Reef carbon seams, Witwatersrand Sequence: Minerals Science and Engineering, v. 10, p. 223-246. 